Universidade de São Paulo

Faculdade de Filosofia, Letras e Ciências Humanas

Departamento de História

Programa de Pós-Graduação em História Econômica

\author{
José Ailton Dutra Júnior
}

\title{
O Líbano e o Nacionalismo Árabe (1952-1967): o Nasserismo como projeto para o Mundo Árabe e o seu impacto no Líbano
}

\author{
Versão Corrigida
}

São Paulo 


\section{José Ailton Dutra Júnior}

\section{O Líbano e o Nacionalismo Árabe (1952-1967): O Nasserismo como projeto para o Mundo Árabe e o seu impacto no Líbano}

Dissertação de Mestrado apresentada ao Programa de Pós-Graduação em História Econômica, do Departamento de História da Faculdade de Filosofia, Letras e Ciências Humanas da Universidade de São Paulo para a obtenção do título de Mestre em História Econômica.

Orientador: Professor Doutor Osvaldo Luis Angel Coggiola

São Paulo

2014 
Autorizo a reprodução e divulgação total ou parcial deste trabalho, por qualquer meio convencional ou eletrônico, para fins de pesquisa, desde que citada à fonte.

\section{DUTRA JUNIOR, José Ailton.}

O Líbano e o Nacionalismo Árabe (1952-1967): O Nasserismo como projeto para o Mundo Árabe e o seu impacto no Líbano; Orientador Osvaldo Luis Angel Coggiola - São Paulo, 2014

320 f.: il.

Dissertação de Mestrado - Faculdade de Filosofia Letras e Ciências Humanas Universidade de São Paulo.

1.História Econômica. 2. História Política e Social. 3. Nacionalismo Árabe vs. Nacionalismo Libanês. 4. Líbano. 5. Oriente Médio I. Título. II. Osvaldo Luis Angel Coggiola. 


\section{AGRADECIMENTOS}

Ao meu grande amigo Ramez Philippe Maalouf, Mestre em Geografia pela USP e formado em História pela UERJ com quem sempre tenho grandes conversas.

Agradeço também aos meus amigos Claudius Robertus Santos Silva, Felipe Ferraz Machado, Tito Lívio Barcellos, Rafael Regiani, Eduardo Fiorentini Votta (O Geleia), Maikel Messias Garcia, Fábio Rogério Casimiro Corrêa, Danilo Sousa, Marcos Favaro, Lucas Cabral e José Augusto Teixeira.

Agradeço também a Clarice Gonçalves Costa, minha maravilhosa companheira, que esteve me apoiando ao longo de todo o Mestrado, incluindo os momentos mais difíceis.

Ao apoio das pessoas do cursinho em que trabalho, a começar pelo seu diretor Manoel Francisco dos Santos Júnior.

Ao meu orientador Osvaldo Luis Angel Coggiola.

Ao professor de História Contemporânea Lincoln Ferreira Secco.

A professora Safa Jubran do curso de Árabe do Departamento de Letras Orientais da USP.

Ao Serviço de Assistência Social da USP, o Coseas e a assistente social Carla Cucollo.

A minha família, especialmente a Senhora Josélia Correia de Lima Dutra, minha mãe, mas também as minhas irmãs Flávia e Gabriela e ao meu pai, o senhor José Ailton Dutra cuja ajuda foi importantíssima durante a revisão após a minha defesa . 
Nome: DUTRA JUNIOR, José Ailton.

\section{Título: O Líbano e o Nacionalismo Árabe (1952-1967): O Nasserismo como projeto para o Mundo Árabe e o seu impacto no Líbano}

Dissertação de Mestrado apresentada ao Programa de Pós-Graduação em História Econômica, do Departamento de História da Faculdade de Filosofia, Letras e Ciências Humanas da Universidade de São Paulo para a obtenção do título de Mestre em História Econômica.

Aprovado em:

Banca Examinadora

Prof. Dr. Instituição

Julgamento Assinatura

Prof. Dr. Instituição

Julgamento Assinatura

Prof. Dr. Instituição 


\section{RESUMO}

DUTRA JÚNIOR, José Ailton: O Líbano e o Nacionalismo Árabe (1952-1967): O Nasserismo como projeto para o Mundo Árabe e o seu impacto no Líbano. Dissertação de Mestrado - Departamento de História da Faculdade de Filosofia, Letras e Ciências Humanas, Universidade de São Paulo. Programa de História Econômica.

O presente estudo tem por finalidade descrever a interação conflituosa entre o nacionalismo árabe e o Líbano entre 1952 e 1967. Nesses anos ocorreu a ascensão do nacionalismo árabe, que teve na figura do presidente egípcio Gamal Abdel Nasser a sua principal liderança. Seu objetivo era promover a luta dos povos de língua árabe contra a dependência tecnológica e dominação econômica e/ou política dos países capitalistas centrais, situados na Europa Ocidental e América do Norte. Bem como desenvolver suas sociedades e combater os setores conservadores internos, aliados dos poderes capitalistas ocidentais e pouco interessados em uma modernização mais profunda ou uma grande melhoria nos padrões de vida das classes populares. O objetivo último dos nacionalistas árabes era a unidade de todos os povos árabes em algum tipo de estrutura estatal. No Líbano a ideia da unidade árabe era mais difícil de realizar, pois uma parcela importante da sua população, os cristãos maronitas, não se viam como árabes e buscaram criar um estado separado para eles no começo do século XX, com apoio de uma potência colonial europeia com quem se identificavam e tinha laços históricos: a França. No entanto, para que o Líbano pudesse existir como estado independente viável economicamente, após a II Guerra Mundial, tiveram os cristão maronitas de entrar em acordo com a população muçulmana, particularmente os sunitas, e aceitar que o Líbano tinha uma face árabe. Esse acordo, conhecido como o Pacto Nacional, garantiu a existência do Líbano e permitiu que este se tornasse um entreposto comercial e financeiro no Oriente Médio, algo desejado tanto por suas elites cristãs (maronita e outras), como pelas muçulmanas. Mas, enquanto o Líbano experimentava um grande crescimento econômico na década de 1950, as suas regiões muçulmanas eram mantida em grande parte alheias a esse crescimento. $\mathrm{O}$ resultado foi o seguinte: as populações muçulmanas passaram a questionar a preponderância cristã e viram em Nasser e no nacionalismo árabe um meio para isso. Suas lideranças tiverem que segui-las, enquanto a população cristã, particularmente os maronitas, sentia-se ameaçada. Estas tensões, mescladas às ambições do presidente Camille Chamoun e ao cenário da Guerra Fria, conduziram a guerra civil de 1958. Posteriormente, entre 1959 e 1964, em um governo 
de unidade nacional, o Presidente Fuad Chehab tentou promover a unidade nacional, fazer investimentos do estado nas regiões muçulmanas, criar um esboço de segurança social e regular o liberalismo desenfreado do país. Seu fracasso parcial e o mau tratamento da população de refugiados palestinos por suas forças de segurança abriu caminho para a grande guerra civil de 1975-1990.

Palavras-chave: Líbano; liberalismo; cristãos; muçulmanos; maronitas; sunitas; nacionalismo Árabe e Nasser. 


\begin{abstract}
DUTRA JÚNIOR, José Ailton. Lebanon and the Arab Nationalism (1952-1967): Nasserism as a project for the Arab World and its impact on Lebanon. Master Thesis Department of History, Faculty of Philosophy, Letters and Human Sciences, University of São Paulo. Program of Economic History.
\end{abstract}

The present study aims at describing the conflicting interaction between Arab nationalism and Lebanon between 1952 and 1967. Those years was the rise of Arab nationalism, which had the figure of Egyptian President Gamal Abdel Nasser your primary leadership. His goal was to promote the struggle of the Arabic speaking people against technological dependence and economic domination and / or policy of the central capitalist countries located in Western Europe and North America. As well as developing their societies and combat domestic conservative sectors, allies of Western capitalist powers and little interested in a deeper upgrade or a major improvement in living standards of the working classes. The ultimate aim of Arab nationalists was the unity of all Arab peoples in some kind of state structure. In Lebanon the idea of Arab unity was more difficult to accomplish, because a significant portion of its population, the Maronite Christians, do not see themselves as Arabs and sought to create a separate state for them in the early twentieth century, with the support of a colonial power European with whom identified themselves and had historical ties: France. However, that Lebanon could exist as economically viable independent state after World War II, Christian Maronites had to come to terms with the Muslim population, particularly the Sunnis, and accept that Lebanon was an Arab face. This agreement, known as the National Pact, ensured the existence of Lebanon and allowed it to become a commercial and financial entrepot in the Middle East, something desired by both her Christian elites (Maronite and other), and by Muslims. But while Lebanon was experiencing great economic growth in the 1950s, its Muslim regions were maintained in large part unrelated to this growth. The result was as follows: Muslim populations began to question the Christian dominance and saw in Nasser and Arab nationalism means for this. Their leaders have to follow them, while the Christian population, particularly the Maronites, felt threatened. These tensions, merged the ambitions of President Camille Chamoun and the scenario of the Cold War, led to civil war in 1958. Later, between 1959 and 1964 in a government of national unity, President Fuad Chehab tried to promote national unity, make investments state in Muslim regions, create an 
outline of social security and regular liberalism rampant in the country. Its partial failure and poor treatment of the population of Palestinian refugees by its security forces paved the way for the great Civil War 1975-1990

Keywords: Lebanon; liberalism; Christians; Muslims; Maronites; Sunni; Nasser and Arab nationalism. 


\section{LISTA DE SIGLAS}

ARAMCO Arabian-America Company

AUB American University of Beirut, Universidade Americana de Beirute

BCAIF Banque de Crédite Agricole, Industriel e Foncier

BDL Banque du Liban

BSL Banque de Syrie et Liban

CCIAB Câmara do Comércio, Indústria e Agricultura de Beirute

CENTO Central Treaty Organization

CGTL Confederação Geral dos Trabalhadores do Líbano

CIA Central Inteligence Agency

DASHNAK Sigla Abreviada em armênio para Federação Revolucionária Armênia

EUA Estados Unidos da América

FAO Food and Agriculture Organization, Organização das nações Unidas para a Agricultura e a Alimentação

FATAH Acrônimo reverso do nome Harakat al-Tahrir al-Watani al-Filastini: Movimento de Libertação Nacional da Palestina

FMI Fundo Monetário Internacional

FLN $\quad$ Frente de Libertação Nacional

FPLP Frente Popular para a Libertação da Palestina

FUN Frente de União Nacional

IIC Intra Investiment Company

IPC Irak Petroleum Company

Intra Bank International Trade Bank

IRFED Institute International de Recherche et de Formation, Éducation e Development

LEPCO Lebanese Petroleum Company

MEA Middle East Airlines 


\begin{tabular}{|c|c|}
\hline MNA & Movimento Nacionalista Árabe \\
\hline OEG & Officé de l`Economie de Guerre \\
\hline OIT & Organização Internacional do Trabalho \\
\hline OLP & Organização para a Libertação da Palestina \\
\hline ONU & Organização das Nações Unidas \\
\hline OTAN & Organização do Tratado do Atlântico Norte \\
\hline PIB & Produto Interno Bruto \\
\hline PCL & Partido Comunista Libanês \\
\hline PCSL & Partido Comunista da Síria e do Líbano \\
\hline PNL & Produto Nacional Líquido \\
\hline PNL & Partido Nacional Liberal \\
\hline PNSS & Partido Nacional Socialista Sírio \\
\hline PSP & Partido Socialista Progressista \\
\hline $\mathbf{R A U}$ & República Árabe Unida \\
\hline TMA & Trans-Mediterranean Airlines \\
\hline TOA & Trans-Ocean Airlines \\
\hline UNOGIL & United Nations Observation Group in Lebanon \\
\hline UNRWA & United Nations and Work Agency \\
\hline URSS & União das Repúblicas Socialistas Soviéticas \\
\hline
\end{tabular}




\section{SUMÁRIO}

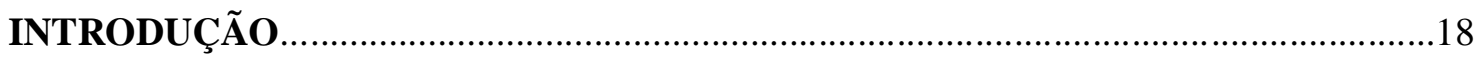

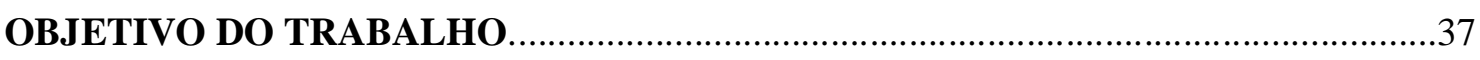

\section{CAPÍTULO 1}

OS ANOS DE FORMAÇÃO DO MODERNO LÍBANO.................................................

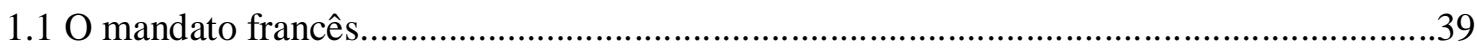

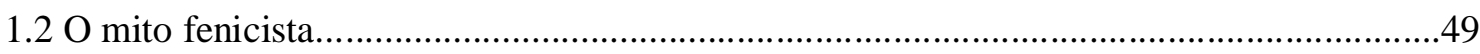

1.3 A revolta drusa

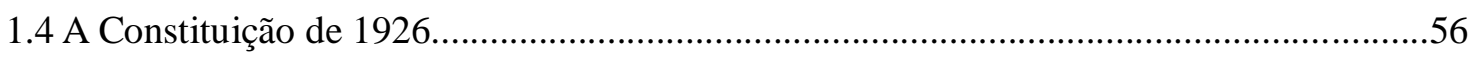

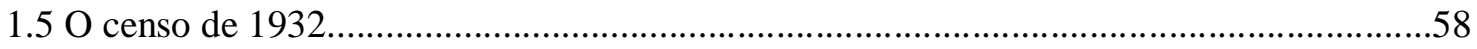

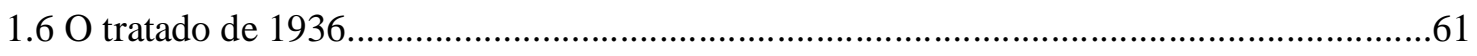

1.7 A economia do Líbano sob o mandato francês...................................................................63

1.8 A economia nos anos da Segunda Guerra Mundial.........................................................70

1.9 A Segunda Guerra Mundial e a independência do Líbano.....................................................74

1.10 Reconhecimento do Líbano por suas elites muçulmanas e pelos sírios...............................88

1.11 A ideologia nacional libanesa.......................................................................................90

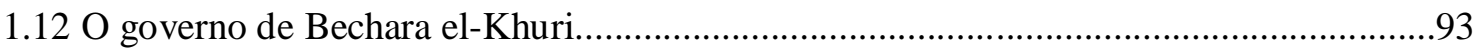

1.13 A política econômica liberal e o Estado fraco................................................................96

\section{CAPÍTULO 2}

O SISTEMA ECONÔMICO LIBERAL DO LÍBANO_.................................................104

2.1 A situação socioeconômica do Líbano...........................................................................115

2.2 A Lei do Trabalho de 1946.................................................................................123

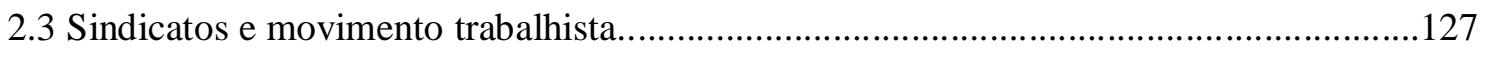

2.4 Perfil dos sindicalistas libaneses..............................................................................134

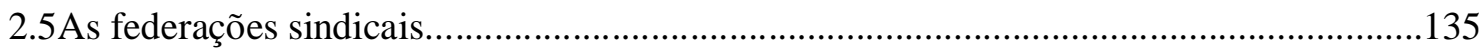

2.6 O projeto de uma Confederação Sindical......................................................................146

2.7 As conquistas do movimento sindical libanês....................................................................147 
2.8 Desigualdades sociais e distribuição de renda...............................................................149

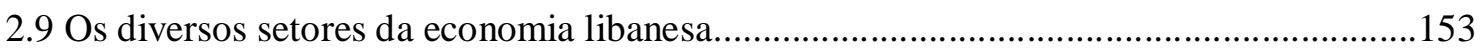

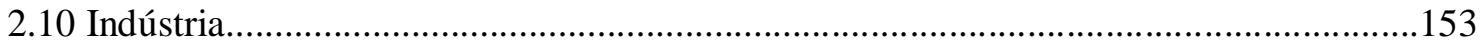

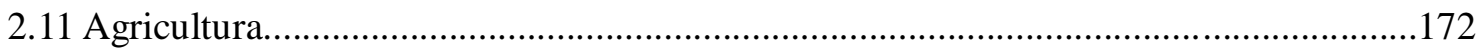

2.12 Comércio, bancos e outros serviços...........................................................................180

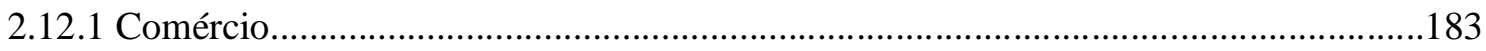

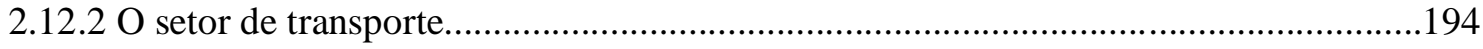

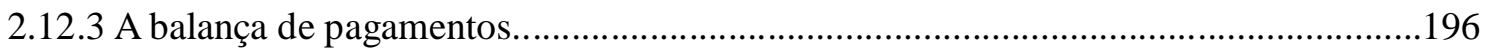

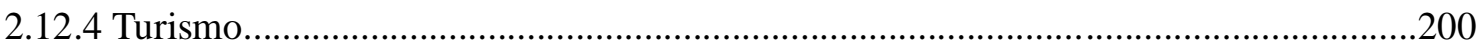

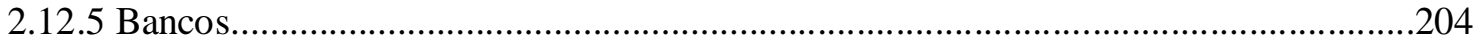

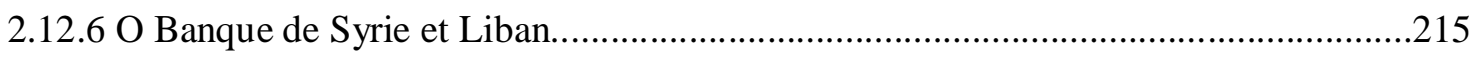

2.12.7 O surgimento do Banco Central Libanês......................................................................219

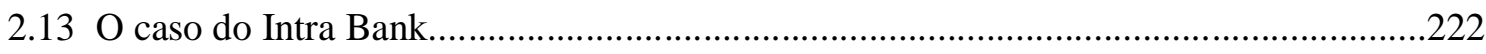

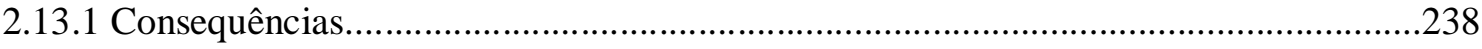

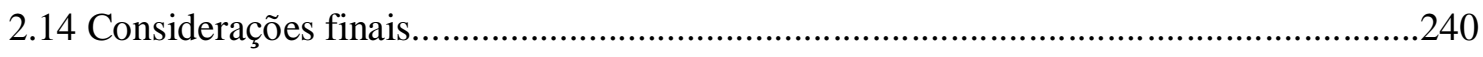

\section{CAPÍtULO 3}

O REGIME DE CAMILLE CHAMOUN E A GUERRA CIVIL DE 1958....................245

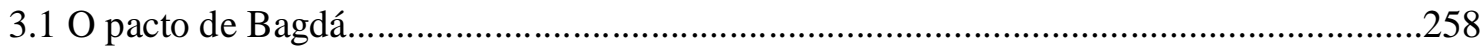

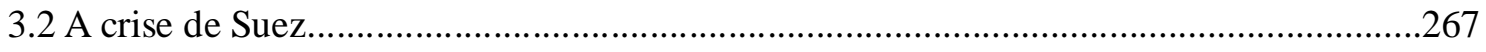

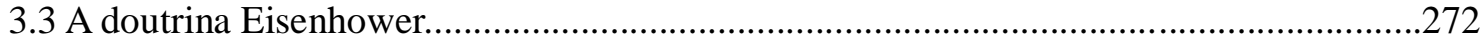

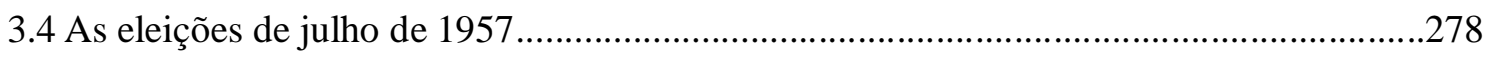

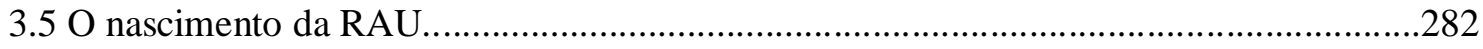

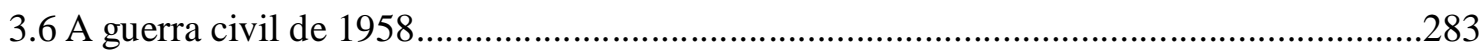

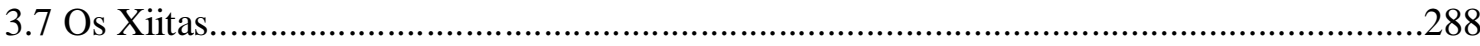

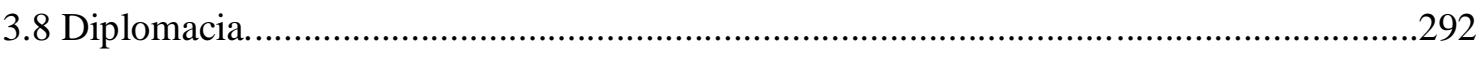

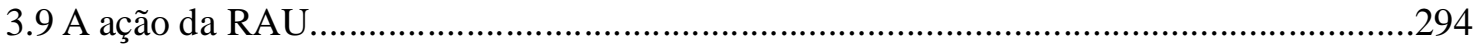

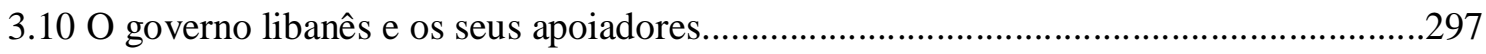

3.11 As negociações entre Nasser e os norte-americanos.....................................................305

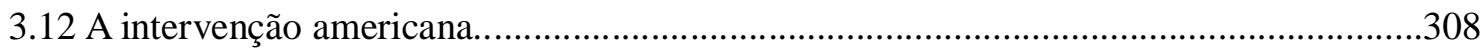




\section{CAPÍTULO 4}

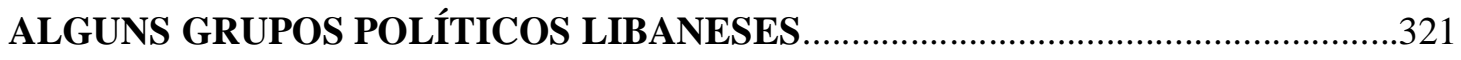

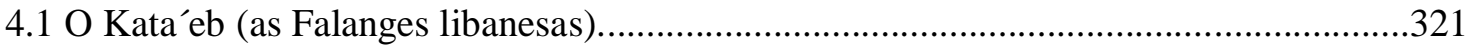

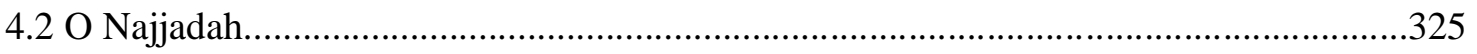

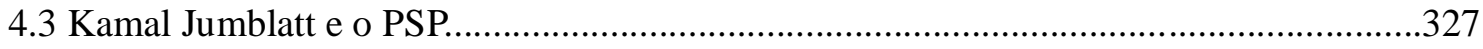

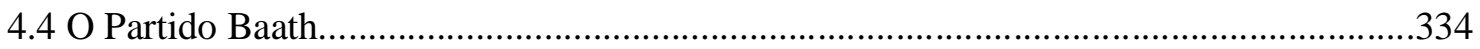

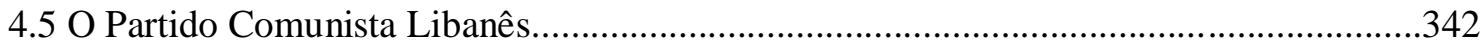

4.6 Partido Comunista Libanês, o Mundo Árabe e o Líbano...................................................350

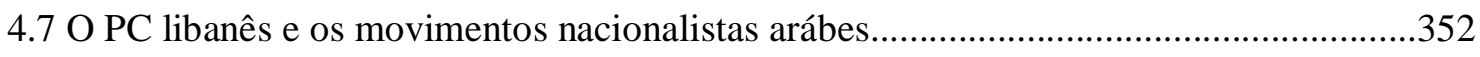

4.8 O PC libanês após o XX Congresso do PC da União Soviética em 1956.........................354

\section{CAPÍtULO 5}

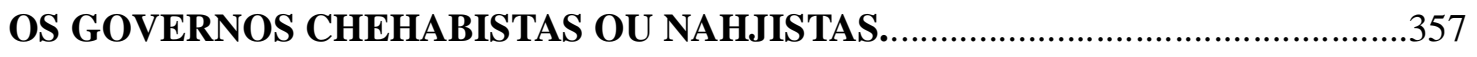

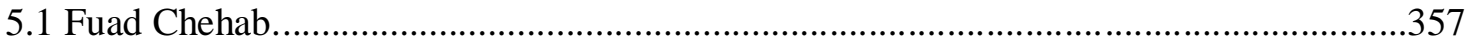

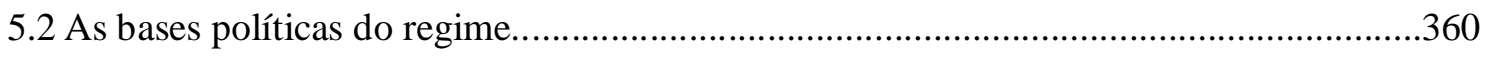

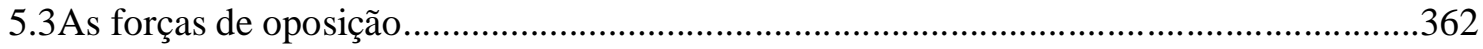

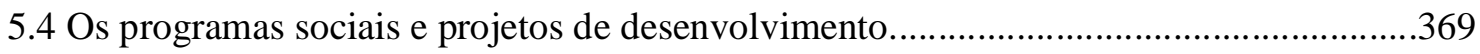

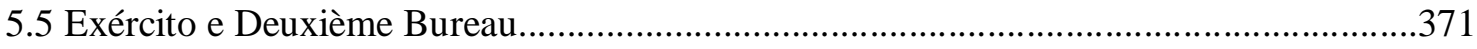

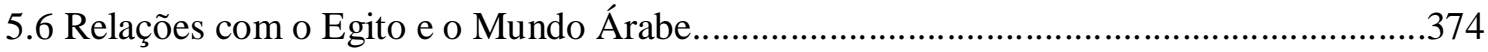

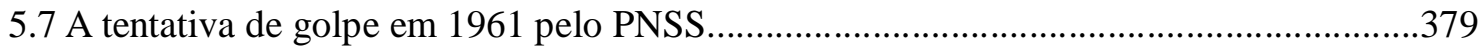

5.8 A tentativa de reeleição de Chehab e a reação da oposição................................................386

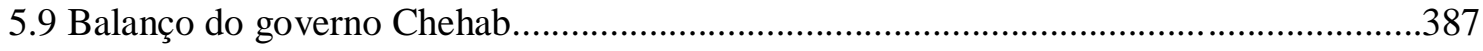

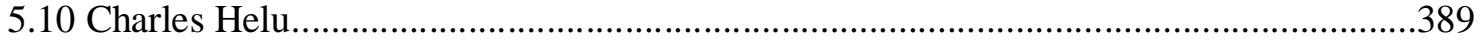

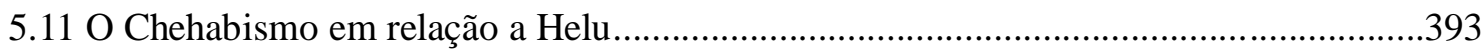

5.12 A política internacional árabe e as grandes crises do regime de Helu............................395

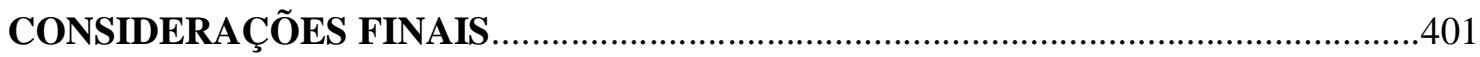

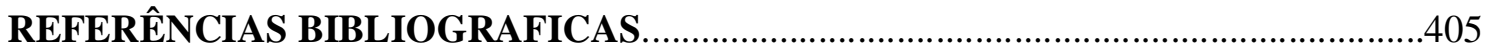

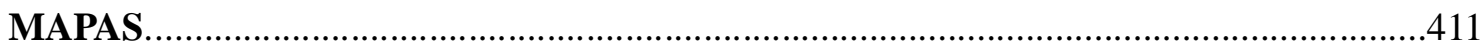




\section{ÍNDICE DE TABELAS}

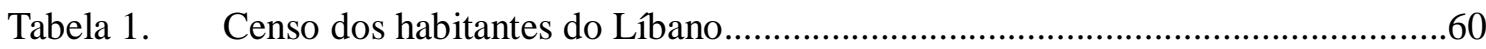

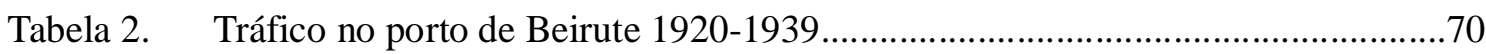

Tabela 3. Taxa de analfabetismo rural (por volta de 1960)............................................106

Tabela 4. Média anual da taxa de câmbio em relação ao dólar dos EUA e a cobertura em

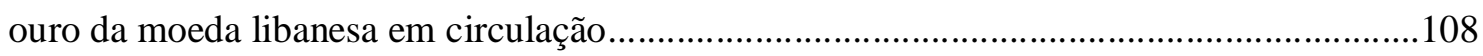

Tabela 5. Notas em circulação e sua cobertura, 1951-1968............................................110

Tabela 6. Produto nacional líquido por setor, 1950-1966...........................................113

Tabela 7. Formação do capital privado por setor, 1951-1957.........................................117

Tabela 8. Diversidade da produção industrial libanesa em 1964_..................................118

Tabela 9. Escala e produtividade na indústria............................................................119

Tabela 10. A indústria nos anos de Fuad Chehab, 1958-1964.......................................120

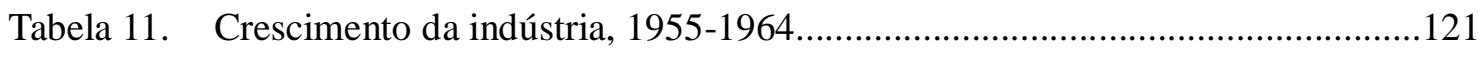

Tabela 12. Atividades de empréstimo do Banque de Credit Agricole, Industriel et Foncier

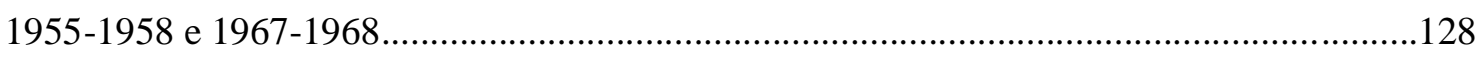

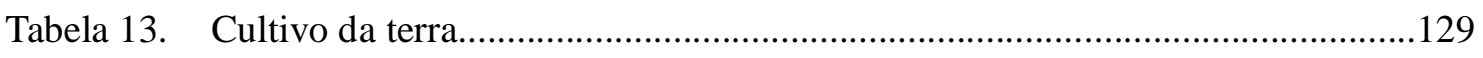

Tabela 14. Exportações de bens e serviços, 1951-1966...................................................130

Tabela 15. Importações libanesas desde os doze maiores mercados, 1951-1966...............149

Tabela 16. Exportações libanesas para os seus doze maiores Mercados, 1951-1966..........150

Tabela 17. Comércio triangular e de trânsito entre 1951-1968.........................................151

Tabela 18. Estrutura do comércio de mercadorias........................................................156

Tabela 19. Estrutura do comércio de mercadorias do Líbano, 1950-1958 (\%).................157

Tabela 20. Valores do comércio externo para o Líbano, 1951-1968...................................160

Tabela 21. Índices de liquidez no Líbano, 1950-1968..................................................163

Tabela 22. Financiamento do déficit comercial libanês, 1951-1966...................................166

Tabela 23. Emigração libanesa, 1945-1970.......................................................................169 
Tabela 24. Atividade laboral, emprego e desemprego, 1950-1970.................................180

Tabela 25. Estrutura do emprego alternativo por ramo da economia...............................182

Tabela 26. Estimativa da estrutura de emprego por atividade econômica...........................184

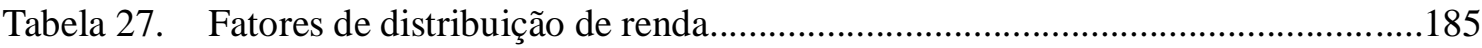

Tabela 28. Sindicatos e nível de sindicalização, 1949-1967...............................................187

Tabela 29. Distribuição de renda por família................................................................189

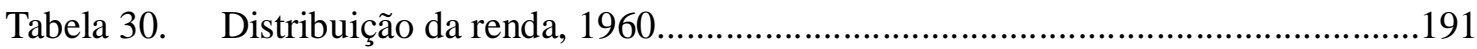

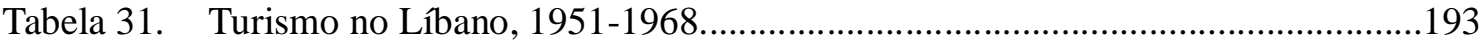

Tabela 32. Comércio e finanças como \% do Produto Nacional Líquido.............................197

Tabela 33. Monetarização no Líbano, 1950-1968............................................................199

Tabela 34. Mudanças nas reservas internacionais das autoridades monetárias e nos ativos

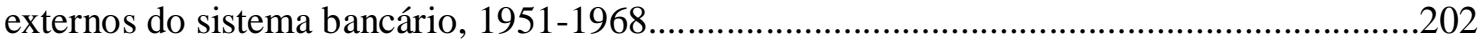

Tabela 35. Alguns índices de liquidez no Líbano, 1951-1968_......................................205

Tabela 36. Mercado de capital e índices monetários no Líbano, 1951-1968.....................207

Tabela 37. Mercado de crédito no Líbano em moedas estrangeiras, 1954-1970 - Anos

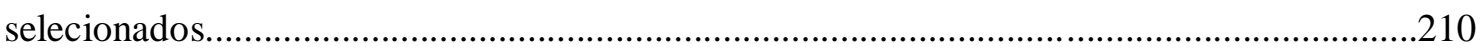

Tabela 38. Alguns índices de liquidez no Líbano, 1951-1968......................................211

Tabela 39. Mercado de capitais e índices monetarios no Líbano, 1951-1968.....................214

Tabela 40. Mercado de crédito no Líbano em moedas estrangeiras, 1954-1970-Anos

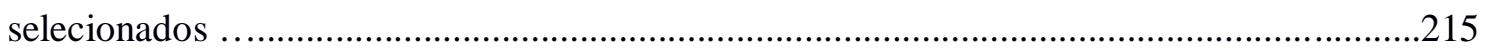

Tabela 41. Taxa de analfabetismo rural (por volta de 1960)...........................................370 


\section{APRESENTAÇÃO:}

Esta dissertação está estruturada em cinco capítulos. Antecedendo o primeiro, a introdução apresenta informações sobre o território e a população do Líbano, além de descrições das principais comunidades religiosas do país e uma apresentação do renascimento cultural Libanês, Nahda, ocorrido no século XIX

Ainda no primeiro capítulo, são abordados também os seguintes pontos fundamentais: o processo de formação do Líbano no período do mandato francês entre 1920 e 1943-46; a aliança entre os cristãos maronitas e os franceses durante a I Guerra Mundial em sua luta contra o Império Otomano; a criação do Grande Líbano a partir da antiga província (Mutassarifiat) do Monte Líbano pela potencia colonial francesa, no qual foram incorporadas terras de população majoritariamente muçulmanas; os mitos fenicista e libanista, que serviram de base para o nacionalismo maronita e libanês; as resistências e depois gradual aceitação das comunidades muçulmanas, e mesmo de outras cristãs, a sua incorporação ao Líbano ou a hegemonia maronita; a luta pela independência; a II Guerra Mundial e seu forte impacto no Líbano; o Pacto Nacional; a economia do Líbano sob o mandato; o desenvolvimento e implantação do modelo econômico liberal baseado do comércio, nos serviços e nas finanças e o Governo Bechara el-Khuri.

O segundo capítulo aborda a situação socioeconômica do Líbano no período entre 1950 e 1970. É dividida em dois subtemas: o primeiro trata dos aspectos socioeconômicos, com destaque para uma pequena história do movimento operário e sindical libanês, suas limitações, relações com a ideologia liberal dominante, bem como com a estrutura política e social comunitária do Líbano; o segundo aborda os diferentes setores da economia libanesa, com destaque para o setor terciário (base da economia entre 1950 e 1975), terminando com a história do Intra Bank, cuja falência calamitosa sintetizou os piores aspectos da história libanesa nos anos 1950 e 1960.

O terceiro capítulo conta a história do Líbano durante o mandato do presidente Camille Chamoun (1952-1958), cujas gravíssimas contradições levaram a guerra civil de maio/setembro de 1958, que teve um forte caráter comunitário, situação na qual o nacionalismo árabe e a figura do presidente egípcio Gamal Abdel Nasser desempenharam um papel central.

No tocante a quarta parte, há uma descrição de seis importantes partidos políticos 
libaneses, cuja participação nos acontecimentos apresentados no período abrangido por esse trabalho é mostrado nos demais capítulos.

Finalmente, na quinta parte, são apresentados os anos do governo reformista de Fuad Chehab (1958-1964) e do seu sucessor Charles Helu (1964-1970), com seus conflitos e contradições, até a Guerra dos Seis Dias (Junho de 1967), que teve forte e negativo impacto na sociedade libanesa, além de assinalar o início do retrocesso do nacionalismo árabe. 


\section{INTRODUÇÃO}

\section{O Líbano}

É um pequeno estado situado no sudoeste da Ásia, na região histórica do Levante, tendo como vizinhos a Síria ao norte e leste e o Estado de Israel ao sul. Pelo oeste o País é banhado pelo Mar Mediterrâneo. Apresenta quatro formações paisagísticas principais: a costa de clima mediterrâneo; a Cadeia do Líbano, que no passado era coberta em sua quase totalidade por florestas temperadas; o Vale do Bekaa e a Cadeia do Anti-Líbano, na fronteira com a Síria.

Como resultado dos problemas referentes à sua formação e história ao longo do século XX há indefinição em relação aos dados sobre a superfície do país. Segundo o Ministério da Agricultura e o Conselho Nacional de Pesquisa Científica do Líbano (CNRSLiban), o Líbano possui uma superfície de $10250 \mathrm{~km}$ quadrados. Porém, o sitio oficial da Agencia Central de Inteligência dos EUA (CIA) sobre temas políticos e geográficos (World FactBook-2014) ${ }^{1}$, o país teria 10400km quadrados. Em termos de comparação, o Líbano teria menos da metade do território do estado brasileiro de Sergipe (21 910 km quadrados).

\section{As Divisões Étnicas e as Comunidades Religiosas do Líbano}

Por razões políticas, desde 1932 não é feito um censo no Líbano e a última vez que o governo fez uma estimativa oficial da população foi em 1956. No entanto existem estimativas feitas por investigadores libaneses e estrangeiros. Atualmente (2014) a população libanesa é estimada em cerca de 5,8 milhões (CIA- World Fact Book). Uma estimativa anterior, de 2007, feita pela universidade libanesa de Saint Joseph e a Administração Central de Estatísticas do Líbano colocou a população do país oscilando entre 3,7 e 4 milhões de pessoas. (Maalouf, 2011). Nos anos 1950 a população libanesa era estimada como sendo de 1,5 a 2 milhões de pessoas.

A população do Líbano é majoritariamente árabe, sendo dividida em três grupos étnicos principais: os libaneses nativos, os refugiados palestinos que vivem principalmente em 15 campos espalhados pelo país e os sírios, em sua maioria, trabalhadores imigrantes. Além disso, há uma significativa minoria armênia (provavelmente $4 \%$ da população), que veio em sucessivas levas para o país ao longo dos séculos, mas cuja onda migratória principal deveuse ao genocídio perpetrado pelos turcos entre 1915-1923. Outros grupos étnicos não árabes

\footnotetext{
${ }^{1}$ https://www.cia.gov/library/publications/the-world factbook/geos/le.html
} 
mais significativos são os curdos, turcomanos, assírios e descendentes dos cruzados, cuja língua materna é o francês.

Com relação às comunidades religiosas, elas começaram a existir como grupos políticos ativos durante o período da Mutassarifiat (1961-1915), mas desde a época do mandato francês (1920-1943) receberam reconhecimento oficial e, possuindo estatuto legal próprio e sendo representadas no sistema político do país. Atualmente (2014) o estado libanês reconhece oficialmente 18 comunidades religiosas. Entre as cristãs temos: os maronitas, greco católico, greco ortodoxo, armênios gregorianos, armênios católicos, sírios ortodoxos (jacobitas), protestantes, etc. Entre as muçulmanas: sunitas, xiitas, drusos, alauítas. Também houve o reconhecimento oficial dos judeus que chegaram a contar com alguns milhares de indivíduos.

Essas comunidades não correspondem necessariamente aos grupos étnicos do Líbano. Dessa forma, os armênios são divididos em três comunidades; católicos armênios, gregorianos e protestantes. Já os sunitas, além da população árabe libanesa, são integrados também pelos curdos e turcomenos locais. greco ortodoxos, Greco católicos, xiitas, drusos, alauítas e a maioria esmagadora dos sunitas são árabes libaneses.

Os maronitas também são uma população de língua árabe e vista pela maioria dos outros libaneses como árabes, embora em quase todo o século XX, e ainda em grande parte de suas gerações mais antigas, eles negassem a sua arabidade, considerando-se como descendentes dos antigos fenícios que teriam passado a falar árabe como resultado do domínio muçulmano na Síria. Inúmeros maronitas discordavam dessa ideia, mas ela era dominante em sua comunidade.

A população palestina é um caso aparte na sociedade libanesa, pois não são considerados cidadãos e nem mesmo parte do país. Eles chegaram ao Líbano expulsos pelos sionistas quando estes criaram o Estado de Israel em 1948. Instalados em 15 campos ao longo do país, não são, em sua esmagadora maioria, reconhecidos como cidadãos e foram vítimas de fortes restrições, preconceitos e hostilidades por todo o século XX, cujas consequências mais trágicas foram os massacres por eles sofridos durante a II Guerra Civil Libanesa de 19751990. Embora, por outro lado, tenham tido, historicamente, boas relações com os sunitas libaneses, pois a grande maioria dos palestinos é sunita. Atualmente devem ser cerca de 300 mil, mas nas décadas de 1950 e 1960 sua população era estimada em cerca de 150 mil pessoas. 
Como resultado dessa diversidade religiosa e do fato de o país ter abrigado muitos grupos de imigrantes ou refugiados ao longo dos séculos, o Líbano apresenta inúmeros santuários e sede de organizações religiosas com populações significativas no Oriente Médio. Dessa forma, localizam-se no Líbano: as sedes da Igreja Católica Armênia (Bzoummar na região do Kisrawan e a Catedral de Santo Elias e São Gregório Iluminador em Beirute), cujo atual patriarca (2014) é Nerses Bedros XIX Tarmouni; nos anos 1950 e 1960 eram Krikor Bedros XV Agagianian e Iknadios Bedros XVI Batanian, a sede da Igreja Católica Maronita, localizada em Bkerke, próxima a Baia de Jounieh. Atualmente Bechara Butrus al-Rai é patriarca, mas nos anos de 1950 e 1960 foi o controvertido e muito ativo politicamente Paul Pierre Meochi; a sede da Igreja Católica Siríaca (localizada em Beirute), sendo o atual patriarca Ignatius Ephrem Iossef III Yonan; a importante sede do Patriarca Catholichos Armênio de Sis da Cilicia (Antelias nas proximidades de Beirute), uma das mais importantes lideranças da Igreja Apostólica Armênia e liderança espiritual dos armênios gregorianos do Líbano, Síria, Chipre, Irã, Kuwait, Grécia e América do Norte.

Entre os muçulmanos cabe citar a região do Monte Amil, cujo clero xiita local teve papel importante na história do xiismo como teólogos, legisladores e ativistas políticos. Sua influencia se fez sentir em países como o Iraque e o Irã e nesse último, os libaneses deram uma grande contribuição ideológica para a deflagração da revolução islâmica em 1979.

Dentre as comunidades religiosas reconhecidas oficialmente pelo estado libanês destacamos:

\section{$\underline{\text { Cristãos }}$}

\section{Os Maronitas}

Os maronitas são a maior e mais importante população cristã na região do atual Líbano e se consideram também uma das mais antigas populações existentes no território da Síria histórica, cuja origem remontaria a alguns séculos antes da expansão árabe pelo Oriente Médio. Essa comunidade se originou a partir dos seguidores de São Maron, um monge asceta sírio do século IV, que se instalou nas montanhas próximas a Ciro, uma cidade localizada nas proximidades de Antioquia a caminho de Alepo, no norte da Síria, para tentar seguir uma vida puramente cristã, tendo atraído inúmeros adeptos enquanto era vivo.

Discípulos de Maron, supostamente, teriam já século IV se dirigido para a região do Monte Líbano, onde, ao chegarem, teriam convertido ao cristianismo comunidades pagãs locais. Conflitos com outras comunidades cristãs por conta da suposta rejeição a doutrina da 
única natureza de Cristo, com o Império Bizantino no século VI (cuja consequência mais radical teria sido o confronto militar de 680) e a pressão dos muçulmanos teriam, ao longo de vários séculos, forçado os maronitas a buscarem as montanhas libanesas como refúgio ${ }^{2}$.

Os maronitas, também em sua formação histórica, contariam com uma população pouco conhecida, os mardaítas, possíveis imigrantes armênios na Síria que teriam combatido os árabes no século VII e mesmo os bizantinos em determinados momentos, com os quais os maronitas teriam se mesclado e que representariam, segundo interpretações do "nacionalismo" maronita, o espírito independente e combativo com o qual esses cristãos diziam caracterizar o seu ethos cultural.

Essa história foi divulgada pelo patriarca maronita Istifan Duwayhi (1668-1704) em sua obra historiográfica Tarikh al-Tai ifah al-Maruniyyah. Já um historiador libanês maronita do século XX, Kamal Suleiman Salibi, em seu livro The House of Many Mansions (1988), afirma que os maronitas seriam uma tribo árabe que entrou na Síria bizantina, durante o século VI, e se instalou entre o Monte Líbano, a cadeia do Anti-Líbano e o vale do rio Orontes. Seriam possivelmente cristãos, mas passariam a seguir uma versão herética e monoteísta ${ }^{3}$.

Ao contrário da maioria das tribos árabes da Síria não teriam se convertido ao islã. No século X, os maronitas foram visitados pelo historiador muçulmano al-Masudi, em seu livro Kitab al-Tanbih wa'l Ishraf, que afirmou que eles eram ainda monoteístas e tinham um historiador de nome Qais al-Maruni, cuja obra ele leu. Outro erudito muçulmano a se referir ao monoteismo dos maronitas foi o teólogo al-Qadi Abd al-Jabbar, em sua obra Al-Mughni ${ }^{4}$.

Nessa época já existia um pequeno grupo maronita no Monte Líbano, organizados como uma confederação tribal de clãs subordinados a um patriarca, mas a maior parte dessa população aí teria se instalado através de sucessivas ondas quando ocorreu a ocupação bizantina da maior parte da Síria entre 970 e 1070, devido às perseguições e ao mau tratamento promovido pelas tropas de Bizâncio ${ }^{5}$. A mudança da maior parte dos maronitas para o Monte Líbano nessa época é afirmada pelo historiador maronita do século XIV Jibriil

\footnotetext{
2 Mahfouz, Joseph: Maronitas, um marco na História. São Paulo, 1991

${ }^{3}$ Salibi, Kamal: The Modern History of Lebanon Pág. 147-148

${ }^{4}$ Salibi, Kamal S.: A House of Many Mansions. Pág.84-85 e 89-90

${ }^{5}$ Salibi, Kamal S.: A House of many Mansions. Pág.91
} 
al-Qilai, em seu livro Shab Marun (Povo de Marun) ${ }^{6}$. Durante as Cruzadas os maronitas, pressionados militarmente pelos turcos seljúcidas, buscaram a ajuda dos invasores europeus com quem promoveram uma forte aliança política e militar. Com essa aliança começou uma aproximação entre o Papado e o Patriarca maronita, com o intuito de se promover uma união entre as duas igrejas. $\mathrm{O}$ alto clero maronita percebia nessa união também como uma maneira de impor a liderança da igreja, sobre o conjunto da sua sociedade aí incluindo a sua aristocracia guerreira.

Finalmente, no ano de 1180 em Jerusalém, chegou-se a um acordo para incorporar os maronitas à igreja latina, no entanto, uma forte oposição surgiu entre a população e o baixo clero maronitas. Com a aceitação da autoridade do Bispo de Roma ocorria a incorporação por parte do clero maronita dos preceitos teológicos da Igreja Católica, embora mantivessem a liturgia síria e o uso da língua siríaca nas missas, o que foi visto por muitos como heresia. Dessa maneira, os religiosos, que haviam aceitado a união, passaram a sofrer perseguição, sendo pilhados, mutilados e mortos por seus compatriotas, que recusavam essa união, sendo que muitos desses maronitas não tinham associação direta com os cruzados ${ }^{7}$.

Esforços foram realizados por parte de Roma para preserva a união como convites feitos aos patriarcas maronitas para participarem de Concílios Católicos ou a emissão de bulas, perdoando os que não aceitavam a autoridade papal, desde que não tivessem cometidos crimes contra o clero maronita pró-Roma. Mesmo assim, a hostilidade era permanente a ponto de patriarcas passarem todo o seu patriarcado encerrados em fortalezas localizadas em vilas no alto de montanhas. Quando o poder dos cruzados estava enfraquecido foram eleitos em 1282 dois patriarcas, um escolhido pela maior parte do clero maronita, a essa altura contrário à união com Roma, e outro indicado pelas autoridades do Condado de Trípoli e que recebeu a aprovação papal ${ }^{8}$.

Com a queda do Condado de Trípoli (1292) as relações entre o papado e a Igreja Maronita ficam dificultadas ao longo do século XIV, mas os maronitas começam a restabelecer seus contatos no século XV e participam graças aos esforços do patriarca Yahia (João), do Concílio de Florença-Ferrara (1439-144), que tentou restabelecer a unidade da

\footnotetext{
${ }^{6}$ Salibi, Kamal: The Modern History of Lebanon Pág.62

${ }^{7}$ Salibi, Kamal: The Modern History of Lebanon Pág.pág. 95-97

${ }^{8}$ Salibi, Kamal: The Modern History of Lebanon Pág. 97
} 
Igreja $^{9}$.

Finalmente, no século XVI a igreja maronita será, como resultado de missões enviadas pela Santa Sé, integrada plenamente ao cristianismo ocidental. Dessa forma. Seu vinculo com a Igreja Católica se manifestou na abertura de um colégio em Roma em 1584. Enquanto alguns religiosos ensinavam árabe ou siríaco em universidades europeias, como Gabriel Sionita e Abraham Ecchellensis, já Yusuf al-Sim`ani foi o autor da Bibliotheca Orientalis, um catálogo de manuscritos orientais da Biblioteca Vaticana ${ }^{10}$.

Além disso, os livros litúrgicos maronitas eram impressos em Roma. Várias mudanças foram feitas em sua teologia como, por exemplo: o reconhecimento da existência do purgatório; o abandono da prática do divórcio; a menção do nome do papa na liturgia; a proibição das crianças de participarem da eucaristia; a aceitação da fé calcedoniana do Filioque $e$ a limitação da autoridade do patriarca, já que ele não poderia tomar qualquer ação disciplinatória sem antes consultar o papa entre outras mudanças mais ${ }^{11}$

Em 1736, o Concílio de Luaize, confirma a incorporação da Igreja Maronita ao catolicismo romano e reconhece definitivamente a soberania do Papa de Roma sobre todos os maronitas, ainda que mantendo as especificidades locais quanto ao uso da liturgia siríaca e da língua aramaica, bem como reconhecendo a autoridade local do Patriarca maronita.

Os maronitas, no plano político, formaram com os drusos, do século XVII ao XIX, um emirado autônomo dentro do Império Otomano na região do Monte Líbano, ao mesmo tempo em que migraram para as regiões centrais do Líbano e se tornaram os principais criadores de bicho da seda para a produção de seda, principal mercadoria exportada pelo emirado.

Com a dinastia Chehab (séculos XVIII e XIX), particularmente durante o reinado de Bashir II, chegaram a controlar o poder político. As lutas e guerras, que acontecem no século XIX, nos anos finais da existência do emirado e nas décadas de 1840 e 1850 até 1861 com os drusos, que terminou em grande massacre nesse ano (12 mil maronitas e outros cristãos mortos), mais a interferência das potencias europeias nos assuntos da Síria, os crescentes contatos comerciais e culturais com a Europa, particularmente a França, que se

\footnotetext{
${ }^{9}$ Salibi, Kamal: The Modern History of Lebanon Pág.99

${ }^{10}$ Salibi, Kamal Suleiman. The Modern History of Lebanon. Westport: Greenwood Press Publisher, reimpressão de 1976. Pág. 122

${ }^{11}$ Phan, Peter C. Editor: Christianity in Asia. Wiley-Blackwell-A John Willians \& Sons, LTDA, Publications. Malden-USA, Oxford and West Susex- England, 2010. Capítulo 12. S.N. P.
} 
apresentará como "protetora" dos maronitas, farão com que essa comunidade desenvolva um sentimento de estranhamento e distancia em relação aos seus vizinhos. Isso culminou no desenvolvimento de uma espécie de nacionalismo comunitário e na negação, especialmente no século XX, do pertencimento dos maronitas ao conjunto dos povos árabes.

\section{Greco Ortodoxos e Greco Católicos}

São duas comunidades cristãs com fortes laços históricos, pois se originam a partir dos cristãos melquitas, ou seja, o grupo de cristãos que na Síria, depois do Concílio de Calcedônia (451), quando a maior parte da população local aderiu a Igreja Siríaca e rejeitou o dogma das duas naturezas separadas de Cristo (divina e humana), permaneceu ligada a Igreja e ao cristianismo oficial de Constantinopla, reconhecendo a autoridade religiosa e espiritual do Patriarca desta cidade.

Ao longo dos séculos a Igreja de Constantinopla (Bizantina) foi cada vez mais se distanciando da Igreja Católica em termos de doutrina e organização e se recusando em reconhecer o Patriarca de Roma (Papa) como autoridade cristã universal. Este distanciamento e divergências, bem como os conflitos que gerou acabaram levando ao rompimento total entre as duas igrejas em 1054 e, apesar de um curto período de reunificação no século XV, devido ao Concilio de Florença, permanece até os nossos dias.

Após a formação do Império Árabe no século VII e o inicio do processo de arabização da maior parte da população da Síria, os melquitas foram se tornando uma população majoritariamente de língua e cultura árabe, tanto que o primeiro intelectual cristão que escreveu em árabe, Teodoro Abuqurra (séculos VIII e IX), Bispo de Harran, era dessa igreja $^{12}$.

Nos séculos XVII e XVIII, como resultado da ação dos missionários jesuítas, capuchinos e carmelitas, muitos cristãos melquitas, incluindo padres e bispos, começaram a se identificar com o catolicismo. O primeiro movimento de uma parte dessa população em direção a sua reincorporação ao catolicismo se deu em 1683, quando Euthimius Sayfi, bispo de Tiro e Sidom e seus seguidores buscaram a comunhão com Roma.

Porém, a divisão definitiva deu-se em 1724 quando foi eleito como Patriarca de Antioquia para os melquitas ortodoxos, Cirilo VI, um pró-católico. Sua eleição contou com a forte oposição do Patriarca de Constantinopla, Jeremias III e de um grande número de

\footnotetext{
12 http://www.academia.edu/4156975/Theodore_Abu_Qurrahs_Debate
} 
melquitas na Síria. A eleição de Cirilo VI foi declarada invalida sendo o próprio excomungado e um monge grego indicado para ser o Patriarca de Antioquia.

No entanto, em 1729, o papa Bento XIII reconheceu Cirilo como Patriarca de Antioquia e o considerou, junto com os seus seguidores religiosos e laicos, como estando em comunhão com a Igreja Católica Apostólica Romana. Desde esse momento a antiga comunidade dos melquitas passou a se dividir em dois grupos: um ramo majoritário, de fé ortodoxa e ligado ao Patriarca de Constantinopla, formando mais uma das igrejas autocéfalas da Cristandade Ortodoxa, usando o grego e, posteriormente, cada vez mais, o árabe como línguas litúrgicas. Sua população passaria a ser chamada de greco ortodoxa; um ramo minoritário, que aceitaria cada vez mais a teologia católica, mas manteria a liturgia bizantina, os modelos artísticos e arquitetônicos bizantinos e a antiga tradição musical ortodoxa. No entanto, usaria cada vez mais o árabe como língua litúrgica em suas igrejas. Essa população passaria a ser conhecida como greco católica ou Melquita Greco Católica. As sedes das duas igrejas encontram-se atualmente em Damasco, capital da Síria.

Como exemplo da Comunhão da Igreja Católica greco melquita com Roma, está o fato de ser o Patriarca dessa igreja o protetor da Ordem Militar e Hospitalaria de São Lázaro de Jerusalém, Belém e Nazaré. De maneira semelhante a outras comunidades católicas nascidas de igrejas orientais no Império Otomano, os greco católicos sofreram forte repressão das autoridades greco ortodoxas e não foram reconhecidos pelas autoridades otomanas como comunidade étnico religiosa, separada e autônoma até 1848 .

É curioso constatar que, embora sempre tenha havido melquitas no Líbano, uma parte expressiva dessa população chegou recentemente ao país. No caso dos Greco católicos, muitos vieram ao Líbano fugindo das perseguições dos greco ortodoxos nas cidades síria, ao longo do século XVIII. Posteriormente, a violenta invasão da Síria pelos wahhabitas da Arábia, na primeira década do século XIX, levou muitos greco ortodoxos e outras levas de greco católicos a buscarem refugio no Líbano, particularmente em suas cidades costeiras.

No Líbano, embora se encontrem em muitas regiões do país, a maior concentração de greco ortodoxos e greco católicos encontram-se no em regiões do vale do Bekaa, o Jabal Amil no sul e as cidades da costa. Embora existam importantes populações camponesas nessas comunidades, historicamente elas, por viverem em áreas urbanas, sempre tiveram grande número de artesãos e mercadores, o que se reflete em seus sobrenomes,nos quais predominam termos ligados ao artesanato e ao comércio. 
Ambas participaram ativamente do renascimento cultural árabe (Nahda) do século XIX e estiveram ligadas tanto a ideologias pan-árabes como pan-sírias, mas os greco ortodoxos tiveram uma identificação maior e firme com o pan-arabismo. No século XX, ambas aceitaram a existência do Líbano como entidade política separada da Síria, embora se ressentissem da preponderância dos maronitas. Como exemplo da sua força social está no fato de que uma parte importante da elite cristã liberal do Líbano é ainda hoje greco católica e greco ortodoxa e há nessas comunidades muitos intelectuais, profissionais liberais e comerciantes.

Por outro lado, dessas comunidades vieram muitos dos mais importantes esquerdistas e lideranças populares do Líbano, como são os casos das figuras de Niqula Shawi, Farajallah el-Helu e Georges Hawi, lideranças históricas do Partido Comunista do Líbano $^{13}$.

\section{As Comunidades Armênias}

Os armênios são um grupo étnico que representariam aproximadamente $4 \%$ da população do Líbano, sendo dividido em três comunidades: os armênios apostólicos, ortodoxos ou gregorianos; os armênios católicos (essas duas comunidades são oficialmente reconhecidas pelo estado libanês); e os protestantes, que integram a comunidade protestante do Líbano.

Os armênios apostólicos são a maior comunidade e a mais antiga historicamente. São seguidores da Igreja Apostólica Armênia, igreja separada do catolicismo em 451, como resultado da recusa em reconhecer as conclusões do Concilio de Calcedônia, que afirmou o dogma das duas naturezas de Cristo (humana e divina). A essa questão teológica acrescentamse fatores nacionais, como a necessidade de se afirma a identidade armênia frente ao Império Bizantino, que controlava grande parte do país no século V. Com essa separação os armênios desenvolveram um cristianismo particular, com suas próprias lideranças, lugares santos, liturgia particular, arquitetura própria para as igrejas e práticas e teologia diferenciadas, tanto do catolicismo quanto do cristianismo ortodoxo bizantino. Sua igreja esteve associada a diversos estados armênios, que existiram na Idade Média tanto na Armênia Histórica como na região da Cilicia (sul da Turquia).

A partir do século XVIII, uma parte dos armênios passará a aceitar a autoridade do

${ }^{13}$ Salibi, Kamal S.: History of Modern Lebanon...; http://melquita.fateback.com/historia.htm 
papa católico e a teologia romana como resultado da ação dos missionários jesuítas e franciscanos em suas comunidades. Estes armênios formarão a Igreja Católica Armênia, criada formalmente pelo papa Bento XIV em 1742 e que teve em Abraham Bedros Ardvizian (então o recém-eleito Patriarca Armênio Apostólico da Sede de Sis na Cilicia) o seu primeiro líder. Sua sede encontrasse no Líbano, sendo liderados por um patriarca reconhecido e nomeado pelo Papa junto a um sínodo da Igreja Católica Armênia.

Os católicos armênios mantém a liturgia criada pela Igreja Apostólica Armênia, o uso do Krapar (armênio clássico) nas missas, a arquitetura e os estilos artísticos tradicionais armênios. Possuem um colégio particular em Roma. Sua separação da Igreja Apostólica Armênia foi vista como uma heresia e um ato de traição nacional pelos demais armênios e, com isto, passaram a perseguir violentamente os convertidos ao catolicismo e conseguiram que o sultão otomano não os reconhecesse como comunidade religiosa ou étnica separada (millet em turco) até 1829. Essas perseguições levaram uma parte dos armênios católicos e o seu patriarca a buscarem refugio no Líbano.

A presença de armênios no Líbano remonta a Idade Média, mas a maior parte deles atualmente vivendo no Líbano descendem de refugiados que chegaram ao país desde o século XVIII, como resultado de sucessivas ondas de perseguição, que atingem em alguma parte do Oriente Médio um setor especifico ou toda a população armênia local. A última e mais terrível onda foi o genocídio promovido pelos turcos entre 1915 e $1923^{14}$.

\section{Muculmanos}

\section{Os Sunitas}

Grande e importante comunidade religiosa do Líbano (a segunda maior do país, segundo o censo de 1932), os sunitas foram os grandes adversários da hegemonia maronita e das ideias associadas a ela como a da exclusiva origem fenícia dos libaneses ou da sua cultura supostamente ocidentalizada ao longo da história.

Devido ao seu tamanho, força econômica, laços com grande parte do mundo árabe e ativa vida urbana, os maronitas dependeram dos sunitas para que o Líbano tivesse viabilidade política e econômica, tendo concedido a essa comunidade o cargo de primeiroministro. Foi à aliança entre as burguesias maronitas e sunitas a base para que o Líbano se tornasse, na segunda metade do século XX, um grande centro comercial, bancário e turístico

\footnotetext{
${ }^{14}$ http://melquita.fateback.com/igrejaarmenia.htm
} 
do Oriente Médio. Por outro lado também foram as classes populares e amplos segmentos das classes médias os maiores porta-vozes do nacionalismo árabe no país.

Os sunitas são de longe os mais numerosos dos ramos da religião islâmica e na região do Levante como um todo (Palestina, Síria e Líbano, Jordânia). Formam a mais numerosa e, desde o século XI até o XX, poderosa comunidade religiosa local, pois todos os grandes impérios duradouros da região (Ayyubida, Mameluco e Otomano) foram sunitas.

No Líbano, os sunitas não eram majoritários em todas as cidades e regiões, mas estavam firmemente instalados nas cidades da costa com uma ativa classe de mercadores, líderes políticos, militares e religiosos. Nas zonas rurais, como ocorria também com outras comunidades, tinha uma elite latifundiária importante.

Porém, sua presença mais significativa no território atual do Líbano começou a se dar com o Império Mamelucof que favoreceu a imigração sunita para as cidades litorâneas e territórios próximos quando não os instalou como colonos à custa dos xiitas e outras populações. Com o passar do tempo, o fato de fazerem parte de impérios sunitas favoreceu enormemente suas elitesf que participaram da administração desses estados, puderam estabelecer redes de comércio mais extensas e firmes no estrangeiro e os manteve vinculados, por meio de casamentos e negócios, a elites sunitas de outras partes do Oriente Médio.

Os sunitas são o principal ramo da religião islâmica (84\% de todos os muçulmanos) e estão amplamente distribuídos pela maior parte da Ásia, Europa Oriental e África convertidas ao islã, além de possuírem amplas comunidades imigradas na Europa e América. O nome dessa vertente do islã deriva da palavra Sunnaf que nomeia um conjunto de escritos com as normas sociais proclamadas por Maomé e os quatro primeiros Califasf recolhidas em livros de Hadithf como o Salih Bukhari e o Sali Muslim, além dos seis livros do Kutubi-Sittah. As práticas e doutrinas do sunismo se consolidaram durante as dinastias Omíada (661-750) e Abássida (750-1258) no Império Árabe como resultado do trabalho de gerações de eruditos e do reconhecimento oficial por parte das famílias governantes desse império. Diferente dos xiitas, eles pensam que qualquer pessoa que esteja preparada pode ser o líder da comunidade islâmica (Umma) não sendo preciso ser, portanto, um descendente da família ou tribo do profeta Maomé ${ }^{15}$.

\footnotetext{
15 http://www.islamismo.org/bem.htm.
} 


\section{Os Xiitas}

Os xiitas são uma das comunidades mais antigas no Líbano e foram o mais numeroso grupo religioso do território libanês na Idade Média. Sua presença é atestada desde os primórdios do xiismo no fim do século VII por conta da presença do seguidor do califa Ali e companheiro (sahaba) do profeta Maomé Abu-Dharr al-Ghifari na região do Jabal Amil, sul do país.

A divisão entre xiitas e sunitas no islamismo começou com uma disputa política sobre quem deveria ser o sucessor de Maomé na liderança da comunidade muçulmana. Os xiitas foram aqueles que defenderam que esse líder deveria ser um membro da família ou da tribo do profeta e, para isso, apoiaram o filho do califa Ali, Hassan, como o legitimo continuador da liderança do seu pai, que foi assassinado em 661. E posteriormente Hussein, segundo filho de Ali, que se recusou a aceitar a liderança do governador da Síria, Muawyah, sobre a comunidade muçulmana, se levantou e foi massacrado com os seus 72 seguidores na Batalha de Karbala, Iraque Central, em 680 d.c.

A partir de então, os partidários de Ali (xi’at Ali em árabe) seguiram a liderança religiosa e mística dos Imans, descendentes de Ali, que possuíam uma investidura sobrenatural divina e, por isso, eram infalíveis, justos e desprovidos de defeitos, sendo que o penúltimo, Hassan al-Askari, foi morto pelos abássidas na cidade de Samarra (Iraque) em 874. Seu filho Muhammad Ibn Hasan Ibn Ali, que tinha apenas 8 anos, despareceu nesse episódio. A corrente majoritária do Xiismo considerou que al-Askari tinha pedido para o seu

filho se ocultar e que este voltaria no fim dos tempos para implantar um reino de justiça sobre a Terra.

Todo esse processo fez com que os xiitas desenvolvessem teologia e práticas religiosas bem diferentes da dos sunitas, no qual o martírio, o sofrimento e a injustiça humana marcaram profundamente a sua visão de mundo. Como em determinadas épocas de sua história sofriam perseguição das autoridades dos estados sunitas, desenvolveram o habito de esconder as suas práticas e crenças e imitar os sunitas (taqiyya-dissimulação) para poderem sobreviver. Por outro lado, nem sempre os xiitas estiveram em posição de subalternidade, como provam a dinastia Fatímida, que fundou Cairo no Egito no século X e o Império Persa Safávida e depois Qajar na Pérsia, durante a Idade Moderna. Divisões também ocorreram dentro do xiismo, criando as seitas ismaelita, zaidita e duodecimal, entre outras. Está última é a mais numerosa e representa, de longe, a maioria esmagadora dos xiitas libaneses. 
No Líbano começaram a perder território e influencia política com o Império Mameluco (séculos XIII-XVI), pois nos primeiros tempos foram alvo de feroz repressão por parte desses sultões sunitas de origem turca, por se recusarem a aceitar a submissão e por serem vistos como hereges. Ao longo dos séculos as migrações de populações cristãs e sunitas fizeram com que os xiitas se tornassem minoria ou desparecessem de muitas regiões do Líbano, acabando por terem duas grandes concentrações no Jabal Amil e no vale do Bekka, onde encontramos as importantes tribos dos Hamadeh e dos Haider. Camponeses em sua maioria ao longo dos séculos XIX e XX, os xiitas foram à última comunidade libanesa a se modernizar e apresentavam frequentemente os piores índices sociais do país ${ }^{16}$.

\section{Os Drusos}

Os drusos são um grupo religioso surgido no século XI dentro do califado xiita Fatímida, que controlava o Egito e a maior parte do Norte da África, Síria, Palestina a partir do islamismo xiita ismaelita, religião oficial desse estado. Seu surgimento data de 1017 como resultado dos grandes debates teológicos existentes no Egito dessa época e da influência nesses debates de inúmeras ideias vindas da filosofia grega (particularmente do neoplatonismo), do gnosticismo, do maniqueísmo e de crenças reencarnacionistas. Hamza Ibn Ali ibn Ahmad, que é considerado o fundador da comunidade e Muhammad al-Darazi, emprestou o seu nome a comunidade. Seu principal texto sagrado é o Kitab al-Hikma (Livro da Sabedoria) escrito por al-Muqtana.

Essa comunidade se pôs na tradição profética do islamismo e cristianismo, mas também passou a considerar personagens da filosofia grega e os seus próprios líderes religiosos. Os drusos creem na existência de um único Deus, mas acrescentam, embora isso não seja aparentemente aceito por todos, ideias sobre reencarnação.

Também fazem uma completa reforma nas práticas e leis islâmicas, abolindo os jejuns, a necessidade de peregrinar a Meca, os templos, a poligamia, a obrigação de rezar cinco vezes por dia, dando um destaque social bem maior para a mulher. Por outro lado conservam certas proibições, como o consumo de carne de porco e bebidas alcoólicas. Dividem suas comunidades em dois grupos: os religiosos iniciados nos textos sagrado e mistérios (Uqqal-sábios) e o restante da população (Juhhal-ignorantes), que incluem tanto os grupos política e socialmente dominantes como os setores médios e as classes trabalhadoras.

\footnotetext{
16 www.islam.org
} 
Consideram a maneira neoplatônica e ismaelita, que o Universo surgiu a partir de uma série de emanações vindas de Deus que terminam na formação do mundo material e na humanidade. Esses poderes espirituais também, segundo suas crenças, estão presentes em determinados indivíduos guiados pela própria divindade e que vieram a terra trazer a mensagem de Deus. Nesse processo também se explica a origem do mal e do pecado.

Chegaram a considerar o califa fatímida Tarik al-Hakim como divinamente guiado, segundo uma visão xiita ismaelita, segundo o qual um líder descendente dos Imã xiitas e do Califa Ali viria a terra enviado por Deus e agiria como um mahdi (figura muçulmana que virá no fim dos tempos anunciar o juízo final e estabelecer o Reino de Deus), destruindo a tirania e estabelecendo a justiça. Este monarca se considerou uma espécie de ser divino, o que foi visto como escandalosos pela maioria das autoridades muçulmanas do Império Fatímida. Este fato, mais os seus excessos e crimes, fez com que fosse combatido e após a sua morte os seus seguidores foram perseguidos, incluídos a jovem comunidade dos drusos.

Esse grupo religioso desenvolveu-se no Líbano, Síria e Palestina como resultado da ação missionária de religiosos egípcios, principalmente entre a população xiita local. Com as perseguições que se seguiram, pois os drusos passaram a ser vistos como hereges ou mesmo apostatas, eles se fecharam sobre si mesmo, proibiram conversões e casamentos com gente de outras comunidades e praticaram a chamada Taqiyya (dissimulação), para se fazerem passar por sunitas em tempos de intolerância das autoridades dos impérios sunitas que controlaram a Síria, Líbano e Palestina. Também reconhecem as liturgias muçulmanas e cristãs.

No Líbano, formado com os cristãos maronitas, entre os séculos XVI e XIX, um estado submetido ao Império Otomano conhecido como Emirado do Monte Líbano, que é considerado o antecessor do Líbano contemporâneo. A liderança política drusa mais importante e cultuada foi Fakhr al- Din II Maan, emir do Monte Líbano entre 1572 e $1635^{17}$.

\section{A Nahda}

No século XIX, após séculos de estagnação cultural, se produziu um movimento de renascimento (Nahda) da cultura árabe, impulsionado pelas reformas modernizadoras Tanzimat (1839-1876) do Império Otomano e pelas políticas modernizadoras do governante

${ }^{17}$ Firro, Kais M.: A History of the Druzes. E. J. Brill, Leiden. 1992. Capítulo 1, Pág 1-25, páginas resumidas 
egípcio Muhammad Ali (1805-1849), muito influenciado pela Revolução Francesa

Isso ocorreu também em virtude da abertura à moderna cultura europeia, seguida da recuperação do idioma árabe como língua literária, com a consequente modernização de sua gramática e vocabulário. Esse processo fez com que o árabe voltasse a ser um importante idioma cultural e isto, obviamente, foi essencial para o surgimento do nacionalismo árabe. Os árabes puderam novamente pensar o mundo a partir de sua própria língua e ela funcionou como um meio de expressão para o pensamento cientifico, político e filosófico moderno, colocando os povos árabes em situação de igualdade cultural com os europeus. Os centros da Nahda foram o Egito, o Líbano e a Síria.

O Egito foi o primeiro e principal centro desse movimento, tendo apresentado figuras como Rifa’a al Tahtawi, que pregava a solidariedade pan-islâmica, tinha uma forte postura anticolonial, denunciava os dogmatismos e promoveu a adaptação de ideias ocidentais modernas ao pensamento do Islã. Apesar de defender um governo autocrático, pensava que deveria existir um bom relacionamento entre o governante (representante de Deus) e os governados baseado em uma educação moderna pública, tanto para os funcionários do governo como para os habitantes do reino. Defendia também a educação feminina e, portanto, a abertura de escolas para elas. Também realizou diversas traduções de obras científicas, literárias e manuais práticos franceses ${ }^{18}$.

Na Síria ocorreu à publicação em 1865 do primeiro romance moderno em língua árabe, o Ghabat Al Haq de Francis Marrash. Seu compatriota Qestaky al-Homsi publicou o primeiro trabalho de moderna crítica literária do mundo Árabe. As ideias e o exemplo desses trabalhos se difundiram pelos países árabes, tendo influenciado profundamente as novas gerações de escritores e intelectuais que surgem na segunda metade do século XIX. Nesse processo de modernização foi importante a participação dos intelectuais cristãos. Vários eram padres e monges que atuavam a partir dos monastérios, já outros eram leigos formados nas escolas das missões religiosas protestantes e católicas. No movimento da Nahda papel destacado tiveram diversos maronitas.

No caso libanês esse movimento está associado à atividade missionária cristã ocidental (primeiramente os americanos), pois foram essas missões que começaram a imprimir texto na escrita e língua árabe. E no caso dos protestantes americanos, foi importante a tradução que fizeram do Novo Testamento em 1844, pois esta foi feita na forma moderna do

18 al-Juburi, M. N.:Islamic Tought From Muhammad To September, 11, 2001. Xlibris Corporations, 2010. 
idioma. Em 1865 foi completada a tradução de toda a Bíblia. Esse trabalho foi feito em parceria com intelectuais árabes de origem cristã e mesmo muçulmana, que tiveram ao longo do século XIX um papel importante no renascimento árabe. Como, por exemplo, o protestante de origem maronita Butrus al-Bustani, que além de ser um dos primeiros professores do Colégio Protestante Sírio, foi um dos primeiros a promoverem a ideia do pan-arabismo e deixou também um importante dicionário do idioma árabe de seu tempo. Posteriormente, um trabalho semelhante foi realizado durante a tradução da Bíblia católica para a ordem dos jesuítas ${ }^{19}$.

Outra figura de destaque nesse círculo de tradutores da bíblia protestante foi o muçulmano sunita Yusuf al-Asir, um doutor da lei islâmica que exerceu cargos judiciários nas cidades costeiras da Síria e no Monte Líbano. Asir foi o primeiro muçulmano a aderir a Nahda no Líbano e trouxe a principal população da Síria para dentro desse movimento. Em 1875 Asir também foi o primeiro muçulmano libanês a fundar um jornal, o Thamarat al-Funum ${ }^{20}$.

Muitos intelectuais cristãos libaneses e sírios se estabeleceram no Egito no século XIX seguindo o grande movimento migratório local em direção a esse país, tanto no período dos Khedivas, quanto sob o domínio colonial britânico.

Nesse país esses intelectuais tiveram uma atuação muito florescente, contribuindo para a modernização cultural egípcia em curso e exercendo forte influencia nos demais países árabes. Vários libaneses promoviam a divulgação do moderno conhecimento científico, escrevendo artigos em jornais, publicando livros de divulgação e até mesmo promovendo debates sobre temas de vanguarda polêmicos como o darwinismo.

Jornais foram levados para o Egito (como o al-Muqtataf) ou lá fundados. Um dos exemplos mais destacados é o importante jornal Al Ahram, que existe até os dias de hoje, tendo forte influencia na vida social árabe e que foi fundado por um grego-católico libanês: Salim Taqla. Revistas também eram fundadas. Uma das mais importantes, a Al-Hilal, criada por um cristão-ortodoxo de Beirute em 1892, também existe até hoje, divulgava ciência e publicava texto sobre literatura. Seu fundador, Jurji Zaidan escrevia livros sobre história, história da literatura árabe e filologia árabe, além de romances históricos ambientados no passado do mundo Árabe e, dessa maneira, contribuía muito para o processo em curso da

${ }^{19}$ Salibi, Kamal: The Modern History of Lebanon Pág. 143-145

${ }^{20}$ Salibi Idem 145 
$\mathrm{Nahda}^{21}$.

Devido a esse processo, no fim do século XIX o idioma árabe era usado para se transmitir o conhecimento cientifico e de humanidades adquirido no mundo contemporâneo, bem como as novas ideologias, propostas de organização político-social e filosofias surgidas na Europa. Assitiu-se, portanto, a um renovado interesse pela literatura árabe clássica e pela herança científica e filosófica dos árabes na Idade-Média.

\section{Mudanças Culturais e Sociais no Líbano sob a Mutassarifiat}

O Líbano assistia durante esse período a uma forte penetração cultural e econômica francesa, e em menor medida de outros países europeus, como a Grã-Bretanha. Isso se refletia na nova cultura desenvolvida por sua burguesia, no qual era muito evidente a ocidentalização de todo o modo de vida, desde os costumes até a arquitetura de parte do centro e o urbanismo dos bairros ricos, onde as mansões dos comerciantes enriquecidos eram construídas segundo os modelos estéticos italianos e franceses. Essa ocidentalização era favorecida pelas boas relações desenvolvidas entre os cristãos e os europeus que visitavam a Síria no Século XIX como comerciantes, missionários, viajantes, estudiosos e funcionários diplomáticos.

Aliás, foi durante o período da Mutassarifiat que ocorreu a fundação das primeiras universidades libanesas, que foram um importante instrumento da difusão de valores e ideais europeus entre as classes dominantes libanesas.

Estas foram criadas por missões religiosas cristãs estrangeiras (seguindo uma tradição começada pelos jesuítas no século XVII) e se destinaram a formação das elites locais. Estavam localizadas fora do Monte Líbano, em Beirute, mas atraíam os filhos das classes dominantes, a aristocracia mais antiga ou as novas elites mercantis e manufatureiras e, dentre essas elites, os cristãos eram dominantes.

O primeiro centro de ensino superior fundado foi o Colégio Protestante Sírio em 1866, criado por missionários norte americanos. Sua construção começou em 1871 e foi por muito tempo dirigido por religiosos protestantes norte americanos. Esteve em sua fundação ligado ao legislativo da cidade de Nova York. Com o tempo esse colégio se tornaria a Universidade Americana de Beirute ${ }^{22}$. Em 1875 a Universidade de Saint Joseph foi fundada

\footnotetext{
21 Salibi. Idem. Pág. 147-148

22 Salibi. Idem. Pág.
} 
por jesuítas franceses. Essa universidade, cujo ensino era dado em francês, foi uma promotora da cultura francesa na Síria e muito contribuiu para os laços culturais que se formaram entre os cristãos, e particularmente os maronitas, e a França. Sua influência era tão grande na formação das elites que dela vieram a maioria dos primeiros altos funcionários do estado libanês na década de $1920^{23}$.

Essas universidades e a difusão da rede de ensino primário, e em menor medida secundário, realizado através da inciativa de particulares,ordens religiosas e grupos missionários, fizeram com que o Líbano se tornasse um centro intelectual nos países de língua árabe e começaram a construir a fama dos libaneses como povo relativamente instruído, que marca o país até os dias de hoje.

Simultaneamente a essas universidades, por iniciativa privada das várias missões religiosas estrangeiras, uma rede de escolas foi montada ao longo do Monte Líbano, a maioria nos anos que se seguiram a retirada egípcia, tendo um segundo impulso ocorrido a partir da década de 1860. Seguindo o exemplo desses missionários, comunidades cristãs locais, como os cristãos ortodoxos, os gregos-católicos ou os maronitas, também passaram a abrir escolas em diversas regiões do país para instruir as elites e grupos sociais médios de sua própria população.

Suas iniciativas eram modestas, mas foram importantes no quadro de suas comunidades. Cabe destacar que nessa época o governo da Mutassarifiat chegou a patrocinar a criação de uma escola para a comunidade drusa, enquanto modestas iniciativas foram tomadas nesse sentido nas cidades da costa por líderes e organizações religiosas sunitas.

Esse conjunto de escolas não eram restritas a população masculina, pois diversas escolas para meninas foram fundadas também. Somente a população xiita não foi atingida por esse movimento educacional devido ao seu caráter fortemente rural, seu forte tradicionalismo e também por viver em regiões distantes e de difícil acesso. Os filhos de suas elites estudavam nas escolas fundadas pelas missões religiosas estrangeiras ou por outras comunidades ${ }^{24}$. É claro, evidentemente, que grande parte da população era analfabeta e, mesmo entre aqueles que chegaram a frequentar alguma escola, o nível de alfabetização na passava do básico na maior parte das vezes. Mas se comparasse o Monte Líbano e as cidades costeiras vizinhas

\footnotetext{
23 Asher, Kaufman: Phoenicianism: The Formation of Identity in Lebanon in 1920. Middle Earsten Studie: Vol. 37, No. 1, Jan., 2001 WTTP: www.jstor.org/stable/428414. Pág. 175.

${ }^{24}$ Salibi. A Modern History of Lebanon. Pág. 136-140
} 
com restante do mundo Árabe nessa época, as suas vantagens culturais eram muito evidentes. Somente o Egito nessa época tinha uma influencia cultural comparável ao Líbano, embora seu sistema educacional não fosse tão desenvolvido quanto o libanês. 


\section{OBJETIVOS DO TRABALHO}

Este trabalho busca descrever como se deram as relações entre o Líbano e o nacionalismo árabe, lembrando que essa ideologia penetrou na sociedade libanesa, porém ficou restrita mais a determinados setores dessa sociedade, especialmente entre a população muçulmana e drusa. Essa adesão parcial da população libanesa ao nacionalismo árabe, junto às tensões comunitárias, como foi dito acima, resultaram na guerra civil de 1958, que se encerrou devido a um acordo entre nacionalistas pan-árabes e defensores da independência do Líbano e de seu regime econômico liberal. No fim parece que o Líbano procurou se adaptar e conviver com esse fenômeno, mantendo relações com os países árabes nacionalistas, mas com as elites libanesas liberais afirmando as especificidades culturais e históricas de seu país.

Estudar as relações entre o Líbano e o nacionalismo árabe pode ajudar a melhor compreender o desenvolvimento desse fenômeno no mundo árabe, pois na República Libanesa, embora o pan-arabismo tenha se difundido em uma parcela importante de sua população(especialmente entre muçulmanos e drusos), também encontrou o rechaço em setores importantes das elites libanesas não cristãs. Esse foi o caso da importante figura do primeiro-ministro na época da guerra civil de 1958, Sami al-Solh, membro de um importante clã de notáveis sunitas, e que permaneceu do lado do presidente Camille Chamoun durante o conflito, tendo rejeitado o pan-arabismo na vertente nasseriana, devido aos seus vínculos com a União Soviética e suas práticas de intervenção estatal nos negócios e assuntos das classes dominantes do Egito.

Essa vertente do pan-arabismo também era rejeitada pelas elites dos estados árabes petroleiros do Golfo Pérsico, que, como foi dito acima, mantinham fortes vínculos econômicos e políticos com o Líbano e fortes laços com as elites sunitas locais. Muito provavelmente as elites do Golfo Pérsico percebiam o modelo econômico libanês como um exemplo alternativo exitoso para poder ser usado pelas forças conservadoras do mundo árabe contra estados e partidos ou movimentos revolucionários que viessem ameaçar a posição das elites tradicionais.

As elites cristãs ocidentalizadas libanesas nunca rejeitaram o contato com mundo árabe, vendo-o como essencial para o desenvolvimento do seu país. Uma prova disso é o papel dominante dos países árabes nas relações comerciais do Líbano, como foi colocado acima. O que elas não aceitavam era o fato de que os acontecimentos do mundo árabe 
pudessem ameaçar a ordem social e política do seu país. Se isto não acontecia, não haveria razão para o Líbano se manter isolado em sua região. Aliás, as elites libanesas, e isso vale tanto para as cristãs quanto para as muçulmanas, até aceitavam se acomodar a existência dos regimes árabes nacionalistas se esses não procurassem interferir nos assuntos internos do Líbano. A prova disso seria o bom relacionamento que o governo de Fuad Chehab manteve com o Egito de Nasser e que foi prosseguido com o governo seguinte de Charles Helu, embora este tivesse uma orientação política e econômica mais liberal do que o seu antecessor.

Essa pesquisa foi realizada através da leitura e análise de uma bibliografia sobre o tema, indicada no final deste trabalho. Foi feito, portanto, um levantamento nesses livros, buscando informações referentes às relações entre o Líbano e o fenômeno do nacionalismo árabe e, em especial, com o Egito de Gamal A. Nasser. Isto para depois realizar uma síntese e demonstrar que o Líbano buscou se acomodar com o nacionalismo árabe quando suas elites perceberam que era um fenômeno dominante nos países árabes vizinhos e, ao mesmo tempo, havia penetrado profundamente na população muçulmana local.

No tocante às informações sobre a economia do Líbano, além da parte escrita demonstrando a sua estrutura e o seu desempenho ao longo das décadas e 1950 e 1960, apresento um conjunto de tabelas mostrando os dados exatos, tanto do seu funcionamento global, quanto de cada setor particular, que ajudam a ilustrar as informações apresentadas no texto. 


\section{CAPÍtULO 1}

\section{Os anos da formação do moderno líbano}

A proposta a seguir é apresentar criticamente as questões que convergiram para a formação do Líbano moderno, abrangendo desde aspectos culturais até os fatores internos, como as políticas econômicas orquestradas neste período, bem como sua relação com a política internacional, com a segunda guerra mundial e a vinculação de dependência com a França.

Perpassando essas relações será tocada a questão fundamental da formação de uma ideologia nacional e os efeitos do liberalismo.

\subsection{O mandato francês (1920-1943)}

Ao longo da Primeira Guerra Mundial o Líbano foi colocado sob um duro governo militar por parte dos otomanos. Constantinopla interveio militarmente na região do Monte Líbano em 1914, derrubando o último Mutassarifiat (dirigente cristão local escolhido pelo sultão otomano com aprovação das potências europeias) em 1915 e instalando o governador turco Ali Munif Bey. Este anula o Réglement (estatuto legal do Monte Líbano estabelecido em 1864) e extingue o Conselho Administrativo. Os outros dois administradores otomanos foram: Ismāe il Haqqi Bey (1917-18) e Mumtāz Bey (julho a setembro de 1918).

Já a Síria como um todo estava sob o controle de Cemal Pashá, um das principais figuras do governo otomano. Qualquer dissidência era severamente reprimida e os bens dos suspeitos sumariamente confiscados. A repressão se intensificou ainda mais após a revolta árabe de 1916. Entre 1915 e 1916 trinta e três líderes nacionalistas árabes e libaneses foram enforcados em Beirute e Damasco, fato esse considerado como o ato fundador da independência do Líbano e da Síria.

Muitos libaneses fugiram para o Egito, a fim de não serem obrigados a lutar na guerra ao lado dos otomanos. No entanto, ainda em 1915, Cemal tentou uma aproximação com a população síria, com o escopo de engajá-los na guerra contra os britânicos e franceses. Essa situação o governo de Istambul declarou ser ser uma Jihad, ou seja, uma guerra santa contra os infiéis que atacavam o califado otomano para atrair as massas muçulmanas do Império, o que acabou não dando certo. Como os libaneses e sírios se recusaram o colaborar, 
Cemal ordenou aos governadores dos vilayets a implantação de uma política marcial. ${ }^{25}$

Enquanto isso os britânicos impõem um bloqueio naval à costa da Síria para prejudicar o esforço de guerra dos otomanos. O resultado desse bloqueio marítimo e os efeitos da economia de guerra, que forçou a entrega de boa parte dos excedentes para abastecer o exército otomano, a proibição de se importar mantimentos e o bloqueio a aldeias consideradas rebeldes provocaram uma grave crise econômica cujo resultado foi a morte de 100 mil libaneses por fome, enquanto inúmeras vilas e aldeias eram abandonadas.

Pragas de gafanhotos (como a do verão de 1915) e a especulação em cima dos alimentos realizada por membros do governo e indivíduos particulares ajudaram a agravar ainda mais a situação. A devastação trazida durante a guerra fez com que episódios de canibalismo fossem registrados até em Beirute, para não citar as regiões montanhosas, enquanto multidões de camponeses famintos se juntavam no subúrbio das cidades litorâneas revirando o lixo em busca de alimentos e vivendo de restos.

Junto à fome vem as epidemias de tifo, cólera e lepra que também matam muito ${ }^{26}$. Nesse período, como resultado da guerra ocorre também a desestruturação da indústria da seda que perde o acesso aos mercados no Ocidente. Ela também foi gravemente prejudicada porque quase toda a madeira da região foi cortada pelos turcos ou pelos próprios libaneses para ser usada como combustível. Como resultado houve o desaparecimento dos bosques de amoreiras que produziam as folhas que alimentavam as lagartas do bicho da seda ${ }^{27}$.

No plano militar os britânicos, após a derrota na batalha de Gallipoli em 1915, quando tentaram ocupar Istambul, começam a pôr em prática em 1916 os planos de ocupação das províncias árabes. Duas frentes são abertas: uma na Mesopotâmia e outra na Síria a partir do Egito. Na Mesopotâmia os britânicos, se utilizando de sua força expedicionária indiana, esperavam conectar-se com os russos que desciam do Cáucaso em direção à Armênia turca para formar um anel de defesa que impediria as potências centrais de tentar chegar até a Índia.

Seu avanço foi impedido pela resistência otomana em Bagdá que se estendeu por um ano. A Campanha da Síria foi confiada ao general Allemby e as tropas se dirigiram do Sinai para capturar Jerusalém. A partir desse momento os britânicos passam a lutar em

${ }^{25}$ WINSLOW, Charles. Lebanon: War \& Politics in a Fragmented Society. London and New Yok: Routledge, 2005. p. 52.

${ }^{26}$ TRABOULSI, Fawwas. A History of Modern Lebanon. London: Pluto Press. p. 72.

${ }^{27}$ SALIBI, Kamal. The Modern History of Lebanon. P.159. 
conjunto com os exércitos árabes sublevados sob a liderança do Xeriff de Meca Hussein alHashemi auxiliados por um homem de Allemby, o coronel T. E. Lawrence, que ficou imortalizado como o Lawrence da Arábia. No Líbano, os britânicos por meio de seus agentes tentavam entrar em contato com os drusos, os seus antigos aliados ${ }^{28}$.

A ação militar de Londres ocorreu simultaneamente à estimulação de uma revolta árabe contra os turcos que começou a partir do xerife de Meca no Hijaz (oeste da Península Arábica), Hussein al-Hashemi, cuja família é considerada como descendente do profeta Maomé. Contatos entre os britânicos por meio do Alto Comissário para o Egito, sir Henry MacMahon e Hussein, começaram em 1915. Nas cartas trocadas entre ambos os britânicos lhes haviam prometido a independência e a criação de um estado árabe que abarcasse todas as províncias árabes do Império Otomano e até mesmo que esse Estado fosse um califado islâmico. Com esse apoio, em 5 de junho de 1916, o shariff Hussein deu início à rebelião proclamando a independência dos árabes em relação ao domínio turco. No dia 5 de novembro Hussein se proclamou "Rei de todos os países árabes"29 . Em janeiro de 1917 a revolta havia libertado o Hijaz e o filho de Hussein, Faisal havia tomado a cidade de Aqaba no fundo do Estreito de Tiram e avançava pela Palestina ${ }^{30}$.

Já os franceses, por sua vez, se moviam para concretizar os seus antigos projetos de controlar a região da Síria. Para isso seria muito útil a aproximação com os nacionalistas cristãos do Líbano, o que já ocorria desde antes da guerra. Comitês de emigrantes católicos sírios e de libaneses foram formados ao redor do mundo. Eles pediam constantemente para que as tropas anglo-francesas interviessem a seu favor visando à criação de um Estado separado para eles e rechaçassem os projetos nacionalistas árabes no levante, especialmente aquele ligado a Hussein de Meca. Isso por conta do seu conteúdo islâmico que poderia trazer as antigas restrições legais aos não-muçulmanos que foram abolidas no Império Otomano no século XIX.

Ao desenvolverem um forte sentimento francófilo, esses grupos estavam prontos para cooperar com a França em seus projetos imperiais na Síria. Para encorajá-los os franceses formaram em 1917 um Comitê Central Sírio em Paris que tinha o objetivo de

\footnotetext{
${ }^{28}$ WINSLOW, Charles... p. 51-53.

${ }^{29}$ SALIBI... p. 159.

${ }^{30}$ Idem. p. 160.
} 
coordenar as suas atividades ${ }^{31}$. Ele contava com a direção de líderes cristãos refugiados, como o advogado maronita Emile Édde. Enquanto no Líbano alianças eram estabelecidas com lideranças locais, como os chefes dos clãs Karam, Eddé e Khazins, que já eram bem ativos contra os turcos. E, o mais importante, o Patriarca maronita Ilyas al-Hawiyyek, cujo contato era feito por meio do seu secretário que recebia e enviava aos franceses cartas constantemente. Papel importante tiveram todas essas pessoas no estabelecimento do domínio francês após a guerra ${ }^{32}$.

Ao mesmo tempo em que ocorriam essas movimentações diplomáticas e militares, secretamente, os britânicos e franceses, juntos com os russos, planejavam a partilha do Império Otomano após o fim da guerra. Em abril-maio de 1916 o ex-cônsul francês em Beirute, François Georges Picot, negociou com o representante britânico, sir Mark Sykes, e o ministro das relações exteriores da Rússia, Sergei Sazonov, a divisão entre seus respectivos Estados das terras do Império Otomano no Oriente Médio. Esse acerto, terminado em 16 de maio, ficou conhecido como o Acordo Sykes-Picot-Sazonov porque fora aceito por essas três autoridades das principais potências da Tríplice Entente.

De imediato esse acordo confirmava a divisão das terras árabes em cinco zonas, conforme segue: uma Zona Vermelha sob o controle direto dos britânicos e que compreenderia Bagdá e Basra na Mesopotâmia, mais o Kuwait (sob o controle de Londres desde 1899) e terras no litoral leste da Arábia; uma Zona B sob a influência britânica que corresponderia à atual Jordânia, áreas do centro-norte do Iraque e terras a oeste da Zona Vermelha; uma Zona A de influência francesa que se compunha da maior parte da Síria mais a região de Mosul na Mesopotâmia; uma Zona Azul controlada diretamente pela França que incluía o litoral sírio atual, o Líbano, a Cilícia de população majoritariamente armênia, partes da Capadócia e da Armênia interior; e por fim a Palestina, que seria um condomínio aliado. O Plano se estenderia para incluir as reivindicações russas da Armênia e zonas curdas ${ }^{33}$.

Esse plano foi denunciado publicamente por Lenin após a Revolução de Outubro em 1917. Mesmo assim serviu de base para a partilha das terras árabes do Império Otomano após a I Guerra Mundial na Conferência de San Remo, que legitimou os domínios anglofranceses por meio dos mandatos da Sociedade das Nações.

\footnotetext{
${ }^{31}$ Idem. p. 161.

32 WINSLOW.... p.53.

33 SALIBI. p. 160.
} 
No fim de 1918 o poder otomano na Síria entra em colapso. Na Batalha de Meggido, no norte da Palestina, em 18 de setembro, os turcos são derrotados. No fim de outubro os britânicos ocuparam praticamente toda a Síria e o rei Faisal entra em Damasco em 1 de outubro, onde estabelece um governo militar árabe proclamando a sua autoridade sobre todo o Levante. Nesse mesmo dia o governador turco de Beirute, Mumtaz Bey, entrega o poder da cidade a um notável muçulmano local.

Ocorre a proclamação de um governo árabe nessa cidade e com o símbolo dessa proclamação é erguida a bandeira dos Shariffs de Meca nos prédios públicos enquanto uma força simbólica do rei Faysal ocupa a futura capital libanesa e um notável maronita, Habib Pasha al-Sad, governa momentaneamente a cidade em nome do monarca árabe. Para os nacionalistas árabes, que desejavam que toda a Síria fizesse parte de um único Estado árabe, as populações cristãs do Monte Líbano eram parte do Mundo Árabe devido a sua cultura, língua e tradições históricas ${ }^{34}$.

Essa ação alarma os cristãos, pois temiam ver suas terras incorporadas em uma

34 Embora atualmente possa parecer natural e óbvio que qualquer povo que fale a língua árabe se considere ou seja considerado árabe, como imaginam várias correntes políticas pan-arabistas, na verdade somente no século XX é que essa ideia de mundo Árabe pode se desenvolver. A noção de que todas as populações de língua árabe, independentemente de raça, religião ou localização geográfica formem um único povo é um fenômeno recente.

Até o começo do século XX, identidades religiosas, sociais, tribais ou geográficas eram muitas vezes mais fortes do que a ideia de nação árabe. Em casos particulares como o Egito, sua população, elite e classe intelectual nem mesmo consideravam o próprio país uma nação árabe, tendo desenvolvido um nacionalismo particular durante o século XIX e começo do XX e considerando a palavra árabe, de certo modo pejorativa, pois esta era aplicada as tribos nômades do entorno do Vale do Nilo, cuja relação com os camponeses e outras populações sedentárias locais costumava ser tensa e conflitiva.

No começo do século XX, com o mal-estar provocado dentro das terras árabes em consequência das politicas de turquificação do Império Otomano, empreendida pelos jovens turcos; Aliada a situação da primeira guerra mundial,quando acontece em 1916 à revolta árabe contra os turcos, lideradas pelo filho do sherif de Meca, Faisal, com a promessa por parte dos ingleses aos árabes de estabelecerem um estado para eles na Arábia, Levante e Mesopotâmia; Mais a tentativa de ser criar esse estado árabe na Síria após o conflito mundial; Mais a partilha das províncias árabes otomanas entre britânicos e franceses, a realidade opressiva da dominação colonial europeia sentida por quase todos os povos de língua árabe e a ainda a presença da ameaça sionista na Palestina (apoiada por Londres) vão contribuindo para o rápido desenvolvimento da consciência nacionalista árabe, especialmente desde a década de 1920.

Diversos intelectuais, principalmente no Oriente Médio, contribuem para o crescimento e aprimoramento do nacionalismo árabe e a sua difusão nos diversos países de língua árabe, tanto na África quanto na Ásia. Mas um papel destacado cabe a figura de Abu Khaldun Sati al-Husri, um sírio nascido em Sana a em uma rica família de mercadores de Alepo, que trabalhou com o Faisal em quanto este era rei da Síria (1918-1920) e posteriormente no Iraque quando os britânicos fizeram dele rei deste país. Sati al-Husri foi responsável pelo sistema de ensino neste país, estruturando o currículo de modo a difundir entre os estudantes as ideias nacionalistas árabes que ele elaborou ao longo de sua carreira. Enfatizava a existência de um espirito comum entre as populações arabófonas demonstrada pela sua língua comum, cujo futuro estava na sua unificação em um único estado como havia feito os alemães no século XIX. Um exemplo importante da influência de Sati al-Husri é o partido nacionalista árabe Ba'ath em cuja Constituição, escrita em 1947, cita este pensador e a sua importância para a elaboração do seu programa politico. Dawisha, Adeed: Arab Nationalism: In The Twentieth Century, From Triumph of Despair. Princeton and Oxford: Princeton University Press, 2003. 
entidade árabe mais vasta onde seriam uma população minoritária em um Estado majoritariamente muçulmano. Também os franceses se incomodam com a ação e, em 7 de outubro, enviam barcos para Beirute, após um acordo com os ingleses ${ }^{35}$. Para poder impor a sua presença na Síria após a guerra os franceses já tinham criado um Alto Comissariado para o Levante em 1917. Georges Picot era o Alto Comissário e aguardava o momento adequando para se estabelecer em Beirute ${ }^{36}$.

Para resolver essa questão os britânicos, comandados pelo general Allemby, desembarcam em Beirute no dia 8 de outubro acompanhados de um pequeno destacamento francês. Na cidade forçam o representante de Faisal a abandonar Beirute, removem as bandeiras árabes dos edifícios públicos e ordenam a entrega da autoridade local para o coronel francês de Piepape.

Em 24 de outubro Allemby anuncia a divisão da Síria ocupada em três zonas das quais a parte ocidental, a Zona Norte Francesa, que compreendia o Líbano e a costa da Síria, ficaria sob o controle de Paris. Essa área passou a ser chamada Zona Ocidental Francesa em 18 de outubro quando a Cilícia (no sul da Anatólia) foi denominada Zona Norte e ficou sob a direção do coronel francês de Piepape; Georges Picot, que havia sido indicado pela Alta Comissão Francesa para o Levante em abril de 1917, só pode assumir as suas funções em Beirute em $1919^{37}$.

Para decidir o futuro arranjo político e territorial do mundo após a guerra, as potências vencedoras e seus aliados menores se reuniram na chamada Conferência de Paz de Versalhes aberta em 18 de janeiro de 1918. Várias delegações maronitas foram a Paris participar da conferência. Uma delas foi chefiada pelo patriarca maronita Ilyas al-Huwayyik. Os maronitas faziam a reinvindicação de um Estado separado para os cristãos do Líbano sob o controle francês e que tivesse o seu território alargado. A afirmação de sua suposta origem fenícia e mediterrânea e do fato de não serem árabes foi feita por autoridades como o patriarca Huwayyik $^{38}$, com o objetivo de convencer os diplomatas ocidentais da necessidade de criar

\footnotetext{
35 Idem. p. 161.

36 Idem. p. 162.

37 Idem. p. 162.

${ }^{38}$ Vale lembrar que, apesar dos estudiosos do alto clero maronita estarem estabelecendo pouco a pouco vínculos entre os fenícios e os maronitas atuais, em diversas ocasiões isso causou um mal-estar na Igreja pelo fato desse povo ser politeísta. Esse foi o caso, por exemplo, do patriarca Elias Howayek, um dos principais defensores da ideia da não-arabidade dos maronitas. Nos comunicados destinados a sua comunidade ele nunca fazia menção ao passado pré-cristão dos maronitas e afirmava que a sua igreja não devia fazer pregação a favor de pagãos e sim
} 
uma entidade política separada para os cristãos do Monte Líbano ${ }^{39}$.

O patriarca também associou os libaneses aos franceses ao afirmar que estes estavam unidos por meio dos fenícios, pois eles tinham estabelecido colônias no litoral francês do Mediterrâneo com populações que por lá permaneceram. Quando, na Idade Média, os Cruzados foram para a Síria partiram do Mediterrâneo francês e teriam trazido esses descendentes de volta que reencontraram os seus parentes, os maronitas. Já o Comité Central Sírio, em Paris, chegou a afirmar a existência de diferenças raciais entre os árabes e os sírios. Devido a esse pensamento, desde o Brasil e a Argentina até os EUA, Canadá e Egito líderes das comunidades de emigrados cristãos libaneses enviaram documentos pedindo a criação de um Estado separado para os cristãos da Síria Ocidental, nos quais afirmavam a sua identidade separada em relação aos árabes ${ }^{40}$. Por isso todos esses grupos se opuseram com veemência à anexação do Monte Líbano à Síria sob o comando do Rei Faisal que, após negociações, chegou a aceitar a separação desse território como uma entidade independente ${ }^{41}$.

Seguindo as decisões da Conferência de Versalhes, a recém-fundada Sociedade das Nações, sob o comando franco-britânico, criou a política dos mandatos para as províncias otomanas e colônias alemãs na Ásia e África. O argumento para justificar a criação dos mandatos era o de que essas terras ainda não estavam amadurecidas para a independência e que, portanto, precisariam de um tempo de tutela estrangeira para prepará-las para a autodeterminação.

Existiram três tipo de mandatos, os de classe A, B e C. Os mandatos classe A eram atribuídos àqueles territórios que teriam alcançado um certo desenvolvimento, o que lhes permitia em um futuro próximo viabilizarem a sua independência, contando sempre com o auxílio e conselho das potências mandatárias. Os das classes $\mathrm{B}$ e $\mathrm{C}$ ou ainda não eram considerados maduros para a entrega da autodeterminação, devido ao baixo nível de desenvolvimento interno, no que necessitariam de um longo período de preparação, ou

pela sua conversão à verdadeira igreja. Quando Howayek falava sobre os fenícios e suas ligações com os libaneses, era apenas para os ocidentais e para defender a criação de uma entidade política libanesa separada da Síria, jamais para o seu próprio povo. Isso mostrava os limites do desenvolvimento do mito fenicista na igreja maronita. No final, quem desenvolveria esse mito seriam os intelectuais laicos a partir do caminho deixado pelos religiosos. KAUFMAN, Asher. Phoenicism: the formation of an identity in Lebanon in 1920. In: Middle Eastern Studies. V. 32, N. 1, Jan. 2001. p. 180.

${ }^{39}$ KAUFMAN. p. 180.

${ }^{40}$ KAUFMAM. p. 185.

41 TRABOULSI . p. 78. 
deveriam estar na situação de colônia por conta da pequena população e distância dos chamados centros civilizados. As ex-províncias árabes do Império Otomano estavam na categoria A. Na prática os mandatos funcionavam como um novo tipo de domínio colonial e os conflitos na Síria, Iraque e Palestina nas décadas seguintes confirmam isso.

Na Conferência Inter-aliada de San Remo na Itália, de 19 a 26 de abril de 1920, ocorreu a aplicação das políticas de mandatos para as terras otomanas no Oriente Médio conforme o estabelecido pela Sociedade das Nações nas quais os governos de Londres e Paris assumem oficialmente o controle das terras que ocupam ou reivindicam nessa região. Essa partilha, como já foi dito, se baseia no antigo plano Sykes-Picot, mas com a confirmação dos ajustes acordados durante a Conferência de Londres em fevereiro. Desse modo a Palestina foi entregue aos britânicos juntamente com Mosul enquanto a França permanecia com a Síria e Cilícia.

As resoluções da Conferência de San Remo foram confirmadas em 24 de julho de 1922 pelo Conselho da Sociedade das Nações. Acordos posteriores, como o de PauletNewcomber de 1922 sobre os limites entre Palestina e Líbano, definiram as linhas das fronteiras entre os territórios. A Turquia reconheceu a perda de suas províncias árabes e a nova realidade política delas com o Tratado de Lausanne de julho de $1923^{42}$.

Como era de se esperar os cristãos do Líbano receberam muito bem o estabelecimento do mandato francês, pois o viram como uma etapa essencial para o futuro do seu Estado independente e uma garantia contra as pretensões dos nacionalistas árabes ou sírios de anexarem o seu país.

O desembarque francês em Beirute ocorreu em 21 de novembro de 1919 com o general Henry Gourraud como Comandante-em-Chefe do Alto Comissariado Francês. Isso é bem recebido por muitos cristãos, ainda mais pelo fato do Comandante-em-Chefe ser um católico devotado $^{43}$. No ano seguinte Gourraud tomou uma série de medidas para garantir o

\footnotetext{
42 WINSLOW. p. 56.

43 Nem todos os grupos cristãos eram favoráveis à defesa dos interesses colônias franceses na Síria como meio de defender os interesses de suas respectivas populações. Esse era o caso da Alliance Libanaise, grupo de emigrados libaneses que defendia a criação de um Estado libanês sob a proteção de uma potência ocidental (KAUFMAN, p. 181). Por outro lado é preciso salientar que essa organização era composta por francófonos e não francófilos. Embora defendessem a proteção francesa ou de outra potência para o Líbano, não defendiam necessariamente os interesses da França no Oriente Médio e eram vistos por estes como adversários aos seus projetos para região que deveriam ser controlados e vigiados (Ibidem, p. 182). Outro exemplo era o intelectual maronita Yusuf al-Saouda. No Líbano, após o estabelecimento do mandato, ele esteve ligado ao nacionalista libanês Bechara el-Khuri e não ao francófilo Émile Édde. Tinha contatos estreitos com o clero maronita em
} 
controle francês sobre a Síria. Derrotou as tropas do rei Faisal na Batalha do Passo Mayssalun em 22 de julho de 1920 e promoveu a ocupação de Damasco acabando com a curta experiência de independência na Síria ${ }^{44}$. Com o decreto de 1 de setembro, proclamado pelo general Henry Gouroud, foi criada a entidade do Grande Líbano, estendendo as fronteiras do país para as regiões majoritariamente xiitas do sul, o Vale do Beka'a até a cadeia do Antilíbano a leste e a Planície do Akkar no norte. Além disso, foram anexadas a essa nova entidade as cidades litorâneas de Beirute, Sidon, Tiro e Trípoli. O Grande Líbano teve o alargamento de suas fronteiras com o objetivo de garantir segurança alimentar para a população cristã da montanha e impedir que se repetisse o episódio da grande fome durante a Primeira Guerra Mundial ${ }^{45}$.

Essas regiões incorporadas de maneira arbitrária ao Grande Líbano eram de população majoritariamente muçulmana e cuja principal comunidade cristã era a dos ortodoxos. Essas populações historicamente se sentiam ligadas ao interior da Síria e durante muito tempo se recusaram a aceitar sua inclusão ao Líbano, além de se ressentirem da proeminência dos cristãos, especialmente dos maronitas, propiciada pelos franceses.

Nos primeiros anos foram frequentes as demonstrações de revolta contra a sua incorporação forçada ao Grande Líbano. Dessa maneira, Picot e o almirante Mormet, comandante das forças navais francesas no Mediterrâneo oriental, sofreram na região do Shuf tentativas de assassinato. Entre 6 de dezembro de 1920 e 6 de janeiro de 1921 trinta vilas cristãs foram atacadas no sul. Também nessa região era frequente o assassinato como retaliação aos cristãos, que colaboravam com os franceses na conquista desse território. Tropas francesas foram despachadas para submeter a população local com práticas de execuções, castigos coletivos e o uso da medida de terra arrasada contra as aldeias sublevadas. Em Beirute os sunitas também reagiam violentamente a sua inclusão no Grande Líbano ${ }^{46}$.

Além dos sunitas, drusos, xiitas e parte dos cristãos ortodoxos se ressentiram da sua incorporação ao Grande Líbano tendo se recusado também a participar de sua vida

Bkerke (sede da Igreja Maronita e localizada 650 metros de altitude nas cercanias da Baia de Jounieh)e percebia o Monte Líbano mais como uma alegoria romântica em um poema em francês do que uma das bases da nacionalidade. Mesmo sendo libanista escreveu em árabe o que demostrava o papel desse idioma como característica da identidade atual dos libaneses (Idem).

44 SALIBI. p. 164.

45 GATES, Carolyn L. The historical role of political economy in the development of modern Lebanon. Centre for Lebanese Studies: Oxford, . 1989. p.21.

${ }^{46}$ TRABOULSI. p. 80. 
política e, como os sunitas, acusavam os franceses de favorecerem os maronitas às suas custas. Nessa época a maioria dos cristãos ortodoxos estava presa ao ideal nacionalista árabe como formulado pelos intelectuais árabes cristãos do século XIX. E muitos dos seus líderes imaginavam que, devido ao fato de serem a maior comunidade cristã da Síria, acabariam dentro de um Estado sírio tendo proeminência sobre os demais cristãos, o que lhes poderia garantir um maior acesso ao poder.

Os cristãos-ortodoxos também se ressentiam da maneira desdenhosa com que os maronitas a eles se referiam e tinham uma história de rivalidade com essa população. Mesmo assim, acabaram apoiando a existência do Grande Líbano, pois ele no fim das contas garantia aos cristãos uma série de privilégios e o acesso às estruturas mais altas de poder, que em uma Síria majoritariamente muçulmana eles dificilmente teriam ${ }^{47}$.

No caso dos drusos do Líbano, além de distúrbios ocorridos entre sua comunidade e os maronitas, eles chegaram a se aliar aos seus conterrâneos da região do Hauran na Síria, que entre 1925 e 1927 se levantaram militarmente contra os franceses e chegaram, por pouco tempo, a ocupar territórios libaneses. Nesse episódio os xiitas também deram momentaneamente o seu apoio a essa revolta ${ }^{48}$. Eles haviam recusado a sua incorporação ao Líbano e promovido as rebeliões e confrontos do sul do país, (comentados mais acima) mas, no fim, preferiram ser uma minoria importante no Líbano em vez de uma pequena minoria em uma Síria sunita, aceitando a existência dessa entidade. Dessa maneira, entre 1926-1927 todos esses grupos esses grupos minoritários islâmicos residentes no Líbano aceitavam a sua existência $^{49}$.

Para isso também contribuía a lembrança das práticas hostis de que haviam sido vítimas pelos dois grandes impérios sunitas que haviam controlado a Síria desde o século XIII: o Estado Mameluco centrado politicamente no Egito e o Império Otomano. Para diminuir a resistência à existência do Grande Líbano e não dar a essa entidade uma impressão mais evidente de que foi construída para os maronitas, os franceses colocaram como primeiro presidente libanês a Charles Debbas que era ortodoxo ${ }^{50}$.

Entre 1920 e 1926 os franceses governaram o Líbano por meio de governadores,

\footnotetext{
${ }^{47}$ SALIBI. p. 169.

${ }^{48}$ WINSLOW. p. 62.

${ }^{49}$ SALIBI. p. 169.

${ }^{50}$ Idem. p. 170.
} 
que eram militares franceses, apontados pelo Alto Comissariado, os quais foram: Capitão Georges Trabaud (1920-1923), M. Privat Aubouard (1923-1924), general Vanderberg (19241925) e Leon Cayla (1925-1926). Trabaud governou o Líbano com um Conselho Consultivo de setenta membros vindos das diversas seitas do país que eram nomeados por Gourraud. Em 8 de março de 1922 houve uma mudança quando Gourraud promulgou um decreto criando o Conselho Representativo do Grande Líbano eleito por sufrágio universal e distribuído ao longo de linhas confessionais. Líderes maronitas chefiavam esse conselho que acabou dissolvido pelo Alto Comissário general Maurice Sarrail em $1925^{51}$.

\section{$1.2 O$ mito fenicista}

O mito fenicista libanês, como foi aceito pelas elites cristãs desse país, pode assim ser resumido: Os cananeus eram uma população de origem indo-europeia (pensá-los como semitas é que seria um mito) que no segundo milênio antes de Cristo chegou ao território histórico da Síria desde o Golfo Pérsico.

Aqueles dentre eles que viviam na parte setentrional da costa síria estabeleceramse em cidades-estados nas quais as atividades comerciais e marítimas eram muito desenvolvidas. Eles construíram uma rede de comércio marítimo e fundaram colônias, da qual Cartago é a mais famosa.

Suas atividades marítimas acabaram levando-os a descobrir terras novas e distantes como as costas da América. Os gregos deram a esse povo o nome de fenícios por causa do tecido cor de púrpura que eles fabricavam. Esse povo deu ao mundo o alfabeto, técnicas navais e diversas técnicas novas nos mais diferentes campos. Com isto a Fenícia tornou-se a ponte entre o Oriente o Ocidente, nas quais influências do primeiro passavam para o segundo. Por isso eles podem ser considerados os antepassados da Civilização Europeia Ocidental e os responsáveis por estabelecer as suas bases no Mediterrâneo.

Com o tempo os fenícios perderam a sua independência, mas mantiveram sua singularidade cultural e meio de vida, porém, após a ocupação árabe, essa cultura sofreu um golpe. Somente um grupo que se retirou para o Monte Líbano conseguiu preservá-la e resistir militarmente às investidas dos invasores. Lá eles mantiveram a herança dos seus antepassados: a cultura mediterrânea, o amor ao mar, às habilidades comerciais e à paz, assim

\footnotetext{
${ }^{51}$ Idem. p. 165.
} 
como a sua impressionante erudição. O cristianismo e a igreja maronita realçaram essas qualidades fenícias.

Com o surgimento do Grande Líbano em 1920, os descendentes dos fenícios poderiam ter uma oportunidade de fazer renascer o melhor de sua herança graças à existência de um Estado moderno no qual estavam instalados e, como o Líbano estava instalado nas mesmas terras em que viveram os antigos fenícios, os habitantes do mesmo país poderiam, graças a essa herança, voltar a contribuir de maneira grandiosa para o progresso da humanidade ${ }^{52}$.

Essas ideias serviram de base para que os nacionalistas libaneses, que em sua maioria pertenciam à comunidade católica maronita, afirmassem que os modernos libaneses, apesar de falarem o árabe, não eram etnicamente ligados aos árabes, mas pertencentes ao antigo grupo dos povos fenício-aramaicos da Síria antiga (embora esses povos sejam de fato falantes de línguas semíticas e, portanto, aparentados com os árabes).

A afirmação segundo a qual os nacionalistas libaneses diziam que os fenícios não eram semitas vinha principalmente da França, onde alguns manuais de História diziam que eles descendiam de Jafet, personagem bíblico dos quais os indo-europeus teriam surgido ${ }^{53}$.

O Início da moderna identidade separada dos maronitas em relação aos outros grupos árabes começou a tomar forma no Monte Líbano na primeira metade do século XIX e se deveu à atividade intelectual do clero maronita. No começo ainda não se fazia a associação entre os libaneses e os fenícios, mas boa parte da narrativa oficial sobre os primeiros estavam assumindo sua forma final. Esse foi o caso do clérigo maronita Niqula Murad. Seu livro 'Notice Historique sur L'Origene de la Nation Maronite et sus ser Rapports avec la France' foi escrito, sintomaticamente, em francês e não em árabe e tinha como objetivo político justificar a reivindicação de um Estado separado para os libaneses. Nesse livro está apresentada a história oficial da comunidade e da igreja maronita como seria posteriormente difundida pelos libanistas no século XX.

No fim do século XIX, com os progressos científicos sobre a história antiga do levante, a narrativa oficial maronita-libanesa começa a incluir o passado pré-cristão, particularmente a antiguidade fenícia. Esse foi o caso dos trabalhos de Yusuf Al-Dibs, o

52 KAUFMAN, Asher. Phoenicism: the formation of an identity in Lebanon in 1920. In: Middle Eastern Studies. V. 32, N. 1, Jan. 2001. p.174.

${ }^{53}$ KAUFMAN. p. 176 . 
arcebispo maronita de Beirute. Ao contar a história de sua comunidade na coleção conhecida como Kitab Tarikh al-Suriyya, ele aborda os fenícios e chega a defender a ideia da sua origem não semita, elegendo suas contribuições para a humanidade como o alfabeto, as habilidades marítimas e as comerciais. Embora Al-Dibs não faça a ligação entre os fenícios e os libaneses de maneira direta, por outro lado, faz uma descrição de um plano cronológico contínuo entre a antiguidade fenícia e os habitantes do atual Monte Líbano ${ }^{54}$.

Vários franceses também contribuíram com seus estudos para a formação do mito fenicista. Entre esses cabe citar o padre Henri Lammens, Maurice Barrés Berard e Victor Berard, que escreveu um livro intitulado 'Les Phéniciens et le Odysée' no qual afirmava que os fenícios, e não os gregos, eram os país da civilização ocidental e os seus disseminadores pela Mediterrâneo. Homero seria um descendente de fenícios e a Odisseia um relato das viagens desse povo. Esse trabalho teve grande influência sobre os fenicistas libaneses ${ }^{55}$. Já Barrés causou influencia ao afirmar que as bases do ser nacional de um povo era o seu Ego devido à situação específica de sua tradição e heranças nacionais.

Assim, ele se encontrava no catolicismo exatamente em seu papel aglutinador, organizador e disciplinador. Também argumentou que o território era importante nesse processo de formação da sua nação - a francesa - e do seu caráter único. Para Barrés ser francês era algo dado culturalmente e não por determinação racial, étnica ou linguística. Suas ideias influenciaram figuras como Chiha, Nujaym e Klat e ajudaram a formular um dos argumentos principais que sempre foi usado pelos libaneses fenicistas para afirmarem a não arabidade de seu país: o fato dos libaneses falarem árabe não os tornavam árabes, pois sua história, cultura e tradições tinham uma firme base não-árabe.

Muitos desses ideólogos libaneses mostraram um vivo entusiasmo com relação à pessoa de Barrès. Klat escreveu de maneira efusiva a respeito desse intelectual conservador francês quando o encontrou durante a sua viagem para o Oriente. Anos depois, quando Barrés esteve no Líbano, Charles Corm dedicou o seu livro, La Montagne Inspirée, a ele ${ }^{56}$.

Entre esses franceses cabe destacar a figura do padre jesuíta belga Henri Lammens. Esse padre teve grande importância na história do Líbano por conta do lançamento de um livro sobre a história da Síria: La Syrie: Précis Historique. Segundo o jesuíta belga, a

\footnotetext{
54 KAUFMAN. p.178-179.

55 KAUFMAN. p. 182.

${ }^{56}$ KAUFMAN. p. 183-184.
} 
Síria possuía uma identidade especifica vinda desde a Antiguidade que compunham uma 'raça síria’ com uma identidade nacional claramente definida. Os sírios já tinham homogeneidade desde o tempo das cidades-estados fenícias, quando a ideia da nação síria começou a se materializar no subconsciente de sua gente.

Os próprios fenícios eram parte dessa nação e qualquer análise cuidadosa de sua cultura demonstrava isso. Apesar de porta-voz do nacionalismo separatista sírio, Lammens contribuiu bastante para o desenvolvimento do nacionalismo libanês. Ele, por exemplo, foi o primeiro a associar o sucesso comercial fenício com uma economia liberal e usou os métodos e os trabalhos de Reclus para dizer que as origens da Civilização Europeia se encontravam no território da Síria ${ }^{57}$.

Fora do Líbano, grupos de intelectuais emigrados para o Egito ou a França começaram a desenvolver ideias relativas a uma suposta identidade separada do Líbano em relação às outras terras vizinhas de língua árabe. No caso particular do Egito, esse país recebeu uma grande emigração síria no século XIX da qual os cristãos eram o principal componente. Essa comunidade cresceu muito às vésperas da I Guerra Mundial e tinha Alexandria como o seu principal centro.

O Egito, da mesma maneira que a Síria, foi alvo de uma intensa penetração cultural e econômica europeia no século XIX que veio acompanha também de uma imigração, sendo que os franceses é que deram início a esse processo, embora, a partir de 1882, os britânicos transformassem o país em um protetorado. No entanto, a presença francesa continuou por meio de instituições culturais e na influência sobre a moderna cultura egípcia. Esse ambiente reforça ainda mais o perfil intelectual e ocidentalizado, adquirido em escolas jesuítas, da elite intelectual síria emigrada para o país que Muhammad Ali governou ${ }^{58}$.

Durante a I Guerra Mundial o Egito, e particularmente a Alexandria, continuou a ser importante para os intelectuais libaneses nacionalistas. Nessa época muitos sírios buscaram refúgio aí entre os quais Michel Chiha, considerado um dos pais fundadores do Líbano moderno, e professores universitários franceses na Síria, como o padre Lammens. Em Alexandria Chiha entrou em contato com um dos maiores e mais ardentes poetas fenicistas francófilos de seu tempo: Hector Klat, filho de imigrantes libaneses, que estudou em uma escola missionária jesuítica francesa e que louvou a França em outra parte de sua produção

${ }^{57}$ KAUFMAN. p. 188-189.

${ }^{58}$ KAUFMAN. p. 178. 
poética $^{59}$.

A ideia fenicista não era uma invenção arbitrária imposta à sociedade libanesa, mas algo que foi incorporado por amplos setores da população. Tanto foi assim que ela esteve presente na diáspora libanesa cristã e fora um elemento importante na constituição de suas identidades frente aos desafios que lhes apresentavam o estrangeiro. Esse era o caso, por exemplo, dos libaneses emigrados para os EUA, onde era muito comum eles compararem as suas experiências com as dos fenícios na antiguidade e dizer que o seu impulso para emigrar provinha da herança dos seus ancestrais dos tempos antigos. Para a emigração, a história dos fenícios e suas atividades comerciais no ultramar era um prenúncio do impulso dela para tentar estabelecer um comércio e ascender social e economicamente por meio dessa atividade $^{60}$.

Um representante da comunidade árabe nos EUA assim se referiu à história de seu povo nesse país:

\footnotetext{
"it thrives today in the age of steel and steam and under the shadow of towering Manhattan skyscrapper at it ever did when the first Phoenician ventured across the billowy main in his wind-driven galleon...Curiously enough, the men supplying the element of romance in America business are the direct descendents of Phoenicians",61.
}

Outro exemplo foi o de Georges Moanack que, ao se referir à emigração libanesa para a Colômbia, disse o seguinte: "This call [to emigrate] is it not the voice of the past, a residue of the Phoennicien soul that continues to inhabit ours souls?" ${ }^{62}$.

Assim, o fenicismo entre os libaneses dos EUA e de outros países americanos teve um papel mais ou menos similar ao da história do Mayflower na formação do mito nacional estadunidense. $\mathrm{O}$ fenicismo dava a esses imigrantes uma origem nobre, o pertencimento a um povo que, eles acreditavam, havia descoberto a América antes de Colombo. Aliás esse mito foi, segundo Gualtieri, um elemento fundamental para a construção da identidade síriolibanesa nos EUA.

\footnotetext{
${ }^{59}$ KAUFMAN. p.183. diaspor. London and Los Angeles: University of California Press, 2009. p. 24.

61 Idem. p. 23.

62 Gualtieri. p. 21.
}

60 GUALTIERI, Sarah M. A. Between Arab and White: race and ethnicity in the early Syrian American 
Já em 1901, no jornal al-Hilal publicado no Cairo, Mulhim Halim Abduh, escrevendo desde a Carolina do Norte, disse que os fenícios haviam sido os primeiros caucasianos a chegar ao Continente Americano. Essa ideia posteriormente foi usada pelos imigrantes libaneses para afirmar, frente aos estadunidenses, mas também aos latinoamericanos - em especial durante as fases em que os governos desses países restringiram a imigração -, que eles não eram nem turcos e nem árabes e a ela deram continuidade por todo o século XX.

Devido a tudo isto a emigração também contribuiu bastante para estimular o desenvolvimento da ideologia fenicista, pois os libaneses, ao se dirigirem ao continente americano, reforçavam a ideia de que o Líbano estava cumprindo o seu papel de ser uma ponte entre o Ocidente e o Oriente e repetiam milênios depois a ousadia dos marinheiros fenícios que tinham desafiado o perigo navegando e atravessando o Mediterrâneo também em busca de vantagens econômicas ${ }^{63}$.

No Líbano, após a Primeira Guerra Mundial, um importante veículo para a difusão do mito fenicista foi à publicação La Revue Phénicienne em julho de 1919. Essa revista era composta por intelectuais cristãos francófilos liderados por Georges Corm. Lá escreviam artigos sobre política, economia e cultura da Síria e Líbano, discutiam a respeito da independência e das ligações culturais com a França. É muito comum em suas páginas uma atitude de hostilidade em relação aos árabes. Já com relação à França havia uma grande aprovação sendo isso acompanhado de expressões e frases fenicistas ${ }^{64}$.

Vários artigos da revista procuravam buscar justificativas para a existência do grande Líbano e isso era feito em termos econômicos. Eles lembravam o grande desenvolvimento que a costa libanesa teve durante a ocupação egípcia na década de 1830 e como tanto os cristãos quanto os muçulmanos apreciavam o desenvolvimento econômico acompanhado de progressos educacionais. Beirute cresceu e progrediu, tornou-se o principal porto da Síria e teve essa prosperidade também ligada ao desenvolvimento de seu sistema bancário.

Tais artigos também falavam sobre comércio, indústria, agricultura, turismo e como seria o futuro do Líbano. Esses temas eram abordados porque a maioria dos seus

\footnotetext{
${ }^{63}$ Idem. p. 23.

64 KAUFMAN, Asher. Phoenicism: the formation of an identity in Lebanon in 1920. In: Middle Eastern Studies. V. 32, N. 1, Jan. 2001. p. 187.
} 
articulistas eram negociantes bem sucedidos, como era o caso de Corm, que possuía uma das maiores firmas de importação de Beirute ${ }^{65}$ e foi um dos distribuidores dos carros da Ford no Líbano e Síria. O grupo de Corm também fazia frequentemente a associação entre o sucesso comercial fenício e o liberalismo, com isso sugerindo esse modelo econômico como o mais adequado para o Líbano ${ }^{66}$.

A equipe da Revue Phenicienne, muito provavelmente, recebia apoio moral e financeiro de Robert de Caix, um dos formuladores da política francesa para o levante ${ }^{67}$, estando, obviamente por isso, muito ligada aos interesses e objetivos imperiais franceses.

Aliás, com relação aos intelectuais fenicistas, eles eram todos cristãos e pertenciam à burguesia urbana de Beirute, a cidade síria mais exposta às correntes de pensamento vindas do Ocidente no século XIX. Foram políticos, advogados e negociantes ao longo de suas vidas. Embora não fossem parte da igreja eram todos homens de fé. Quase todos eram graduados pela Faculdade Oriental da Universidade de Saint Joseph. Seu movimento foi uma combinação de fé cristã e um modelo orgânico de nacionalismo cujas origens estão em determinados pensadores franceses. Eles nunca buscaram providenciar uma visão global de suas ideias, mas uma seleção de algumas delas que pudessem expressar os seus objetivos. O passado fenício, como imaginado por eles, deveria ser a fonte de inspiração para se construir o Líbano moderno e direcioná-lo em uma perspectiva ocidental ${ }^{68}$.

Após o estabelecimento do Grande Líbano pelos franceses em 1920, ao longo de toda essa década, foram divulgadas no país as ideias mencionadas acima, tanto por eles quanto pelos padres jesuítas franceses e belgas que eram professores na Universidade de Saint Joseph, embora sem o fervor dos dias do estabelecimento do mandato ${ }^{69}$.

\subsection{A revolta drusa}

Embora tenha ocorrido principalmente na Síria, a revolta drusa atingiu o Líbano fazendo com que por um breve período parte do seu território fosse ocupado pelos rebeldes; A luta promoveu agitações em Trípoli e no Akkar, fazendo com que os drusos libaneses, os

\footnotetext{
65 Idem. p. 187.

66 Idem. p. 189.

${ }^{67}$ Idem. p. 187.

${ }^{68}$ Idem. p 190.

${ }^{69}$ Idem. p. 189.
} 
xiitas e até os cristãos-ortodoxos dela participassem por algum tempo ${ }^{70}$.

A revolta durou dois anos, de 1925 a 1927 e fez com que os cristãos maronitas se aferrassem ainda mais ao seu recém-fundado estado contra a 'ameaça muçulmana'. Ela foi causada pelo fervor anticlerical do Alto Comissário Sarrail, pelas reformas políticas que visavam a diminuir o poder dos clãs locais a favor dos governadores de província e do governo mandatário, além da diminuição da autonomia do Jabal druso.

No Líbano os mais sérios embates ocorreram na região do Wadi-al-Taim e nas encostas ocidentais do Monte Hermon. A cidade de Marjayoun também foi ocupada e tentativas foram feitas para ocupar o centro xiita de Nabatiya. A cidade cristã de Rashayya também não caiu devido à resistência da guarnição local. Por fim, em 1926 duas colunas de tropas francesas arrasaram as forças dos rebeldes nos embates travados nas regiões por eles ocupadas, enquanto os drusos locais, os xiitas e cristãos ortodoxos retiravam seu apoio dos revoltosos por perceberem que certos rebeldes estavam mais identificados com uma futura Síria sunita. Com esses acontecimentos a revolta terminou no Líbano ${ }^{71}$.

\subsection{A Constituição de 1926}

No ano de 1926 foi realizada a Assembleia Nacional Constituinte para a promulgação de uma constituição para o país. Nessa constituição (que se encontra em vigor, com modificações, até os dias de hoje) determinou-se que o Líbano seria uma república parlamentar. Seu modelo foi a constituição francesa de 1874 da Terceira República. Devido a acordos com os franceses se determinou que as diferentes seitas do país teriam representação no parlamento de acordo com o seu número na população. A Constituição afirmava as prerrogativas mandatárias francesas sobre o país, estando o governo libanês livre para administrar os assuntos internos da nação. Posteriormente, o Alto Comissariado Francês colocou o seu poder de veto sobre toda legislação importante, mais os poderes de dissolver o parlamento e de suspender a constituição.

A partir de 1926, apesar do país está sob a administração direta francesa, um presidente (com mandato de três anos e renovável, depois modificado para seis anos e sem renovação) e um primeiro-ministro passaram a ser eleitos pelo parlamento como determinava

\footnotetext{
${ }^{70}$ WINSLOW. p. 62.

${ }^{71}$ Idem.
} 
a nova constituição. Os primeiros presidentes e primeiros-ministros eram nessa época cristãos e para serem eleitos os políticos precisavam antes ter a concordância dos franceses.

Quanto ao parlamento, por sua vez possuía inicialmente duas casas: Uma Câmara dos Deputados, composta de membros eleitos para mandatos de quatro anos, e um Senado, no qual o presidente indicava sete dos dezesseis membros. As duas casas elegiam o presidente. Dificuldades no funcionamento dessas duas casas fizeram com que uma emenda constitucional, em 1927, abolisse o Senado ${ }^{72}$.

A divisão sectária da sociedade libanesa foi realizada por etapas sucessivas durante o mandato, tendo começado com o artigo 95 da Constituição de 1926. E foi confirmada pelas autoridades mandatárias do país por meio da emissão de dois decretos, o número 60 L. R. de 1936 e o número 46 L. R. de 1938 por parte do Alto Comissariado Francês.

O primeiro reconhece a noção de Comunidade Histórica e o segundo completa e modifica o primeiro. A ela é reconhecido um estatuto especial e são concedidos tribunais para tratarem dos seus assuntos relativos à 'vida civil'. Embora estivesse prevista a instituição de comunidades de direito comum que escapassem dos estatutos religiosos, elas até hoje nunca foram aplicadas, mesmo que numerosos grupos políticos e sociais tivessem feito reivindicações nesse sentido ${ }^{73}$.

Nesse processo todos os muçulmanos permaneceram afastados do poder político, o que aumentava o seu descontentamento vindo da sua inclusão forçada no estado libanês. $\mathrm{O}$ problema da integração das populações muçulmanas, especialmente as sunitas, era a questão fundamental para se manter a viabilidade do Líbano. Se por um lado existiam grupos e personalidades cristãs que publicamente menosprezavam os muçulmanos, como o presidente Emilé Eddé, também haviam outros nacionalistas libaneses, como o futuro presidente Beshara el-Khuri, que buscavam uma fórmula de compromisso para que o Líbano pudesse existir no futuro como país independente ${ }^{74}$.

Porém, por um bom tempo, mesmo se fossem chamados a fazer parte do governo, muitos muçulmanos recusavam, pois para muitos deles participar da vida política libanesa

\footnotetext{
72 SALIBI. p. 167-168.

${ }^{73}$ CORM, Georges. El Líbano Contemporáneo: história y sociedad, in: Biblioteca del Islam Contemporáneo. Barcelona: Edicions Bellaterra, 2006. p. 105.

${ }^{74}$ Idem. p. 100.
} 
seria reconhecer a legitimidade de sua incorporação ao novo país.

Para integrar os muçulmanos, ao longo dos anos 20 e 30, diversos membros das elites políticas e intelectuais cristãs começaram a conceber uma fórmula de compromisso. Entre as tentativas de se trazer ao menos alguns muçulmanos para participar da direção do poder está a tentativa de se eleger um presidente sunita em 1932. Muhammad al-Jirs foi esse indivíduo, tendo o apoio do primeiro presidente, Charles Debbas, e mesmo de muitos franceses que desejavam integrar os muçulmanos nas estruturas de poder do Líbano. Além do mais, até mesmo um determinado número de políticos maronitas o apoiou, fora as comunidades sunita e cristã-ortodoxa.

No entanto, o alto Comissário Francês Henry Ponsot decidiu suspender a constituição, dissolver o parlamento e adiar a eleição, sendo que no fim ele próprio tinha resolvido nomear o próprio presidente e o primeiro-ministro. O motivo para impugnar a candidatura de Al-Jirs teria sido o fato de o líder muçulmano não reconhecer o cristão do Líbano e a sua separação em relação ao mundo Árabe ${ }^{75}$.

Esse fato demonstra, no entanto, que já no fim dos anos vinte e começo dos trinta existiam líderes e ativistas sunitas que percebiam a existência do Líbano como um fato definitivo e que a incorporação de regiões como Trípoli à Síria seria impossível de ocorrer sem que um grande confronto com os cristãos e com a potência mandatária francesa acontecesse.

\subsection{0 censo de $1932^{76}$}

Em 1932 foi realizado o único censo populacional feito até hoje na história do Líbano. Esse censo confirmou que os cristãos eram a maioria da população, embora admitisse que os muçulmanos fossem uma grande minoria. Dentre as comunidades religiosas determinaram-se que os maronitas eram a maior comunidade, os sunitas a segunda e os xiitas a terceira. Os resultados do censo serviram de base para o Pacto Nacional de 1943 e a organização do sistema político libanês após a independência.

A realização do censo não foi feita de maneira neutra sem que nenhum viés

\footnotetext{
75 SALIBI. p. 176.

76 MAKTABI, Rania. The Lebanese census revisited: who are the Lebaneses? In: British of Middle Eastern Studies Journal, Nov. 99, V. 26.
} 
político ou comunitário nele interferisse. Pelo contrário, quando foi elaborado, o censo foi planejado visando a fazer com que os cristãos tivessem a maioria da população. Sua realização foi anunciada por uma lei emitida pelo presidente Charles Debbas em 24 de novembro de 1931, mas cerca de um mês depois, em 19 de dezembro, uma outra lei foi emitida e em seu artigo 2 englobava no censo a ser realizado tanto os libaneses residentes em seu país como os emigrados. Finalmente, o Decreto 8.837 de 15 de janeiro de 1932 alinhava as regras para a realização do recenseamento ${ }^{77}$.

Dessa forma, ao se incluir entre a população aqueles libaneses que haviam emigrado (187 mil antes de 1942 e 68 mil entre esse ano e 1932) se favoreciam os cristãos, pois eles eram a maioria (85\%), especialmente os maronitas que constituíam $48,4 \%$ dos emigrados. Estes quando foram incluídos no censo da população libanesa aumentavam o número dos maronitas de $29 \%$ para $33,5 \%$, reduzindo o número de sunitas residentes de $22,5 \%$ para $18 \%$ e o de xiitas de $19,5 \%$ para $16 \%$. Os muçulmanos eram apenas $14 \%$ dos emigrantes $^{78}$. No resultado final do censo os cristãos emigrantes representavam $35 \%$ de sua população enquanto os não-cristãos eram apenas $9 \%$.

Também importante para o censo foi que o Decreto 8.837 fazia referência aos refugiados armênios, siríacos e caldeus que eram cristãos e foram considerados cidadãos libaneses com o Decreto 2.825 de 30 de agosto de 1924 (p. 4). Mas o mesmo não era seguido com relação aos imigrantes muçulmanos como os curdos que, como os cristãos, se assentaram no Líbano como resultado dos conflitos envolvendo a desagregação do Império Otomano e a formação da moderna Turquia, bem como os beduínos residentes nas fronteiras do Líbano.

O artigo 12 do Decreto 8.837 afirmava que apenas os beduínos residentes por mais de seis meses no Líbano seriam considerados cidadãos, o que levou à exclusão de uma parte dessa população sunita da cidadania libanesa. Por fim, durante a realização do censo cerca de 60 mil pessoas residentes no Líbano não foram consideradas libanesas e sim vistas como 'estrangeiros' e nenhum decreto foi emitido pelo governo para considerá-las como libanesas. Essas pessoas não possuíam as carteiras de identidade que deveriam ser apresentadas aos recenseadores como prova de que eram consideradas libanesas ${ }^{79}$. Um outro grupo não considerado como libanês eram os residentes em aldeias de fronteira que foram

\footnotetext{
${ }^{77}$ Idem. p. 3.

78 Idem. p. 8.

${ }^{79}$ Idem. p. 5.
} 
amputadas pelos acordos fronteiriços franco-britânico em 1922. Também haviam aqueles que tinham registro de nascimento e pessoais imprecisos. Essas pessoas eram em sua maioria muçulmanas ${ }^{80}$.

Tabela 1 - Censo dos habitantes do Líbano

\begin{tabular}{|c|c|c|c|c|c|}
\hline & Residentes & $\begin{array}{c}\text { Emigrantes } \\
\text { de antes } \\
\text { de } 30 \text { de } \\
\text { agosto de } \\
1924 \text { que } \\
\text { pagaram as } \\
\text { taxas }\end{array}$ & $\begin{array}{c}\text { Emigrantes } \\
\text { de antes de } \\
30 \text { de agosto } \\
\text { de } 1924 \text { que } \\
\text { não pagaram } \\
\text { as taxas }\end{array}$ & $\begin{array}{l}\text { Emigrantes } \\
\text { após } 30 \text { de } \\
\text { agosto de } \\
1924 \text { que } \\
\text { pagaram as } \\
\text { taxas }\end{array}$ & $\begin{array}{c}\text { Emigrantes } \\
\text { após } 30 \text { de } \\
\text { agosto de } \\
1924 \text { que não } \\
\text { pagaram as } \\
\text { taxas }\end{array}$ \\
\hline Sunitas & 178.100 & 2.653 & 9.840 & 1.089 & 3.623 \\
\hline Xiitas & 155.035 & 2.977 & 4.543 & 1.770 & 2.220 \\
\hline Drusos & 53.334 & 2.067 & 3.205 & 1.183 & 2.295 \\
\hline Maronitas & 227.800 & 31.697 & 58.457 & 11.434 & 21.809 \\
\hline Greco-Católicos & 46.709 & 7.190 & 16.544 & 1.855 & 4.038 \\
\hline Greco-Ortodoxos & 77.312 & 12.547 & 31.521 & 3.922 & 9.041 \\
\hline Protestantes & 6.869 & 607 & 1.575 & 174 & 575 \\
\hline $\begin{array}{l}\text { Armênios } \\
\text { Ortodoxos }\end{array}$ & 26.102 & 1 & 60 & 191 & 1.718 \\
\hline $\begin{array}{l}\text { Armênios } \\
\text { Católicos }\end{array}$ & 5.890 & 9 & 50 & 20 & 375 \\
\hline $\begin{array}{l}\text { Siríacos } \\
\text { Ortodoxos }\end{array}$ & 2.723 & 6 & 34 & 3 & 54 \\
\hline $\begin{array}{l}\text { Siríacos } \\
\text { Católicos }\end{array}$ & 2.803 & 9 & 196 & 6 & 101 \\
\hline Judeus & 3.588 & 6 & 214 & 7 & 188 \\
\hline Caldeus Ortodoxos & 190 & 0 & 0 & 0 & 0 \\
\hline Caldeus Católicos & 548 & 0 & 6 & 0 & 19 \\
\hline Diversos & 6.393 & 212 & 758 & 59 & 234 \\
\hline TOTAL & 793.396 & 59.981 & 127.003 & 21.713 & 46.290 \\
\hline
\end{tabular}

Disso

$\begin{array}{cc}\text { Homens } & \text { Mulheres } \\ 44,749 & 15,232 \\ \text { Homens } & \text { Mulheres } \\ 72,447 & 54,556\end{array}$

(continua)

${ }^{80}$ Ibidem. p. 5-6. 
(conclusão)

Tabela 1 - Censo dos habitantes do Líbano

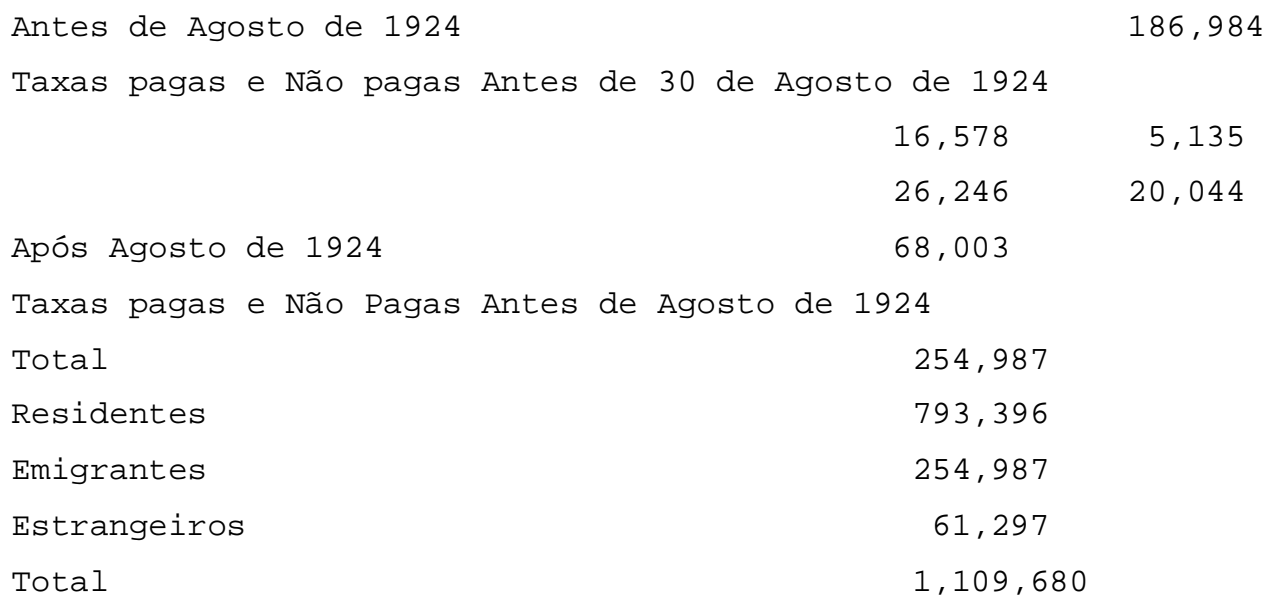

Fonte: Al-Jarida a-Rasmiyya, Official Gazette, 2718 (5 Out. 1932) citado em: Rania Maktabi in: The Lebanese Census Revisited: Who Are the Lebaneses? In: British of Middle Eastern Studies Journal, Nov. 99, V. 26.

\section{$1.6 O$ tratado de 1936}

Em 1936, o novo governo francês da Frente Popular comandado por Leon Blum deu início a negociações com as autoridades sírias e libanesas para acertar os termos da independência dos dois países como lhes havia sido prometido durante a instalação dos mandatos.

As negociações na vizinha Síria, que contavam com forte apoio popular, estimularam os libaneses a fazer o mesmo, tendo o partido Bloco Constitucional do futuro presidente Bechara el-Khuri encorajado de maneira firme os políticos libaneses a empreender com os franceses conversações sobre a independência do seu país. Como resultado das negociações foi acordado por meio do chamado Tratado de Amizade Franco-Libanês que até o fim de 1939 o Líbano seria um país plenamente independente com direito a uma vaga na Sociedade das Nações. No dia 17 de novembro o parlamento ratificou o tratado, tendo sido assinado pelo presidente libanês Emile Eddé e o Alto Comissário francês, o Conde de 
Martel $^{81}$. No entanto, no verão de 1939 o governo francês não tinha ainda ratificado o tratado e a eclosão da II Guerra Mundial adiou indefinidamente a sua implementação ${ }^{82}$.

A negociação desse tratado causou revolta na população muçulmana, pois isso confirmava a separação plena entre Líbano e Síria, algo que esse povo e suas lideranças mais temiam. Quando ocorreu a sua aprovação houve greves, demonstrações nas ruas dos bairros e cidades muçulmanas e choques de muçulmanos com cristãos ocorreram em diversas regiões do país. Essas manifestações também aconteceram quando as autoridades sírias concluíram com os franceses o seu tratado de independência também em 1936. Dessa vez um grande número de sunitas pedia que os territórios onde viviam fossem reincorporados a uma Síria agora independente. Os líderes muçulmanos aproveitaram as negociações entre os sírios e os franceses para pedir a anexação à Síria dos territórios libaneses de maioria muçulmana. Para isso organizaram uma série de encontros na casa do notável sunita Salim Salam, conhecidos como as 'Conferências da Costa' para formalizar essa proposta que era muita popular em sua comunidade.

Essas atitudes provocaram reações diversas entre os cristãos: de um lado houve a fundação de partidos e movimentos de cunho nacionalista como o Kataeb (Falange), fundado pelo farmacêutico maronita Pierre Gemayel e inspirado tanto ideologicamente quanto em sua organização em grupos fascistas da Espanha e Itália. Publicamente defensores da independência do Líbano eram cristãos exclusivistas que sonhavam com um estado separado para sua comunidade. Nas ruas os seus militantes entravam em confronto com os sunitas partidários da união com a Síria e com cristãos nacionalistas sírios, como os militantes do Partido Nacional Social Sírio do líder Antun Saadeh, que acreditavam existir uma identidade pansíria histórica unindo os habitantes do levante e estando acima dos particularismos locais e regionais e dos confessionalismos.

Por isso, os seguidores de Saadeh defendiam a existência de um Estado independente no levante unindo sírios, libaneses, palestinos e jordanianos. Nesse contexto eles apoiavam as reivindicações separatistas dos muçulmanos dos anos 30, pois as percebiam como um passo para se conseguir trazer de volta a unidade nacional da Síria, rompida pelo colonialismo europeu e pelo particularismo dos cristãos libaneses ${ }^{83}$.

\footnotetext{
${ }^{81}$ SALIBI. p. 181.

82 Idem. p. 183.

${ }^{83}$ Idem. p. $180-181$.
} 
Já outros grupos cristãos insistiam na necessidade de se buscar um acordo com os muçulmanos, como o bloco constitucionalista liderado por Bechara el-Khuri, enquanto intelectuais liberais como Michel Chiha afirmavam que a força do Líbano estava em sua pluralidade, uma marca secular do país e que, caso isso não pudesse ser reconhecido, era o seu futuro que estaria ameaçado. Sua atitude ia em direção contrária à de figuras como Charles Corm, um defensor da identidade cristã do Líbano que chegava a afirmar ser o francês a língua de sua população cristã e que o árabe era um idioma supostamente imposto por meio de massacres e pelo medo, vendo os muçulmanos como adversários históricos dos cristãos e afirmando a ligação entre o cristianismo e os antigos fenícios. O que distinguiria o Líbano dos países árabes vizinhos ${ }^{84}$.

Um passo importante para a incorporação dos muçulmanos no Estado libanês foi a indicação do líder sunita e um antigo ativista do pan-arabismo Khair al-Din al-Ahdab para o cargo de primeiro-ministro em 1937. Ahdab havia abandonado as suas reivindicações já no começo da década e havia sido eleito para o parlamento com a plataforma do entendimento entre as comunidades muçulmanas e as cristãs. Depois dele todos os primeiros-ministros passaram a ser sunitas, o que seria reconhecido pelo Pacto Nacional em $1943^{85}$.

\subsection{A economia do Líbano sob o mandato francês}

Apesar das declarações das autoridades francesas e apesar do que pensavam os cristãos, na prática o Líbano era mais uma possessão francesa como a Argélia, a África Ocidental Francesa e o Vietnã e deveria servir para atender aos interesses econômicos e geoestratégicos de Paris no Oriente Médio. Ainda que o tratamento dado pelos franceses aos libaneses fosse bem menos duro do que ao dado a africanos subsaarianos, magrebinos e vietnamitas.

Os franceses trataram de garantir a predominância dos seus interesses econômicos no país, ainda que abrissem parcialmente a economia libanesa para a produção de países industrializados como a Grã-Bretanha, os EUA, a Itália e até o Japão como um meio de conseguir o acesso também aos mercados coloniais ou nacionais desses países ${ }^{86}$. As

\footnotetext{
84 TRABOULSI. p. 95.

85 SALIBI. p. 183.

${ }^{86}$ GATES, Carolyn L. The merchant republic of Lebanon: rise of an open economy. Londres e Nova Iorque: The Centre for Lebanese Studies in association with I. B. Tauris, 1998. p. 23.
} 
autoridades do Alto Comissariado francês eram em grande parte ligadas e influenciadas pelos interesses comerciais, industriais e financeiros de Lyon e Marselha e buscaram favorecerem esses grupos econômicos no Líbano. Dessa maneira, diversas concessões que estavam sobre o controle de capitais de outros países europeus antes da I Guerra foram entregues para empresários franceses. Esse controle econômico sobre o Líbano ficou conhecido pelo nome de économie de traité. Nesse sistema as relações comerciais entre o Líbano e a França eram bem parecidas às existentes entre Paris e suas colônias: Os libaneses vendiam aos franceses bens primários agrícolas e produtos semi-industrializados importando bens industriais de sua metrópole em um circuito comercial elaborado para promover a exclusão de comerciantes estrangeiros $^{87}$.

Para facilitar a administração econômica os franceses promoveram a unificação alfandegária e monetária da Síria e do Líbano criando um cenário econômico unificado, apesar de que a separação dos dois Estados tenha destruído a sua antiga unidade política. Outra consequência do controle mandatário francês foi que a emissão da moeda local, bem como simultaneamente a da Síria (a libra sírio-libanesa), foi indexada à cotação do franco por meio de um decreto legislativo francês no valor de vinte francos para cada libra, o que acabou entregue a um banco particular, o BSL, Banco da Síria e do Líbano.

Esse banco até 1964 controlou a emissão de dinheiro no país e teve um papel central na elaboração das políticas monetárias libanesas e a distribuição do crédito no tempo do mandato e nos vinte primeiros anos do Líbano independente ${ }^{88}$. Esse banco também tinha a função de guardar os depósitos dos governos locais sírio e libanês.

Em janeiro de 1924 os governos da Síria e do Líbano e o BSL assinaram um acordo estabelecendo como convenção oficial que o valor do Franco Francês em 1920 funcionaria como padrão de câmbio. Essa convenção reafirmou a libra sírio-libanesa como a única moeda de curso legal nos dois territórios e a única unidade monetária oficial. Também se revalidou o Decreto Legislativo francês que havia estabelecido a paridade entre uma libra e vinte francos franceses e se determinou que as emissões monetárias do BSL fossem de no máximo 25 milhões de libras. Em 1939 os franceses assinariam com o Líbano uma nova convenção que prorrogaria a concessão ao Banco da Síria e Líbano por mais 25 anos,

\footnotetext{
${ }^{87}$ Idem. p. $18-19$.

${ }^{88}$ GATES. p. 20; MALLAT, Raymond A. 70 years of money muddling in Lebanon: A guide in monetary managemement for economic development in Lebanon. Beirute: Aleph, 1977.
} 
removeu o limite de 25 milhões de libras para a emissão monetária e transferiu a emissão de moedas no valor abaixo de 1 libra para o tesouro libanês ${ }^{89}$.

A indexação da moeda sírio-libanesa ao franco francês fez com que as economias locais sofressem, e de maneira pesada, os efeitos das crises financeiras por que passava a metrópole mandatária. As enormes flutuações da moeda francesa entre 1919 e 1926 fez com que a economia sírio-libanesa perdesse cerca de 10 milhões de libras turcas ${ }^{90}$. Por volta de 1925 havia no Líbano uma forte demanda por divisas estrangeiras como resultado de uma forte especulação. Quando em 1928 os franceses restabeleceram o padrão-ouro, tanto o franco quanto a moeda libanesa passaram por uma relativa estabilidade que durou apenas oito anos, pois em 1936 a França abandonou novamente o padrão-ouro e sua moeda sofreu uma violenta desvalorização que levou junto a libra sírio-libanesa. Nesse processo a moeda libanesa, entre 1920-1939, sofreu uma desvalorização de 64\% (82\% de desvalorização) ${ }^{91}$ em relação ao dólar americano como resultado das desvalorizações do franco ${ }^{92}$.

Outra consequência negativa para a economia libanesa (e também simultaneamente para a da vizinha Síria) foi o fato de que a sua incorporação ao sistema financeiro francês rompeu a unidade do Líbano com as terras que havia pertencido ao império otomano promovendo o declínio comercial com países da região como o Egito ou a Turquia.

O mercado financeiro do Líbano era caracterizado por apresentar dois setores distintos: Um organizado, que empregava métodos modernos de transação e intermediação, tendo Beirute como centro, com grande controle do capital francês (quatro dos cinco maiores bancos eram franceses) e em menor extensão de outros grupos estrangeiros e estruturado para financiar o comércio e os serviços; E um segundo setor rural que era desorganizado, composto por pequenos bancos, discounting houses, agiotas, mercadores e latifundiários. Estes providenciavam empréstimos para pequenos agricultores e outros clientes de poucas posses.

No setor organizado os bancos estrangeiros expandiram o raio de alcance de suas operações durante a depressão dos anos 30, já que as taxas de juros no Líbano eram mais altas do que na Europa e por conta da crise financeira que havia nesse continente o capital local

\footnotetext{
${ }^{89}$ MALLAT, Raymond. A. 70 years of money muddling in Lebanon: A guide in monetary managemement for economic development in Lebanon. Beirute: Aleph, 1977. p. 98.

${ }^{90}$ ABDALLAH Hanna apud MEDAWAR apud GATES. p. 20.

${ }^{91}$ MALLAT. 70 years of money muddling in Lebanon... p. 99.

92 Idem. p. 99.
} 
fluía para o País do Cedro onde a rentabilidade era maior ${ }^{93}$.

Como parte dessa política para favorecer os capitais metropolitanos, a indústria da seda, já muito combalida pelos efeitos da Grande Guerra de 1914-1918, foi desmantelada pela política econômica dos primeiros governadores franceses. Também contribuiu para o fim da indústria da seda o aparecimento de variedades sintéticas, como o rayon, e a competição com produtores estrangeiros. O golpe final a essa indústria foi a crise de $1929^{94}$.

Nos anos vinte os franceses favoreceram a importação de produtos industrializados, o que prejudicou os interesses industriais locais, muitos dos quais eram fábricas recém-fundadas e que estavam iniciando as suas operações. Estes também pediam às autoridades mandatárias que os protegessem por meio de altas tarifas, embora isto não acontecesse devido ao peso dos grandes grupos econômicos franceses no alto comissariado. Durante os anos vintes as tarifas alfandegárias eram baixa, sendo de apenas 11,5\% em $1921 \mathrm{e}$ somente em 1934 chegaria a 28\%. Porém, após a quebra da Bolsa de Valores de Nova Iorque em 1929, seguida pela crise econômica dos anos 30, deu-se prosseguimento um aumento das tarifas que acontecia desde 1926, tendo propiciado alguma proteção à indústria libanesa nascente contra a concorrência de produtos de países como Japão e Grã-Bretanha ${ }^{95}$.

A partir dos anos 30, começou a se expandir a classe industrial no Líbano com o aparecimento de um grande número de novas empresas. Dessa maneira, o número de estabelecimentos industriais passou de 200 em 1933 para 340 em 1940 ${ }^{96}$. Uma parte importante desses investimentos provinha do capital dos emigrantes que haviam se enriquecido no exterior e ao voltar para o Líbano abriam fábricas no país, como é o caso de George Arida, dono de uma fiação de algodão em Trípoli. Até mesmo um alto membro da igreja maronita participava de investimentos na área industrial, como se trata do caso do patriarca Antoun Arida (muito influenciado pela política de industrialização sionista na Palestina) no estabelecimento da fábrica de cimento Chekka em 1929 e a companhia de eletricidade Kadicha em $1922^{97}$.

Como prova do crescimento da indústria nos anos 30 está o fato de que a

\footnotetext{
93 GATES. p. 20.

94 GASPARD, Tufic K. A political economy of Lebanon, 1948-2002: the limits of Laissez-Faire. Leiden e Boston: Brill, 2004. p. 50.

95 GATES. The Merchant Republic... p. 23.

96 Idem. p. 26. Gráfico 2. 2.

97 Ibidem. p. 26.
} 
tonelagem de maquinário industrial importado mais que quadruplicou entre 1934 e $1938^{98}$. Essas indústrias eram geralmente de bens de consumo, de setores como o alimentício, têxtil e vestuário, sapatos, bebidas, produtos de couro e madeira, sabão, móveis, produtos metálicos, cerâmicos, fósforos, cimento e outros materiais de construção ${ }^{99}$.

Essa expansão não aconteceu devida à existência de uma política industrial pelos franceses que nunca acreditaram na viabilidade da indústria no Líbano ${ }^{100}$, mas devida à iniciativa pessoal dos empresários libaneses. Talvez por isso esse setor no período mandatário sempre permaneceu em pequena escala funcionando a partir de pequenas fábricas sem que ocorresse o aparecimento de empresas em escalas maiores que pudessem exercer uma hegemonia ou mesmo monopólio sobre um determinado ramo da indústria ${ }^{101}$.

A indústria libanesa enfrentou já nos anos 30 um problema que a acompanharia pelo século XX: o tamanho reduzido do mercado nacional, o que levava a um acúmulo de mercadorias que não encontravam consumidores para comprá-las. Outro problema era que esse mercado ainda estava aberto à produção estrangeira, que era um duro concorrente da indústria nacional. Para piorar os mercadores ainda estocavam bens de valor relativamente baixo, o que abaixava ainda mais o preço das mercadorias industriais libanesas. O resultado disso foi que às vésperas da Segunda Guerra uma grande quantidade de indústrias corriam o risco de falir. Outro motivo que fragilizava a indústria libanesa era o fato de o país ser dependente da importação de tecnologia e bens de capital, o que tornava os investimentos ainda mais custosos e foi um sério obstáculo à expansão e modernização da indústria quando houve a deflagração da Segunda Guerra Mundial ${ }^{102}$.

Importante para a economia e a sociedade libanesa durante o mandato era a agricultura, pois quase $2 / 3$ da população dela vivia nessa época. Esse ramo havia saído da I Guerra Mundial muito combalido e a crise da indústria da seda aumentou ainda mais o estado de penúria desse setor. Devido a sua fraqueza a agricultura não conseguia produzir renda suficiente para sustentar de maneira adequada entre $1 / 3$ a $2 / 3$ da população libanesa

\footnotetext{
98 GASPARD. p. 52.

${ }^{99}$ GATES. The Republic Merchant... p. 27.

${ }^{100}$ GATES. The Historical Role of Political Economy... p. 27.

101 GATES. The Republic Merchant... p. 28.

102 Idem. p. 28-29.
} 
dependente dessa atividade, tendo sido isso a grande causa da emigração nessa época ${ }^{103}$.

Um acontecimento que poderia ter sido um grande estímulo para a agricultura nativa foi o aumento da quantidade de terras férteis com a anexação ao Líbano de novos territórios. Desse modo, aos 80 mil hectares de terras cultiváveis existentes na montanha foram acrescidos outros 140 mil encontrados no Akkar, Beka'a, Kura, na planície entre Beirute e Tiro e nas zonas ao redor de Trípoli. Essas novas zonas correspondiam a 64\% das terras agrícolas do Grande Líbano. No entanto, os baixos rendimentos impediam a atração de capitais suficientes para modernizar e reorganizar a agricultura. A queda dos preços agrícolas internacionais após a I Guerra foi um outro desestímulo para se investir nesse setor. As autoridades mandatárias chegaram a promover políticas para a agricultura, dentre as quais buscou-se recuperar a antiga cultura da seda, porém a queda dos preços internacionais desses produtos, a difusão da seda artificial e a falência da indústria libanesa da seda impediram que isso fosse bem sucedido.

Também os franceses investiram em projetos de irrigação e na construção de novas rodovias ao longo do país que ajudaram na distribuição da produção agrícola. Enquanto isso começava um lento processo de modernização das técnicas de cultivo e organização das grandes propriedades o que incluía a mecanização das fazendas ${ }^{104}$. Mesmo assim, o Líbano nunca alcançou a autossuficiência agrícola. Somente com a produção de frutas e legumes na década de 1940 é que isso aconteceu. Nos outros setores o país dependia da importação de gêneros alimentícios dos países vizinhos ${ }^{105}$.

A grande realização do governo mandatário francês no Líbano se concentrou nos setores mercantil e de serviços. Os franceses estabeleceram as bases físicas e econômicas para que na segunda metade do século XX o Estado libanês pudesse ser um centro de comércio, serviços e finanças. Transformaram Beirute no centro econômico do Líbano, promoveram o desenvolvimento de seu porto e cuidaram para que fosse o único no país em que se realizava o comércio internacional. Continuaram, dessa maneira, a orientação internacional da economia e do comércio libanês que já vinha desde o século XIX, mas orientaram a direção desse comércio também para o Oriente-Médio fazendo com que os países da região tivessem um volume de comércio com o Líbano maior no período entre guerras do que tinham tido antes

${ }^{103}$ GATES. The Historical Role of Political Economy... p. 21 .

104 GATES. The Merchant Republic... p. 24-25.

${ }^{105}$ GATES. The Historical Role of Political Economy... p. 21-22. 
de 1914.

Desses países vizinhos o principal mercado para os produtos libaneses acabou sendo a Palestina, destino de grande parte das exportações libanesas e sírias (até o rompimento da União Aduaneira em 1950 o comércio externo da Síria e do Líbano e suas contas eram considerados como um só, compostas por produtos agropecuários, alimentos processados, sapatos, têxteis e vestuários, cimentos e produtos de couro. A Palestina era um destino tão importante que o valor das exportações a esse mercado, que eram no valor de 8 milhões de libras sírio-libanesas, superavam em 2 milhões o valor das exportações destinadas à França. Também eram importantes as importações vindas do Oriente-Médio que representavam cerca de $1 / 4$ do total ${ }^{106}$.

Essa política favoreceu as elites cristãs que se dedicavam a essas atividades e eram sócias dos franceses nos empreendimentos econômicos organizados por eles no Líbano, mas também refletia a estratégia francesa de, a partir do Líbano, promover sua influência econômica no Oriente Médio e, ao mostrar o desenvolvimento, ao menos feito na capital libanesa e no Monte Líbano, promover a França como um país responsável por estimular no mundo os avanços técnicos, econômicos e sociais do século XX.

Como parte dessa política de desenvolvimento das regiões do Líbano, importantes para as atividades mercantis das elites cristãs e dos capitais franceses aí instalados, estavam os investimentos públicos e privados que eram direcionados para lugares como o Monte Líbano e a cidade de Beirute. No caso da capital libanesa esses investimentos visavam a transformá-la em um centro regional de comércio e serviços que deveria competir com Haifa na Palestina. A infraestrutura da cidade foi modernizada com a instalação de redes de táxis e ônibus e o sistema de bondes elétricos melhorado. Também correios, telégrafos e telefones foram melhorados. Um aeroporto foi inaugurado em 1936 e aberto oficialmente três anos depois. A Rádio Orient foi fundada nessa época como um elo comunicativo moderno e forte entre o Líbano e Paris. Beirute foi propositadamente favorecida para ser o porto internacional da Síria e do Líbano, sendo este beneficiado com um plano de modernização iniciado pela Cia. Porto de Beirute de capital privado e que custaria 49 milhões de francos franceses ${ }^{107}$.

Para favorecer Beirute, o governo mandatário francês havia em 1933/34 estabelecido um plano de seis anos para promover o desenvolvimento de estradas, projetos de

106 GATES. The merchant republic... p. 29.

107 Idem. p. 33. 
irrigação, ferrovias e portos para estimular as atividades econômicas, particularmente o comércio do Líbano com os países vizinhos. E o tratado de aliança franco-libanês de 1936 assegurou a primazia de Beirute dentro do Líbano, chegando os seus negociadores libaneses a pedir aos franceses para retirar o projeto de desenvolver Trípoli como porto naval e base militar $^{108}$.

Tabela 2 - Tráfico no porto de Beirute 1920-1939 (000,000 toneladas)

\begin{tabular}{lllll|}
\hline Ano & Desembarque & Embarque & Total & Trânsito \\
\hline 1920 & 132.0 & 27.6 & 156.9 & n.a \\
1922 & 214.6 & 26.6 & 241.2 & n.a \\
1925 & 361.8 & 58.4 & 420.2 & n.a \\
1927 & 350.8 & 72.1 & 422.9 & n.a \\
1928 & 434.1 & 34.4 & 468.5 & n.a \\
1929 & 493.5 & 73.8 & 567.3 & n.a \\
1930 & 441.5 & 65.8 & 507.3 & n.a \\
1931 & 484.5 & 53.6 & 538.1 & n.a \\
1932 & 509.7 & 36.9 & 546.6 & n.a \\
1933 & 514.8 & 40.3 & 555.1 & n.a \\
1934 & 423.6 & 40.3 & 463.9 & n.a \\
1935 & 429.1 & 39.3 & 468.4 & 13.4 \\
1936 & 421.1 & 58.0 & 479.1 & 11.2 \\
1937 & 448.4 & 97.5 & 545.9 & 22.2 \\
1938 & 402.6 & 115.4 & 518.0 & 21.5 \\
1939 & 522.8 & 110.4 & 633.2 & 25.0 \\
& & & & \\
\hline
\end{tabular}

Fonte: Compagnie du Port de Beirut citado por GATES, Carolyn L. The merchant Republic of Lebanon: rise of an open economy. p. 33.

\subsection{A economia nos anos da Segunda Guerra Mundial}

A deflagração da II Guerra Mundial levou o governo mandatário a estabelecer

${ }^{108}$ Idem: Pág. 31 
fortes controles sobre a economia para adaptá-la à nova realidade do conflito. Ao mesmo tempo o contato do Líbano com a Europa e o resto do mundo se tornou mais difícil levando a uma queda no comércio internacional desse país. As importações, por exemplo, chegaram a ter uma queda de $43 \%$. A derrota da França e a instalação do governo pró-alemão do marechal Phelippe Petain na cidade de Vichy piorou a situação econômica e resultou em um isolamento do Líbano e da sua vizinha Síria. Seus portos foram bloqueados pela marinha britânica, o fluxo de petróleo desde o Iraque através do oleoduto da IPC (Irak Petroleum Company, controlada pelo capital britânico) foi cortado, os países vizinhos, então quase todos sob o controle de Londres, fecharam os seus mercados aos produtos libaneses e havia uma grande escassez de moedas estrangeiras sendo que as contas em libra esterlina estavam bloqueadas levando a uma demanda por ouro.

Para enfrentar esse bloqueio, o governo de Vichy no Líbano deu continuidades a algumas políticas já adotadas antes da derrota da França, como a construção de uma refinaria de petróleo em Trípoli feita pelos militares franceses em associação com empresários libaneses e companhias francesas, e aplicou outras novas como a implantação de novas fábricas e oficinas para produzir alguns produtos para abastecer o país e manter as tropas francesas, como foi o caso da usina de açúcar de cana de Al-Abdé, cidade próxima a Trípoli.

Outras medidas incluíam o abandono da manutenção da infraestrutura libanesa e o racionamento dos produtos de primeira necessidade, o que, junto com a diminuição do comércio internacional em um primeiro momento e depois a sua quase interrupção, levou à escassez de mantimentos, à especulação e inflação, resultando na piora das condições de vida da população. Esses anos iniciais da guerra presenciaram um aumento no desemprego e uma ameaça de instabilidade e agitação social ${ }^{109}$.

No plano financeiro as autoridades mandatárias estabeleceram um controle cambial, chamado em francês de 'Office des Changes', por meio do qual adquiriram o controle imediato de todas as divisas estrangeiras existentes no país. Sua administração estava a cargo do BSL que reuniu todas as divisas estrangeiras acumuladas no Líbano contra os ativos franceses e creditadas na conta do BSL em Paris ${ }^{110}$.

A ocupação aliada em junho de 1941 mudou a situação do Líbano. As relações comerciais com os países vizinhos sob o controle ou influência britânica foram restabelecidas,

${ }^{109}$ Idem. p. 35,37 e 42.

${ }^{110}$ MALLAT. 70 Years of Money Muddling in Lebanon... p. 100. 
os investimentos em infraestrutura foram retomados, o oleoduto da IPC foi reaberto, bens importados dos EUA e Grã-Bretanha voltaram ao país - se bem que em quantidades bem menores que antes da guerra -, houve a incorporação do Líbano e sua vizinha Síria à zona da libra esterlina para facilitar as transações internacionais, o que favoreceu muito os comerciantes libaneses.

Isso acima descrito acontecia junto com a instalação de uma forte estrutura burocrática para gerenciar a economia na qual também se regulava o comércio e a entrada e saída de bens e pessoas. As duas mais importantes burocracias eram a seção econômica da britânica Spears Mission e a da França Livre Officé de l'Economie de Guerre (OEG). Assistência técnica e de gerenciamento foi fornecida à indústria e à agricultura para aumentarem e melhorarem sua produção e assim abastecerem o Líbano, ajudarem no abastecimento dos países vizinhos e fornecer mantimentos para as tropas aliadas.

Com relação à indústria isso significou promover uma política de substituição de importações ao se fornecer capital e bens de capital para as manufaturas libanesas e proteger o mercado local para que o Líbano fosse autossuficiente em determinados produtos, já que importá-los era complicado. Porém, diversos problemas e limitações dificultaram esses planos, como a força de trabalho desqualificada, escassez de matéria-prima, baixa produtividade em certos ramos, obsolescência técnica, a falta de integração entre vários ramos da indústria, produção de qualidade medíocre e limitação do mercado nacional.

Apesar disso tudo, grandes lucros foram obtidos na indústria e os salários registraram diversos aumentos (em alguns ramos de até 800\%) ao longo dos anos da II Guerra - porém a renda desses trabalhadores só não melhorou devido à persistência da inflação ao longo desse período. Houve um crescimento do emprego na indústria sendo que uma parte desses trabalhadores eram migrantes vindos do campo ${ }^{111}$.

Os anos da ocupação aliada propiciaram um aumento das reservas externas de moeda do Líbano, propiciaram o acúmulo de moeda estrangeira por parte de suas burguesias comerciais e financeiras e criaram as condições para que grandes fortunas fossem formadas através da especulação de ativos financeiros como as commodities, imóveis, ouro, terras etc. Muitas empresas de comércio e comerciantes individuais se enriqueceram por meio do contrabando, como é o caso da firma importação de Alfred Kettaneh. Um membro importante da elite política e econômica libanesa, ele que vendia produtos norte-americanos.

${ }^{111}$ Idem. p. 37-38 e 47-49. 
O boom econômico eliminou o desemprego e somente não aumentou mais ainda a renda popular devido à inflação da época como já foi dito mais acima. Essa inflação crescente acontecia, mesmo variando de setor para setor da economia como, por exemplo, no caso dos têxteis cujos preços subiram $900 \%$ enquanto os alimentos subiram $600 \%$ devido a diversas causas como o aumento da oferta de dinheiro em circulação, a escassez de determinados produtos e a grande demanda de bens e serviços pelas tropas aliadas. Tentou-se combater a inflação por meio de medidas de estabilização e controle de preços, porém sem resultados ${ }^{112}$.

O comércio externo do Líbano nessa época estava, por conta da guerra, concentrado no Oriente Médio. $90 \%$ das importações vinham da região que também era o destino de 97\% das exportações, quando em 1938 era 37\%. No seu entorno o Líbano continuava a ter na Palestina o seu principal mercado. Esse país também fornecia bens industrializados que a indústria libanesa não fornecia em quantidade suficiente ou não produzia. Só as importações de todos os países da zona da libra esterlina (Iraque, Palestina, Transjordânia, Egito, Chipre e Reino Unido) representavam 47\% do total em 1945. Nos anos da guerra as exportações do Líbano para os EUA e a Europa eram poucas. Em 1943 foram apenas 3,5\% do total. De maneira geral houve uma grande queda do comércio internacional: O volume das exportações caiu em 71\% nos anos entre 1942 e 1945 se comparado com o período de 1935 a 1938; já o volume das importações decresceu em 21 \% entre 1939 e $1945^{113}$.

Os anos da Segunda Guerra Mundial foram uma reversão temporária da orientação externa da economia libanesa, algo que a caracterizava nos séculos XIX e XX, tanto que suas medidas de controle das atividades econômicas foram revertidas nos anos seguintes ao fim da guerra. No entanto, os grandes ganhos econômicos e os benefícios dos investimentos em infraestrutura feitos pela administração dos aliados tiveram uma contribuição decisiva para o desenvolvimento que o Líbano teve no pós-guerra quando adotou o livre-mercado como programa econômico a partir de 1948.

Por outro lado, para Gaspard (2004) os anos da Segunda Guerra Mundial foram uma segunda oportunidade histórica perdida para que o Líbano pudesse seguir um caminho distinto do laissez-faire que marcou a história do país na segunda metade do século XX. Entre 1940 e 1944 as forças aliadas gastaram cerca de 76 milhões de libras libanesas tanto na Síria

\footnotetext{
112 Idem. p. 52-53, 55 e 57.

${ }^{113}$ Idem. p. 60.
} 
como no Líbano. Sendo que a cota anual do Líbano nesses gastos representava cerca de $10 \%$ da renda nacional enquanto, ao mesmo tempo, ambos os países acumulavam um saldo de conta corrente de 60 milhões de libras libanesas ao longo do conflito. Isso, mais o pequeno desemprego e o excedente no tesouro nacional, que foi entre 1939 e 1944 de 23 milhões de libras libanesas, permitiriam ao Estado promover uma política de industrialização após o fim da guerra, ou ao menos de crescimento econômico, se as elites libanesas assim desejassem. Porém, o caminho escolhido foi completamente diferente ${ }^{114}$.

Ainda durante a guerra, no ano de 1944, o governo libanês estabeleceu com a Síria vizinha um programa de gestão cooperativa sobre a economia. Durante esse período ocorreu um acordo financeiro entre o governo da França Livre e a Grã-Bretanha por meio do qual se promoveu uma desvalorização do franco francês em relação à libra esterlina, o que levou os sírios e libaneses a depreciarem a taxa de câmbio do franco de 20 para 22,65 francos e pela mesma razão foi anunciada a livre convertibilidade da libra sírio-libanesa em relação à moeda britânica no valor S1\$ 8,83 para cada libra esterlina. Essa foi uma medida que indicava a libertação da Síria e do Líbano do controle francês. Nesse processo, prometeram providenciar a esses dois países as libras esterlinas necessárias na taxa de câmbio existente e garantir o valor das reservas de franco no BSL contra qualquer depreciação da moeda francesa no futuro ${ }^{115}$.

\subsection{A Segunda Guerra Mundial e a independência do Líbano}

A Segunda Guerra Mundial foi um acontecimento decisivo para a independência do Líbano. A ocupação da França pelos alemães em junho de 1940 colocou o país sob o controle do governo colaboracionista de Vichy do marechal Phelippe Petain. Isto deixou o país, juntamente com a vizinha Síria, numa situação de vulnerabilidade militar, pois estava quase que cercado por territórios sob o controle direto ou indireto dos britânicos.

Além disso, os alemães em 1941 passaram a usar as bases aéreas da Síria, governos do Oriente Médio e movimentos nacionalistas, em parte devido a sentimentos anticolonialistas, e mostravam simpatias para com os alemães que poderiam apoiá-los a partir do levante francês. Era só questão de tempo para que os britânicos ocupassem o Líbano e

\footnotetext{
114 GASPARD. p. 52-55.

${ }^{115}$ MALLAT. 70 Years of Money Muddling in Lebanon...p. 100-101.
} 
expulsassem o governo mandatário de Vichy. Essa operação militar finalmente ocorreu em junho de 1941 a partir das bases localizadas no Iraque, Palestina e Transjordânia, na operação que durou cerca de um mês e meio e terminou em julho com a retirada do governo mandatário do levante após a assinatura de um armistício na cidade de Acre na Palestina.

Sob o governo de Vichy nos primeiros meses o Líbano ainda continuou sob a administração de Gabriel Puaux que havia declarado lealdade ao novo regime, mas em dezembro Henry Dentz, um militar membro do novo governo de Petain, foi indicado como novo Alto Comissário do país ${ }^{116}$. O Líbano atravessou momentos difíceis devidos à escassez de alimentos, autoritarismo, a incapacidade administrativa do governo Dentz e o quase desaparecimento do comércio internacional. Contra essa situação se verificaram no país diversos e frequentes motins ${ }^{117}$.

A campanha da Síria contou com a participação de regimentos franceses do governo da França livre, no exílio em Londres, sob o comando do general Charles de Gaulle. Ele enviou um alto comissário para o Líbano, o general Georges Catroux, que chegou com a promessa de conceder a independência ao país, conforme o tratado de 1936.

Em 26 de novembro de 1941 Catroux decretou formalmente a independência do Líbano, mas, na prática, fez de tudo para postergá-la ao máximo, pois o governo da França Livre não desejava verdadeiramente conceder a independência ou sequer retirar as tropas francesas do Líbano ou da Síria. No entanto, os franceses enfrentavam a oposição dos britânicos que desejavam expulsá-los do Oriente Médio e começaram a apoiar os grupos libaneses favoráveis à independência. O governo britânico, para estimular os nacionalistas sírios e libaneses, ainda em 1941 reconheceu a independência de seus países.

Logo após a declaração de independência, continuando a intenção do governo da França Livre de continuar controlando o Líbano, Catroux renomeou como presidente Alfred Naccache que já estava no cargo desde o governo de Dentz. No entanto, existia uma novidade importante no gabinete do novo governo, a existência de um ministro das relações exteriores que era uma manifestação clara dos libaneses de terem sua independência reconhecida de fato $^{118}$.

${ }^{116}$ ATTIÉ, Caroline. Struggle in the Levant: Lebanon in the 1950s. Londres e Nova Iorque: I. B. Tauris in association with Centre for Lebanese Studies, 2004. p. 19.

${ }^{117}$ GORIA, Wade R. Sovereignty and leadership in Lebanon, 1943-1976. Londres: Ithaca Press, 1985. p. 24.

${ }^{118}$ SALIBI. p. 185. 
A população e a classe política do Líbano ficaram divididas quanto a sua lealdade durante esse período da rivalidade franco-britânica em seu país. Um setor importante da população cristã, que tinha na figura do ex-presidente Emile Eddé e seu Bloco Nacional o seu principal líder, ficou do lado dos franceses, pois desejava manter alguns laços com a antiga metrópole mandatária e não ver o Líbano absorvido em um Estado pan-árabe, enquanto outro grupo, que também incluía os muçulmanos, passou a apoiar Bechara el-Khuri e o seu bloco constitucionalista ou o partido Desturi, que advogava pela completa independência e era apoiados pelos britânicos.

Em janeiro de 1943 os franceses, sob pressão de Spears, anunciaram o restabelecimento em breve da vida constitucional no Líbano suspensa há mais de três anos e anunciaram a realização de eleições. Eles procuravam estender ao máximo o controle sobre o país para negociar um tratado de independência que lhes concedesse privilégios econômicos e diplomáticos após o fim do mandato como havia feito o tratado de 1936. O controle das chamadas Troupes Speciáles du Levant e a presença dos soldados da França Livre serviam como uma força de pressão dos franceses sobre os sírio-libaneses para que estes cedessem a sua vontade.

Foi apontado então para administrar de maneira interina o país o protestante Ayub Thabit, figura muito próxima de Émile Éddé. Thabit estabeleceu a primeira divisão das cadeiras do parlamento entre cristãos e muçulmanos em uma proporção de 32 para os cristãos e 22 para os muçulmanos. Também concedeu o direito de voto para os imigrantes que na época eram 160 mil e majoritariamente cristãos.

Os dois projetos foram rejeitados de maneira firme pelos muçulmanos, o que acabou provocando a renuncia de Thabit. O cristão-ortodoxo Petro Trad foi então indicado para o posto e, com a mediação do primeiro-ministro egípcio Nahas Pashá, conseguiu emitir um decreto da nova Lei Eleitoral, que cancelou o voto dos imigrantes e estabeleceu que o parlamento deveria ter 55 cadeiras: 30 para os cristãos e 25 para os muçulmanos em uma proporção de $6 / 5$ que se manteve até $1990^{119}$.

A nomeação de Riad el-Solh para o cargo de primeiro-ministro também era uma vitória dos nacionalistas sírios e mesmos dos pan-arabistas ao confirmar a decisão das elites cristãs, particularmente das maronitas, a despeito das pressões e chantagens dos fenicistas e libanistas, que estavam dispostas a se livrarem dos franceses.

119 TRABOULSI, Fawwaz. A modern history of Lebanon. Londres e Nova Iorque: Pluto Press, 2007. p. 106. 
Em outubro uma delegação de alto nível do governo sírio, encabeçada pelo primeiroministro Mardam Bey, chegou a Beirute. Eles chegaram com os libaneses a um acordo a respeito de questões essenciais no que dizia respeito à independência de ambos os países e a suas futuras relações: Dessa maneira a Síria reconhecia e defenderia a soberania do Líbano junto com a sua. Já o Líbano comprometia-se a não permitir que o seu território fosse usado como base para ataques à Síria por parte de forças que ameaçassem a sua soberania. Finalmente os dois países estabeleceriam uma estreita colaboração nos terrenos social e econômico.

Após o estabelecimento desse compromisso os libaneses pediram ao Comitê Nacional da França Livre a transferência dos poderes e do controle dos Intérêts Communs ${ }^{120}$. Os franceses recusaram afirmando que o Líbano ainda se encontrava na situação de mandato e que não haveria discussão a respeito do seu fim sem um tratado ${ }^{121}$.

No dia 21 de setembro, durante as eleições para o parlamento, o bloco constitucionalista foi o mais votado. Em 7 de outubro o parlamento libanês elegeu Bechara elKhuri como presidente e este nomeou como primeiro-ministro a Riad el-Solh. Era uma vitória das forças independentistas apesar dos esforços dos franceses para alterar o resultado das eleições incluindo na Câmara um grande número de deputados pró-mandato ${ }^{122}$.

A formação do gabinete também refletiu um desejo de se chegar a um acordo com as elites de todas as comunidades. Dessa forma houve uma divisão das pastas ministeriais de acordo com a importância numérica de cada uma das seis principais seitas do país. Dessa forma também eram representados os xiitas, drusos, cristão-ortodoxos e greco-católicos ${ }^{123}$.

120 Os Intérêts Communs (Interesses Comuns em francês) eram um conjunto de serviços, como aduana, correios e telégrafos, serviços de antiguidade e supervisão das empresas concessionárias. Eram administrados pelo Alto Comissariado por meio do departamento dos Intérêts Communs que foi estabelecido em 1928 e controlava totalmente o seu orçamento cuja origem vinha maciçamente $(95 \%)$ das receitas aduaneiras. Como o Líbano e a Síria faziam parte de uma única zona alfandegária era difícil saber a contribuição de cada um para as despesas desses serviços e ambos reivindicavam $70 \%$ das receitas dos Intérêts Communs, os sírios devido ao território e população maiores do seu Estado e os libaneses por afirmarem que, devido ao alto padrão de vida de sua população, esta tinha um alto consumo de mercadorias estrangeiras. Para resolver essa disputa o Alto Comissariado havia imposto em 1930 o Acordo de União Alfandegária que dividiu a receita dos Intérêts Communs da seguinte maneira: 53\% para a Síria e 47\% para o Líbano. CHAITANI, Yussef. P. 18-19.

121 TRABOULSI. p. 106-107.

122 CHAITANI, Yussef. Post-colonial Sirya and Lebanon: the decline of Arab nationalism and the triumph of State. p. 16.

123 SALIBI, Kamal S. The modern history of Lebanon. Westport-Connecticut: Grenwood Press, 1976 (reimpressão). p. 188. 
No discurso realizado após a sua nomeação como presidente, el-Khuri afirmou o seu compromisso de defender as fronteiras do Líbano, mas afirmou a necessidade de firmar um acordo com os sírios para assumir o controle conjunto dos Intérêts Communs e romper o isolamento do Líbano no mundo Árabe levando-o a cooperar com esses países. Porém, o novo presidente, embora se lembrasse das características árabes dos Líbano, afirmou que seu país desejava manter relações com as nações ocidentais, mas isso não significava que o Líbano devesse ser uma colônia ou um meio pelo qual os outros países árabes fossem colonizados. No dia seguinte el-Khouri viajou a Damasco para conversar com os líderes nacionalistas sírios que haviam recebido com satisfação a sua eleição para a presidência, bem como o seu discurso de posse ${ }^{124}$.

A independência completa do Líbano foi estabelecida em 1943. Em 25 de outubro daquele ano, o governo libanês enviou uma carta ao delegado-geral francês Jean Helleu pedindo a independência e afirmando o seu desejo de rever a constituição para que ela reconhecesse esse fato. Também pediam aos franceses que todos os serviços públicos fossem transferidos ao governo libanês e que a sua delegação fosse transformada em missão diplomática. Ele recusa afirmando que o Líbano ainda estava muito prematuro para a autodeterminação $^{125}$.

Em 8 de novembro de 1943 a Câmara libanesa passa uma série de emendas revisando a Constituição, estabelecendo o árabe como a única língua oficial do país, adotando um novo desenho para a bandeira nacional e, mais importante, afirmando que a autoridade mandatária não era a única fonte de poder político e jurisdicional no país. No dia seguinte elKhuri imediatamente ratificou as decisões do parlamento. Sendo essas medidas um desafio aos franceses, Jean Helleu imediatamente as declarou nulas por terem sido estabelecidas sem consulta às autoridades francesas. No dia 11, ao amanhecer, o presidente el-Khuri, el-Solh, Karami e os ministros Salim Taqla e Camille Chamoun foram presos em suas casas e levados para a fortaleza de Rachaya na região de Wadi el-Taym no sudeste do país. Émile Éddé foi então apontado novamente como presidente, mas foi fortemente rejeitado pela classe política. Helleu suspendeu novamente a Constituição e dissolveu o parlamento. Imediatamente greves e manifestações foram deflagradas por todo o Líbano. Um governo provisório foi formado por

124 CHAITANI, Yussef. Post-colonial Sirya and Lebanon: the decline of Arab nationalism and the triumph of State. I. B. Tauris, 2007. p. 16.

125 WINSLOW, Charles. Lebanon: war \& politics in a fragmented society. Londres e Nova Iorque: Routledge, 1996. p. 72. 
Habib abu Chahla, presidente do parlamento, e o líder druso Majid Arslan, o ministro da Defesa, na aldeia de Bshamun nas montanhas ${ }^{126}$.

Grupos políticos antagônicos como o Kataeb, nacionalista libanês de base maronita, e o Najjada, uma espécie de versão muçulmana do primeiro, juntaram os seus esforços para combater os franceses e exigir a libertação dos líderes libaneses presos. Os deputados do parlamento dissolvido continuam a se reunir em suas casas onde decidem pela manutenção das decisões tomadas antes da precisão do presidente e seu gabinete. Em resposta, os franceses impõem um forte toque de recolher em Beirute enquanto suas tropas atiram na multidão que protesta matando e ferindo inúmeros libaneses. Em Bshamun, o governo provisório recebe apoio popular e o respaldo dos deputados. Mesmo os círculos mais radicais entre os maronitas apoiam esse governo. Ao mesmo tempo, o general Spears estimula-o e condena publicamente os franceses ${ }^{127}$.

Nas principais cidades a população, comandada por lideranças de diversos partidos e movimentos nacionalistas e sindicais, manteve uma série de protestos e greves exigindo a libertação do presidente e seus ministros e a independência do país. Muitos libaneses foram para frente da residência do enviado britânico Edward Spears e pediram para que intercedesse junto aos franceses e conseguir dessa maneira a libertação dos prisioneiros de Rashayya, utilizando assim, a favor do Líbano, a rivalidade anglo-francesa.

Os britânicos agiram rapidamente enviando um ultimato aos franceses ameaçando usar suas tropas no Líbano caso eles não libertassem o presidente libanês e seus ministros e substituíssem Jean Helleu como delegado-geral, dando um prazo até às 10 da manhã de 22 de novembro para que suas exigências fossem cumpridas. De imediato os franceses ignoraram as ameaças britânicas, mas havia um ambiente totalmente desfavorável a eles, com os regimes árabes vizinhos apoiando a demanda libanesa por independência, o apoio dos EUA às posições de Londres, além da fragilidade política e militar do governo da França livre que dependia dos britânicos para existir.

Dessa maneira, em 17 de novembro, de Gaulle enviou Georges Catroux ao Líbano para negociar a independência. Ao chegar removeu Jean Helleu de seu posto e procedeu à libertação dos prisioneiros em Rashayya no dia 22, sendo recebidos em triunfo em Beirute ${ }^{128}$.

\footnotetext{
126 TRABOULSI. p. 107.

127 SALIBI. p. 189-190.

${ }^{128}$ SALIBI. p. 188-189. ATTIÉ, C. p. 23-25.
} 
Vale lembrar nesse episódio a participação das lideranças árabes, pois a prisão de boa parte dos membros do governo libanês teve grande repercussão no mundo Árabe. Os governos de Egito, Arábia Saudita e Iraque condenam os franceses e juntos com o primeiroministro Winston Churchill interviram diante do governo da França livre de Charles de Gaulle em Argel ${ }^{129}$. Aliás, o Egito, o fiador do Pacto Nacional, é o primeiro país árabe a reconhecer a independência do Líbano ${ }^{130}$.

Desde então, essa data passou a ser comemorada como o dia oficial da independência libanesa. Nos anos seguintes os franceses foram entregando mais prerrogativas do mandato ao novo Estado libanês, como o controle das alfândegas, das forças de seguranças e os instrumentos de censura à impressa e editoras.

A independência do Líbano foi produto da rivalidade anglo-francesa no Oriente Médio e, particularmente, da situação de fraqueza do governo da França livre frente a Londres. Desde a ocupação britânica da Síria e do Líbano eles haviam publicamente se comprometido com a independência desses dois países. Em 1941, o embaixador de Londres no Cairo, Sir Miles Lampson, havia confirmando a declaração de Catroux e reconhecido, em nome do rei, o direito à independência de sírios e libaneses ${ }^{131}$. No Líbano os britânicos buscaram afastar a potência rival do Oriente Médio para garantir com quase exclusividade o acesso de seu capital aos investimentos e mercados da região. Dessa forma, desde o início apoiaram o bloco constitucional de Bechara el-Khuri contra o bloco nacional pró-francês de Éddé. Por conta disso eram frequentes as reuniões das lideranças nacionalistas independentistas libanesas com o general Spears, bem como suas queixas a ele com relação aos franceses.

Quanto aos franceses, estes percebiam a manobra dos britânicos, mas não tinham condições de fazer nada. A sua raiva só ficou publicamente demonstrada alguns anos depois quando o general Catroux acusou os britânicos de se aproveitarem da crise de 1943 no Líbano para se beneficiarem e minarem a posição dos franceses no Oriente Médio ${ }^{132}$.

Entretanto, para que a independência fosse real e não fictícia era necessário que tanto Damasco quanto Beirute tivesse total controle dos serviços do país. Por isso os

129 ATTIÉ, Caroline. Struggle in the Levant: Lebanon in the 1950s. Oxford, Londres e Nova Iorque: I. B. Tauris in association with Centre for Lebanese Studies, 2004. p. 24.

${ }^{130}$ SALIBI. p. 190. TRABOULSI. p.108.

131 ATTIÉ. p. 20.

132 Idem. p. 24-25. 
nacionalistas sírios e libaneses vinham pedindo ao alto comissariado que repassasse o controle sobre os Intérêts Communs. Isto finalmente ocorreu em 1 de janeiro de 1944, após a assinatura de um acordo entre o delegado-geral francês Georges Catroux e os representantes dos governos de Damasco e Beirute em 22 de dezembro de 1943 na capital síria.

Junto com o controle desses serviços foi permitido aos dois governos emitirem leis e regulamentos para organizar o seu funcionamento. Ao mesmo tempo, os governos da Síria e do Líbano aceitaram partilhar entre si as receitas e as diferenças entre os dois Estados a respeito delas foram colocadas momentaneamente em segundo plano. Esse acordo foi então submetido ao parlamento de ambos os países sendo aprovado com unanimidade e grande entusiasmo. Para administrar os Intérêts Communs ambos os governos concordaram no estabelecimento de um alto conselho para os Intérêts Communs que iria vigiar as contas destes e garantir a distribuição de suas receitas entre os dois Estados. Em 4 de janeiro foi realizada a cerimônia oficial de entrega desses serviços aos sírios e libaneses e assinado oficialmente o acordo de entrega.

Outro aspecto importante a destacar nesse processo é que pela primeira vez em 25 anos os libaneses e os sírios estavam juntos em uma negociação enquanto os franceses compunham a outra parte. Isto mostrava um desenvolvimento novo da política libanesa, tanto em relação ao seu vizinho, como, em breve, em relação ao restante do mundo Árabe. Poucos anos antes, em 1938, as negociações a respeito dos Intérêts Communs e suas receitas haviam chegado a impasse devido à atitude inflexível do então presidente libanês Émile Eddé. O resultado havia sido a manutenção do controle francês dos Intérêts Communs. Em 1943 foi diferente e, por sua vez, foi essencial para que as negociações com os franceses fossem bem sucedidas o empenho conjunto de Bechara el-Khuri e Riad el-Solh ${ }^{133}$.

No começo de 1944, logo após a assinatura do acordo de entrega dos Intérêts Communs ocorreu um incidente que poderia prejudicar as relações entre sírios e libaneses: $\mathrm{O}$ patriarca maronita Antun Arida veio a público e afirmou que esse acordo estava violando a soberania do Líbano. Ele pediu ao presidente que o cancelasse, pois a entrega do alto conselho dos Intérêts Communs se dava desde que este se tornasse independente tanto do Executivo quanto do Legislativo.

As declarações do patriarca atiçaram os nacionalistas libaneses mais extremistas

133 CHAITAN, Yussef. Post-colonial Syria and Lebanon: the decline of Arab nationalism and the triumph of State. p. 19-20. 
que eram, na realidade, contra o Pacto Nacional e a favor da manutenção do mandato. Estes de imediato apoiaram as posições de Arida e afirmavam que o acordo entrava em choque com a Constituição do país ao criar dois conjuntos de legislações. Os nacionalistas árabes libaneses criticaram essa posição afirmando que isso não iria acontecer, pois tanto Síria quanto Líbano cooperariam no estabelecimento de impostos aduaneiros e começaram a fazer uma campanha no parlamento pela ratificação do acordo.

Enquanto isso Bechara el-Khuri havia emitido uma declaração reconhecendo a existência de certas ambiguidades no acordo e que, devido a isso, estava enviando um projeto de lei ao parlamento removendo as partes ambíguas do acordo, afirmando que apenas o governo libanês tinha autoridade para legislar a respeito. O patriarca assim mesmo não se deu por convencido e emitiu outra declaração reafirmando a sua posição inicial. Ele concentrou as suas críticas no ponto quatro do acordo que previa a manutenção da zona alfandegária única como no tempo do mandato e a livre circulação de bens nos dois países. Mas dizia que, da mesma maneira que os sírios estavam autorizados a cobrar uma taxa de trânsito para os produtos que passassem por seu território caso estes prejudicassem sua economia, então os libaneses deveriam também cobrar uma taxa sobre as importações sírias que passassem sobre o território libanês e assim seriam removidos todos os motivos de diferenças. Arida ainda afirmou que não deveria existir nenhum tipo de união entre as economias de ambos os países como aconteceu sob o domínio francês. Por isso os Intérêts Communs deveriam ser extintos, pois eles eram um meio para uma futura integração entre Síria e Líbano, algo que ele rejeitava assim como qualquer tipo de unidade árabe ${ }^{134}$.

A situação era complicada e poderia vir a comprometer as boas relações com os sírios na luta pelo fim definitivo da presença francesa nos dois países, além de ser um grande estímulo para os cristãos conservadores antiárabes. Para tentar resolver a contenda, o próprio primeiro-ministro Riad el-Solh foi encontrar-se com Arida em seu palácio na cidade de Bkerke. Jantando com o patriarca, el-Solh destacou as vantagens do acordo para o Líbano e após o final do encontro o líder sunita disse que Arida acabou convencido do quanto esse acordo era benéfico para o Líbano. Também foi prometido a este que o artigo três seria refeito e onde se dizia "putting the necessary legislation for all the directorates of the Common Interests" se substituiria por "drafting or preparing the necessary legislation". Essa aceitação por parte do patriarca foi simbolizada pela entrega ao primeiro-ministro de uma caixa com

${ }^{134}$ Idem. p. 21-22. 
doces sírios $^{135}$.

Por fim, após forte debate no parlamento e na sociedade, Bechara el-Khuri assinou um decreto em 18 de março de 1944 estabelecendo o Alto Conselho dos Intérêts Commun. Como não se estabeleceu nenhuma comissão executiva conjunta com os sírios para administrá-los, o governo libanês conseguiu desramar os ataques dos nacionalistas libaneses como George Aql e Alfred Naccache. O acordo também havia limitado a união alfandegária e deixou para futuras negociações outros aspectos da união econômica. Nenhuma obrigação contratual havia sido estabelecida entre sírios e libaneses sobre esses temas ${ }^{136}$.

No entanto, o aspecto mais espinhoso da transferência de poder dos franceses para os sírios e libaneses era a questão das chamadas Tropas Especiais do Levante, uma força militar composta de sírios e libaneses, mas dirigida pelos franceses. Bem como o da Sûréte Générale, os serviços de segurança criados e equipados pelos colonizadores.

Para os sírios e libaneses era uma questão central para a afirmação de sua soberania a formação de exércitos nacionais sob o comando de seus respectivos governos. Tanto na Síria como no Líbano os respectivos governos haviam enviado para os seus parlamentos projetos de lei direcionando somas do orçamento geral para o estabelecimento de suas respectivas forças armadas no valor de 5 milhões de libras no Líbano e 15 milhões na Síria. No entanto, os franceses não desejavam transferir o mais rápido possível esses serviços e diziam que, para isso acontecer, era necessário que uma Convention Universitaire fosse assinada primeiro. Porém, como tanto Beirute quanto Damasco não desejavam assinar nenhum acordo internacional antes do final da Segunda Guerra Mundial, a situação com relação às Tropas Especiais e ao Sûréte Générale estava em um beco sem saída.

Para resolver esse problema Damasco e Beirute começaram a buscar apoio internacional e líderes de ambos os governos encorajaram as suas respectivas populações a realizarem manifestações contra a presença francesa nos dois países ${ }^{137}$.

Logo após a delegação libanesa retornar do Egito onde foi assinado o Protocolo de Alexandria, tanto os franceses quanto os grupos políticos libaneses pró-franceses começaram a pressionar Riad el-Solh para que assinasse a Convention Universitaire. Houve uma reunião entre o presidente Khuri e o representante francês, o general Beynet, o qual disse

\footnotetext{
135 Idem. p. 22.

136 Idem. p. 27.

137 Idem. p. 24.
} 
que a assinatura por parte do Líbano do Protocolo de Alexandria impedia a França de assinar qualquer tratado e que até mesmo à declaração de independência emitida pelo general Catroux poderia ser revogada.

Em resposta à ameaça francesa, o parlamento libanês emitiu um sonoro voto de aprovação ao Riad el-Solh por seu trabalho em Alexandria. No entanto, como não se conseguiu atacar el-Solh no campo diplomático, começaram a pressioná-lo no campo econômico e social onde havia uma grande insatisfação da população com o crescimento do custo de vida. As pressões o forçaram a renunciar em 7 de janeiro de 1945. Ao mesmo tempo, os nacionalistas libaneses começaram uma campanha afirmando que o Protocolo de Alexandria era uma ameaça à soberania do Líbano e que deveria levar à dominação muçulmana $^{138}$.

Pouco depois, em uma declaração para a imprensa do representante em Londres dos governos de Damasco e Beirute, Camille Chamoun - futuro presidente do Líbano afirmou que o seu país não se envolveria em nenhum acordo com a França ou outro país sem consultar os seus parceiros do Protocolo de Alexandria, o acordo então recém assinado entre os Estados árabes independentes para a criação da Liga Árabe.

Os círculos nacionalistas cristãos reagiram com furor vendo nas declarações do maronita Chamoun uma ofensa ao seu país e que deveriam puni-lo com o silêncio. Eles exigiram do governo uma explicação e várias de suas lideranças políticas fizeram proclamações destacando o direito do Líbano em assinar os acordos que desejasse e que fossem do seu interesse nacional. O governo foi então obrigado a emitir um comunicado no qual afirmava que, segundo uma seção do Protocolo de Alexandria, nenhum Estado árabe era obrigado a buscar a aprovação dos outros membros para assinar qualquer tratado. Após esse comunicado, o arcebispo maronita de Beirute Ignatius Mubarak proferiu um discurso em companhia do primeiro-ministro Abdul Hamid Karami, no qual louvava os esforços do governo para esclarecer a situação e refutar as afirmações de Camille Chamoun afirmando que: "in the name of the whole Lebanese people, regardless of their religion or sect, [...] they wish to preserve their independence". Mais tarde o próprio Chamoun se retratou afirmando o mesmo que o governo havia dito a respeito do Líbano estar livre para assinar os tratados que quisesse $^{139}$.

138 Idem. p. 26.
${ }^{139}$ Idem. p. 26. 
No começo de 1945, mediados pelos britânicos em Londres, os sírios e libaneses reabriram conversações com os franceses a respeito do início das negociações para a transferência das forças de segurança e das Tropas Especiais. Ao mesmo tempo negociavam com os britânicos a evacuação das tropas destes de seus territórios. Os franceses esperavam que essas negociações forçassem os sírios e libaneses a lhes conceder privilégios econômicos e diplomáticos quando se retirassem de ambos os países.

Em abril tanto Damasco quanto Beirute receberam um comunicado do entendimento a que haviam chegado os Estados ocupantes a respeito da retirada de suas tropas. Os britânicos decidiram retirar as suas forças antes do estabelecimento de um acordo entre sírios e libaneses com os franceses. Essa declaração trouxe profunda preocupação sobre os dois governos árabes, pois recordava os eventos de 1920 quando a saída do exército britânico foi seguida da ocupação militar francesa. Havia, portanto, o temor de que Paris se aproveitasse dessa situação para obter vantagens no levante.

Em 19 de abril houve um encontro entre o primeiro-ministro sírio Mardam Bey e o conde Stanilas Ostrorog que atuava como Alto Comissário. Este demandou do líder sírio a assinatura de um acordo cultural que os sírios não desejavam, bem como afirmara que seu governo assinaria um acordo global se Damasco aceitasse rever a Convention Universitaire. Imediatamente após o fim da reunião que havia se tornando extremamente tensa, Mardam Bey reuniu-se com o primeiro-ministro Karami e ambos declararam publicamente que a revisão da Convention Universitaire era inaceitável ${ }^{140}$.

Em 14 de maio o governo libanês soube que um destacamento de tropas francesas havia partido de Túnis em direção a Beirute tendo chegado algum tempo depois. Esse desembarque veio acompanhado de novas propostas por parte de Paris. Nas maiores cidades sírias e libanesas ocorreram greves e manifestações contra esse ato de provocação que mais parecia indicar que os franceses não desejavam sair do levante.

Enquanto isso, os representantes dos governos de Damasco e Beirute reuniram-se com os delegados da França. Estes apresentaram um memorando contendo uma série de exigências francesas que destacavam a sua posição especial nos dois países como a necessidade de garantir os seus interesses financeiros, os de suas companhias e salvaguardar as atividades de seus grupos religiosos. As duas delegações levantinas se recusaram a debater essas questões afirmando que o mais urgente era debater sobre a presença das tropas francesas

140 Idem. p. 28. 
recém-chegadas da Tunísia, algo de que os franceses procuraram o tempo todo se evadir.

Cinco dias após o encontro com os franceses, os presidentes da Síria e do Líbano junto com os seus primeiros-ministros se reuniram em Shtura, no próprio Líbano. Na reunião foram analisadas as relações dos dois países com a França e o conteúdo do memorando. Decidiu-se que nenhum dos lados entraria em conversações com a França sem uma consulta com o outro. Ambos os lados concordaram em elaborar um relatório destinado aos demais governos árabes e às grandes potências informando sobre o desenvolvimento de suas respectivas ações. No fim da reunião, um comunicado foi emitido afirmando que o desembarque das tropas francesas era uma violação da soberania tanto do Líbano quanto da Síria e que o memorando apresentava propostas que eram contrárias à independência de ambos os Estados e, portanto, as negociações com Paris estavam suspensas. Pouco depois, o próprio ministro das relações exteriores do Líbano afirmou publicamente que o seu país não negociaria sob coerção ${ }^{141}$.

É impressionante nessa situação que mesmo a demonstração de força por parte da França não era vista pelos nacionalistas libaneses como um ato arbitrário e colonial. Eles estavam mais preocupados com as cláusulas da carta da recém-criada Liga Árabe que impediam o Líbano, bem como qualquer outro Estado membro, de assinar acordos com potências lhes concedendo posições privilegiadas ou tratados que ameaçassem violar as suas independências. Perguntavam se havia uma cláusula secreta afirmando isso, pois caso contrário nada impediria o Líbano de assinar um tratado com a França, pois esse país havia legado a sua cultura aos libaneses, bem como a todas as suas instituições.

Manifestações aconteciam tanto no Líbano como na Síria, país em que a população passou a desafiar abertamente as tropas ocupantes francesas e, para demonstrarem a sua força, bombardearam Damasco entre 29 e 30 de maio, o que incendiou a cidade. E só pararam devido à intervenção dos britânicos que ordenaram aos agressores retornar aos seus quartéis tendo assumido o controle militar da capital até que o governo sírio pudesse reassumir normalmente as suas funções ${ }^{142}$. Essa ação foi totalmente condenada pelas autoridades libanesas. Seu governo enviou 100 mil libras em ajuda e o próprio Karami entregou pessoalmente esse dinheiro aos damascenos. A prefeitura de Beirute doou 20 mil e

\footnotetext{
141 Idem. p. 29.

142 Idem. p. 30.
} 
enviou os seus bombeiros à capital síria ${ }^{143}$.

Em junho uma comunicação verbal dos governos sírio e libanês endereçada ao governo de Londres se posicionava "not willing to concede any influence to France or conclude any treaty with her" e afirmava que as relações com a França somente seriam estabelecidas com base nas leis internacionais. O Conselho da Liga Árabe também emitiu uma declaração apoiando a posição de Damasco e Beirute e condenando a agressão francesa. Em 21 de junho, um novo comunicado conjunto de sírios e libaneses pediu a implementação da decisão da Liga Árabe, a demissão dos funcionários franceses que trabalhavam nos dois governos, a retirada das tropas de Paris, a entrega a ambos das Tropas Especiais do Levante e a recusa de conceder qualquer privilégio à França ${ }^{144}$.

No Líbano, os franceses enquanto isso procuravam fomentar a discórdia entre as comunidades religiosas libanesas. Eles começaram a pressionar o patriarca maronita que até então tinha tomado posições a favor da independência e dos grupos que a defendem. Como resultado das pressões Arida subitamente mudou de posição e declarou publicamente que, sem os franceses, os cristãos libaneses corriam o risco de se verem dominados ou perseguidos pelos muçulmanos.

A solução para isso seria permitir a formação de um 'pequeno Líbano' cristão protegido pela França enquanto as zonas, como Trípoli, de maioria muçulmana, seriam devolvidas à Síria. Quem também pressionou o patriarcado maronita a defender a presença dos franceses no país foi o Vaticano com a declaração do Papa Pio XII defendendo a proeminência francesa na região do levante. No entanto, tudo isso foi em vão, pois em julho os franceses aceitaram se desfazer das tropas especiais do levante e para isso foram importantes as negociações mantidas entre eles e o governo britânico de Clement Atlee a respeito de suas posições no Oriente Médio com o fim da Segunda Guerra Mundial, que ficaram conhecidas como Acordo Bevin-Bidault.

Como resultado desse acordo, os governos sírio e libanês decidiram levar a sua contenda com a França, em conjunto, para o recém-criado Conselho de Segurança da ONU. O representante norte-americano, então, introduziu uma resolução pedindo a saída das tropas anglo-francesas de ambos os países. Como o mundo que acabava de sair da Segunda Guerra Mundial era radicalmente distinto do que havia seis anos antes e nesse novo contexto Grã-

\footnotetext{
143 Idem. p. 31.

144 Idem. p. 30.
} 
Bretanha e França eram potências decadentes sob a hegemonia de Washington, seus governos não tiveram alternativa além de reconhecer que estavam perdendo influência sobre o Oriente Médio.

Dessa forma em um comunicado conjunto, ambos os governos reconheceram a necessidade de garantir a independência da Síria e do Líbano conforme havia sido anunciado ainda durante a guerra e ainda aceitaram que os dois países árabes estivessem representados na ONU. Em 21 de dezembro, especialistas militares das potências ocupantes se reuniram em Beirute para acertar a evacuação que se daria em $1946^{145}$. Nessa mesma época as tropas especiais do levante foram finalmente cedidas aos governos da Síria e do Líbano, tornando-se assim a base de seus respectivos exércitos. $\mathrm{O}$ mesmo aconteceu com os serviços de segurança.

\subsection{O reconhecimento do Líbano por suas elites muçulmanas e pelos sírios}

Inicialmente os nacionalistas sírios consideravam o parlamento libanês e o seu presidente como totalmente ilegítimos e não representativos, as elites libanesas eram vistas como fantoches dos franceses e o Estado do Líbano como um satélite deles contra o mundo Árabe. Porém, essa atitude foi mudando, pois os sírios perceberam que, sem o apoio dos libaneses, caso buscassem enfrentar os franceses sozinhos, a luta pela independência não seria exitosa. Isso implicava reconhecer o Líbano como país independente com as suas fronteiras como foram estabelecidas em 1920. Porém também significava atrair o Líbano para o Mundo Árabe como mais um Estado membro desse concerto de nações quando as potências coloniais europeias fossem expulsas de seus territórios e pedir aos libaneses que afastassem do poder indivíduos ou grupos ligados à França e com posturas hostis em relação aos países árabes, como era o caso do ex-presidente Émile Éddé ${ }^{146}$.

A Eleição de Bechara el-Khuri e a nomeação de Riad el-Solh como primeiroministro foi resultado do entendimento entre as burguesias cristã e muçulmana que acontecia desde a metade da década anterior. Foi esse entendimento a base do acordo não escrito (e que deveria ser temporário até que outro melhor fosse elaborado) forjado entre Solh e el-Khuri cujo entendimento definitivo se deu em 1943: O Pacto Nacional (al-Mithaq al-Watani). Nele os muçulmanos reconheceram definitivamente a existência do Líbano com as suas fronteiras

\footnotetext{
145 Idem. p. 32.

146 Idem. p. 14.
} 
como estabelecidas em 1920 enquanto os cristãos reconheciam o Líbano como parte do Mundo Árabe (face árabe do país) e renunciavam a qualquer proteção por parte das potências ocidentais.

No entanto, se aceitava que o país também possuía laços com o Ocidente e que deveria manter relações amistosas com os países dessa região. Esse entendimento para as elites muçulmanas foi uma forma de arrancar concessões das classes dominantes cristãs e melhorar a sua posição em um país onde foram incluídas contra a sua vontade. Também para elas era melhor fazerem parte do Líbano onde eram o segundo principal grupo confessional do que serem absorvidos dentro da Síria onde seriam apenas elites regionais senão locais ${ }^{147}$.

As lideranças independentistas libanesas também procuraram dialogar com os líderes nacionalistas sírios para juntar e coordenar os esforços na luta contra os franceses e, ao mesmo tempo, conseguir deles o reconhecimento da existência do Líbano, devido ao seu caráter nacional peculiar, porém pertencendo simultaneamente ao conjunto das nações árabes e com elas lutando contra o colonialismo europeu.

Ao longo da década de 1930, as lideranças libanesas e sírias estabeleceram relações políticas e pessoais cujos resultados concretos seriam vistos na década seguinte durante o processo de independência sírio e libanês. É o caso da relação entre Bechara elKhuri, líder do bloco constitucional, e Jamil Mardam Bey, um dos principais responsáveis pela independência da Síria. Mardam procurou manter relações até mesmo com os nacionalistas libaneses pró-franceses como era o caso de Émile Édde, com quem manteve frequentes conversações por meio de reuniões ${ }^{148}$.

Após a ocupação britânica na II Guerra Mundial, ao longo de 1942, os libaneses juntamente com os sírios deram prosseguimento a sua luta política pela independência de seus países. Para isso obtiveram facilmente o apoio dos chefes de Estados árabes da época bem como das populações de seus países. Um dos Estados árabes que mais se empenhou em ajudar os sírios e libaneses foi o Egito. Seu primeiro-ministro Mustafa Nahhas Pashá patrocinou em junho de 1942 uma reunião entre Bechara el-Khuri e o líder nacionalista sírio Jamil Mardam Bey, onde foi decidido o retorno à vida constitucional bem como o estabelecimento da independência total dos seus países.

\footnotetext{
147 Idem. p. 15.

148 Idem. p. 14.
} 
Nessa reunião el-Khuri foi reconhecido como o representante tanto dos cristãos quanto dos muçulmanos libaneses pelos nacionalistas sírios que passaram a apoiar a sua candidatura à Presidência. Nesse encontro também esteve presente o líder sunita Riad el-Solh, que ali chegou a um entendimento com Bechara el-Khuri que ficaria conhecido como o Pacto Nacional. Algum tempo depois, em uma nova visita ao Cairo em maio de 1943 e já tratado como Presidente, el-Khuri assinou com os representantes da Jordânia, Iraque e Síria mais o governo egípcio um tratado econômico. Por outro lado, curiosamente ainda existiam dúvidas dos líderes árabes em relação a el-Khuri e dos ingleses em saber se ele defenderia os seus interesses na região. Tanto era assim que se cogitava em apoiar o jovem advogado Camille Chamoun, um anglófilo casado com uma britânica. Chamoun chegou até a se reunir com o primeiro-ministro iraquiano Nuri al-Said ainda em 1943. No entanto, rapidamente ficou claro que Bechara el-Khuri era a figura política mais adequada para representar os interesses angloárabes $^{149}$.

\subsection{A ideologia nacional Libanesa ${ }^{150}$}

Para a existência do moderno estado Libanês e da sua trajetória posterior, especialmente o modelo econômico adotado, foi importante a atividade de um grupo de intelectuais cristãos adeptos de ideias de cunho liberal e responsáveis por ampliar a noção de nacionalidade libanesa para além das comunidades cristãs ao apresentarem o Líbano mais como um mosaico de comunidades religiosas devido ao caráter de refugio montanhoso do país para comunidades religiosas perseguidas. Eles provinham das elites econômicas, sendo vários banqueiros ou comerciantes, mas a figura de maior destaque foi o banqueiro, economista e jornalista Michel Chiha (1891-1955). Ele foi considerado um dos arquitetos do

\footnotetext{
149 TRABOULSI, Fawwaz. A modern history of Lebanon. Londres e Nova Iorque: Pluto Press, 2007. p. 105106.

${ }^{150}$ Uma observação é importante de se fazer em relação ao Líbano: As origens da sua ideologia nacional estão diretamente associadas à ação do colonialismo francês na cultura e no sistema educacional nacionais. Dessa forma, o sistema educacional implantado pelos franceses nesse país era diferente do que eles implantaram na África Subsaariana ou no Magreb pois, enquanto nestas terras procurou-se ensinar a história da França e as suas diversas glórias enquanto os colonizados "became inanimate objects in their own countries" (KAUFMAN, p. 177), no Líbano buscou-se associar o país e a sua população (no caso, especificamente os cristãos) à própria herança histórica e cultural da metrópole. Isso era facilitado por conta dos vínculos históricos dos maronitas com a França. Assim, os professores jesuítas franceses estimularam pesquisas arqueológicas na Síria e no Líbano como meio de se estudar mais profundamente o seu passado pré-islâmico. Nesses estudos destacam-se os trabalhos de estudiosos franceses como Ronzavelle, Jalabert, Planchet e o padre Henri Lammens, figura importante na formulação dos mitos nacionais libaneses. KAUFMAN. p.177
} 
sistema confessional libanês e principal formulador do moderno ideário nacional de seu país, que serviu como um substituto da visão do Líbano como um país para os cristãos do Monte Líbano, o que causava a rejeição dos muçulmanos.

Chiha definiu a identidade libanesa em três bases: o Líbano como refúgio pra minorias, a herança fenícia e os vínculos com o Mediterrâneo e o Líbano como terra de oportunidades.

Ao afirmar que o Líbano era um herdeiro da antiga fenícia Chiha defendia a ideia de que o seu país possuía desde o seu remoto passado uma vocação para o comércio e o contato com o mundo exterior pois, como os seus ancestrais fenícios, os modernos libaneses tinham no comércio e nos serviços as suas principais atividades econômicas, emigraram para o exterior onde formaram colônias (no caso libanês, comunidades de imigrantes) e ajudaram no desenvolvimento das terras onde eram estrangeiros.

Chiha dizia que essa vocação histórica do Líbano era também resultado da geografia do país (determinismo geográfico), pois a estreita costa e a cadeia montanhosa que a acompanha sempre exerceu uma pressão no sentido de fazer com que os libaneses buscassem no mar os seus meios de vida e ajudou a formar o seu suposto caráter aventureiro e empreendedor, ao transformá-los em navegadores e comerciantes.

Como o Mediterrâneo no passado ligou os fenícios à Grécia e às terras do Ocidente, hoje conectava os libaneses com a Europa e o mundo no entorno do Mar Mediterrâneo isolando-o do Oriente asiático. Os libaneses hoje usavam as mesmas rotas de comércio e navegação dos fenícios acrescidas das rotas aéreas, dos meios modernos de comunicação e das técnicas comerciais e empresariais contemporâneas. A imagem dos fenícios também era importante por dar aos libaneses um ancestral que estava além das divisões comunitário-religiosas contribuindo como um símbolo para a unidade nacional ${ }^{151}$.

Outro conceito importante para Chiha e as suas ideias a respeito da nacionalidade libanesa foi o antigo mito do Líbano como refúgio para minorias perseguidas pelos poderes despóticos de diversos impérios do Oriente Médio ao longo dos séculos. Os conflitos trouxeram às montanhas libanesas diversas comunidades de cristãos e muçulmanos heterodoxos que ao longo dos séculos aprenderam a conviver, cooperar e tolerar as diferenças de seus vizinhos, mostrando um suposto desejo de viver juntos para construir a sociedade das

${ }^{151}$ HARTMAN, Michelle; OLSARETTI, Alessandro. "First boat and the first oar": inventions of Lebanon in the writings of Michel Chiha. Radical History Review, 86 (primavera 2003). p. 45-47. 
montanhas e apreciando uma suposta liberdade em relação ao despotismo existente em outras partes do Oriente.

Nos últimos séculos o emirado druso-maronita do Monte Líbano foi a encarnação dessas aspirações de convivência e desejo de liberdade que caracterizam os libaneses. Por isso o Líbano deveria existir como uma federação de minorias religiosas em cooperação para o desenvolvimento das potencialidades do país. Por conta disso, para Chiha, o sistema político confessional do Líbano não era um erro e sim a manifestação dessa necessidade de se representar todas as comunidades que compõem a população, dando-lhes voz na vida política nacional de acordo com o seu tamanho dentro da sociedade libanesa ${ }^{152}$.

Já a ideia do Líbano como 'terra das oportunidades', apesar de à primeira vista não ser muito convincente por causa do grande número de libaneses que emigravam devido a dificuldades para encontrarem na economia nacional sequer um meio para continuar vivendo e à devastação causada pela I Guerra Mundial que resultou em dezenas de milhares de mortos, principalmente por fome.

No entanto, o fato de que muitos desses imigrantes voltaram e reinvestiram o capital acumulado em diversos empreendimentos no país, o impacto econômico e social que as remessas dos emigrados causavam, a ascensão, desde o século XIX, de uma ativa classe média nas grandes cidades e o enriquecimento da elite comercial devido aos seus contatos com as potências ocidentais faziam com se apreciassem no Líbano do mandato a existência de uma certa prosperidade que vinha associada a uma confiança na economia mercantil e se manifestaria, depois da II Guerra Mundial, no desejo de ver no livre comércio a base da vida econômica nacional.

Isso, acreditavam, faria do Líbano uma 'terra de oportunidades' no Oriente que poderia atrair capitais e homens para impulsionar ainda mais o desenvolvimento do país. Para essa imagem contribuíam as descrições feitas do Líbano por Michel Chiha como uma 'nação de classe média', habilidosa no comércio, inventiva, inteligente, adaptável, empreendedora, que possuía uma grande confiança na eficácia da livre empresa e era uma defensora do liberalismo político $^{153}$.

Na realidade, no final das contas, Chiha forneceu legitimidade ideológica para a

\footnotetext{
152 Idem. p. 49-51.

153 Idem. p. 52-56.
} 
aliança formada entre a oligarquia mercantil financeira e os antigos latifundiários bem como para a participação das elites muçulmanas na administração e nos negócios privados do Líbano após a independência. O que também foi um meio para enfrentar as pressões políticas ideológicas e sociais das classes trabalhadoras, dos movimentos que as representavam e dos partidos e movimentos que tinham um projeto alternativo para o Líbano.

A imagem do Líbano construída por Chiha servia para justificar a aplicação do projeto econômico de sua classe, bem como seus desejos e visões de mundo. Generalizando as características reais e imaginárias de sua classe para toda a sociedade libanesa eles criavam uma imagem tida como positiva que servia para atrair todos os segmentos sociais para o modelo de Estado e economia que estavam construindo e que acabou visto como parte de uma identidade nacional histórica pela maioria dos libaneses ao longo do século XX.

\subsection{O governo de Bechara el-Khuri}

Bechara el-Khuri foi o primeiro presidente do Líbano independente tendo governado o país de 1943 até 1952 em dois mandatos sucessivos. Em seu governo o Líbano começou a ser governado segundo os acordos do Pacto Nacional, assistiu à retirada das tropas francesas em dezembro de 1946, iniciou uma primeira aproximação econômica e política com os EUA, a nova superpotência, rompeu a união aduaneira com a Síria, viu o país entrar na Liga Árabe e ter suas fronteiras e existência reconhecidas pelos demais países árabes, foi membro fundador da ONU e viu a implementação da política econômica de livre mercado que caracterizaria o Líbano nas décadas seguintes.

O governo Khuri foi marcado pela formação de uma rede de interesses de empresários e banqueiros que gravitavam em torno da figura do Presidente buscando favores e contratos milionários com o governo. Esse grupo ficou conhecido como o Consortium e era considerado o núcleo de poder da classe dominante libanesa.

Segundo um gráfico elaborado por Samuel O. Ruff, membro da Legação norteamericana no Líbano (Gendzier, 1997), esse grupo se dividia em três círculos concêntricos em torno da figura de Bechara el-Khuri. No primeiro estavam os indivíduos que se caracterizavam por seus vínculos pessoais com o Presidente e sua família, sua conexão com o capital francês e o grande tamanho de sua riqueza. Exemplos desse caso são os grandes banqueiros cristãos como os Chiha e Faraoun. 
No segundo círculo haviam os membros da classe comercial e financeira com fortes vínculos com o capital francês, mas com poucos vínculos pessoais com o Presidente. Esse é o caso dos Trad e dos Sabbagh, famílias de banqueiros ou os Salem que eram donos da fábrica da Coca-Cola no Líbano.

Finalmente, o terceiro círculo era composto pelos principais empresários dos ramos industriais e agrícolas e proprietários de imobiliárias. Devido à existência desse Consortium (que continuou existindo sob o seu sucessor Camille Chamoun) nos anos de elKhuri foram frequentes as acusações de corrupção e nepotismo.

No plano internacional o Líbano de Bechara el-Khuri, embora mantivesse relações econômicas e políticas com os EUA, optou pela política do neutralismo, evitando tomar uma posição exclusivamente pró ocidental nas questões internacionais que poderiam, em caso de conflitos relacionados à descolonização ou lutas contra a hegemonia econômica e militar ocidental, colocar o Líbano contra os demais países árabes e assim causar um sério dano a sua economia e desestabilizar a sua própria sociedade.

No fim do seu primeiro mandato Bechara el-Khuri planejava se reeleger, embora a constituição proibisse isso. Para atingir essa meta ele recorreu a meios fraudulentos tanto nas eleições realizadas para o Legislativo (foram usados policiais e soldados do exército para interferir no processo de votação), em maio de 1947, quanto depois no parlamento para assegurar o segundo mandato. Este passou uma emenda permitindo ao Presidente uma renovação especial de seu mandato no ano seguinte. Isso aconteceu, apesar das fortes críticas existente no Líbano ao governo de el-Khuri, por conta da enorme corrupção que lhe permitia comprar aliados e dos muitos desmandos administrativos. Também contribuíram para a vitória do Presidente as dificuldades para que a oposição se articulasse, escolhesse um nome para liderá-la e elaborasse uma lista de candidatos às eleições legislativas ${ }^{154}$.

Em 1948, o Líbano recém-independente enfrentou o seu primeiro desafio quando a Palestina foi destruída pela ação dos judeus sionistas que expulsaram 700 mil árabes de suas terras, dos quais cerca de 120 mil buscaram o Líbano como refúgio se instalando em campos ao longo das principais cidades do país que passaram a ser administrados pela ONU, por meio de uma agência por ela criada para esse fim, a United Nations Relief and Work Agency (UNRWA).

154 WINSLOW. p. 90-91. 
Esses campos eram bem pobres, não recebendo nenhuma assistência do governo libanês que, pelo contrário, passou a marginalizar os palestinos, impondo restrições de acesso a determinados tipos de trabalho para não competirem com os libaneses ${ }^{155}$. A chegada dos palestinos assustou a direita cristã pois, como eram majoritariamente sunitas, se adquirissem cidadania tonariam os sunitas a população mais numerosa do país e desse modo mudariam todo o sistema politico nacional. No entanto, sua presença foi vista como positiva para a economia contribuindo para impulsioná-la ao trazerem mão-de-obra barata e trabalhadores qualificados ${ }^{156}$. Por outro lado, a destruição da Palestina arruinou certos setores da indústria e empresas que tinham nesse país o seu principal mercado como foi o caso, por exemplo, da cerâmica da cidade de Rashayya ou dos calçados de Bint Jubail ${ }^{157}$.

O Líbano também se engajou na luta contra os sionistas, embora de maneira simbólica por meio de uma missão militar que se dirigiu para a estrada que ia em direção à cidade de Acre tendo como objetivo atingir Haifa. Isso aconteceu desse modo porque o governo libanês não desejava participar dos esforços de guerra árabe e a direita cristã tampouco, porém a pressão da população muçulmana obrigou o governo de el-Khuri a promover algum tipo de participação do Líbano na guerra ${ }^{158}$. Ao mesmo tempo o exército sírio fora chamado para atuar na Palestina a partir do Líbano junto com soldados libaneses e voluntários árabes, partindo de Bint Jubail em direção a Safad na Galileia chegando a ocupar uma parte desse território.

No entanto, a contraofensiva sionista levou a ocupação de cerca de 14 vilas libanesas na fronteira meridional com a Palestina. Os conflitos continuaram e o governo de elKhuri somente assinou um armistício com Israel após os egípcios também assinarem, entrando em negociações em março de 1949 e assinando o cessar-fogo com Israel no dia 23 daquele mês. Nesse acordo os israelenses se comprometeram a se retirar dos territórios libaneses ocupado no sul do país ${ }^{159}$.

Em 1949 o PNSS de Saadeh se envolveu em incidentes com o governo libanês.

155 MAALOUF, Ramez Ph. Geoestratégias em confronto no Líbano. Dissertação de Mestrado apresentada ao programa de Pós-Graduação em Geografia Humana do Departamento de Geografia da FFLCH-USP, São Paulo, 2011. p. 219

${ }^{156}$ WINSLOW. p. 93.

157 TRABOULSI. p. 113.

158 MAALOUF. p. 218.

${ }^{159}$ Idem. p. 113. 
Como os militantes desse partido com frequência entravam em choques com militantes de outros movimentos contrários aos seus ideais, como era o caso da Falange que, em junho daquele ano, incendiou o escritório de impressa deles em Beirute, o governo libanês, por meio do primeiro ministro Solh, resolveu perseguir o PNSS, acusando-o de provocar agitações e de conspirar contra o país.

Isso levou à prisão de cerca de 2.500 militantes nacionalistas sírios enquanto Antun Saadeh se refugiou na vizinha Síria e lá fez um apelo para um levante contra o governo libanês. Os membros do seu partido responderam realizando uma série ataques a delegacias, bases policiais e alvos civis. O primeiro-ministro Solh pediu ao governo sírio a extradição de Saadeh e foi atendido tendo o líder nacionalista pan-sírio sido preso e entregue às autoridades libanesas. Levado a um tribunal militar, foi julgado de maneira secreta e sumária, praticamente não podendo se defender e condenado à morte foi fuzilado pouco tempo $\operatorname{depois}^{160}$.

Por causa disso, Riad el-Solh tornou-se um homem marcado e militantes do PNSS o assassinaram durante sua visita ao rei da Jordânia em Aman em 1951. Essa ação do governo libanês aconteceu devida em parte às críticas de Saadeh aos líderes árabes pela derrota de 1948, especialmente as endereçadas ao primeiro-ministro libanês, também por conta das aproximações do líder pan-sírio com o ditador da Síria Hosni Zaim que havia expressado simpatias com relação às ideias sobre a Grande Síria ${ }^{161}$.

\subsection{A política econômica liberal e o Estado fraco}

O mandato de Bechara el-Khuri enfrentou uma série de desafios e dificuldades econômicas ao longo do seu governo que foi, em poucos anos, fazendo com que se percebesse cada vez mais pelos membros mais importantes das classes dominantes locais que sua solução seria a adoção do livre mercado como o modelo adequado para estruturar a economia libanesa.

Um dos primeiros problemas foi a crise econômica provocada pela saída das tropas aliadas, cujas despesas permitiam a diversos setores, especialmente na indústria, manter altas taxas de lucros. Essa crise se manifestou no aumento do desemprego e do

\footnotetext{
${ }^{160}$ GORIA. p. 34 .

${ }^{161}$ TRABOULSI . p. 114.
} 
subemprego.

Estima-se que entre 30 mil e 75 mil trabalhadores tenham perdido seus empregos com a crise econômica do pós-guerra tendo como uma das consequências imediatas a retomada da imigração propiciada pela reabertura das rotas de comunicação ${ }^{162}$. Ao longo da segunda metade dos anos 40 cresceu a sindicalização dos trabalhadores libaneses.

Dessa maneira, petroleiros, operários têxteis, da indústria de tabaco e da construção civil, funcionários públicos municipais, portuários, taxistas e outros organizaram os seus próprios sindicatos. No total havia 34 sindicatos com 18.800 filiados ${ }^{163}$.

As greves se tornaram comuns e os sindicalistas pressionavam o governo para que adotasse um código trabalhista progressista. Muitos desses sindicatos estavam sob a direção do Partido Comunista, fato esse que preocupou os membros do establishment libanês, ainda mais devido às tensões internacionais causadas pelo começo da Guerra Fria na segunda metade dos anos 40. A principal federação sindical da época era a Fédération des Syndicats des Ouvriers et de Employées du Liban, cujo líder era o ativista comunista Mustapha Ariis. Por isso, o Ministério do Interior promoveu uma política de sabotagem do movimento sindical, criou um escritório de espionagem para monitorar a atividades dos sindicalistas e procurou comprar e cooptar ativistas sindicais para enfraquecer ou mesmo anular o movimento trabalhista no Líbano, além de dificultar a promulgação de licenças para que os sindicatos funcionassem ${ }^{164}$.

Em 1946, respondendo em parte à pressão dos sindicatos e ao mesmo tempo visando a desmobilizar o ativismo sindical no país, o governo promulgou um exaustivo Código Trabalhista. Esse código estabeleceu a semana de 48 horas - embora permitisse algumas exceções - fixou a idade mínima de 8 anos para se empregar alguém, o que permitia a exploração do trabalho infantil e criou as condições gerais de contrato e obrigações para os trabalhadores da indústria e do comércio (mas excluía os funcionários civis e os trabalhadores rurais, que na época eram a grande maioria da classe trabalhadora, dessas determinações). Também permitia aos patrões um amplo poder de contratar e demitir ${ }^{165}$ (mais informações no capítulo II).

162 GATES. The merchant republic... p. 110.

${ }^{163}$ CHAMI apud GASPARD. Tabela 2.4, p. 65.

164 GENDZIER, Irene. Notes from the minefields: United States intervention in Lebanon and Middle East, 1954-1958. Boulder (USA): Westview Press, 1999. p. 117-118.

${ }^{165}$ GASPARD. p. 64. 
Seria durante o mandato de el-Khuri que o Líbano viria a adotar o laissez-faire como modelo para a sua economia após um grande debate em sua sociedade e a aplicação de outros tipos de políticas que, porém, não trouxeram os resultados esperados.

Embora, após a independência em 1943 e a saída das tropas franceses no fim de 1946, ainda demorassem alguns anos para se decidir pelo livre-mercado, as regulações econômicas que dificultavam o trânsito de bens e capital, implantadas pelos aliados, começaram a ser desmontadas logo após o término da II Guerra. No entanto, ainda em 1947, o governo libanês retomou as medidas de controle devido ao rápido aumento das importações e a inadequada distribuição de divisas pela França. Os decretos promulgados em julho e agosto pelo Ministro da Economia Nacional Suleiman Nawfal promoveram controles na alocação de moeda forte na economia libanesa, o que provocou inúmeras críticas por parte do establishment liberal do país. Um ano depois, diante da deterioração da situação cambial foi anunciado que as moedas fortes seriam reservadas exclusivamente para as mais urgentes necessidades do governo.

Enquanto isso florescia no país o mercado negro baseado no câmbio de moeda nacional por moedas fortes estrangeiras. Também por essa época o Líbano ia perdendo suas reservas cambiais. Finalmente, em 17 de novembro de 1948 o governo liberalizou o mercado cambial permitindo ao capital libanês se difundir pelo mundo. Algumas restrições foram ainda deixadas com o intuito de assegurar a balança de pagamentos e apoiar o comércio e as finanças, mas até 1952 foram sendo paulatinamente eliminadas ${ }^{166}$.

Para que o Líbano pudesse ser um centro financeiro e comercial foi necessário estabelecer medidas que tornassem a libra libanesa uma moeda estável e de confiança e tornassem o sistema financeiro libanês eficiente e estabilizado. A primeira delas foi o acordo monetário com a França assinado em 1948 que tinha como objetivo fazer dessa moeda uma divisa forte e plenamente convertível, na qual os mercados internacionais pudessem ter confiança e que acabasse com instabilidade do até então subdesenvolvido mercado financeiro libanês.

Sob esse acordo, o Banco Central Francês garantia a convertibilidade de $67 \%$ dos saldos em francos franceses do Líbano na fixação da taxa de câmbio franco francês/libra esterlina nos dez anos seguintes. Esse acordo foi criticado por prejudicar o Líbano e favorecer de maneira acintosa a França, mas o presidente el-Khuri afirmava que o seu país não tinha

${ }^{166}$ GATES. The merchant republic... p. 87. 
escolha já que diversos países do Ocidente e do Oriente Médio, como os EUA ou a Arábia Saudita, tinham se recusado a assinar um acordo que garantisse a cobertura da libra libanesa não restando outra alternativa que assinar com os franceses apesar das desvantagens grandes.

Uma dessas falhas era o fato de $1 / 3$ dos saldos em francos franceses do Líbano (FF4.000 milhões) não estavam sob a garantia desse acordo. Entre outras políticas para fortalecer a libra libanesa estava a criação do Fundo de Estabilização do Câmbio, em outubro de 1949, responsável por intervir no mecanismo de funcionamento da moeda libanesa quando esta corresse um sério risco de se desestabilizar.

Também foi estabelecida a cobertura em ouro dessa moeda, pela Lei Monetária de 24 de maio de 1949, que também a libertou definitivamente da dependência do franco francês e, por isso, também das políticas econômicas francesas. Essa cobertura, que garantia estabilidade ao valor do câmbio, foi crescendo, saindo de $2 \%$ em 1949 até atingir $95 \%$ em $1955^{167}$. A Lei Monetária tinha quatro objetivos básicos: 1) assegurar a independência da moeda libanesa impedindo-a de se vincular com qualquer moeda nacional; 2) redefinir sua paridade em termos do ouro na taxa de 405, 512 miligramas de ouro puro para a libra libanesa em uma medida aprovada pelo Fundo Monetário Internacional (FMI); 3) providenciar 100\% de moedas de reserva do que $50 \%$ seriam lingotes de ouro, moedas desse metal e divisas estrangeiras enquanto o restante se comporia de dívidas e bônus do tesouro, títulos do governo e notas promissórias comerciais ou commercial papers; 4) estabelecer as normas pelas quais o ouro e as moedas estrangeiras seriam transacionados no Líbano ${ }^{168}$.

O resultado disso tudo seria visto na década seguinte quando o Líbano atravessou crises como a nacionalização do Canal de Suez e a Guerra Civil de 1958, pois o BSL adquiriu uma grande flexibilidade sobre o controle da oferta de dinheiro aumentando a sua emissão para impedir um aprofundamento da crise econômica ${ }^{169}$. A estabilidade do câmbio libanês foi outra característica que o país passou a ter a partir do regime de el-Khuri que sempre manteve o valor da moeda libanesa em relação ao dólar na década seguinte entre LL3,00 e LL4,00 para cada US\$1,00. Isto foi possível devido à constante entrada de ouro e dinheiro na economia libanesa que permitiam aos administradores da política econômica um alto nível de controle

\footnotetext{
${ }^{167}$ Idem. p. $97-98$

168 MALLAT. 70 years of money muddling in Lebanon ... p.102

${ }^{169}$ MALLAT. Idem. p. 103.
} 
sobre a moeda ${ }^{170}$.

Essas políticas de livre-mercado também puderam ser implementadas porque existia uma grande expectativa de que sua implantação fosse um sucesso, pois se acreditava que a economia libanesa estivesse preparada para recebê-las e que o cenário internacional a favoreceria. Isso acontecia porque havia uma grande fonte de capital privado disponível, o país já tinha uma orientação externa de sua economia desde o século XIX e havia no Oriente Médio o crescimento do mercado de capitais e bens. Isso permitia ao Líbano exercer o desejado papel de entreposto entre o Ocidente e sua região, a qual não possuía infraestrutura física e financeira para absorver as receitas, especialmente as petrolíferas, que iam em ascensão a partir do fim dos anos 40 .

Um outro acontecimento, embora trágico, que favoreceu o Líbano foi a destruição da Palestina pelos sionistas em 1948, responsável por eliminar o maior rival do Líbano, algo que foi visto com bons olhos pela elite econômica libanesa ${ }^{171}$.

No entanto, cabe ressaltar que, entre 1947 e 1952, o governo de Bechara el-Khuri estava dividido entre apoiar temporariamente os defensores do livre-comércio ou apoiar a indústria, ainda mais porque as medidas liberalizantes em um primeiro momento tiveram um efeito negativo sobre grande parte da economia. As pressões dos dois grupos forçavam o governo a promover políticas para resolver as crises que surgiam com frequência, embora fossem temporárias e aplicadas com frouxidão. Somente após as tensões que envolveram o fim da união alfandegária com a Síria o país encaminhou-se para uma crescente liberalização de sua economia ${ }^{172}$.

Foi em 1950 que aconteceu o rompimento da união aduaneira com a Síria. Essa dissolução foi um passo importante no processo de liberalização da economia no Líbano ao liberar o país dos efeitos das políticas sírias de restrição ao comércio externo. Desde a independência a união aduaneira era motivo de frequentes conflitos entre os governos de Beirute e Damasco por conta de suas distintas políticas econômicas que, no caso dos sírios, era caracterizada pela adoção de práticas protecionistas visando a defender as indústrias e a agricultura local da concorrência externa, bem como a desenvolver programas por parte do

170 IDEM. p. 137. MALLAT, Raymond A. A fiscal policy for social justice and economic development in Lebanon: a guide in fiscal management for social and economic development in Lebanon. Beirut, 1980. p. 124. 171 GATES. The merchant republic ... p. 83 .

${ }^{172}$ Idem. p. 88 e 89. 
Estado para estimular o crescimento desses setores.

Para isso era importante para os sírios implantarem políticas alfandegárias como uma medida essencial para garantir a sobrevivência de setores como as nascentes indústrias têxteis, muito prejudicadas pela concorrência estrangeira (aí incluindo a indústria libanesa) ou as recém-instaladas indústrias de artigo de vidro. Os sírios também se preocupavam com as consequências adversas que o acordo monetário franco-libanês tinha para seu país e com a presença excessiva dos comerciantes libaneses que dominavam o comércio sírio e eram os responsáveis por trazer as mercadorias importadas que prejudicavam sua indústria.

Já os libaneses desconfiavam do nacionalismo econômico sírio e tinham receio da intervenção militar na vida política desse país e seu controle sobre o fluxo de bens, capital e pessoas que afetavam os negócios deles na Síria. Muitos economistas viam como arrogância nacional o nacionalismo sírio e defendiam o rompimento da união aduaneira como uma condição para o Líbano se estabelecer como uma zona de livre comércio. Os mercadores libaneses se ressentiam das obras que buscavam desenvolver o porto de Latakia, pois ele poderia vir a ser um rival de Beirute, além de terem detestado a política do governo sírio de estimular os mercadores locais a assumirem o controle do comércio nacional afastando, para isso, os libaneses. O resultado final desse conflito de interesses, perspectivas e ideologias diferentes, que se desenrolou por três anos, foi o rompimento da união aduaneira em março de $1950^{173}$.

Apesar das tensões e desconfianças que o rompimento da união aduaneira causou em ambos os lados, os dois governos se esforçaram por realizar negociações com o objetivo de decidir como se dariam a partir de então as relações econômicas entre os dois países. Isso levou em 1952 a um acordo sobre as relações econômicas que tinha como base nove pontos $^{174}$. Esse acordo havia sido realizado através do recém-criado Conselho de Planejamento e Desenvolvimento, comandado pelo Ministro da Economia e Finanças, Trabalho, Assuntos Sociais e Agricultura. Assim foi estabelecido um acerto econômico transitório com os sírios que permitia a circulação de capitais, a liberdade de importar e exportar e a exoneração recíproca das taxas aduaneiras em 55\%. Somente a livre circulação de pessoas e a unificação monetária ficaram de fora.

No entanto, a assinatura desse acordo produziu uma divergência dentro da classe

\footnotetext{
173 Idem. p. 90-91.

${ }^{174}$ Idem. p. 91.
} 
dominante libanesa. Determinados setores afirmam que deveria ser apenas um mero pacto econômico que poderia ser cancelado no futuro, enquanto que para outros deveria ser o início de um processo de unificação com o país vizinho. Essa divisão acontecia dentro do próprio governo, o que levou à demissão do Ministro das Relações Exteriores, Mubarak. Ao mesmo tempo, o líder das Falanges Pierre Gemayel criticava publicamente qualquer perspectiva de integração econômica total com a Síria afirmando que isto seria uma ameaça à independência do Líbano. Já o deputado por Trípoli, Rachid Karami, defendia a união econômica. Um prazo de seis meses foi concedido para que se fizesse uma análise do alcance do acordo com os sírios. Em 1953 o Parlamento ratificou o acordo e o novo presidente Chamoun o assinaria em 15 de $\operatorname{março~}^{175}$. Por fim, o acordo acabou incorporando todos os elementos em negociação, menos a unificação monetária ${ }^{176} 177$.

Enfim, seria com o governo de el-Khuri que o Líbano assumiria as características que marcaram seu desempenho econômico até 1975, quando ocorreu a deflagração da segunda guerra civil libanesa. Embora tenha terminado em desastre politicamente, a política econômica do primeiro mandatário do Líbano independente foi bem-vinda e considerada um sucesso, tendo sido continuada por seu sucessor Camille Chamoun caracterizando aquilo que estudiosos como Carolyn L. Gates e outros chamam de República Comercial. Ou seja, um país onde os grandes comerciantes, banqueiros e prestadores privados de serviços constituem

${ }^{175}$ HAYEK, Domingo Garí. História contemporánea del Líbano: confesionalismo y política (1840-2005). Santa Cruz de Tenerife e las Palmas de Gran Castilla: Ideal Global, 2006. p. 57-58.

${ }^{176}$ Idem. p. 60.

${ }^{177}$ Apesar da existência de um grande setor pró-Síria nas elites e nas populações muçulmanas, e dos esforços para se buscar um entendimento, conflitos graves na área econômica surgiriam nos anos seguintes. Assim, ao longo de 1955 desenrolou-se o conflito com a Síria a respeito de questões relativas ao comércio e acordos econômicos. Devida à hegemonia comercial libanesa e às travas que seu governo impunha a importação de determinados produtos, os sírios ameaçaram impôr um embargo às suas exportações de trigo para o Líbano. Em reposta os libaneses levantaram a proibição de importar trigo de outros países (HAYEK. p. $56-57$ e 60). Os sírios então tentaram convencer os libaneses a firmarem com eles um tratado econômico que incorporaria uma unificação aduaneira, uma política fiscal coordenada, a mesma posição a respeito do comércio com outros países, a paridade entre as duas moedas e a obrigatoriedade de uma empresa que instalasse uma sucursal em um país também instalar em outro e tudo isso dirigido por um Conselho Econômico Comum com uma presidência quinquenal rotativa. Em reposta os libaneses não apenas se recusavam a fazer qualquer acordo econômico com os seus vizinhos como faziam questão de afirmar que o país continuaria liberal e pretendiam se tonar um dos centros financeiros do mundo. Simultaneamente a tudo isto, Chamoun inaugurou o Banco Libanês para o Comércio formado com capital libanês da emigração, no caso os grandes algodoeiros maronitas da família Jaoudé instalados no Brasil (HAYEK. p. 66-67). Esse conflito se somaria aos surgidos por conta do aparecimento do Pacto de Bagdá também em 1955. Essa disputa era intermediada pelos setores do governo favoráveis a um entendimento com os sírios que procuravam sempre buscar uma posição de consenso entre as duas partes como era o caso do zaim sunita Rachid Karami. Ele chegou a propôr aos sírios que deixassem as multinacionais e ao capital internacional escolher os lugares onde eles se instalariam. Isso não foi aceito, pois manteria a posição comercial favorável aos libaneses já que as companhias assentadas em Beirute dificilmente iriam para a Síria (p. $68)$. 
o principal setor das classes dominantes, acreditando serem a representação do etos nacional.

Esse ideal do Líbano como república mercantil não ficou restrito apenas às elites, tendo atingido as classes médias e uma boa parte da camada popular, especialmente entre os cristãos, como pôde demonstrar o apoio que Camille Chamoun recebeu no começo de seu mandato e o fato das políticas liberalizantes de Bechara el-Khuri não terem recebido um rechaço das camadas populares apesar da oposição dos sindicatos de trabalhadores. 


\section{CAPÍTULO 2}

\section{O Sistema Econômico Liberal do Líbano}

O modelo econômico adotado no Líbano nas décadas que se seguiram à Segunda Guerra Mundial pode ser considerado uma exceção dentro do cenário mundial daquela época e, ainda mais, quando se observa as estratégias de desenvolvimento adotadas pelos países do chamado Terceiro Mundo e, dentro desse, do Mundo Árabe em particular. Nesses casos, a atitude mais frequente dos governos era utilizar a força do Estado para promover o desenvolvimento das forças produtivas com a criação de empresas estatais que, ao controlarem setores estratégicos como minérios, petróleo, geração de eletricidade, siderurgia etc., formariam as bases para dirigir o processo de desenvolvimento da economia como um todo e da indústria em particular, no caso dos países. Procurava-se orientar as elites econômicas através de políticas determinadas pelo Estado para dirigirem os seus negócios no sentido dos planos traçados pelos governantes ou grupos que controlavam o Estado.Isso ao mesmo tempo em que se buscava controlar as ações dessas elites econômicas para que não pudessem vir a agir contra os interesses das forças que controlavam o Estado ou o interesse nacional em um sentido mais amplo. No Líbano ${ }^{178}$ agiu-se no sentido contrário. Até 1958 o

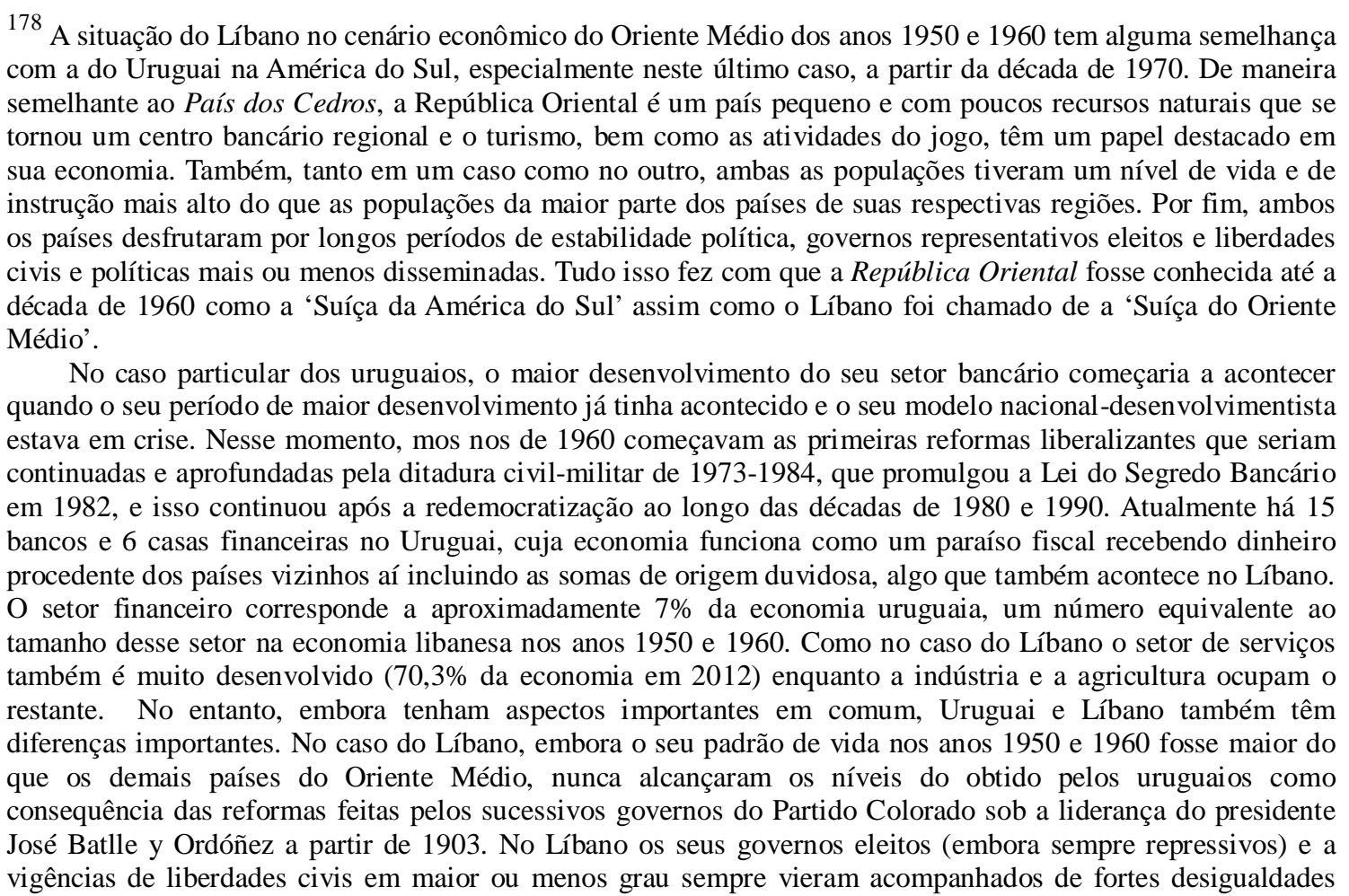


Estado foi afastado do planejamento econômico e as elites econômicas foram deixadas livres para realizarem os seus negócios com o mínimo de normas e medidas que pudessem interferir em seus assuntos e interesses. Também a economia foi voltada para o exterior, tendo os ramos comerciais e de serviços sido colocados como os setores que comandariam a vida econômica, com o país desempenhando o papel de entreposto financeiro e comercial entre o os países árabes e os ocidentais.

Os resultados dessa escolha ao longo dos anos 1950 e 1960 podem ser apreciados na tabela 7 da página 285, onde vemos que o comércio sozinho em 1966 correspondia a 40,6\% do Produto Nacional Líquido (PNL) do Líbano, sendo que dez anos antes já havia

sociais com um nítido aspecto regional e sectário, apesar das tentativas de reforma do presidente Fuad Chehab (1958-1964). No aspecto econômico o Líbano foi sempre liberal enquanto que a liberalização da economia do Uruguai virá com a crise do modelo nacional-desenvolvimentista (o Batllismo). Além disso, o setor bancário libanês sempre foi muito maior do que o uruguaio. Tanto era assim que em 1966 havia cerca de 86 bancos no País do Cedro.

A diferença mais significativa se encontra no fato de que o Uruguai teve um projeto de desenvolvimento nacional com forte participação do Estado na administração da economia e a extensão de direitos sociais e econômicos para as populações das classes subalternas. Esse projeto começou a ser construído ao longo das duas administrações do já citado presidente José Batlle y Ordóñez (1903-1906 e 1911-1915) e se caracterizava pela busca do entendimento entre as várias facções das classes dominantes, representadas em boa parte pelas várias tendências dentro do governista Partido Colorado, mas também pelo oposicionista Partido Blanco, porta-voz dos setores rurais que tiveram os seus interesses reconhecidos e atendidos pelo governo e eram representados no Estado através do complicado sistema de Lemas. Esse sistema incorporou as classes médias e reconheceu grande parte das demandas das classes trabalhadoras criando uma avançada legislação social, sistema de seguridade social, disseminação da instrução escolar e de uma excelente rede de saúde pública. Dessa forma, ao mesmo tempo em que garantia os vários interesses dos diversos setores de sua classe dominante, o Estado Uruguaio buscou promover a redistribuição da riqueza entre todas as classes de sua sociedade. O Líbano nunca teve nada sequer próximo a isso em todo o século XX.

O modelo intervencionista uruguaio estimulava o antigo setor pecuário a exportar os seus produtos primários como a lã, couro e carne a fim de trazer divisas ao país que eram usadas (junto com outras divisas vindas de outros setores da economia) para a criação e administração de empresas de um desenvolvido setor estatal que controlava ramos como a distribuição de combustível ou participava em outro, onde existia um importante capital privado como era o caso do abate do gado e processamento da carne; o financiamento do desenvolvimento da indústria local em uma política de substituição de importações (semelhante à seguida por Brasil e Argentina), o que levava à implementação de diversas políticas fiscais protecionistas para salvaguardar a existência dessas empresas ao impedir que o excesso de importações a baixo preço as levasse à falência e com isso aumentasse a dependência do Uruguai para com os países mais industrializados; por fim também se procurava financiar os importantes serviços sociais do país.

Foi só com a crise do modelo nacional-desenvolvimentista Batllista, cuja consequência seria o aumento das lutas sociais e da repressão política que desembocariam no regime militar em 1973, que conduziria a uma liberalização da economia cujo resultado foi fazer o Uruguai se parecer cada vez mais com o Líbano.

No Líbano, como já foi dito em capítulos anteriores, o laisse-faire foi transformado em elemento básico da identidade nacional pelas classes dominantes e seus porta-vozes na intelectualidade e qualquer tipo intervencionismo rechaçado como um caminho para o socialismo e algo contrário a 'vocação' do Líbano para o comércio e as finanças. Para os ideólogos do liberalismo econômico libanês seguir no caminho do intervencionismo era terminar como a Síria, o Egito e o Iraque, países governados por ditaduras militares e com supostas ineficiências no funcionamento de suas economia. FINCH, Henry. Uruguay since 1930. In: BETHELL, Leslie. The Cambridge history of Latin America. V. 8 (VIII). Cambridge University Press, 1996. p. 195-209. Ministério de Economia y Finanzas del Uruguay: <http://www.mef.gub.uy> e <https://www.cia.gov/library/publications/the-world-factbook/geos/uy.html〉. 
chegado a ser $31,1 \%$. Já a agricultura, setor que mais empregava mão de obra, e a indústria, os setores produtivos, oscilaram entre 1950 e 1966, respectivamente, entre 19,7\% e 11,4\% e entre e $13,5 \%$ e $13,2 \%$. Alcançando o seu máximo apenas em 1958, ano em que aconteceu a primeira guerra civil no século XX, com 13,6\%. Aliás, a indústria - um setor vital para qualquer projeto de modernização e desenvolvimento econômico - somente ultrapassaria a agricultura em 1964 quando corresponderia a 12,8\% do PNL enquanto esta correspondia a 11,9\%. Ao longo desses anos também se assistiu a ascensão de outro setor não produtivo como consequência do liberalismo: o imobiliário, que em 1961 era 11,1\% do PNL. Seu crescimento estava ligado à enorme entrada do capital árabe no país, cujos donos consideravam mais lucrativo aplicá-lo na compra de imóveis do que investi-lo no setor industrial, agrícola ou fazer parcerias com empresários desses setores.

Com a tabela 4 podemos ver melhor o resultado da escolha dos setores comercial e de serviços para a economia do Líbano: a formação do capital privado nos anos de 19511957 estava maciçamente concentrada nesses setores que, em 1955, corresponderam a 82,1\% de todo o capital formado. Já a agricultura oscilou nesses anos entre 21,4\% e 12\% com uma ascensão em 1954 (14,3\%) e uma grande queda no ano seguinte (9,6\%), enquanto a indústria assistiu a uma queda até 1955, quando saiu de 1,3\% para 8,3\%, seguindo uma forte recuperação até atingir 18\% em 1957. Cabe assinalar o seguinte fato: a maior parte da classe trabalhadora libanesa estava na agricultura nos anos 1950, o que significa que a grande maioria do povo desse país participa muito pouco da formação da riqueza privada.

Tabela 3 - Formação do capital privado por setor, 1951-1957

\begin{tabular}{lcrrr}
\hline & $\begin{array}{l}\text { Formação de capital privado } \\
\text { (em milhões de LL) }\end{array}$ & \multicolumn{3}{c}{$\begin{array}{c}\text { Agricultura } \\
\text { (\% da formação do capital privado) }\end{array}$} \\
\hline 1951 & 113 & 12,4 & 13,3 & 74,4 \\
1952 & 128 & 11,7 & 11,7 & 76,3 \\
1953 & 132 & 12,9 & 11,4 & 75,8 \\
1954 & 140 & 14,3 & 10,7 & 73,0 \\
1955 & 157 & 9,6 & 8,3 & 82,1 \\
1956 & 176 & 12,5 & 13,6 & 73,9 \\
1957 & 150 & 12,0 & 18,0 & 70,0 \\
\hline
\end{tabular}

Fonte: KHALAF, Nadim G. Economic implications of the size nations: with special reference to Lebanon. Leiden: E. J. Brill, 1971. Adaptado da Tabela 53. p. 166. 
Com isso, o desenvolvimento do país fora feito por meio de medidas econômicas de cunho liberal em uma época em que o liberalismo econômico estava desacreditado no mundo por conta das crises produzidas na economia mundial, particularmente o crash de 1929, e das tragédias que as seguiram nos anos 30 e 40. Isso foi justificado da seguinte maneira: entre vastos setores das elites e classes médias libanesas, o planejamento era visto como um erro que sempre causava a alocação insuficiente de recursos e todo tipo de ineficiências. Além do mais, políticas intervencionistas eram consideradas contrárias ao 'espírito libanês', que sempre teria sido marcado pela iniciativa individual, o empreendedorismo, a habilidade nos comércios e nos negócios de maneira geral no qual prevaleceria uma grande capacidade para acumular riquezas, inteligência e adaptabilidade a situações novas.

Para um povo com essas características se supunha que o liberalismo econômico era o regime ideal e, por isso, qualquer tipo de intervencionismo era considerado um ataque à democracia e um passo em direção ao comunismo. Somente a partir do governo de Fuad Chehab (1958-1962) é que se procurou algum tipo de política intervencionista, mas, até 1975, o liberalismo, em uma forma modificada, continuou sendo apreciado e marcou todo o processo de evolução da economia libanesa. Esse período (1948-1958), em que as empresas privada tiveram ampla liberdade de ação dentro da economia libanesa, passou à história como a República Comercial.

1948 pode ser considerado como o ano em que se implantaram as primeiras medidas de liberalização da economia no Líbano com as medidas tomadas pelo presidente Bechara el-Khouri em 17 de novembro, que liberalizaram o mercado de câmbio e permitiram ao capital libanês fluir pelo mundo, enquanto as quotas e restrições existentes para o comércio foram, em grande parte, abandonadas. Também foram desmantelados muitos dos controles burocráticos sobre a economia. Com o tempo, grande parte das medidas de proteção à indústria (bem como a qualquer outro setor da economia) foi bastante reduzida, apesar dos protestos constantes dos setores atingidos por essas medidas. As últimas restrições foram levantadas aos poucos entre 1949 e maio de 1952, ainda no mandato de Bechara el-Khuri.

Para que essa política pudesse ser viável foram tomadas medidas que permitissem ao Líbano ter uma moeda forte e uma economia estável para o país poder realizar o seu objetivo de ser um centro mercantil e de serviços. Essas medidas incluem o acordo monetário com a França, assinado em 1948, a adoção da cobertura em ouro para a emissão da libra 
libanesa com a consequente estabilização financeira, mais a Lei Monetária de 1949.

Também se buscou no período entre 1948 e 1975 manter a moeda libanesa sempre próxima do dólar americano no valor de LL 3,00 para cada US\$1,00, como indica a tabela 5, na qual também vemos que esse objetivo realmente foi alcançado em 1962, durante o mandato de Fuad Chehab. E a taxa de câmbio, embora subisse um pouco, se manteria nos anos seguintes próximas a esse valor.

Outras medidas incluem a manutenção de um excedente orçamentário nas contas do Estado e a implantação de um Fundo de Estabilização do Câmbio em 1949 para promover a estabilização da libra libanesa, caso ela viesse a ser abalada por algum evento como foram os casos da recessão pós-guerra da Coreia, a crise de Suez de 1956 e a guerra civil de $1958^{179}$.

Tabela 4 - Média anual da taxa de câmbio em relação ao dólar dos EUA e a cobertura em ouro da moeda libanesa em circulação

\begin{tabular}{l|c|c}
\hline Ano & Taxa de câmbio & Cobertura em ouro \\
\hline 1948 & - & 2 \\
1949 & 3,26 & 25 \\
1950 & 3,44 & 36 \\
1951 & 3,72 & 45 \\
1952 & 3,65 & 55 \\
1953 & 3,40 & 62 \\
1954 & 3,22 & 90 \\
1955 & 3,24 & 95 \\
1956 & 3,22 & 79 \\
1957 & 3,18 & 87 \\
1958 & 3,20 & 78 \\
1959 & 3,15 & 86 \\
1960 & 3,17 & 92 \\
1961 & 3,08 & 91 \\
1962 & 3.00 & 92 \\
1963 & 3.10 & 92 \\
1964 & 3.07 & 86 \\
1965 & 3.07 & 81 \\
1966 & 3.13 & 84 \\
(continua) & & \\
\hline
\end{tabular}

${ }^{179}$ GATES, Carolyn L. The merchant republic of Lebanon: rise of a open economy. Londres: Centre For Lebanese Studies in association with I B Tauris \& Co LTD, 1998. p. 96. 
(conclusão)

\begin{tabular}{l|c|c}
\hline Ano & Taxa de câmbio & Cobertura em ouro \\
\hline & & \\
1967 & 3.20 & 85 \\
1968 & 3.16 & 85
\end{tabular}

Fonte: MALLAT, Raymond A. 70 years of money muddling in Lebanon, 1900-1970-77: a guide in monetary management for economic development in Lebanon. Beirute: Aleph, 1977. Tabela 2. p. 117.

A estabilização da taxa de câmbio teve como resultado manter os níveis dos preços em um valor bem baixo durante boa parte do período entre 1950 e 1970 embora, partir de 1965, eles começassem a se elevar. Isso foi favorecido pela inexistência de pressões domésticas, pela emergência de um excedente nos balanços de pagamento relativamente modesto e a ausência de inflação importada. A taxa de câmbio nesse período também influenciou a estabilidade dos preços por conta do fato que as transações econômicas externas formavam grande parte do PIB do Líbano ${ }^{180}$.

Em relação ao acordo monetário, ele foi assinado com os franceses, pois, apesar de custoso e de favorecer amplamente a antiga metrópole mandatária, permitia a liberação dos saldos em moedas estrangeiras acumulados durante a II Guerra Mundial e concediam à libra libanesa um forte apoio, tornando-a plenamente convertível, estável e amplamente aceita nos mercados financeiros internacionais. O que seria essencial para o comércio e as finanças internacionais do país.

Esse acordo também promoveu a estabilização do volátil mercado financeiro libanês, outra pré-condição para o país se tornar um centro financeiro ${ }^{181}$.A cobertura do ouro consistia na compra pelo Estado de ouro monetário para aumentar a cobertura da moeda em circulação e estabilizar o seu valor impedindo uma desvalorização e assim garantir o seu valor de troca. Essa cobertura, como indica a tabela 6, chegou a 95\% em 1955, nove anos após começar. Em 1970 era de 85\%. Esse ouro era adquirido graças aos excedentes obtidos do comércio invisível (turismo, transporte, remessas dos lucros do petróleo vindos dos países do

180 MAKDISI, Samir. Financial policy and economic growth: the Lebanese experience. Nova Iorque, Columbia University Press, 1979. p. 96.

${ }^{181}$ GATES. The merchant republic of Lebanon... p. 96. 
Golfo etc.) que permitia ao governo comprar e estocar ouro ${ }^{182}$. Essas compras tornaram Beirute o principal centro financeiro do Oriente Médio.

Tabela 5 - Notas em circulação e sua cobertura, 1951-1968

\begin{tabular}{lcccc}
\hline Ano & Emissão de notas (milhões de LL) & Cobertura em ouro\% & Ativos ext. Ativ. lib. \\
\hline 1951 & 208 & 45 & 6 & 49 \\
1952 & 200 & 55 & - & 45 \\
1953 & 205 & 62 & 3 & 35 \\
1954 & 242 & 90 & - & 10 \\
1955 & 266 & 95 & - & 5 \\
1956 & 333 & 79 & - & 21 \\
1957 & 356 & 87 & - & 13 \\
1958 & 399 & 78 & - & 22 \\
1959 & 400 & 86 & - & 14 \\
1960 & 431 & 92 & - & 8 \\
1961 & 437 & 91 & - & 9 \\
1962 & 470 & 92 & - & 8 \\
1963 & 505 & 92 & - & 8 \\
1964 & 539 & 86 & - & 14 \\
1965 & 590 & 81 & - & 19 \\
1966 & 705 & 84 & - & 16 \\
1967 & 846 & 85 & - & 15 \\
1968 & 914 & 85 & - & 15 \\
& & & & \\
\hline
\end{tabular}

Fonte: MALLAT, Raymond A. 70 years of money muddling in Lebanon, 1900-1970-77: a guide in monetary management for economic development in Lebanon. Beirute: Aleph, 1977. Tabela 2. p. 106.

Quando em 25 de maio de 1958 expirou o acordo monetário com a França, o governo de Camille Chamoun promoveu a assinatura de um novo a respeito de 6 milhões de francos que o Líbano ainda tinha direito. Os franceses renovaram suas garantias no caso de uma desvalorização de sua moeda, mas modificaram a garantia que passou a ser baseada em

182 MALLAT, Raymond A. Fiscal policy for social justice and economic development in Lebanon: a guide in fiscal management for social and economic development in Lebanon. Beirute, 1980. p. 123-125. 
relação à taxa entre o franco e o dólar americano ao invés da libra esterlina. Os franceses também permitiram a liberação dos saldos dos emigrantes libaneses residentes na zona do franco francês para ajudar a equilibrar a balança de pagamentos do Líbano. Por sua vez os libaneses prometeram fazer concessões importantes às companhias concessionárias francesas $^{183}$.

A Lei Monetária de 24 de maio de 1949 junto com um decreto de junho do mesmo ano davam à moeda libanesa uma paridade com o ouro no valor de uma libra para uma taxa de 405,512 miligramas de ouro puro e estipulava que 50\% das reservas dessa moeda eram compostos pela dívida pública, títulos do governo, bônus do tesouro e outros valores imobiliários, enquanto os outros $50 \%$ por ouro e divisas estrangeiras trocadas. Uma lei promulgada pelo governo no dia 27 de maio regulou as reservas de ouro e divisas externas e que ambos deveriam ser avaliados de acordo com a taxa de câmbio oficial. Esta taxa acabou sobrevalorizando em $30 \%$ a moeda libanesa e permaneceria, ao longo do período entre 1950 e 1970, restritas a pouquíssimas transações oficiais.

Essa lei deu credibilidade e estabilidade à libra libanesa e reduziu a dependência em relação ao franco francês ${ }^{184}$. Com o tempo, como consequência da Lei de 1949 que levou a um crescente aumento no lastro em ouro da libra libanesa, acabou fazendo com que ocorresse a liquidação de todas as reservas libanesas em divisas externas. Com isso elas iam cair de $67 \%$ a zero em 1954 tendo sido nulas no período compreendido até $1970^{185}$.

Uma medida que sempre foi perseguida pelo governo do Líbano foi à busca pelo excedente orçamentário, uma prática constante do Estado libanês e meta que sempre se procurou atingir independentemente da situação econômica. Costumava-se ajustar as despesas do orçamento ordinário ao fluxo de receita, mantendo ou expandindo os níveis dos gastos em segurança ou administração de acordo com a entrada dessas receitas. Com a adoção dessas políticas que buscavam manter o excedente orçamentário, poucas vezes se presenciou um déficit desse tipo, como foi o caso do ano de 1950. De maneira geral, o Estado libanês acumulou excedentes que de 1951 a 1959, por exemplo, cresceram de 33, 5 milhões de libras

183 MALLAT, Raymond A. 70 years of money muddling in Lebanon, 1900-1970-77: a guide in monetary manangement for economic development in Lebanon. Beirute: Aleph, 1977 (segunda impressão). p. 104.

${ }^{184}$ Mallat: Idem... p. 102

${ }^{185}$ Mallat: Ibidem..... p. 138 
libanesas para LL125 milhões ${ }^{186}$.

Outro fator que permitiu ao Líbano promover a política econômica liberal foi o grande acúmulo de capital ocorrido durante a Segunda Guerra Mundial, após a ocupação aliada do país em 1941 e que puderam ser usados para financiar os setores mercantil e financeiro. Entre 1939 e 1945 Síria e Líbano (que estavam unificados alfandegária e monetariamente) acumularam um excedente de 607 milhões de libras libanesas ${ }^{187}$.

186 Gates, Carolyn L.: The Merchant Republic...Tabela 5.3, Pág. 101

${ }^{187}$ ISSAWI, Charles apud GENDZIER. Notes from the minefield... p. 44 
Tabela 6 - Produto nacional líquido por setor, 1950-1966 (em porcentagens)

\begin{tabular}{lccccccccccccccccc}
\hline Setor & 1950 & 1951 & 1952 & 1953 & 1954 & 1955 & 1956 & 1957 & 1958 & 1959 & 1960 & 1961 & 1962 & 1964 & 1965 & 1966 \\
\hline & & & & & & & & & & & & & \\
Agricultura & 19,7 & 19,4 & 19,3 & 18,9 & 18,0 & 16,2 & 16,3 & 15,8 & 16,5 & 14,6 & 14,1 & 14,1 & 14,2 & 11,9 & 11,6 & 11,4 \\
Indústria & 13,5 & 13,5 & 13,9 & 13,7 & 13,2 & 12,7 & 12,9 & 12,5 & 13,6 & 12,2 & 12,1 & 12,1 & 11,7 & 12,8 & 13,1 & 13,2 \\
Construção & 4,1 & 3,2 & 4,3 & 4,0 & 4,7 & 4,3 & 3,5 & 2,7 & 2,8 & 3,3 & 3,5 & 3,4 & 3,4 & 5,6 & 5,7 & 6,0 \\
Transporte & 4,1 & 4,2 & 4,0 & 4,3 & 4,7 & 5,4 & 5,5 & 5,3 & 4,3 & 4,0 & 3,9 & 4,0 & 4,7 & 8,1 & 8,2 & 8,0 \\
Comércio & 28,8 & 31,0 & 29,4 & 29,3 & 29,6 & 28,8 & 31,2 & 27,5 & 31,8 & 32,0 & 32,0 & 31,4 & 32,1 & 30,8 & 30,6 & 40,6 \\
Finanças \& Seguros & 3,8 & 4,2 & 4,5 & 4,3 & 4,5 & 5,1 & 5,6 & 6,0 & 7,0 & 6,3 & 6,3 & 6,4 & 6,5 & 3,4 & 3,4 & 3,6 \\
Imóveis & 9,2 & 8,9 & 8,8 & 8,6 & 8,8 & 8,4 & 9,2 & 9,2 & 11,7 & 11,0 & 11,0 & 11,1 & 10,8 & 7,8 & 7,6 & 7,3 \\
Governo & 6,9 & 5,9 & 5,7 & 6,1 & 5,8 & 6,0 & 6,7 & 7,2 & 8,5 & 8,0 & 7,8 & 7,7 & 8,2 & 7,7 & 8,0 & 8,2 \\
Serviços & 9,6 & 9,5 & 9,5 & 10,5 & 10,6 & 12,0 & 11,3 & 9,8 & 7,8 & 8,9 & 9,2 & 9,2 & 9,1 & 10,6 & 11,3 & 11,5
\end{tabular}

Fonte: KHALAF, Nadim G. Economic implications of the size of nations. Leiden: E. J. Brill, 1971. p. 1. 
Decisivo também foi o fato de a república libanesa possuir uma série de vantagens em relação aos seus vizinhos árabes que em muito facilitaram a adoção do liberalismo econômico como a posição geográfica do país que lhe permitia contatos tanto com o Ocidente quanto com o todo o Mundo Árabe.

O fato de possuir uma elite com fortes vínculos com o capital ocidental e mesmo nos setores cristãos, na cultura e em sociedades ocidentais, enquanto outro setor era muito vinculado ao seu entorno árabe e muçulmano, como era o caso das estreitas relações existentes entre diversos membros das elites sunitas libanesas e as famílias principescas dos reinos do Golfo Pérsico, ${ }^{188}$ foi essencial para o Líbano assumir esse papel de entreposto entre o Oriente e o Ocidente, bem como ajudaram bastante na instalação do laissez-faire.

No caso das elites árabes, elas preferiam se relacionar diretamente com os libaneses que, pelo fato de serem árabes, conseguiam entender a sua mentalidade, cultura e costumes. Essas elites usaram o Líbano para as suas políticas de comércio exterior e investimento, além de utilizarem os seus bancos para guardar boa parte de suas fortunas. Já os contatos com as elites ocidentais por parte de amplos setores das classes dominantes cristãs, mas também das muçulmanas, ajudavam os grandes capitalistas e empresas europeias e norte americanas no momento de realizarem negócios nos países árabes.

Outra grande vantagem era a existência (ao menos em Beirute, Monte Líbano e certas cidades costeiras) de uma infraestrutura mais desenvolvida do que a que era encontrada na maior parte do mundo Árabe da metade do século XX com redes de transportes, comunicações e serviços de todo tipo, que sempre foram reforçadas por investimentos do Estado desde antes da independência em 1943. Essas infraestruturas com suas estradas, rodovias, portos, serviços de cabotagem, aeroportos, linhas telefônicas, telégrafos, empresas de transportes de passageiros e cargas, marítimas, terrestres e aéreas foram aproveitadas pelas elites dos outros países árabes para

\footnotetext{
188 Ao longo da segunda metade século XX, como resultado da ascensão do nacionalismo árabe, muitos árabes, aí incluindo lideranças, como Nasser, começaram a questionar o uso da expressão Golfo Pérsico para se referir ao trecho de mar localizado entre a Península Arábica e o Irã, preferindo chamá-lo de Golfo Árabe. Essa reivindicação dos árabes foi sempre questionada pelos iranianos desde os tempos do Shah Reza Pahlevi. Para resolver a disputas se propôs o uso da expressão Golfo Arábico-Pérsico. HABIBI, Nader; El-NAJJAR, Hassan. The dispute about the Persian/Arabian Gulf name: how should it be resolved? Al Jazeera, 11 Fev. 2005. Eu, neste trabalho, continuo a usar a expressão Golfo Pérsico por ser a de uso mais frequente no Brasil.
} 
realizar suas viagens, negócios e comércio até que pudessem começar a montar essa infraestrutura em seus próprios países.

Vantagem importante, ao longo de todo o período situado entre 1950 e 1970, foi o fato de o Líbano se sobressair em virtude de possuir uma liderança cultural que somente o Egito poderia desafiar. O país possuía importantes universidades no contexto do mundo Árabe, que atraíam estudantes de todos esses países.

Havia no Líbano uma maior porcentagem de pessoas com instrução superior e os índices de alfabetização eram melhores do que nos países vizinhos. Existia ainda ali uma ativa indústria editorial que publicava uma quantidade importantes de livros. O Líbano também possuía algo ainda hoje raro no mundo Árabe e que não era permitido nem nos países conservadores e nem nos nacionalistas e revolucionários e fazia do País do Cedro uma caixa de ressonância dos acontecimentos no seu entorno árabe: liberdade de expressão, que se traduzia na publicação e um grande número de jornais diários do país, refletindo todas as tendências políticas árabes existentes.

Essa posição de destaque cultural havia sido herdada do século XIX, quando a montanha libanesa foi um dos centros da Nahda, o renascimento cultural árabe, que modernizou a língua, criou as bases da cultura árabe contemporânea e era mantida através da existência de uma importante rede cultural e informativa, cuja influência atingia todo o mundo Árabe. Essas vantagens culturais também foram importantes para fazer do Líbano uma ponte entre o Ocidente e o Oriente, pois esse país era uma porta de entrada no mundo Árabe para novidades culturais vindas dos países europeus e dos EUA.

Finalmente, é fundamental destacar as importantes consequências da chegada dos refugiados palestinos, que impulsionou a economia libanesa pelas seguintes razões: 1) os seus empresários que se assentaram no Líbano trouxeram modelos de administração de empresas mais sofisticados do que os existentes no Líbano. Suas atividades compreendiam as bancárias, os seguros, empresas de exportação e importação etc.; 2) os capitais trazidos para os bancos libaneses, que em 1948 ainda eram poucos e o sistema bancário nacional pequeno, estavam por trás do financiamento da construção de muitos edifícios em Beirute, bem como em Amman e Damasco também; 3) a classe média palestina foi muito útil como empreendedores comerciais e 
industrias na economia do Líbano; 4) já os pobres, sofridos e muitas vezes humilhados moradores dos campos, forneceram sua mão de obra a um preço baixo, o que permitiu o desenvolvimento da industria e garantiu a esses capitalistas altos lucros e uma boa taxa de reinvestimento $^{189}$.

\subsection{A situação socioeconômica do Líbano}

O número de libaneses que emigravam chegou a diminuir nos anos 50, mas só foi crescendo a partir de 1960 (8.566 libaneses emigraram na década de 1960, como mostra a tabela 23), assim demonstrando que o crescimento econômico desse período era incapaz de absorver a mão de obra, que anualmente entrava no mercado de trabalho, ou os camponeses que migravam para as cidades.

Desse modo, a imigração foi considerada a única saída possível para o desemprego. O destino desses libaneses que emigravam eram os mais variados: África Ocidental (onde havia uma grande emigração xiita), Austrália, América Latina, Líbia, América do Norte e Europa Ocidental. Essas ondas migratórias não eram compostas apenas de trabalhadores com baixo nível de instrução e mal qualificados, mas também de muita gente com formação superior e que não encontrava emprego no Líbano. Dessa maneira, de 1962 a 1969, a título de exemplo, o Líbano perdeu para os EUA, o Canadá e a França 405 engenheiros, 212 médicos, 127 biólogos, 107 enfermeiras e 1.455 técnicos ${ }^{190}$. Estima-se que dois terços dos engenheiros e 1/3 dos médicos que se formaram nos anos 60 tenham emigrado para a América do Norte ${ }^{191}$. Outra direção que tomavam os imigrantes libaneses mais qualificados eram a Arábia Saudita e as outras monarquias do Golfo Pérsico responsáveis por importar grande número de mão de obra qualificada do Líbano já na década de 1960.

Esse dreno de cérebros foi um dos aspectos mais preocupantes do período por retirar do país trabalho qualificado, porém o governo libanês nunca elaborou uma política para resolver

\footnotetext{
189 MEYER apud KHAYYAT. p. 46.

${ }^{190}$ E. Seis apud NARS. Backdrop to civil war... p. 11.

191 NARS... p. 12.
} 
ou sequer amenizar esse problema.

Tabela 7 - Emigração libanesa, 1945-1970

\begin{tabular}{lc}
\hline Período & Indivíduos por ano \\
\hline $1945-1950$ & 3.300 \\
$1951-1959$ & 2.850 \\
$1960-1970$ & 8.566 \\
\hline
\end{tabular}

Fonte: GASPARD, Tufic K.. A political economy of Lebanon, 1948-2002: the limits of laissez-faire. Leiden e Boston: E. J. Brill, 2004. Adaptado da Tabela 3.12. p. 97.

A existência da emigração era a indicação que, para a população libanesa, essa experiência do liberalismo econômico trouxe bem poucos benefícios, especialmente para as camadas populares das comunidades muçulmanas que foram completamente negligenciadas pelos dois primeiros presidentes libaneses.

Isso fica bem evidente pelos dados da tabela 27, nos quais vemos que de todo o Produto Interno Bruto produzido os lucros corresponderam a 59\% nos anos 1950 e $51 \%$ na década seguinte. Essa negligência e o abandono das regiões de população majoritariamente muçulmana foram às causas profundas da guerra civil de 1958, bem como a adesão dessa população ao nacionalismo árabe e sua forte identificação com presidente egípcio Gamal Abdel Nasser.

Após o conflito, os problemas sociais graves que atingiam grande parte da população libanesa fizeram com que o governo de Fuad Chehab, entre 1958 e 1964, procurasse realizar obras de infraestrutura nas regiões que ficaram até então às margens do desenvolvimento dos anos 50 e estabelecesse um projeto de seguridade social para aliviar a pobreza que atingia a maior parte da população libanesa, especialmente das pessoas que residiam nas áreas rurais. 
Tabela 8 - Atividade laboral, emprego e desemprego, 1950-1970

\begin{tabular}{lccc}
\hline & 1950 & 1960 & 1970 \\
\hline População (milhares) & 1.443 & 1.857 & 2.469 \\
Taxa de atividade (\% da população) & 31,7 & 31,7 & 32,0 \\
População ativa (milhares) & 457 & 589 & 790 \\
Emprego (milhares) & 411 & 558 & 702 \\
$\quad$ No governo & 18 & 38 & 60 \\
$\quad$ Nas forças armadas & 5 & 11 & 15 \\
& & & \\
Desemprego (\% da pop. ativa) & 10,0 & 5,3 & 11,1 \\
Taxa de atividade estimada pela ONU & & & \\
Homens & 48,2 & 42,9 & 44 \\
Mulheres & 7,6 & 10,2 & 11,5 \\
Total & 28 & 26,7 & 27,9 \\
& & & \\
\hline
\end{tabular}

Fonte: GASPARD, Tufic K.. A political economy of Lebanon, 1948-2002: the limits of laissez-faire. Leiden e Boston: E. J. Brill, 2004. Adaptado da Tabela A.II.1. p. 242.

Outro problema que atingia a população libanesa pobre entre os anos de 1950 e 1970 foi à persistência do desemprego disfarçado, especialmente, mas não somente, na agricultura, setor que empregava até os anos 60 a maior parte da força de trabalho libanesa. Nesse caso o indivíduo não se encontrava formalmente desempregado, mas a sua renda era muito baixa e costumava declinar constantemente. Em geral isso acontecia por que nessa situação o empregado recebia um salário muito baixo e o aumentava de acordo com a sua produção de cada mês. Ou então o indivíduo fazia parte daquele conjunto de pessoas que se dedicavam a todo tipo de atividades de auto remuneração, sem nenhum tipo de amparo pela legislação social e poderiam ser desde vendedores de rua e entregadores até encanadores, eletricistas e taxistas.

Esse desemprego disfarçado ou o subemprego foi uma consequência das políticas voltadas para estimular os setores comerciais e de serviços que acabou impedindo os ramos que mais poderiam absorver mão de obra, a indústria e a agricultura, de crescer a ponto de utilizar 
esse excedente de trabalhadores ${ }^{192}$.

Tabela 9 - Estrutura do emprego alternativo por ramo da economia (\%)

\begin{tabular}{lccc}
\hline & 1950 & 1960 & 1970 \\
\hline Agricultura & 55 & 44 & 26 \\
Indústria & 11 & 12 & 16 \\
$\quad$ ou & & & \\
Manufatura & $(10)$ & $(11)$ & $(15)$ \\
Construção & 5 & 6 & 8 \\
Serviços & 29 & 38 & 50 \\
Total & 100 & 100 & 100 \\
Total (milhares) & 411 & 558 & 702 \\
& & &
\end{tabular}

Fonte: GASPARD, Tufic K.. A political economy of Lebanon, 1948-2002: the limits of laissez-faire. Leiden e Boston: E. J. Brill, 2004. Adaptado da Tabela A.II.3. p. 245.

Como desde 1932 nunca mais foi realizado nenhum censo populacional no Líbano, também não se conhecia com exatidão o número da força de trabalho no país. Por isso, o número para o período entre 1950 e 1970 são estimativas realizadas por vários órgãos de pesquisa. Dessa forma, em 1950 um estudo da ONU estimou que o número de pessoas trabalhando no Líbano era de 410 mil e que haveria uma taxa de $10 \%$ de desemprego.

Essa taxa aparece em um estudo de Churchill em 1954 para um estudo socioeconômico da região de Beirute entre 1952 e 1953. Posteriormente, a população produtiva do Líbano foi estimada pela missão do IRFED (Institute International de Recherche et de Formation, Éducation e Development) a partir de um estudo da Universidade Americana de Beirute em 1959 com 813 mil pessoas, das quais 450 mil eram plenamente empregadas e 130 mil possuíam empregos parciais.

Em 1964 o Ministério do Planejamento realizou outro estudo no qual estimou a

192 GATES. The merchant republic of Lebanon... p. 141. 
população empregada em 616 mil pessoas. Os dois estudos excluíram as forças armadas sendo que, caso o seu pessoal fosse incluído, elevaria a população empregada no estudo do IRFED para 590 mil e no do Ministério do Planejamento para 630 mil. Outra pesquisa realizada por PAL70, já em 1970, estimou o número de empregados no Líbano em 702 mil $^{193}$. Também importante para o mundo do trabalho no Líbano foi à diminuição do número de trabalhadores na agricultura no período entre 1950 e 1970, tendo isso acontecido principalmente na década de 1960, como indica a pesquisa do IRFED apresentada na tabela 26. Dessa maneira, enquanto em $196055 \%$ da força de trabalho encontrava-se na agricultura, em 1970 esse número havia sido reduzido para 19\%. Essa mão de obra foi em sua maior parte absorvida pelo setor de serviços que empregava nesse último ano $56 \%$ da força de trabalho libanesa.

Tabela 10 - Estimativa da estrutura de emprego por atividade econômica (\%)

\begin{tabular}{lclccc}
\hline & 1950 & & 1960 & \multicolumn{2}{c}{1970} \\
\hline & ILO & ILO & IRFED & ILO & PAL70 \\
Agricultura & 55 & 38 & 55 & 20 & 19 \\
Indústria & 20 & 23 & 18 & 25 & 19 \\
Serviços & 25 & 39 & 28 & 55 & 56 \\
Total & 100 & 100 & 100 & 100 & 100
\end{tabular}

Fonte: GASPARD, Tufic K.. A political economy of Lebanon, 1948-2002: the limits of laissez-faire. Leiden e Boston: E. J. Brill, 2004. Adaptado da Tabela A.II.2. p. 244.

O estudo do Ministério do Planejamento foi considerado por Gaspard (2004) mais preciso por ser mais abrangente e ter realizado uma cobertura mais sistemática do conjunto da população libanesa. Outro problema dos estudos da Universidade Americana de Beirute e do IRFED é que eles implicariam em uma baixa taxa de crescimento do emprego nos anos de 1959 a

193 GASPARD. A political economy of Lebanon...p. 130-131. Apêndice 2. 
64, quando o Líbano presenciou o desenvolvimento econômico dos anos do mandato de Chehab.

Já Mallat (1977) crítica o estudo do IRFED, pois este ao afirmar que a taxa de desemprego no Líbano era de 28-44\% subestimou a proporção do subemprego no país. Além disso, se esse altíssimo desemprego existisse, afirma o autor, o Líbano teria presenciado uma forte agitação social. $\mathrm{O}$ autor também estima que o número de gente trabalhando no Líbano em 1959-1960 era menor do que o estudo do IRFED sugere, pois era preciso nessa época excluir até $78 \%$ da população feminina, ainda impedida de entrar no mercado de trabalho por conta de costumes tradicionais e tabus, bem como os estudantes das escolas de segundo grau e das universidades. A quantidade de gente empregada estaria em torno de 470 mil.

Tabela 11 - Fatores de distribuição de renda (em \% do PIB)

\begin{tabular}{lcc}
\hline & 1950 & $1964-1970$ \\
\hline Produto interno bruto & 100 & 100 \\
Menos: Administração pública & -6 & -8 \\
$=$ & & \\
Renda bruta produzida & 94 & 92 \\
$=$ & & 33 \\
Salário - setor privado & 30 & 51 \\
Lucros & 59 & 8 \\
Taxas indiretas líquidas & 5 & 7 \\
Salários - setor público & 5 &
\end{tabular}

Fonte: GASPARD, Tufic K.. A political economy of Lebanon, 1948-2002: the limits of laissez-faire. Leiden e Boston: E. J. Brill, 2004. Adaptado da Tabela 5.7. p. 161.

A questão da estimativa dos números sobre o trabalho feminino no Líbano é difícil de ser resolvida, sendo frequentemente subestimada, principalmente na agricultura. Por exemplo, os números da ONU para o trabalho feminino fora do setor agrícola foram fixados em $11 \%$ de toda a 
mão de obra, enquanto outro estudo de 1961 conduzido sob a supervisão da Organização Internacional do Trabalho (OIT) afirmou que as mulheres eram 17\% da força de trabalho no setor privado não agrícola do Líbano ${ }^{194}$.

Também sempre foi complicado estimar o trabalho estrangeiro no Líbano, pois esse país desde a época do mandato sempre recebeu grandes contingentes de trabalhadores sírios e depois de 1948 contou com a grande mão de obra palestina dos campos de refugiados. Em 1965 o Ministério das Obras Públicas divulgou um documento no qual se dizia que 560 mil pessoas - um número que parece muito grande - viviam e trabalhavam no Líbano sem serem cidadãos e, no mesmo ano, esse mesmo ministério recebeu apenas 14.962 pedidos de permissão de trabalho, sendo que apenas 8.846 licenças foram concedidas.

No entanto, outras 110 mil pessoas trabalhariam no país sem nenhum tipo de permissão das instituições do governo ${ }^{195}$. A maioria esmagadora desses trabalhadores poderia ser composta dos já referidos sírios que vinham todos os anos trabalharem por alguns meses na construção civil e na agricultura. Uma estimativa realizada em 1967, a partir dos balanços de pagamentos, estimou que naquele ano o Líbano recebeu 75 mil trabalhadores temporários sírios, dos quais 30 mil na agricultura e 21 mil na construção civil sendo o restante nos demais setores da economia. Já com relação aos palestinos, a economia libanesa empregaria por volta de 42 mil no fim dos anos 60 , dos quais, um quarto na agricultura ${ }^{196}$. Os palestinos, como não podiam se associar às organizações trabalhistas libanesas, acabaram formando a sua própria organização, a Federação dos Trabalhadores Palestinos, porém tinha pouca adesão e o seu poder de barganha era muito limitado ${ }^{197}$.

Com relação à classe trabalhadora libanesa é interessante constatar a existência de uma divisão de perfil comunitário nela: os cristãos eram encontrados principalmente no setor de

\footnotetext{
194 GASPARD. A political economy of Lebanon... p. 240. Apêndice 2.

${ }^{195}$ MALLAT. 70 years of money muddling in Lebanon... p.33 e 36.

196 GASPARD. A political economy of Lebanon... p. 241. Apêndice 2.

197 KHAYYAT, Muhammed Adnan Salah. Aspects of Lebanese labour movement post the labour law of 1946. Tese: Universidade Americana de Beirute, 1973. Nota 1, p. 42.
} 
serviços e comercial, os mais importantes da economia libanesa ${ }^{198}$. Já a maioria dos trabalhadores na indústria, agricultura e na construção civil eram muçulmanos.

Entretanto, por volta de 1970, mais da metade desses trabalhadores muçulmanos não era de libaneses e sim sírios, palestinos, de pessoas de outros países árabes vizinhos e, em menor medida, não árabes. Eles costumavam estar em uma situação desvantajosa em relação aos seus colegas libaneses devido às seguintes razões: 1) encontravam-se majoritariamente na agricultura onde as leis trabalhistas não eram aplicadas até a década de 1970; 2) não tinham influência no movimento trabalhista nos seus estágios iniciais e posteriormente ela sempre foi limitada; 3) não tinham reconhecimento legal por parte do governo ${ }^{199}$.

\subsection{Lei do trabalho de 1946}

Essa lei foi criada como resultado da pressão dos setores organizados da classe trabalhadora libanesa, uma conquista da então recém independente nação libanesa por ter assegurado - ainda que de maneira limitada - uma série de direitos trabalhistas. Esse código teve grande influência da legislação trabalhista francesa visível no estabelecimento da semana de 48 horas de trabalho e no pagamento de horas extras $150 \%$ acima do pagamento da hora normal de trabalho. Garantiu também o abono familiar, férias anuais, auxílio-doença e o estabelecimento da justiça do trabalho $^{200}$.

Entre as conquistas cabe ressaltar a igualdade de direitos entre homens e mulheres. Concedia a elas licença para se ausentar temporariamente do emprego devido à gravidez. No entanto proibia o trabalho de mulheres nas seguintes atividades que eram identificadas pelo artigo 27: minas e pedreiras; fornos de fundição, refino e preparo de metais; extração da prata usando o mercúrio; produção e manuseio de explosivos; fundição e esfriamento do vidro; soldagem de metais através de derretimento parcial; elaboração de bebidas alcoólicas; pintura pelo método Deco; tratamento de cinzas contaminadas com chumbo; extração de prata por meio de chumbo; soldagem de metais que contenham mais de $10 \%$ de chumbo; fabricação de alumínio ou sulfatos

\footnotetext{
198 Idem. p.42.

199 Idem. p. 42-43.

${ }^{200}$ Idem. p. 72.
} 
de silicone de chumbo; preparação e fixação de cabines elétricas; dirigir máquinas com motores muito grandes; fixação ou limpeza de máquinas cujos motores estejam ligados; produzir asfalto; curtir ou esfolar animais, trabalhar em lojas de fertilizantes extraídos de excrementos, adubos, ossos ou sangue ${ }^{201}$.

Por outro lado, por conta do caráter vago de muitas de suas passagens, que foram deixadas para solução em negociações posteriores, das grandes concessões feitas aos empregadores, da pressa com que foi elaborada e do fato de estabelecer uma conexão estreita entre o mundo do trabalho, o governo e os empregadores tiveram como resultado a limitação da autonomia do movimento sindical. Além disso, possibilitaram a intervenção do governo nas relações entre empregados e empregadores quase sempre a favor dos interesses destes últimos. Isso também se dava pelo fato de que muitas questões foram deixadas em aberto para serem resolvidas posteriormente, mediante determinações administrativas ou por litígios ${ }^{202}$.

Já em uma série de outros artigos ela foi elaborada de maneira evidente para favorecer os patrões em suas relações com os seus empregados. Esse é os casos dos artigos 50, 84, 85, 86 e 105. No artigo 50, por exemplo, se permite aos empregadores despedirem trabalhadores que não estejam contratados com uma duração específica sem conceder um aviso legal, ou seja, explicar a razão da sua demissão ao trabalhador. Este apenas tem direito a um pagamento igual a um salário de um mês para cada ano de serviço ou um pagamento proporcional para cada mês pago se ele estivesse a menos de um ano no emprego. Essa separação nos pagamentos era regulada pelo artigo 51. Com isto o artigo 50 acabou tendo um efeito nefasto sobre o movimento sindical impedindo o seu crescimento, ainda mais pela inexistência de estruturas na sociedade libanesa que ajudassem o trabalhador se este se encontrasse desempregado ${ }^{203}$.

Uma das mais graves restrições aos sindicatos vindas dessa lei era a sua proibição de participar de manifestações e reuniões políticas (artigo 84). O Ministério do Interior poderia suspender qualquer sindicato que realizasse uma atividade tida como política segundo o artigo

\footnotetext{
${ }^{201}$ Disponível em: <http://lb2.mofcom.gov.cn>.

202 KHAYYAT. Aspects of Lebanese labour movement ... p. 112.

${ }^{203}$ Idem. p. 73 e 74. Lebanon a year later: the crisis deepens. In: MERIPS. Report, N. 30, ago.1974. p.28.
} 
105, o que incluía até mesmo manifestações ${ }^{204}$. Como também não existia uma definição clara do que separava uma ação política de uma estritamente sindical, os sindicatos e suas federações estavam sempre sobre a pressão do ministro do Interior que, por conta da origem social dos seus altos funcionários e dirigentes, sempre costuma estar do lado dos empregadores ${ }^{205}$.

Também para enfraquecê-los se determinou que o artigo 85 proibisse qualquer sindicato de incluir trabalhadores de ocupações diferentes. No entanto, por sorte essa norma foi burlada, pois poucos sindicatos libaneses se enquadravam nela ${ }^{206}$. Mesmo assim, o artigo 85 também prejudicava o trabalhador, não individualmente, mas sim coletivamente ao impedir que os sindicatos incluíssem pessoas de diferentes ocupações, mas apenas de profissões e trabalhos similares sem, no entanto, especificar quais são essas profissões similares. Além do mais, afirmava que cabia ao Ministério dos Assuntos Sociais decidir isso. Essa indefinição e o fato de que o governo libanês sempre era ocupado por governos conservadores teve como resultado o uso desse artigo para enfraquecer o movimento sindical do país ${ }^{207}$.

Foi dado ao Ministério dos Assuntos Sociais o direito de conceder licença de funcionamento para os sindicatos pelos artigos 83 e $106^{208}$. Porém essas concessões nunca foram simples trâmites burocráticos. Isso fica claro tanto pela história de um sindicato combativo como o dos gráficos de Beirute (dirigido pelo histórico líder comunista Mustafá Ariis), como em uma declaração do general Jamil Lahoud, que foi ministro do Trabalho e dos Assuntos Sociais em 1962-1963, durante o mandato de Fuad Chehab.Esse militar assim se referiu à questão das licenças: "In Lebanon the question of licensing and financing of labor organizations is directly related to the interest of government. There are many cases where the authorities were behind the formation of a certain union or federation". Ainda segundo Lahoud, o interesse dos trabalhadores ou a legalidade dos pedidos na liberação das licenças é algo de menor importância ${ }^{209}$.

Onze anos depois, durante o mandato de Camile Chamoun, em 1957 com o Decreto

\footnotetext{
204 KHAYYAT. p. 113.

${ }^{205}$ Idem... p. 75.

${ }^{206}$ Idem... p. 117.

${ }^{207}$ Idem... p. 74.

${ }^{208}$ KHAYYAT. Nota 1. p. 86.

${ }^{209}$ KHAYYAT.. p. 116.
} 
18.071, o governo passou a subsidiar os sindicatos e dessa forma a controlá-los indiretamente ${ }^{210}$. A distribuição das verbas não levava em conta o tamanho dos sindicatos, mas era determinada por questões políticas. Assim, a federação pró-governo Jami at sempre recebeu um subsídio maior embora contasse com pouco filiados.

Por outro lado, os sindicatos não podiam recusar esse dinheiro, pois devido ao pequeno número de filiados e a renda baixa deles, em especial quando eram trabalhadores manuais, dos quais muitos não recebiam um salário regular, não conseguiam obter receita suficiente para manter-se $\mathrm{s}^{211}$.

Nem todas as categorias de trabalhadores foram sujeitas à Lei Trabalhista. Esse foi o caso dos trabalhadores agrícolas, que até a década de 1960 era o grupo mais numeroso da classe trabalhadora. Na época da promulgação da lei o governo de Bechara el-Khuri havia prometido um código trabalhista separado para os trabalhadores agrícolas, mas isso não foi feito ${ }^{212}$. Também ficaram de fora os professores, funcionários públicos cuja profissão não fosse regulada pelos códigos do funcionalismo público, trabalhadores domésticos, empregados familiares sob o comando do pai, mãe ou guardião, além de assalariados e trabalhadores eventuais do governo ou municípios $^{213}$.

Em um caso a extensão legal dos direitos trabalhistas a um grupo acabou sendo anulada na prática pelo tipo de ocupação dominante entre esses trabalhadores: Trata-se do trabalhadores estrangeiros, pois a exclusão dos trabalhadores domésticos das leis trabalhistas também significou a exclusão de um grande número deles da cobertura dessa lei ${ }^{214}$.

Em longo prazo, para ilustrar as consequências dos aspectos negativos da Lei Trabalhista de 1946, podemos citar as conclusões que Muhammad Khayyat chegou em sua tese de 1973:

\footnotetext{
${ }^{210}$ Idem... p. 76.

${ }^{211}$ Idem. p. 115.

212 Idem. Nota 1. p. 72.

213 Disponível em: <http://lb2. mofcom.gov.cn>.
}

${ }^{214}$ International Organization for Migration (IOM): intra-regional labour mobility in the Arab World. p. 104. 
"The Labor Law of 1946 has been able to mantain its status quo and enable administrators to wield it against labor largely because of the social-economic setup of the country [liberalismo, confessionalismo] (...) The three main factor that were played up by the labor law are (I) the lack of an industrial base, (II) sectarian divisiveness, (III) blue-collar vs white-collar antagonism, 215 .

Com relação à fraca base industrial, o autor afirma que isso teria fragilizado os sindicatos, pois fazia com eles se subdividissem em blocos por cada estabelecimento. Isso teve como resultado fazer com que os seus membros se tornassem leais apenas à empresa onde trabalhavam e não tentassem estabelecer contatos com trabalhadores de outras empresas, mas pertencentes ao mesmo ramo. Por outro lado, eles viam as recompensas salariais e de outros tipos como um prêmio pela lealdade aos seus patrões e firmas de trabalho ${ }^{216}$.

\subsection{Sindicatos e movimento trabalhista}

Com relação aos níveis de sindicalização, os números do Líbano não eram dos melhores. Embora desde o começo do século XX existissem sindicatos no país e apesar das eventuais mobilizações e da demonstração da capacidade de negociar e conseguir, frente aos patrões ou ao Estado, obter conquistas de direitos laborais ou aumento de salários, de maneira geral, no período entre 1950 e 1970 (e mesmo depois), os sindicatos no Líbano eram fracos.

Estimativas do número de trabalhadores sindicalizados variavam entre 14 e 28 mil em 1952, apesar do potencial de sindicalização ser de 100 mil trabalhadores. Na década de 60 cresceu a sindicalização, chegando o Líbano em 1967 a contar com 34 mil (ver tabela 28) trabalhadores ligados a algum dos 121 sindicatos da época. Porém os números continuaram baixos como, por exemplo, com relação à indústria, que contava nos anos 50 e 60 com apenas um terço dos seus trabalhadores ligados a algum sindicato ${ }^{217}$. Por outro lado esses números eram os melhores do Oriente Médio entre 1950 e 1970, pois a média de sindicalização no Líbano era de 4,6\%, enquanto em nações como Irã, Síria, Egito, Iraque, Turquia e até Chipre a média era de

\footnotetext{
215 p. 139

${ }^{216}$ KHAYYAT... p. 140

${ }^{217}$ GASPARD. Political economy of Lebanon... p. 65
} 
insignificantes $0,58 \%^{218}$.

Outro autor, M. Khayyat, apresenta números diferentes para o movimento sindical libanês e a quantidade de trabalhadores no Líbano, mas também concorda com a existência de um baixo nível de sindicalização da força de trabalho. No final da década de 1940 haveria no Líbano 40 sindicatos, reunindo 35 mil trabalhadores, correspondendo esse número a $15 \%$ da força de trabalho na época, cujo número era de 250 mil.

Em 1967 havia 125 sindicatos, dos quais 70 eram de trabalhadores manuais, 25 de funcionários de escritórios e 30 juntavam as duas categorias (sindicatos mistos). No total eles compreendiam 48.400 filiados dos quais o maior número (20.800) pertencia aos mistos, enquanto os de operários contavam com 19.500 , embora fossem $70 \%$ do total de sindicatos. Os sindicatos mistos tinham outra característica; eles se caracterizavam por serem sindicatos restritos a um estabelecimento ou empresa. No entanto, a força de trabalho havia alcançado o número de 500 mil pessoas. Assim, menos de $15 \%$ de toda a força de trabalho libanesa era sindicalizada no fim da década de $1960^{219}$. A tabela 12 apresenta os maiores sindicatos do Líbano.

Tabela 12 - Os doze maiores sindicatos por volta de 1970

\section{Sindicato}

Trabalhadores têxteis

Empregados da Regie de Tabacs

Empregados da Middle Eastern Airlines

Estabelecimentos hoteleiros

Estabelecimentos bancários

Estabelecimentos ferroviários

Sindicatos dos professores

Escritório de transporte comum

\section{Número de filliados}

3.500

2.600

2.440

2.100

1.300

1.200

1.000

1.000

(continua)

218 MALLAT. 70 years of money muddling in Lebanon... p. 36

${ }^{219}$ KHAYYAT... p. 95,97, Tabela 9. p. 97 
(conclusão)

Tabela 12 - Os doze maiores sindicatos por volta de 1970

Empregados da Universidade Americana de Beirute $\quad 1.000$

Escritório de Eletricidade do Líbano $\quad 1.000$

Companhia do Porto de Beirute 1.000

Empresa de Cimento Chekka $\quad 1.000$

Fonte: KHAYYAT, Muhammed Adnan Salah. Aspects of Lebanese labour movement post the labour law of 1946. Tese: Universidade Americana de Beirute, 1973. Tabela 10. p. 98-99.

Os sindicatos libaneses também podem ser divididos em outras três categorias: artesanais, industriais e de estabelecimentos particulares ou públicos/estatais. Havia sindicatos de artesãos: barbeiros, alfaiates, serralheiros, marceneiros. E também entram nessa categoria os professores, motoristas, taxistas e atendentes de loja. Sindicatos industriais: representam os trabalhadores empregados em estabelecimentos exercendo uma atividade de tipo industrial independentemente do tamanho ou tipo destes.E sindicatos de Estabelecimentos: são os sindicatos ligados a uma única empresa, como é o caso dos Sindicatos dos Empregados da Middle East Airlines, a maior empresa aérea do Líbano.

Tabela 13 - Os três tipos de sindicatos do Líbano

\begin{tabular}{lccccc}
\hline Tipo de sindicato & Número & Porcentagem & Filiados & Porcentagem & Tamanho médio \\
\hline Artesanal & 46 & $36,8 \%$ & 11.265 & $23,3 \%$ & 244 \\
Industrial & 45 & $36 \%$ & 18.555 & $38,1 \%$ & 412 \\
Estabelecimento & 34 & $27 \%$ & 18.655 & $38,6 \%$ & 548 \\
Total & 125 & $100 \%$ & 48.475 & $100,0 \%$ & 387,8
\end{tabular}

KHAYYAT, Muhammed Adnan Salah. Aspects of Lebanese labour movement post the labour law of 1946. Tese: Universidade Americana de Beirute, 1973. Tabela 11. p. 100. 
Tabela 14 - Distribuição dos sindicatos ao longo dos setores da economia

\begin{tabular}{lccccc}
\hline Setor econômico & Número de sindicatos \% & \multicolumn{2}{c}{ Filiados } & Tamanho médio \\
\hline Comércio \& Serviços & 62 & 49,6 & 19.505 & 40,4 & 314,6 \\
Indústria & 43 & 34,4 & 15.920 & 32,5 & 370,3 \\
Transporte \& Serviços públicos & 20 & 16,0 & 13.050 & 27,1 & 652,3 \\
Total & 125 & 100,0 & 48.475 & 100,0 & 387,8 \\
& & & & \\
\hline
\end{tabular}

KHAYYAT, Muhammed Adnan Salah. Aspects of Lebanese labour movement post the labour law of 1946. Tese: Universidade Americana de Beirute, 1973. Tabela 12, p.102.

Para Khayyat (1973) a fraqueza do sindicalismo libanês nas décadas seguintes à independência do país se deveu a uma conjunção de fatores internos e externos ao movimento operário libanês, conforme segue: a orientação econômica do país baseada no comércio e nos serviços quando a maior parte de sua classe trabalhadora estava fora desses setores e concentrada na agricultura; a forte fragmentação da sociedade libanesa em linhas confessionais que dificultava ou, dependendo do contexto histórico, impedia a unidade da classe trabalhadora; além do fato gravíssimo da predominância dos cristãos nos quadros de direção das empresas ao longo das décadas que antecederam a guerra civil de 1975-1990, que sempre davam aos conflitos trabalhistas, quando ocorriam, um forte viés confessional.

Essa divisão também se manifestava no aspecto regional (Monte Líbano versus sul do Líbano) e político (pró-ocidentais versus nacionalistas árabes), o que aumentava a fraqueza da classe trabalhadora, o caráter recente da maioria das empresas libanesas e o fato de a maioria ser de pequena escala. Isso por que a maior parte dos seus trabalhadores era de origem rural ou ainda mantinham fortes vínculos com suas comunidades no campo (muitos continuavam a ter a suas casas lá) e até mesmo continuavam a realizar trabalhos agrícolas em determinados períodos do ano. Então sua presença nas cidades não era permanente e nem haviam adquirido o sentimento de pertencimento à classe operária ou mesmo trabalhadora urbana.

Também não estavam, por outro lado, acostumados à rígida disciplina do trabalho em 
uma fábrica, o que fazia com que não se dedicassem com mais afinco a essas atividades, que faltassem com certa frequência e tivessem uma alta rotatividade no emprego, fazendo assim mais difícil organizá-los até mesmo para lutas mais locais em seu ambiente de trabalho ${ }^{220}$.

A isso se juntaram outras razões, como o fato de que a maioria dos sindicatos libaneses não era do ramo industrial devido à já mencionada proibição de organizar sindicatos agrupando trabalhadores de atividades muito diferentes. O que, dentro de uma determinada empresa, havia a situação na qual os seus empregados terminavam por estar associados a sindicatos diferentes.

Outro problema era a maneira como muitos trabalhadores se comportavam em relação a seus empregadores com os quais reproduziam as relações paternalistas que tinham com seus chefes ou notáveis locais trazidas de suas aldeias. Assim, acabavam vendo as suas conquistas mais do prisma do favor do que um direito do qual eles mereciam usufruir.

Também existia em muitos sindicatos a presença tanto de trabalhadores e operários quanto de empregados de escritórios que podiam ter interesses diferentes, e mesmo contrapostos aos dos trabalhadores, bem como pontos de vista sobre a política, da sociedade libanesa e da economia muito diferentes, o que acaba enfraquecendo ou mesmo inviabilizando muitas lutas . Outro problema grave que também limitava muito a ação do movimento sindical libanês era a ausência de estrutura a nível local de suas federações. Em nível local havia apenas os sindicatos, mas não um órgão da federação sindical que fizesse a ligação entre eles ou entre o sindicato e a cúpula da federação ou mais tarde da confederação. Por fim, outros problemas são a fragmentação e dispersão do movimento sindical como um todo e o já comentado pequeno número de trabalhadores sindicalizados, cujo resultado é impedir o surgimento de federações fortes e bem financiadas ${ }^{222}$.

Entre as mais debilitantes divisões existente no movimento sindical estavam as que levavam a formação de sindicatos ou federações baseadas em critérios regionais ou locais, como

\footnotetext{
220 KHAYYAT... p. 78 e 79.

221 Idem...p.80 e 81

222 Idem... p. 81.
} 
eram os casos da Federação dos Trabalhadores do Norte do Líbano e da Federação dos Trabalhadores do Sul do Líbano. A formação dessas federações, além do caráter regional, se deveu também ao fato de que tanto no sul quanto no norte do país predominavam populações muçulmanas (sunitas no norte e xiitas no sul), enquanto na região do Monte Líbano se encontrava uma maioria de cristão. Portando uma identidade e visão de mundo em muitos aspectos oposta à dos grupos muçulmanos ${ }^{223}$.

Os motivos para a formação de novos sindicatos em muitos casos têm pouco ou nenhuma relação com a defesa dos direitos dos trabalhadores. Em seu lugar, rivalidades e ambições pessoais, lealdades aos locais de trabalho, a interferência de lideranças políticas e o orgulho regional que faziam surgir dentro de uma única categoria profissional vários sindicatos. Um dos casos mais extremos que ilustram esses fatos é o dos motoristas de táxis que chegaram, no fim da década de 1960, a ter oito sindicatos, dos quais três eram filiados a três distintas federações e cinco não pertencia a nenhuma. $\mathrm{O}$ resultado disso foi a falta de unidade, pois não havia comunicação entre os motoristas de táxi, o que enfraqueceu muito o poder de barganha da categoria frente aos seus empregadores e fez com que as suas inúmeras greves realizadas desde 1946 acabassem fracassando, pois sempre acontecia de algum sindicato decidir boicotá-la, descumprindo a decisão de realizar a greve ${ }^{224}$.

Outro exemplo são os trabalhadores das padarias que tinham quatro sindicatos, cada um dos quais pertencendo a uma federação diferente. Devido a isso, como não existia comunicação entre os quatro sindicatos, todas as tentativas de organizar uma greve geral da categoria ao longo do período abordado por esse trabalho acabaram fracassando. É por isso que, tanto entre os padeiros quanto entre os motoristas de táxis, bem como outras categorias, a fragmentação foi estimulada e aprovada pelo governo, por que era uma forma de enfraquecer os trabalhadores de maneira permanente frente aos empresários e acabou conduzindo a disputas desgastantes entre aqueles por conta das ambições entre as várias lideranças ${ }^{225}$.

Essa política enfraquecia tanto eles que várias categorias como as já citadas, mais os

\footnotetext{
223 Idem. p. 83.

224 Idem... p. 86.

225 Idem... p. 87.
} 
estivadores, assistentes de farmácia, motoristas particulares, operários das fábricas de aspirador de pó, entre outros, tinham enormes dificuldade em organizar reuniões e encontros, bem como agir coletivamente.

Uma característica do Líbano é o fato de que oito dos doze maiores sindicatos do país por volta de 1970 não eram de categorias profissionais, mas sim de empresas particulares ou estatais e todas de grande porte ${ }^{226}$. Dentre as razões para o surgimento de sindicatos ligados a grandes empresas temos o fato de que esses sindicatos costumavam oferecer benefícios a seus membros que os pequenos não ofereciam normalmente. Também a direção dessas empresas costumava estimulá-los a formarem um sindicato como meio para melhor controlá-los ${ }^{227}$.

Apesar de tantos problemas o movimento sindical libanês também desfrutava de algumas importantes vantagens que permitiu a ele se organizar e manter-se ativo. Esse foi o caso da concentração dos trabalhadores e indústrias em Beirute e Monte Líbano. Relação complexa, pois se por um lado estimulava-se a sindicalização e facilitava-se a organização de suas lutas, por outro o isolavam em relação ao restante do país ${ }^{228}$. Outro exemplo foi à preponderância de sindicatos no setor terciário onde o nível de alfabetização dos trabalhadores era maior.

Dessa forma, apesar de todas essas limitações e poucas vantagens, ao longo dos anos 1960 as greves no Líbano foram aumentando em número e em duração, sendo os motivos principais da sua deflagração as questões de ordem econômica. 1968 foi o auge de todo esse processo com a deflagração de greves em grande parte dos setores econômicos do Líbano ${ }^{229}$. Outro resultado dessas greves foi aumentar os vínculos entre as federações e trabalhadores tornando-as mais efetivas na defesa de seus direitos do que haviam até então sido ${ }^{230}$. Nos anos setentas a agitação sindical continuaria em ascensão, apesar das medidas de repressão do Estado, sendo muito estimuladas pelas lutas políticas em curso no país como a dos palestinos e somente seria interrompida com a eclosão da guerra civil em 1975.

\footnotetext{
${ }^{226}$ Idem... p. 89.

${ }^{227}$ Idem...p. 98-99.

${ }^{228}$ Idem....p. 59-60.

${ }^{229}$ Idem. p. 106.

${ }^{230}$ FARHAT apud KHAYYAT. p. 106.
} 


\subsection{Perfil dos sindicalistas libaneses}

Os líderes sindicais, em sua maioria, vinham das bases dos próprios sindicatos, muitos não tinham instrução formal em um nível muito alto, embora, em sua maioria, fossem cristãos. As questões políticas e ideológicas entre eles costumam não ser muito desenvolvidas e geralmente costumam não estar interessados nos assuntos da política de seu país, a menos que adquirisse um caráter religioso Á exceção dos poucos comunistas e esquerdistas em geral que existiam entre eles.

Esse foi o caso da filiação à Confederação dos Sindicatos Árabes. Os sindicalistas muçulmanos costumavam desejar a sua filiação a ela por motivos mais religiosos que pan-árabes, pois associavam o nacionalismo árabe ao islamismo. Já os cristãos não eram tão entusiasmados a se juntar a essa organização nasserista e, de maneira geral, costumavam dizer que os sindicatos libaneses não deveriam se afiliar a nenhuma confederação sindical internacional. Como é fácil perceber, esse desinteresse pela política misturado com a presença do sectarismo e a inabilidade para conseguir fazer com que as coalisões agissem na esfera política enfraqueceu de maneira severa os trabalhadores socialmente e fez com que eles tivessem grandes dificuldades em resistir às investidas dos patrões contra os seus direitos quando elas acontecem.

Essa fragilidade fez com que as poucas demandas trabalhistas reconhecidas pelo Estado tenham sido iniciativa dos políticos mais que resultado da ação dos sindicatos e suas federações como foi o Ato de Segurança Social de 1963 e, já em 1971, o Seguro Médico ${ }^{231}$.

\subsection{As federações sindicais}

O moderno movimento dos trabalhadores no Líbano começou a surgir na década de 1920 graças em grande parte aos comunistas que se tornariam, daí para frente, a principal força ativa do movimento sindical libanês até a década de 1970. Embora, cabe ressalvar, enfrentassem a concorrência de outras correntes e a repressão e sabotagem do governo e dos empresários.

Eles estavam concentrados entre os gráficos de Beirute e os trabalhadores da indústria

${ }^{231}$ KHAYYAT... p. 104. 
tabacaleira em Bikfaya no Monte Líbano ${ }^{232}$. Os gráficos de Beirute seriam a principal vanguarda do movimento sindical libanês e sua luta estava diretamente ligada a muitas das conquistas dos trabalhadores libaneses no século XX. Sua atuação firme e orientação ideológica comunista também fizeram com que sempre sofressem perseguições desde a época do domínio francês e tivessem sua licença de funcionamento cancelada. Ariis, o líder histórico dos gráficos, por diversas vezes foi preso e perseguido pelo governo. A existência do sindicato dos gráficos e o seu espírito combativo e corajoso serviram de estímulo para a formação de outros sindicatos em Beirute e outras regiões do Líbano ao longo da década de 1930. Esse crescimento e a pressão exercida forçaram o governo a abrir a discussão, em 1939, para a criação de código trabalhista no país ${ }^{233}$.

A Segunda Guerra Mundial trouxe uma nova onda de perseguições ao movimento trabalhista libanês que veio, evidentemente, junto à nova suspensão da constituição pelo governo mandatário. Muitas lideranças sindicais foram presas, numerosos trabalhadores sindicalizados foram sumariamente demitidos ou ameaçados de demissão se mantivessem suas atividades de militância. Empresas estrangeiras e capitalistas libaneses a encorajaram e, diferente de muitos outros setores sociais libaneses, inclusive vários dentro da elite, eram muito influentes frente às autoridades mandatárias.

Durante os anos da guerra, os sindicalistas dirigiram o movimento trabalhista na clandestinidade $^{234}$. Após a ocupação britânica, com o crescimento, em 1943, do movimento pela independência, a pressão sobre o movimento sindical e os seus líderes diminuiu. Sete sindicatos tiveram suas licenças de funcionamento recuperadas, dentre estes a dos gráficos. Logo os sindicatos começaram a organizar greves pedindo aumento de salários, melhores condições de trabalho e a criação de um código trabalhista. Já em 1943 houve duas conquistas importantes: o salário mínimo foi aumentado de 45 libras libanesas para 75 e, pouco depois, foi criado o abono familiar $^{235}$. Aliás, no Líbano - e da mesma maneira simultaneamente na Síria - o primeiro

\footnotetext{
232 Idem... p. 63.

233 Idem. p. 65.

234 Idem. p. 65.

235 Idem. p. 66.
} 
conjunto de legislação trabalhista foi introduzido nessa época ${ }^{236}$.

Desde os anos 1940 os sindicatos sempre procuraram se reunir em uma federação que pudesse representar de maneira mais coletiva o conjunto da classe trabalhadora. Logo após a independência começou o processo de formação da primeira federação sindical: a Ittihad alNiqabat comunista, surgida em 1944 e composta por 30 sindicatos. Ela era evidentemente fortemente ligada ao Partido Comunista. Mustafa al-Ariis foi eleito líder e porta-voz dessa federação. Assim que foi formada, a Ittihad apresentou ao governo de el-Khuri uma série de demandas que melhorassem as condições de vida dos trabalhadores e estabelecessem condições justas para a emissão de licenças de funcionamento para os sindicatos.

As ações e ameaças de se deflagrar uma greve geral fizeram o governo ceder com a promulgação de uma Lei do Trabalho provisória ainda em 1944, na qual forçou um aumento dos salários dos empregados em grande parte do setor privado. Porém, essa lei não foi aplicada para as grandes empresas. Os trabalhadores responderam com greves e o governo também teve que conceder esses primeiros diretos aos trabalhadores dessas empresas. Muitas greves aconteceriam em 1945 e 1946, dentre as quais as históricas dos trabalhadores da Companhia de Bonde de Beirute e dos trabalhadores da indústria tabacaleira ${ }^{237}$.

Os patrões e o governo iriam então buscar dividir, para enfraquecer, o emergente movimento sindical dos trabalhadores libaneses e eliminar, ou ao menos neutralizar nele, a presença dos comunistas. Nesse contexto vieram a criar uma federação rival sob o forte controle do governo: a Jabhat al-Amal em março de 1946, cujos membros eram dissidentes da Ittihad e sindicatos de funcionários dos setores administrativos das empresas.

A Jabhat afirmou publicamente que era anticomunista e que combateria o comunismo dentro do movimento sindical ${ }^{238}$. A Frente Sindical (Jabhat al-Amal) funcionava com o patrocínio de Henri Pharaon, então Ministro das Relações Exteriores de Bechara el-Khuri.

Mesmo assim, apesar das posições e atitudes dos líderes da Jabhat, isto não impediu a deflagração da greve geral de 20 de maio de 1946. Um dia antes, el-Khuri chamou os delegados

${ }^{236}$ BAER, Gabriel. Population and society in the Arab East, V. 11. p. 238.

237 KHAYYAT: Aspects of Lebanese Labour Movement... p. 66-68.

${ }^{238}$ DEPARTAMENTO DE ESTADO DOS EUA apud GENDZIER. Notes from the mine field... p. 119. 
da Ittihad para discutir a criação de um Código do Trabalho definitivo. Eles enviaram um esboço para o Parlamento e delegados para conversar com o Presidente. El-Khuri, que exigiu que a greve fosse cancelada, mas os delegados disseram que não poderiam fazer isso sem a autorização de suas bases. Porém, para não romper totalmente com o governo, foi então organizada uma greve simbólica com $80 \%$ de adesão dos trabalhadores, apesar dos esforços do governo para quebrá-la. Foi essa luta, apesar das medidas de el-Khuri para combater os comunistas, que levou à aprovação da Lei do Trabalho de 1946 em 23 de setembro de $1946^{239}$. Na organização das atividades de luta pela legislação trabalhista um papel destacado cabe à figura de Mustafa alAriis $^{240}$.

Também, além dos comunistas, o Ministério do Interior, sob a direção de Saeb Salam, e o Escritório de Assuntos Sociais trabalharam de maneira coordenada com a Sûreté Libanesa (o serviço de informações e segurança da época) para enfraquecer todos os sindicatos mais independentes. Assim, diversos sindicalistas, mas particularmente al-Ariis, foram alvos de investigação e perseguição por parte das autoridades libanesas que infiltraram vários informantes na Federação dos Sindicatos de Operários e Empregados do Líbano. Nesse contexto é que se entende o apoio a uma terceira federação sindical: a Liga dos Sindicatos de Trabalhadores e Empregados (Jamiat an-Naqabat al-Ummal wal-Mustakhdamin).

Da parte do governo, Salam financiou e providenciou a assistência técnica aos líderes dela. Devido a esse processo, nos anos 1950 o Líbano possuía cinco federações sindicais. Essas federações se utilizavam de um órgão de impressa sob controle do anticomunista PNSS, cujo editor era Fayez Sayegh, um importante professor de Filosofia da Universidade Americana de Beirute $^{241}$.

A Jami’at foi formada por quatro sindicatos dissidentes da Ittihada. Essa federação teve todas as facilidades para funcionar: o governo lhe concedeu facilmente uma licença para funcionar, grandes subsídios e permissão para editar um jornal diário. Saeb Salam, primeiroministro, por várias vezes, entre as décadas de 1950 e 1970, foi presidente honorário de um de

\footnotetext{
${ }^{239}$ KHAYYAT... p. 69-70.

240 GENDZIER... p. 56-57.

${ }^{241}$ Idem. p. $117-119$.
} 
seus sindicatos ${ }^{242}$.

No cenário da Guerra Fria também se assistiu à intervenção dos EUA na vida dos sindicatos e do movimento trabalhista em geral do Líbano, como tantos outros países do mundo capitalista nessa época, tanto para limitar a sua influência quanto para garantir os interesses de suas empresas, as quais também pressionavam o governo do Líbano para conter a ação organizada de seus trabalhadores, como fez a Irak Petroleum Company e a TAPLINE. Esta última passou a fazer contratos de curta duração para impedir a sindicalização de seus trabalhadores ${ }^{243}$.

A representação diplomática americana, após a Segunda Guerra Mundial, passou a colaborar com os serviços de segurança libaneses na investigação da ação de ativistas comunistas do Líbano em sua sociedade. Ela se manifestou no fornecimento de informações da seguinte maneira:

a.Listar as organizações libanesas nacionalistas que eram ou foram penetradas por comunistas;

b.Oferecer uma lista de líderes comunistas;

c.Oferecer uma lista de jornais comunistas de Beirute e Trípoli;

d.Oferecer exemplares de panfletos comunistas impressos no Líbano, bem como jornais, instruções e panfletos estrangeiros vendidos ou distribuídos no país;

e.Apresentar documentos mostrando as táticas e operações dos partidos comunistas em outros países;

f.Apresentar uma lista de congressos comunistas realizados em outros países para os quais facilidades de passaportes poderiam ser recusadas.

g.Oferecer material para uma campanha de propaganda anticomunista.

Todas essas ações incluíram o conjunto do movimento operário libanês e dos movimentos sociais, comunitários e confessionais em geral, tanto no campo como na cidade, nas

242 KHAYYAT. Nota 1. p. 83.

${ }^{243}$ Gendzier. p. 117. 
décadas que se seguiram à deflagração da Guerra Fria. Aliás, embora o movimento comunista fosse bastante débil no Líbano, ainda assim era fortemente vigiado e alvo de grande preocupação por parte dos norte-americanos por ser visto, obviamente, como estando em constante desafio às suas políticas e interesses no Oriente Médio. Também, essa cruzada norte americana se caracterizou por uma pressão constante sobre toda a classe política libanesa, independente de suas posições ideológicas, aí incluindo figuras como Jumblatt e Fuad Chehab ${ }^{244}$.

Após a promulgação da Lei do Trabalho, o governo suspendeu todos os sindicatos e federações existentes, sendo estas obrigadas a pedir outra vez uma nova licença de funcionamento para o Ministério da Economia. Este somente as concedia após consultar o Ministério dos Assuntos Sociais, na época um departamento daquele Ministério, como afirmava o artigo 87. Com isso, o governo eliminou os sindicatos mais militantes e independentes. Esse foi o caso da federação Ittihad al-Niqabat, de orientação comunista, cuja licença foi negada embora todos os sindicatos afiliados a ela já contassem com o reconhecimento legal ${ }^{245}$.

Aliás, a suspensão da licença de funcionamento dos sindicatos após a promulgação da Lei do Trabalho em 1946 tinha especificamente como alvo o combativo sindicato dos gráficos por conta de sua orientação comunista. Mas, para azar do governo, essa política fez com que vários sindicatos, movimentos e a opinião pública em geral simpatizassem com os gráficos por considerar tal atitude do governo um ataque aos direitos legítimos dessa categoria.

O próprio Mustafa al-Ariis se candidatou para o Parlamento em 1947 e somente não foi eleito por conta da interferência do governo. Esse fato aumentou a raiva dos gráficos contra Bechara el-Khuri, levando a novos confrontos entre o governo de um lado e esses trabalhadores e seus líderes do outro. No fim, para evitar uma radicalização social maior dos gráficos e, junto a eles, dos outros trabalhadores e simpatizantes por conta das repercussões das manipulações e fraudes de el-Khuri nas eleições de 1947, é que foi concedida uma nova licença de funcionamento para o sindicato dos gráficos, como para outros sindicatos mais.

Em 1948, aproveitando-se da guerra contra os sionistas na Palestina, em nome da segurança nacional, foi proibido o Partido Comunista e os seus sindicatos foram alvos de forte

244 Idem. p. 122.

${ }^{245}$ KHAYYAT. p. $112-113$. 
repressão, tendo os seus líderes sido presos, entre eles Mustafa al-Ariis, junto com o conselho diretor de seu sindicato. Por sua vez, el-Khuri emitiu uma licença de funcionamento para um sindicato ( pouco compromissado com a causa dos trabalhadores) representar a categoria dos gráficos. Essa medida foi aplicada também para os outros sindicatos comunistas ${ }^{246}$.

Entre 1946 e 1950 acontecimentos internacionais graves fizeram com que o Partido Comunista e os seus sindicatos sofressem um forte revés. Nessa época ocorreu a primeira guerra árabe-israelense por conta da expulsão de 700 mil palestinos pelos sionistas e da fundação do Estado de Israel. O apoio da URSS, a criação do estado judeu à custa da população árabe da Terra Santa e a defesa dessa política pelo Partido Comunista libanesa através de floreios retóricos lhe causou um forte rechaço na sociedade libanesa, o que também atingiu os sindicatos controlados por ele. Além disso, houve também o início da Guerra Fria, cujo resultado foi à perseguição dos partidos comunistas em boa parte do mundo capitalista ${ }^{247}$.

Nessa época, os sindicatos oficiais haviam perdido muito de seu prestígio para o dos comunistas, que criticavam abertamente os especuladores e grupos monopolistas, além de fazerem esforços para defenderem os salários e rendas dos trabalhadores frente ao crescente custo de vida. Os sindicatos comunistas pediam abertamente em seus memorandos a criação de um sistema de seguridade social, a ampliação da legislação trabalhista, serviços médicos para os trabalhadores entre outros serviços e direitos sociais. Ao mesmo tempo se colocaram contra a assinatura do acordo de Ponto IV com os EUA e a entrada do Líbano em qualquer esquema militar montado pelas potências capitalistas no Oriente Médio ${ }^{248}$.

Após o período de regressão em sua atividade entre 1946-1950, os comunistas voltaram a ter influência nos sindicatos libaneses ao instalarem entre 150 e 200 militantes na direção de diversos sindicatos e através da fundação de novos. Por outro lado, a presença de trabalhadores nas fileiras do Partido Comunista continuava bem minoritária, o que mostrava os grandes e graves limites do movimento comunista no Líbano ${ }^{249}$.

\footnotetext{
${ }^{246}$ Idem. p. 118-122.

247 ZISSER, Eyal. Lebanon: the challenge of independence. Londres e Nova Iorque: I. B. Tauris, 2000. p 216.

248 TAYLOR; FRANCIS. Comunism and nationalism in the Middle East. p. 165.

${ }^{249}$ Idem. p. 165
} 
Em 1953 ocorreu o quarto desmembramento do movimento sindical libanês, quando Abdel Majid Mehyo, presidente do sindicato dos trabalhadores mecânicos e presidente da Jami áat, foi derrotado nas eleições daquele ano para a presidência desta. Por motivos pessoais ele abandonou a Jami'at e junto com alguns outros sindicatos e o seu fundou em maio de 1954 a Federação dos Sindicatos Independentes (al-Mustakilla), cuja licença foi rapidamente concedida pelo governo.

Este último fato estimularia outros sindicalistas a fundarem novas federações nos anos seguintes, como foi o caso da Federação dos Sindicatos de Empregados e Trabalhadores do Norte do Líbano em 1955 e a Federação dos Sindicatos de Empregados e Trabalhadores do Sul do Líbano logo depois.

Aliás, o próprio governo libanês acabou estimulando isso (como foi já dito), sendo essa uma política copiada do governo francês para estimular a fragmentação do movimento sindical como meio de enfraquecer o movimento comunista dentro do sindicalismo francês. No caso particular do Líbano, essa política acabaria levando à formação de 15 federações sindicais no fim dos anos $1960^{250}$.

Se por um lado o governo estimulava a divisão das federações sérias e a proliferação de sindicatos em uma mesma categoria de trabalhadores, por outro buscava dificultar a formação de federações em categorias combativas e seguidoras de ideologias opostas ao liberalismo das classes dominantes libanesas. Esse foi o caso dos gráficos, cujo ramo de Beirute continuava a estar entre os lugares dos trabalhadores mais conscientes do país nos anos 1950 e 1960, por exemplo. Assim, em 25 de outubro de 1960, foi apresentado ao Ministério do Trabalho um documento contendo a assinatura dos membros dos conselhos administrativos dos dois sindicatos pedindo a autorização para a formação de uma Federação dos Trabalhadores Gráficos.

O Ministério não respondeu tentando assim fazer com que os sindicalistas desistissem, mas eles continuaram tentando até que houve uma resposta negando o pedido. Ainda assim, algum tempo depois, por temor de uma agitação que pudesse contagiar os outros setores da classe trabalhadora, foram concedidas duas licenças para a formação de novos sindicatos entre

${ }^{250}$ KHAYYAT. Aspects of Lebanese labour movement... p. 89. 
os gráficos e, desse modo, fragmentar ainda mais a categoria. Porém, os gráficos continuaram obstinados no seu objetivo de criar uma federação e a resposta do governo foi conceder uma nova licença para o funcionamento de um quinto sindicato entre eles.

Em resposta, os membros dos outros sindicatos rapidamente conseguiram atrair para a sua causa os filiados desse quinto sindicato, pois convenceram os seus membros a pressionar a sua direção para se juntarem em uma campanha para formar a federação da categoria. Em 1968 o quinto sindicato acabou cedendo e os cinco se juntaram para estabelecer as bases para a fundação de sua federação. Mais uma vez, a resposta do governo, por meio do Ministério do Trabalho, foi conceder uma licença para o funcionamento de um sexto sindicato, mas este também acabou por se juntar aos demais. Somente no mandato de Suleiman Frangié, em 1972, após uma árdua luta, e enfrentando vários obstáculos e resistências, dentro do novo governo e entre as elites libaneses, é que os gráficos conseguiram uma licença para formar a sua federação ${ }^{251}$. Histórias semelhantes encontramos em outras categorias, embora poucas sejam tão combativas, obstinadas e com filiados tão esclarecidos como era o caso dos gráficos.

A partir de 1960, os comunistas passaram a sofrer a concorrência dos baathistas na organização dos trabalhadores pobres no norte do Líbano, em Nabatieh e Baalbek (JOHNSON, p. 181). Com tantas concorrências à esquerda e à direita, os comunistas, que quarenta anos antes haviam dado início ao moderno movimento trabalhista no Líbano, por volta de 1965 controlavam apenas a Federação dos Sindicatos de Trabalhadores que compreendia os carpinteiros, gráficos, operários da construção civil, cozinheiros, trabalhadores de restaurantes, hotéis e cafés, sapateiros e pintores. No total reuniam entre 3.000 e 4.000 trabalhadores e era afiliada à Federação Mundial dos Sindicatos de orientação comunista ${ }^{252}$.

Durante o mandato de Fuad Chehab foi grande o apoio dos sindicatos ao seu governo por conta da sua política reformista. Isso se devia ao fato do Partido Comunista estar na ilegalidade e, por isso, não poder liderar e organizar abertamente a luta dos trabalhadores.

Já o Partido Socialista Progressista apresentava oposição, por conta de sua aparição

${ }^{251}$ Idem. p. 123-126.

252 JOHNSON, Michael. All honorable men: the social origin of war in Lebanon. Londres e Nova Iorque: Centre for Lebanese Studies of Oxford and I. B. Tauris, 2001. p. 181-182. 
recente bem como devido ao fato de que Kamal Jumblatt, o seu líder, advir da classe dos Zaims e estar assimilado à política tradicional. A classe trabalhadora libanesa ressentia-se de um partido, liderança ou conjunto de lideres que a representasse no cenário político.

Por isso, depois de 1958, os sindicalistas libaneses viram no general Chehab a liderança que defenderia os trabalhadores e corrigiria os abusos do liberalismo econômico. Isso aparecia em órgãos da imprensa sindical como o jornal al-Awassef ${ }^{253} 254$.

Mesmo assim, existiam divergências sérias entre o movimento sindical e o Presidente e os seus seguidores (chehabistas), bem como com os políticos a ele aliados. Isso foi o caso nas eleições de 1960 quando os sindicatos se mostraram decepcionados com a plataforma política de todos os candidatos, pois haviam negligenciado os problemas sociais e econômicos do Líbano e orientaram os seus membros a votarem apenas em políticos que apresentassem soluções para esses problemas e tentaram pôr na campanha essas questões, porém com pouco sucesso ${ }^{255}$.

Também nessa época, por conta das questões postas acima, a partir de 1960 e principalmente em 1961, os sindicatos voltaram a organizar uma série de greves e manifestações nas quais reivindicavam aumentos salariais e a diminuição dos custos de vida. No governo, indivíduos como o Ministro do Abastecimento Maurice Gemayel percebiam os motivos dessas agitações. Em uma fala ao Parlamento ele assim se manifestou: "If we do not succeed in persuading the employers to pay realistic wages, riots certainly break out throughout the country” ${ }^{256}$. Além das questões salariais, uma das razões para a deflagração das greves em 1960 foi à promulgação de uma lei autorizando o governo a demitir trabalhadores grevistas ${ }^{257}$.

Nesses anos, apesar da grande divisão no movimento sindical e das ações do governo, a comunista Federação dos Sindicatos Unidos (Ittihad na-Niqabat al-Muttahidah) era a maior do Líbano. Seu líder era Gabriel Khuri. Compreendia 18 sindicatos: ferroviários, portuários de

\footnotetext{
253 MALSAGNÉ, Stéphane. Fouad Chéhab, 1902-1973: une figure oubliée de l'histoire Libanaise... p. 310.

254 Al-Awassef foi fundado em 1953 e tinha uma tiragem de 8.000 exemplares na metade dos anos 60 e seus redatores defendiam a escolarização e o trabalho como meio de promoção social dos trabalhadores. MALSAGNÉ. p. 311.

255 LANDAU, Jacob: Election in Lebanon. In: The western political quaterly, V. 14, N. 1, mar. 1961. p. 133-134.

${ }^{256}$ Editor Yitzhak Oron. Middle East Record, V. 2, 1961. p. 404. Published by the Israel program for scientific translation for Tel Aviv University: The Reuven Shloah Research Center, 1962.

${ }^{257}$ Idem. p. 405.
} 
Beirute, os trabalhadores da Régie de Tabacs, bancários, funcionários da Shell, trabalhadores da Shell, trabalhadores da Esso, trabalhadores da Companhia de Petróleo Libanesa (LEPCO), trabalhadores da Total, trabalhadores da Mobil Oil, trabalhadores do setor hoteleiro e de entretenimento, eletricitários do sul do Líbano, trabalhadores da refinaria de Trípoli, trabalhadores da Irak Petroleum Company e funcionários da Universidade Americana de Beirute.

No total a Federação dos Sindicatos Unidos representava 21 mil trabalhadores. No entanto, ela também sofreria com divisões políticas. Em 1 de dezembro de 1961 ocorreu um desmembramento da Ittihad, resultado da decisão de Gabriel Khuri - seguindo a decisão da maioria nas suas próprias palavras - de promover a entrada da Federação dos Sindicatos Unidos na Federação Internacional dos Sindicatos Livres, uma organização anticomunista.

Dessa forma, os ferroviários, os trabalhadores da Régie de Tabacs e os portuários de Beirute abandonaram a federação e se juntaram aos eletricitários, que haviam se retirado anos antes, para formar uma nova entidade: a Federação dos Sindicatos no Líbano (Ittihad al-Niqabat al-Ummaliyah fi Lubnan). Durante a sua reunião de fundação, representantes de outros dois sindicatos também estiveram presentes: o dos trabalhadores da Irak Petroleum Company e da refinaria de Trípoli. Essa reunião aconteceu no mesmo dia em que ocorria a da Federação dos Sindicatos Unidos ${ }^{258}$.

Já a Jami’at, no começo dos anos 1960, continuava a ser a principal federação sindical governista do Líbano. Em 1961 tinha 17 sindicatos e era membro da Federação Internacional dos Sindicatos Livres. Seu presidente no começo dos anos 60 era Hussein Ali Hussein. Os sindicatos filiados a essa Federação eram: os padeiros, tapeceiros, assistentes de farmácia, operadores de projetor de cinema, motoristas de táxi, atores de cinema e teatro, barbeiros, empregados em mercearias, comerciários, trabalhadores de cinema, trabalhadores de estúdios cinematográficos, gráficos, costureiras, trabalhadores das agências turísticas e trabalhadores de quitandas 259 .

Já a sua "filha", a Federação de Sindicatos Independentes (Ittihad an-Niqabat alMustaqillah) era comandada por Naim Kraydi e em 1961 tinha treze sindicatos: ofícios

${ }^{258}$ Idem. p. 404. 
mecânicos, curtidores, 'vendedores' de querosene, trabalhadores de olarias, portuários (excetos os do porto de Beirute), funcionários e balconistas de farmácia, tintureiros, ourives, camareiros, empregados de navios e funcionários alfandegários. Essa federação nos anos Chehab se considerava defensora do neutralismo e era filiada à Federação Internacional dos Sindicatos Árabes, então patrocinada pelo governo da República Árabe Unida ${ }^{260}$.

Outras federações que tinham alguma representatividade maior eram: a Federação dos Sindicatos Não-Afiliados (Ittihad an-Niqabat al-Munfaridah), que era uma federação pequena com tendências esquerdistas e pertencente à Federação Internacional das Associações Sindicais, e a Federação dos Sindicatos do Norte (Ittihad an-Niqabat as-Shimal), comandada por Mustafa Hamzah, que reunia treze sindicatos da região de Trípoli e era membro da Federação Internacional das Associações Sindicais ${ }^{261}$.

Embora houvesse muitos sindicatos e confederações nem sempre estes conseguiam organizar e conduzir greves sem a interferência e a pressão governo. Um exemplo disso foi a que seria deflagrada pelo Sindicato dos Trabalhadores de Hotéis e Restaurantes que compreendia 8.000 trabalhadores permanentes e 6.000 temporários. Essa greve, que ocorreu em agosto de 1961, reivindicava aumento nos salários e melhores condições de trabalho. Antes de começar, o governo enviou representantes para negociar um acordo entre os patrões e os trabalhadores e pressionou o sindicato para não iniciá-la, pois não se queria prejudicar os lucros do setor. O acordo concedeu aos trabalhadores o pagamento pelos feriados, a entrega de uniformes de trabalho, pensão familiar e a exclusão dos estrangeiros do setor ${ }^{262}$.

No Líbano, como resultado da pulverização do movimento trabalhista, os sindicatos e as federações sindicais acabaram sendo controladas por grupos moderados e mesmo anticomunistas. Em 1969, das seis centrais sindicais do país, cinco eram comandadas por lideranças anticomunistas. No entanto, muitos trabalhadores nos 1950 e 1960 permaneciam fora dos sindicatos e de qualquer agremiação política mais à esquerda no espectro político. Esses trabalhadores tendiam a serem atraídos por partidos e movimentos confessionais como o Kataeb

\footnotetext{
260 Idem. p. 404.

261 Idem. p. 405.

262 Idem. p. 405.
} 
maronita, que atuava entre os cristãos pobres do Líbano, particularmente entre aqueles que vinham da comunidade onde ele foi fundado. O Kataeb também procurava penetrar nos sindicatos disputando influência com os grupos socialistas e os comunistas ${ }^{263}$. Por sua vez, era muito comum aos sindicatos estarem sobre o domínio de políticos poderosos e de membros da elite financeira comercial ${ }^{264}$.

\subsection{O projeto de uma confederação sindical}

Em 1958 o Jami’at propôs a criação de uma confederação agrupando todas as federações existentes e que, ao mesmo tempo, mantivesse a autonomia de cada uma delas. A maioria dos líderes sindicais concordou, mas devido à guerra civil daquele ano, não foi possível criá-la. No entanto, em 1962, foi finalmente formada a primeira confederação sindical do Líbano, a Confederação Libanesa do Trabalho composta por 15 federações e 103 sindicatos $^{265}$. Também contava com $60 \%$ dos trabalhadores sindicalizados (22 mil em um total de 37 mil). A CGTL foi uma grande apoiadora da política social de Fuad Chehab ${ }^{266}$.

Nela as divergências políticas e ideológicas fizeram com que internamente acabasse dividida em duas alas fortemente antagônicas: 1) a comandada pelo Jamíat e o Sindicato Unido dos Empregados e Trabalhadores, de direita; e 2) do outro lado a Federação dos Trabalhadores Empregados do Norte do Líbano e a Federação dos Sindicatos Independentes, grupos dissidentes da Jami 'at desde a metade dos anos 1950 e que internacionalmente eram associadas à nasserista Confederação dos Sindicatos Árabes, que passou a possuir em 1964 um escritório em Beirute ${ }^{267}$.

Entretanto, a Confederação também nasceu com uma grande limitação. Como para os sindicatos, o governo impôs como pré-requisito para a formação dela a necessidade de se afastar de qualquer atividade política tendo o próprio Jamíat aceito e imposto essa condição para a

${ }^{263}$ ENTELIS, John P. Pluralism and party transformation in Lebanon: Al-Kataib, 1936-1970. Leiden: E. J. Brill, 1974. p. 100.

264 JOHNSON, Michael. All honorable men: the social origin of war in Lebanon... p.21.

${ }^{265}$ KHAYYAT. Aspects of Lebanese labour movement... p. 84.

${ }^{266}$ MALSAGNE. Fouad Chehab: une figure... p. 310.

${ }^{267}$ KHAYYAT... p. 84. 
adesão a sua federação ${ }^{268}$.

A Confederação, como resultado dos inúmeros problemas que caracterizavam o movimento sindical libanês, também não conseguiu atuar como um representante da classe trabalhadora frente ao governo, às elites e aos partidos políticos. Os líderes sindicais não a respeitavam e tinham forte desconfiança de seus líderes, pois os acusavam de defender as ações e políticas do governo que iam contra os trabalhadores, suas organizações e interesses ${ }^{269}$. Como resultado dessa situação, as decisões tomadas pela Confederação em diversos casos não eram seguidas pelos vários sindicatos.

O caráter de heterogeneidade da Confederação também acabou enfraquecendo-a, pois, embora existisse o principio de um voto por cada sindicato a respeito das questões debatidas, na prática isso acabava não ocorrendo por conta da pressão do governo a favor dos sindicatos favoráveis a ele, ao conceder licenças para formar novas federações. Como consequência houve o aumento do número de entidades à direita no espectro político e que assim se posicionavam contra o movimento operário e os seus interesses ${ }^{270}$.

\subsection{Conquistas do movimento sindical libanês}

O Fundo Nacional de Segurança Social de 1965 pode ser considerado a única conquista importante da classe trabalhadora libanesa, embora ela não tenha vindo de seus próprios esforços e sim da ação determinada do presidente da república na época.

Essa lei estabeleceu um fundo nacional de seguridade para administrar as indenizações dos trabalhadores demitidos. Antes dessa lei, como afirma Khayyat (1973), as relações entre empregados e empregadores eram irregulares, instáveis e sujeitas aos caprichos dos patrões. Os empregadores quando tinham direito a demitir um empregado providenciavam um pagamento que era usado para negar o pagamento oficial e de maior valor. Após a lei diminuiu o arbítrio dos patrões sobre os empregados ao fazer com que eles tivessem que pagar as obrigações

\footnotetext{
268 Idem. p. 83.

269 Idem. p. 91.

270 Idem. p. 93-94.
} 
diretamente ao fundo que o repassava ao seu assegurado.

Essa lei era prevista pelo código do trabalho de 1946, mas foi deixada de lado por conta da pressão dos capitalistas, bem como do desinteresse dos governos seguintes. Foi somente com Chehab que ela foi aplicada quando ele enviou, em 1961, ao Parlamento um projeto de lei para colocá-la em prática. Porém, o Parlamento a negligenciou, então Chehab, usando do artigo 85 da Constituição que lhe concedia poderes para emitir projetos de leis e decretos que deviam ser enviados para audiência e votação urgente no Congresso e, caso o Parlamento não fizesse isso, então dentro de 40 dias o próprio Presidente poderia emiti-la como uma lei. Foi o que acabou acontecendo e, com isso, esse projeto de lei foi aprovado em abril de $1963^{271}$.

Já a Lei de Negociação Coletiva de 1964 ajudou a diminuir o poder que os empregadores exerciam sobre o seus trabalhadores no momento de realizar um contrato, pois estabeleceu a possibilidade de se realizar acordos coletivos com validade por dois anos desde que pelo menos $60 \%$ dos assalariados de uma empresa concordasse com ele. Também foi dado ao Ministério dos Assuntos Sociais o poder de estender esses acordos a toda uma determinada categoria se isso for possível ou necessário. Outros ministros podiam por meio de um decreto também fazer isso.

No entanto, ainda nos anos sessenta os acordos coletivos eram raros e isso acontecia por conta das deficiências organizacionais dos trabalhadores, sua fragmentação, bem como a dificuldade em se conseguir a aprovação de $60 \%$ dos trabalhadores para um acordo, sendo nesse caso resultado da ignorância deles sobre a importância de tais contratos, bem como as pressões feitas sobre eles pelos empregadores e gerentes para não assiná-los ${ }^{272}$.

\footnotetext{
271

272

Idem. p. 110.

Idem. p. 105-106.
} 
Tabela 15 - Sindicatos e nível de sindicalização, 1949-1967

\begin{tabular}{lccc}
\hline Ano & Número de federações sindicais & Número de sindicatos & Trabalhadores sindicalizados \\
\hline 1949 & 1 & 34 & 18.837 \\
1956 & 5 & 72 & 18.439 \\
1961 & 5 & 101 & 21.568 \\
1967 & 9 & 121 & 34.871 \\
\hline
\end{tabular}

Fonte: GASPARD, Tufic. K. A political economy of Lebanon, 1948-2002: the limits of laissez-faire. Leiden e Boston: Brill, 2004. Adaptado da Tabela 2.4. p. 65.

\subsection{Desigualdades sociais e distribuição da renda}

Para ter uma melhor compreensão da realidade socioeconômica do Líbano o governo Chehab encomendou em 1959 um amplo estudo sobre o país ao IRFED, uma famosa e importante instituição de investigação social, comandada pelo padre dominicano francês Louis Joseph Lebret, que era muito conhecida e respeitada pelos estudos das condições sociais e econômicas realizadas em diversos países do antigo mundo colonial europeu. Seu objetivo era criar propostas para que os governos dos países que contratavam seus trabalhos pudessem, em cima delas, elaborar políticas para diminuir ou mesmo erradicar a pobreza e conseguir o máximo possível de igualdade econômica entre seus cidadãos.

No caso do Líbano, os estudos do IRFED demonstraram com números, dados e mapas a concentração da pobreza em lugares como o sul desse país, o Vale do Bekáa, a Planície de Akkar e os bairros muçulmanos das grandes cidades, bem como os campos de refugiados palestinos. Esses estudos afirmaram que as áreas rurais eram marcadas pelo subdesenvolvimento cultural e uma precariedade socioeconômica e infraestrutural que as tornava comparáveis às regiões mais pobres do Mundo Árabe, destoando fortemente da imagem de dinamismo, sofisticação e pujança econômica de Beirute.

Usando-se 140 indicadores para se obter um ranking de desenvolvimento que iam de 0 a 4 , sendo 0 e 1 os graus mais extremos de subdesenvolvimento e 3 e 4 a situação oposta, os 
estudiosos do IRFED obtiveram uma média para o Líbano de 1,92, abaixo do índice 2, que significava parcialmente desenvolvido. Beirute e Monte Líbano atingiam ou superavam o índice 2, mas, as áreas rurais, que concentravam a maior parte da população, estavam em um 1 ou abaixo $^{273}$. Na vida concreta esses dados se manifestavam na infraestrutura econômica deficiente dessas regiões, onde faltavam pequenas fábricas, projetos de moradia para a população de baixa renda, mercados locais e boas redes de comunicação. E isto se contar com a infraestrutura de lazer, educação, cultura e saúde.

Tabela 16 - Distribuição de Renda Por Família

\begin{tabular}{lcccc}
\hline $\begin{array}{l}\text { Renda máxima anual/família } \\
\text { (em milhões de LL) }\end{array}$ & \multicolumn{2}{c}{ \% do total da população } & \multicolumn{2}{c}{ \% cumulativa da pop. total } \\
& Estudo de Churchill & IRFED & Estudo de Churchill & \multicolumn{1}{c}{ IRFED } \\
\hline 1.200 & 8 & 9 & 8 & 9 \\
2.500 & 26 & 41 & 34 & 50 \\
5.000 & 31 & 32 & 65 & 82 \\
15.000 & 25 & 14 & 90 & 96 \\
Mais de 15 mil & 10 & 4 & 100 & 100
\end{tabular}

Fonte: KHALAF, Nadim G. Economic implications of the size of nations: with special reference to Lebanon. Leiden: E. J. Brill, 1971. Tabela 55. p. 169.

273

GASPARD, Tufic K. A political economy of Lebanon... p. 78 
Tabela 17 - Distribuição da renda, 1960

\begin{tabular}{|c|c|c|}
\hline \multicolumn{2}{|c|}{ Parcela da população na renda nacional } & \multirow[t]{2}{*}{ Índice GINI } \\
\hline $20 \%$ mais pobres & $5 \%$ mais ricos & \\
\hline & $35 \%$ & $0,535^{*}$ \\
\hline \multicolumn{2}{|c|}{ Nível de renda (em LL) } & Parcela da população(\%) \\
\hline \multicolumn{2}{|c|}{1.200 ou menos (miserável) } & 9 \\
\hline \multicolumn{2}{|l|}{$1.200-2.500$ (pobre) } & 40 \\
\hline \multicolumn{2}{|c|}{ 2.500-5.000 (nível médio) } & 30 \\
\hline \multicolumn{2}{|c|}{ 5.000-15 mil (abastado) } & 14 \\
\hline \multicolumn{2}{|c|}{15 mil ou mais (rico) } & 4 \\
\hline
\end{tabular}

Fonte: GATES, Carolyn. G. The merchant republic of Lebanon: rise of an open economy. Londres e Nova Iorque: The Centre for Lebanese Studies in association with I. B. Tauris Publisher, 1998. Tabela 7.5. p.143.

Avaliações comparativas foram realizadas sobre quatro importantes cidades libanesas: Beirute, Trípoli, Sidom e Zahlé. Nesses estudos ficou evidente que Beirute e Zahle (esta última tem uma população majoritariamente cristã) eram mais desenvolvidas, com melhores moradias, atividades de lazer, instalações educativas e comodidades domésticas, do que Trípoli e Sidom, com suas grandes populações muçulmanas ${ }^{274}$.

Estudos também foram realizados a respeito do crescimento anual da renda nacional. Nesses trabalhos o IRFED sugeriu que ela cresceu em 1959 4,4\%, enquanto a renda per capita crescia a 2,1\% anuais. Esses números correspondiam aos das estatísticas oficiais realizadas pelo Ministério das Finanças que avaliaram a taxa de crescimento anual em 4,4\% entre 1961 e 1964. Uma pesquisa realizada em 1957 pelo Doxiadis Associates estimou o crescimento da renda per capita em 3\% ao ano, sendo que ela saiu de \$235 em 1950 para \$310 em 1956 e atingiu $\$ 400 \mathrm{em}$ $1963^{275}$. Em um estudo da Organização das Nações Unidas para a Agricultura e Alimentação (F.A.O. na sigla em inglês) feito em 1959 afirmava-se que a renda per capita dos grupos de baixa

${ }^{274}$ HUDSON, Michael C. The precarious republic: political modernization in Lebanon. Nova Iorque: Ramdom House, 1968. p. 66.

${ }^{275}$ HUDSON. Idem. p. 62. 
renda era de $\$ 147$, comparado com a média nacional de cerca de $\$ 327^{276}$. Esse problema persistiu ao longo da década de 1960.

Com relação aos níveis de distribuição da riqueza, como resultado do que foi dito mais acima, metade da população libanesa em 1960 vivia abaixo ou na linha da pobreza, enquanto $1 / 3$ se encontrava em um nível médio de renda ${ }^{277}$. Em $195982 \%$ da população possuíam $40 \%$ da riqueza nacional enquanto os $4 \%$ mais ricos tinham $32 \%$. Dez anos depois esses números praticamente não haviam mudado com esses poucos $4 \%$ recebendo os mesmos $32 \%$ da renda nacional. Isso pode ser visto também pelas Tabelas 29 e 30, que mostram a divisão da riqueza de acordo com o nível de renda e o número de famílias. Com relação a esse último fator se verá que em 1960 16\% das famílias tinha renda de LL15 mil ou acima desse valor, enquanto $49 \%$ delas tinham renda entre LL 1.200 e 2.500, estando entre as categorias de miseráveis e pobres.

Embora as obras do governo de Chehab, e em alguma medida as de Helu, tenham melhorado a infraestrutura das aldeias do interior ao levar serviços de abastecimento de água, eletricidade, escolas, hospitais e postos de saúde, as desigualdades continuaram grandes no Líbano.

Um grande fator na manutenção da desigualdade social foi à inflação que resultou no grande aumento do custo de vida, especialmente a partir do fim do governo de Chehab ${ }^{278}$. Além do mais havia outro grave problema social: apesar de existirem pobres em todas as comunidades, seu número era menor em comunidades cristãs como as dos maronitas.

Os cristãos eram os principais proprietários de empresas, sendo que a maioria dos bancos, indústrias e serviços lhes pertenciam. Também a maioria dos lojistas e artesãos era cristã. Entre os profissionais liberais havia a predominância de indivíduos dessas comunidades, apesar de também existirem entre esses profissionais os sunitas. Porém, entre os trabalhadores pouco qualificados e com baixo nível de instrução predominavam os muçulmanos, dos quais os xiitas eram o maior contingente. Também os xiitas eram a maioria dos camponeses. Nesses anos era

\footnotetext{
${ }^{276}$ HUDSON... p. 64.

277 GASPARD. A political economy of Lebanon... p. 75.

${ }^{278}$ MALSAGNE. Foud Chehab: une figure obliée... p. 350
} 
grande a associação entre a imagem do trabalhador pouco qualificado e de baixa escolaridade com as comunidades muçulmanas. Já a imagem do cristão, embora não fosse inteiramente real, era o oposto do muçulmano ${ }^{279}$.

\subsection{Os diversos setores da economia libanesa}

A seguir uma explanação concernente aos segmentos que abarcavam a economia Libanesa entre o final da década de 40 e 1970, tendo como horizonte sua vinculação com as economias vizinhas, o cenário internacional, à influência do sistema liberal e seus impactos à população em virtude desta política.

\subsection{Indústria}

A indústria foi provavelmente a grande prejudicada com a liberalização da economia, tendo ela já passado em 1945 por um primeiro abalo com o término da Segunda Guerra Mundial, que trouxe o fim dos enormes pedidos das tropas aliadas estacionadas no Líbano. Durante a guerra a indústria ainda se beneficiava com as altas tarifas protecionistas existentes no período para, ao protegê-la, estimulá-la a aumentar ainda mais a sua produção ao ter o mercado interno em grande parte para si, devido aos enormes custos de importar mercadorias dos EUA e a impossibilidade de se importar da Europa. Esse abalo foi sentido, aliás, em toda a economia libanesa, que registrou queda nos índices econômicos e um aumento no desemprego, tendo este levado a uma queda do valor dos salários na indústria ${ }^{280}$.

A indústria libanesa passou por um novo grande abalo a se ver concorrendo em grande desvantagem com os produtos importados, que passaram a entrar livremente no país a partir de 1949. Muitas vezes esses produtos eram de qualidade superior aos libaneses, mais baratos e vendidos através de técnicas de marketing mais avançadas.

Os industriais libaneses, dessa maneira, enfrentavam uma enorme dificuldade em

${ }^{279}$ KLIOT, N. Collapse of the Lebanese State. In: Middle Eastern Studies. Jan. 1987. p. 68-69

${ }^{280}$ GASPARD, Tufic D. A political economy of Lebanon, 1948-2002: the limits of laissez-faire. Leiden e Boston: E. J. Brill, 2004. p. 53. 
concorrer com essas mercadorias importadas, estando sempre sob o risco de falirem. Um terceiro grande golpe foi à destruição da Palestina, que privou os industriais libaneses de um mercado importante para os seus produtos, pois o fechamento da fronteira com o novo Estado de Israel impediu que existissem relações comerciais entre os dois territórios. O contrabando existente nessa fronteira, apesar de grande, nunca compensou a perda desse mercado. Ironicamente, por outro lado, de maneira contrária a tudo isso, a perda da Palestina, com o tempo, acabaria sendo boa para a indústria libanesa por ter eliminado o seu maior concorrente na região ${ }^{281}$.

Por fim, o último grande golpe recebido pela indústria libanesa durante o governo de Bechara el-Khuri foi o rompimento da união aduaneira com a Síria em 1950, que privou essa indústria do seu mais importante mercado. Muitas indústrias vendiam metade de sua produção nesse mercado, como a fábrica de malhas Abro Abroyan, ou a Companhia Jabre de alimentos, fósforos e velas, por exemplo.

No caso dos fios de algodão produzidos pelas fábricas libanesas, as vendas nesse país representavam $85 \%$ da produção. No total $60 \%$ dos bens manufaturados libaneses eram vendidos na Síria. Após 1950 um grande número de fábricas foi obrigado a baixar a produção entre 35 e $70 \%{ }^{282}$, enquanto outras reorientaram as suas linhas de montagem para produzirem outros produtos.

Com o rompimento a quantidade de produtos libaneses que entravam na Síria era bem limitada e eles estavam restritos por fortes barreiras alfandegárias desse país. Esses exemplos citados acima mostram que a principal base de sustentação da indústria libanesa era o mercado sírio e o rompimento da união aduaneira com os sírios, na maneira em que foi feito, pode ser considerado um ato desastroso que quase destruiu a indústria nacional. E talvez somente tenha ocorrido devido à decisão do governo e das elites mercantis e financeiras a ele associados de fazerem do laissez-faire a base da economia do Líbano.

A indústria libanesa era representada praticamente pelas indústrias leves, produtoras de bens de consumo, como alimentos, bebidas, mobiliário, tecidos e roupas, papel, produtos de limpeza, couros, sapatos, artigos domésticos, minerais não metálicos e produtos de metal. Sendo

281 GATES, Carolyn 1. The merchant republic... p. 95.

282 GATES, Carolyn L. The merchant republic... p. 128. 
essa uma característica dos países do Terceiro Mundo, que centraram a sua economia na exportação de bens primários e assumiam uma posição subalterna na ordem internacional capitalista.

Desse modo, somente três setores até 1964 (roupas e tecidos, calçados e alimentos processados) representavam $75 \%$ do total da produção industrial ${ }^{283}$. Do número total de empresas $59 \%$ pertenciam àqueles setores, mais o de minerais não metálicos. Essas indústrias contavam com $52 \%$ dos empregos, $38 \%$ dos salários e $49 \%$ do valor acrescido no setor em $1964^{284}$. Na tabela 8 vemos, por exemplo, que somente os setores de alimentos e bebidas empregavam em 1964 18,3\% da mão de obra e possuía 19,3\% do valor agregado de toda a indústria. Os setores têxteis e de vestuário vinham a seguir com o emprego, reciprocamente, de 11,7\% e 10,1\% da mão de obra.

Apesar da preponderância desses setores acima citados e com todas as limitações existentes, ainda assim a indústria experimentou progressos. Como mostram os seus indicadores e os anos do governo de Chehab, caracterizados por um enfoque menor nas atividades mercantis e de serviços, nos quais houve um aumento no número de empresas e de trabalhadores na indústria quando o número de estabelecimentos industriais saltou de 3.200 em 1958 para 6.854 em 1964, bem como o capital investido subisse nesses mesmos anos de LL 212,3 milhões para LL 827,5 milhões (ver tabela 10).

$\mathrm{Na}$ tabela 9 se pode visualizar isso em inúmeros setores, embora também houvesse aqueles que experimentaram retrocessos. Assim, os setores dos têxteis, calçados e vestuários, junto com os de madeira, mobiliário, papel, indústria gráfica, couro, minerais não metálicos, produtos químicos e produtos metálicos experimentaram crescimento no número de estabelecimentos. Com isso os estabelecimentos subiram de 113 para 121 no setor têxtil, de 245 para 271 nos de calçados e vestuários, de 45 para 154 no de couros, de 37 para 54 no de produtos químicos, de 155 para 309 no de minerais não metálicos e assim por diante.

\footnotetext{
283 DIB, Kamal. Warlord and merchants: the Lebanese business and political establishment. Londres: Ithaca Press, 2004. p. 94.

${ }^{284}$ MALLAT. 70 years of money muddling in Lebanon... p. 29.
} 
Já nos setores de bebidas e de produtos de borracha houve diminuição, embora neste último o número de estabelecimentos tenha caído de 15 para 14, enquanto no primeiro aconteceu uma grande redução de 74 para 43. Também isso se processou entre as indústrias alimentícias, cujos estabelecimentos se reduziram de 554 para 491, embora este setor continuasse a ser o principal da indústria libanesa.

Houve sempre pouco estímulo para investir em setores mais pesados, o que requereria um Estado ativo no planejamento e na direção da economia e a retirada (ou ao menos conceder uma menor importância) do enfoque nos setores mercantil e financeiro, embora isso não signifique que não houvesse tentativas. Desse modo, em 1962, apareceram as duas primeiras siderúrgicas libanesas $^{285}$.

Tabela 18 - Diversidade da produção industrial libanesa em 1964

\begin{tabular}{lcc}
\hline & Mão de obra empregada & Valor acrescido \\
& 1964 & 1964 \\
\hline Alimentos \& Bebidas & 18.3 & 19.3 \\
Tabaco & 4.5 & 13.0 \\
Têxteis & 11.7 & 7.7 \\
Vestuário & 10.1 & 7.1 \\
Madeira \& Cortiça & 4.4 & 2.5 \\
Móveis & 8.7 & 5.6 \\
Papel & 1.4 & 1.7 \\
Gráficas & 8.4 & 8.1 \\
Produtos químicos & 3.2 & 3.2 \\
& & \\
(continua) & & \\
\hline 285 KHAYYAT Aspects of Lebanese labour movement... p. &
\end{tabular}


(conclusão)

Tabela 18 - Diversidade da produção industrial libanesa em 1964

$\begin{array}{lcr}\text { Couros } & 2.5 & 2.5 \\ \text { Borracha } & 0.6 & 0.4 \\ \text { Minerais não-metálicos } & 14.4 & 19.1 \\ \text { Metais Básicos } & 2.0 & 1.3 \\ \text { Artigos e produtos de metal } & 7.0 & 6.1 \\ \text { Maquinaria } & 1.5 & 1.4 \\ \text { Diversos } & 1.3 & 1.0 \\ \text { Total } & 100 & 100\end{array}$

Fonte: KHALAF, Nadim G. Economic implications of size nations: with special reference to Lebanon. Leiden: E. J. Brill, 1971. Tabela 60. p. 184.

Tabela 19 - Crescimento da Indústria, 1955-1964

\begin{tabular}{lccccccc}
\hline & \multicolumn{2}{c}{$\begin{array}{c}\text { Número de } \\
\text { estabelecimentos }\end{array}$} & \multicolumn{2}{c}{$\begin{array}{c}\text { Número de } \\
\text { trabalho }\end{array}$} & \multicolumn{2}{c}{$\begin{array}{c}\text { Número de } \\
\text { trabalhadores } \\
\text { por estabelecimento }\end{array}$} \\
\hline Prods. Alimentícios & 554 & 491 & 6468 & 6681 & \multicolumn{2}{c}{1955} & 1964 \\
Bebidas & 74 & 43 & 1040 & 1556 & 12 & 14 \\
Têxteis & 113 & 121 & 6049 & 5277 & 14 & 36 \\
Calçados \& & & & & & & 53 & 44 \\
Vestuário & 245 & 274 & 3632 & 4563 & & & \\
Prod. madeira & 71 & 82 & 755 & 1962 & 15 & 17 \\
\end{tabular}




\begin{tabular}{|c|c|c|c|c|}
\hline Mobiliário & 168 & 230 & $2643 \quad 3918$ & 16 \\
\hline Papel e Art. papel & 16 & 36 & $204 \quad 610$ & 13 \\
\hline \multicolumn{5}{|l|}{ Ind. gráfica \& } \\
\hline Produtos relacionados & 108 & 185 & 16603798 & 15 \\
\hline Couro & 45 & 154 & 9371112 & 21 \\
\hline Prod. de borracha & 15 & 14 & $523 \quad 276$ & 35 \\
\hline Prod. químicos & 37 & 54 & $630 \quad 1425$ & 17 \\
\hline Min. não-metal. & 155 & 309 & 43386506 & 28 \\
\hline Prod. metálicos & 128 & 137 & 24564346 & 19 \\
\hline \multicolumn{5}{|l|}{ Transp. \& } \\
\hline Prod. elétricos & 20 & 21 & $434 \quad 394$ & 22 \\
\hline Outros produtos & 43 & 47 & $702 \quad 527$ & 16 \\
\hline Total & 1790 & 2098 & $32471 \quad 72951$ & 21 \\
\hline
\end{tabular}

Fonte: KHALAF, Nadim G. Economic implications of size nations: with special reference to Lebanon. Leiden: E. J. Brill, 1971. Tabela 57. p. 175.

Como dito mais acima, dentro da economia libanesa, ao longo do período abordado por este trabalho, a indústria nunca teve um peso significativo, estando sempre abaixo dos $20 \%$ do PIB em uma média de cerca de 13 ou quase 14\%, apesar de haver acontecido o aumento do número de estabelecimentos e de operários.

Dessa maneira, se em 1952 representava 13,7\% da economia, em 1965 representaria 13\%, embora houvesse em certos anos caído para 12 ou até $11,7 \%{ }^{286}$. Somente nos anos 70 (até a deflagração da segunda guerra civil em 1975) seu índice cresceria acima dessa média.

${ }^{286}$ KHALAF, Nadim G. Economic implications of size nations: with special reference to Lebanon. Leiden: E. J. Brill, 1971. Tabela 50. p. 161. Nesta dissertação essa tabela é a de número 7. 
Já o Produto Nacional Líquido do setor industrial foi estimado em 1957 em LL 189 milhões (nove anos antes era de LL 134 milhões). Em 1964 foi estimado em LL 411 milhões e em 1970 atingiria os LL 661 milhões. Porém esse bom crescimento era insuficiente para sanar as suas deficiências na economia do Líbano. Tanto assim que, por exemplo, com relação à porcentagem de empregos oferecidos pela indústria, ela também era baixa e a capacidade de absorção da mão de obra que emigrava do campo, portanto, era limitada.

Por isso que, dos 118 mil trabalhadores migrantes rurais do Líbano nos anos 60, apenas 23 mil ou $19,5 \%$ foram para a indústria ${ }^{287}$. No fim dos anos 50 apenas 10 , $5 \%$ dos empregos estavam na indústria ${ }^{288}$, enquanto que nos anos 60 chegaria a $15 \%$. Já a produtividade do trabalhador aumentou $1,8 \%$ entre os anos 50 e $70^{289}$. Uma taxa considerada baixa devido à baixa qualificação da mão de obra.

Outro dado curioso e revelador dos limites da indústria foi o fato de que o ritmo de aparecimento de novas firmas era maior (cerca de duas vezes mais) do que o número de trabalhadores que entravam para a indústria ${ }^{290}$. Seu número era em 1955 de 35.013 trabalhadores, em 1964 de 61.761 trabalhadores e, por volta de 1970, chegaria a 95.535 trabalhadores $^{291}$. Quanto à participação da indústria na formação do capital privado, como já foi dito na primeira seção deste capítulo, sempre foi secundária na economia libanesa.

${ }^{287}$ NARS, Salim. backdrop to civil war: the crisis of Lebanese capitalism. In: MERIP. Report. N. 3, dez. 1978. p. 10.

${ }^{288}$ KHALAF, Nadim G. Economic Implications... p. 1.

${ }^{289}$ GASPARD, Tufic K. A political economy of Lebanon... p.116.

290 DIB. Warlords and merchants... p. 94 .

${ }^{291}$ MALLAT. 70 Years of Money Muddling in Lebanon... p. 29. 
Tabela 20 - Escala e produtividade na indústria (\% distribuição pelo tamanho do estabelecimento)

\section{5}

$\underline{\text { Número de estabelecimentos }}$

$<5$ trabalh./ estabelec.

$<10$

$<25$

Emprego

$<5$ trabalh./estabelec.

$<10$

$<25$

$\underline{\text { Valor acrescido }}$

$<5$ trabalh./estabelec.

$<10$

$<25$

$\underline{\text { Produtividade relativa do trabalho }}$

$<5$ trabalh./ estabelec.

$10-24$

25-49

$\geq 50$

$\underline{\text { Produtividade média }}$

$\underline{\text { Produtividade do trabalho }}$
77

90

97

33

46

61

22

30

44

33

36

44

49

59

60

1970

89

93

97

98

\section{.}


Também sempre se debateu a viabilidade da indústria em um país pequeno como o Líbano, cujo mercado consumidor de cerca de 1 milhão de habitantes não era capaz de absorver toda a produção industrial. Esse problema era uma das justificativas usadas pelos defensores do livre mercado para que o Líbano tivesse a sua economia baseada nos serviços, finanças e comércio. Outro obstáculo levantado para se opor à industrialização era a ausência de recursos naturais importantes no subsolo libanês, o que sempre obrigou o país a importar matéria-prima, aumentando assim os custos da produção dos bens manufaturados. Além disso, argumentava-se que seria impossível o Líbano competir com as grandes economias industriais do Ocidente e que, portanto, sua vantagem, desse modo, estaria nos setores econômicos acima mencionados. Mencionavam os problemas sociais trazidos pela industrialização, entre estes, pra eles, a ameaça do comunismo. Aliás, isso era algo que um dos principais formuladores da ideologia nacional libanesa e um dos criadores do sistema político do país, Michel Chiha, costumava dizer publicamente ${ }^{292}$.

A classe industrial libanesa sempre procurou reagir a essa situação desvantajosa. Tanto foi assim que, nos anos que se seguiram ao estabelecimento do laissez-faire e ao rompimento da união aduaneira com os sírios, os industriais buscaram a renovação e modernização das instalações, diminuição dos custos de produção e aumento da produtividade através da contratação de técnicos estrangeiros.

Para isso foram investidos 157 milhões de libras libanesas no setor manufatureiro entre 1950 e $1957^{293}$. Também se buscou a exploração dos mercados árabes, aproveitando-se do fato de que, entre esses, os países produtores de petróleo possuíam um nível baixo ou nulo de industrialização, tinham uma alta demanda por bens manufaturados e uma grande renda derivada da produção e venda do petróleo. Os países árabes recebiam metade dessas exportações nos anos 50 e receberiam por volta de 1970 dois terços delas. Essas exportações cresceram em diversidade ao longo dos anos. No começo dos anos 50 eram em grande parte produtos têxteis, mas no fim dos anos 60 e começo dos 70 incluíam também roupas prontas para usar alimentos processados,

292 CHIHA apud GENDZIER, Irene. Notes from the minefield... GASPARD, Tufic. K. A political economy of Lebanon... p. 105 p. 82.

293 GATES, Carolyn. The merchant republic... p. 106. 
produtos químicos, joias e até algum maquinário elétrico ${ }^{294}$.

Em 1967 chegaram a totalizar cerca de 87 milhões de libras libanesas. Nesses anos os investimentos dobraram e houve até mesmo o aumento do emprego em determinados setores, como os têxteis ou óleos e gorduras comestíveis, por exemplo. A taxa anual média dos salários cresceu até a metade dos anos 60, cerca de 2,8\%, declinando após essa data, quando passou a crescer apenas a 1,8\%, embora se comparado com o comércio e os serviços fossem baixos.

Houve alguns incentivos do governo, como a redução das tarifas aduaneiras para importação de determinadas matérias-primas e maquinário. A Guerra da Coreia, entre 1950 e 1953, também ajudou a impulsionar indiretamente a indústria indiretamente devido ao seu impacto nos países produtores de petróleo do Oriente Médio, que aumentaram a sua produção para atender ao esforço de guerra dos EUA, desse modo acumulando mais capital, o que lhes permitiam comprar mais mercadorias industriais libanesas ${ }^{295}$. Ao longo do período 1950-1970 as diversas taxas de crescimento da indústria foram as seguintes: $5 \%$ nos anos 50 e $11 \%$ na década seguinte $^{296}$.

Um problema que a indústria libanesa enfrentou no período abordado por esse texto, e que nunca foi resolvido, tratou-se da fraca conexão entre o sistema bancário e o setor industrial.

Embora existisse uma grande abundância de capital no Líbano, tanto em moeda nacional quanto estrangeira, ele chegava com dificuldade àquele setor, pois os bancos preferiam emprestar seu capital preferencialmente para as redes de comércio e as empresas de serviço, como transportes, ou empresas de manutenção ou entrega de produtos, onde o retorno financeiro era mais rápido e maior. Quando esse crédito era concedido, ele era dado apenas para as grandes empresas financiarem as importações de produtos usados em seus complexos industriais e poucas vezes chegavam às empresas de médio e pequeno porte.

Outro problema foi à inexistência de um mercado de capitais desenvolvido no Líbano, no qual as empresas pudessem recorrer para se financiarem. Como resultado, no Líbano os industriais confiavam mais no autofinanciamento a partir dos seus próprios lucros, sendo que

\footnotetext{
294 GASPARD, Tufic K. A political economy of Lebanon... p. 115.

295 GASPARD, Tufic. K. A political economy of Lebanon... p. 105-107.

${ }^{296}$ NARS, Salim. Backdrop to civil war... p. 10.
} 
no caso das pequenas empresas esse autofinanciamento chegava a estar acima de $90 \%$.

$\mathrm{Na}$ metade dos anos 60 a maior fonte de financiamento originava-se de parentes, amigos e familiares. A indústria libanesa sentiu entre os anos 50 e 70 os efeitos dessa dificuldade de se capitalizar, sendo a baixa produtividade e um ritmo menor na mecanização dois casos importantes $^{297}$. Por outro lado, mesmo esse autofinanciamento era feito a uma taxa baixa para permitir uma maior expansão do setor industrial. Devido aos riscos e ausência de uma política industrial consistente por parte do Estado, uma boa parte dos lucros da indústria se perdia no consumo de luxo, ajudando assim a financiarem os setores "inimigos", cujo desenvolvimento e o amplo domínio da economia libanesa aconteceram à custa do subdesenvolvimento daquele setor $^{298}$.

Tabela 21 - A indústria nos anos de Fuad Chehab (1958-1964)

\begin{tabular}{lccccccc}
\hline & $\mathbf{1 9 5 8}$ & $\mathbf{1 9 5 9}$ & $\mathbf{1 9 6 0}$ & $\mathbf{1 9 6 1}$ & $\mathbf{1 9 6 2}$ & $\mathbf{1 9 6 3}$ & $\mathbf{1 9 6 4}$ \\
\hline $\begin{array}{l}\text { N. de trabalhadores } \\
\text { N. de fábricas }\end{array}$ & 21814 & 39033 & 50403 & 50523 & 60867 & 63091 & 61716 \\
$\begin{array}{l}\text { Capital investido } \\
\text { (milhões de LL) }\end{array}$ & 212,3 & 434,6 & 578,0 & 640,8 & 691,3 & 805,7 & 827,5 \\
Valor agregado* & & & & & & & \\
*1958 foi um ano de crise política no qual houve uma grande retração da atividade econômica.
\end{tabular}

Fonte: HUDSON, Michael C. The precarious republic: political modernization in Lebanon. Nova Iorque: Ramdom House, 1968. p. 68.

${ }^{297}$ GASPARD, Tufic K. A political economy of Lebanon... p. 128.

${ }^{298}$ GASPARD... p. 131. 
Além do problema do financiamento, a indústria do Líbano tinha graves deficiências técnicas e gerenciais. Esses problemas afetavam a indústria libanesa e dificultavam o seu crescimento. Eles eram: falta de gerenciamento profissional; falta de mão de obra qualificada; utilização de maquinário obsoleto e atrasado; produtos com qualidade deficiente; extensa duplicação dos mesmos produtos, o que acabava fazendo com que os primeiros, a chegar a um determinado mercado, acabassem se concentrando nos setores de lucros mais rápidos.

A falta de um grande mercado interno também não só impedia um maior desenvolvimento da indústria como se constituía um obstáculo. Outros impedimentos foram: inexistência de escolas para treinar mão de obra qualificada; ausência de um mercado de trabalho qualificado; irregularidade no fornecimento de energia elétrica, o que levava muitas fábricas a construírem os seus próprios geradores; e a necessidade de importar matéria-prima, o que aumentava os custos de produção.

Por fim, as políticas econômicas de diversos países árabes vizinhos também dificultavam um maior desenvolvimento da indústria, pois como eles protegiam e, em diversos casos, dirigiam o seu mercado, costumavam dificultar ou mesmo impedir a entrada dos produtos industriais libaneses. Isso era um grande golpe para indústrias como a do alumínio, ferro e cimento, que foram criadas com o objetivo de abastecer os países árabes vizinhos ${ }^{299}$.

Por outro lado é preciso reconhecer que, se as condições técnicas das empresas eram caracterizadas por fortes deficiências na década de 50 e começo da de 60, na metade da década de 60 as condições técnicas melhoraram com o aparecimento de setores mecanizados, com fábricas eficientes em sua produção nos setores como têxteis, cerâmicas, cimento e produtos químicos. Mesmo assim, a grande maioria das indústrias continuava com as mesmas deficiências de sempre $^{300}$.

O Governo libanês nos anos 50, com Camille Chamoun, chegou a criar um instituto para promover o desenvolvimento industrial do país, o Instituto da Indústria em Beirute, no ano de 1954, tendo sido o primeiro desse tipo no mundo Árabe. No entanto ele sempre recebeu pouco

${ }^{299}$ MALLAT. 70 years of money muddling in Lebanon... p. 31.

${ }^{300}$ GASPARD. A political economy of Lebanon... p. 109. 
apoio do setor privado ${ }^{301}$.

Também foi fundado, em conjunto pelo governo e por um consórcio de bancos privados, um banco, o Banque de Crédit Agricole, Industriel e Foncier (BCAIF) sendo que uma de suas funções, como o seu nome indica, era financiar a indústria. Como mostra a tabela 12, suas operações começaram em 1955 com um capital de 5 milhões de libras libanesas, das quais 3 milhões tinham origem no capital privado, que também controlava $60 \%$ do capital desse banco.

O BCAIF também obteve uma garantia do governo para um empréstimo de 65 milhões de libras libanesas do Banque de Syrie et Liban (BSL), o banco privado francês que, até 1964, funcionou como o banco central do Líbano. Em 1960 o BCAIF já possuía um capital de giro de 85 milhões de libras libanesas e oferecia empréstimos a curto, médio e longo prazo, tendo até o começo dos anos 60 emprestado cerca de 35 milhões para a indústria, cinco milhões a menos do que foi emprestado para a agricultura (em grande parte para os notáveis rurais e grandes empresários do setor de origem urbana) no mesmo período.

Se considerarmos que mais 10 milhões foram emprestados para o setor imobiliário (basicamente o ramo hoteleiro, vital para o turismo), pode-se chegar à conclusão que mais da metade, por volta de $60 \%$ desse dinheiro, não foi destinado à indústria e que provavelmente não existia um plano de financiamento para a indústria destinada a fazer dela um setor vital da economia. Como mostrado acima, com o fenômeno do autofinanciamento sendo dominante na indústria, pode-se talvez dizer que o BCAIF acabou sendo bem ineficiente como instrumento para promover esse setor da economia nacional ${ }^{302}$.

${ }^{301}$ ATTIÉ, Caroline. The struggle in the levant... p. 52.

${ }^{302}$ T. YALFI apud MALLAT. Fiscal policy for social justice... p. 101; SAYGH, Yusuf Abdallah. Economies of the Arab World... p. 297 
Tabela 22 - Atividades de empréstimo do Banque de Credit Agricole, Industriel et Foncier 1955-1958, 1967-1968 (em milhões de LL)

\begin{tabular}{lcccccc}
\hline Empréstimo para & $\mathbf{9 5 5}$ & $\mathbf{1 9 5 6}$ & $\mathbf{1 9 5 7}$ & $\mathbf{1 9 5 8}$ & $\mathbf{1 9 6 7}$ & $\mathbf{1 9 6 8}$ \\
\hline Agricultura & 3,4 & 7,7 & 10,1 & 10,1 & 131,3 & 132,6 \\
Indústria e Construção & 1,0 & 5,8 & 10,6 & 11,3 & 611,2 & 650,9 \\
Comércio: & - & - & - & - & 1240,4 & 1207,0 \\
$\quad$ Doméstico & 0,4 & 2,6 & 4,4 & 4,6 & - & - \\
$\quad$ Externo & - & - & - & - & 379,9 & 367,5 \\
$\quad$ Hotéis & - & - & - & - & 548,8 & 542,5 \\
$\quad$ Serviços & - & - & - & - & 171,3 & 170,3 \\
Inst. financeiras & - & - & - & - & 134,7 & 121,5 \\
Diversos & - & - & - & - & 237,9 & 236,6 \\
& ----- & ----- & ----- & ---- & ------ & ------ \\
Total & 4,8 & 16,1 & 25,1 & 26,0 & 2355,4 & 2348,5
\end{tabular}

Fonte: MALLAT, Raymond A. 70 years of money muddling in Lebanon, 1900-1970-77: a guide in monetary management for economic development in Lebanon. Beirute: Aleph, 1977. Tabela 2. p.135.

Uma característica que mostrava o quanto a indústria libanesa era fraca foi à existência de um grande número de pequenos estabelecimentos com cerca de cinco operários. Entre 1955 e 1970 esses empreendimentos variaram entre 60 e $67 \%$ do total das indústrias no país 303 .

Para Dib (2004) o grande número de pequenas empresas nesse setor era consequência do fato da maioria delas serem familiares, o que criava problemas de escala, e era um obstáculo

${ }^{303}$ GASPARD, Tufic K. A political economy of Lebanon... p. 111. 
para a competitividade regional e internacional da indústria libanesa.

Por outro lado, a persistência do trabalho artesanal na produção de manufaturados libaneses (que com frequência colaborava com a indústria, pois era muito comum industriais subcontratarem equipes de artesãos para realizarem determinados trabalhos) era uma prova para certos estudiosos, como Gaspard (2002, p. 133-135), da fraqueza do processo de industrialização nesse país.

Aliás, o ambiente econômico liberal do Líbano nos anos 50 e 60 em muito favoreceu a expansão dos estabelecimentos artesanais, que disporiam de uma flexibilidade e capacidade de resistência que faltava à indústria. Também o alto nível de produtividade era maior nas pequenas escalas de operação desses estabelecimentos do que nas indústrias médias ou maiores.

Outro dado revelador da debilidade do setor industrial é que o empreendedorismo sempre foi pouco atuante nesse setor da economia libanesa, diferentemente do comércio, por exemplo. Embora a indústria libanesa tenha se modernizado ao longo dos anos, seu ritmo de inovações técnicas esteve sempre bem abaixo dos países industrializados e sua expansão esteve pouco ligada à melhora da eficiência na produção ou na qualificação técnica dos operários ${ }^{304}$. A qualificação dos trabalhadores da indústria sempre foi muito baixa, aliás, das mais baixas entre as atividades econômicas não rurais. Por volta de 1970, cerca de 90\% dessa mão de obra tinha nível educacional que não ia além do primário ${ }^{305}$.

Se as indústrias maiores eram poucas, por outro lado acabaram por controlar, no fim dos anos 60 e começo dos 70, metade do valor da produção e dois terços da produção industrial. Esse fenômeno não era exclusivo desse setor, mas era perceptível em toda a economia libanesa, em setores como o comércio e a agricultura e, nesse caso, a concentração da propriedade da terra ajudava a expulsar para as cidades gente que podia se transformar nos operários mal qualificados da indústria. Essas indústrias maiores também se concentravam em determinados ramos como o têxtil, o de material elétrico ou o metalomecânico.

Outro dado interessante se refere ao fato de que mesmo no setor industrial, como em

\footnotetext{
304 GASPARD... p. 137.

GASPARD... p. 107.
} 
outros ramos da economia libanesa, verificava-se a penetração do capital ocidental, que controlava $35 \%$ dos investimentos ${ }^{306}$. A forma de propriedade dominante na indústria era a do proprietário individual (mais da metade). Menos de 10\% das empresas são corporações e mesmo nesses casos elas eram controladas por determinadas famílias, o que as torna, em muitos aspectos, semelhantes a empresas de propriedade individual ${ }^{307}$.

Um dado também muito importante era a localização geográfica da indústria libanesa, que em muito revelava a inexistência de um projeto para ela por parte do governo, além de demonstrar como ela estava influenciada pelo dinamismo dos setores dominantes da economia: o comércio e os serviços.

As indústrias praticamente estavam localizadas na região de Beirute e Monte Líbano e algumas em Trípoli, ou seja, nas regiões mais beneficiadas pelo desenvolvimento da economia libanesa e onde, até o advento do governo de Fuad Chehab, o governo mandatário e os dois primeiros presidentes do Líbano independente concentraram os investimentos estatais em infraestrutura, como estradas, redes de telefones, de eletricidade e de abastecimento de água etc.

No caso das indústrias localizadas em Beirute e arredores sempre foi importante para as suas atividades a presença do porto local como meio para o escoamento da produção em direção aos outros países árabes e para a importação de matéria-prima, maquinas e peças ${ }^{308}$. Dessa maneira, em 1954, 78\% das fábricas e oficinas do Líbano encontravam-se em Beirute e nas cidades ao seu redor. Enquanto $12 \%$ estavam no norte, $5 \%$ no Beka'a e os outros $5 \%$ no sul. Em 1957 o número de indústrias na região de Beirute caiu para 61\%, mas em 1964 havia voltado a aumentar atingindo $84 \%$, enquanto no Norte era $10 \%$, no Beka'a $4 \%$ e no sul $3 \%$.

Em Beirute mesmo estava o maior polo industrial do país: o al-Madinat al-Sinahia (Cidade Industrial) nos subúrbios orientais de Tell az-Za`atar (onde existia um grande campo de refugiados palestinos que fornecia abundante mão de obra), Sin al-Fil, Jirs al-Basha e Mkalless $^{309}$.

\footnotetext{
${ }^{306}$ NARS, Salim. Backdrop to civil war... p.10.

${ }^{307}$ GASPARD, Tufic. A political economy of Lebanon.. p.111.

${ }^{308}$ GASPARD. Idem. p. 110.
}

${ }^{309}$ DIB. Warlords and merchants... p.93 
Tabela 23 - Distribuição geográfica das atividades industriais em 1964

\begin{tabular}{lcccc}
\hline Região & Valor Agregado & Vendas & Trabalhadores & Salários \\
\hline Beirute & $25,4 \%$ & $25,5 \%$ & $43 \%$ & $27,4 \%$ \\
Monte Líbano & $52,3 \%$ & $46,7 \%$ & $36 \%$ & $50,8 \%$ \\
Sul do Líbano & $14,6 \%$ & $18,0 \%$ & $14 \%$ & $16,4 \%$ \\
Norte do Líbano & $3,2 \%$ & $3,2 \%$ & $3 \%$ & $2,3 \%$ \\
Bekaa & $4,5 \%$ & $0,6 \%$ & $3 \%$ & $2,0 \%$
\end{tabular}

Fonte: KHAYYAT, Muhammed Adnan Salah. Aspects of Lebanese labor movement post the labor law of 1946. Tese: Universidade Americana de Beirute, 1973. p. 55.

Apesar de todos os problemas acima colocados, a classe industrial libanesa, apesar de não ter a força e o tamanho da classe mercantil e bancária, nunca desistiu de defender os seus interesses ao longo da história recente do Líbano. Uma luta ideológica e política não bem sucedida fora travada contra os mercadores da Associação de Comerciantes de Beirute. O principal lobby dos empresários do setor mercantil pelos industriais dentro da Associação dos Industriais Libaneses, uma entidade que representava o grande empresariado manufatureiro libanês, embora ela falasse em nome de toda a classe, independentemente do tamanho de suas indústrias.

Tendo a sua associação sido fundada em 1943, eles sempre militaram para que o Estado estabelecesse políticas de proteção à indústria nacional contra a concorrência desenfreada das mercadorias importadas. Já a Associação dos Comerciantes de Beirute sempre teve em seus estatutos a defesa a qualquer custo do livre-comércio e do Ato de Segredo Bancário, militando contra qualquer intervencionismo na economia, especialmente no que se refere ao controle das importações.

Para isso, sempre manteve contatos importantes com o governo e os principais partidos das elites políticas cristãs e muçulmanas. Um dos maiores momentos de confronto haviam sido os 
anos posteriores à II Guerra Mundial, quando existia no Líbano o debate sobre qual o melhor caminho a se adotar para a economia nacional. Quando se anunciou a intenção de se abrir os mercados, os industriais, apoiados pelo movimento operário, partiram para o enfrentamento com os defensores do laissez-faire. Realizaram diversos lock-out paralisando a produção, promoveram manifestações e atos públicos e ameaçaram com greves em escala geral por toda a indústria. Tudo isso para ao menos impedir, ao menos, que as políticas liberais fossem aplicadas de maneira radical $^{310}$.

Como os industriais não possuíam porta-vozes na sociedade à altura dos que os comerciantes tinham e nem representantes na classe política alinhados com eles com força suficiente para pôr em prática seus ideais, acabaram por fim sendo vencidos quando Bechara ElKhuri anunciou suas medidas liberalizantes em novembro de 1948.

A recuperação da indústria nos anos 50 e 60, em grande parte devido à exploração dos mercados árabes, bem como o crescimento do mercado interno propiciado pela expansão da classe média, trouxeram os industriais e sua associação de volta à ativa para propor alterações na política econômica libanesa para proteger os seus interesses. Como foi o caso do episódio do Decreto 1.943 de setembro de 1971, que tentou estabelecer restrições alfandegárias para a importação de todos os produtos. Aliás, nessa época a Associação dos Industriais de Beirute estava no auge de seu poder, mas a força da Associação dos Comerciantes - que organizou uma greve - foi mais forte devido ao seu peso na economia e seus fortes vínculos em quase todos os setores importantes da classe política libanesa ${ }^{311}$.

Porém nem sempre essas duas classes se hostilizavam. Em diferentes circunstâncias elas procuravam um entendimento ou os seus pontos de vistas eram iguais. Tanto comerciantes quanto industriais também se faziam representar em outra associação, a Câmara do Comércio, Indústria e Agricultura de Beirute (CCIAB), em que podiam ter como presidente tanto um grande industrial como um rico e poderoso comerciante.

As duas categorias eram, aliás, os principais integrantes da associação. Sua divisão, como no

${ }^{310}$ GATES, Carolyn L. The merchant republic... p. 88.

${ }^{311}$ BAROUDI, Sami. Conflict and cooperation within Lebanon`s business community: relation between merchants` and industrialists' associations. In: Middle Eastern Studies, V. 37, N. 4, out. 2001 
sistema político libanês e dentro das associações de cada uma dessas classes, seguia uma divisão comunitária estabelecendo cargos para cada um dos grupos religioso principais ali presentes. Antes de a CCIAB surgir, os dois grupos formaram com o tempo também estâncias (os Fóruns Econômicos a partir da década de 1960) nas quais procuravam dialogar e tentar chegar a um consenso mínimo sobre os temos principais da economia libanesa como taxação, salários ou benefícios aos trabalhadores. Nesses fóruns, ambas as classes procuravam resolver em conjunto as questões trabalhistas, contando para esse objetivo, além disso, com a participação dos representantes dos trabalhadores ${ }^{312}$.

No fim dos anos 60, simultaneamente à crise bancária de 1966, que danificou a imagem de segurança e prosperidade que o Líbano passava para o mundo com o objetivo de manter funcionando sua economia de orientação externa voltada para os serviços e o comércio e como resultado dessa crise, o setor financeiro sentiu uma importante contração em suas operações no estrangeiro. E, juntamente com as crises que vieram com a guerra árabe-israelense de 1967, ocorreu um desenvolvimento da indústria libanesa como nunca havia acontecido até então.

Embora a economia ainda estivesse baseada nos princípios liberais e o governo não tivesse elaborado nenhuma política industrial significativa, o setor manufatureiro chegaria no começo da década de 1970 a representar $18 \%^{313}$ da economia, superando definitivamente a agricultura. Para isso, houve a exploração dos mercados árabes, apesar da concorrência dos países do leste da Ásia, que já nos anos 60 representavam entre 20 e $25 \%$ do consumo da indústria libanesa ${ }^{314}$.

Porém essa expansão não continuaria, pois os graves problemas políticos, citados mais acima, trazidos pelos eventos do fim da década de 60, se faziam sentir fortemente no Líbano na primeira metade dos anos 70, levando à deflagração de uma longa guerra civil em abril de 1975, que arruinou a indústria. Por fim, sobre o papel da indústria na economia durante o período 1950-1970, pode-se concordar com Mallat (1977) quando ela afirma que o setor industrial estava:

\footnotetext{
312 BAROUDI. Idem. p. 11.

313 GASPARD, Tufic K. A political economy... Tabela 3.1, p. 69.

${ }^{314}$ GATES, Carolyn L. The merchant republic... p. 106.
} 
"[...] thus having no impact on the structure of the economy. Indeed industrialization as such has not yet occurred in Lebanon for industrial investment has been throughout the post-war period irregular, whimsical and with no definite plannning,"315.

\subsection{Agricultura}

O Líbano possui três regiões agrícolas principais, onde se cultivam diferentes culturas adaptadas ao clima desses locais: a faixa litorânea, a montanha e o vale do Bekáa.

A faixa litorânea é úmida e de clima mediterrâneo (verões quentes e invernos suaves onde raramente neva), na qual são cultivados oliveiras, grãos, legumes, verduras e frutas de climas mais quentes, como as cítricas e bananas.

Nas montanhas temos um clima mais temperado com o inverno pesado, no qual ocorrem grandes tempestades de neve. É local de exploração tradicional de madeira nas florestas temperadas das áreas mais altas compostas de cedros (hoje raros), pinheiros, faias, abetos, carvalhos e outros tipos de árvores de clima temperado. Cultivam-se frutas de clima temperado como maçãs, cerejas, damascos e peras, grãos como a cevada e o centeio, mas também vários legumes e verduras, bem como se prática a criação de ovelhas e cabras. No Vale do Beka'a, situado entre as cadeias montanhosas do Líbano e Anti-Líbano, no interior do país, há um clima quente e seco no verão e frio no inverno. Apesar do clima seco, existem muitos lagos, rios e fontes subterrâneas, que permitem a prática da agricultura, que se caracteriza pelo cultivo de cereais, algumas frutas, legumes e verduras e a criação de animais.

Esse setor da economia foi o que mais empregou até os anos 60 (55\% da força de trabalho em 1955), apesar de representar sempre menos de $20 \%$ do PIB. Ao longo dos vinte anos seguintes o peso da agricultura foi progressivamente diminuindo dentro da economia libanesa, até chegar a $19 \%$ em $1970^{316}$. Possuía ao mesmo tempo um setor atrasado, composto de pequenos proprietários que utilizavam técnicas tradicionais, e um setor dinâmico, capitalista, que se voltaria para o mercado externo.

315 p. 28.

${ }^{316}$ GASPARD, Tufic K. A political economy of Lebanon... p. 91 
No sul e norte do Líbano, especialmente, mas não exclusivamente, a propriedade da terra era mais concentrada nas mãos dos notáveis rurais locais, os Zu`ama (Za'im no singular). No centro do país a terras era mais distribuída, com uma maior quantidade de pequenos proprietários. Nars (1973), citando fontes do ministério da Agricultura, afirma que na Região do Monte Líbano, no centro do país, na metade da década de 1950, 90\% dos fazendeiros tinham suas propriedades.

No norte, no Vale do Beka'a e no sul essa taxa era de $81 \%, 75 \%$ e $70 \%$ respectivamente. Claro que a despeito da existência dessa pequena propriedade assim mesmo existia a concentração da propriedade da terra. Se incluirmos os empresários rurais que vieram ou vivem nas cidades, a concentração de terras no Líbano em 1960 era da seguinte maneira: 5\% dos proprietários rurais possuíam metade as terras agrícolas.

No entanto, pouca gente no período entre 1950 e 1970 defendeu a necessidade de uma reforma agrária no Líbano, à exceção dos partidos de esquerda ou nacionalistas pan-árabes e pan-sírios, sempre pequenos no cenário político do país. Entre as grandes lideranças políticas somente o líder druso Kamal Jumblatt a defendeu, chegando a realizá-la em suas próprias $\operatorname{terras}^{317}$.

Para estimular a agricultura (além de prover o fornecimento de energia elétrica), o governo desenvolveu a partir dos anos 50 o projeto do Rio Litani, por meio do qual, junto a outros ao longo do país, previa-se irrigar cerca de 50 mil acres de terras. Esse projeto, que havia sido herdado do abandonado programa do Ponto IV, para ser realizado precisou que o governo libanês realizasse um empréstimo de US\$24 milhões do Banco Mundial ${ }^{318}$. Sendo que quando pronto responderia, no caso da agricultura, a uma necessidade de aumentar a pequena parcela de terra fértil irrigada no Líbano, que era de apenas 20\%, do total ou 73 mil hectares, em um total de 365.500 em todo o país ${ }^{319}$.

Ele começou em 1957 e tinha um prazo de trinta anos para ser realizado, com um

\footnotetext{
317 GENDZIER, Irene. Notes from the minefields... p. 47

${ }^{318}$ SAYGH, Yusuf Abdallah. Economies of the Arab World: development since 1945. Londres, 1978. p. 293

319 HANUSH, Basim A. apud RAPHAELI, N. Development planing: Lebanon. Political Research Quaterly, Set. 1967, V. 20, N. 3. p. 718.
} 
custo estimado em 341,9 milhões de libras libanesas. Embora, evidentemente, nunca tenha sido concluído dentro do período abrangido por esse texto, alguns setores do projeto entraram em funcionamento já nos anos 60 .

Desse modo, em 1965 o primeiro estágio já havia sido concluído com o termino da represa de Qar'um que, além de reservatório de água para as turbinas dos geradores, deveria utilizar essa água para os projetos agrícolas de sua região e, assim, teoricamente ajudar a desenvolver o sul do Líbano para diminuir a sua diferença de desenvolvimento com relação à região do Monte Líbano e Beirute ${ }^{320}$.

Esse projeto vinha na esteira dos investimentos que o governo libanês realizava em irrigação desde a época da independência, que totalizariam 31 milhões de libras libanesas em $1954^{321}$, mas que eram regionalmente concentrados até então. Porém, sua aplicação foi lenta e complicada devido aos desacordos, interesses e disputas entre os $\mathrm{Zu}$ 'ama, junto com os seus grupos de pressão a respeito de quem e quais localidades seriam beneficiadas, erros de execução de projetos, insuficiência dos estudos de base, análises de solos, fontes cadastrais e fotos aéreas $^{322}$.

Um plano que envolveu a agricultura libanesa foi o programa Ponto IV, que começou a ser negociado entre os governos do Líbano e dos EUA, ainda durante o mandato do presidente el-Khuri, mas foi assinado durante o governo de Chamoun, embora sua implementação tenha encontrado muitos entraves dentro da burocracia libanesa, descrenças em sua aplicabilidade devido à realidade social e cultural local, bem como o receio de muitos libaneses das consequências políticas de um excessivo alinhamento com os norte-americanos.

Ratificado pelo parlamento libanês no outono de 1951, esse amplo programa previa a assistência técnica norte americana para promover o desenvolvimento libanês em diversas áreas da economia e sociedade, como transporte, pesca, abastecimento de água potável, saúde pública, moradia, agricultura e turismo. O maior projeto, o que envolvia o Rio Litani, previa a construção de uma represa, redes de irrigação, produção de energia elétrica a um custo de US\$365.000 no

\footnotetext{
320 RAPHAELI, N. Development planing: Lebanon..... p. 719

${ }^{321}$ GATES, Carolyn L. The merchant republic... p. 106

322 SAYGH, Yusuf Abdallah. Economies of the Arab World: development since 1945. Londres, 1978. p. 293
} 
qual o governo libanês providenciaria US\$90 $\mathrm{mil}^{323}$. Com relação à agricultura previa-se o apoio aos produtores e o envio de técnicos norte-americanos, maquinário e produtos para aumentar e melhorar a qualidade da produção agrícola ${ }^{324}$.

Entretanto, ele tinha um preço e isso estava associado à aceitação política americana do período que se caracterizava pela Guerra Fria com a URSS e a contenção de movimentos nacionalistas e revolucionários no Terceiro Mundo, bem como a aceitação da hegemonia americana, o que implicaria abrir o país para a penetração do capital estadunidense.

Também seria uma compensação pela política americana de reconhecimento de Israel, que tantos perigos trazia à existência do Líbano. Por isso o projeto Ponto IV foi denunciado por membros da oposição da "Frente Socialista Nacional", no Parlamento e na imprensa $^{325}$. O programa Ponto IV na verdade era um meio de promover o alinhamento do Líbano ao EUA, aí incluindo a própria sociedade libanesa que seria beneficiada pela "bondade" norte americana e, com isso, faria desse país mais uma cabeça de ponto de Washington no Oriente Médio e, em especial, nos países árabes. Pois o País do Cedro seria uma vitrine para a região de como seria algo "bom" e "benéfico" para esses países o fato de estarem alinhados a Washington. Esse plano era tão importante para os EUA, na época, que o representante americano para o Líbano, Harold Minor, pressionava el-Khuri para a sua aprovação e exigia de seu sucessor C. Chamoun a sua aplicação ${ }^{326}$.

Inicialmente incapaz de abastecer completamente o país, o Líbano, por exemplo, produzia apenas $30 \%$ do trigo que consumia nos anos 40, sendo obrigado a comprar 100 mil toneladas por ano da Síria. Também a agricultura libanesa produzia menos do que a da Palestina, que até a destruição desse país pelos sionistas era uma concorrente importante ${ }^{327}$. No período entre 1950 e 1970 a agricultura libanesa assistiu ao desenvolvimento de dois fenômenos paralelos: a diminuição da mão de obra empregada devido à introdução de maquinário moderno,

${ }^{323}$ GENDZIER, Irene L. Notes from the minefield... p. 126.

${ }^{324}$ GENDZIER... P. 128.

${ }^{325}$ GENDZIER... p. 128.

${ }^{326}$ GENDZIER... p. 136, 145.

${ }^{327}$ MALLAT, Raymond A. Fiscal policy for social justice and economic development in Lebanon. Beirute, 1980. p. 100 . 
entre eles tratores e colheitadeiras, cujo resultado mais nefasto foi o êxodo rural; e a melhora técnica com a aplicação de processos científicos no gerenciamento e trato das plantações, que teve como resultado o crescimento do valor da produção agrícola, que saltou de LL206 milhões em 1950 para mais de 650 milhões no começo da década de $1970^{328}$.

Porém, esse crescimento veio com um grande número de problemas. O primeiro foi o fato da agricultura libanesa se concentrar na produção de frutas e legumes largamente exportados e algumas culturas para uso industrial, como o tabaco. E, por conta disso, dispensou uma atenção menor para a produção de cereais e outros produtos para o abastecimento de alimentos. Tanto foi assim que a área cultivada ocupada pelos cereais caiu de 102 mil hectares em 1959 para 53 mil dez anos depois, enquanto as frutas no mesmo período cresceram, em termos de área cultivada, de 55.460 hectares para 81.600, e os legumes e verduras foram de 39 mil hectares para 46,5 mil hectares.

Outro número que revelou a diminuição da produção de cereais nesse período foi à queda de sua produtividade de 4,5 toneladas em 1959 para 3,1 toneladas dez anos depois. Os principais mercados para a exportação dessas frutas e legumes eram os países árabes vizinhos que compravam $75 \%$ dessas mercadorias exportadas ${ }^{329}$.

Um segundo problema que essa orientação externa da agricultura trouxe teve como resultado dentro da economia libanesa a sua fraca conexão com outros setores da economia, como a indústria, que não recebia a quantidade certa de produtos agrícolas e estes ainda vinham com uma qualidade inferior. Essa tendência, que tem suas origens no século XIX, foi fortalecida no período entre 1950 e 1970 pela economia de orientação externa do Líbano, que levou tanto os latifundiários tradicionais quanto muitos membros da burguesia urbana (incluída aí até mesmo a Palestina) a investirem na agricultura de grande escala para a exportação, com o objetivo de abastecer os mercados árabes vizinhos e penetrar nos mercados ocidentais e até mesmo na Europa Oriental comunista ${ }^{330}$.

${ }^{328}$ GATES, Carolyn L. The historical role of political economy in the development of modern Lebanon. Oxford: Centre For Lebanese Studies, 1989. p. 22.

${ }^{329}$ MALLAT, Raymond A. Fiscal policy.... Tabela 15. p.

${ }^{330}$ GATES, Carolyn L. The historical role of political... p. 26-27. 
Essa burguesia rural tem origens diversas: no norte, na região da planície do Akkar, se originou dos comerciantes agiotas de Trípoli; nas montanhas do centro e sul e na costa adjacente esses capitalistas eram os mercadores agiotas de Sidom, Tiro e mesmo Beirute e a burguesia exilada palestina de Haifa e Jaffa, que já se dedicava à agricultura capitalista de grande escala antes de 1948. No Beka'a eram os mercadores da cidade de Zahle e até mesmo de Beirute $^{331}$.

Outro problema foi a pouca atenção dada à pequena agricultura que muitas dificuldades tinham em atrair capital, uma vez que os bancos quase nunca emprestavam a pequenos fazendeiros e, como tinham interesse em financiar a grande agricultura capitalista, desencorajaram o Estado a promover o crédito agrícola ${ }^{332}$, bem como em adquirir maquinário, muitos dos insumos e técnicas modernas.

As políticas governamentais eram feitas para favorecer os grandes proprietários, dos quais um bom número era de políticos importantes que ocupavam cargos em todas as esferas de governo. Ainda que, desde a época do mandato, o governo tivesse criado instituições para financiar a pequena agricultura, ela sempre foi descapitalizada pelos motivos acima colocados, tendo por issopouquíssimo impacto nesse setor ${ }^{333}$. Um exemplo dessas instituições foi o Crédito Bancário Imobiliário, Agrícola e Industrial de propriedade parcial do Estado e que foi criado em 1954. Nesse caso, como exemplo da falta de vontade em financiar os setores não comerciais, os bancos particulares somente aceitaram participar desse fundo quando o governo comprou $40 \%$ do seu capital e garantiu a esse fundo um empréstimo de LL25 milhões. Todavia, ainda assim essa instituição de crédito não conseguiu cumprir com o seu papel por conta das fortes debilidades e limitações de suas estruturas internas ${ }^{334}$.

Aliás, ao longo do período entre 1950 e 1970 a agricultura libanesa sentia a falta de instituições de crédito que, em outros países, eram instituições vitais do setor agrícola da economia. Esse era o caso das cooperativas agrícolas de crédito, que em muitas partes do mundo

\footnotetext{
${ }^{331}$ NARS, Salim. Backdrop to civil war... p. 6.

332 BADRE, Albert apud GATES, Carolyn L. The historical role... p. 24.

333 GATES. Idem. p. 22.

${ }^{334}$ KHALAF. Economic implications of the size of nations... p.167-168.
} 
são responsáveis por canalizar capital para a agricultura e que são importantes para que os fazendeiros possam acumular as suas poupanças. Embora o governo libanês tenha promulgado várias legislações para favorecer o desenvolvimento das cooperativas agrícolas de crédito, estas não se formaram. Segundo Khalaf (1971) as estruturas sociais do campo e a baixa capacidade de formação de poupança ali existente dificultavam a superação das clivagens comunitárias e dos hábitos individualistas, grandes obstáculos para a formação de cooperativas.

Por conta das dificuldades de financiamento, para adquirir capital, os pequenos agricultores recorriam aos agiotas, que eram muito numerosos no meio rural libanês, que emprestavam com juros que chegavam a 25-30 \% ao ano. Esse endividamento tinha como consequência o fato de retardar a expansão da mecanização, de impedir que os agricultores realizassem investimentos em irrigação e limitava os investimentos no terraceamento de encostas, mantendo assim a pequena agricultura subdesenvolvida. Com o tempo, como era comum o endividamento excessivo, muitos pequenos agricultores perdiam as suas terras e eram obrigados a emigrar para a cidade, onde costumavam se transformar em mão de obra barata e pouco qualificada residindo em favelas e cortiços ${ }^{335}$.

Por conta do que foi dito acima a população rural do Líbano sempre teve os níveis de vida mais baixos do país, aí incluindo tanto os pequenos camponeses quanto os trabalhadores rurais, que sempre receberam os piores salários entre todas as categorias e, por muito tempo, estiveram de fora de qualquer tipo de seguridade social. No caso dos pequenos proprietários, sua pobreza também era acentuada pelo fato de muitas de suas propriedades situarem-se em regiões montanhosas, com poucas terras férteis disponíveis e, quando elas eram divididas entre os herdeiros de um pequeno fazendeiro que havia falecido, essas terras ao serem partilhadas entre os filhos daquele eram tornadas economicamente inviáveis. Essa era outra causa do êxodo rural em direção às cidades e da emigração para o estrangeiro ${ }^{336}$.

Quando os pequenos agricultores não migravam eles costumavam buscar outras fontes de renda para compensar os pequenos rendimentos tirados de suas propriedades ou usar o trabalho de todos os membros da família para tentar aumentar a produtividade de suas exíguas

335 GATES, Carolyn L. The merchant republic... p. 133

${ }^{336}$ GASPARD, Tufic K. A political economy of Lebanon... p. 91 
terras. No caso de buscarem outros trabalhos, eles costumavam realizar tarefas não agrícolas ou se empregar em grandes fazendas. Segundo Gaspard, citando fontes oficiais (Republique Libanaise, 1966, Annex, N. 10, p. 2; NARS, 1978, p.9), mais da metade dos fazendeiros libaneses na década de 1960 tinha esse tipo de atividade, demonstrando, desse modo, quão precária era a pequena agricultura libanesa naquela época. Outro grupo já suplementava sua renda com a remessa de dinheiro de parentes que viviam no exterior como acontecia com outros setores da sociedade libanesa.

Outro mal que afetava a agricultura de pequena e média escala era o papel nefasto dos intermediários na compra dos produtos agrícolas para a revenda nos centros urbanos (e mesmo no mercado externo). Como apenas tinham esses atravessadores para vender, os fazendeiros libaneses eram obrigados a comercializar nos preços que aqueles queriam, o que os obrigava a vender sua produção a um valor abaixo do que realmente ela valia. Assim, eles chegavam a vender a produção de leite para os consumidores em um valor que era o dobro do que pagaram aos agricultores. Em outro exemplo, no caso das uvas vinícolas, pagavam 18,5-30 piastras o quilo para os produtores e revendiam por 50 ou 100 piastras. Exemplos assim se encontram em todos os ramos da pequena e média produção agrícola libanesa. Esses intermediários eram um punhado de gente, dessa forma, no fim dos anos 60, vinte e cinco deles controlavam o mercado de maçãs e vinte o mercado de frutas cítricas, por exemplo. Apenas três deles se apropriariam de um quarto da produção agrícola ${ }^{337}$.

Por fim, o que foi colocado acima mostrou que as duas faces da realidade do meio rural libanês, os dois setores em que se dividia, tiveram histórias bem diferentes. De um lado a existência de um setor tradicional, atrasado tecnologicamente, com dificuldades de conseguir financiamento e apoio do Estado, ocupando terras pouco produtivas e vítimas da ação de intermediários na venda de seus produtos nos mercados urbanos. Esse setor foi por tudo isso quase destruído nos anos entre 1950-1970.

Do outro lado, o setor moderno e capitalista, que teve amplo acesso ao financiamento privado (mesmo sendo a quantidade desse empréstimo pequeno se comparado com o comércio) e público com juros razoáveis, se utilizou da mão de obra barata dos palestinos e imigrantes sírios e

${ }^{337}$ NARS, Salim. Backdrop to civil war... p. 6 
se aproveitou das técnicas, produtos e do maquinário mais moderno. Além disso, em muito se beneficiaram dos vínculos do Líbano com o mundo Árabe, aí incluindo até mesmo os Estados nacionalistas e estadistas, como o Egito de Nasser e o Iraque, e Síria posteriores a 1958, que continuaram a comprar produtos agrícolas libaneses, mas também dos ricos mercados europeu e norte-americano. A agricultura capitalista de grande porte pôde prosperar, se desenvolver e marginalizar a pequena propriedade, tornando-se o ramo dominante da agricultura libanesa na segunda metade do século XX.

Tabela 24 - Cultivo da terra

\begin{tabular}{lccccccccccccc}
\hline $\begin{array}{l}\text { Tipo de produtos } \\
\text { hectares (ton.) }\end{array}$ & \multicolumn{1}{c}{ Área cultivada em hectares } & \multicolumn{1}{c}{ Valor da produção agrícola (em milhões de LL) } & Produtividade por \\
& $\mathbf{1 9 5 9}$ & $\mathbf{1 9 6 0}$ & $\mathbf{1 9 6 4}$ & $\mathbf{1 9 6 8}$ & $\mathbf{1 9 5 9}$ & $\mathbf{1 9 6 0}$ & $\mathbf{1 9 6 4}$ & $\mathbf{1 9 6 8}$ & $\mathbf{1 9 5 9}$ & $\mathbf{1 9 6 0}$ & $\mathbf{1 9 6 4}$ & $\mathbf{1 9 6 8}$ \\
\hline Cereais & 102000 & 91.600 & 91.700 & 85.704 & 23,2 & 18,0 & 25,4 & 17,2 & 4,5 & 3,9 & 5,1 & 3,1 \\
Verduras & 39.075 & 32.775 & 41.495 & 45.276 & 41,5 & 40,0 & 56,7 & 69,0 & 303,4 & 279,9 & 317,4 & 288,7 \\
Produção & & & & & & & & & & & & & \\
p/ indútria & 36.710 & 6.130 & 11.800 & 16.763 & 32,1 & 8,3 & 23,6 & 45,3 & 38,2 & 59,1 & 87,3 & 76,1 \\
Frutas & 55.460 & 84.700 & 86.179 & 75.254 & 98,5 & 142,3 & 234,5 & 199,8 & 112,6 & 101,7 & 173,4 & 187,5
\end{tabular}

Fonte: MALLAT, Raymond A. 70 years of money muddling in Lebanon, 1900-1970-77: a guide in monetary management for economic development in Lebanon. Beirute, Aleph, 1977. p.

\subsection{Comércio, bancos e outros serviços}

Esses foram os setores principais da economia libanesa, os grandes beneficiados pelo liberalismo econômico e os setores para quem os governos libaneses trabalharam, especialmente nos mandatos de el-Khuri e Chamoum, quando o Líbano recebeu a denominação de República Comercia. Mas também continuaram a dominar amplamente a economia, sob o governo desenvolvimentista de Fuad Chehab e o de seu sucessor Charles Helu, que nunca desafiaram a 
hegemonia desses dois setores, embora tenham procurado promover algum controle por meio de instituições estatais criadas ao longo dos seus mandatos.

Os conjuntos dos interesses comerciais dentro das estruturas de poder do governo ficaram conhecidos pelo nome de Consortium e caracterizaram os governos dos dois primeiros presidentes do Líbano após a independência, mas também, embora afastados dos círculos internos de poder nos mandatos de Chehab e Helu, continuaram a comandar as estruturas do poder econômico no Líbano em todo o período até a eclosão da guerra civil em 1975. Esse conjunto de interesses formava um bloco de poder estimado em umas 100 grandes famílias de banqueiros-comerciantes, notáveis rurais e a elite político-burocrático urbana. Deles vieram muitas das principais figuras da política libanesa ${ }^{338}$.

Todas essas atividades levaram a um desenvolvimento exagerado do setor terciário, que já em 1950 correspondia a 62\% da economia libanesa e continuaria a crescer até chegar, vinte anos depois, a ser $72 \%$ do PIB. Desse total no final desse período aproximadamente $36 \%$ era vinculado ao setor externo, o que correspondia a $25 \%$ de todo o PIB $^{339}$. Esse crescimento tinha sido tão rápido que o Líbano, ainda em 1939, tinha metade do PIB procedente dos setores produtivos. Ao longo do período entre 1950 e 1970, o Líbano presenciou um contínuo crescimento de sua economia, em cerca de 6,6\% ao ano, mas o ritmo do crescimento começou a diminuir nos anos $60^{340}$, particularmente durante o mandato de Charles Helu.

\footnotetext{
${ }^{338}$ GATES, Carolyn L. The historical role... p. 32

${ }^{339}$ SAYGH, Yusuf Abdallah. Economies of the Arab World... p. 305

${ }^{340}$ GASPARD, Tufic K. A political economy of Lebanon... p. 71
} 
Tabela 25 - Exportações de bens e serviços, 1951-1966 (em milhões de LL)

\begin{tabular}{lccc}
\hline Mercadorias & $\begin{array}{c}\text { Serviços (a) } \\
\text { Exportados }\end{array}$ & $\begin{array}{l}\text { Proporção de } \\
\text { Serviços para } \\
\text { Mercadorias } \\
\text { Exportadas }\end{array}$ \\
\hline 1951 & 124,9 & 244,1 & 1,9 \\
1952 & 121,1 & 288,6 & 2,3 \\
1953 & 134,4 & 233,0 & 1,7 \\
1954 & 172,1 & 314,7 & 1,8 \\
1955 & 196,5 & 391,2 & 2,0 \\
1956 & 247,6 & 335,4 & 1,4 \\
1957 & 210,5 & 445,0 & 2,1 \\
1958 & 117,0 & 315,0 & 2,7 \\
1959 & 152,0 & 435,0 & 2,9 \\
1960 & 162,0 & 517,0 & 3,2 \\
1961 & 230,9 & 701,3 & 3,0 \\
1962 & 320,6 & 758,2 & 2,4 \\
1963 & 323,4 & 798,9 & 2,5 \\
1964 & 424,0 & 922,5 & 2,2 \\
1965 & 447,3 & 1039,7 & 2,3 \\
1966 & 584,1 & 1164,8 & 2,0 \\
& & & \\
a) Compreende transporte, seguros e viagens internacionais, rendimentos de investimentos e diversos outros serviços \\
de trânsito incluídos. & & \\
\hline
\end{tabular}

Fonte: KHALAF, Nadim G. Economic implications of the size of nations: with special reference to Lebanon. Leiden: E. J. Brill, 1971. Tabela 71. p. 208.

O modelo econômico adotado pelo Líbano foi ideologicamente sendo formulado nos anos anteriores à instalação do laissez-faire por um conjunto particular de pensadores. Esses ideólogos, da República Comercial, foram os chamados neofenícios, um pequeno grupo de 
intelectuais, comerciantes e banqueiros, especialmente de Beirute, e, em sua maioria, cristãos. Eram organizados através da Societé Libanaise de Economie Politique (SLEP), cuja tarefa era difundir o liberalismo econômico no Líbano. Seu mentor era o economista Gabriel Menassa ${ }^{341}$. Entre os seus membros estavam Michel Chiha, o mais famoso e influente de todos, Henry Far'aon e Alfred Kettaneh, entre outros. Foram eles que deram forma à ideia segundo a qual somente por meio do comércio e das finanças internacionais é que o Líbano poderia alcançar o seu desenvolvimento.

Essa era a única riqueza que o país produzia, pois carecia de recursos naturais importantes que poderiam sustentar um processo de industrialização e, devido às suas limitações agrícolas, não poderia encontrar nesse setor a base de sua economia. Por isso, o Líbano deveria confiar na grande capacidade e inteligência de seu povo para as atividades mercantis, para a sua capacidade para emigrar, se adaptar e acumular capital no estrangeiro. Como no passado faziam os seus ancestrais fenícios que colonizaram o Mediterrâneo, fundando colônias e feitorias comerciais, tendo funcionado como uma ponte entre o Oriente e o Ocidente ao transmitir para essas terras o conhecimento acumulado pelas civilizações asiáticas.

No século XX, o Líbano teria um papel semelhante devido aos seus vínculos tanto com o oriente árabe como com a Europa. A atividade mercantil e financeira seriam os meios para se realizar essa "missão histórica". Dessa forma, o comércio, as finanças e o capitalismo liberal, que seria a ideologia por trás dessas atividades, foram alçados à condição de elementos da identidade nacional libanesa ${ }^{342}$.

\subsubsection{Comércio}

O Líbano conseguiu por meio de seu modelo econômico estabelecer fortes vínculos com o mundo Árabe. Em 7 de setembro de 1953, por meio da Liga Árabe, Chamoun estabeleceu acordos comerciais com todos os países árabes vizinhos, que nos anos seguintes foram grandes

341 Autor de um importante estudo sobre o Líbano: Plan de Reconstruction de l'Économie Libanaise et de Reforme de $1^{\prime}$ État (1948).

342 GATES, Carolyn L. The merchant republic... p. 83 
parceiros econômicos do Líbano ${ }^{343}$, enquanto as representações diplomáticas desses países eram elevadas à categoria de embaixadas. Devido a esses vínculos e à natureza da economia libanesa, as exportações desse país eram em grande parte restritas a um punhado de países clientes e estavam concentradas geograficamente nesses seus vizinhos árabes nos anos entre 1951 e 1975.

Dos doze maiores importadores de mercadorias libaneses, seis eram árabes e, desses, cinco eram os principais parceiros comerciais da república libanesa: Arábia Saudita, Síria, Jordânia, Kuwait e Iraque. O sexto parceiro era o Egito que estava em décimo lugar. Os outros parceiros eram EUA, Grã-Bretanha, França, Itália, URSS e Alemanha Ocidental. Os dois primeiros compradores de mercadorias libanesas adquiriam juntos $26.9 \%$ das mercadorias, sendo que a Arábia Saudita comprava $14.9 \%$, o que corresponde a $15 \%$ do total. Enquanto a Síria correspondia a 12. Esse doze países compravam $74 \%$ das mercadorias libanesas, sendo que $51 \%$ desse número acima correspondem aos países árabes ${ }^{344}$.

No entanto, ao longo das décadas de 50 e 60 , embora continuassem a ser mercados importantes para os produtos libaneses, os seis países árabes citados acima foram recebendo uma parcela cada vez menor das exportações libanesas, caindo a sua participação de 38\% em 1951 para 25\% em 1966, embora os valores dessas exportações houvessem subido de LL37 milhões para LL86,4 milhões ao longo desses anos ${ }^{345}$.

Tabela 26 - Importações libanesas desde os doze maiores mercados (1951-1966)

\begin{tabular}{lc}
\hline Países exportadores & Porcentagem do total de importações \\
\hline Grã-Bretanha & 18,6 \\
Estados Unidos & 13,2 \\
França & 9,2 \\
& \\
(continua) & \\
\hline${ }^{343}$ Gates: Idem. p. 107 & \\
${ }^{344}$ KHALAF. Economic implications of the size of nations...Tabela 61. p. 193. \\
${ }^{345}$ KHALAF. Idem. p.196-197.
\end{tabular}


(conclusão)

Tabela 26 - Importações libanesas desde os doze maiores mercados (1951-1966)

Síria

Alemanha Ocidental

Itália

Iraque

Suíça

Bélgica

Holanda

Egito

Jordânia

Total
7,5

7,5

5,8

2,7

2,7

2,6

2,5

1,3

$\underline{1,0}$

76,1

Fonte: KHALAF, Nadim G. Economic implications of the size of nations: with special reference to Lebanon. Leiden: E. J. Brill, 1971. Tabela 63. p. 195.

Tabela 27 - Exportações libanesas para os seus doze maiores mercados (1951-1966)

\begin{tabular}{lc}
\hline País importador & Porcentagem do total exportado \\
\hline Arábia Saudita & 14,9 \\
Síria & 12,0 \\
Jordânia & 8,6 \\
Kuwait & 6,8 \\
Iraque & 6,0 \\
Estados Unidos & 5,9 \\
&
\end{tabular}


(conclusão)

Tabela 27 - Exportações libanesas para os seus doze maiores mercados (1951-1966)

Grã-Bretanha

França

Itália

Egito

União Soviética

Alemanha Ocidental

Total
4,5

3,7

3,7

2,9

2,7

2,4

74,0

Fonte: KHALAF, Nadim G. Economic implications of the size of nations: with special reference to Lebanon. Leiden: E. J. Brill, 1971. Tabela 61. p. 193.

Dentre os países de quem o Líbano importava suas mercadorias ao longo do período entre 1951 e 1966, as principais fontes de produtos para o país eram a Grã-Bretanha com 18,6\%, os Estados Unidos com 13,2 \%, a França com 9,0, a Síria com 9,0\% e a Alemanha Ocidental com $7,5 \%$.

Esses cinco países, mais os sete países que compõe a tabela acima, forneciam 76,1\% das importações para o Líbano. Desses 12, oito eram do Ocidente e apenas eles forneciam 62\% das mercadorias compradas pelo Líbano ${ }^{346}$. Os outros demais países eram nações árabes vizinhas (a já citada Síria, mais o Egito, a Jordânia e o Iraque).

O que chama a atenção nesse caso é o fato de que, ao longo do período 1951-1966/70 (excetuando três anos particulares: 1952, 1963 e 1964), houve uma constante queda na quantidade de bens importados desses países, tendo a participação deles declinado de $27 \%$ para 10\%. Entre as possíveis explicações podemos citar o fato de que o Líbano, por conta de atividades como o turismo e o comércio de luxo, demandava produtos e capitais que somente as nações industrializadas do Ocidente podiam fornecer, levando a uma diminuição das importações

${ }^{346}$ KHALAF ... p. 195. 
de seus vizinhos árabes ${ }^{347}$.

Tabela 28 - Comércio triangular e de trânsito entre 1951-1968 (em milhões de LL)

\begin{tabular}{c|c|c}
\hline Ano & Reexportações & Trânsito \\
\hline 1951 & 8,2 & 1137,0 \\
1952 & 19,5 & 1039,0 \\
1953 & 12,5 & 1063,0 \\
1954 & 18,9 & 1033,0 \\
1955 & 16,4 & 1148,0 \\
1956 & 14,7 & 1100,0 \\
1957 & 25,8 & 1245,0 \\
1958 & 16,3 & 980,0 \\
1959 & 24,5 & 792,0 \\
1960 & 23,0 & 813,1 \\
1961 & 23,2 & 890,9 \\
$1962 *$ & 90,5 & 799,9 \\
1963 & 97,4 & 892,4 \\
1964 & 85,9 & 933,1 \\
1965 & 103,9 & 997,4 \\
1966 & 137,6 & 1050,0 \\
1967 & 128,5 & 957,7 \\
1968 & 153,5 & 1532,9
\end{tabular}

* Começando em 1962 as cifras de reexportação incluem as taxas de armazenamento personalizadas que são incorporadas como parte das cifras de trânsito.

Fonte: MALLAT, Raymond A. Fiscal policy for social justice and economic development in Lebanon: a guide in monetary management for econonomic development in Lebanon. Beirute: Aleph, 1980. p. 110.

A atividade comercial internacional do Líbano não foi uniforme ao longo das décadas

${ }^{347}$ KHALAF... p. 197. 
de 50 e 60. No período entre 1951 e 1960 a taxa composta de crescimento anual das importações cresceu mais rápida $(11,7 \%)$ do que a taxa de exportações $(5,9 \%)$.

Já durante a década de 60 aconteceu o inverso: a taxa de importações cresceu 11,4\%, enquanto a taxa de exportações subiu $13,5 \%{ }^{348}$. Já o movimento médio tri-anual das importações subiu de $36 \%$ para 58,7\% entre 1951 e 1961, mas caiu para 48\% no fim da década de $60^{349}$.

Isso pode ter acontecido devido às mudanças ocorridas entre a proporção das importações em relação às exportações. O movimento tri-anual médio desta cresceu de 3,2 para 5,1 entre 1951 e 1961, mas diminuiu para 3,1 em 1966. Com isso o valor das mercadorias exportadas, que chegou a crescer até o começo da década de 60, acabou voltando a ser três vezes mais baixo do que o das importadas, como acontecia em 1951.

Tudo isso estava ligado ao permanente déficit comercial do Líbano que apenas cresceu ao longo das décadas de 50 e 60, indo de LL260 milhões em 1951 para LL1,138 bilhão em 1966, um crescimento de $22 \%$ ao ano em uma taxa média simples ${ }^{350}$. Essa propensão a importar levou o Líbano a gastar metade de sua renda anual na compra de mercadorias no exterior. Os motivos para esse aumento constante das importações estariam no aumento da renda de determinados setores da sociedade, no crescimento de determinados ramos da economia, como a construção civil, e no aumento da aquisição de matéria-prima e bens de capital por outros setores.

O fato do Líbano ter um setor turístico desenvolvido também contribuiu para o aumento das importações pois, como no país existia uma grande quantidade de moedas estrangeiras, cujo uso era bem difundido, as taxas de importação eram bem reduzidas e, como puderam encontrar nos principais centros uma grande variedade de produtos, os turistas sentiamse estimulados a consumir.

Por sua vez as empresas importadoras, além de contarem com um mercado para a venda dos seus produtos, eram estimuladas a exercerem suas atividades devido ao abundante capital existente no país, particularmente os encontrados nos bancos, por conta da sempre grande

\footnotetext{
${ }^{348}$ KHALAF... Nota 1. p. 199.

349 KHALAF... p. 202.

350 KHALAF... p. 199-200.
} 
remessa de capital para o Líbano, que era facilmente concedido como empréstimos para as firmas importadoras. Por fim, os hábitos fortemente consumistas dos setores com renda mais alta na sociedade libanesa também ajudaram a contribuir para o crescimento das importações ao longo das décadas de 50 e $60^{351}$.

Tabela 29 - Estrutura do comércio de mercadorias (médias anuais em \%)

1951-1952 1964-1966

\section{Mercadorias exportadas}

Manufaturas (\% do Total)

46

55

-Alimentos processados

12

-Têxteis e produtos de vestuários

13

-Madeira e produtos químicos

-Metais e maquinarias

12

-Outros

11

Destino das exportações

Países árabes

49

66

Países industriais

39

18

Outros

12

16

Total

100

100

Uso de mercadorias importadas

Consumo

43

39

Intermediação

44

51

Investimento

13

11

Total

100

100

Fonte: GASPARD, Tufic K. A political economy of Lebanon, 1948-2002: the limits of laissez-faire. Leiden e Boston: E. J. Brill, 2004. Adaptado da Tabela 5.3. p. 149.

${ }^{351}$ KHALAF ... p. 202-203. 
Diferentemente dos países vizinhos e do restante do Terceiro Mundo, as exportações do Líbano não eram concentradas em um ou uns poucos produtos sendo, ao contrário, bastante diversificadas. O principal grupo eram as frutas e legumes, que permaneciam acima ou abaixo dos $30 \%$ desde 1954. Os demais itens eram óleos vegetais, tabaco, madeira, couro cru, algodão, fertilizantes, têxteis e roupas ${ }^{352}$.

A partir da década de 60 aumentou cada vez mais a quantidade de produtos industrializados na pauta de exportação do Líbano. Muito mais diversificada era a pauta de importações, que incluíam desde alimentos e gado até os veículos, meios de transporte e máquinas, passando por uma grande variedade de produtos industrializados ${ }^{353}$. Quanto a sua proporção, cerca de $52 \%$ eram bens de capital e bens intermediários e $48 \%$ eram bens de consumo. Dentre estes últimos $40 \%$ eram itens de luxo ou bens de consumo duráveis ${ }^{354}$. Um detalhamento maior da pauta de exportação e importação libanesa pode ser vista na tabela 19.

Com relação ao valor, outra tabela, a 20, mostra que as importações no período entre 1951 e 1968 subiram de LL321 milhões para LL1.865,1 bilhões, embora tivessem ocorrido anos de queda nessa trajetória. Como foi o caso de 1958, em virtude da guerra civil, quando o valor das importações foi de LL518,3 milhões, sendo que no ano anterior havia sido de LL626,6 milhões. E de 1967, em virtude do conflito israelense com seus vizinhos árabes que resultou no fechamento do canal de Suez, ocasionado a queda do valor das importações de LL1.770 bilhões, quando em 1966 havia sido de LL1913,7 bilhões.

Já as exportações cresceram nesse período de LL97,6 milhões para LL510,3 milhões, sendo que apenas houve queda em 1958: nesse ano as exportações foram de LL110,5 milhões, quando no ano anterior haviam sido de LL152,3 milhões. Junto cresceu o perigoso déficit que saltou de LL223,4 milhões em 1951 para LL1.354,8 bilhões em 1968. Somente em duas oportunidades ele caiu e, em ambas, esteve ligado a situações de guerra: 1958 e 1967. Ainda assim, nesses anos o déficit foi de: LL 474,3 milhões no primeiro e de LL 1316,7 bilhões no segundo.

\footnotetext{
352 Mallat, Raymond A. Fiscal policy... p.109,

353 MALLAT. 70 years of money muddling in Lebanon... p. 40

${ }^{354}$ Khalaf: Economic Implications of The Size of Nations... p.203
} 
Tabela 30 - Estrutura do comércio de mercadorias do Líbano, 1950-1958 (\%)

\begin{tabular}{lcc}
\hline Bens & Importados & Exportados \\
\hline Manufaturados & 44 & 28 \\
Ouro & 9 & - \\
Bens primários & 18 & 35 \\
Alimentos & 22 & 30 \\
\end{tabular}

Fonte: GATES, Carolyn L. The merchant republic of Lebanon: rise of an open economy. Londres e Nova Iorque: Centre for Lebanese Studies in association with I. B. Tauris, 1998. Tabela 6.3. p. 115.

Para o Mundo Árabe (e mesmo para o Irã e Turquia) também iam boa parte das importações dos países industrializados do Ocidente. Como, por um bom tempo, os países árabes vizinhos não possuíam portos adequados para trazer diretamente do Ocidente os produtos industrializados que precisavam, eles se utilizavam do Líbano como intermediário. Isso permitiu um grande desenvolvimento das empresas de transporte libanesas, que levavam mercadorias industriais importadas pelo seu país de origem (junto com os produtos aí manufaturados) e traziam os produtos agrícolas e artesanais feitos nesses países que eram reexportados pelo porto de Beirute.

Esse comércio de trânsito sempre foi importante para o Líbano. Suas receitas em 1951 eram de LL1.137 bilhão. Elas cresceram nos anos seguintes, tendo atingido 1.245 bilhões em 1957. Nos anos 60 elas voltaram a crescer, atingindo em 1966 LL1.050 bilhões. As duas quedas que aconteceram ao longo desse período: a de 1958, quando o comércio de trânsito atingiu a cifra de apenas LL980 milhões, e a de 1967 com 957,7 milhões de libras libanesas como resultados, respectivamente, da guerra civil e da guerra dos seis dias ${ }^{355}$.

Posteriormente a 1967 houve um novo aumento do comércio de trânsito e isto

${ }^{355}$ Mallat: Fiscal Policy... p. 111 
aconteceu apesar de que ao longo desse período de vinte anos os países árabes vizinhos desenvolvessem as suas infraestruturas, incluindo portos, aeroportos e marinha mercante, passando assim a comprar diretamente dos países industrializados as suas manufaturas e para eles vendendo os seus produtos, dessa forma recorrendo menos ao intermediário libanês. Por isso, o desenvolvimento da infraestrutura desses países impactou no volume do comércio do Líbano, pois diminuiu a quantidade de mercadorias que por ali passavam e, portanto, também a quantidade de renda que poderia ficar no país. Outro obstáculo para esse comércio eram os embargos e elevações de tarifas que, de tempos em tempos, o governo sírio promovia contra o Líbano devido a algum importante desentendimento ou conflito entre os dois países ${ }^{356}$.

Esses vínculos com o mundo Árabe encontravam-se na maior parte da economia libanesa (tanto no comércio de bens materiais como no comércio invisível) e em grande parte de sua sociedade, apesar da existência de um sentimento de distância em relação aos árabes existente entre populações cristãs como os maronitas.

Isso acabou tendo como resultado fazer com que o país se mantivesse dependente dos acontecimentos políticos e econômicos dos seus vizinhos. Qualquer crise por que passasse um desses países podia prejudicar o funcionamento da economia libanesa como um todo, ou de determinados setores, e gerar instabilidade social. Essa fragilidade foi para o Líbano o preço que o país teve que pagar por desenvolver uma economia voltada para o exterior.

Por conta dos enormes ganhos que trazia para o Líbano e suas elites o comércio sempre foi uma atividade que sempre contou com a maior parcela do produto interno libanês ao longo do período entre 1950 e 1970: por volta de 30\% das atividades econômicas ${ }^{357}$. Somente durante o ano de 1958, quando ocorreu a guerra civil, é que houve uma grande queda da renda obtida das atividades comerciais, que foi no valor de $12,7 \%$ em relação a $1957^{358}$.

Como ocorreu em outros setores da economia libanesa, também no comércio houve a concentração das atividades econômicas em poucas mãos. Dessa maneira, no fim do período aqui abrangido a maior parte do comércio de importação do Líbano estava sob o controle de quatro

\footnotetext{
356 MALLAT. 70 years of money muddling in Lebanon... p.42.

357 MALLAT. 70 years of money muddling in Lebanon. Tabela 3. p. 15.

${ }^{358}$ MALLAT: Idem. p. 17.
} 
grandes grupos: o Fattal, Abu Nadal, Kettaneh e Faraon \& Chiha. Eles controlavam juntos até 2/3 desse comércio ${ }^{359}$.

Tabela 31 - Valores do comércio externo para o Líbano, 1951-1968 (em milhões de LL)

\begin{tabular}{lccc}
\hline Ano & Importações & Exportações & Déficit \\
\hline 1951 & 321,0 & 97,6 & 223,4 \\
1952 & 344,0 & 77,6 & 266,4 \\
1953 & 363,0 & 86,7 & 277,1 \\
1954 & 485,1 & 105,6 & 379,5 \\
1955 & 529,1 & 120,6 & 408,5 \\
1956 & 561,2 & 145,8 & 415,4 \\
1957 & 626,6 & 152,3 & 474,3 \\
1958 & 518,3 & 110,5 & 407,8 \\
1959 & 699,8 & 139,1 & 560,7 \\
1960 & $1.112,0$ & 144,0 & 968,0 \\
1961 & $1.272,0$ & 155,6 & $1.116,4$ \\
1962 & $1.366,2$ & 192,0 & $1.174,2$ \\
1963 & $1.314,2$ & 196,3 & $1.117,9$ \\
1964 & $1.573,4$ & 216,0 & $1.357,9$ \\
1965 & $1.683,5$ & 324,1 & $1.359,4$ \\
1966 & $1.913,7$ & 369,5 & $1.544,2$ \\
1967 & $1.770,0$ & 453,3 & $1.316,7$ \\
1968 & $1.865,1$ & 510,3 & $1.354,8$ \\
& & &
\end{tabular}

Fonte: MALLAT, Raymond A. Fiscal policy for social justice \& economic development in Lebanon. Beirute: Aleph, 1980. p. 107.

${ }^{359}$ NARS, Salim. Backdrop to civil war ... p. 4. 


\subsubsection{O setor de transportes}

Para poder desenvolver a sua economia de serviços e comércio o governo do Líbano sempre deu uma grande atenção à maior parte do setor de transporte, procurando desenvolver esse tipo de infraestrutura com a construção de uma malha bem desenvolvida de rodovias, estradas, a modernização e ampliação de portos, em especial o porto de Beirute (feito conjuntamente com a iniciativa privada que controlava a maior parte de suas ações), mas também nos portos petrolíferos de Sidom e Trípoli. Bem como sempre investiu no aeroporto internacional da capital e em outros regionais. Como parte de sua política liberal procurou estimular o surgimento de empresas privadas nos setores de transporte com o desenvolvimento dessas nos transportes marítimos, terrestres e aéreos.

Nesse último caso apareceram diversas empresas especializadas no transporte de cargas ou passageiros que foram vitais para o funcionamento da economia libanesa, como era o caso da Middle East Airlines (MEA), da qual, ao longo do tempo, dois dos principais sócios foram Saeb Salam, primeiro-ministro em várias oportunidades, e o banqueiro Yussef Beidas, o maior do país no período entre 1950 e 1966.

A MEA ligava o Líbano com os emirados do Golfo a partir do começo dos anos 50 permitindo o contato dos banqueiros libaneses com os príncipes locais e também trazia desses Estados e dos demais países do Oriente Médio turistas, empresários, estudantes para as universidades privadas libanesas e compradores para os produtos a venda nos mercados libaneses, que em muito contribuíam para o comercio invisível e visível do país.

Através dos aviões cargueiros da MEA também circulava boa parte do ouro destinado a esses principados, cuja movimentação foi essencial para o sistema financeiro libanês e muitas das mercadorias libanesas, tanto as produzidas pela indústria local como as importadas pelas companhias de comércio ${ }^{360}$.

Outra empresa aérea libanesa importante foi a Air Liban, ligada a empresas de aviação francesas e outros interesses econômicos franceses, que, embora menor que a MEA, também realizava o transporte de passageiros e cargas entre o Líbano e os países árabes vizinhos

${ }^{360}$ GENDZIER, Irene L. Notes from the minefield... p. 105 
e tinha contratos para prestar serviços para multinacionais do petróleo em operação na região. Se a MEA tinha como um dos seus proprietários Saeb Salam, a Air Liban era associada a Hussein 'Uwayni, alto ministro durante o governo el-Khuri e um dos responsáveis pela política liberal do Líbano. A Air Liban tinha conexões também com o sistema bancário libanês, pois muitos de seus acionistas eram banqueiros ou administradores de bancos libaneses ou estrangeiros ${ }^{361}$.

Também eram empresas importantes a Trans-Mediterranean Airlines (TMA) e a Trans-Ocean Airlines (TOA). Esta última era uma empresa de origem norte americana, cuja filial no Líbano estava sob a direção de Carlos Arida (um membro do importante clã maronita dos Aridas) e do estadunidense John Russel. Ela esteve associada a empresas aéreas do Oriente Médio e do leste da África como a Air Jordan e a Air Djibouti e participava do comércio internacional do Líbano, transportando parte da produção de frutas e verduras desse país para as companhias petrolíferas instaladas nos Estados do Golfo Pérsico.

A TOA, além disso, se especializou em oferecer serviços de treinamentos para pilotos, fumigação aérea de plantações e manutenção e revisão de aeronaves que passassem pelo Líbano. Por fim era um dos braços da CIA no Oriente Médio, recebendo por isso apoio financeiro desse serviço secreto norte americano ${ }^{362}$. Também pode ser citada a TMA, do empresário Munir Abu Haydar, que se especializou em serviços de fretes aéreos. Ela usava seus aviões cargueiros para transportar produtos manufaturados (artigos completos ou peças) dos países industrializados para os países árabes do Oriente Médio e levar parte da produção de gêneros alimentícios da região para a Europa e o Japão ${ }^{363}$.

No transporte por terra havia, por exemplo, a Companhia de Transporte Expresso do Levante Libanês, que chegou a controlar no começo dos anos $5075 \%$ do comércio terrestre por caminhões entre Beirute e Bagdá, transportando grande parte das mercadorias iraquianas destinadas ao Ocidente para serem exportadas via Beirute. No caso particular do Iraque, os libaneses substituíram no comércio os judeus que abandonaram o país em direção a Israel, após a

\footnotetext{
361 GENDZIER. Idem. p. 101 e 104.

362 GENDZIER... p. 104

363 GORDON, David. The republic of Lebanon: nation in jeopardy. Boulder, Colorado: Westview Press, 1983. p. 58.
} 
guerra de $1948^{364}$. Fornecedores importantes eram os irmãos Abela, cuja empresa, uma das maiores do mundo na época, entregava no fim dos anos 60 refeições quentes para trinta países e cujo volume de negócio chegava a US\$70 milhões ${ }^{365}$.

\subsubsection{Balança de Pagamentos}

O modelo econômico adotado pelo Líbano trazia contínuos déficits na balança comercial nacional. Isso não acarretava prejuízos maiores, porque o chamado comércio invisível ajudava bastante a compensar os crescentes déficits na balança comercial libanesa, sendo uma atividade vital para o bom funcionamento da economia libanesa. A importância desse comércio pode ser vista nos seguintes dados: em 1960 ele foi de LL482 milhões, enquanto em 1971 era LL902 milhões.

Se juntarmos o comércio invisível com as exportações conseguia-se equilibrar a balança comercial. Ele era composto pelas remessas de dinheiro dos emigrados, pelo fluxo de capital dos países petrolíferos para os bancos ou para o setor imobiliário, pelo dinheiro deixado no país pelos turistas, pelos lucros dos serviços de transportes de gente e mercadorias, o valor das taxas pagas pelo trânsito do petróleo pelo território libanês por parte da Irak Petroleum Company (IPC) e da Arabian-American Company (Aramco).

Aliás, a transferência dos terminais da IPC de Haifa para Trípoli e Sidon, após a destruição da Palestina, e o boicote árabe a Israel trouxe milhões de dólares de dividendos para a economia libanesa. A importância dos terminais petrolíferos de Sidon e Trípoli pode ser demonstrada pelo seguinte dado: no começo dos anos 50 passavam pelo Líbano 78\% do petróleo produzido na Arábia Saudita e no Iraque que ia para a Europa Ocidental e 22\% do que ia para os EUA e o Canadá ${ }^{366}$.

No entanto, entre 1951 e 1970 o Líbano presenciou um crescente prejuízo em sua balança comercial como consequência do modelo econômico adotado. Esse déficit era de 223

\footnotetext{
${ }^{364}$ GATES: The merchant republic of Lebanon...p. 112.

${ }^{365}$ GORDON, David. The republic of Lebanon: nation in jeopardy... p. 58.

${ }^{366}$ Beirut to DOS, Annual Petroleum apud GENDZIER. Notes from the minefield... p. 91.
} 
milhões de libras libanesas em 1951, 968 milhões em 1960 e 1,6 bilhões em 1970. Apesar do seu crescimento ele foi em parte reduzido, em termos relativos, pelo crescimento das exportações nesse período ${ }^{367}$. Entre 1951 e 1957 o valor das mercadorias exportadas cresceu 25\% em média em relação ao valor das mercadorias importadas. Mesmo assim, a média anual do déficit só cresceu ao longo desses anos, indo de LL349 milhões, durante o período de 1951 a 1957, para LL727 milhões entre 1958 e 1964 até atingir LL1427 bilhões, entre 1964 e 1970. O resultado disso para o valor das mercadorias exportadas durante a década de 60 foi a sua diminuição quando atingiu então o valor médio de um sexto, ou aproximadamente $15 \%$ do valor das importações ${ }^{368}$.

Tabela 32 - Índices de liquidez no Líbano 1950-1968

\begin{tabular}{|c|c|c|c|c|}
\hline & $\begin{array}{c}\text { PNL } \\
\text { atual } \\
\text { (milhões de LL) }\end{array}$ & $\begin{array}{l}\text { (2) } \\
\text { Oferta } \\
\text { monetária } \\
\text { (milhões de LL) }\end{array}$ & $\%^{(2 / 1)}$ & $\begin{array}{c}\text { Índices } \\
\text { de preços } \\
\text { ao atacado }\end{array}$ \\
\hline$\underline{\text { Ano }}$ & \multicolumn{4}{|c|}{ 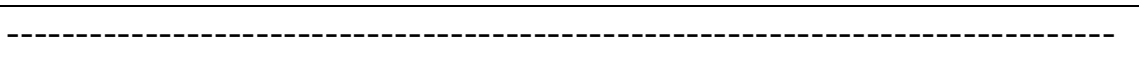 } \\
\hline 1950 & 1.042 & 410 & 39 & 100 \\
\hline 1951 & 1.086 & 465 & 43 & 124 \\
\hline 1952 & 1.115 & 510 & 46 & 116 \\
\hline 1953 & 1.168 & 537 & 46 & 103 \\
\hline 1954 & 1.256 & 665 & 53 & 95 \\
\hline 1955 & 1.374 & 774 & 56 & 96 \\
\hline 1956 & 1.417 & 844 & 59 & 101 \\
\hline 1957 & 1.503 & 1.008 & 67 & 103 \\
\hline 1958 & 1.325 & 1.083 & 82 & 104 \\
\hline 1959 & 1.500 & 1.316 & 88 & 105 \\
\hline (contins & & & & \\
\hline
\end{tabular}


(conclusão)

Tabela 32 - Índices de liquidez no Líbano 1950-1968

$\begin{array}{rrrrr}1960 & 1.800 & 1.714 & 95 & 103 \\ 1961 & 2.000 & 1.913 & 96 & 104 \\ 1962 & 2.120 & 2.125 & 100 & 101 \\ 1963 & 2.247 & 2.145 & 95 & 104 \\ 1964 & 2.861 & 2.660 & 93 & 106 \\ 1965 & 3.154 & 3.188 & 101 & 107 \\ 1966 & 3.460 & 3.325 & 96 & 110 \\ 1967 & 3443 & 3.299 & 96 & 115 \\ 1968 & 3.862 & 3.779 & 98 & 114\end{array}$

Fonte: MALLAT, Raymond A. 70 years of money muddling in Lebanon, 1900-1970-77: a guide in monetary management for economic development in Lebanon. Beirute: Aleph, 1977. Adaptado da Tabela 1. p. 198.

Dentro do comércio invisível, a remessa de dinheiro dos emigrados sempre foi uma das fontes de financiamento familiar no Líbano desde o século XIX e impediu sempre que os níveis de miséria no Líbano fossem maiores do que os registrados nas estatísticas sociais. No período entre 1950 e 1971 essas remessas foram crescendo, passando de $6 \%$ do PIB para $16 \%{ }^{369}$. Se incluirmos todos os tipos de remessas feitas pelos libaneses no exterior (doações, ajuda para a caridade, remessas de indivíduos para familiares) elas eram de 69,1 milhões de libras libanesas em 1951. Em 1957 subiram para 162,7 milhões e, apesar de uma queda em 1960 (LL120 milhões), chegaram a LL145 milhões em $1969^{370}$.

Já o movimento médio trianual das doações experimentou um declínio nesse período de $16,7 \%$ para $6,4 \%^{371}$. Mais importante ainda eram os serviços exportados, que sozinhos representavam $50 \%$ das receitas totais do comercio externo libanês (enquanto as doações e as

${ }^{369}$ GASPARD. A political economy of Lebanon... p. 96

${ }^{370}$ MALLAT. 70 years of money muddling in Lebanon... p. 114.

${ }^{371}$ KHALAF. Economic implications of the size of nations... p. 209. 
contas de capital representavam juntas 28\%), chegando aquelas a serem maiores do que as exportações de mercadorias em si. Aliás, a exportação de serviços chegava a gerar mais divisas externas para o Líbano do que as doações, exportações de mercadorias e capital externo, combinados. Seu movimento médio trianual teve um aumento de 51\% para 54\% entre 1951 e 1966, enquanto seu crescimento anual nesse período foi de $28 \%$, estando acima do da exportação de mercadorias, que foi de $24 \%$.

Por um lado, se houve ao longo da década de 50 um declínio da importância relativa dos serviços, ela acabou sendo revertida durante a década de 60. Naquela década suas receitas não demonstravam qualquer tendência de declínio em sua importância relativa ${ }^{372}$. Por fim, havia o movimento de capitais que experimentou um grande crescimento entre 1951 e 1966 e cujo movimento médio trianual cresceu de 6,9\% em 1951 para 15,4\% em 1966. No fim dos anos 60 o fluxo de capitais externo acabou se tornando maior e mais importante do que o das doações e remessas, porém sendo menos importante do que os serviços ${ }^{373}$.

Tabela 33 - Financiamento do déficit comercial libanês, 1951-1966

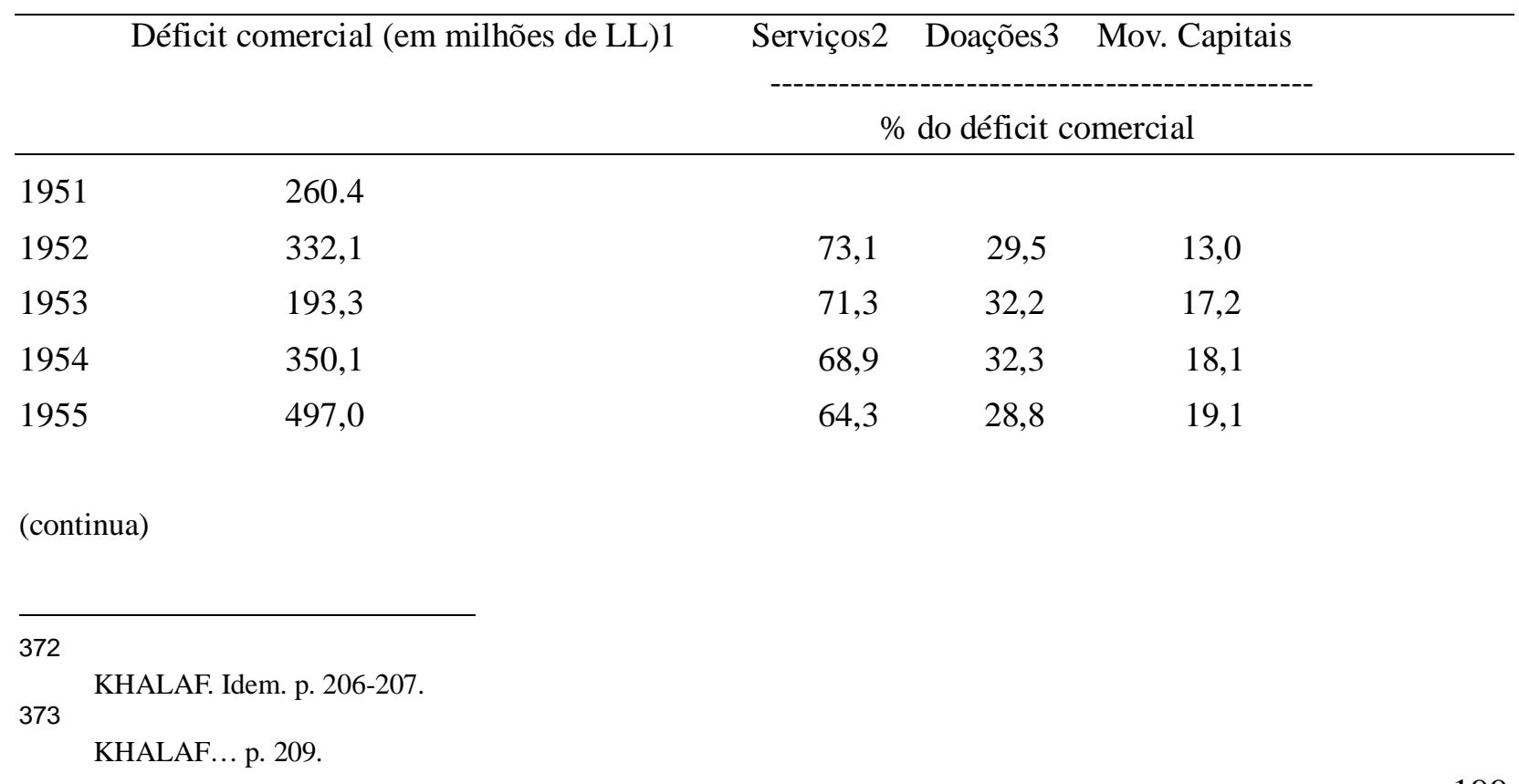


(conclusão)

Tabela 33 - Financiamento do déficit comercial libanês, 1951-1966

$\begin{array}{llrrr}1956 & 492,6 & 63,6 & 27,3 & 17,5 \\ 1957 & 549,3 & 57,8 & 28,7 & 20,7 \\ 1958 & 556,0 & 59,7 & 25,4 & 22,3 \\ 1959 & 610,0 & 57,0 & 20,3 & 26,5 \\ 1960 & 768,0 & 64,7 & 15,4 & 26,4 \\ 1961 & 812,9 & 71,8 & 13,9 & 24,2 \\ 1962 & 737,9 & 76,6 & 13,6 & 21,0 \\ 1963 & 855,9 & 77,0 & 12,7 & 22,3 \\ 1964 & 899,7 & 71,8 & 11,6 & 24,5 \\ 1965 & 1.064,5 & 70,3 & 9,4 & 29,2 \\ 1966 & 1.138,3 & & & \end{array}$

1) Excluindo o ouro não monetarizado.

2) Compreendendo viagens ao estrangeiro, transporte, seguros, rendimentos de capital e uma série de outros serviços inclusive trânsito.

3) Compreende as remessas e transferências dos emigrantes, ajuda externa e doações privadas para caridade e instituições culturais.

Fonte: KHALAF, Nadim G. Economic implication of the size of nations: with special reference to Lebanon. Leiden: E. J. Brill, 1971. Tabela 72 p. 210.

A exportação dos serviços era a atividade que mais contribuía para compensar o déficit comercial do Líbano e gerar o seu excedente na balança de pagamentos. Os seus ganhos pagavam em média $68 \%$ do saldo excedente enquanto os ganhos líquidos das doações custeavam aproximadamente $21 \%$ e os movimentos de capitais $22 \%$.

\subsubsection{Turismo}

Outra atividade muito estimulada pelo governo foi o turismo, especialmente advindo dos países árabes vizinhos, além da Europa e América do Norte. Esses turistas eram em sua maior

${ }^{374}$ KHALAF... p. $210-211$. 
parte membros das elites dos outros países árabes que aproveitavam os meses de verão para passear ou descansar nas montanhas libanesas, cujo clima era muito mais ameno do que nas terras do Egito, do Iraque ou da Península Arábica. Os sírios eram sempre uma parte importante do fluxo de turistas, apesar de que muitas vezes o seu próprio governo, por diversos motivos e com frequência, desencorajava os seus cidadãos a visitar o Líbano. Mesmo assim, o seu número cresceu de 37.800 em 1951 para 810 mil em 1969, como mostra a tabela $34^{375}$.

A situação política do Oriente Médio influenciou o desempenho do setor turístico. Dessa forma, conflitos com a vizinha Síria faziam que com esse país restringisse as viagens que os seus cidadãos faziam ao Líbano e, ao mesmo tempo, procurasse dificultar, por meio de elevadas taxas, o trânsito por seu território de turistas que vinham por terra desde o Iraque, Jordânia e outros países da região ${ }^{376}$.

Atitude semelhante teve o Egito nos anos em que Nasser enfrentou Camille Chamoun $^{377}$. Quando isso acontecia às autoridades libanesas procuravam compensar a perda desses turistas árabes estimulando europeus e norte americanos a visitar o país. Estes, por sua vez, como tinham um poder aquisitivo muito maior, acabavam trazendo mais dinheiro para o Líbano do que os sírios ${ }^{378}$.

Dentro do setor turístico, os sírios, no entanto, sempre foram os maiores contingentes de turistas. Em 1955, quando as relações entre Damasco e Beirute ainda aconteciam normalmente, embora com tensão, mais de 540 mil turistas sírios visitaram o Líbano contra 151 mil de outras nacionalidades, árabes ou não.

Em 1958, quando o governo da RAU apoiava a oposição contra Chamoun, em maio começava a guerra civil e o setor turístico, obviamente, estava em crise, 125 mil sírios visitaram o Líbano contra 98 mil de outros países. Nos anos 60 o número de turistas cresceria ainda mais,

\footnotetext{
${ }^{375}$ MALLAT, Raymond A. Fiscal policy for social justice... p.113.

376 MALLAT. 70 years of money muddling in Lebanon... p.44. 
chegando a mais de 1,5 milhão em $1966^{379}$.

Tabela 34 - Turismo no Líbano, 1951-1968

\begin{tabular}{l|rcc}
\hline Ano & \multicolumn{1}{|c}{ Sírios } & Outras Nacionalidades & Estimativas de despesas diretas (em Milhöes de $L L)$ \\
\hline 1951 & 37.891 & 84.412 & 17,8 \\
1952 & 95.865 & 120.553 & 30,2 \\
1953 & 160.833 & 123.762 & 39,8 \\
1954 & 544.008 & 151.233 & 97,3 \\
1955 & 722.336 & 179.128 & 107,0 \\
1956 & 668.339 & 190.815 & 100,0 \\
1957 & 369.095 & 180.498 & 97,0 \\
1958 & 125.913 & 98.132 & 48,0 \\
1959 & 179.626 & 173.258 & 74,1 \\
1960 & 379.000 & 233.083 & 128,5 \\
1961 & 235.055 & 297.675 & 124,7 \\
1962 & 294.204 & 321.153 & 135,1 \\
1963 & 340.338 & 389.814 & 157,7 \\
1964 & 488.720 & 472.176 & 203,6 \\
1965 & 619.862 & 600.504 & 257,7 \\
1966 & 812.259 & 701.184 & 301,9 \\
1967 & 702.891 & 516.228 & 240,4 \\
1968 & 790.510 & 710.010 & 359,3 \\
\hline
\end{tabular}

Fonte: MALLAT, Raymond A. Fiscal policy for social justice $\&$ economic development in Lebanon. Beirute: Aleph, 1980. p. 112.

379

MALLAT. 70 years of money muddling in Lebanon... Tabela 18. p. 45. 
Como uma boa parte desses turistas possuía um bom poder aquisitivo, sempre trazia um grande aporte de capital para a economia libanesa ajudando, por exemplo, a movimentar o comércio, pois costumava consumir os produtos de luxo comprados no exterior pelos mercadores libaneses. O turismo foi uma preocupação constante das autoridades do governo, que incentivaram o capital privado a investir no estabelecimento de hotéis, casas de veraneio, pousadas, restaurantes, estações de esqui, lojas, butiques, passeios, empresas de ônibus, casas de espetáculos, casas de câmbio e outras infraestruturas para lazer.

Nessa época também as grandes redes hoteleiras internacionais vieram se instalar no país com o apoio do governo, assim como lojas de luxo internacionais. Como resultado da Lei do Jogo de 1954, o Estado financiou a construção de um grande cassino com 55 mil metros quadrados na região da Baia de Junieh, 22 quilômetros ao norte de Beirute, o Cassino do Líbano (Cassino du Liban em francês). Tendo ele sido inaugurado em 1959, o cassino funcionou por concessão, cuja licença durava 25 anos. O projeto para a construção dele estava sob a responsabilidade de uma comissão subordinada ao Ministério das Finanças, que também criou uma comissão especifica para a direção da atividade do jogo no Líbano.

Com relação a essa atividade, o governo libanês a legalizou, na década de 50, nas zonas de resorts. Fez isso, pois o objetivo era atrair, principalmente os turistas sauditas, iraquianos e egípcios que eram conhecidos por gastar grandes somas de dinheiro. Para facilitar as transações comerciais dos turistas o governo liberalizou as regulações monetárias para favorecêlos e subsidiava os custos dos transportes para os visitantes árabes no verão ${ }^{380}$. Os ganhos estimados com a atividade turística só na década de 1950 fora de LL17,8 milhões em 1951 para LL107 milhões em 1955, tendo caído em 1958 para LL48 milhões devido à guerra civil ${ }^{381}$. Nos anos 60 os ganhos seriam ainda maiores, tendo atingido em 1966, 1967 e 1968 respectivamente LL301,9 milhões, 240 milhões e 359,3 milhões. A queda em 1967 foi resultado da guerra árabeisraelense de junho ${ }^{382}$.

380 GATES. The merchant republic of Lebanon... p. 117; HAYEK, Domigo Garí. História contemporânea del Líbano. p. 66

381 GATES. The merchant republic of Lebanon.. p.118; MALLAT. 70 years of money muddling in Lebanon... Tabela 18. p. 45.

${ }^{382}$ MALLAT. 70 years of money muddling in Lebanon... Tabela 18. p. 45. 


\subsubsection{Bancos}

Quanto ao sistema bancário, embora não chegasse a $10 \%$ da economia (sua porcentagem no Produto Nacional Liquido variou entre 3,4\% e 7\%, sendo esta a cifra mais alta referente ao ano de 1958, como mostra a tabela 32), sempre foi um termômetro por meio do qual se podia medir o bom ou mau funcionamento da economia libanesa, sendo essencial para o seu funcionamento o financiamento dos empreendimentos comerciais e turísticos.

Desde Bechara el-Khuri, o governo libanês sempre procurou atender aos interesses do setor bancário e muitos banqueiros sempre tiveram intimas relações com os membros das instâncias mais altos do governo. Tanto foi assim que, para promover ainda mais o desenvolvimento desses setores, em 1956 um decreto de Camille Chamoun estabeleceu a Lei do Segredo Bancário, inspirada em uma lei semelhante existente na Suíça e que impedia aos bancos de revelarem qualquer informação relativa aos seus clientes e as quantias depositadas nos bancos. Qualquer informação somente poderia ser fornecida caso houvesse um consentimento por escrito do cliente, se o seu negócio entrasse em falência ou se acontecesse um litígio entre o banco e o cliente, dentro do contexto das atividades bancárias. Permitiu-se completo anonimato aos clientes para abrirem diversas contas em um banco. O descumprimento das normas presentes na Lei do Segredo Bancário, segundo o seu artigo oitavo, era considerado um delito, punido com prisão. E qualquer denúncia de descumprimento era seguida de uma ação pública contra o banco onde foi violado o segredo bancário ${ }^{383}$.

Outras vantagens oferecidas por essa lei concerniam ao fato que os depósitos à vista recebiam juros (o que não acontecia na Suíça, por exemplo) e os fundos podiam ser depositados em qualquer moeda ${ }^{384}$.

Essa lei permitiu já em 1957 atrair uma grande soma de capital para o sistema bancário libanês, consolidando Beirute como centro financeiro do Oriente Médio. O movimento de capital líquido no Líbano cresceu, dessa maneira, de 14,7 milhões em 1951 para 84 milhões em 1957.

383 ASSEILY, Antoine E. Central banking in Lebanon: a central banking for the economic development of the country. Beirute: Khayat Books, 1967. p.33.

${ }^{384}$ ASSEILY. Idem. p. 61. 
Três anos depois atingia a cifra de 236,1 milhões e em 1968 era de 360 milhões $^{385}$. Muito desse dinheiro vinha dos países produtores de petróleo na Península Arábica e eram suplementados por outros fundos como as remessas dos imigrantes ao redor do mundo. Uma boa parte desse dinheiro fora investido em imóveis, como vilas de veraneio, apartamentos, prédios comerciais e terrenos, sendo que todos eram comprados, principalmente, em Beirute e na região do Monte Líbano. Enquanto o número de bancos era apenas sete em 1945, subiu para 21 em 1952 e, com a ampla liberalização da economia, chegaria em 1966 a $86^{386}$.

Tabela 35 - Comércio e finanças como \% do produto nacional líquido, 1950-1966

\begin{tabular}{|c|c|c|c|c|c|c|c|c|c|c|}
\hline & 1950 & 1951 & 1952 & 1954 & 1955 & 1957 & 1958 & 1959 & 1960 & 1961 \\
\hline Comércio & 28,8 & 31,0 & 29,8 & 29,3 & 29,6 & 31,2 & 27,5 & 31,8 & 32,0 & 32,0 \\
\hline Finanças & 3,8 & 4,2 & 4,5 & 4,5 & 5,1 & 6,0 & 7,0 & 6,3 & 6,3 & 6,4 \\
\hline \multirow[t]{2}{*}{ Total } & 32,6 & 35,2 & 34,3 & 33,8 & 34,7 & 37,2 & 34,5 & 38,1 & 38,3 & 38,4 \\
\hline & 1962 & 1964 & 1965 & & 1966 & & & & & \\
\hline Comércio & 31,4 & 32,1 & 30,8 & & 30,6 & & & & & \\
\hline Finanças & 6,5 & 3,4 & 3,4 & & 3,6 & & & & & \\
\hline Total & 37,9 & 35,5 & 34,2 & & 34,2 & & & & & \\
\hline
\end{tabular}

Fonte: Khalaf, Nadim G. Economic implications of the size of nations: with special reference to Lebanon. Leiden: E. J. Bril, 1971. Tabela 65. p.199.

O crescimento do setor bancário foi um dos objetivos da liberalização da economia e foi um dos principais motores do grande desenvolvimento econômico que o país conheceu na

${ }^{385}$ MALLAT, Raymond A. Fiscal policy... p. 115.

${ }^{386}$ GASPARD, Tufic K. A political economy of Lebanon... p. 193. 
década de 50. Ele foi muito estimulado pelas reservas em moedas estrangeiras deixadas no Líbano pelas tropas aliadas durante a Segunda Guerra Mundial, bem como a livre convertibilidade da libra libanesa, que estimularam as atividades dos bancos libaneses, capacitando-os a receber depósitos em moedas estrangeiras ${ }^{387}$.

A expansão das atividades bancárias no Líbano refletiu na maneira como a população costumava lidar com o dinheiro por ela acumulado e com as maneiras de aumentar o seu valor. Tanto foi assim que as décadas seguintes à Segunda Guerra Mundial assistiram uma ampla difusão das atividades bancárias entre a população libanesa. Houve nesse período uma grande difusão do uso dos cheques, tanto para pequenos pagamentos quanto para as transações de grandes somas de dinheiro ${ }^{388}$.

Quando os bancos abriam filiais em regiões fora do entorno da capital eles estimularam na população local o hábito de possuir contas correntes e criar uma mentalidade favorável à utilização dos serviços bancários como meio de acumular dinheiro e valorizá-lo ${ }^{389}$.

O crescimento da monetarização da economia libanesa se vê na tabela 33, na qual se percebe que houve um aumento enorme da oferta de dinheiro, que passou de LL45 milhões em 1951 para LL528 milhões em 1965, só caindo em 1966 em decorrência da crise provocada pela falência do Intra Bank. Em alguns anos essa oferta foi bem grande em relação aos anos anterior e posterior, como se trata, por exemplo, do caso de 1957, no qual ela chegou a LL164 milhões, quando em 1956 havia sido de LL70 milhões e em 1959 de LL75 milhões. Já o total de dinheiro em circulação subiu no período entre 1951 e 1968 de LL212 milhões para LL914 milhões (ver tabela 36).

O sistema bancário libanês de tempos em tempos recebia, devido aos acontecimentos políticos no Oriente Médio, grandes fluxos de dinheiro que o tornavam ainda mais dinâmico. Dessa forma, os bancos libaneses beneficiaram-se do dinheiro trazido pelos refugiados palestinos em um primeiro momento, que foi avaliado em um total de 60 milhões de libras libanesas ${ }^{390}$.

\footnotetext{
${ }^{387}$ MALLAT. 70 years of money muddling in Lebanon...p. 124.

${ }^{388}$ MALLAT. Idem... p. 125.

389 MALLAT. Ibidem... p. 123.

390 GATES, Carolyn L. The merchant republic... p. 95
} 
Crises que aconteciam entre os diversos países árabes também favoreciam as transferências de capital para o Líbano, como foi o caso da forte tensão entre o Iraque e o Kuwait ocorrida em 1961, que trouxe ao país aproximadamente $\$ 100$ milhões $^{391}$.

Nos anos 50 e 60 os bancos libaneses beneficiaram-se do capital privado que fugia das nacionalizações no Egito, Síria e Iraque. Esses benefícios não estiveram restritos apenas aos bancos. A economia libanesa como um todo também se beneficiou dos emigrantes qualificados que vieram desses países em grande quantidade (aos milhares) como engenheiros, advogados, empresários, políticos e até intelectuais das atividades por eles desenvolvidas no Líbano.

Quanto ao setor financeiro, ele foi tão próspero que nos anos 50 eles tiveram um grande crescimento, chegando a ser 7\% do PIB em 1958, quando menos de 10 anos antes era apenas 3,8\% ${ }^{392}$. Só no ano de 1954 os depósitos nos bancos libaneses eram de 392,2 milhões de libras libanesas ${ }^{393}$.

Tabela 36 - Monetarização no Líbano, 1950-1968

\begin{tabular}{|c|c|c|c|c|c|}
\hline & 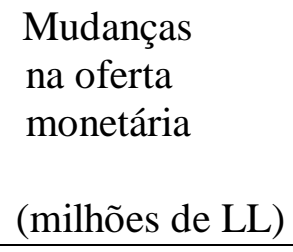 & $\begin{array}{c}\text { Déficit } \\
\text { em conta } \\
\text { corrente } \\
\text { externa } \\
\text { (milhões de }\end{array}$ & $\begin{array}{l}\text { Monetarização } \\
\text { total } \\
\text { L) (mil. LL })\end{array}$ & $\begin{array}{c}\text { Taxa de } \\
\text { crescimento } \\
\text { composta } \\
\text { monetarizada } \\
(\mathrm{em} \mathrm{\% )} \\
\end{array}$ & $\begin{array}{l}\text { Taxa de } \\
\text { crescimento } \\
\text { composta } \\
\text { líquida } \\
(\text { em \%) } \\
\end{array}$ \\
\hline \multicolumn{6}{|l|}{ Ano } \\
\hline 1950 & 63 & n.d. & - & - & 5.5 \\
\hline 1951 & 55 & 61 & 116 & - & 10.2 \\
\hline 1952 & 45 & 102 & 147 & 27 & 6.9 \\
\hline 1953 & 27 & 107 & 134 & -9 & 0 \\
\hline 1954 & 128 & 122 & 250 & 86 & 15,2 \\
\hline \multicolumn{6}{|c|}{ (continua) } \\
\hline \multicolumn{6}{|l|}{391} \\
\hline \multicolumn{6}{|c|}{392 HUDSON. The precarious republic: political modernization in Lebanon... p. 63} \\
\hline \multirow[t]{2}{*}{393} & ates, Carolyn L.: The H & Iistorical Role of I & litical... p. 15 & & \\
\hline & he Issawi apud Ge & er. Pág. 200 & & & \\
\hline
\end{tabular}


(conclusão)

Tabela 36 - Monetarização no Líbano, 1950-1968

$\begin{array}{rlrrrr}1955 & 109 & 176 & 285 & 14 & 5,6 \\ 1956 & 70 & 207 & 277 & -3 & 5,3 \\ 1957 & 164 & 205 & 369 & 33 & 13,5 \\ 1958 & 75 & 295 & 370 & 0 & 7,4 \\ 1959 & 233 & 240 & 473 & 28 & 7,3 \\ 1960 & 398 & 199 & 497 & 1 & 7,9 \\ 1961 & 199 & 310 & 509 & 2 & 1,0 \\ 1962 & 212 & 233 & 445 & -13 & 4,0 \\ 1963 & 20 & 187 & 207 & -53 & -5,0 \\ 1964 & 515 & 252 & 767 & 270 & -2,1 \\ 1965 & 528 & 352 & 880 & 15 & 8,6 \\ 1966 & 137 & 411 & 548 & -38 & -4,9 \\ 1967 & -30 & 209 & 170 & -206 & 0 \\ 1968 & 484 & 184 & 668 & 273 & 2,0\end{array}$

Fonte: Mallat, Raymond A. 70 years of money muddling in Lebanon, 1900-1970-77: a guide in monetary management for economic development in Lebanon. Beirute: Aleph, 1977. Adaptado da Tabela 2. p. 199.

Como comentado mais acima, o sistema bancário libanês sempre teve poucos vínculos com os setores que não estavam diretamente envolvidos nas atividades de comércio e serviços. Tanto era assim que em 1968 o crédito bancário foi fornecido principalmente para o comércio (53,6\% do total), enquanto a indústria e a agricultura ficaram com, respectivamente, $16 \%$ e $4,3 \%{ }^{394}$.

Isso aconteceu apesar da proporção do crédito doméstico em relação à renda nacional ter crescido, de 1951 até a metade dos anos 60, de estimados $27 \%$ até estimados $85 \%{ }^{395}$. Depois disso houve uma queda no crescimento dessa taxa. Esses créditos tinham em sua maior parte prazos de vencimento de três a seis meses, sendo que um número bem pequeno (exceções) possuía um prazo inicial de um ano de vencimento ${ }^{396}$. Embora, em muitos casos, como o

\footnotetext{
394 NARS, Salim. Backdrop to civil war... p. 1

${ }^{395}$ Hudson. The precarious republic: political modernization in Lebanon... p. 63

${ }^{396}$ MALLAT. 70 years of money muddling in Lebanon... p. 127.
} 
vencimento da dívida pudesse ser rolado de ano para ano, isso tinha como resultado fazer com que os empréstimos de curto prazo acabassem se transformado em empréstimos de médio prazo $^{397}$. Mesmo assim, essa falta de vínculos mais firmes foi considerada uma das principais razões pelo fraco desenvolvimento dos setores produtivos. Isso se deveu tanto à inexistência de um planejamento econômico por parte do Estado por um longo período que pudesse levar os bancos a investirem naqueles setores, quanto como consequência da mentalidade dominante dentro da comunidade financeira libanesa, que preferia os grandes lucros em curto prazo obtidos no financiamento do comércio ou na reciclagem dos depósitos em seus cofres, do que os retornos demorados e mais baixos vindo dos investimentos nas áreas produtivas.

Um dado que revela como era débil a conexão do sistema bancário e os investimentos do setor privado é o fato de que ao longo do período 1950-1970 o crédito bancário representou menos de um terço dos investimentos totais

${ }^{397}$ MAKDISI. Financial policy and economic growth... p. 46. 
Tabela 37 - Mudanças nas reservas internacionais das autoridades monetárias e nos ativos externos do sistema bancário, $1951-1968$

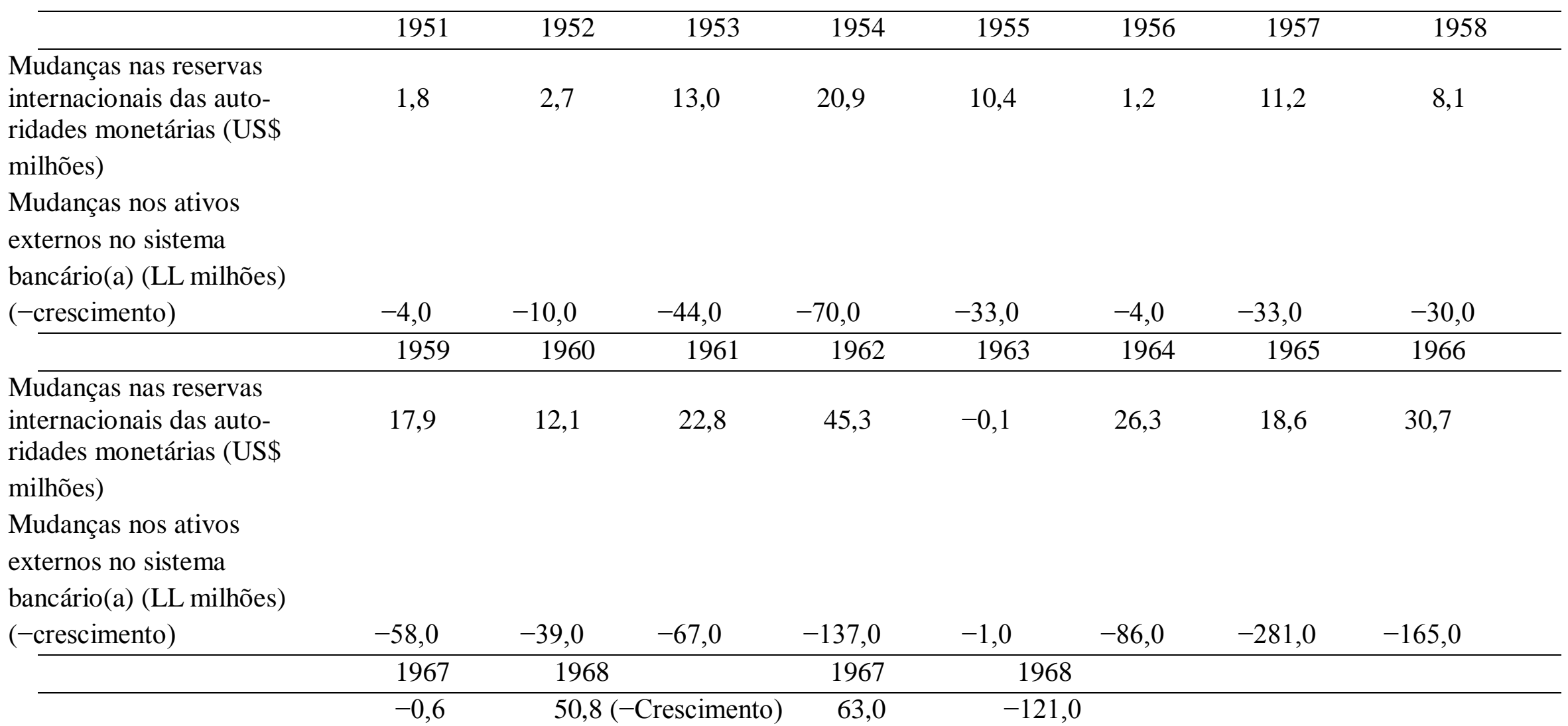

a)Bruto para o período pré-1964 e líquido para o pós-1964

Fonte: MAKDISI, Samir A. Financial policy and economic growth: the Lebanese experience. Nova Iorque: Columbia University Press, 1979. Adaptado da Tabela 11. p $156-157$ 
Ainda assim, na falta de outros tipos de intermediários financeiros importantes, os bancos ainda eram os principais responsáveis pelos processos de poupança e investimento. Isso por que os bancos eram muito ativos no processo de monetarizar fundos estrangeiros guardados em suas reservas e assim realizavam o papel de intermediários entre investidores e poupadores.

Por outro lado, a oferta de crédito sempre foi influenciada pelos acontecimentos na vida politica e econômica libanesa. Eventos como as repercussões sobre o Líbano da crise de Suez, a guerra civil de 1958, o episódio da falência do Intra Bank em outubro de 1966 e as repercussões nacionais e internacionais da derrota árabe em 1967 fizeram com que os bancos diminuíssem os seus empréstimos. Fato esse acompanhado de uma grande diminuição de todas as demais atividades bancárias enquanto o país estivesse em crise ${ }^{398}$.

Os banqueiros libaneses também possuíam investimentos em empreendimentos que eram diferentes das atividades bancárias propriamente. Desse modo, desde 1956, uma parte destacada dos investimentos dos bancos se concentrou no mercado imobiliário. No fim dos anos 50 e ao longo da década de 60 muitas encostas rochosas e topos de montanhas foram comprados por bancos e transformados em projetos residenciais que atraíam muitos clientes, nos quais os riscos eram baixos e a renda liquida dos alugueis tirada pelos bancos alta ${ }^{399}$.

Tabela 38 - Alguns índices de liquidez no Líbano, 1951-1968

\begin{tabular}{|c|c|c|c|}
\hline \multicolumn{2}{|c|}{ Índice de crédito bancário $(\mathbf{0 , 4 4 8 5})$} & \multirow{2}{*}{$\begin{array}{c}\text { Índices de inflação } \\
\text { Índices }\end{array}$} & \multirow{2}{*}{$\begin{array}{c}\text { Índices de oferta monetária } \\
\text { Índices } \\
\end{array}$} \\
\hline Ano & Índices & & \\
\hline 1951 & 142 & 153 & 121 \\
\hline 1952 & 159 & 147 & 133 \\
\hline 1953 & 160 & 128 & 140 \\
\hline 1954 & 197 & 138 & 174 \\
\hline (contin & & & \\
\hline
\end{tabular}


(conclusão)

Tabela 38 - Alguns índices de liquidez no Líbano, 1951-1968

$\begin{array}{lrll}1955 & 237 & 147 & 202 \\ 1956 & 259 & 162 & 220 \\ 1957 & 317 & 187 & 263 \\ 1958 & 313 & 231 & 282 \\ 1959 & 377 & 250 & 343 \\ 1960 & 505 & 267 & 447 \\ 1961 & 569 & 271 & 499 \\ 1962 & 582 & 276 & 555 \\ 1963 & 667 & 270 & 560 \\ 1964 & 784 & 268 & 694 \\ 1965 & 944 & 296 & 832 \\ 1966 & 1028 & 290 & 868 \\ 1967 & 1012 & 306 & 860 \\ 1968 & 905 & 310 & 986\end{array}$

Fonte: MALLAT, Raymond A. 70 years of money muddling in Lebanon, 1900-1970-77: a guide in monetary management for economic development in Lebanon. Beirute: Aleph, 1977. Adaptado da Tabela 3. p. 200.

O sistema bancário libanês, apesar do grande volume de dinheiro recebido anualmente, era considerado pouco desenvolvido pelo fato de existirem poucas relações financeiras entre os diferentes bancos e também porque a bolsa de valores de Beirute não era muito desenvolvida.

Os instrumentos de gerenciamento eram considerados muito elementares e as atividades dos bancos, embora intensas, eram limitadas e quase inteiramente centradas nos já referidos empréstimos de curto prazo ou ao depósito de remessas de rendas vindas de outros 
países árabes $^{400}$. No caso do mercado de valores imobiliários sua limitação devia-se a um conjunto de razões: 1) existia apenas uma única bolsa de valores em todo o país, na qual participavam algumas dezenas de firmas que promoviam uma quantidade bastante pequena de negócios com os valores da venda de cada dia; 2) no Líbano muitas empresas evitavam colocar as suas ações em subscrição pública ou, se o fizessem, seria em pequena quantidade; 3) os bancos satisfaziam sua necessidade de lucros com suas operações de empréstimo de curto-prazo, cujo volume de negócios era enorme e os lucros rápidos.

Já os mercados de títulos corporativos e do governo praticamente não existiam porque o sistema judicial libanês era lento e corrupto e o governo estava sempre administrando as suas contas para evitar déficits de financiamento. Outra razão importante para o subdesenvolvimento do mercado de valores acionários no Líbano foi a baixa taxa de poupança do país $^{401}$.

Uma consequência do subdesenvolvimento do mercado de capitais no Líbano era a inexistência de um meio pelo qual as empresas pudessem se capitalizar e assim financiar investimentos de longo prazo. Essa grande limitação da economia naquele país teve uma importante contribuição para dificultar o desenvolvimento dos setores produtivos da economia libanesa $^{402}$.

No caso dos depósitos, eram os advindos do exterior que ajudaram em muito o grande desenvolvimento das atividades bancárias. Por isso, a quantidade deles tornou-se tão grande que a sua média total em relação à renda nacional cresceu de 20\% em 1952-1954 para $85 \%$ em 1964 e atingiria os $112 \%$ por volta de $1970^{403}$.

Outros dados reveladores mostram que, quanto ao tipo, os depósitos a vista cresceram, no período entre 1949-1970, de LL176 milhões para LL3.820 milhões ou 2.075\% . E os depósitos a prazo saíram dos LL5 milhões para LL161 milhões, um aumento de 31 vezes ${ }^{404}$, embora nesse último caso eles tivessem presenciado uma queda, pois em 1956 atingiram o valor de LL444 milhões.

\footnotetext{
400 GASPARD, Tufic K. A political economy of Lebanon... p. 193

${ }^{401}$ MALLAT. 70 years of muddling in Lebanon... p. 131.

402 KHALAF. Economic implications of the size of nations... p. 167.

${ }^{403}$ MAKDISI. Financial policy and economic growth.. p. 40.

${ }^{404}$ MALLAT. 70 years of muddling in Lebanon... p. 125.
} 
No tocante aos depósitos a prazo, boa parte do seu crescimento deveu-se ao dinheiro que vinha na forma de fundos de curto prazo, trazidos pelas elites milionárias dos países árabes produtores de petróleo, pelos libaneses emigrantes no exterior e empresas estrangeiras instaladas no Líbano. Esses depósitos buscavam refúgio nos bancos libaneses e seus depositantes acreditavam que dificilmente modificariam a sua situação, transformando-os em depósitos a vista, pois aqueles a prazo pagavam taxas de juros duas ou três vezes maiores, sendo que qualquer ganho era imediatamente guardado para usos futuros, como um meio de investimento, ou para serem usados com a finalidade de se ganhar ainda mais juros. Dos três grupos que criavam depósitos a prazo o mais importante eram os milionários árabes ${ }^{405}$.

Tabela 39 - Mercado de capital e índices monetários no Líbano (1951-1968)

$$
\text { (1) }
$$

Ano final Total de moeda em circulação (milhões de LL)

\section{1}

1952

1953

1954

1955

1956

1957

1958

1959

1960

1961

1962

437

443

477
(2)

$$
\begin{aligned}
& \text { Total de } \\
& \text { depósito } \\
& \text { a prazo }
\end{aligned}
$$
(milhões de LL)
(3)

Total de depósitos a vista (milhões de LL)

$\begin{array}{rrr}253 & 6 & 259 \\ 305 & 12 & 317 \\ 328 & 19 & 347 \\ 419 & 34 & 453 \\ 503 & 52 & 555 \\ 506 & 57 & 563 \\ 647 & 68 & 715 \\ 679 & 70 & 749 \\ 910 & 111 & 1021 \\ 1277 & 167 & 1444 \\ 1470 & 210 & 1680 \\ 1648 & 262 & 1910\end{array}$

259

317

347

453

555

563

715

749

021

444

1648

910
Total de depósitos (milhões de LL) 
(conclusão)

Tabela 39 - Mercado de capital e índices monetários no Líbano (1951-1968)

$\begin{array}{lllll}1963 & 505 & 1640 & 323 & 1963 \\ 1964 & 539 & 2121 & 388 & 2509 \\ 1965 & 590 & 2598 & 444 & 3042 \\ 1966 & 705 & 2620 & 317 & 2937 \\ 1967 & 846 & 2449 & 276 & 2725 \\ 1968 & 914 & 2865 & 269 & 3134\end{array}$

Fonte: MALLAT, Raymond A. 70 years of money muddling in Lebanon, 1900-1970-77: a guide in monetary management for economic development in Lebanon. Beirute: Aleph, 1977. Adaptado da Tabela 1A. p. 185.

Tabela 40 - Mercado de crédito no Líbano em moedas estrangeiras, 1954-1970-Anos selecionados (em milhões de libras libanesas)

\begin{tabular}{lcccc}
\hline Ano Final & Depósito a Vista & Depósito a Prazo & Total de Depósitos \\
\hline 1954 & 7 & 47 & 54 \\
1956 & 16 & 66 & 82 \\
1958 & 17 & 120 & 137 \\
1959 & 33 & 132 & 165 \\
1961 & 72 & 388 & 460 \\
1963 & 140 & 238 & 378 \\
1969 & 68 & 1173 & 1141 \\
1970 & 65 & 1403 & 1468
\end{tabular}

Fonte: MALLAT, Raymond A. 70 years of money muddling in Lebanon, 1900-1970-77: a guide in monetary management for economic development in Lebanon. Beirute: Aleph, 1977. Tabela 2. Pág. 188.

\subsubsection{O Banque de Syrie et Liban}

Até 1964 o Líbano não possuía um banco central, como já foi falado mais acima. 
Esse papel era executado pelo BSL (Banque de Syrie et du Liban), um banco privado francês originado a partir dos interesses financeiros de Lyon, a quem o governo mandatário francês havia concedido a função de emitir papel-moeda - a libra sírio-libanesa - e de ter as funções de um banco central a partir de uma convenção assinada em 1924, e renovada em 1937 entre o Líbano e as autoridades francesas.

Como funcionava como um banco central ele também tinha a função de ser um financiador e credor para os outros bancos e uma câmara de compensação para eles, bem como era um fundo de custódia para o governo ${ }^{406}$. O BSL também controlava o acesso ao capital para os projetos de desenvolvimento locais e estrangeiros, como a construção do novo aeroporto de Beirute, projetos de modernização do porto da cidade, um grande número de edifícios públicos e inúmeras companhia de seguros.

Esse banco representava a continuação da influência da França após a independência e sempre atuava para proteger e favorecer os interesses do capital francês dentro da economia libanesa. Graças ao BSL fora fundada a Seriac (Société d’Etudes et de Réalization Industrielle, Agricoles e Commerciales) - da qual o governo francês era proprietário de $25 \%$ - que realizava estudos visando a promover e melhorar a situação dos investimentos franceses no Líbano.

Por representar os interesses franceses, nos anos 50 o Seriac foi fonte constante de atrito com os britânicos e americanos, rivais dos franceses no Líbano, e alvo de críticas ferrenhas por parte dos comerciantes nativos que temiam ser afastados do comércio com a França. O Seriac também era muito criticado por políticos nacionalista, como o líder druso Kamal Jumblatt, que a considerava como uma instituição que interferia nos assuntos econômicos de seu país e tinha uma influência política perigosa ${ }^{407}$.

Também, para muitos libaneses o BSL, por ser um banco privado e vindo de um país imperialista, atuou quase sempre contra os interesses econômicos do Líbano. Ele, por exemplo, promovia políticas de crédito que eram inadequadas para os projetos de estabilidade monetária dos governos libaneses após a independência ${ }^{408}$. Como era ao mesmo tempo um banco comercial, era visto como um concorrente desleal dos outros bancos libaneses ou estrangeiros instalados no

\footnotetext{
${ }^{406}$ MAKDISI. Financial policy and economic growth... p. 50

407 GATES. The merchant republic... p. 94

${ }^{408}$ DIB. Warlords and merchants... p. 97
} 
Líbano, pois por conta de sua função de banco central tinha acesso a dados sobre a economia e conhecimento antecipado sobre políticas do governo que os concorrentes não possuíam, além de sua capacidade de interferir no sistema financeiro.

No entanto, a sua dupla - e às vezes conflitiva - função fazia com que o BSL não desempenhasse adequadamente a sua função de banco central, assim ele tinha várias limitações na sua função de providenciar crédito para os outros bancos por conta de restrições existentes em seu estatuto. No cenário nacional a inexistência de regulações financeiras não proporcionou ao BSL instrumentos monetários adequados para ele empregar em conformidade com as políticas governamentais $^{409}$.

Devido às convenções de 1927 e 1934, da época do mandato, o BSL possuía a custódia dos fundos do governo, do Tesouro e dos municípios libaneses, sendo que eles pagavam juros sobre esses depósitos. O conjunto desses depósitos chegou ao valor de LL445 milhões em $1964^{410}$. Os depósitos a vista receberam uma taxa de juros igual à taxa de desconto do Banque de France, menos 2\%, enquanto os depósitos a prazo recebiam uma taxa que era menos de 1,5\%.

Em geral as taxas pagas eram menores do que as obtidas em outros bancos, fato esse que era alvo de fortíssimas críticas. O BSL também concedia empréstimos para os municípios libaneses, os correios e outras instituições semi públicas do país que, ou encontravam em outros bancos as condições para empréstimos muitos onerosas, ou para os quais não havia capitais disponíveis.

Nesses casos as taxas de juros empregadas variavam entre 1,5 e 4\% e eram bem mais baixas do que as encontradas em outras instituições financeiras. Além disso, o BSL também era a instituição que custodiava o governo libanês quando este subscrevia acordos com as instituições financeiras internacionais e ajudava a administrar a dívida pública, embora apenas uma pequena parcela dela estivesse sob a responsabilidade do banco. Essas duas últimas funções o banco realizava de graça. Quando o governo criou o Fundo de Equalização do Cambio, o BSL participava de seu comitê administrativo por meio do seu diretor do Departamento de Emissão de Dinheiro. A primeira vez que o Fundo de Equalização atuou também foi devida a uma iniciativa do BSL: isso ocorreu em 1953 em razão de uma solicitação de compra de dólares americanos

\footnotetext{
${ }^{409}$ MAKDISI. Financial policy and economic growth... p.50

${ }^{410}$ MALLAT. 70 years of money muddling in Lebanon... p.139
} 
feita pelo banco francês no mercado de câmbio livre. A ação do Fundo de Equalização nesse caso foi para evitar que a taxa do dólar, graças à ação do BSL, caísse abaixo de LL3,20 ${ }^{411}$.

Quanto à função do BSL de emprestador de última instância (o banco dos banqueiros), ela se dava por duas vias distintas: aliviando a situação dos bancos quando esses sofriam pela falta temporária de liquidez e ajudando os bancos a manter seus saldos com o objetivo de garantir a compensação. Para socorrer os bancos com falta de liquidez o BSL realizava empréstimos en pension, sistema esse desenvolvido para ajudar com prazos de liquidez pequena ou muito curta e minimizar as suas perdas, e promovendo o redesconto de suas notas promissórias para lhes fornecer linhas de crédito. Essas consistiam em fornecer aos bancos créditos abertos não assegurados até determinadas quantidades. O reembolso era garantido por contrato e geralmente estendido até um ano ${ }^{412}$. Em momentos de crise o Estado fazia com que essa função de emprestador de última instância fosse ainda mais ampliada. Dessa forma, durante todo o desenrolar da crise de 1958, o governo de Chamoun aplicou fortes pressões no BSL para que ele providenciasse a demanda de liquidez necessária para socorrer os bancos libaneses, pois eles estavam passando por terríveis dificuldades devido à paralisação da economia por conta da guerra. Mais tarde, nos anos 60, nas crises do Intra Bank e da guerra árabe-israelense de 1967, o recém-fundado Banco Central desempenharia o mesmo papel. ${ }^{413}$

Apesar do BSL ter a função de emprestador de última instância (ou talvez por conta de seu funcionamento imperfeito como Banco Central) se formou no sistema bancário libanês um fenômeno que já havia se manifestado nos Estados Unidos e na França, conhecido pelo nome francês como Marché Hors Banque - um mercado não-oficial de capitais criado por determinados bancos para financiar outros bancos.

No caso libanês, por conta da abundância de capitais existente no nos anos 50 e 60, os bancos não precisavam recorrer sempre ao BSL e posteriormente ao Banco Central (Banque du Liban) para se capitalizar ou para resolver os seus problemas de liquidez. Por isso era comum que determinados bancos - sendo nesse caso os estrangeiros - que contavam com um excedente de capitais - emprestassem para aqueles que estavam em situação de carência.

\footnotetext{
411 ASSEILY. Central banking in Lebanon... p. 167-168

412 ASSEILY. Idem. p.168.

${ }^{413}$ MALLAT. 70 years of money muddling in Lebanon... p. 111.
} 
Nessa situação, havia ao menos teoricamente uma situação de oferta ilimitada de dinheiro a disposição dos bancos locais libaneses, pois os bancos estrangeiros podiam, caso não houvesse uma crise no país de origem, sempre trazer capitais de suas matrizes no exterior. Essa atividade era tão importante para os bancos estrangeiros que, em determinados casos, metade do crédito emprestado por eles ia para os bancos libaneses ${ }^{414}$. A quantidade de dinheiro que vinha para as subsidiárias dos bancos estrangeiros em Beirute era substancial, tendo chegado a LL614 milhões no fim de 1964 e, por isso, foi um elemento fundamental para o funcionamento da economia libanesa $^{415}$.

O BSL como instituição chegou a ter um tamanho impressionante, pois no começo dos anos 50, quando o Líbano liberalizou completamente a sua economia, esse banco chegou a possuir metade dos depósitos do país, embora no fim dessa mesma década, em razão do grande desenvolvimento das atividades bancárias, esse número tenha caído bastante e, em 1964, quando o Banco Central foi criado, a quantidade de depósitos que possuía seria cerca de 10 a $15 \%$ do total $^{416}$.

\subsubsection{O surgimento do Banco Central libanês}

Até o começo dos anos 60 não existia um conjunto escrito específico de normas para regular o sistema bancário, prevalecendo o Código Comercial. Para acabar com essa situação existente no sistema bancário o governo libanês, a partir de 1958, planejou instrumentos e regras que estabelecessem um mínimo de controle do Estado sobre essas atividades. Em 1964, no último ano do governo Chehab, com o término do prazo fixado na época do mandato francês para que o BSL atuasse como uma instituição bancária central na economia libanesa, foi estabelecido o Banco Central libanês, o Banque du Liban (BDL).

Isso a partir da promulgação do Decreto 13.513 de 13 de agosto de 1963, que criou o Código da Moeda e do crédito, no qual se previa a criação de um banco central. A partir desse momento, o BDL passou a coordenar o sistema bancário e a conceder aprovação para os bancos funcionarem no Líbano. Por meio do mesmo Código da Moeda e do Crédito surgiu um conjunto

\footnotetext{
414 ASSEILY. Central banking in Lebanon... p.45.

${ }^{415}$ ASSEILY, Idem. p.45.

${ }^{416}$ ASSEILY ... p. 170
} 
de normas, regulações e autoridades encarregadas de supervisionar o sistema bancário libanês.

De acordo com as regulações estabelecidas por esse código determinou-se que o Banco Central Libanês, embora fosse de propriedade completa do Estado, que providenciava inteiramente o seu capital (artigo 15 da legislação bancária), estava livre de interferência política e contaria com um conselho administrativo independente. O Banque du Liban também era uma instituição que foi dotada de grande autonomia em relação ao governo (embora na prática fosse um pouco diferente), sendo essa medida era para adequá-lo em relação ao liberalismo econômico existente no Líbano.

O presidente era nomeado pelo governo ( mandato de seis anos), bem como os três vice-presidentes ( mandato de cinco anos). O Grande Conselho, responsável, entre outras funções, pela determinação da política monetária, tinha entre os seus membros os diretores-gerais dos Ministérios das Finanças e Economia Nacional e Comércio e do Ministério do Planejamento.

Eles tinham um papel essencial na manutenção dos contatos entre o Banque du Liban e o Ministério das Finanças e o Ministério do Planejamento, para assim coordenarem as suas respectivas políticas. Em outro artigo (o de número 28) afirmava-se que aqueles dois altos funcionários do governo não poderiam atuar como agentes do governo, mas apenas como membros do conselho e responsáveis pela política monetária. Por fim o Comitê Consultivo sem poder contava com representantes do comércio, agricultura, indústria, bancos e um professor universitário de Economia ${ }^{417}$.

Então, por conta da quase completa desregulação do sistema bancário até o começo dos anos 60, os bancos libaneses tinham uma pequena quantidade de depósitos compulsórios e não existia uma norma estipulando qual era a quantidade mínima de capital para se fundar um estabelecimento bancário.

A instabilidade também existia pelo fato de que muitos bancos mantinham atividades especulativas fora de suas áreas tradicionais de atividade. As regulamentações promulgadas no começo da década de 60 garantiram maior estabilidade e segurança para o funcionamento do setor bancário, no entanto sofreram forte oposição dos banqueiros que temiam que as regulações

${ }^{417}$ ASSEILY... p. 181-182. 
interferissem em seus negócios ou mesmo obstruíssem muitos deles ${ }^{418}$. Além de considerar o surgimento de uma instituição como um Banco Central um ataque aos valores e práticas liberais e, em especial, temiam que a prática do segredo bancário estivesse ameaçada.

Entre essas práticas de controle das atividades dos bancos a cargo do Banco Central, estabelecidas pela Lei da Moeda e do Crédito, estavam: a) a obrigação dos bancos em oferecer periodicamente ao futuro Banco Central relatórios sobre os detalhes das suas operações; b) as autoridades poderiam, em caso de necessidade, pedir aos bancos mais informações para aprofundar o seu conhecimento sobre as operações e insistir para que os administradores dos bancos concedessem autenticidade às suas declarações; c) os administradores dos bancos deveriam oferecer aos responsáveis pelo Banco Central documentação de apoio para comprovar as suas afirmações nos relatórios entregues ${ }^{419}$.

Por isso, sabendo da oposição que suscitaria em meio aos banqueiros, o governo libanês discutiu por um ano com a Associação dos Bancos do Líbano o que seria e como funcionaria o Banque du Liban. Nessas discussões os banqueiros chegaram a propor que o governo estabelecesse dois conjuntos distintos de regulamentações legais, conforme seguem: uma para o Banco Central e as questões relativas à moeda nacional e outra para regulamentar a profissão bancária.

Fizeram isso porque partiam do pressuposto de que a emissão de dinheiro, elemento básico da soberania nacional, pertencia ao Estado, enquanto que a organização dos negócios bancários deveria ficar a cargo de grupos privados. Dessa maneira os mecanismos de controle dos negócios bancários deveriam ser construídos com base nessas duas distinções, que as duas leis separadas deveriam estabelecer ${ }^{420}$.

Reuniões entre um representante da Associação dos Bancos com o Ministro das Finanças e um representante do Banque de Syrie et Liban foram realizadas em 1963, nas quais os banqueiros tentaram, sem sucesso, convencer o governo a aprovar sua proposta de duas leis distintas para regular a atividade bancária. Por fim, a Associação dos Bancos chegou a sugerir que o controle dos bancos fosse dado a um conselho composto por um representante do Banco

\footnotetext{
418 DIB. Warlords and merchants... p.98-99.

419 SABA, E. Lebanon's New Banking Law apud MALLAT. 70 years... Nota 8. p. 143.

420 ASSEILY, Antoine. Central banking in Lebanon... p. 19.
} 
Central, um da Associação dos Bancos e um do Ministério das Finanças. Esse projeto também não foi aceito pelo governo ${ }^{421}$.

Com isso, embora tenha conseguido concessões do governo a respeito dos mecanismos de controle dos bancos e sua organização, a Associação dos Bancos permaneceu contrária à Lei do Crédito e da Moeda tendo, ao longo dos anos sessenta, se apoiado na Lei do Segredo Bancário de 1956 para combatê-la. Somente no fim da década é que os banqueiros e o governo chegaram a um acordo e o Banco Central foi, de certa maneira, aceito pelos primeiros ${ }^{422}$.

\subsection{O caso do Intra Bank}

O maior dos bancos libaneses e a maior instituição financeira do Oriente Médio até essa época era o Intra Bank, de propriedade de Yussef Beidas, um palestino cristão refugiado de 1948, que se naturalizou libanês, tinha mãe, mulher e filhos libaneses. Ele nos anos 50 e 60 juntou uma grande fortuna dentro do sistema financeiro libanês por meio de seus contatos no governo, habilidade nas finanças, capacidade para jogar com investimentos de risco e métodos pouco limpos no trato dos negócios em que se envolvia.

O Intra surgiu em 7 de novembro de 1951 e, além de Beidas, também eram sócios dois libaneses: Munir al-Khouri e Munir Abu Fadel. Este último se tornaria um importante membro do establishment político ortodoxo, tendo sido vice-presidente do Parlamento por diversas vezes entre 1957 e 1987. Sua sobrinha, Wadad Salameh, também greco-ortodoxa, era a esposa de Beydas. O Intra Bank surgiu com apoio de altas figuras do governo libanês, como os ministros Philip Bulus e Abdallah al-Yafi e o próprio presidente Bechara el-Khouri ${ }^{423}$. O banco começou com um capital de LL6.400 milhões. O nome Intra era a sigla do nome de uma empresa anterior de comércio de importação e exportação de mercadorias, International Trade, da qual Beidas era acionista e Abu Fadel havia participado da criação ${ }^{424}$.

Beidas controlava diversas empresas de grande porte no Líbano, como a companhia aérea MEA. Também era dono de boa parte das ações do porto de Beirute, tinha a propriedade de

\footnotetext{
421 ASSEILY. Idem... p.22

422 MALLAT. 70 years of money muddling in Lebanon.... p. 125

423 DIB, Kamal. Warlord and merchants... p. 109.

424 ALAMMUDDIN, Najib. The flying Sheikh. Londres: Quartet Book, 1987. p.141.
} 
hotéis de luxo em Beirute, em Lugano na Suíça e em Nova Iorque, do Cassino do Líbano, da Radio Orient e de prédios de escritórios na capital libanesa. Bem como de docas em Marselha, no sul da França, empresas de mineração na Inglaterra e imóveis em Londres, Paris e Nova Iorque. No total o Intra bank tinha, em 1966, investimentos em 26 companhias no Líbano, sete na França, três na Inglaterra, três na Suíça, uma no Canadá e uma no Brasil. As filiais do banco estavam abertas em 40 cidades ao redor do mundo. O Intra possuía várias estratégias de investimentos na Europa, América Latina e África. No Líbano, um terço do total dos depósitos do país estavam nesse banco, aí incluindo um grande número de clientes palestinos ${ }^{425}$. Possuía 750 acionistas, $79,68 \%$ dos quais libaneses e os $20,32 \%$ restantes eram árabes, sendo os mais importantes os alSabah, a família real do Kuwait, com 5,9\% das ações, o Emir do Qatar, Ahmad al-Thani e sua família com $4,2 \%$ e um grande negociante saudita com $3,4 \%$.

No futuro, a presença desses acionistas árabes fez com que os inimigos de Beidas acusassem o seu banco de ser libanês apenas no nome e diziam que, por conta de sua presença entre os acionistas naquele que era o maior banco do Líbano, acabariam por controlar a economia libanesa $^{427}$.

Os ativos e reservas do Intra Bank representavam cerca de $56 \%$ de todo o sistema bancário libanês, sendo que isto excedia o competidor mais próximo em uma razão de onze para um. Os oito maiores bancos após o Intra controlavam juntos apenas $15 \%$ do total de ativos. Devido a isso esse banco era o sustentáculo do sistema bancário libanês, a ponto de influenciar as taxas de câmbio e juros nele praticados ${ }^{428}$. Calcula-se que o capital do Intra Bank chegava a U\$S500 milhões e que, das seis mais lucrativas empresas do Líbano, Yussef Beidas estava presente em todas $^{429}$. Além disso, muitos empresários palestinos tinham no Intra uma base de apoio para os seus negócios, pois esse banco fazia a eles empréstimos para financiarem os seus negócios, algo que tinham muita dificuldade em conseguir nos bancos libaneses ${ }^{430}$. O sucesso desse banqueiro palestino era tão grande que ele foi apelidado de "o gênio vindo de Jerusalém”,

\footnotetext{
425 SMITH, Pamela An: The Palestinian diaspora. In: Journal of Palestinian Studies, Primavera de 1986. p.95.

426 ALAMUDDIN. The flying Sheikh... p. 141.

427 Idem. p. 141.

428 DIB. Warlord and merchants... p. 106-107.

${ }^{429}$ DE CARVALHO, George. The fall of the 'Genius from Jerusalém'. Revista Life, 27 jan. 1967. p.15.

430 SMITH, Pamela An. The Palestinian diaspora... p. 95.
} 
em alusão a sua cidade natal.

Talvez a jogada mais espetacular do Intra Bank tenha sido a compra de um arranha céus em Manhattan, em Nova Iorque, na Quinta Avenida, em 1963. Essa compra foi um passo importante para Beidas se firmar no mercado financeiro dos Estados Unidos, o qual ele já começara a penetrar em 1960.

A entrada nesse mercado financeiro havia sido possível devido ao apoio de David Rockefeller, dono do Chase Manhattan Bank e parceiro de negócios do banqueiro líbanopalestino, além do próprio governador do Estado de Nova Iorque, Nelson Rockefeller, que era irmão do dono do Chase Manhattan. A compra do edifício custou U\$S4 milhões, dos quais 1 milhão foi pago diretamente em dinheiro e o restante por meio de bônus pagáveis no fim do ano com juros, emitidos e garantidos pelo próprio Intra Bank. Nessa operação importante, teve participação o Chase Manhattan Bank para viabilizá-la. Após a sua inauguração, uma das primeiras operações dessa filial foi o financiamento da exportação de trigo americano para o Líbano e o Oriente Médio. Como resultado desse negócio e outros menores, o arranha-céus da Quinta Avenida em poucos meses teve seu valor dobrado, chegando a U\$S10 milhões ${ }^{431}$.

A aquisição desse edifício teve uma grande repercussão no Líbano e mostrava o sucesso não apenas do Intra Bank, mas também do sistema financeiro libanês. Era algo que avivava o orgulho nacional libanês. Como o Intra também possuía filiais e negócios em grande parte do Mundo Árabe, esse banco era o maior símbolo existente então do projeto nacional do Líbano, de tornar seu país uma ponte entre o Ocidente e o Mundo Árabe.

Durante os anos do governo Chehab o Intra Bank esteve também associado aos projetos de desenvolvimento promovido por essa administração e dela recebeu um grande apoio para os seus empreendimentos. Beidas tinha laços de amizade com importantes figuras do governo, como Elias Sarkis, ministro da Casa Civil; Abdallah al-Yafi (já citado acima), que foi primeiro-ministro e ministro da Economia e Philippe Takla (diretor do Banco Central e chanceler), além de diversos líderes de partidos e membros importantes das forças armadas e dos serviços de inteligência, bem como o próprio presidente Chehab.

Esses contatos com o alto escalão do regime Chehab lhe dava grandes vantagens, como o acesso a informações privilegiadas sobre as políticas econômicas e financeiras. Além do

${ }^{431}$ DIB. Warlords and merchants... p. 105. 
mais, Beidas era frequentemente consultado para opinar a respeito das medidas e políticas que o governo estava planejando ou aplicando e, em diversos casos, participou dos investimentos do Estado, financiando-os. Beidas apoiou a eleição de Helu para a Presidência, pois ele esperava continuar mantendo as boas relações com os membros do governo que havia construído no mandato anterior ${ }^{432}$.

Suas relações com os chehabistas fizeram com que fosse chamado a participar da elaboração dos planos para as eleições parlamentares de 1968 e as presidenciais de 1970. A participação de Beidas se daria por meio do financiamento das campanhas, no entanto ele esperava que em troca o governo desse apoio, por meio do Banco Central, concedendo um empréstimo de 100 milhões de libras libanesas (ou US\$35 milhões) para o Intra Bank.

A taxa interbancária da época era de 6\%, mas a taxa de empréstimos seria estabelecida em 3\% para o Intra Bank e o empréstimo seria fixado em um prospecto. Os outros $3 \%$ de juros seriam guardados e destinados a financiar as campanhas. Tudo isso parecia ser muito vantajoso para Beidas, pois ele percebera que com o controle do Estado pelos chehabistas, sua associação com eles levaria o Intra Bank a dominar as finanças e a vida política nacional.

No entanto, nem todos dentro do governo eram simpáticos a Beidas. Quando ele se reuniu com o presidente Helu para conversar a respeito do empréstimo, este, embora tenha se declarado pronto para ajudar, no momento em que Beidas pediu os 100 milhões de empréstimos para iniciar os investimentos no Líbano, respondeu apenas que iria ver com mais atenção o seu caso. Como o Presidente não havia se oposto ao empréstimo, embora se soubesse que não lhe agradava, mas sim dito que iria analisar o caso, recomendou-se a Beidas conversar com o vicepresidente do Banco Central ,Joseph Orghurlian.

Contudo, no encontro com o vice-presidente este demonstrou sua aversão pessoal conhecida a Yussef Beidas, questionando-o porquê desejava investir no Líbano se não era um libanês, apesar de ser naturalizado e, por fim, recusou conceder o empréstimo. Nessas reuniões ficara bem claro que membros do governo de Helu tinham por ele tanta aversão quanto à elite cristã $^{433}$.

Nos anos que antecederam a quebra do Intra Bank, os inimigos de Beidas espalhavam

\footnotetext{
432 DIB. Idem. p. 110

${ }^{433}$ Dib... p.111-112
} 
todo tipo de boatos contra e ele e o seu banco. Segundo Alamuddin, eles eram tão fortes que chegaram a indispor o presidente Chehab contra Yussef Beidas e o seu banco. Já quando o banqueiro de origem palestina estava procurando se estabelecer na França, o acusaram de financiar a Frente de Libertação Nacional argelina, que lutava pela independência de seu país contra a França. Em outra ocasião chegaram a dizer que Beidas estava vendendo terras da Palestina para Israel, o que provocou uma reação das autoridades libanesas, que enviaram investigadores à Suíça com o objetivo de provar essas acusações, embora sem sucesso. Então, convocaram Beidas para comentar publicamente frente a um promotor público a respeito das acusações de venda de terras. Esse expediente também não foi bem sucedido ${ }^{434}$.

Por essa época o sistema bancário libanês começou a atravessar um período de crise e isso se deu como resultado de um processo de valorização do dólar que ocorria desde o início de 1966, o que tornava os investimentos na moeda americana um negócio mais atrativo em detrimento do Líbano.

Simultaneamente a isso, banqueiros e financistas dos EUA e da Europa começaram a oferecer taxas atrativas para os países e investidores que tinham os seus serviços bancários no Líbano. Como resultado, o capital estrangeiro começou a deixar Beirute, trazendo um sério problema de liquidez para os bancos locais. O Intra Bank não passou inicialmente pelos problemas dos outros bancos libaneses, como a falta de liquidez, mas como o governo passou a agir procurando buscar uma solução para a crise do seu sistema bancário, Beidas temia que uma comissão de investigação pudesse descobrir suas práticas bancárias irregulares, algo que poderia colocar em xeque a sobrevivência de inúmeras instituições bancárias e, com isso, produzir uma crise ainda mais séria na economia.

Então, Beidas começou um plano de reestruturação de seu banco. Contratou uma firma de consultoria dos EUA para analisar a situação financeira e administrativa do banco e recomendar reformas, além de reestruturar o Conselho de Administração do banco visando a fortalecê-lo contra a crise. As avaliações feitas nos registros do Intra descobriram que ele tinha uma posição de liquidez muito pobre e isso começou a piorar com a retirada dos depósitos por parte dos grandes clientes. Nesse contexto foram realizadas as reformas internas que por um curto

${ }^{434}$ ALAMUDDIN. p. 143-144 
período de tempo melhoraram a situação do banco ${ }^{435}$.

A situação de crise do banco começou a se manifestar já em setembro, quando seu índice de liquidez era de 3,5\%, algo que poderia ser considerado uma infração penal em qualquer outra parte do mundo, mas não no Líbano. Então, dois dos seus maiores clientes, os sauditas e os kuaitianos, ameaçaram retirar os seus depósitos para colocá-los em bancos da Europa. Até mesmo os soviéticos que possuíam depósitos no banco por conta de suas políticas no Oriente Médio retiraram seus 6 milhões de dólares.

Quando tudo isso aconteceu o Intra Bank começou a entrar em ruína. Esses pedidos chegaram em um único dia a 100 milhões de libras libanesas em depósitos, o que causou alarme nos correntistas. Para evitar uma onda de pânico o governo fechou por três dias o mercado financeiro, mas mesmo assim uma massa de pequenos correntistas foi às portas dos bancos libaneses solicitar a retirada dos seus depósitos. Nesse momento, Joseph Orghurlian fez uma jogada na qual enganou a direção do Intra e ajudou a precipitar de maneira ainda mais rápida a sua crise: ele prometeu um pequeno empréstimo de 15 milhões de libras libanesas, representando apenas $21,5 \%$ dos ativos do banco. Isso com a condição de que os seus títulos e ações, representando LL120 milhões de ativos das principais e mais lucrativas empresas, fossem usados como garantia e enviados aos depósitos do Banco Central com grande segredo.

Entretanto, Orghurlian exibiu publicamente essas garantias do Intra Bank, dando a entender que o banco estava numa situação caótica à beira da falência, enquanto que uma multidão desesperada se juntava nas portas das agências do banco em busca de seus depósitos ${ }^{436}$. Os administradores do Intra, então, vieram a público anunciar que o banco não possuía liquidez suficiente para cobrir os depósitos dos seus clientes ${ }^{437}$.

Ao longo do processo de destruição do banco de Beidas, a campanha para destruir o Intra fora realizada pelos seus conspiradores por meio de uma bem organizada ação, que envolvia o envio de cartas a clientes importantes, telefonemas contínuos a pessoas de posição estratégica na economia libanesa, visitas pessoais realizadas por agentes cuidadosamente selecionados e

\footnotetext{
${ }^{435}$ DIB ... p. 113 .
}

${ }^{436}$ DIB... p.116-117.

${ }^{437}$ WINSLOW. War and politics in a fragmented society. Londres e Nova York: Routledge, 2005. p. 84. 
avisos e sinais para fazer com que os milhares de clientes retirassem seus depósitos do banco ${ }^{438}$.

Para desmoralizar completamente Beidas, Orghurlian e seus aliados realizaram um ato muito sórdido. Vale lembrar que essas ações e bônus deixados como garantias nos cofres de uma instituição como o Banco Central sempre eram analisadas e contadas em segredo por funcionários especializados. Mas no caso do Intra Bank foi o oposto. A contagem das ações foi feita às vistas do público no salão de entrada do Banco Central, em um espetáculo de degradação da imagem da instituição e de seu proprietário.Isso apesar dos pedidos de Najib Salha, presidente interino do banco, enquanto Yussef Beidas não pudesse retornar ao Líbano, feitos pessoalmente a Joseph Oghourlian. Essa cena estimulou muita gente a retirar os seus depósitos do banco, pois, de repente, para todo o país o banco estaria à beira da falência.

A corrida aos bancos começou no dia 12 de outubro. Ao mesmo tempo o Banco Central recusou dar qualquer assistência, o que forçou o Intra a fechar as suas portas no dia 14, uma sexta-feira, após pagar mais de LL100 milhões para evitar a corrida. Mesmo assim, no dia seguinte, houve uma corrida geral aos bancos como uma consequência das intrigas feitas contra Beidas.

O sistema bancário libanês estava ameaçado de entrar em colapso, o que deixou o governo preocupadíssimo. Então foi organizada pelo Conselho de Ministros uma reunião de emergência no domingo, que decidiu estabelecer um feriado bancário por três dias, começando já na segunda. Além de que foi decidido que o Banco Central socorreria todos os bancos para evitar a sua falência e permitir que retomassem as suas atividades. O único banco que não foi socorrido foi o Intra, apesar dos fortes apelos de ministros como Kamal Jumblatt. Como desculpa para negar o empréstimo foi usado o argumento de que o banco de Beidas havia fechado as suas portas e que ele estava sob o regime da 'Concordat Préventif' 439 - Concordata Preventiva -, aplicado pela justiça. Porém isso não era verdadeiro, pois a aplicação da Concordat Préventif foi realizada

\footnotetext{
438 ALAMUDDIN. p. 146.

${ }^{439}$ A Concordata é um procedimento jurídico do direito falimentar utilizado para proteger o crédito do devedor comerciante para assim recuperar a sua situação econômica e é considerado mais suave do que a falência. A Concordata Preventiva, um tipo de concordata, em particular, busca "prevenir a decretação da falência do devedor comerciante e, sendo concedida, impede a decretação da falência, ressalvada a hipótese de rescisão de concordata". WIKIPEDIA. Disponível em: 〈http://pt.wikipedia.org/wiki/Concordata_(jur\%C3\%ADdica)〉.
} 
pelo primeiro ministro al-Yafi, em seu papel de ministro da Justiça na segunda dia $17^{440}$.

A aplicação dessa concordata, no entanto, segunda a lei libanesa, demorava dez dias para acontecer, mas al-Yafi convocou uma reunião com os advogados do Intra Bank na mesma manhã do dia 17, onde exigiu a aplicação da medida a partir das 13 h daquele dia ou então o banco seria declarado como em falência. A chantagem funcionou e nos três anos seguintes, como consequência da Concordat Préventif, ocorreu o pagamento de todos os passivos do Intra Bank. Nesse mesmo dia 13, al-Yafi ordenou às cortes de justiça do país que permanecessem abertas, embora no Líbano elas fechassem pela tarde, só para receberem a aplicação da Concordat do Intra, o que foi feito às $17 \mathrm{~h} 30$. Nessa mesma tarde uma equipe de especialistas libaneses auditou, às pressas, as contas do Intra Bank e os valores dos seus ativos ${ }^{441}$.

Também foi tomada outra medida: o governo, por meio do Conselho de Ministros, para evitar as consequências sociais imediatas que a perda dos depósitos e poupanças dos pequenos clientes (aqueles cujas contas não passassem de LL15 mil) causaria, aprovou uma medida, por meio da legislação existente. Ordenou ao Tesouro Nacional oferecer ao Banco Central um empréstimo de mais de LL50 milhões (ALAMUDDIN. p. 153).

O governo aprovou no Parlamento, após uma sessão muito tensa e tumultuada, uma lei que lhe permitia socorrer os bancos afetados pelo processo de falência do Intra Bank. (ALAMUDDIN. p. 153). A ajuda oferecida foi tão volumosa que chegou no final de 1967 à quantia de LL221 Milhões ${ }^{442}$.

No dia 15 de outubro de 1966, o Intra Bank subitamente parou de funcionar. O banco deixou de pagar os seus depósitos e no dia seguinte fechou as suas portas e declarou a sua falência. Entre os responsáveis por essas retiradas em massa que precipitaram a falência do banco de Beidas estaria o emir do Kuwait, que enviou seu dinheiro para bancos na Grã-Bretanha. Outros responsáveis por esses grandes saques eram membros das famílias principescas da Arábia Saudita e o próprio rei Faisal, que enviaram seu dinheiro para bancos suíços.

Segundo Winslow (1996 p. 148), diversos jornalistas de esquerda na época tinham promovido denúncias em seus jornais, acusando o emir Sabah III de ter participado da

\footnotetext{
440 ALAMUDDIN. p. 146.

${ }^{441}$ Idem. p. 147.

442 idem. p. 154.
} 
conspiração para destruir o Intra Bank. Por causa dessas denúncias, vários desses jornalistas foram processados e presos e dois desses jornais fechados. Se Sabah III contribuiu para a destruição do banco de Beidas, isso era parte de sua política anti-nasserista e ele poderia fazer isso devido à influência, por sua grande participação, que os kuaitianos tinham na economia libanesa e ao fato de serem grandes credores do governo.

Dib (2004. p. 116-117) afirma que a retirada dos depósitos do Intra Bank por Sabah III se deveu à pressão dos britânicos para que ele retirasse de Beirute o seu dinheiro e o enviasse a Londres, para ajudar a fortalecer a libra esterlina em sua luta contra o dólar. Já o rei Faisal teria retirado seu dinheiro, entre outras razões, por conta das críticas constantes que boa parte da impressa libanesa fazia a esse monarca, que tantos incômodos políticos causava no contexto da disputa com o Egito pela hegemonia sob o mundo Árabe e, ao mesmo tempo, os suíços haviam feito propostas de acordos financeiros mais lucrativos.

Nasser Qalawoun (2000. p. 119) colocou a falência do Intra Bank como uma medida que indicava a desaprovação por parte da Arábia Saudita da política pró-egípcia do primeiroministro Abdallah Al-Yafi. A retirada dos depósitos pelos investidores sauditas foi uma arma utilizada pelo governo de Riad para mudar ou ao menos para atenuar as posições da política do Líbano em relação ao projeto do Pacto Islâmico, anti-nasserista e liberal.

Para impedir um colapso do sistema bancário, enquanto tomavam medidas para evitar a difusão da crise para os outros membros do sistema socorrendo-os financeiramente, anunciou o governo, nos dias seguintes ao anúncio da falência do Banco de Beidas, um feriado bancário. Mesmo assim, a crise afetou o sistema bancário libanês, levando à falência de vários pequenos bancos, especialmente aqueles ligados ao Intra Bank. Na reunião realizada pelo presidente e os membros do governo mais figuras do alto escalão do sistema financeiro libanês no palácio presidencial de Baabda estavam presentes, o primeiro-ministro al-Yafi, Joseph Orghurlian (presidente do Banco Central), ${ }^{443}$ Elias Sarkis, vários ministros, o presidente da Associação dos Banqueiros Libaneses Pierre Éddé (um inimigo de Beidas), Najib Allamuddin, chefe da MEA e sócio de Beidas nessa empresa, bem como diversos outros banqueiros e políticos.

O Intra Bank fora representado pelo presidente do Conselho de Administração, Najib Salha. Nessa reunião é que se discutiram, além das medidas para impedir um colapso do sistema

${ }^{443}$ Phelippe Takla não pôde participar por estar no exterior em um encontro com dirigentes do FMI. 
bancário libanês e com isso uma grande crise na economia, os procedimentos que seriam tomados em relação ao Intra Bank. O clima era de completa hostilidade em relação à Beidas e ao seu banco. Os representantes do Intra haviam trazido balanços que demonstravam que seu banco ainda possuía muitos ativos no exterior, que poderiam servir como garantias para um empréstimo de socorro por parte do governo, porém ninguém na reunião deu atenção a isso e muitos dos presentes culparam o Intra Bank pela crise ${ }^{444}$.

Um exemplo da hostilidade em relação à Beidas pode ser demonstrado pelo relato de Najib Alamuddin: nessa reunião, para a qual ele foi convidado, por conta da suas relações pessoais e o fato de ser sócio do empresário palestino na MEA, o primeiro-ministro Abdallah alYafi, que havia sido um dos responsáveis pelo sucesso do Intra Bank, se mostrava extremamente furioso em relação a Beidas. Dizia que o banqueiro era um trapaceiro, cujo banco estava em mal estado e havia se envolvido em transações questionáveis e repulsivas.

Ele rejeitava qualquer ideia relacionada à necessidade de socorrer o Intra afirmando que nenhuma assistência poderia salvar um banco falido, pois apenas se estaria jogando dinheiro fora. Al-Yafi afirmava ter recebido um relatório com as provas das falcatruas de Beidas, mas não poderia revelá-lo e nem divulgar o nome do seu autor, pois era confidencial. Nessa reunião também, segundo Alamuddin, ele havia pedido tanto ao presidente Helu quanto ao primeiroministro al-Yafi a promessa dos dois para que Beidas não fosse preso ou sofresse qualquer constrangimento ao desembarcar no aeroporto de Beirute. Helu concordou, aparentemente dando a sua palavra, mas al-Yafi nada respondeu, permanecendo mudo e, com o rosto sério. Al-Yafi, particularmente, poderia vir a tomar qualquer atitude contra Beidas porque ele, além de primeiroministro, também era ministro da Justiça e ministro das Finanças ${ }^{445}$.

Como resultado da reunião, o governo por meio do Banco Central do Líbano recusou conceder empréstimos ao Intra para assim salvá-lo da falência e, ao mesmo tempo, já se negociava a partilha de parte dos bens de Beidas, como foi o caso da MEA, cujos compradores já apareceram durante a reunião ${ }^{446}$.

Mais tarde, investigações das autoridades do Banco do Líbano (o Banco Central)

\footnotetext{
444 DIB. Warlords and merchants... p. 118. WINSLOW. War and politics ... p. 147.

445 ALAMUDDIN. p. 138-139.

${ }^{446}$ DIB. p. 118.
} 
descobriram uma série de irregularidades nos livros de registro do Intra, que mostravam as manobras arriscadas e um grande número de irregularidades realizadas pelo seu proprietário para ter mais lucros. Serviram para que fosse declarada a prisão de Beidas, que se encontrava no Brasil para onde se dirigiu após a quebra de seu banco e a crise que se seguiu. Beidas foi posteriormente preso na Suíça, de onde deveria ser extraditado para o Líbano, mas morreu em novembro de 1968 por um ataque cardíaco. Nesse processo todo o Conselho Administrativo do banco foi processado, sendo culpado de fraude, roubo e falência premeditada.

Essa investigação começou pouco tempo depois das ações tomadas pelo governo contra o banco de Beidas. A justiça libanesa apontou duas equipes para analisar a situação do Intra Bank em seus aspectos financeiro, jurídico, patrimonial etc. A primeira era composta por seis indivíduos e comandada pelo juíz aposentado Shawkat al-Munla, um amigo de confiança de Abdallah al-Yafi, que não tinham nenhum conhecimento sobre bancos e o sistema bancário.

A segunda equipe era composta de quatro especialistas que deveriam avaliar os ativos do banco. Ambas as equipes deveriam apresentar o resultado dos seus trabalhos em um relatório dentro de uma semana. Para Alamuddin, esse episódio era a prova do desejo do governo de destruir o Intra Bank, pois era humanamente impossível auditar em prazo tão curto e com equipes tão pequenas um banco tão grande. Na época mesmo, esse fato provocou fortíssimas críticas e protestos na sociedade libanesa, e mesmo em outros países, pois muitos dos maiores clientes eram membros das mais altas elites árabes e temiam perder os seus depósitos no caso da falência ser decretada. Em resposta a essa onda de protestos, o governo contratou uma empresa de auditoria, a Price Waterhouse, auditores do Banco Mundial, para auditarem as contas do Intra Bank.

Pouco depois, o sócio majoritário da Price Waterhouse - Eric McMillan - declarou à impressa britânica que o Intra Bank estava em situação de solvência e que o seu problema era de liquidez, também considerou vital para a economia libanesa manter esse banco em operação, mas que para isso era necessário, antes de fazê-lo voltar a funcionar, que recebesse apoio financeiro do Estado. Também percebeu que a situação era muito propícia para que qualquer grupo financeiro internacional estendesse a sua influência sobre o Oriente Médio e ele mesmo desejaria participar desse processo e ajudar na venda do Intra Bank. No entanto, quando suas declarações saíram no jornal The Observer, em 5 de novembro, o governo libanês imediatamente demitiu Price Watrehouse, pois McMillan falou demais e revelou que o Intra não estava em situação de 
falência. A auditoria foi deixada a cargo das duas equipes libanesas iniciais, que entregaram os seus relatórios em 14 de novembro.

Neles se constatou um déficit de LL25 milhões ou 3,7\% dos ativos, que chegavam a um total de LL627 milhões. No entanto, esses relatórios estavam incompletos, pois, devido à falta de tempo, não incluíram propriedades importantes do Intra Bank, como o arranha-céus de Nova Iorque e as filiais de Roma e Frankfurt, sendo que, se eles estivessem sido incluídos, mostraria que o banco não tinha nenhum déficit ${ }^{447}$.

O relatório, por conta de suas imprecisões, causou um grande descontentamento entre os grandes clientes do Intra Bank que exigiram uma nova auditoria do governo libanês. Assim, em 23 de dezembro, o governo contratou outra firma para fazer uma nova auditoria, a também britânica Cooper Brothers. Esta também foi colocada sob pressão para produzir um relatório em um prazo limitado, não podendo confirmar todas as informações obtidas e não conseguindo entrar em contato com todos os membros do alto escalão do banco ou os seus próprios auditores para obter informações. Com isso a Cooper Brother teve que confiar nas informações dadas por gente como Shawkat al-Munla e membros de sua equipe ${ }^{448}$.

O seu primeiro relatório foi apresentado a Abdallah al-Yafi em 3 de fevereiro de 1967. Como resultado de todas essas dificuldades e obstáculos, a Coopers Brothers fez uma estimativa muitíssimo conservadora dos ativos do Intra Bank, como foi o caso do arranha-céus de Nova Iorque que, segundo eles, daria um lucro de US\$1,5 milhões, mas, posteriormente, ao ser vendido em um leilão público ainda em 1967 deu um lucro de US\$6,5 milhões. O mesmo ocorreu com diversas outras propriedades do Intra Bank. No caso dos ativos, a Cooper Brothers os estimou em LL737.827 milhões e os passivos em LL788.813 milhões. Isto então mostrava um déficit de LL50.986 milhões ou 6,9\% aproximadamente. No relatório eles afirmaram que não tiveram tempo de verificar os dados a eles oferecidos o que indica que sua avaliação poderia estar $\operatorname{errada}^{449}$.

Um dos assessores de Beidas, Badr Fahum, apresentou a al-Yafi a análise detalhada dos trabalhadores dos auditores britânicos como um prova de que os ativos do banco haviam sido

\footnotetext{
447 ALAMUDDIN. p. 148-149.

448 Idem. p. 149.

${ }^{449}$ Idem. p. 152-153.
} 
subavaliados e a história das dividas ruins exageradas. No entanto, o primeiro-ministro teria dado pouca atenção a esses fatos ${ }^{450}$.

Muitas ilegalidades foram cometidas durante o processo de destruição do Intra Bank. Uma das mais graves, que foi uma violação flagrante do Código Comercial Libanês, foi à lei que permitia ao presidente do Banco Central pedir a um tribunal competente uma autorização para nomear um gestor temporário junto com um comitê administrativo para o banco, assumindo as funções e responsabilidades do Conselho de Diretores, da Assembleia Geral dos Acionistas e ao mesmo tempo a dos representantes dos credores ${ }^{451}$.

Outra ação abusiva que mostrava o interesse em destruir o Intra Bank, segundo Alamuddin, foi a decisão da justiça libanesa em decretar a falência do banco em 4 de janeiro, quando o relatório da Coopers Brothers ainda não estava pronto e o Intra estava sob o regime de concordata provisória. Isso foi tão acintoso que o jornal an-Nahar declarou: "The intention was bankrupt the bank despite the fact that it was solvent". Ao processo de falência ainda foi dada uma grande publicidade, tanto no Líbano quanto no mundo para humilhar e desmoralizar a Yussef Beidas. Porém, tendo alcançado esse objetivo ela foi revogada silenciosamente em uma corte de apelação. Pouco depois, uma corte comercial apontou para direção do banco um executivo libanês, que trabalhava em um banco estrangeiro, para dirigir o Intra Bank junto com um comitê de 10 gerentes, a fim de administrar as atividades cotidianas e elaborar um relatório sobre as contas do banco com um prazo de seis meses para realizá-1o ${ }^{452}$.

No entanto, essa mesma corte indicou para presidência a Shawkat al-Munla, o juiz aposentado e homem de confiança de Abdallah al-Yafi. Desses 10 gerentes, 4 se recusaram a assumir as suas funções, mas outros três foram mais tarde indicados para as vagas dos que renunciaram.

O comitê formou um subcomitê junto com dois contadores da Cooper Brothers para verificar o valor dos ativos. No entanto, em um novo relatório apresentado em 11 de maio, o tamanho das dívidas duvidosas cresceu e o valor dos ativos diminuiu. Diziam que ao apresentar esses dados estavam obedecendo às instruções de al-Munla, responsáveis por fornecer grande

\footnotetext{
${ }^{450}$ Idem. p. 153.

451 Idem. p. 154.

452 Idem. p. 155.
} 
parte dos dados que foram aceitos sem nenhuma verificação.

Além disso, esse indivíduo ofereceu essas informações aos contadores da Cooper Brothers sem informar o comitê de gerentes o que os deixou indignados e gerou um conflito forte entre eles. Todavia, o subcomitê apresentou outro relatório com um resultado bem diferente daquele da Cooper Brothers, no qual afirmava que o Intra tinha um excedente de LL50 milhões. Esse relatório foi aprovado pelo Comitê após reuniões onde foram feitas avaliações cuidadosas dos dados. Entretanto, Al-Munla recusou aprová-lo, usou de uma discussão que teve com um dos integrantes do comitê para se retirar, dizendo que havia sido pessoalmente ofendido. Como ele não retornou, o prazo para a entrega do relatório para a justiça expirou. Mesmo assim, cinco dos integrantes do comitê resolveram apresentar o relatório à justiça, que o recusou por não ter a assinatura de al-Munla. No fim, mesmo sob as a ordens da justiça esse indivíduo se recusou a assinar o relatório e a sua equipe de gerentes foi dissolvida em 17 de agosto, demonstrando assim, mais uma vez, a vontade do governo libanês em destruir o Intra Bank ${ }^{453}$.

Um novo comitê foi formado com o objetivo de encontrar compradores para o Intra Bank, suas filiais, empresas, investimentos e ativos. Esse novo comitê funcionava sob um novo decreto emitido em 5 de agosto pelo Parlamento. Essa lei dava à justiça apenas um mês para aprovar qualquer acordo estabelecido a respeito do patrimônio do banco. Esse comitê se compunha de grandes nomes do cenário político e econômico do Líbano, como Elias Sarkis, presidente do Banco Central e uma figura muito ligada ao governo anterior de Fuad Chehab, mas também o próprio Shawkat al-Munla.

Nesse meio tempo os ataques ao Intra continuaram na imprensa com a ajuda do governo. Por fim, foi o comitê de Sarkis, que acabou terminando a existência do Intra como um banco e organizou a sua venda a um consórcio estrangeiro, comandado pela Kidder Peabody, uma empresa de corretagem norte americana ${ }^{454}$.

Estes fatos acima relatados aconteceram por conta da suspeita, já comentada, de que o caso Intra Bank escondesse disputas de poder dentro do mundo Árabe e, ao mesmo tempo, o sucesso do banco despertava a aversão e temor que os maronitas como um todo, mas especificamente suas elites, tinham em relação aos palestinos por serem estrangeiros árabes

\footnotetext{
453 Idem. p.156-157.

454 Idem. p. 157-159.
} 
muçulmanos e, também, por conta de suas ligações com o movimento nacionalista árabe.

No tocante a Beidas, especificamente as elites libanesas cristãs tinham inveja de seu sucesso, ressentiam-se do controle que ele tinha de importantes setores da economia nacional e, além disso, o consideraram sempre um intruso, apesar de ele possuir cidadania e uma família libanesa. Um exemplo das ligações do dono do Intra Bank com o nacionalismo árabe, e como elas costumavam ser obscuras, foi o episódio do assassinato do jornalista Kamal Mroweh, do diário al-Hayat, um crítico de Nasser e do nasserismo, que foi morto por um homem que era funcionário do Intra e havia conseguido trabalho lá devido à ajuda de Ibrahim Kulaylat, chefe do al-Murabitun, um importante movimento nasserista libanês e que era amigo de Beidas ${ }^{455}$. Outro exemplo, agora com relação às conexões com o movimento armado palestino, foi o fato do Intra ter guardado os depósitos em dinheiro da OLP até que o desentendimento de Beidas com os mais importantes membros das elites políticas palestinas tivesse feito com que todo esse dinheiro fosse retirado e depositado no Arab Bank Limited da Jordânia ${ }^{456}$.

Além disso, Beidas não agradava os membros da elite financeira libanesa, especialmente a cristã, que se sentia ameaçada com o seu crescente poder e riqueza e sua atitude confiante e orgulhosa (ele desdenhava, por exemplo, a Associação dos Bancos do Líbano) em relação a essa elite nativa. As ligações de Beidas com os chehabistas, que muito desagradava a maior parte das elites libanesas, aumentavam ainda mais a aversão que sentiam pelo banqueiro de origem palestina.

No plano inter-árabe, os vínculos de Beidas e seu banco com grupos políticos ligados ao nacionalismo árabe teriam trazido em relação a ele uma grande aversão por parte dos líderes e elites dos regimes conservadores árabes e, por isso, essas elites teriam passado a ver o Intra Bank como uma ameaça. Por conta disso se teria formado essa conspiração, na qual parece que participara até mesmo o presidente Charles Helu, apesar de ser considerado um Chehabista, de manter relações estreitas com Nasser e seu governo se alinhar oficialmente a favor do nacionalismo árabe $\mathrm{e}^{457}$.

Essa característica anti palestina do episódio de falência do banco de Yussef Beidas e

\footnotetext{
455 WINSLOW. War and politics... p. 147.

${ }^{456}$ DIB. Warlords and merchants... p. 115.

${ }^{457}$ Winslow, Charles. Lebanon: war and politics... p. 148-149.
} 
os efeitos que provocou entre os palestinos fizeram com que diversos autores vissem no Intra Bank e no seu dono duas das primeiras vítimas da guerra civil de 1975-1990 e, portanto, um dos acontecimentos que contribuíram para a sua deflagração. Essa, por exemplo, é a opinião de Najib Allamuddin, autor de um livro autobiográfico sobre a empresa de aviação Middle East Arlines, 'The flying sheikh' (1987).

Essa ideia também aparece em Edward Said na sua autobiografia 'Out of place: a memoir'. Questão também discutida por Charles Winslow em sua obra 'Lebanon, the fragmented nation' de 1996. Dentro da esquerda libanesa a falência do Intra Bank também ocasionou repercussões negativas, pois para eles esse episódio demonstrava que o sistema libanês havia sido construído apenas para as elites cristãs e que estas não deixariam espaço para indivíduos ou grupos que não fossem pertencentes a sua comunidade. Essa também foi à percepção de boa parte da população muçulmana e drusa.

Por outro lado, a falência do Intra Bank também foi provocada pelas próprias fragilidades do banco devido às arriscadas jogadas e manobras nas quais se envolvia para realizar os seus contratos e operações mais lucrativas. Também contribuiu muito para a sua falência a falta de conexões de Beidas com os membros mais importantes das elites cristãs, que tiveram como resultado isolá-lo e ao seu banco.

Quanto ao próprio Beidas ele sempre denunciou que a falência estrepitosa dessa sua empresa teria sido consequência da conspiração de seus inimigos. Em entrevistas coletivas ele excitado de raiva e revolta atacava as pessoas que ele considerava responsáveis por sua falência. Em uma delas, por exemplo, ele assim se expressou:

"My enemy knifed me! Tragically! It was all well-planned conspiracy, a very well
planned conspiracy indeed". Profundamente magoado, ele acusava publicamente: "They
sent out thousand leaflets full of lies", "They employed 100 peoples to divide up the
telephone book and call every member in Beirut, saying "Take our money out of
Intra" 458 .

Também, como exemplo da aversão sentido por muitos membros da elite libanesa contra Beidas, podemos citar trechos retirados da autobiografia de Alamuddin, quando ele fala de

${ }^{458}$ DE CARVALHO, George. The Fall of the 'Genius from Jerusalém'. Revista Life, 27 jan. 1967. p.87-88. 
sua relação com o banqueiro. Nessa obra o presidente da MEA afirmava que Beidas comentava o seguinte: "A leading Lebanese politician has vowed publicly: 'Yousef Beidas will never again set foot in Lebanon'. He sent an emissary to tell me his agents would kill me if I ever returned to Lebanon".

Beidas também teria dado os nomes dos políticos libaneses que o ameaçavam e os que conspiraram contra ele, mas como teriam ameaçado a vida dos seus filhos ele nunca publicou essas memórias $^{459}$.

O banco foi posteriormente reaberto, mas com outros donos e uma nova cara. Um plano elaborado por Roger Tamraz, um jovem executivo de menos de trinta anos de origem libanesa do banco de investimento Kidder, Peaboby and Co, foi aplicado para recuperar o capital contido no Intra, mas a favor desse grupo americano, já que devido à falta de liquidez, os pagamentos dos credores estavam suspensos. Nesse plano as obrigações dos depósitos do banco foram substituídas por ações de uma nova empresa, na qual o governo libanês participava.

Por essa lei muitos acionistas legais perderam tudo o que tinham. Enquanto isso uma nova equipe foi instalada no Conselho Administrativo. Esse plano foi imposto por meio de um decreto governamental e a Peabody and Co. recebeu milhões de dólares em taxa de consultoria para recomendar uma medida que era impossível de ser aplicada na América do Norte e que a favorecia. Os ativos remanescentes do Intra Bank foram divididos entre o Banque al-Machrek (um consórcio entre bancos libaneses e o Morgan Guaranty Trust dos EUA) e a recém-criada empresa Intra Investiment Company (IIC), da qual o governo libanês tinha $45 \%$ das ações, o governo do Kuwait $20 \%$ e o do Qatar $10 \%$.

\subsubsection{Consequências}

A quebra do Intra Bank foi um golpe para o sistema bancário libanês, pois, apesar da crise que provocou ter sido contida pelos funcionários do governo do Líbano, ela acabou com a confiança que se tinha no sistema financeiro libanês. Isso levaria nos anos seguintes a uma diminuição no ritmo de operações e de negócios, enquanto as elites árabes dos países petrolíferos cada vez menos usavam o Líbano como intermediário financeiro entre elas e o Ocidente.

459 ALAMUDDIN. The flying Sheikh... p. 139. 
Também houve uma crescente desnacionalização do sistema bancário libanês, com a propriedade por nacionais caindo de $60 \%$ para $45 \%{ }^{460}$ entre 1966 e 1968.

A partir dessa época os maiores bancos em Beirute eram americanos. Estes eram o Chase Manhattan, o Bank of America e o Citibank. O domínio estrangeiro levou a estudiosos como Hishan Bsatt a acusarem os Estados Unidos de promoveram a crise com o objetivo de controlar o sistema financeiro libanês e, por meio deste, o mercado financeiro do Oriente Médio $^{461}$.

Outra consequência vinda da crise do Intra foram às mudanças nos mecanismo de funcionamento do setor bancário. Dessa forma, em 9 de maio de 1967 foi promulgada a Lei 2867, que criou um conselho superior dos bancos que tinha entre as suas funções a obrigação de assumir o controle de bancos que estivessem em más condições financeiras e administrativa,s enquanto foi dado ao BCAIF o poder de administrar bancos confiscados pelo governo e executar a sua liquidação ou vendê-los.

Já o Decreto 8.284 de 28 de setembro desse mesmo ano permitia às instituições financeiras do Estado providenciar créditos e incentivos fiscais para bancos que estavam fundindo-se ou em processo de autoliquidação, por serem relativamente fracos.

Outro conjunto de medidas tinha como objetivo um controle mais efetivo das operações bancárias para se tentar restaurar a confiança no sistema bancário libanês. Dessa forma foi dada à Comissão de Controle Bancário a autorização para controlar e supervisionar os bancos por meio de minuciosos exames dos investimentos dos bancos, a partir dos recursos existentes, simultaneamente procurando fazer com que os bancos adotassem as regulamentações existentes. Estabeleceu-se no fim de 1967 um fundo de seguros para depósitos e, com isso, todos os depósitos que um cliente colocava em um banco eram garantidos por esse fundo até o valor de LL30 mil. Posteriormente, em 1970, uma emenda à Lei 28-67 permitia ao Banco Central fixar a taxa de juros máxima que os bancos podiam aplicar aos depósitos de seus clientes se eles fossem enviados para um seguro de depósitos ${ }^{462}$.

A crise representou o primeiro teste para o recém-criado Banco Central Libanês, o

\footnotetext{
460 AL-HOSS, Salim apud DIB. p. 122.

461 DIB. Warlords and merchants... p.121-122.

462 MAKDISI. Financial policy and economic growth... p.53-54.
} 
Banque du Liban. Esse banco interveio no mercado nos dias seguintes à quebra do Intra, providenciando a liquidez necessária aos bancos para que não houvesse uma quebra completa do sistema bancário nacional aumentando, em apenas um mês, a quantidade de notas em circulação de LL575 milhões para LL648 milhões, colocando com isso LL73 milhões a mais em circulação. No ano seguinte, como consequência da derrota árabe frente a Israel, o Banco Central repetiria a política com um aumento ainda mais espetacular de LL156 milhões postas em circulação no mês de junho, indo à quantidade de dinheiro em circulação de LL 713 Milhões em maio para LL 869 milhões no mês seguinte. Essa medida também tinha a função de evitar uma falência maciça dos bancos libaneses e assim impedir a quebra da economia e tranquilizar os donos dos depósitos com seguros que garantissem as contas com depósitos no valor de até 15 mil libras libanesas ${ }^{463}$.

No plano social é que as consequências foram mais graves e danosas. Para os muçulmanos libaneses (aí incluindo vários de seus líderes) a crise do Intra Bank mostrava que o sistema laissez-faire era na verdade feito apenas para as elites cristãs e que elas nunca aceitaram no seu íntimo o Pacto Nacional. Já para os palestinos mostravam que não eram bem-vindos no Líbano e que nunca poderiam ter qualquer tipo de autonomia ou perspectiva para melhorar suas duras condições de vida. Isso os fora alienando cada vez mais do Líbano.

Existia, portanto, um forte elo entre a quebra do Intra Bank e o aparecimento da guerrilha palestina nos anos que se seguiram à derrota árabe em 1967.A situação era a seguinte: tensões e conflitos resultantes da presença armada das organizações palestinas que dividiram a sociedade libanesa entre apoiadores (geralmente muçulmanos e drusos) e críticos (cristãos em sua maioria); problemas sociais trazidos pelo laissez-faire, como inflação, incapacidade da economia para absorver a força trabalho, o êxodo rural, as condições econômicas ruins dos muçulmanos, particularmente dos xiitas, que ainda persistiam apesar das políticas de Chehab; a falta de políticas sociais nos bairros pobres das grandes cidades, etc. Tudo isso junto foi fazendo da realidade libanesa um barril de pólvora que finalmente explodiu em abril de 1975.

\subsection{Considerações finais}

Durante o período que coincidiu com a ascensão do nacionalismo árabe, o Líbano assistiu ao maior período de crescimento econômico de sua história no século XX. Com uma

${ }^{463}$ MALLAT. 70 years of money muddling in Lebanon... p. 111 e 114 e Tabela IB da p. 113. 
média de 6\% ao ano na década de 1950 e 4\% na de 1960, o país consolidou-se como o grande centro de serviços e trocas do Oriente Médio, funcionando como um intermediário econômico entre os países árabes e os países capitalistas centrais.

No final da década de 1960, o volume das importações do país chegou a LL1.913,7 milhões, enquanto as exportações chegaram a LL510,3 milhões (ver Tabela 28), sendo a Arábia Saudita e a Síria, com, respectivamente, 14,9\% e 12\% (ver Tabela 24), os maiores importadores de mercadorias fabricadas ou que passaram pelo país do cedro.

Nessa época, bem antes da crise de 1966, os bancos libaneses haviam chegado a corresponder a $7 \%$ da economia nacional, enquanto o comércio representaria 40,6\% (ver Tabela 6), sendo o valor dos serviços vendidos de LL1.164,8 bilhões e das mercadorias LL584,1milhões (ver Tabela 22). Esse crescimento pôde ser sentido no PIB do Líbano, que no Oriente Médio era superado apenas pelos Estados petroleiros, então fortemente ligados à República Libanesa pelo comércio, transporte, finanças, turismo, setor imobiliário e o sistema de educação superior libanês. Aliás, esses vínculos eram consolidados pelas fortes ligações entre as elites sunitas libanesas e as da Península Arábica, as quais envolviam até casamentos e relações de parentesco. Esses vínculos fortíssimos se acentuariam nas décadas de 1970 e 1980, como exemplificam a emigração libanesa para esses países durante a guerra civil de 1975-1990, bem como a visita de Bachir Gemayel à Arábia Saudita pouco depois de se eleito presidente em 1982, na qual foi acompanhado pelo líder sunita Saeb Salam, além do papel do governo Hariri nos anos 1990, quando o governo saudita apareceu como uma das forças políticas externas hegemônicas na sociedade libanesa.

Porém, essa prosperidade não se desenvolveu em um cenário de tranquilidade. Embora as tensões nunca criassem crises suficientemente duradouras ou profundas para fazer o sistema econômico entrar em colapso, houve um clima permanente de tensão, tanto entre o governo e seus adversários. Como, por exemplo, entre muçulmanos e cristãos como resultado da hegemonia destes últimos (particularmente dos maronitas) e de sua maior prosperidade e melhores condições de vida em relação à maioria dos muçulmanos (podemos lembrar que, por volta de 1960, 39\% dos homens muçulmanos no campo eram analfabetos, enquanto para os cristãos na mesma situação esse número era de $23 \%$ e entre as muçulmanas esse número chegava a $69 \%$ - ver tabela 6 ), excluindo nesse aspecto os importantes setores de sua elite, então sócias da burguesia cristã. 
Essa tensão era muito fortalecida pelos acontecimentos e processos do cenário internacional das décadas de 1950 e 1960, como a ascensão do nacionalismo árabe e, particularmente, da figura de Gamal Abdel Nasser, da ação dos governos médio orientais inimigos, como Arábia Saudita e Irã, do permanente conflito árabe-israelense, da presença dos refugiados palestinos no Líbano, que são maltratados e discriminados nesse país, da forte presença norte americana e ainda francesa e britânica no Oriente Médio.

Várias crises de origem interna e externa se sucederam rapidamente nesses anos: a "Revolução das Águas de Rosas", a questão da adesão do Líbano ao Pacto de Bagdá, a crise de Suez, a guerra política entre Chamoun e Nasser, a guerra civil de 1958, que levou à intervenção dos EUA, a tentativa de golpe do PNSS em $1^{\circ}$ de janeiro de 1962, a falência do Intra Bank, o despertar da luta armada palestina e a guerra de junho de 1967, que levou ao fechamento do Canal de Suez, prejudicando assim seriamente o comércio libanês.

Essas crises dividiam a sociedade libanesa. Os muçulmanos apoiavam o campo antiimperialista, os palestinos e o nacionalismo árabe, enquanto os cristãos eram pró-ocidentais, embora não pró-israelenses, como aconteceria mais tarde durante a segunda guerra civil. Isto porque esse Estado era visto como uma ameaça à existência do Líbano, apesar de existirem setores minoritários cristãos - particularmente maronitas - que, movidos por um exclusivismo racista, viam na aliança com o sionismo um meio de combater o nacionalismo árabe e garantir a existência de um Estado cristão como entidade política e militar viável.

Nesse período cabe destacar o mandato presidencial do general Fuad Chehab. Esse descendente dos emires dos séculos XVIII e XIX, embora conservador, anticomunista e defensor do Líbano como entidade política separada da Síria, soube compreender que a existência de seu país somente seria assegurada pela inclusão social da população muçulmana e o reconhecimento de seu valor para a nação libanesa. Ao longo dos seus seis anos de mandato tentou estabelecer a ideia de um acordo entre as comunidades e classe sociais, da qual o seu próprio gabinete multiconfessional era o primeiro exemplo Isso para implantar um sistema de segurança social e promover determinadas políticas de intervenção no sistema econômico que diminuíssem as desigualdades integrasse nacionalmente todas as regiões e buscassem impedir o aparecimento de crises periódicas devido à natural instabilidade do mercado.

No entanto, as elites libanesas não aceitaram e aqui se incluem tanto as cristãs quanto 
as muçulmanas e, por sua vez, muitos cristãos, particularmente os maronitas, se opuseram às políticas de investimento social nas regiões pobres majoritariamente muçulmanas do sul, Bekaa e Akkar, como se fossem uma espécie de "privilégio" ou de postura pró-muçulmana de um Estado que havia sido criado para os cristãos.

Com isso, Fuad Chehab, embora contasse ao logo de todo o seu mandato com a presença do Kataeb ultralibanista de Pierre Gemayel em seu governo, nunca atraiu o apoio da grande massa dos maronitas. No máximo uma aceitação de sua presidência. Seu rival, Camille Chamoun, o herói da "resistência" cristã libanesa contra a "ameaça" nasserista na guerra de 1958, é quem atraía a simpatia dos integrantes da própria comunidade de Fuad Chehab.

Por outro lado, existia uma política repressiva de Chehab em relação aos palestinos, acossados por um forte controle das forças de segurança, que os fazia viver permanentemente em uma situação de ditadura real, na ausência de direitos políticos, econômicos e sociais. Isso somado à constante discriminação por parte dos libaneses cristãos e a nunca reconhecida importância de sua comunidade para o desenvolvimento do país, como provava uma figura das dimensões de Yussef Beidas, provocou um ressentimento e uma alienação em relação ao país. Tal condição foi acentuada pela destruição do Intra Bank de Beidas, que se manifestaria na adesão crescente de sua juventude à luta armada, quer nas fileiras da OLP ou de outros grupos.

A guerra de 1967 acentuou de maneira radical essa tendência e muito contribuiu para dividir a sociedade libanesa. Isto por que os palestinos, cada vez mais autônomos, apoiados pela Liga Árabe e dispostos a recuperar por todos os meios as suas terras, receberam um forte apoio da maioria dos muçulmanos, que identificou na luta dos irmãos palestinos com a sua própria, contra a elite cristã e os defensores do confessionalismo ou da hegemonia cristã (ou particularmente a maronita) dentro do sistema político libanês.

Já os cristãos viram a ação palestina, tanto pelo seu caráter independente em relação ao governo, por seu apoio recebido dos Estados árabes, quanto por provocar retaliações por parte de Israel, uma ameaça à independência ou mesmo à integridade do seu país. Isto além de atiçar a metade muçulmana para que tentasse mudar o sistema ou mudar as relações de poder existentes, assumindo o papel de liderança que muitos cristãos consideravam como natural para as suas comunidades. Por isso ocorreu o apoio crescente a políticos e grupos com discurso cada vez mais extremista, como o Kataeb pós-governo Chehab e o Partido Nacional Liberal de Chamoun. As 
eleições de 1968 mostrariam nas urnas essa postura dos cristãos.

Dessa forma, o Líbano permaneceria até 1975 no padrão que caracterizou a sua história desde a independência: crescimento econômico acompanhado de exclusão das regiões e camadas populares muçulmanas e uma constante tensão política e sectária, agora mesclada ao conflito árabe-israelense. Em 10 de abril as grandes tensões acumuladas finalmente explodiram em um violento conflito, inicialmente maronita palestino e cristão-muçulmano. Essa situação levou a várias invasões estrangeiras, arruinou a economia, as finanças e a sociedade libanesa por quinze anos, acabando com a autoimagem de Suíça do Oriente Médio. 


\section{CAPÍTULO 3}

\section{O governo de Camille Chamoun e a guerra civil de 1958}

Os anos finais do governo el-Khuri foram agitados devido à forte militância da oposição reunida em torno da "Frente Socialista Nacional", uma coalizão frouxa de lideranças políticas de várias tendências, como Kamal Jumblatt, Camille Chamoun, o Bloco Nacional dos Eddés, a Falange de Gemayel e o Najjada muçulmano. Essa frente conseguiu o apoio de muitos setores da sociedade libanesa, enquanto a posição de el-Khuri estava cada vez mais enfraquecida, especialmente após o assassinato de seu ex-primeiro-ministro Riad el-Solh pelos militantes do PNSS. Solh era o responsável pela articulação do presidente com as elites muçulmanas e tinha a capacidade de controlar a população muçulmana. Na sua ausência, a capacidade de manobra de el-Khuri era muito comprometida.

As denúncias de corrupção e o autoritarismo do Presidente estimularam a oposição a organizar manifestações e greves contra ele exigindo a sua renúncia. Para piorar a sua situação um pedido de renúncia também foi formalmente pedido por um grupo de cinquenta deputados no parlamento libanês. Como pesavam contra Khuri inúmeras acusações de nepotismo e corrupção, que marcaram todo o seu mandato, isso levou um grupo de 14 deputados a assinarem uma petição exigindo a renúncia dele.

O seu próprio primeiro-ministro (que no Líbano era nomeado pelo Presidente na época) Sami el-Solh havia acusado Khuri, juntamente com o irmão dele, de comandarem os esquemas de corrupção no governo, o que levou Khuri a demitir Solh. Para enfrentar a oposição, el-Khuri buscou usar o exército para esmagá-la, porém esbarrou na resistência de diversos militares, entre os quais o comandante-em-chefe Fuad Chehab, um membro da antiga família principesca. Ele governou a montanha libanesa nos séculos XVII e XIX. Sem capacidade para enfrentar os seu opositores, o presidente el-Khuri renunciou em 18 de setembro de 1952 no episódio que ficou conhecido como a "Revolução da Água de Rosas", "Revolução Gloriosa" ou "Revolução Branca", por seu caráter não violento ${ }^{464}$.

A queda de Bechara el-Khuri foi o resultado de uma combinação de fatores

464 SALIBI, Kamal S.. The modern history of Lebanon. Westport-Connecticut: Grenwood Press, reimpressão de 1976. p. 194-195; WINSLOW. War and politics... p. 96-97 
domésticos e externos, resultados da conjuntura política do Oriente Médio no começo dos anos 50. Tanto suas posturas políticas dentro do Líbano quanto sua política externa causaram um grande descontentamento em amplos setores das classes dominantes libanesas e nos governos ocidentais, particularmente o dos EUA. No que diz respeito aos norte-americanos, eles estavam insatisfeitos com a política de el-Khuri que, frente a um quadro de antagonismo com a URSS e o seu bloco de países, não comprometia o Líbano com um alinhamento pleno às posições de Washington, o que era considerado por eles como uma ameaça ao conjunto dos seus interesses no Oriente Médio, bem como aos planos de defesa daqueles para essa região ${ }^{465}$.

Essa recusa no alinhamento total era bem exemplificada pelo fato do Líbano se recusar a assinar com os EUA um Tratado de Navegação, Amizade e Comércio, um acordo padrão que os americanos assinavam com os países aliados no pós-Segunda Guerra. Ainda mais porque a assinatura desse tratado implicava abandonar vantagens comerciais do Líbano no Oriente Médio e fazer concessões e privilégios a empresas americanas instaladas no país .

Incomodava também bastante os norte americanos a recusa do presidente libanês em fazer o seu país entrar no Comando de Defesa do Oriente Médio, apesar da grande pressão de Washington e do fato do governo libanês ter apoiado o esforço para se criar essa organização ${ }^{467}$. O resultado disso era que o neutralismo de Bechara el-Khuri foi considerado uma política pró americana insuficiente ${ }^{468}$.

Essa política de el-Khuri desgostava a um número importante de membros das elites libanesas que desejavam ver seu país alinhado com os EUA por conta da afinidade de interesses, apesar de nunca defenderem isso em público. Porém, essa postura levou muitos desses indivíduos a se afastarem do Presidente e a tirar o seu apoio ao governo. O próprio el-Khuri percebeu a influência que sua posição em relação aos EUA causou para o seu governo. Ele afirmou em suas memórias que o fato de ter se recusado a se juntar ao Comando de Defesa do Oriente Médio levou as potências ocidentais a abandoná-lo e como resultado ele foi derrubado pelas pressões

465 ZISSER, Eyal: The downfall of the Khury administration: a dubious revolution. In: Middle Eastern studies, Vol. 30, No 3, Jul. 1994. p. 497

466 GENDZIER, Irene L. Notes from the minefields: United States intervention in Lebanon and the Middle East, 1945-1958. Nova York: Columbia University Press, 1997.1 p.111-112

467 ZISSER, Eyal. The downfall of the Khury administration... p. 494

${ }^{468}$ GENDZIER, Irene L. Notes from the minefields... p.129. 
políticas $^{469}$.

Os norte americanos também mostravam interesse em saber se el-Khuri promovia a estabilidade econômica e social do seu país e se sua política econômica produzia prosperidade. Isso se devia ao fato de que eles se preocupavam com o crescimento e influência do Partido Comunista no Líbano e uma situação de crise, acreditavam os americanos, poderia criar uma situação na qual esse partido poderia atrair amplas parcelas da população libanesa e começar a questionar o status quo libanês. Como o governo el-Khuri foi considerado como responsável por causar instabilidade interna, acabou considerado como inadequado para administrar o seu país ${ }^{470}$. Por isso deram ordens a sua embaixada em Beirute para apoiar as forças de oposição quando elas se mobilizaram, encorajando-as a enfrentar o Presidente. Os britânicos também eram da mesma posição $^{471}$.

A situação conturbada do Oriente Médio também teve grande influência na queda de el-Khuri. Como resultado do trauma da derrota árabe em 1948, os governos responsáveis por esse fracasso perderam apoio e legitimidade em suas sociedades e, até 1955, todos eles havia sido derrubados. Dessa forma, o rei Abdallah da Jordânia foi assassinado em 1951 por um militante palestino e o rei Faruk do Egito foi derrubado pelo movimento dos Oficiais Livres, em julho de 1952, em um processo que levaria ao poder um grupo de militares reformistas e nacionalistas que pretendiam libertar o seu país do subdesenvolvimento e da dependência econômica do Ocidente. O próprio Khuri percebeu o significado desse acontecimento para o seu governo quando disse: "when a minarets fall in Egypt, the lebanese should take care not be hit by its splinters",472.

Por fim, a situação de instabilidade da vizinha Síria trouxe uma série de transtornos para o Líbano entre o fim dos anos 40 e o começo dos anos 50.

Desde que Hosni Zaim derrubou Shukri al-Quwatli, em abril de 1949, a Síria passou a sofrer uma série de golpes de Estado e os governantes que subiam ao poder nesse país costumavam ter atitudes hostis com relação ao Líbano. Com Quwatli e o seu grupo no poder o governo libanês de el-Khuri conseguia dialogar, uma vez que ambos vinham das mesmas

\footnotetext{
${ }^{469}$ KHURY apud ZISSER... p.494.

470 ZISSER... p.494.

${ }^{471}$ ZISSER... p.504.

472 KHURY apud ZISSER... p.495.
} 
camadas sociais, tinham laços de amizade e negócios (e até familiares em certos casos). Mesmo quando havia divergências e desentendimentos ainda havia condições para o dialogo ${ }^{473}$.

Depois da queda de Quwatli isso ficou bem mais difícil. Tal fato se devia aos governos sírios possuírem projetos políticos e econômicos bem distintos dos do governo libanês, pautado mais por um nacionalismo que buscava o desenvolvimento das forças produtivas internas e a independência em relação ao Ocidente. Isso ficou claro no episódio do rompimento da União Aduaneira em 1950. Como a Síria cercava por quase todos os lados o Líbano e como o território sírio era rota de passagem para o interior do Mundo Árabe das mercadorias exportadas pelos libaneses, os desentendimentos entre Damasco e Beirute muitas vezes levavam os primeiros a fechar as suas fronteiras, o que acabava prejudicando a economia libanesa ${ }^{474}$. No caso de Zaim havia até a suspeita de que tivesse apoiado a tentativa dos nacionalistas pan-sírios de derrubarem el-Khuri em 1949.

O surgimento de Israel também pressionava negativamente o Líbano, pois poderia estimular grupos separatistas maronitas a promover o rompimento do Pacto Nacional, o que poderia colocar em xeque a existência do país, bem como criava uma situação de tensão permanente na fronteira sul ( não delimitada por acordos internacionais e que permanecia fechada), já que o Líbano continuava tecnicamente em guerra com o recém-criado estado judeu e temia que ele pudesse tentar se expandir invadindo o território libanês.

Existia também o temor de que Israel pudesse vir a ser um centro econômico dinâmico e dessa forma ameaçar a posição do Líbano inviabilizando o seu projeto de livre comércio. A paralisação da Liga Árabe por conta da guerra de 1948 também deixava o Líbano só para enfrentar a ameaça israelense, fora as pressões dos outros países árabes, a começar pela Síria $^{475}$.

No plano interno Khuri foi perdendo o apoio de amplos setores da opinião pública nacional, apesar dos seus esforços para aparecer como um fundador do Líbano independente. Os setores mais instruídos da população libanesa começaram a ver em el-Khuri um governante que trazia instabilidade para o país e fracassara em resolver os problemas básicos do Líbano. Era

\footnotetext{
473 ZISSER... p. 495.

474 COBBAN, Helena. The making of modern Lebanon. Londres: Hutchinson and Co., 1985. p. 80

475 ZISSER. The downfall of the Khury administration.. p. 495
} 
muito comum no cotidiano libanês o mau funcionamento e a corrupção dos serviços governamentais. Essa situação havia se agravado com a chegada em massa dos refugiados palestinos, que necessitavam de grandes recursos por parte do Estado, uma vez que haviam perdido tudo quando foram expulsos do seu país.

A corrupção em seu governo era outro mal de que muitos libaneses se queixavam tão evidente ela era. Exemplificação dessa corrupção eram os próprios irmãos do Presidente, Salim e Fuad el-Khuri, mas também envolvia os próprios filhos Khalil e Michel. No caso de Salim, ele se aproveitava do fato de seu irmão ser Presidente não apenas para obter ganhos econômicos, mas também para conseguir poder. Dessa forma ele se tornou o "chefão" do partido presidencial, o "Bloco Constitucional", passou a ser o líder do bloco governista no parlamento (controlado após as eleições de 1951) e uma figura muito poderosa no Monte Líbano onde recebia o apelido de "Sultão Salim", prova do tamanho de sua força nessa região.

Salim era tão forte que ele chegava até a controlar a gendarmaria. Esse poder adquirido pelo irmão de Bechara era usado por ele para conseguir mais ganhos econômicos. Tudo isso causava um profundo mal estar que se manifestava em uma série de críticas na imprensa. Para enfrentá-las o governo promoveu campanhas de censura contra jornais e revistas, que publicavam reportagens e artigos criticando o Presidente. Isto se tornou tão comum no Líbano que o país vivia como se estivesse em uma ditadura. Essa perseguição levou à prisão de muitos editores e ao fechamento de diversas publicações. Como resultado, isso jogou uma boa parte da opinião pública liberal contra el-Khuri que era acusado de querer se manter indefinidamente no $\operatorname{cargo}^{476}$.

A crescente concentração de poder nas mãos de el-Khuri, sua família e os indivíduos mais próximos ao poder havia causado consternação em muitos círculos das elites libanesas de modo geral e levou as diversas figuras que haviam participado desse governo a buscar as fileiras da oposição, como foram os casos de Hamid Franjié, Camille Chamoun e Kamal Jumblatt, entre outros.

Muitos desses políticos percebiam que não teriam oportunidade de ter uma carreira mais exitosa ou mesmo chegar aos cargos mais altos do governo se Bechara e o grupo que o cercava se mantivesse indefinidamente no poder. Em especial, Chamoun, Jumblatt e o seu Partido

${ }^{476}$ ZISSER. Idem... p.497 
Socialista Progressivo (PSP) e Raymond Eddé com o seu Bloco Nacionalista foram as figuras centrais da oposição, que se articulou na Frente Patriótica Socialista de oposição a el-Khuri.

Não havia coerência entre eles, pois Chamoun e Eddé eram liberais e representantes das elites mercantis e financeiras, enquanto Jumblatt defendia um governo nacional desenvolvimentista, que priorizasse os setores produtivos da economia e uma política de bem estar social para as camadas mais pobres e as regiões mais desfavorecidas do Líbano.

Havia também, entre os membros menos proeminentes, aqueles que estavam na oposição por ressentimento pessoal contra o Presidente, muitas vezes por não terém conseguido um cargo no governo, como foram os casos de Majid Arslan, rival druso de Jumblatt, e os zu`amas xiitas Adil Osseiran e Sabri Hamade. No entanto, todos compartilhavam uma forte rejeição a el-Khuri e seus métodos ao mesmo tempo em que tinham em vista projetos pessoais como era o caso de Chamoun, que ambicionava se tornar Presidente. Quem também se mostrou insatisfeito foi o primeiro-ministro Riad el-Solh, que via o seu poder diminuir cada vez mais no governo.

Esse conflito entre Solh e o presidente começou pouco antes das eleições de 1951. Para agradar a oposição el-Khuri e os membros do seu circulo interno de poder começaram a sugerir a ideia de que Solh deveria renunciar e em seu lugar ser estabelecido um governo neutro para supervisionar as eleições como havia acontecido em 1943. Com essa medida el-Khuri também apaziguaria os rivais sunitas de Solh e assim impediria que eles se juntassem à oposição. Também com isso se enfraqueceria Solh e o poder estaria mais concentrado nas mãos do Presidente e o seu circulo de familiares e amigos ${ }^{477}$.

Por fim, a situação econômica não era boa. A guerra da Palestina, a pressão econômica dos refugiados, os efeitos da quebra da União Aduaneira com a Síria, principalmente em certos setores da economia e determinadas regiões como Trípoli, a destruição da Palestina - o que levou à perda desse mercado para a indústria e a agricultura - e os efeitos negativos do começo da guerra da Coreia haviam provocado a deterioração da economia. Isso afetou os meios de subsistência da população como um todo. Tal situação, junto com a atuação dos líderes da oposição, fez com que el-Khuri fosse perdendo popularidade até entre os maronitas, que

${ }^{477}$ ZISSER... p.498-500. 
acabaram transferindo seu apoio para o seu rival Chamoun ${ }^{478}$.

Em 1952 a situação de el-Khuri era bem crítica. A oposição se articulava para exigir a sua queda. Greves foram organizadas em vários setores como na companhia telefônica, nas companhias de transporte, na indústria do petróleo e entre os advogados. Até os consumidores de eletricidade organizaram sua própria greve. Os jornais controlados pela oposição começaram uma campanha orquestrada para responsabilizar o Presidente por todos os males e forçar a queda de todo o seu grupo de poder. Sua imagem de "pai fundador da pátria" foi destruída pela feroz campanha de propaganda da oposição. A ação deles levou as elites das várias seitas a duvidar da capacidade de el-Khuri para garantir a estabilidade do país por meio do equilíbrio entre as diversas confissões e assegurar a manutenção da antiga ordem social.

O apoio das embaixadas das potências ocidentais foi um grande estímulo para a oposição. Por fim escândalos e o aprofundamento da crise econômica criaram um clima de desordem pública no país. El-Khuri no fim ainda tentou promover uma coalizão em que entravam nomes da oposição como o liberal Raymond Édde para tentar sobreviver politicamente, mas já era tarde. Também afastou o seu irmão e reorganizou a polícia e a gendarmaria. Até mesmo do PNSS pan-sírio ele tentou se aproximar para evitar o seu fim previsível. Toda ocasião pública, como o aniversário do assassinato de Riad el-Solh, era utilizada pela oposição para atacar o governo e apresentar el-Khuri como um monstro e o único responsável pelos males do país ${ }^{479}$.

Finalmente, por ocasião da renúncia de Sami el-Solh como primeiro-ministro e da greve geral que a oposição organizou para exigir sua queda, el-Khuri se viu forçado a renunciar em 18 de setembro. Uma semana depois, o parlamento elege como Presidente, em 23 de setembro, a Camille Chamoun, o advogado e diplomata que havia se transformado em um político muito popular e fora um dos dois maiores líderes da Frente Socialista Patriótica. A queda de el-Khuri e a eleição de Chamoun, que veio com uma promessa de efetuar reformas, era a vontade das elites libanesas de impedir que o poder político se concentrasse em um pequeno grupo ou líder. E que, por meio de um sistema liberal-representativo, promovesse algumas liberdades, assim como garantisse a harmonia entre as seitas e permitisse a participação, ainda

\footnotetext{
478 ZISSER... p. 497.

${ }^{479}$ ZISSER... p.503-504.
} 
que desequilibrada, quanto à representação das elites de todas a seitas que compunham o país ${ }^{480}$.

Quanto ao novo Presidente, além de ele não pertencer às elites tradicionais, costumava aparecer em público conversando com gente do povo, beijando bebês e cumprimentando senhoras. Dessa forma cultivando uma imagem populista, sendo nessa época popular até entre os muçulmanos. Chamoun também se mostrava contrário aos notáveis e sua influência deletéria no país como a corrupção e o nepotismo ${ }^{481}$. Além do mais, Chamoun fazia pronunciamentos públicos a favor da unidade árabe e ficara conhecido por defender a Palestina e falar em nome dos árabes na ONU em 1947 e 1948 quando correu a partilha desse território entre árabes e judeus e depois a expulsão dos palestinos e fundação do Estado de Israel $^{482}$.

Este fato the granjeou fortes simpatias entre os círculos nacionalistas árabes no Líbano. Por isso no começo de seu mandato Chamoun despertava fortes esperanças de mudança. Por outro lado também foi importante o apoio da Grã-Bretanha (que ainda era a potência hegemônica no Oriente Médio, apesar de já estar em decadência) por meio do embaixador Edwin Chapman Andrews, que chegou a intervir junto aos deputados do parlamento libanês. Isto para que elegessem Chamoun, dos regimes conservadores da região, como a Turquia, o Iraque, a Síria, a Arábia Saudita ou a Jordânia e, internamente, de membros da classe politica muçulmana, bem como das elites cristãs, os verdadeiros responsáveis pelo controle da vida econômica e financeira do país. Chamoun, assim, chegou ao poder com uma base sólida de apoio que lhe permitiu governar sem muitas dificuldades nos primeiros anos de seu mandato ${ }^{483}$.

Tendo sido eleito para promover mudanças, no começo de seu governo Chamoun conseguiu junto com o seu primeiro-ministro Khalid Chehab, um notável sunita que havia sido presidente do Parlamento durante a época do mandato francês, que o parlamento lhe votasse um decreto que lhes davam plenos poderes, por seis meses, para implementar uma série de reformas que tornaram a máquina do Estado mais eficiente e um pouco menos marcada pela corrupção e pelo nepotismo (um problema histórico no Líbano que o regime de el-Khuri havia, em muito, piorado) e melhoraram o sistema eleitoral libanês. Essas mediadas consistiram na demissão de

\footnotetext{
${ }^{480}$ ZISSER... p.508.

${ }^{481}$ GORIA, Wade R. Sovereignty and leadership in Lebanon, 1943-1976. Londres: Ithaca Press, 1985. p. 36.

482 ATTIÉ, Caroline. Struggle in the levant: Lebanon in 1950s. Londres e Nova Iorque: I B Tauris in association with Centre For Lebanese Studies, 2004. p. 45.

${ }^{483}$ ATTIÉ, Caroline. Idem. p. 47.
} 
300 servidores públicos, a emissão de decretos que tornaram o judiciário independente, a promulgação de legislação definindo os deveres administrativos dos servidores e uma nova Lei de Imprensa, que reduziu o controle do Estado sobre essa atividade.

Também houve a introdução de exames civis para os cargos administrativos. No plano eleitoral foi concedido o voto às mulheres, houve a ampliação dos distritos eleitorais de cinco para trinta e três, o Parlamento foi reduzido de 77 cadeiras para 44. Com as duas últimas medidas eleitorais Chamoun buscou reduzir a influência dos notáveis feudais, que poderiam ser um obstáculo à classe dos mercadores e banqueiros que estava em ascensão. Essa última classe, como se verá mais adiante, foi o setor da sociedade libanesa que mais se beneficiou das políticas econômicas liberais de Chamoun, tendo ela sido uma das suas principais bases de apoio. No entanto, o alcance das reformas foi bastante limitado. Um certo número de notáveis rurais continuou a participar ativamente da vida política libanesa por várias décadas e a corrupção continuou a imperar na máquina do Estado.

Em 1955 foram suspensos os exames para os cargos administrativos estatais, sendo que ficou estipulado que, embora os candidatos realizassem uma prova, a decisão final sobre quem ocuparia uma vaga seria feita por indicação, fato esse que na prática manteve o nepotismo e a ocupação de cargos por conchavos políticos, amizade etc. Pressões sectárias estavam por trás dessas medidas, pois nessa época a maior parte da administração do Estado estava em mãos dos cristãos, sendo a comunidade maronita mais beneficiada nesse processo ${ }^{484}$. No fim Chamoun percebeu que era impossível governar sem o apoio e a presença dos notáveis das várias comunidades e vários deles acabaram fazendo parte de seu governo.

Outro grupo de propostas havia sido apresentado por Kamal Jumblatt em um programa de reformas de 10 pontos do governo, da administração publica e da maneira como era gerenciada a economia, que estavam ligados a um projeto do líder druso para conseguir o controle de seis pastas ministeriais. Jumblatt, entre outras exigências, reivindicava a nacionalização de indústrias importantes, a aplicação de um plano de reforma agrária, um programa de segurança social e o uso do excedente dos fundos públicos para projetos econômicos e sociais $^{485}$. Esse projeto foi inteiramente rejeitado por Chamoun, principalmente por

\footnotetext{
484 ATTIÉ, Caroline... p. 53.

${ }^{485}$ HUDSON, Michael C. The precarious republic: political modernization in Lebanon. Nova Iorque: Random
} 
divergências ideológicas em relação ao líder druso ${ }^{486}$.

Por outro lado, já em 1953, diversos políticos e jornalistas criticavam no Parlamento e na imprensa o presidente libanês por não conseguir levar adiante um programa de mudanças para o Líbano, em especial no que se refere à reforma judicial e a promulgação de uma Lei de Prestação de Contas para os serviços públicos em todos os seus níveis ${ }^{487}$. Esses críticos também queriam medidas que combatessem o sectarismo no governo e na administração, promovesse um novo censo e criasse comissões para investigar as fontes de renda de muitos deputados. Ao mesmo tempo, se a lentidão na execução do projeto de reformas pelo governo Chamoun exasperava os setores reformistas, criava tensões com os notáveis tradicionais que viam como uma ameaça as tímidas reformulações postas em prática pelo governo com as lideranças dos grupos sectários muçulmanos, que reclamavam da baixa representatividade de suas comunidades nos cargos administrativos do Estado ${ }^{488}$.

Essas divergências com relação ao programa de reformas, que dificultaram a formação de seu primeiro gabinete,sendo o início de discordâncias profundas entre o presidente e os defensores de um programa de reformas profundas para o Líbano que só acentuou ainda mais com o passar dos anos.

No plano econômico as reformas empreendidas por Chamoun dariam continuidade às políticas liberais de el-Khuri e o Líbano conheceria um grande desenvolvimento das atividades comerciais, bancárias e de serviços de maneira geral. Dessa maneira, portanto, cumprindo o antigo projeto das elites locais de fazerem de seu país um entreposto econômico entre o Oriente Médio (e o Mundo Árabe em particular) e o Ocidente.

Nesse cenário a indústria e a agricultura serão negligenciadas, apesar de Chamoun ter criado em 1954 o Instituto da Indústria em Beirute e de suas afirmações a respeito da importância dos setores produtivos para o desenvolvimento do Líbano. Essa política econômica liberal seria alvo de fortíssimas críticas de diversos setores da oposição, particularmente de Jumblatt e dos membros do seu partido. Ainda mais porque esse desenvolvimento se concentraria

House, 1968. p. 277.

486 WINSLOW. War and politics... p.98; Hudson. The precarious republic: political modernization in Lebanon...p. 277.

487 ATTIÉ. Struggle in the levant... p. 52.

${ }^{488}$ HUDSON. The precarious republic. p. 278. 
principalmente no Monte Líbano e Beirute, regiões onde o governo concentrava os seus investimentos em infraestrutura ${ }^{489}$.

Um segundo programa de reformas apareceria durante o outono de 1954 com o governo, se valendo de um novo período para governar por meio de decretos. Nesse novo programa foram chamados dois especialistas em administração,o da Holanda e dos EUA, para ajudar na elaboração e execução do projeto de reformas. Foi criado um Conselho de Serviço Civil e estabelecidos fundamentos para a instalação de uma escola nacional de administração pública. Entretanto, a implantação ainda mais vagarosa desse segundo programa reformista suscitou críticas ainda mais ácidas contra o governo Chamoun, vindo tanto da esquerda quanto, até mesmo, da direita do espectro político, porém era da oposição que partiam os ataques mais virulentos $^{490}$.

Simultaneamente a essa luta em torno das reformas havia a crescentemente tensa disputa sectária, muitas vezes associada a propostas econômicas ou políticas distintas das seguidas pelo governo. Dessa maneira, no começo dos anos cinquenta havia entre os muçulmanos aqueles que defendiam aprofundar a unidade econômica com a Síria e isso apenas alguns anos após o rompimento da união aduaneira com esse país, por conta das divergências sobre a maneira de conduzir a economia que cada Estado possuía. Essa era a postura de Rachid Karami, filho de um dos arquitetos da independência libanesa, Abdul Hamid Karami, e, portanto, membro de uma das mais importantes famílias sunitas do Líbano.

Karami também era identificado com posições pan-arabistas, implicando em apoio aos países árabes que lutavam por sua independência frente às potências coloniais e que assumiam posturas contrárias à hegemonia dos EUA. Essa atitude de Karami não era algo isolado e estava presente em grande parte da população muçulmana, já no começo dos anos 50. Ao mesmo tempo movimentos e partidos muçulmanos como o Najjadah (partido pan-árabe conservador ligado à comunidade sunita) e Hay'at al-Watania (uma organização de notáveis sunitas) pressionavam por um novo censo, questionando assim a hegemonia cristã-maronita sobre o Líbano ${ }^{491}$.

${ }^{489}$ ATTIÉ, Caroline. Struggle in the levant... p. 52-53.

${ }^{490}$ HUDSON. The precarious republic... p. 280.

${ }^{491}$ Idem. p. 280. 
Essa tensão estava presente também por conta das negociações em curso com a Síria a respeito do acordo econômico e aduaneiro com esse país, cujo resultado foi dividir a sociedade libanesa entre os que são a ele favoráveis e aos contrários, sendo que essa divisão se agrupava de maneira confessional: de maneira geral, os muçulmanos são a ele favoráveis enquanto que os cristãos, particularmente os maronitas e outros uniatas, são contra.

Nesse meio tempo, os sunitas, particularmente os do norte do país, organizaram um congresso islâmico para defender a ideia da união total com a Síria e a condição para a sobrevivência econômica do Líbano. Enquanto isso, os deputados Karami e Husseini enviaram um memorando a Chamoun, solicitando um estatuto de autonomia para a região de Trípoli, além de uma divisão justa das funções do Estado entre as seitas do país e a revisão da constituição no sentido de se abrir a possibilidade da unificação com a Síria. Essas ideias foram difundidas nas mesquitas por todo o país. Já os cristãos fizeram o oposto. Seus líderes políticos e os patriarcas de diversas comunidades vieram a público defender o status quo e recusaram veementemente qualquer mudança na fisionomia do país e o Kataeb organizou um congresso cristão, que contou com a participação dos maronitas, outros católicos, protestantes e até dos ortodoxos.

Essa tensão ocorreu também nas ruas com o enfrentamento entre militantes de diversos partidos, atentados e outros tipos de violência. Também o Parlamento apresentou essas divisões. Em Sidon e no sul foi deflagrada uma greve geral na qual foi pedida a unificação econômica com a Síria e se exigiu que o governo desse atenção à região sul do Líbano, a mais pobre do país, repleta de graves problemas sociais e habitada majoritariamente por muçulmanos, especialmente os xiitas ${ }^{492}$.

Contudo, foi devido à política externa, a partir de 1955, que Chamoun tomou as medidas mais polêmicas, cujas repercussões na sociedade libanesa acabaram tendo uma grande contribuição para a deflagração da guerra civil de 1958. Porém, nos primeiros anos, Chamoun fortaleceu as relações com os regimes árabes vizinhos tanto através do estabelecimento de relações diplomáticas plenas, como por meio de acordos econômicos dentro da Liga Árabe. O que favoreceu a economia libanesa ao garantir o funcionamento de seu modelo de orientação externa baseado no comércio e nas finanças. Publicamente, o Líbano tentou aparecer como

492 HAYEK, Domingo Garí. História contemporánea del Líbano: confesionalismo y política (1840-2005). Santa Cruz de Tenerife e las Palmas de Gran Castilla: Ideal Global, 2006. p. 60. 
árbitro nas disputas interárabes, como a que se desenvolveu entre a monarquia iraquiana e o Egito ou a Arábia Saudita, bem como procurou ter um papel intermediário nas relações entre as potências ocidentais e os países árabes. Como foi o caso da luta egípcia contra a presença britânica no Canal de Suez e o status do Sudão quando os libaneses pediram aos britânicos para abrirem conversações com os egípcios ${ }^{493}$. Como prova dessa política, Chamoun visitou o Cairo em 21 de abril de 1953 quando expressou apoio público às queixas e reivindicações egípcias em relação aos britânicos ${ }^{494}$. Essa política seria mantida com dificuldade até a crise de Suez em 1956 quando as atitudes libanesas frente à Grã-Bretanha e França, países que atacaram o Egito, levaram ao rompimento e ao enfrentamento entre os governos de Beirute e Cairo.

Na realidade, a política de Chamoun se caracterizou pelo abandono do chamado neutralismo, característico do mandato de Bechara el-Khuri, e buscaria o alinhamento incondicional do Líbano aos EUA e o bloco ocidental no cenário da Guerra Fria dos anos 50. Já no começo de seu mandato Chamoun demonstrou por meio de contatos diplomáticos e declarações em privado para autoridades europeias e americanas o posicionamento pró-ocidental de seu governo. Dessa forma ele chegou a afirmar até mesmo que colocaria portos e aeroportos do seu país a disposição dos EUA, no caso de uma guerra com a União Soviética, ${ }^{495}$ e tentaria com essa posição obter um acordo de assistência militar tanto com os britânicos como com os americanos. Ainda em 1953 os americanos ofereceram uma ajuda econômica de 6 milhões de dólares, o que era uma prova da fidelidade do regime Chamoun ${ }^{496}$. Nessa época Chamoun também estreitou as relações diplomáticas com os sauditas, aliados estratégicos dos norteamericanos, o que foi bem visto em Washington ${ }^{497}$.

A postura pró-americana de Chamoun esteve evidente também em sua política com relação às empresas petroleiras americanas que controlavam a refinaria de Trípoli e estavam construindo a de Sidom, bem como controlavam os oleodutos que vinham do Iraque e da Arábia

493 ATTIÉ. Struggle in the levant... p.78.

494 QALAWOUN, Nasser M. The struggle for Lebanon: a modern history of Lebanese-Egyptian relations. Londres e Nova Iorque: I B Tauris publisher, 2000. p. 7.

495 CHAMOUN apud GENDZIER, Irene L. Notes from the minefields: United States intervention in Lebanon and the Middle East, 1945-1958. Nova Iorque: Columbia University Press, 1997. p. 145. ATTIÉ, Caroline. Struggle in the levant: Lebanon in 1950s... p. 8.

${ }^{496}$ TRABOULSI, Fawwas A history of modern Lebanon. Londres e Nova Iorque: Pluto Press, 2007. p.130.

${ }^{497}$ GENDZIER, Irene L. Notes from the minefields: United States intervention in Lebanon and The Middle East, 1945-1958. Nova Iorque: Columbia University Press, 1997. p. 171. 
Saudita.

Embora as propostas em curso não incluíssem a nacionalização das companhias de petróleo, eram grandes as críticas aos enormes lucros que essas empresas adquiriam na venda para a Europa e América do Norte do petróleo e também no mercado libanês que, por sua vez, era dominado por três grandes firmas: a Socony-Vacuum, a Shell e a Esso. Muitos políticos libaneses pediam uma partilha dos lucros obtidos por essas multinacionais através, principalmente, do trânsito do petróleo pelo território e portos do Líbano.

Nesse contexto, um dos principais críticos dessas companhias era o líder druso Kamal Jumblatt, que fazia parte do primeiro gabinete de Chamoun, que exigia uma melhor partilha dos lucros das atividades de trânsito pelo território libanês. Porém, os americanos pensavam que Jumblatt queria nacionalizar as companhias de petróleo, já que no programa de seu partido havia a proposta de nacionalizar as empresas francesas de serviços públicos e gravações obtidas pelos serviços de espionagem das empresas de petróleo teriam descoberto que as intenções do líder druso seria realmente a nacionalização ou ao menos aumentar o valor pago pelas companhias de petróleo ao Estado libanês. Comprometido como estava com os EUA, Chamoun acabou ficando do lado das multinacionais petroleiras. Essa atitude, mais o abandono das propostas da Frente Socialista e a recusa em processar Bechara el-Khuri, fizeram com Jumblatt saísse do governo e entrasse para a oposição onde, como foi dito mais acima, tornou-se um feroz crítico do governo Chamoun ${ }^{498}$.

\subsection{O pacto de Bagdá}

Como consequência de sua postura pró-ocidental, o Líbano foi o primeiro país a ser convidado a ser juntar ao pacto firmado entre Iraque e Turquia no dia 13 de janeiro de $1955^{499}$.

\footnotetext{
498 GENDZIER, Irene L. Notes from the minefields... p. 163-166.

499 Na verdade, em 1954, quando Paquistão e Turquia assinaram um acordo de cooperação militar, que seria o embrião do futuro Pacto de Bagdá, o Líbano já começou a sofrer pressões para se somar ao acordo. Simultaneamente os EUA pressionavam o país para que reconhecesse Israel. Essa pressão vinha acompanhada de atentados e a promoção da desestabilização por parte dos israelenses contra o país. Esses temas têm forte impacto sobre a sociedade libanesa. Esta, em sua grande maioria, rechaça qualquer acordo de paz com os sionistas, bem como a incorporação do país em acordos militares promovidos pelo Ocidente. Naquele momento o governo libanês aproveitou a situação para pedir à Liga Árabe uma diplomacia comum para que os árabes pudessem se defender da pressão diplomática ocidental e formulassem uma política de defesa comum. Todavia, nos meios políticos a ação do governo não era unânime. Determinados grupos como o Najjadah sunita, o PSP e a União dos Jovens Muçulmanos
} 
Como o Egito imediatamente se opôs a esse pacto que fora percebido pelo Cairo como um movimento contra a revolução egípcia, Chamoun em resposta recusou-se a entrar nessa aliança afirmando que primeiro preferiria consultar os membros da Liga Árabe antes de tomar uma posição. Sua política visava, em um primeiro momento, a evitar um enfrentamento com o regime nacionalista egípcio. Um segundo pedido foi realizado em abril com o governo libanês, também recusado 500 .

No entanto, como prova da inclinação do governo libanês em relação a essa aliança, Chamoun nessa época viajou à Turquia com o seu primeiro-ministro al-Solh e, em junho, o Presidente turco Celal Bayar e o primeiro-ministro Adnan Menderes foram a Beirute em retribuição a visita dos líderes libaneses ${ }^{501}$. Rapidamente esse acordo se ampliou ao se juntarem Paquistão, Irã e Grã-Bretanha, com os EUA patrocinando e se envolvendo em suas operações, assistindo às suas reuniões como observador, mas sem fazer parte formalmente, embora no início os líderes estadunidenses vissem o Pacto de Bagdá como um projeto que deveria servir exclusivamente aos interesses britânicos no Oriente-Médio ${ }^{502}$. Essa aliança adotou o nome de Organização do Tratado Central (Central Treaty Organization - CENTO em Inglês). No quadro mais amplo da Guerra Fria ela deveria ter um papel semelhante ao da OTAN na Europa como uma força militar de contenção da URSS, de aliados dela que pudessem surgir no Oriente Médio e da influência comunista nessa região.

A formação desse pacto também acabou estando ligada à estratégia americana de garantir o controle das imensas jazidas de petróleo da região, particularmente daquelas nas terras em torno do Golfo Pérsico, que eram consideradas essenciais para as economias dos países ocidentais e de membros da OTAN como a Turquia. Sendo que essas reservas na época eram estimadas entre 100 e 150 milhões de barris, cerca de três a cinco vezes maiores do que as

rechaçaram qualquer aliança militar com os países imperialistas ocidentais. Já as Falanges se dirigiram publicamente a Chamoun se oferecendo para combater qualquer ato subversivo e afirmaram que respaldavam qualquer política de aproximação com o Ocidente. Como todas as questões em disputas na sociedade libanesa da época, essa também gerou confrontos e mortes nas ruas do país como foram os confrontos ocorridos entre os estudantes e a polícia na metade daquele ano que terminaram com dois estudantes mortos e 36 feridos, dos quais 24 eram policiais. Os estudantes da UAB (Universidade Americana do Líbano) estavam na liderança dessas várias manifestações contra as pressões sofridas por seu país para se ajustar às políticas ocidentais para o Oriente Médio da época. HAYEK. p. 6465.

500 QALAWOUN, Nasser M. The struggle for Lebanon... p. 10.

501 GENDZIER, Irene L..Notes from the minefields... p.207.

502 ATTIÉ, Caroline. The struggle in the lervant... p. 75. 
reservas americanas nos anos cinquenta.

Eram grandes os temores dos norte-americanos que esta região - ou uma parte importante dela - saísse da órbita ocidental por meio de algum processo revolucionário ou pela subida ao poder de um governo nacionalista ou de esquerda nos poucos países onde existiam eleições. Em um documento do governo americano escrito para o presidente do Estado-Maior Conjunto por Alfred Johnson - o subdiretor para assuntos logísticos do Estado-Maior -, pode-se perceber essa preocupação pois, além de explicitamente dizerem que os países da Aliança Ocidental dependiam por volta de $90 \%$ do seu fornecimento de petróleo de entregas vindas do Oriente Médio, afirmavam:

\begin{abstract}
As there are already substantial communist elements in Syria, Iraq and Iran, any expansion of communist influence into Saudi Arabia could, if properly organized and with concentred actions in the other areas, disrupt the flow of oil to Western Europe through strikes, sabotages and political action, and create havoc with the supply and economy of Western Europe ${ }^{503}$.
\end{abstract}

Dentro desse quadro, o Líbano, embora fosse pequeno e sem recursos naturais importantes, tinha um papel estratégico, seja por conta de seus vínculos econômicos com os outros países árabes, como a Arábia Saudita e o Kuwait, ou por conta de sua posição geográfica, seus portos e o aeroporto de Beirute. Porém, dentro da estratégia americana a segurança das redes de comunicação da região caberia aos governos locais que receberiam para isso assistência técnica e econômica das potências ocidentais ${ }^{504}$. Por conta disso, desde antes da formação do Pacto de Bagdá e do conflito com o Egito, quando Nasser ainda era cortejado pelos líderes das potências ocidentais, Chamoun já manifestava aos britânicos a sua vontade de servir aos interesses ocidentais. Já em setembro de 1952 ele fez essa proposta ao embaixador britânico em troca da ajuda de Londres para modernizar o exército libanês ${ }^{505}$.

Em resposta ao aparecimento do Pacto de Bagdá, Nasser criou uma outra aliança, o Pacto Tripartite Árabe, em 2 de março de 1955, que englobava o Egito, a Síria e a Arábia Saudita. Os dois últimos Estados, mais o Iêmen, haviam publicamente condenado a formação da Aliança

\footnotetext{
503 GENDZIER. Notes from the minefields... p. 207.

${ }^{504}$ GENDZIER. Idem. p.207.

505 ATTIÉ. The struggle in the lervant... p. 77.
} 
entre Bagdá e Ancara. Para o líder egípcio o Pacto de Bagdá era uma maneira dos britânicos manterem a sua hegemonia no Oriente Médio após a descolonização dessa região, e isso era ainda mais grave pelo fato de que o Canal de Suez ainda permanecia sobre o controle de Londres, com quem eles haviam acabado de assinar um acordo de evacuação das tropas britânicas em novembro de 1954. Por conta disso, os egípcios recusaram um convite feito pelo próprio primeiro-ministro britânico Anthony Eden, em uma visita ao Cairo, em fevereiro, para que o seu país se juntasse a essa aliança. O Pacto Árabe de Nasser lutava contra esses planos britânicos através de uma estratégia de não-alinhamento e do neutralismo. O que seria reforçada internacionalmente por meio de sua exitosa participação na Conferência de Bandung, que o projetou como grande liderança do recém-formado Terceiro Mundo e onde estavam presentes lideranças importantes da época como Tito e Nehru, que manifestaram seu apoio às posições do Rais egípcio ${ }^{506}$.

O Líbano nesse contexto permaneceu fora do Pacto de Bagdá, mas manteve boas relações com a Turquia (que além do mais acabara de entrar para a OTAN, a aliança militar ocidental comandada pelos EUA em 1955) afirmando atuar como um intermediário entre esse país e o Mundo Árabe, assim como com o Iraque. Em uma declaração pública, o presidente libanês assim se referiu ao Pacto de Bagdá:

Le Pacte de Bagdad, utile, peut-être, à la defense des frontiers setentrionales de l'Trak, ne m'avait inspiré aucun intérêt particulier. Je souhaitais cependant voir les Arabes sortir du cercle étroit dans lequel ils continuaient du vouloir s'enfermer, et s'ouvrir à la cooperation politique et militaire avec des etats voisins tels que le Pakistan, 1'Iran et la Turquie $^{507}$.

A atitude de desconfiança com Líbano aumentou devido à posição que Chamoun tomou em relação ao episódio do assassinato do coronel sírio Adnan Malki em 22 de abril, o mais importante oficial baathista pró-Nasser de seu país, por um militante do PNSS, um partido contrário ao pan-arabismo do líder egípcio. O presidente libanês deu asilo aos militantes desse partido, que passaram a ser perseguidos na Síria por conta do assassinato de Malki, tendo recusado pedidos de extradição do governo sírio para líderes desse partido acusados de serem os

\footnotetext{
506 ATTIÉ. Idem. p.75-76.

${ }^{507}$ Fala de Chamoun em Seale, PATRICK apud HUDSON . p. 282.
} 
mandantes do crime contra o coronel sírio. Para a maioria dos atores políticos da época essa atitude de Chamoun se deu principalmente por conta da convergência não-assumida publicamente entre ele e o PNSS a respeito do nasserismo ${ }^{508}$.

Como consequência das atitudes suspeitas e das posições oficialmente ambíguas de Chamoun, mas que denunciavam uma oculta inclinação pró-ocidental, o Líbano foi alvo de forte desconfiança por parte dos países do Pacto Tripartite Árabe, que chegaram até a ameaçar romper relações ou impôr sanções econômicas caso Beirute entrasse para a CENTO. Isto, mais a pressão da oposição, fizeram com que o Líbano continuasse mantendo relações diplomáticas com o Egito e procurasse manter publicamente, ainda que em uma situação cada vez mais precária, a política oficial de neutralidade no Oriente Médio. Ainda em 1955, para não aparecer como antiegípcio ou antiárabe, o governo libanês chegou a assinar em 1 de setembro um acordo no qual os dois países deveriam trocar informações e se reunir conjuntamente para comentar sobre política externa, defesa, segurança e até comércio ${ }^{509}$.

No entanto, nesse período, as conversações diplomáticas mantidas entre os governos egípcio e libanês a respeito do Pacto de Bagdá e da política em relação ao Ocidente só reforçaram o progressivo afastamento entre eles, tornando-se impossível estabelecer qualquer tipo de compromisso entre essas nações, pois Chamoun deixava claro sua posição mais pró-ocidental. Em um memorando escrito enviado a Nasser, o presidente libanês chegou até mesmo a comentar a respeito das supostas vantagens de fazer parte de uma aliança militar ocidental e dos custos que causava uma política de isolamento ${ }^{510}$.

Nessa época os egípcios começaram a buscar aliados dentro da sociedade libanesa e enviaram uma série de agentes a partir de 1954 para estabelecer aliança com eles. Rapidamente encontraram apoio em amplos setores da parcela muçulmana da sociedade libanesa, que era receptiva à mensagem anti-imperialista e de justiça social de Nasser, reconhecendo o presidente egípcio como o líder legítimo dos povos árabes. No campo político, os apoiadores de Nasser eram principalmente políticos de oposição como Kamal Jumblatt e mais tarde os notáveis sunitas

\footnotetext{
508 BESHARA, Adel. Lebanon: the politics of frustration - the failed coup of 1961. Londres e Nova Iorque: Routledge-Taylor and Francis Group, 2005. p.39. HUDSON. The precarious republic: political modernization in Lebanon. p.283.

${ }^{509}$ Qalawoun, Nasser M. The struggle for Lebanon... p. 12.

${ }^{510}$ ATTIÉ. Struggle in the levant... p. 76.
} 
como Saeb Salam, Abdalla al-Yafi e Rachid Karami que, embora nem sempre apoiassem todos os aspectos da política nassserista, perceberam que não sobreviveriam politicamente caso não mostrassem simpatia ao líder egípcio que era adorado pela população muçulmana. Quase todos os mais importantes políticos muçulmanos realizaram visitas ao Cairo e se posicionavam publicamente contra a adesão do Líbano ao Pacto de Bagdá e ao alinhamento de Chamoun ao Ocidente, enquanto defendiam a causa da unidade árabe e a luta contra o domínio ocidental e a independência dos países árabes que ainda eram colônias ou protetorados dos europeus ${ }^{511}$.

Também uma parcela importante dos meios de comunicação libaneses, e mesmo da intelectualidade, se aproximou dos egípcios. Esses grupos passaram a defender a política de Nasser e a criticar os seus inimigos no exterior e as forças que, dentro do Líbano, se opunham ao programa do líder egípcio ou defendiam o alinhamento incondicional ao Ocidente e, mais tarde, a política externa de Chamoun. Essa imprensa nasserista teve fortes contatos diplomáticos com o governo do Cairo e passou a receber financiamento dele via embaixada egípcia em Beirute.

Vários dos donos desses jornais chegaram a viajar à capital egípcia para se encontrar pessoalmente com o próprio Nasser. Entre os jornais pró-egípcios temos o Beirut al-Massa, o alSyassa do ex-primeiro-ministro Abdallah al-Yafi, o Sawt Al’Urubah, do partido islâmico Najjadah, e o Dar al Sayad ${ }^{512}$. Além dos egípcios, nessa época também os sauditas passaram a comprar jornalistas para defender posições contrárias ao Pacto de Bagdá. Segundo um relatório de inteligência do Departamento de Estado, o ex-primeiro-ministro Hussein al-Uweini teria recebido 16 mil dólares por mês para influenciar a imprensa libanesa e outros 150 mil dólares seriam usados para subsidiar jornais tanto no Líbano quanto na vizinha Síria ${ }^{513}$.

O apoio da imprensa libanesa era importante não apenas para se conseguir o apoio popular dentro do Líbano, mas também pela influência que essa imprensa tinha no Mundo Árabe, pois os seus jornais eram lidos do Atlântico até o Oceano Índico. Aliás, durante todo o período de 1950-1970 e também até os dias de hoje, o Líbano foi palco da guerra midiática entre os diversos regimes árabes rivais que se aproveitavam da existência de liberdade de imprensa no Líbano para difundir os seus projetos políticos e combater os seus rivais.

\footnotetext{
511 QALAWOUN. The struggle for Lebanon... p. 14-16.

512 QALAWOUN. Idem. p. 91-92.

513 ATTIÉ. Struggle in the levant... p. 82.
} 
Internamente, a pressão da oposição a Chamoun crescia e esta assumia cada vez mais posições contrárias ao Pacto de Bagdá e à atitude oficialmente neutra do governo que para eles, da mesma maneira que para Nasser, escondia uma inclinação pró-ocidental do Presidente. Por isso, quando Chamoun voltou de sua viagem à Turquia (que aconteceu às vésperas da Conferencia de Bandung) em abril, quatro importantes notáveis muçulmanos, Saeb Salam, Abdallah al-Yafi, Sabri Hamadeh e Ahmad al-Assad, boicotaram a cerimônia de retorno do Presidente $^{514}$. Também, ao longo de todo esse período, manifestações eram organizadas por todo o país por importantes políticos muçulmanos e movimentos, como o dos estudantes universitários, enfrentando proibições do governo e contando com a presença de muitos populares. Nessas manifestações ocorriam choques com a polícia que em certos casos atiravam contra os manifestantes - mesmo em frente de instituições como a Universidade Americana de Beirute - causando mortes e inúmeros feridos ${ }^{515}$.

Nessa época, um dos mais importantes nomes da oposição, Rachid Karami, além de defender a posições de Nasser publicamente também desejava que o Líbano promovesse um acordo militar com a Síria. Outro importante político libanês que se destacaria como um dos principais nomes da oposição foi Kamal Jumblatt que, em 1955, apareceu como liderança destacada da Conferência Nacional dos Partidos Libaneses, uma coalizão de partidos e movimentos libaneses de oposição formada em 1954 e que nos anos seguintes se posicionariam contra o Pacto de Bagdá ${ }^{516}$.

Com relação ao seu próprio grupo político, o PSP, Jumblatt e o seu partido organizaram um congresso nacional, para o qual convidaram associações de mulheres, organizações estudantis e sindicatos operários para se unir e pedir ao governo que condenasse o Pacto de Bagdá. Ele afirmava que a posição de neutralidade em relação a tal pacto era uma traição à causa árabe e um perigo para o país, pois o colocava sob a sombra do imperialismo ocidental $^{517}$. Ao mesmo tempo, diante da agitação da esquerda e dos pan-arabistas, a direita cristã, liderada pelo Kataeb de Gemayel, aceitou a proposta de neutralidade e o realinhamento com o Ocidente em nome do anticomunismo. Receberam pelo mesmo motivo o apoio do idoso

\footnotetext{
${ }^{514}$ HUDSON. The precarious republic... p. 283.

515 TRABOULSI, Fawwaz. A history of modern Lebanon. Londres: Pluto Press, 2008. p. 131.

516 ATTIÉ. Struggle in the levant... p. 83.

${ }^{517}$ HAYEK. História contemporánea del Líbano... p. 60.
} 
patriarca Antun Arida ${ }^{518}$.

Diante do risco que implicava um confronto aberto com a oposição, o Presidente libanês começa a colocar em seu gabinete indivíduos que se mostravam publicamente simpáticos em relação ao Egito. Dessa forma, em julho, entregou a pasta das Relações Exteriores a Hamid Frangié, antigo notável maronita do norte do Líbano, mas que acabou renunciando em setembro. Enquanto esteve no cargo Hamid Frangié promoveu um acordo informal com Nasser contra pactos militares imperialistas ${ }^{519}$. Em 19 de setembro, Chamoun realizou uma grande manobra política, visando conter a pressão da oposição ao escolher como primeiro-ministro Rachid Karami, em substituição ao mais pró-ocidental Sami al-Sulh (ele contava com a simpatia da embaixada americana).

Durante todo esse processo o Presidente libanês recebeu o apoio (nunca tornado público) das embaixadas americana e britânica, que buscavam mantê-lo em sua orientação próocidental, apesar das pressões internas que recebia e em seus comunicados internos, mostrando preocupação em relação ao futuro dos seus interesses no Líbano e no Oriente Médio com a crescente agitação política libanesa, bem como com a saída do governo de políticos comprometidos com os países ocidentais e sua geopolítica e suas multinacionais ${ }^{520}$.

Karami buscaria seguir os princípios da oposição e por isso seguiu os passos de Hamid Frangié, só que com muito mais desenvoltura por ser primeiro-ministro. Dessa maneira reafirmou o acordo não-escrito realizado com Nasser e se esforçou por assinar um acordo militar com a Síria, demonstrando simpatia pelo eixo Cairo-Damasco-Riad. Esse acordo era desejado por setores das elites muçulmanas por conta da necessidade de defesa do Líbano contra as consequências da aplicação dos planos israelenses de desviar as águas do rio Jordão.

Para discutir essas questões e buscar forjar uma aliança o chefe de governo sírio, Said al-Ghazi, foi a Beirute em fevereiro de 1956. Porém desconfianças dos líderes libaneses incluindo o próprio Karami - fizeram com que esse acordo não fosse assinado, pois se temiam as consequências para o Líbano da presença em seu território de soldados sírios ${ }^{521}$. Porém, devido a

\footnotetext{
518 IDEM. p. 60.

${ }^{519}$ HUDSON. The precarious republic: political modernization in Lebanon... p. 283-284.

520 ATTIÉ. Struggle in the levant... p. 84.

521 Malsagne, Stephane: Fuad Chehab,1902-1973-Une Figure Oubliée de 1'Histoire Libanaise. Karthala-Paris e
} 
essas políticas assumidas por Karami, o primeiro-ministro não contaria com o apoio do Presidente que buscou preencher o seu gabinete com políticos conservadores para assim tentar neutralizar Karami e fez declarações públicas negando qualquer desejo de fazer o Líbano assinar acordos que pudessem ir contra os interesses de outros países árabes, como o Iraque. Posteriormente manobras realizadas por Chamoun com os seus seguidores no governo em janeiro fragilizaram a posição do líder tripolitano, até que em março ele acabou renunciando junto com o seu gabinete ${ }^{522}$. Em seu lugar foram colocados dois líderes sunitas rivais: Abdallah al-Yafi e Saeb Salam.

Já dentro da sociedade libanesa se verificou uma crescente e cada vez mais rígida divisão em sua população, que viria a ser nos anos seguintes uma das causas da guerra civil de 1958: o apoio a Nasser e ao pan-arabismo partiria, em grande parte, dos muçulmanos e drusos, que já portavam em suas casas, lojas e veículos retratos de Nasser que eram distribuídos pela embaixada egípcia, enquanto que a maioria dos cristãos, independente de sua condição socioeconômica, apoiaram as políticas de Chamoun, se opondo até mesmo a uma política neutralista no cenário internacional da época.

Por outro lado, entre as elites, particularmente a do mundo dos negócios, essa divisão era menor, pois tanto a burguesia mercantil e financeira cristã, quanto a muçulmana, era antipática em relação a Nasser por conta de sua cada vez maior aproximação com os soviéticos e os demais países comunistas. Como ficou demonstrado pelo episódio da compra de armas da Tchecoslováquia e de sua política econômica cada vez mais intervencionista nos negócios das elites egípcia. Mesmo assim, existiam importantes membros dessa comunidade de negócios que se aproximaram de Nasser por perceber sua influência sobre as camadas populares de sua comunidade apesar de defenderem o regime laissez-faire libanês como foi o caso de Saeb Salam que além de um importante político (havia sido primeiro-ministro em 1952 e em 1953, desta vez durante o governo Chamoun) era um grande empresário dono da empresa aérea Middle East Airlines $(\mathrm{MEA})^{523}$.

IFPO-Beirute,2011. p. 155

${ }^{522}$ HUDSON. The precarious republic: political modernization in Lebanon... p. 285-286

523 ATTIÉ. The struggle in the levant... p. 102. 


\subsection{A crise de Suez}

Em novembro de 1956, os eventos da crise da nacionalização do Canal de Suez, realizada em junho pelo governo Nasser, levaram a uma enorme hostilização entre os governos do Egito e do Líbano, seguida do alinhamento público deste em relação aos EUA e uma aberta hostilidade entre os Presidentes de ambos os países, que culminou em 1958 no apoio de Nasser aos rebeldes que tentavam derrubar Chamoun. Isso tudo ocorreu devido à atitude do governo libanês frente à Grã-Bretanha e França, países que, juntamente com Israel, haviam atacado o Egito naquele momento. Embora o governo libanês tenha condenado o ataque, sediado uma reunião de emergência da Liga Árabe em Beirute e tomado medidas simbólicas, como impedir os navios britânicos e franceses de transportar petróleo desde os portos do Líbano, ele se recusou a romper relações diplomáticas e comerciais com esses dois Estados como certos países árabes haviam feito.

Na reunião de cúpula da Liga Árabe, que ocorreu entre 13 e 15 de novembro, havia sido decidido que os seus membros deveriam atuar em solidariedade ao Egito como maneira de se condenar os imperialismos francês e britânico, mas não foi decidido o rompimento diplomático com Londres e Paris e se resolveu buscar um cessar-fogo patrocinado pela ONU a ser implementado no Sinai e na Zona do Canal de Suez ${ }^{524}$. A Conferência também havia estabelecido, de acordo com a carta da ONU em seu artigo 41, a necessidade de se aplicar sanções econômicas à França e à Grã-Bretanha como os Estados que haviam cometido uma agressão armada a um Estado soberano. Mas o governo libanês fez de tudo para não aplicá-las, procurando desviar o assunto ao abordar a necessidade de se exigir uma retirada imediata de Israel do Sinai ${ }^{525}$. Enquanto isso a ONU aplicava um plano de cessar-fogo para a Zona do Canal de Suez e a região do Sinai, que foi aceito pela Liga Árabe, sendo que esta via como positiva a participação das Nações Unidas para a resolução da crise ${ }^{526}$.

A recusa de Chamoun em romper relações diplomáticas com os britânicos e franceses mostrava o seu alinhamento político com o Ocidente, mesmo em um caso grave de agressão como esse, e os fortes vínculos econômicos mantidos com esses países e essenciais para a

\footnotetext{
524 ATTIÉ, Caroline. The struggle in the levant... p. 104.

525 TRABOULSI, Fawwaz. A history of modern Lebanon... p. 131.

526 ATTIÉ. The struggle in the levant... p.104.
} 
economia nacional. Esta atitude do Presidente libanês, levou de imediato à renuncia de membros do governo como o primeiro-ministro Abdallah al-Yafi e o ministro de Estado para Negócios Petrolíferos Saeb Salam, que entraram para as fileiras da oposição ${ }^{527}$. Essa queda, embora a primeira vista parecesse um golpe para Chamoun, acabou sendo no final uma espécie de vitória, pois segundo Hudson (290) isso enfraqueceu fortemente a facção pró-Cairo no governo com um mínimo de tensão. Porém, por outro lado, revelou publicamente a sua posição, o que impedia o Presidente de buscar um compromisso com a oposição, o que levou a um forte crescimento da tensão política no país já nos meses seguintes.

A ação de Chamoun não foi exatamente isolada dentro do Mundo Árabe, pois apenas a Síria e a Arábia Saudita, aliadas do Egito, romperam relações com Londres e Paris. O Iraque e a Jordânia apenas romperam relações com a França e não com o seu patrono britânico. Era, no entanto, a menos dura em relação aos governos britânico e francês. Quatro anos depois Chamoun, agora um ex-Presidente, em uma entrevista procurou justificar a posição assumida a respeito das relações com os países que atacaram o Egito. Dizendo que, se rompesse as relações, não poderia atuar como um intermediário entre Nasser e os anglo-britânicos. Nessa perspectiva ele declarou:

I did what I could do and able less than forty-eight hours later to give him good News about cease-fire. Well, this is the proof that it has never been either in Nasser mind's or my mind that diplomatic relations would be cut off. Otherwise, how could you cut off diplomatic relations and still intervene with these two nations? ${ }^{528}$.

Porém, não foi assim que Nasser compreendeu a posição tomada por Chamoun. Em uma fala pronunciada no Cairo, dois anos após a crise de Suez, o Rais egípcio assim se referiu à atitude do Presidente libanês: "The rulers of Lebanon stabbed us in the back during our time of stress, at the time when Britain, France and Israel were attacking us ${ }^{\text {"529. }}$

Apesar disso, do lado egípcio, eles no calor da guerra mantiveram relações com o regime de Chamoun, enviando o famoso jornalista egípcio Mustafa Amin como emissário, como forma de manter um canal de contato aberto com o Ocidente. Todavia, os egípcios rapidamente o

\footnotetext{
${ }^{527}$ ATTIÉ. Idem. p. 104.

${ }^{528}$ GENDZIER. Notes from the minefields... p.214-215.

${ }^{529}$ AGWAMI apud ATTIÉ. p.104.
} 
perceberam como um inimigo no curso dos eventos da crise de Suez, por conta das políticas que adotou. De imediato os egípcios, para mostrar sua oposição às medidas de Chamoun, retaliaram o governo de Beirute impedindo por algum tempo a entrada em seus aeroportos de aviões libaneses. O conflito de Suez terminou com ambos os governos se hostilizando, apesar de que nenhum dos dois lados tentasse romper totalmente as relações diplomáticas, retirando os seus embaixadores. ${ }^{530}$

Por fim, para piorar a sua situação em relação aos egípcios, Chamoun durante a crise de Suez realizou uma visita a Reza Pahlevi, no Irã, um inimigo do pan-arabismo, para conversarem a respeito da situação no Oriente Médio ${ }^{531}$. Apesar da posição que Chamoun tomou em relação a Londres e Paris, ele condenou o ataque ao Egito, da mesma maneira que havia defendido a ação egípcia de nacionalizar o canal de Suez e tentado buscar apoio para a ação de Nasser entre governos não-árabes da região. Como foi o caso dos turcos (então recém-admitidos à OTAN), no qual havia sido despachado o prefeito de Beirute para conversar e conseguir o apoio do primeiro-ministro Menderes ${ }^{532}$. Todo esse esforço diplomático era para que o governo de Chamoun não aparecesse como antiárabe e pró-imperialismo ocidental frente à opinião pública árabe e muçulmana libanesa e também para tentar diminuir a pressão egípcia.

No entanto, como resultado de todos esses acontecimentos o Presidente libanês, em resposta às pressões egípcias e internas, terminou montando um gabinete novo no qual colocou como ministro das Relações Exteriores a Charles Malik. Uma figura conhecida por seus pontos de vistas pró-ocidentais e chamou de volta, como primeiro-ministro, Sami el-Sulh que, como já foi dito mais acima, tinha inclinações ocidentais embora moderadas. Também incluiu em seu novo gabinete, como ministro da Defesa, ao general Fuad Chehab-o chefe das forças armadas, com quem tinha discordâncias ideológicas e havia tido sérios atritos nos anos anteriores a respeito da resolução de pequenos conflitos armados internos libaneses ${ }^{533}$. Este ficou pouco até a

\footnotetext{
${ }^{530}$ QALAWOUN, Nasser M. The struggle for Lebanon... p. 25-26.

531 TRABOULSI. A history of modern Lebanon... p. 131.

532 QALAWOUN. The struggle for Lebanon... p. 24-25.

533 Essas crises internas menores foram, em 1954, a luta tribal que opôs a tribo Dandach da região do Hermel (extremo leste do Líbano) aos habitantes do distrito de Ras-Baalbeck na qual um oficial do exército foi morto e a outra, em 1955, foi uma briga matrimonial surgida entre dois clã maronitas do norte do Líbano (Frangié e Duwayhi) que levou a confronto na cidades de Zghorta e Ehden. Nos dois episódios Chamoun ordenou ao exército reprimir os envolvidos nos incidentes, mas Chehab, o seu comandante, se recusou a cumprir as ordens, ameaçando renunciar e afirmando que o Presidente deveria antes de enviar o exército promover investimentos nessas regiões para
} 
situação interna do Líbano se estabilizar, no começo de janeiro de 1957, mas essa ação foi cada vez mais projetando o seu nome na sociedade.

A entrada de Charles Habib Malik no governo de Chamoun era uma demonstração muito clara da posição que o governo libanês estava tomando no Oriente Médio. Malik havia feito parte do governo de el-Khuri como diplomata nos anos 40 e desde essa época era conhecido por suas fortes posições libanistas, contrárias ao nacionalismo árabe e anticomunistas. Formado em Matemática e Física pela Universidade Americana de Beirute (AUB) e com Ph.D. em Harvard, ele era professor de Filosofia naquela primeira. Havia em 1947 participado da elaboração da Carta da ONU e da conferência de fundação das Nações Unidas em São Francisco dois anos antes em 1945. Mais tarde, atuou como embaixador de seu país em Washington. Quando retornou para o Líbano entrou para a AUB e, por conta de suas posições pró-americanas, chegou a ser cogitado para ser reitor dessa universidade. Em 1957 seria eleito para o Parlamento devido a pressão norteamericana quando já era chanceler de Chamoun. Sua entrada no governo contribuiu para aumentar as tensões na sociedade libanesa, pois sua figura causava forte ojeriza entre a população muçulmana e drusa e nos setores políticos arabistas e esquerdistas. No entanto possuía um grande apoio e consideração por parte das representações diplomáticas ocidentais e dos membros de seus governos. Georges Middlelton, embaixador britânico em Beirute, assim se referia a Malik em dezembro de 1956:

As far as I know Malik is persona gratissima in Washington and can always count on a sympathetic hearing. I believe too that he may be able to put across to the State Departament and other some of the realities of the present situation in the Middle East more effectively than other spokesman, either Eastern or Western",534.

Já o embaixador Americano em Beirute em 1956, Donald Heath, assim se referia a Malik em um cabo no qual sugeria que a revista norte Americana Time deveria fazer uma ampla reportagem sobre o novo chanceler libanês:

desenvolvê-las. Devido às repercussões negativas que se poderia ter nas forças armadas devido ao prestigio que Chehab tinham entre os soldados e boa parte dos oficiais, Chamoun voltou atrás em suas medidas. Essa ação criou uma forte inimizade entre os dois homens e ao mesmo tempo reforçou a relativa independência das forças armadas (que eram compostas basicamente pelo exército) em relação ao Executivo cuja ação seria decisiva anos depois durante a guerra civil de 1958. MALSAGNE, Stéphane. Fuad Chehab,1902-1973: une figure oubliée de l’histoire libanaise... p. 127.

534 Carta de Middleton para E. M. Rose apud ATTIÉ. p. 108. 
"Malik is especially newsworthy at this time as public figure in Middle East most vocally in favour of cooperation with America and the leading Arab proponent of President Eisenhower's proposals. He also chief source attack on Nasser-type Arab nationalists and communists. Time is well distributed in Arab world and would help our cause if Malik were leading subject of an early issue, ${ }^{, 535}$.

Já entre a população libanesa, especialmente os muçulmanos, houve um grande apoio ao Egito, no qual grandes manifestações foram organizadas nas ruas das cidades libanesas e em frente às representações diplomáticas britânica e francesa. Eles estavam a favor do estabelecimento de sanções contra os agressores e do rompimento das relações diplomáticas. Já as maiorias dos cristãos se opunham ao estabelecimento das sanções quer fossem econômicas ou diplomáticas, assim como não desejavam o rompimento das relações. A divisão criada teve consequências sérias, pois acentuou a desconfiança mútua crescente entre as duas maiores populações do Líbano o que acabou minando as bases do Pacto Nacional de 1943 e, junto com o ressentimento muçulmano por conta de sua situação social e política, levaria o país, dois anos depois, a uma guerra civil ${ }^{536}$. Essa divisão acabou sendo acentuada pelas renúncias de Salam e alYafi, pois os cristãos passaram a ver com desconfiança e crescente hostilidade a maioria dos políticos muçulmanos de seu país que apareciam aos seus olhos como traidores ${ }^{537}$.

As tensões geradas por conta da crise de Suez foram tão grandes que o governo libanês chegou a declarar estado de emergência, estabelecendo-o no dia em que expirou o ultimatum anglo-francês ao Egito em 31 de outubro ${ }^{538}$, sendo nomeado o general Fuad Chehab como governador militar do país.

Ao longo dos dias da campanha militar franco-anglo-israelense, vários ataques foram realizados contra alvos britânicos e franceses no Líbano como as respectivas embaixadas, o Banco da Síria e do Líbano, o British Bank of the Middle East e o clube Saint George. Em 6 de novembro o oleoduto do IPC foi dinamitado em uma área próxima à refinaria de Trípoli, o que forçou o seu fechamento temporário. Esses atentados podem ter sido realizados pelos egípcios ou seus simpatizantes como vingança contra o ataque a Suez. Isto porque as forças de segurança libanesas encontraram no carro do Conselheiro Comercial da embaixada do Egito explosivos,

535 Cabo de HEALTH para Dulles apud ATTIÉ.

536 ATTIÉ, Caroline. The struggle in the levant... p. 104.

537 ATTIÉ. Idem. p.106.

538 ATTIÉ... p. 106. 
bem como no carro do Adido Militar Assistente desse país que, além de explosivos, carregava armas. Também esconderijos de armamento foram descobertos em Tiro nos quartos onde residiam seis professores escolares egípcios e até no campo de refugiados palestinos de Burj alBarajne $^{539}$.

O resultado final disso tudo foi a derrota política britânica, francesa e israelense, como consequência da intervenção diplomática norteamericana e soviética ao lado do Egito, obrigando os invasores a efetuar uma retirada militar. Isso significou que, a partir de 1956, os americanos assumiram a plena hegemonia no Oriente Médio e os britânicos, por sua vez, acabaram por ver a sua liderança rapidamente desaparecer, passando a atuar na região sob a direção do governo de Washington.

A crise de Suez representou a morte do colonialismo britânico (e por extensão do europeu) no Oriente Médio. Também foi a primeira derrota histórica do sionismo pelo fato de Israel ter sido obrigado a sair do Sinai, ainda que não tenha sido de maneira imediata. Para reafirmar a sua posição nessa região, os EUA, no ano seguinte, emitiram a Doutrina Eisenhower, que prometia aos aliados na região assistência militar para proteger qualquer um desses países de uma possível agressão soviética ou de aliados locais desses, bem como barrar a influência subversiva comunista. A consequência dos acontecimentos de Suez repercutiu por mais de uma década no Oriente Médio, estando presente em eventos como a derrubada da monarquia iraquiana em 1958, a guerra civil libanesa daquele ano, a formação da República Árabe Unida a partir da união entre Síria e Egito, a guerra de independência do Iêmen do Sul etc. Também levou ao auge a liderança de Nasser, que era nesse momento o grande herói dos povos árabes e um dos principais líderes do então chamado Terceiro Mundo.

\subsection{A Doutrina Eisenhower}

De imediato estava estabelecido o conflito entre Nasser e Chamoum. O Presidente egípcio, assim que a questão de Suez foi resolvida, começou uma intensa campanha de propaganda por meio da imprensa escrita e através do rádio contra o governo libanês, sendo nisso muito apoiado pela oposição. Essa campanha teve forte impacto no país e ajudou a posicionar a

539 ATTIÉ... p. 102. 
população muçulmana, já muito desconfiada e avessa, contra o governo de Chamoun definitivamente, enquanto Nasser aparecia cada vez mais como o herói dessa população e da oposição libanesa que curiosamente não conseguia criar uma liderança a altura do Presidente egípcio.

Esse apoio vinha na esteira de uma crescente ajuda material dos egípcios às atividades da oposição. Nessa situação, temendo as possíveis consequências futuras, o governo de Chamoun assumiu abertamente a sua orientação pró-ocidental. Em 16 de março de 1957, o Líbano tornou-se o primeiro país do Oriente Médio a aceitar formalmente a Resolução do Oriente Médio, mais conhecida como Doutrina Eisenhower. Ela havia sido anunciada pelo Presidente norte-americano ao Parlamento em janeiro, tendo sido aprovada pela Câmara dos Deputados no dia 30 daquele mês e pelo Senado no dia 5 de março. Esse pedido se baseou no fato de que o regime egípcio era então aliado da União Soviética e sua ação no Líbano ser tida como uma atividade subversiva ao tentar derrubar o governo libanês por meio do incentivo a uma oposição cada vez mais hostil e ao incitamento de uma parcela importante da população, por meio da imprensa, para que se rebelasse ${ }^{540}$.

Em 4 de abril o Parlamento libanês aprovou com votação maciça a adesão do seu país à nova doutrina político-militar proclamada pelos EUA. Outros países da região, também aliados dos EUA, aprovaram a Doutrina Eisenhower como foi o caso do Iraque, Jordânia, Líbia, Arábia Saudita e Israel, mas de modo geral não tornaram público o seu apoio devido às consequências internas ou regionais graves que isso poderia trazer.

O Líbano, com base na Doutrina Eisenhower, pediu ajuda militar para melhorar a capacidade de guerra de seu pequeno exército e equipar as suas forças policiais, algo que Chamoun vinha tentando desde o começo de seu mandato, oferecendo em troca um total apoio aos EUA no caso de uma guerra com a União Soviética. Já em março de 1957 veio a resposta de Washington por meio da concessão de US\$10 milhões em ajuda econômica e US\$2,7 milhões em ajuda militar, em um acordo que já vinha sendo negociado entre Líbano e EUA antes que Beirute aceitasse formalmente a Doutrina ${ }^{541}$.

Enquanto o enviado de Eisenhower, James Richards, assinava com Chamoun na

\footnotetext{
${ }^{540}$ GENDZIER, Irene L. Notes from the minefields... p. 215-216.

541 GENDZIER. Idem. p. 219.
} 
capital libanesa um programa de assistência econômica e militar, essa aproximação de Washington com o governo libanês era explicada pelos americanos como consequência; 1) da necessidade de combater a ação de forças subversivas, atribuídas em grande parte aos comunistas a partir da Síria e do Egito; 2) da posição, agora abertamente pró-ocidental, do governo libanês e seu compromisso com as políticas americanas em sua região e 3) do forte impacto na opinião pública (no caso a cristã) que teve a missão de Richards por, entre outras razões, ter escolhido o Líbano como o primeiro país a visitar ${ }^{542}$.

Em documentos internos os americanos reafirmavam o valor estratégico do Líbano por conta de sua localização geográfica e suas relações com os países vizinhos, como mostra este trecho de um relatório do Comitê Conjunto sobre Programas para Assistência Militar a respeito de ajuda militar para o Oriente Médio, de 3 de fevereiro de 1957:

Lebanon is important to the USA because of its line of communication and bases which could be provided in the development of a forward defense in the Middle East. Lebanon possesses one of the best harbors and communications centers on the Eastern Mediterranean shore and potentially good air bases. Most of the pipeline which transport oil from Persian Gulf area and Iraq terminate in Lebanon ports. Theses consist of pipeline wich emanates from the Dhahran area on the Persian Gulf (capacity 33, 000 barrels day) and two of the five pipeline which emanate from the Kirkuk fields in Iraq (capacity of the three of five normally in use: 560,000 barrels day) ${ }^{543}$.

Em documentos internos os americanos reafirmavam o valor estratégico do Líbano por conta de sua localização geográfica e suas relações com os países vizinhos, como mostra este trecho de um relatório do Comitê Conjunto sobre Programas para Assistência Militar a respeito de ajuda militar para o Oriente Médio, de 3 de fevereiro de 1957:

\footnotetext{
At the time of its inception in the 1950, the Nasserite regime and its ambitions to dominate the Arab World had not yet seen the light of day and the communism did not constitute a menace to any Arab country. In any case the Tripartite Declaration did not provide for indirect aggression, that which comes about through subversion within the victimized country ${ }^{544}$.
}

\footnotetext{
542 QALAWOUN. The struggle for Lebanon... p. 29.

543 GENDZIER. Notes from the minefields... p. 218.

544 Chamoun Crise apud Attié... p. 115.
} 
Além do mais, a crise de Suez havia mudado o papel das potências ocidentais no Oriente Médio e com isso compromissos políticos anteriores como a Declaração Tripartite haviam deixado de existir.

As políticas de Chamoun receberam o apoio de amplos setores da população cristã que era avessa ao nacionalismo árabe (associado por ela ao Islã e ao domínio dos muçulmanos sobre os não-islâmicos) e observava com temor a aliança de Nasser com a oposição e sua fortíssima campanha midiática contra o presidente libanês. Para eles isso era uma conspiração para mudar o sistema político e econômico nacional a favor dos muçulmanos. Também, por conta dessa situação, estavam do lado de Chamoun partidos cristãos de direita nacionalistas libaneses como as Falanges de Pierre Gemayel ${ }^{545}$.

Já a resposta da oposição a Chamoun foi uma ampla condenação ao Presidente e o acusaram de agir contra o Mundo Árabe e os seus interesses. A oposição, então, buscou intensificar a sua pressão sobre o governo e mobilizar a população para repudiar Chamoun e votar contra os seus candidatos nas eleições legislativas de 1957. Entretanto, enquanto Nasser ainda não se pronunciava abertamente contra a Doutrina Eisenhower, muitos líderes sunitas libaneses evitaram durante um determinado tempo assumir uma postura mais francamente hostil face ao governo, pois ainda se imaginava haver alguma possibilidade de uma negociação que pudesse chegar a um entendimento entre o Egito e o Líbano, bem como entre o governo e a oposição.

Quem compartilhava de uma opinião parecida com a oposição libanesa eram os governos árabes nacionalistas, como o do Egito e da Síria, que condenaram a Doutrina Eisenhower, pois a viram como mais um instrumento de intervenção imperial de uma potência ocidental no Oriente Médio. Nasser particularmente a condenou, rejeitando a ideia de "vazio de poder", deixado nessa região pela derrota anglo-francesa em Suez, que foi apresentada por Eisenhower em sua doutrina. Vendo nisso apenas mais um pretexto para os EUA introduzirem tropas no Oriente Médio e se intrometerem nos assuntos dos países árabes do que um instrumento de contenção da influência da União.

E isso era ainda mais claro, tanto para Nasser quanto para outros nacionalistas árabes, por conta do fato de que no Egito o Partido Comunista havia sido suspenso e seus militantes

${ }^{545}$ QALAWOUN, Nasser M. The struggle for Lebanon... p. 35-36. 
perseguidos, apesar das relações existentes entre o Cairo e Moscou. Na Síria e no Líbano os Partidos Comunistas funcionavam de maneira clandestina e no Líbano (onde estava desde 1948 proibido) ele atraia bem menos simpatizantes do que em seu vizinho sírio, sendo na verdade um pequeno partido. Também havia o fato de que o comunismo era uma doutrina pouco atrativa para muitos muçulmanos por conta de seu ateísmo apesar de sua mensagem igualitária ${ }^{546}$.

Um exemplo de como o governo egípcio apresentava a postura de Chamoun e seu grupo no poder e procurava combatê-los pode ser observado abaixo em um comentário feito pelo popular propagandista egípcio Ahmad Said na Rádio "Voz dos Árabes" do governo do Egito:

The Lebanese Government has accepted the Eisenhower Doctrine for the Middle East, while the Opposition, like the ever-vigilant Arab people, has decided to oppose and not to accept any aid which might restrict the freedon of Lebanon in her foreign policy [...]. This is the battle which is being engaged today in the Lebanon [...]. It is the Lebanese people who will gather the fruits of this batlle. They are the people who may enjoy peace or suffer from war, who may be enriched by the American alliance mentioned in Eisenhower`s doctrine, who may be colonized and be destroyed as a result of the very same American aid ${ }^{547}$.

Durante o período de conflito aberto com Nasser e a guerra civil de 1958 foi importante para Chamoun em seu contato com os americanos a figura de Charles Malik, seu ministro das Relações Exteriores. Malik era um indivíduo com importantes contatos com os mais altos níveis da administração norteamericana, propiciados pelas suas posturas abertamente próamericana e ocidental e antiarabista e anticomunista. Por causa disso, sua presença no governo durante todo o período de conflito com Nasser foi muito apreciada pelas representações diplomáticas britânica e americana bem como pelos formuladores políticos nesses dois países ${ }^{548}$.

Ao longo dos dois últimos anos do governo Chamoun, Malik reiteradamente apresentou na ONU e diante dos representantes dos EUA o conflito do Líbano com o Egito como um ato constante de agressão e subversão dos egípcios (e seus aliados sírios) contra um legitimo governo libanês tentando derrubá-lo para colocar no lugar um governante fantoche. E, depois, da formação da República Árabe Unida, acusou o governo do Cairo de querer anexar o Líbano.

\footnotetext{
546 ATTIÉ. The struggle in the levant... p. 111-112.

${ }^{547}$ QALAWOUN. The struggle for Lebanon... p. 29.

${ }^{548}$ ATTIÉ, Caroline. Struggle in the levant... p.108.
} 
Malik, enquanto ministro das Relações Exteriores procurou sempre envolver o seu país nas políticas regionais americanas incluindo os pactos militares. Desde antes de entrar para o governo Chamoun ele procurava mostrar aos americanos que eles deveriam criar um segundo sistema de defesa para além daquele do Pacto de Bagdá que incluísse países como a Grécia ou o Líbano ${ }^{549}$. Posteriormente, Malik acrescentou a isso um forte discurso anticomunista no qual representava o Líbano como sendo um baluarte do 'Mundo Livre' em luta contra a agressão indireta de um Estado, a República Árabe Unida, patrocinada pelo comunismo soviético. Seu discurso, em certo momento, chegou ao extremo de ligar o comunismo ao sionismo apresentando desse modo essa ideologia de esquerda como inimiga dos árabes. Nessa situação afirmava que o único verdadeiro defensor dos países árabes eram os EUA por meio da Doutrina Eisenhower ${ }^{550}$.

No entanto, apesar do clima permanente de conflito, tanto o governo libanês quanto o egípcio procuravam assim mesmo dialogar para tentar chegar, se possível, a algum entendimento mínimo e Malik participava dessas negociações. Dessa maneira, em janeiro de 1957, o chanceler Malik foi ao Cairo conversar com Nasser e explicar as posições de seu governo e as relações que tanto Egito quanto Líbano tinham com os EUA ${ }^{551}$. Aliás, Malik buscou aparecer frente aos egípcios como um porta-voz diante do Ocidente, o que também tentava fazer em relação aos países árabes em geral. Isso foi recusado pelo governo do Cairo ${ }^{552}$.

O conflito de Chamoun com a oposição e Nasser vinha acompanhado do seu desejo nunca declarado em público, mas conhecido da oposição, de permanecer no poder que só poderia ser alcançado através de uma emenda no Parlamento que lhe garantisse a reeleição ${ }^{553}$. Ao mesmo tempo os norte-americanos olhavam para Chamoun como o homem que garantiria a proteção dos seus interesses no Líbano e uma figura importante na contenção do nacionalismo árabe e dos projetos de Nasser para o Mundo Árabe ${ }^{554}$. Os americanos também perceberam que o sistema político libanês lhes favorecia por permitir que um Presidente cristão pró-ocidental estivesse sempre no poder. Por isso resolveram garantir a existência do sistema confessional libanês na

\footnotetext{
549 GENDZIER. Notes from the minefields.... p. 188.

${ }^{550}$ QALAWOUN. The struggle for Lebanon... p. 30.

551 ATTIÉ, Caroline. Struggle in the levant... p.115

552 QALAWOUN. The struggle for Lebanon... p. 27-28

553 ATTIÉ, Caroline. Struggle in the levant... p. 143

554 GENDZIER. Notes from the minefields... p. 204
} 
maneira que ele se encontrava nos anos 50 e esse foi mais um motivo do porquê resolveram apoiar Chamoun. Para Washington, tudo isso significaria a vitória de Nasser no plano internacional. Por conta desse risco os americanos resolveram intervir financiando secretamente Chamoun e através de agentes da CIA o governo dos EUA enviou dinheiro a seu aliado libanês, sendo que era responsabilidade do embaixador americano decidir como usar o dinheiro ${ }^{555}$. Já o governo libanês desejava a ajuda americana como forma de combater a força social da oposição que por sua vez recebia fundos egípcios e sírios.

\subsection{As eleições de julho de 1957}

O embate decisivo tanto para a oposição quanto para Chamoun seriam as eleições parlamentares de julho de 1957. Como elas formariam um congresso que era a favor ou contra o governo, foram consideradas como um plebiscito contra ou a favor da política externa de Chamoun. Se a oposição conseguisse maioria no Parlamento isso significava que o governo libanês estava praticamente derrotado e que tinham um amplo rechaço da população por conta dos posicionamentos assumidos internacionalmente.

Já a possibilidade de reeleição de Chamoun estava eliminada. Para isso começou a tomar uma série de medidas para assegurar a vitória. Uma das primeiras foi a promulgação de uma nova Lei Eleitoral em abril que aumentou as vagas no parlamento de 44 para 66 cadeiras. Além disso, para influenciar nos resultados, interveio nas municipalidades tirando funcionários que lhe seriam hostis e procurando recrutar gente nos locais de votação que trabalhassem a seu favor e contra a oposição, bem como modificou os limites das circunscrições eleitorais e mudou o seu número de modo a prejudicar os seus inimigos políticos ${ }^{556}$.

Essas eleições foram marcadas pela forte interferência externa, americana e britânica, a favor de Chamoun e egípcia e Síria a favor da oposição. Os norte-americanos enviaram fundos por meio da CIA para o Presidente organizar a campanha dos seus candidatos ao Parlamento. Essa ação de Washington havia sido pedida pelo governo libanês já em fevereiro quando Charles Malik visitou a capital dos EUA e se encontrou com Eisenhower. Como o governo libanês temia que a sua oposição tomasse a mesma atitude em relação ao Egito e a Síria Malik, diante dos

\footnotetext{
555 ATTIÉ, Caroline. Struggle in the levant... p. 136

${ }^{556}$ ATTIÉ. Idem. p. 132.
} 
norte-americanos, lembrou-se da "ameaça comunista" que pairava sobre o Líbano no caso de uma vitória da oposição nas eleições legislativas de junho, já que um Parlamento controlado por eles acabaria elegendo um Presidente com uma política contrária à de Chamoun, algo que os próprios estadunidenses já previam que poderia acontecer. Aliás, a própria embaixada americana já recomendava ao Departamento de Estado o apoio financeiro a Chamoun durante as eleições já como uma antecipação da mesma ação que seria feita por Nasser e Al-Quwatli com relação à oposição $^{557}$. Em uma declaração feita pelo agente da CIA Wilbur Eveland (que também dizia que era o embaixador Donald Health quem decidiam quando e como o dinheiro estadunidense deveria ser usado) pode-se perceber como era feita a entrega de fundos a Chamoun:

\begin{abstract}
Throughout the elections I traveled regularly to the presidential palace with a briefcase full of Lebanese pounds, then returned late at night to the Embassy with an empty twin case I'd carried away for Harvey Armada's CIA finance-office people to replenish. Soon my gold DeSoto with its stark white top was a common sight outside the palace, and I proposed to Chamoun that he use an intermediary and a more remote spot. When the president insisted that he handle each transaction by himself, I reconciled myself to the probability that anybody in Lebanon who really cared would have no trouble guessing precisely what I was doing 558 .
\end{abstract}

Já a ajuda britânica, que tinha o mesmo objetivo mais geral que a dos norteamericanos, também visava a fazer com que Chamoun se mantivesse próximo a Londres e, embora a sua quantia total ainda seja desconhecida, ela foi muito ativa até a época das eleições como afirmou o vice-subsecretário do Foreign Office, sir Willian Hayter, em um documento de 20 de dezembro de 1957, no qual ele dizia que o seu governo havia sido muito ativo durante o processo eleitoral parlamentar no Líbano ${ }^{559}$.

A oposição recebeu financiamento e auxilio político via embaixada egípcia na qual o embaixador Abdul Hamid Ghalib era muito ativo junto a lideranças libanesas anti-Chamoun como Kamal Jumblatt, Rachid Karami e Saeb Salam entre outros. Os egípcios também procuraram sondar os líderes cristãos, incluindo autoridades religiosas como o Patriarca maronita Paul Meushi, que era muito elogiado pela Voz dos Árabes (que o chamava de o "Patriarca dos Árabes") e outros órgãos de imprensa egípcios por conta de suas declarações incitando Chamoun

557 ATTIÉ... p. 133.

${ }^{558}$ WILBUR apud ATTIÉ... p.136.

559 ATTIÉ, Caroline. Struggle in the levant... p.135. 
a promover as boas relações com os países árabes vizinhos e buscar uma posição de unidade política com eles.

A oposição era muito estimulada pelos meios de propaganda egípcios, como a "Voz dos Árabes', a imprensa escrita egípcia (cujos jornais tinham ampla circulação no Líbano) e a imprensa de oposição libanesa. Seus líderes denunciavam as posições assumidas por Chamoun continuamente, ao mesmo tempo em que elogiavam as políticas de Nasser e congratulavam os egípcios por sua vitória sobre os anglo-franceses e israelenses, como foi o caso de Saeb Salam que visitou o Cairo na metade de janeiro de 1957.

Como exemplo das declarações da oposição pode-se citar Jumblatt, que acusou Chamoun de exagerar suposta ameaça egípcia e síria para os cristãos libaneses com o objetivo de conseguir benefícios materiais e militares dos EUA. Fora isso, Jumblatt negava que o comunismo estivesse a ponto de ser implantado no Egito e na Síria para assim, em breve, ser instalado no Líbano. O desejo de Nasser de restaurar as relações com Grã-Bretanha e França seria uma prova de que o Egito não era comunista e sim que buscava promover o equilíbrio político no OrienteMédio. Essa politica de Nasser não significava tornar o seu país uma base para o colonialismo, afirmava o líder druso, diferentemente de Chamoun que estava fazendo o Líbano assumir esse $\operatorname{papel}^{560}$.

Às vésperas das eleições, em 30 de maio, um sério incidente envolvendo a oposição aconteceu em Beirute, o que demonstrou claramente a enorme tensão que as políticas e ações de Chamoun estavam provocando. A oposição havia nesse dia resolvido promover protestos contra o presidente pedindo a renúncia do gabinete do primeiro-ministro el-Solh e a indicação de um novo gabinete neutro para supervisionar as eleições. Isso por conta da enorme manipulação que Chamoun estava fazendo e na qual se percebia que o governo iria vencer as eleições por meio de todo tipo de manobras escusas.

Nesse dia os manifestantes ergueram barricadas nos bairros muçulmanos enquanto a gendarmeria foi instalada nas proximidades desses acampamentos. Logo começou um confronto entre manifestantes e as forças de segurança, que resultaram em sete mortes e no qual Saeb Salam acabou sendo ferido. Enquanto esse confronto acontecia na capital, greves comandadas pela oposição eclodiram em Tripoli, Sidon e Nabatieh (cidades nas montanhas do sul do Líbano) e

${ }^{560}$ QALAWOUN. The struggle for Lebanon... p. 34-37. 
manifestações foram realizadas em Hermel (leste do país). A força dessa onda de manifestações foi tão impressionante que a embaixada britânica chegou a considerar essa ação uma tentativa de golpe contra o governo libanês ${ }^{561}$.

Quando as eleições aconteceram, em quatro domingos sucessivos do mês de junho, uma enorme máquina montada pelo Estado levou a vitória do governo. As forças de segurança, junto com bandos armados e indivíduos pagos, forçavam os eleitores das vilas cristãs a votarem nos candidatos do governo. O resultado levou à derrota de líderes importantes da oposição, como Kamal Jumblatt, Abdallah al-Yafi e Saeb Salam. Enquanto um Parlamento favorável a Chamoun era eleito.

Alguns líderes tradicionais da oposição, como o notável Rachid Karami, conseguiram a reeleição, mas a oposição saiu do pleito muito prejudicada. Em protesto, os dois ministros 'neutros', Yusuf Hitti e Muhammad Bayhun, um cristão e um muçulmano, escolhidos em um acordo entre a oposição e o governo para supervisionar as eleições, renunciaram ${ }^{562}$.

Chamoun foi acusado de fraude e de tentar permanecer a todo custo no cargo. Para reagir a Chamoun a oposição resolveu criar uma frente política de lideranças e partidos contrários ao Presidente: a Frente de União Nacional (FUN), passando a realizar um grande número de greves e manifestações pelo país. Ela incluía o líder druso Kamal Jumblatt, os sunitas Salam, Yafi, Marouf Saada e Adnan Hakim do partido islâmico Najjada, mais o líder xiita Ali Bazzi. A FUN era uma organização composta em grande parte por líderes da burguesia muçulmana libanesa, mas também alguns cristãos, unidos em torno da oposição à figura de Chamoun e suas políticas, que desejavam que o Líbano se orientasse em direção a uma cooperação com os países árabes sem promover um rompimento com o Ocidente e a economia capitalista. Eles rejeitavam a ajuda militar americana considerando-a uma quebra da neutralidade libanesa e acusavam Chamoun de estar rompendo o Pacto Nacional ${ }^{563}$.

Também estavam na oposição, mas sem pertencer à FUN, por conta dos abusos de Chamoun e dos riscos que isso representava para a estabilidade e segurança do Líbano, figuras como o Patriarca maronita Paul Meushi e lideranças cristãs como Hamid Frangié, Philippe Taqla,

\footnotetext{
561 ATTIÉ, Caroline. Struggle in the levant... p. 139.

562 ATTIÉ... p. 144-145.

${ }^{563}$ WINSLOW, Charles. Lebanon: war and politics.... p. 106.
} 
Ghassan Tuwaini e Charles Helou, futuro Presidente ${ }^{564}$.

Muitos dessas figuras e lideranças liberais pertenciam a uma nova e crescente oposição - composta principalmente de cristãos pró-ocidentais - começaram a fazer uma distinção entre as políticas internas e externas de Chamoun, condenando o seu crescente autoritarismo, truculência e desrespeito às normas constitucionais libanesas. Esse grupo publicou uma declaração em 3 de outubro condenando o Presidente libanês ${ }^{565}$. No plano nacional, o resultado das eleições foi aprofundar a divisão sectária existente na sociedade libanesa. Para a maioria muçulmana e seus líderes, Chamoun agora não possuía mais legitimidade para governar e, como se sabia de suas intenções em ganhar mais um mandato, começaram a pedir a sua renúncia.

Já a maioria dos cristãos apoiava fervorosamente Chamoun, que ia se transformando em um herói nacional. Para tentar atuar como força intermediária entre a oposição e governo, esse grupo de políticos liberais acabou formando uma coalizão, que ficou conhecida como a Terceira Força e tinha entre os seus membros figuras como o político e negociante Henri Pharaon, o político e também banqueiro Raymond Eddé (um ex-aliado de Chamoun), Ghassan Tueni, editor do importante jornal conservador Al-Nahar e o ex-primeiro-ministro durante o mandato francês, Alfred Naccache, entre outros ${ }^{566}$.

\subsection{O nascimento da RAU}

Nesse período de crescente tensão política e divisão sectária no Líbano, um acontecimento acirrou ainda mais o conflito interno no Líbano e contribuiu para a deflagração da guerra civil em maio de 1958: o nascimento da República Árabe Unida (RAU). Vindo em direção a uma crescente aproximação com o Egito por parte do governo nacionalista de Damasco e após uma série de eventos ocorridos no país em 1957, como uma fracassada tentativa de golpe contra o presidente Shukri al-Quwatli, promovido pelos EUA e a ameaça de invasão turca dissuadida pelo envio de tropas egípcias, os governos egípcio e sírio, no intuito de promover a união entre os diferentes países árabes, promovem a formação da República Árabe Unida em 1 de fevereiro de 1958.

\footnotetext{
${ }^{564}$ GORIA, Wade R. Sovereignty and leadership in Lebanon ... p. 41.

565 ATTIÉ, Caroline. Struggle in the levant... p. 146.

${ }^{566}$ ATTIÉ. Idem... p. 132.
} 
A formação da RAU foi reconhecida de jure pelo governo libanês em 21 de fevereiro. No Líbano, essa união foi comemorada nas ruas por parte da população muçulmana e drusa que instalou por toda a parte retratos de $\operatorname{Nasser}^{567}$. Nas escolas muçulmanas as aulas foram interrompidas nesse dia. Líderes da oposição foram no fim do mês de carreata a Damasco para congratular os Presidentes da Síria e do Egito. Para a maioria da população não-cristã era só questão de tempo antes que o próprio Líbano fizesse parte da República Árabe Unida ${ }^{568}$.

Entretanto, para os cristãos o nascimento da RAU foi um acontecimento negativo, pois sentiam que o seu país poderia ser tragado por uma entidade política em que a maioria da população seria esmagadoramente muçulmana, perdendo assim os privilégios que desfrutavam no sistema político libanês. Isso poderia ser possível não por conta de uma invasão militar, mas em razão da própria população muçulmana que demonstrava rejeitar a ideia de um Líbano independente. Muitos líderes muçulmanos, enquanto isso, faziam declarações a favor da incorporação do Líbano à RAU e o próprio Presidente sírio al-Quwatly convidou o Líbano a se integrar nesse novo Estado ${ }^{569}$. Já os líderes cristãos continuaram a afirmar o desejo seu e da maior parte de suas comunidades de verem o Líbano independente.

\subsection{A guerra civil de 1958}

O ano 1958 começou tenso com uma série de enfrentamentos políticos entre o governo e a oposição da Frente Nacional Unida. Chamoun abusava do autoritarismo, mandando prender jornalistas, proibir a publicação de jornais e acossar membros da oposição. Esta acusava o Presidente de buscar a reeleição e afirmava que depois das fraudes da eleição de julho do ano anterior ele havia perdido a legitimidade ${ }^{570}$.

As tensões comunitárias também foram crescendo simultaneamente à rivalidade entre Chamoun e a oposição. Em abril, o Mufti da República (a maior autoridade religiosa sunita) não aceitou as congratulações tradicionais feitas pelas autoridades libanesas no dia de encerramento

${ }^{567}$ ATTIÉ. Idem. p. 154-155.

${ }^{568}$ GORIA, Wade R. Sovereignty and leadership in Lebanon... p.41.

569 ATTIÉ... p. 155-156.

${ }^{570}$ WINSLOW. War and politics... p.108. 
da celebração do mês de Ramadan ${ }^{571}$ (o nono mês do calendário muçulmano), enquanto que o Alto Conselho Islâmico, durante o banquete anual que dava em comemoração ao fim desse mês sagrado, pela primeira vez não convidou as autoridades governamentais. Já os líderes de oposição que assistiram ao banquete o transformaram em um comício contra o governo no qual se declararam publicamente contra a reeleição do Presidente. No lado cristão, na vila onde Chamoun nasceu, Dair el-Qamar, os sinos soaram em protesto lamentando uma possível declaração do patriarca Meoushi na qual os maronitas seriam uma gota de sangue em um oceano muçulmano e que, por conta disso, deveriam apoiar o nacionalismo árabe ou deixar o Oriente Médio $^{572}$.

Em 9 de maio aconteceu o assassinato do jornalista opositor Nasib el-Matni, editor do jornal al-Teleghraf e um grande crítico de Chamoun, por indivíduos ligados ao governo. Esse crime incendiou o Líbano. Em um dia a FUN chamou uma greve geral e acusou o governo pelo crime. Por todo o país ocorreram manifestações de repúdio ao Presidente. Os líderes da oposição exigiram que o Presidente e todo o seu gabinete renunciasse. Enquanto isso foi transmitido ao comandante em chefe Fuad Chehab um pedido para que ele assumisse com o primeiro-ministro, mas o general Chehab não aceitou afirmando que, embora fosse contra a reeleição, era a favor que ele terminasse o seu mandato. Esse fato demonstrava a grande confiança que a oposição tinha em Fuad Chehab e isso a tal ponto de oferecerem a ele, um maronita, um cargo reservado aos sunitas ${ }^{573}$.

Enquanto isso choques armados se verificaram entre aliados de Chamoun e as forças

\footnotetext{
${ }^{571}$ No Ramadan se comemora a principal festividade da religião muçulmana, pois durante esse mês se recorda o principal evento da história islâmica: o anúncio a Maomé, por parte de Deus, da revelação contida no Alcorão, o livro sagrado. A principal atividade do Ramadan consiste no jejum diário, acompanhado de abstinência das relações sexuais, pensamentos e atos imorais ou maliciosos, frequência maior as mesquitas, leituras mais frequentes do Alcorão e uma prática mais intensa da caridade e da comunhão com o próximo. Pessoas que estejam em situação de enfermidade, mulheres gravidas, menstruadas e lactantes, idosos e crianças são dispensados do Jejum. Antes do começo do jejum e após o seu fim ocorrem importantes refeições rituais: o Su-Hoor pela manhã e o Iftar no começo da noite. Essas refeições são acompanhadas de orações e reuniões familiares e de amigos. O Ramadan começa no chamado Laylat al Kadr (Noite do Decreto), quando houve o anúncio a Maomé do começo da revelação e se encerra com o Eid al-Fitr (O Banquete do Fim do Jejum), quando a lua nova é avistada e começa o mês seguinte-o Shawwal. Ocorrem então três dias de feriados, banquetes, são trocados presentes, há uma congregação entre familiares e amigos, agradecimentos são feitos a Deus e é dado alimento para os pobres No século XX, como resultado do dialogo inter-religioso é frequente a presença de pessoas de outras religiões no Iftar e no Eid al-Fitr. Fonte: www.islamismo.org/bem.htm.

572 ATTIÉ, Caroline. Struggle in the levant... p.171.

${ }^{573}$ ATTIÉ... p.172."'"
} 
da oposição. Em Beirute foram, em poucos dias, levantadas barricadas nos bairros muçulmanos e o governo impôs toques de recolher e fechou a estrada Beirute-Damasco. Em breve, conflitos armados se verificaram em todo o país. A oposição, nesse momento, recusou negociar e exigiu a imediata renúncia de Camile Chamoun ${ }^{574}$. Dois episódios demonstraram que a revolta tinha, ao menos entre a população muçulmana, um caráter anti-imperialista por conta do apoio das potências ocidentais ao Presidente: os incêndios de bibliotecas construídas pelos norteamericanos em Trípoli e no bairro de Basta em Beirute. Outro episódio que demonstrava uma intenção anti-imperialista de setores dos rebeldes foi o rompimento e incêndio do oleoduto da IPC a poucos quilômetros da fronteira com a Síria ${ }^{575}$.

Essa oposição foi composta pelos seguintes grupos: o PSP do líder druso Kamal Jumblatt, pelo Partido Comunista libanês e pelo Al-Murabitun, um grupo nasserista baseado na população sunita. Diversos notáveis sunitas e xiitas como Rachid Karami, Saeb Salam, os Assad do sul do Líbano e Sabri Hamade, lider xiita do Vale do Beka'a no interior do país, entre outros. A FUN foi apoiada pelo governo da RAU que enviou armas e dinheiro e ampliou a já intensa guerra de propaganda contra o regime de Chamoun ${ }^{576}$. Esse fato levou o governo libanês a acusar a RAU, frente aos seus aliados ocidentais e na ONU, de fomentar a rebelião no país. Isto levou à formação de uma força-tarefa pelas Nações Unidas em missão no Líbano, a UNOGIL na sigla em inglês, para verificar o contrabando de armas, munições e a entrada de homens através da fronteira síria ${ }^{577}$.

Já Chamoun, além do apoio da maioria da população cristã, tinha ao seu lado o PNSS nacionalista sírio, que era anti-nasserista e anticomunista, e recebia proteção do Presidente, o rival druso de Jumblatt, Magid Arslan, os falangistas cristãos e a gendarmaria. No plano internacional, os governos conservadores da Turquia, Irã, Jordânia, Paquistão e Iraque apoiaram Chamoun junto com as potências ocidentais ${ }^{578}$. Essas potências e vários governos conservadores do Oriente Médio forneceram armamentos para o governo libanês. Israel também forneceu armas, no caso as que havia capturado no Egito em 1956, para Chamoun enviando-as por meio

\footnotetext{
${ }^{574}$ WINSLOW, Charles. Lebanon: war and politics... p. 108.

575 ATTIÉ, Caroline. Struggle in the levant... p.173.

576 ATTIÉ. Idem. p. 186.

577 GENDZIER, Irene L. Notes from the minefields.. p. 267.

${ }^{578}$ ATTIÉ, Caroline. Struggle in the levant... p. 192.
} 
do governo do Irã $\tilde{a}^{579}$.

Enquanto ocorriam os enfrentamentos armados, alguns políticos muçulmanos e cristãos, como Raymond Eddé e o presidente do Parlamento Adel Osseiran, atuavam como intermediários mantendo canais de negociação abertos entre os rebeldes e o governo. Também a Terceira Força tentou mediar a negociação entre os dois lados em lutas, mas não foi bem sucedida $^{580}$. Ambos os lados estavam intransigentes, a oposição exigindo a renúncia imediata do Presidente e Chamoun, afirmando que a crise libanesa não era apenas uma questão interna do Líbano.

Nos campos de batalha, em pouco tempo, a oposição tomou grande parte do território libanês, ocupando grande porção do Shuf (onde as forças de Jumblatt tentaram capturar o palácio presidencial de verão de Beitelddin, mas foram rechaçados pelas forças do governo), a região do Akkar no norte e a maior parte de Trípoli, Sidon, boa parte do Vale do Beka'a e a fronteira com a Síria $^{581}$. Também alguns bairros da capital, como Basta, estavam controlados pelos rebeldes. No fim de maio, batalhas eram travadas entre as forças de Chamoun e os rebeldes em diversos pontos do país. Ainda em maio o Presidente tentou organizar um arranjo político que pudesse agradar a oposição. Ele tentou fazer com que o general Chehab liderasse a formação de um governo de coalizão, mas como os rebeldes apenas aceitavam a renúncia de Chamoun e Chehab tinham uma antipatia pessoal e desconfiança em relação à figura do Presidente essa ideia acabou não dando certo $^{582}$.

Na primeira semana de junho houve um período de calmaria, tanto que na capital entre 60 e $70 \%$ das lojas estavam abertas. Nesse momento os rebeldes esperavam em breve conseguir a vitória sobre as forças do governo. Em seis de junho os revoltosos esperavam juntar as forças do Shuf com aquelas do Beka'a para contar as linhas de comunicação do governo e preparar uma grande ofensiva em direção a Beirute. Enquanto isso uma ofensiva no Akkar, no extremo norte, foi realizada para distrair as forças de Chamoun.

Por volta da metade de junho as forças da oposição levaram a guerra para as

\footnotetext{
${ }^{579}$ SAMII, Abbas William. The Shah`s Lebanon policy: the role of Savak. Middle Eastern Studies, V. 33, N. 1, jan. 1997. p. 67.

${ }^{580}$ ATTIÉ.... p. 189.

581 ATTIÉ... p. 172.

582 ATTIÉ ... p. 174.
} 
proximidades do palácio presidencial A ordem era atacar o palácio presidencial e capturar o Presidente vivo ou morto ${ }^{583}$. Nessa situação, para o governo, uma das piores acontecimentos foi a recusa do comandante-em-chefe das Forças Armadas, o general Fuad Chehab, de reprimir os rebeldes, somente intervindo no conflito quando posições estratégicas do governo estavam ameaçadas e mantendo sempre aberto um canal de diálogo com a oposição. Chehab afirmou ter tomado a decisão de não entrar em guerra com a oposição para não desmontar o exército que acabaria dividido em linhas confessionais caso atacasse a oposição. Essa postura de Chehab melhorou ainda mais a reputação que o comandante-em-chefe das Forças Armadas possuía junto à população muçulmana e consequentemente com a sua fama de incorruptível e de indiferença em relação aos políticos e suas atividades faria com que fosse indicado como sucessor de Chamoun mais tarde ${ }^{584}$.

Dentre as ações militares tomadas por Chehab na guerra civil podemos citar, em Trípoli, os embates que o exército travou contra as forças de Rachid Karami, que controlavam parcialmente a cidade, pelo controle do porto da cidade e outros pontos. No fim de junho, entre os dias 27 e 30, as forças de Karami tentaram assumir o controle do porto local, mas foram repelidas pelas forças do exército, aí já instaladas há várias semanas. Foram utilizados tanques, aviões e armamento pesado para conter a forte ofensiva dos rebeldes que tentavam assumir o controle total da cidade e dos seus arredores. No começo de julho o exército continuava a controlar o porto e os pontos onde havia se instalado na cidade. Por volta do dia 12 os rebeldes desistiram de tentar controlar o porto pelo fato de que a área em que se localizava tinha perdido sua posição como um centro da oposição. Outra ação importante do exército aconteceu na região do Shuf contra as forças de Kamal Jumblatt que tentavam avançar em direção a Beirute ${ }^{585}$.

\subsection{Os Xiitas}

No desenrolar do conflito cabe destacar a participação da população xiita. No sul do Líbano (Jabal-Monte Amil), nos subúrbios do sul de Beirute e no Vale do Beka'a, essa população se mobilizou para a guerra visando a derrubar o governo, apesar de que algumas lideranças dessa comunidade permaneceram do lado de Chamoun. Grupo tradicionalmente composto em maior

\footnotetext{
${ }^{583}$ ATTIÉ ... p. 185-186.

584 ATTIÉ... p. 187.

585 ATTIÉ... p. 191.
} 
parte por camponeses pobres tendo muitos dos piores indicadores sociais do país, os xiitas viviam em sua quase totalidade nas regiões que haviam sido ignoradas pelo governo libanês ao longo da década de 50. E, como os sunitas, também a maioria dos deles foi atraída pela mensagem panarabista de Nasser. Os xiitas do vale do Beka'a viviam organizados em comunidades tribais dos quais os Haider e os Hamade eram as principais. Essas comunidades possuíam os seus próprios líderes que costumavam ser eleitos para o parlamento em Beirute e suas comunidades tinham aliança com famílias poderosas no Jabal Amil.

Todavia essa comunidade também possuía a sua elite que era composta, como nas demais comunidades libanesas, por um setor religioso e outro laico. Este último era o mais importante, dominando econômica, social e culturalmente os xiitas. Seus membros eram compostos principalmente por grandes proprietários de terras - os zu amas xiitas. Era entre eles que se escolhia o presidente do Parlamento de acordo com o Pacto Nacional de 1943. Embora fosse poderosa em sua comunidade ela nunca alcançou a força e a influência que as elites sunitas e maronitas tiveram no Líbano. Antes da guerra houve uma divisão entre os líderes e políticos xiitas: um grupo permaneceu do lado de Chamoun, como foi o caso do presidente do Parlamento Adel Osseiran; Kazem al-Khalil, secretário-geral do Partido Liberal do Presidente; Ibrahim Haider, o líder da Tribo de Haider do Beka'a; Muhammad al-Fadl do Jabal Amil e o veterano za im Yussef al-Zein, entre outros. No campo opositor havia: Hamed al-Assad e o seu filho Kamal, membros de uma importante família de zu ama do Jabal Amil, Sabri Hamade, líder da outra grande tribo do Beka'a - os Hamades, figuras políticas controladas por Ahmad al-Assad como Riad Taha, Ali Bazzi e Rafic Chehin dentre outros ${ }^{586}$.

Quando a guerra começou, os xiitas da oposição se juntaram à Frente Nacional Unida de Karami, Jumblatt e Saeb Salam e liderando suas próprias milícias se levantaram contra o governo. No começo da revolta, o filho de Kamal Assad, Ahmad, juntou-se a aliados locais em sua própria região (Tiro) e ao líder sunita de Sidon, Ma'aruf Saada. As milícias dos Assad rapidamente dominaram toda a região das montanhas em torno de Tiro e o Jabal Amil. Os Assads também organizaram grandes greves com milhares de apoiadores no Sul e, a partir de seu quartelgeneral na vila de Banyas, forneceram uma grande quantidade de armamentos e munição para os

${ }^{586}$ ATTIÉ.... p. 191. 
rebeldes. As fontes americanas afirmaram que seu grupo era composto de 5.000 homens ${ }^{587}$. Evitavam atacar áreas fora de sua região de influência, mas por suas ações contra Chamoun foram sentenciados a morte em julho pelo governo ${ }^{588}$.

Al Bazzi era outro líder xiita de oposição, possuindo posições de esquerda e antiimperialistas, criticando a ação dos britânicos e dos norte-americanos no Oriente Médio, em particular pelo apoio deles a Chamoun. Defendia abertamente a independência dos países árabe em relação ao domínio ocidental e sempre esteve aliado a líderes vinculados ao nacionalismo árabe e a Nasser como Hamid Frangié. Era um apoiador de Ahmad al-Assad ${ }^{589}$.

O líder da tribo Hamade, Sabri Hamade, esteve do lado da oposição durante todo o conflito militar contra Chamoun. Ele havia abandonado o governo quando a Doutrina Eisenhower foi adotada e se dizia alinhado com o pan-arabismo. A proximidade de sua região, o Vale do Beka'a, com a Síria tornava a tribo de Hamade muito perigosa para o governo o que levava a diversos incidentes com as forças governamentais. Os mais fortes confrontos aconteceram em maio e junho na Batalha do Hermel ${ }^{590}$. A tribo de Hamade estava desde antes da guerra contra Chamoun e quando o conflito foi deflagrado eles foram apoiados por oficiais sírios como o tenente Abdul Hakim. que também era responsável por outras tribos xiitas. Desde março os Hamades recebiam armas dos sírios e em 18 de abril se declararam em rebelião por meio de um manifesto ${ }^{591}$.

Dos líderes xiitas que estavam do lado de Chamoun, Adel Osseiram eram o mais importante, bem como a principal liderança xiita até 1958. Quando o nasserismo começou a crescer no Líbano, Osseiran, mesmo sem afirmar que rompera com Chamoun, começou a se aproximar de Nasser, tendo visitado o líder egípcio em março de 1958 no Cairo e depois em suas férias em abril. No Egito fez pronunciamentos a favor do pan-arabismo e da necessidade do Líbano de se juntar ao movimento, devendo seu país trabalhar junto com a RAU pela causa do nacionalismo árabe. Embora afirmasse que Nasser não pretendesse anexar o Líbano à RAU. Suas declarações causaram espanto entre as lideranças e populações conservadoras e pró-

\footnotetext{
${ }^{587}$ NIR, Omri. The Shiites during the 1958 Lebanese crisis. Middle Eastern Studies, V. 40, N. 6, nov. 2004. p.117.

${ }^{588}$ NIR. Idem. p. 117.

${ }^{589}$ NIR... p. 119 .

${ }^{590}$ Nir... p. 120

${ }^{591}$ Nir... p. 126
} 
chamounistas, mesmo quando ele reiterava sua defesa da independência libanesa.

Durante todo o desenrolar da crise e da guerra civil, Osseiran manteve contatos com ambos os lados e até mesmo com os embaixadores estrangeiros, como foi o caso do corpo diplomático norte-americano ${ }^{592}$. Esteve também sob a forte pressão dos líderes xiitas que exigiam que renunciasse, pois era acusado de se utilizar do cargo de presidente do Parlamento para proveito próprio e de ter uma posição pouco enérgica durante as primeiras fases da guerra civil $^{593}$. Mais tarde, Osseiran passou a defender a renúncia de Chamoun e condenou a intervenção americana ${ }^{594}$. Durante a eleição de Chehab liderou e organizou os procedimentos legais na Câmara para que o então chefe das Forças Armadas pudesse ser tranquilamente eleito e depois empossado $^{595}$. Após a guerra deixou o cargo de presidente do Parlamento.

Outro aliado xiita de Chamoun, Kazem El-Khalil, manteve-se ao lado do Presidente durante toda a crise quando então era um dos ministros que compunham o seu gabinete na administração do primeiro-ministro Sami el-Solh. Controlou o seu feudo no Jabal Amil, fazendo frente às tropas dos Assad e ali sofreu diversos ataques pessoais de homens armados devido a seu apoio ao governo. Em um relatório da embaixada dos EUA, baseado em fontes do exército libanês, afirma-se que essa luta de el-Khalil e outras travadas no sul não tinham relação direta com o governo libanês e se deviam às disputas e rivalidades locais ${ }^{596}$. Mesmo assim, devido ao seu apoio a Chamoun, após a guerra perdeu influência e prestígio sendo derrotado nas eleições de 1960 pelos Assad $^{597}$.

Ibrahim Haider, como já foi dito acima, foi outro aliado de Chamoun, embora a sua tribo, os Haider, estivesse contra o Presidente. Mesmo tendo sido eleito como um opositor, por sua postura anti-Nasser, Haider apoiou a queixa feita na ONU contra a RAU por Chamoun, como um membro do Comitê de Relações Exteriores do Parlamento. Sua posição causou uma forte reação dentro de sua tribo, levando vários de seus membros a escrever um manifesto contra ele que saiu com as seguintes palavras: "We are sons of Haider Tribe, oppose MP Ibrahim Haider`s

\footnotetext{
592 Nir... p.114

593 Nir... p. 115

${ }^{594}$ Nir... p.116

${ }^{595}$ NIR... p. 126

${ }^{596}$ NIR... p. 118 .

${ }^{597}$ NIR... p. 119.
} 
deviation from the Road of Arab Nationalim... declare our lack of loyalty to him, and our sincere loyalty to the independent arab Lebanon and liberation from a foreign intervention"

Já o clero xiita evitou tomar uma atitude complexa em relação ao conflito, pois, embora convocasse os muçulmanos para lutar, também preferia fazer um chamado à moderação buscando a reconciliação e condenando os efeitos destrutivos da guerra. Suas reuniões com Adel Osseiran, que em um primeiro momento chegaram a pedir a renúncia, visavam a pedir ao presidente do Parlamento que iniciasse conversações com os dois lados em luta para encontrar um compromisso. Sua atitude revelava cautela contra os efeitos negativos que sua comunidade poderia sofrer durante a guerra, já que boa parte das baixas eram de xiitas, mas também era devida ao temor que a rebelião levasse a uma alteração no status quo, que bem ou mal lhes favorecia pelo fato de dar, ao promover a preponderância das comunidades religiosas na organização social e política do Líbano. Dessa maneira, portanto, tendo um papel de destaque aos religiosos nos assuntos do dia a dia das pessoas individualmente bem como na vida coletiva.

Também o fato de que os xiitas não lutavam por uma causa de sua seita e sim a favor de causas políticas, várias das quais externas ao Líbano e mesmo com potencial antirreligioso, fazia com que o clero xiita fosse cauteloso 599 .

A população xiita por sua vez apoiou aberta e maciçamente a luta contra Chamoun, tendo os seus homens se alistado em várias das milícias anti-Chamoun. Parte desse apoio pode ter vindo da influência dos campos de refugiados palestinos, pois o contato com eles fortaleceu sua identidade árabe e intensificou o seu sentimento de solidariedade árabe. Porém a principal razão foi o seu desejo de melhorar suas difíceis condições socioeconômicas através da mudança do status quo. Como afirmou Nir (2004): "As in a previous occasion in the modern history of Lebanon, the Shi'ite population was [...] motived by its long-term feelings of neglect, abandon, and great anger at the Lebanese authorities" ${ }^{600}$.

A ação da maior parte dos xiitas contra Chamoun foi algo que chamou a atenção por conta da ideia de que eles eram aliados naturais dos cristãos e que nunca se aliariam aos sunitas em caso de uma crise série que desembocasse em uma guerra civil, como no caso da crise de

\footnotetext{
598 NIR... p. 120.

${ }^{599}$ NIR...p. p.123-124.

600 NIR.. p. 125.
} 
1958. Esse episódio mostrou que isso não era verdadeiro, pois embora existissem xiitas que apoiaram Chamoun, entre os quais diversos líderes conservadores, a maior parte da população ficou do lado da oposição aliando-se aos sunitas e aos drusos do Shuf por conta das razões econômicas, sociais e políticas acima colocadas.

\subsection{Diplomacia}

No terreno diplomático no começo da crise, o chanceler Charles Malik procurou se reunir com os embaixadores francês, britânico e norte-americano quando acusou a RAU de estar interferindo nos assuntos internos libaneses e ameaçando a independência do país. São citados como prova disso a prisão junto à fronteira da Síria do Cônsul Geral da Bélgica, quando contrabandeava armas para dentro do Líbano, seguindo instruções dos líderes rebeldes; a prisão de soldados sírios nas manifestações em Beirute e um possível ataque de 500 soldados da RAU em um posto na fronteira entre os dois Estados ${ }^{601}$.

Ao longo de todo o conflito Malik insistira junto às potências ocidentais sobre a necessidade de proteger a soberania do Líbano e acusou Nasser de promover uma agressão contra o Líbano e de ser o verdadeiro causador da guerra civil. A esse respeito os britânicos pretendiam oferecer uma resposta rápida e contundente aos pedidos do ministro das Relações Exteriores libanês, afirmando o seu compromisso em defender o status quo do Líbano. Porém os norteamericanos se mostram cauteloso, receosos que uma aberta intervenção a favor de Chamoun incendiasse ainda mais o Líbano e favorecesse Nasser no mundo Árabe.

Para eles tropas somente deveriam ser despachadas em último caso para proteger propriedades (interesses) americanas e impedir que o Líbano fosse anexado à RAU, algo visto como extremamente perigoso para os interesses americanos no Oriente Médio. O secretário de Estado Foster Dulles afirmou que eram três as razões que levariam a uma intervenção americana na guerra civil libanesa: a) uma queixa do governo do Líbano no Conselho de Segurança da ONU alegando interferência ou agressão da RAU; b) apoio público dos Estados árabes para as queixas libanesas e c) o reconhecimento por parte de Chamoun de que a crise libanesa transcendia a questão eleitoral e a promessa que ele não forçaria pela aprovação de sua candidatura se isso

${ }^{601}$ ATTIÉ, Caroline. Struggle in the levant... p.174. 
ameaçasse a integridade nacional $^{602}$.

Como Chamoun durante todo o tempo em que a guerra civil se desenrolou, mas principalmente nos momentos mais críticos para ele, sempre insistia na necessidade da intervenção militar dos EUA para salvar o seu regime; os americanos, embora afirmassem o seu apoio ao Presidente libanês, pediam a Chamoun que procurasse resolver a crise sem a necessidade de buscar a intervenção norteamericana. Eles afirmavam diretamente para o Presidente libanês, que a intervenção acirraria os conflitos comunitários e poderia causar a divisão do país ${ }^{603}$. Além disso, como já haviam dito privadamente com os seus aliados britânicos, a intervenção poderia trazer consequências perigosas no Oriente Médio para a posição dos EUA promovendo o nasserismo na região. Diversos outros pedidos de Chamoun até o golpe militar no Iraque, na metade de julho, receberam a mesma resposta por parte dos norte-americanos ${ }^{604}$.

Nesse contexto as posições de Charles Malik proferidas publicamente na ONU e outros lugares contra a RAU foram um importante elemento de propaganda do governo Chamoun para buscar internacionalizar a crise e forçar a seu favor uma intervenção ocidental. Os argumentos eram sempre os mesmos: acusava-se a RAU de agredir o Líbano e fomentar a subversão local, nunca se comentando a respeito das causas internas da guerra civil e, simultaneamente, Malik sempre defendia o alinhamento exclusivo do Líbano com o campo ocidental, por conta dos tais laços históricos de seu país com a França e o Ocidente de maneira geral. Como exemplo disso podem-se citar trechos de seu pronunciamento, dia 6 de junho, ante o Conselho de Segurança da ONU, no qual chegou a afirmar que a situação do Líbano era análoga à da Manchúria e ao caso de Munique, nos anos 30, e que, portanto, a RAU estava ameaçando o Oriente Médio e a paz mundial ao "atacar'”o Líbano ${ }^{605}$.Ele se referiu ao governo do Cairo da seguinte maneira:

That arms are flowing into Lebanon; that Lebanese nationals are trained in subversion in Syria; that Syrian civilian nationals are also infiltrating into Lebanon and taking part in subversive activities... United Arab Republic governmental elements direct and, in some instance, take an active part in the subversive activity... ${ }^{606}$.

\footnotetext{
602 ATTIÉ... p. 175.

603 DULLES, Foster apud TRABOULSI: A history of modern Lebanon... p. 134.

${ }^{604}$ GENDZIER. Notes from the minefield... p. 277-278.

605 GENDZIER. Idem. p. 224

${ }^{606}$ Fala de Charles Malik na ONU em 6 de junho apud GENDZIER. p. 266
} 
Na mesma ocasião também afirmou, no contexto da Guerra Fria, que a guerra civil era uma luta contra a expansão do comunismo e, por isso, o Líbano se batia pela humanidade ${ }^{607}$. Nos EUA, em encontros com Foster Dulles, Eisenhower ou outros membros do governo americano, ele deixava transparecer claramente suas opiniões contrárias ao nacionalismo árabe, a Nasser e a qualquer movimento contrário à presença imperialista ocidental no Oriente Médio que aparecesse nessa região $^{608}$. Prova do estreito alinhamento ideológico de Malik com os membros do governo americano foi a forte amizade desenvolvida, por conta da visão de mundo semelhante, entre o chanceler libanês e Foster Dulles. Tendo ela sido muito bem conhecida e comentada dentro do Departamento de Estado, a ponto de os dois serem vistos orando juntos ${ }^{609}$.

\subsection{A ação da RAU}

Embora na realidade a guerra não fosse causada por uma ação de subversão de Nasser contra Chamoun, o governo da RAU apoiou os rebeldes fornecendo fundos, armas e até homens para lutar contra o governo libanês, além de promover uma intensa e pesada campanha de propaganda por meio de jornais, mas principalmente através das ondas de rádio nas quais a Voz dos Árabes se dirigia à população libanesa estimulando-a a se rebelar contra o seu governo.

O forte carisma de Nasser entre os muçulmanos fazia com que eles o apoiassem em sua disputa contra o seu próprio Presidente e era um estímulo a essa gente para a sua luta armada contra o seu próprio governo. Dessa maneira, a propaganda da RAU contra Chamoun durante a guerra acusava-o de ser um preposto do imperialismo ocidental e de conspirar contra o nacionalismo árabe, condenando-o por buscar a reeleição e agir de maneira autoritária com relação à oposição.

Também eram alvos da campanha de propaganda membros do governo, partidos e aliados do Presidente libanês. Nesse caso um alvo importante era Malik. A defesa do governo se fazia por meio da imprensa dos partidos aliados do governo e declarações na imprensa governamental, escrita ou radiofônica, que, se por um lado não surtiam efeito entre a maior parte

\footnotetext{
${ }^{607}$ GENDZIER. p. 270

${ }^{608}$ GENDZIER. p. 219

${ }^{609}$ GENDZIER. p. 261
} 
dos muçulmanos drusos, eram aceitas pela maioria da população cristã que ficou do lado de Chamoun. A propaganda da RAU também vinha de dentro do Líbano por conta dos inúmeros órgãos de imprensa das forças de oposição, principalmente jornais e revistas. Os editores desses órgãos se aproximaram ou se aliaram a Nasser, passando a fazer intensa campanha contra Chamoun ao mesmo tempo em que defendiam o líder egípcio e o seu projeto para o mundo Árabe.

A atitude em relação a Chamoun contrastava fortemente com o tratamento dado a Chehab, durante o conflito, mas especialmente após a sua eleição como Presidente. No caso do comandante-em-chefe das Forças Armadas sempre eram ressaltados os seus pontos positivos e sempre se ressaltavam nele todas as qualidades. Além de sempre se recordar a origem de sua família, supostamente na linhagem da tribo do profeta Maomé, os coraixitas, uma informação obviamente importante para atrair o apoio dos muçulmanos, e que seu avô, o emir Bashir Shihab, havia colaborado com o Egito no século $\mathrm{XIX}^{610}$.

A própria população da RAU apoiava a luta dos rebeldes libaneses, vendo-a como uma luta do nacionalismo árabe contra os representantes do imperialismo ocidental. Alistamentos de voluntários eram realizados especialmente nas vilas e cidades do centro-sul da Síria, sendo que eles eram principalmente drusos da região do Hawran (organizados pelo sultão Pashá Al Atrash, um dos mais importantes líderes da revolta drusa contra os franceses em 1925-1927) e eram enviados ao Líbano para combater ao lado da oposição ${ }^{611}$.

Já como exemplo do abastecimento dos rebeldes, relata-se que na metade de junho foram visto caminhões cheios de munição deixando Alepo em direção ao oeste. Os gastos da RAU na assistência aos rebeldes podem ser observados pelo relatório do diretor do Banque de Syrie, Pierre Muqannas, e teriam chegado a 70 milhões de libras sírias ${ }^{612}$.

Dentro do Líbano o embaixador da RAU, o general Abdul Hamid Ghalib, continuou a agir de maneira extremamente ativa distribuindo fundos para membros da oposição, bem como continuou a financiar jornalistas. Os valores corretos não são conhecidos, mas segundo duas supostas listas compiladas pelo coronel Abd al Hamid al-Sarraj, chefe dos serviços de

\footnotetext{
${ }^{610}$ QALAWOUN. The struggle for Lebanon... p. 69.

${ }^{611}$ GENDZIER, Irene L. Notes from the minefield... p. 269.

${ }^{612}$ ATTIÉ, Caroline. Struggle in the levant... p.186.
} 
inteligência síria na RAU, que apareceu em um livro de 1962 escrito pelo jornalista Nuhad alGhadri, al-Kitab al-Aswad (o Livro Negro), indivíduo que frequentava os círculos de poder na Síria na época da RAU e que depois passou a criticar Nasser e suas políticas, com relação aos próprios rebeldes colocaram-se os seguintes valores: 23 milhões de libras sírias para Saeb Salam; 6 milhões de libras sírias para Kamal Jumblatt; 5 milhões para Adnan al-Hakim; 7 Milhões para Rachid Karami; 2 milhões para Ahmad al-Assad e 2 milhões para Abdallah al-Yafi.

Tudo isso distribuído em 1958 e que totalizaria 50 milhões de libras sírias ${ }^{613}$. Já outro dado provém do general Fuad Chehab que teria dito ao encarregado de negócios britânico I. D. Scott que, segundo os seus serviços de inteligência, os rebeldes teriam recebido 80 milhões de libras sírias da Síria ${ }^{614}$. Saeb Salam anos depois afirmou ter recebido de Ghalib 1,3 milhões de libras libanesas que foram gastos com pouco mais de 120 combatentes vindos da Síria para ajudálo na guerra ${ }^{615}$. Kamal Jumblatt ao menos confirmou que recebeu ajuda da RAU e sempre pronunciou declarações muito positivas a respeito de Ghalib ${ }^{616}$.

Essa ajuda era, obviamente, intolerável para o governo e por causa dela Chamoun expulsou Ghalib em 24 de julho sem dar qualquer explicação para essa ação e promoveu uma forte limpeza na representação diplomática da RAU, reduzindo o pessoal da missão diplomática egípcia para apenas quatro indivíduos. Para evitar as consequências políticas e militares de uma ruptura completa com a RAU poderia ter o governo libanês afirmado que a expulsão de Ghalib não significava o fim das relações diplomáticas ${ }^{617}$. As ingerências de Ghalib no Líbano não eram uma exclusividade sua. Todos os embaixadores dos países com influência sobre o governo libanês faziam a mesma coisa, como foi mostrado mais acima no caso da vitória de Chamoun nas eleições de 1957. Essa ingerência era realizada também por outros países árabes e acontecia devido à fragilidade militar e geopolítica do Líbano.

\subsection{O governo libanês e os seus apoiadores}

\footnotetext{
613 ATTIÉ ... p. 142-143.

${ }^{614}$ ATTIÉ ... p. 144.

${ }^{615}$ QALAWOUN. The struggle for Lebanon... p.67.

${ }^{616}$ ATTIÉ... p. 194.

${ }^{617}$ QALAWOUN. The struggle for Lebanon... p. 58-59.
} 
No lado do governo, durante o conflito teve o PNSS um papel marcante para a defesa das posições chamounistas, ainda que o nível da importância das ações militares dos nacionalistas pan-sírios seja objeto de debate. Esse partido era contrário ao pan-arabismo de Nasser, visto como um projeto que ia contra o do PNSS, cujo objetivo é o de unificar o Crescente Fértil. Tendo uma ideologia anticomunista, o PNSS via sua oposição crescer em relação a Nasser e ao nacionalismo árabe por conta da aproximação do Egito com a URSS.

Sua aproximação do Presidente libanês também se deveria ao fato de terem em Chamoun um protetor contra as ações dos serviços de inteligência sírios e egípcios. Embora tivessem se aproximado de Chamoun já nos anos 40, seria nos anos 50 que aconteceria a aliança entre ambos, primeiramente para derrubar Bechara el-Khuri e depois quando Chamoun foi Presidente. Este oferecera amparo aos membros do PNSS libanês e daria asilo a inúmeros exilados sírios desse partido que fugiam de perseguições políticas em seu país, como as promovidas por Nasser após a formação da RAU. Também puderam ser uma base de apoio político para o Presidente libanês, enquanto ele sofria a pressão política de indivíduos e grupos importantes da cena política libanesa ${ }^{618}$.

O PNSS pôde ajudar a defender o governo de Chamoun por conta da sua excelente capacidade organizativa e experiência, muitas vezes trazidas pelos oficiais do exército sírio exilados no Líbano ${ }^{619}$. As ações militares do PNSS em diversos pontos do país ajudaram a impedir os rebeldes de tomar diversas posições estratégicas que poderiam fazer com que Chamoun ficasse em uma situação crítica. A luta dos nacionalistas pan-sírios se desenrolou em quatro principais frentes, das quais três eram vitais para o governo: no norte, no distrito do Akkar, se opuseram ao forte avanço dos rebeldes na 'Batalha de Edbil', que durou quarenta e oito horas, para impedir que eles se juntassem aos rebeldes de Trípoli, bem como pudessem controlar a fronteira norte com a Síria; ainda no norte, no distrito cristão-ortodoxo de Kura, onde o PNSS tinha uma de suas maiores bases, eles organizaram bloqueios e patrulhas impedindo todo o tráfego e a comunicação entre os rebeldes localizados em Zgharta e aqueles de Trípoli; no Vale do Beka'a foram bem sucedidos na manutenção do controle por parte do governo da cidade de Hirmel impedindo os rebeldes de Baalbeck de estabelecer contato com os do Akkar.

\footnotetext{
618 BESHARA, Adel. Lebanon: the politics of frustration - the failed coup of $1961 \ldots$ p. 38-39.

${ }^{619}$ LENCZOWSKI, George apud BESHARA, Adel ... p. 43.
} 
Também a presença dos nacionalistas pan-sírios no Beka'a meridional e ocidental impediu que as tropas de Kamal Jumblatt estabelecessem contatos com a fronteira síria; por fim na importante 'Batalha de Shemlan', iniciada no fim de junho, quando os rebeldes de Jumblatt atacaram as vilas localizadas nas colinas situadas nas imediações do aeroporto internacional de Beirute, para assim marcharem em direção à capital. Nessas localidades enfrentaram a resistência do governo apoiados por 150 combatentes do PNSS, que forçaram os rebeldes a recuar. Posteriormente ocuparam a vila rebelde de Kayfoon e, quando acontecia o terceiro dia de batalha, tomaram a vila Shemmun, obrigando as forças de Jumblatt a recuar 10 milhas ${ }^{620}$.

O PNSS também ajudou o governo de outras maneiras, como quando apresentaram uma nota razoavelmente detalhada sobre a situação nos campos de batalha aos representantes da missão da UNOGIL. Enviaram um memorando ao Secretário Geral da ONU Dag Hammarskjold, no qual apresentavam uma imagem ideológica da crise libanesa, que mais parecia uma maneira ocidental de olhar para o Oriente Médio. Mais tarde, quando o relatório da UNOGIL minimizou a extensão da infiltração da RAU no Líbano, o PNSS emitiu outra nota questionando a qualidade da investigação. Essa nota foi usada por Chamoun para, junto a outros documentos, reforçar o seu pedido de uma intervenção ocidental na guerra civil a seu favor. Isso foi um resultado indesejável, pois os líderes do PNSS não pensavam que uma intervenção militar pudesse ser útil para encerrar a guerra a não ser em circunstâncias especiais, devido ao fato de que ela poderia levar a uma ação armada da RAU na forma de uma invasão regular para se contrapôr à intervenção estrangeira a favor de Chamoun ${ }^{621}$.

Chamoun em uma tentativa de adquirir apoio no Mundo Árabe, um dia antes de se dirigir à ONU, fez um pedido à Liga Árabe para que ela organizasse uma reunião a respeito da interferência da RAU na guerra civil libanesa. As delegações árabes reuniram-se em Bengazi, leste da Líbia, por iniciativa dos egípcios, entre 31 de maio e 6 de junho, em seis reuniões a portas fechadas. Os representantes da RAU e do Líbano trocaram acusações mútuas e a delegação libanesa pediu que a Liga Árabe tomasse medidas efetivas contra o governo do Cairo, por conta de suas ações contra o Presidente libanês, enquanto o representante da República Árabe acusava o governo de Beirute de minar a Liga Árabe para poder se valer do Conselho de Segurança da

\footnotetext{
${ }^{620}$ BESHARA... p. 43-44.

${ }^{621}$ BESHARA. Idem. p. 44-45.
} 
ONU na solução de uma disputa entre dois Estados árabes.

Em 4 de junho o Conselho da Liga adotou o projeto de resolução do governo da Líbia , no qual se decidiu pedir que o governo do Líbano retirasse sua queixa contra a RAU na ONU e que buscassem resolver internamente e de maneira pacífica o seu conflito civil, interrompendo as lutas e os distúrbios ${ }^{622}$. A delegação libanesa presente na reunião aceitou as recomendações da Liga Árabe, mas Chamoun não, o que gerou um constrangimento diplomático. Nesse encontro Charles Malik não participou, o que pode demonstrar que o governo libanês dava pouca importância a esse encontro ${ }^{623}$.

Foi, no entanto, nas Nações Unidas que o governo de Chamoun percebia que poderia ver atendidas as suas denúncias contra a RAU. Desde 14 de maio já havia sido apresentada uma queixa por parte dos libaneses. No dia 22 do mesmo mês acontece a apresentação de uma carta do governo libanês ao presidente do Conselho de Segurança na qual acusa a RAU de interferência na guerra civil do Líbano. Em 6 de junho ocorre um debate sobre o Líbano e nos dias 10 e 11, em novas reuniões, as potências ocidentais defendem o ponto de vista do governo libanês, enquanto a URSS defende a RAU afirmando que o conflito no Líbano era uma questão interna sem nenhuma ameaça para a paz mundial.

Nesses dias o representante sueco, Gunnar Jarring, apresenta um plano e defende a ideia de se criar uma comissão para investigar a situação no Líbano e descobrir se as queixas do governo de Chamoun procedem ou não e que isso deveria ser feito com a colaboração de todos os lados na disputa. Jarring então apresenta um esboço de resolução, mostrando preocupação pela independência do Líbano sem implicar que o Conselho de Segurança tenha aceitado a queixa do governo de Chamoun. Decide-se no dia seguinte estabelecer o Grupo de Observação das Nações Unidas no Líbano (United Nations Observation Group in Lebanon - UNOGIL), com apoio tanto do Líbano e das potências ocidentais quanto da RAU e aceitação da URSS, apesar de sua abstenção na votação da resolução. Tendo existido por seis meses - de 11 de junho a 9 de dezembro de 1958 - essa missão da ONU deveria investigar e descobrir se existia ou não provas de contrabando de armas para os rebeldes e infiltração de combatentes da RAU no território

\footnotetext{
622 QALAWOUN. The struggle for Lebanon... p. 54.

${ }^{623}$ GENDZIER. Notes from the minefields... p.265
} 
libanês e o seu responsável era o Secretário Geral da ONU ${ }^{624}$.

Os comandantes da operação no terreno eram o ex-presidente do Equador Galo Plaza, Rajeshwar Dayal da Índia e Odd Bull, um major-general da Noruega. Os primeiros cinco observadores chegaram a Beirute já no dia 12. Os demais foram chegando até o dia 14. No dia 18 os três comandantes da operação tiveram sua primeira reunião informal. Galo Plaza tornou-se o chefe do grupo e Bull o responsável pelos observadores militares. Existia também um grupo de conselheiros que se reunia para consultas dos planos, composto de sete indivíduos vindos de sete países diferentes. Esse grupo fora criado em julho e, provavelmente, estava previsto para ser utilizado em uma ampliação das operações da UNOGIL ${ }^{625}$. As relações entre os comandantes da UNOGIL e o governo libanês eram realizadas através do ministro da Saúde, Dr. Albert Mokheiber $^{626}$.

As ações dos observadores da ONU começaram dois dias após a sua chegada, primeiramente em Beirute e nos arredores da capital. Uma semana depois se instalaram em diversas localidades do interior do Líbano, principalmente na fronteira. Os observadores rapidamente enfrentaram dois tipos de dificuldades que atrapalharam as suas observações: a natureza montanhosa do terreno na fronteira com a Síria e a pouca vontade da oposição em colaborar com os observadores da ONU. Com relação à acessibilidade física o próprio grupo de observadores relatou que: "physical acessibility to the border by road is considerably restricted in the area lying between the frontier itself and the main roads running the length of the Bekaa Valley" ${ }^{\prime 27}$. Nas regiões sob controle dos rebeldes, que praticamente incluía toda a fronteira com a Síria, foi necessário realizar acordos com os chefes da oposição. Mesmo assim, os rebeldes faziam de tudo para afastar os observadores e as missões noturnas se tornaram impossíveis de serem realizadas por conta dos enormes riscos que implicavam. Em regiões como a fronteira norte na planície do Akkar os observadores da ONU conseguiram chegar apenas no dia 9 de julho, embora desde o dia 3 houvesse operações nessa região. As dificuldades das operações terrestres fizeram com que se passasse a confiar nas operações de reconhecimento aéreo, tendo

\footnotetext{
${ }^{624}$ CURTIS, Gerald L. The United Nations group observation in Lebanon. In: International organization, V. 18, N. 4, outono de 1964. p. 741-742.

625 CURTIS: Idem. p.746-747.

${ }^{626}$ ATTIÉ, Caroline. Struggle in the levant... p. 215.

627 Trecho do Primeiro Relatório da UNOGIL, parágrafo 6 apud G. CURTIS. p. 748.
} 
sido realizado 35 voos ao longo do Akkar, vinte deles à noite. No Vale do Beka'a, nas suas regiões central e setentrional, os observadores tiveram o seu acesso restrito a princípio, mas puderam explorar a região e patrulhar as áreas de fronteira durante o dia e usar aviões para o reconhecimento aéreo durante a noite. Nas regiões sul e sudeste do Beka'a a UNOGIL teve um acesso limitado e os observadores não conseguiram detectar qualquer movimento substantivo de veículos trafegando entre a Síria e o Líbano. Patrulhas aéreas no litoral também não conseguiram detectar qualquer atividade de infiltração de elementos da RAU no Líbano. Já a patrulha marítima foi deixada a cargo do governo libanês, apesar de fazer parte da missão da ONU ${ }^{628}$.

No dia 3 de julho foi tornado público o primeiro relatório de trabalho dos observadores da UNOGIL, que gerou grande polêmica, pois nele se afirmava que foram encontradas evidências sobre as atividades de interferência massiva da RAU no Líbano e que isto era um exagero do governo libanês. Durante o conflito Chamoum falava que entre 10 e 12 mil homens compunham as tropas dos rebeldes, dos quais $25-30 \%$ seriam soldados sírios ou egípcios $^{629}$. Os observadores da ONU tinham um número diferente. Estimavam os combatentes da oposição entre 5.000 e 12 mil dos quais entre 300 e 1.000 talvez fossem sírios ${ }^{630}$. As armas encontradas eram de origem britânica, francesa e italiana e pertenciam a libaneses ${ }^{631}$. No entanto, as declarações da equipe da ONU não foram consideradas conclusivas por conta das grandes limitações a que estavam sujeitos os seus observadores.

Já o primeiro-ministro Sami el-Solh se mostrou aborrecido com as conclusões dos observadores de que a vasta maioria dos rebeldes eram libaneses, pois aquela equipe composta de estrangeiros teria muita dificuldade em distinguir entre sírios e libaneses, pois se diferenciavam apenas por dialetos. Por outro lado, as potências ocidentais evitaram qualquer crítica ou condenação, afirmando que a infiltração de homens e armas existia e que continuava a ocorrer e que a UNOGIL deveria tomar medidas adicionais para evitar a entrada de ajuda para os rebeldes $^{632}$. Apesar do relatório da ONU, Chamoun continuou a afirmar que existia infiltração maciça da RAU no Líbano, sendo que o número de sírios ou egípcios nas fileiras da oposição

\footnotetext{
${ }^{628}$ CURTIS. The United Nations group observations in Lebanon... p.749-750.

${ }^{629}$ ATTIÉ, Caroline. Struggle in the levant... p.190; GENDZIER. Notes from the minefields... p. 270.

${ }^{630}$ GENDZIER. Idem. p. 270.

${ }^{631}$ GENDZIER. Idem. p. 268.

${ }^{632}$ CURTIS. The United Nations group observation in Lebanon... p.752.
} 
chegavam às centenas e que 30 mil armas haviam sido entregues por Nasser à oposição, além de que possuíam campos de treinamento no outro lado da fronteira com a Síria. A prova disso seriam supostas fontes de informação nas quais os aliados ocidentais de Chamoun confiavam ${ }^{633}$.

Enquanto a UNOGIL realizava as suas observações, Hammarskjöld viajava entre Beirute, Cairo e Jerusalém conversando com os líderes do Oriente Médio a respeito de uma solução para a crise libanesa. Rumores que circulavam nos meios diplomáticos da época afirmavam que, em um encontro entre Hammarskjöld e Nasser, o líder egípcio teria se comprometido com o secretário-geral da ONU a não mais enviar ajuda para os rebeldes e, assim, contribuir para direcionar o conflito libanês para uma solução negociada ${ }^{634}$. Cabe destacar que as relações do secretário-geral com Chamoun eram tensas. Hammarskjöld não gostava do Presidente libanês e se considerava que ele tinha simpatias para com Nasser. Em uma das discussões com Chamoun, o secretário-geral chegou a dizer que a unidade do Líbano era mais importante do que sua independência ${ }^{635}$ e que "Lebanon was of only slight importance when compared with events in Europe, and that the execution of Nagy was of far greater importance". As discordâncias entre os dois eram tão fortes e a irritação de Chamoun com a missão da ONU tão grande que o presidente libanês chegou ao ponto de dizer publicamente que os observadores das Nações Unidas eram indolentes e passavam a maior parte do seu tempo em cafés e clubes noturnos da capital $^{636}$.

No dia 15 de julho foi publicado um relatório especial onde se destacava que a missão havia superado as dificuldades do primeiro mês. O comando da equipe da ONU conseguiu chegar a um acordo para que os homens de sua equipe pudessem vistoriar todos os veículos e carregamentos que entravam e saíam do Líbano pela fronteira norte e postos de observação permanentes fossem montados em todas as zonas controladas pela oposição. Em 15 de julho 16 postos haviam sido instalados com um total de 163 observadores. Havia também a proposta de se estabelecer 16 novos postos próximo ou nas fronteiras e mais oito planos para operações de reconhecimento com quatro helicópteros de apoio e mais equipamentos e pessoal. Esperava-se

\footnotetext{
633 GENDZIER. Notes from the minefields.... p. 270.

634 GENDZIER. Idem. p.270.

635 ATTIÉ, Caroline. Struggle in the levant... p.216.

636 ATTIÉ. Idem... p. 217.
} 
dentro em breve obter-se o acesso a toda a fronteira ${ }^{637}$. A invasão americana a partir da metade de julho mudaria a situação da missão da ONU, pois lhe retirava totalmente sua força política para que esta procedesse à resolução da crise libanesa e criou entre as forças rebeldes desconfianças e temores de que a bases da UNOGIL pudessem ser usados pelos americanos. Um resultado imediato do desembarque foi a limitação do acesso à fronteira, somente conseguida quando da eleição de $\mathrm{Chehab}^{638}$.

Como foi dito mais acima, no Oriente Médio, para além do mundo Árabe, regimes conservadores da região como o de Adnan Menderes na Turquia e o do Shah Reza Pahlevi apoiaram e ajudaram Chamoun durante a guerra civil libanesa. Os turcos deram apoio diplomático e forneceram armamentos como muitos rifles, submetralhadoras e munição ${ }^{639}$. Turcos e iraquianos também pediram a Chamoun para que ele fizesse o Líbano entrar na União Árabe, associação formada em março entre as duas monarquias Hachemitas - Iraque e Jordânia para se opôr ao nasserismo e ao nascimento da RAU. No entanto, Chamoun declinou pois, além de não defender a entrada do Líbano nessa união, não confiava na capacidade dos exércitos árabes e temia a sua imprevisibilidade. Uma outra razão para não aderir à União Árabe era o receio de que os rebeldes convocassem voluntários de todo o mundo Árabe e mesmo de outros lugares, caso tropas iraquianas e jordanianas interviessem no conflito ${ }^{640}$.

No caso do Shah, da mesma maneira que os turcos, o apoio ao governo libanês se devia ao receio que ele sentia do pan-arabismo e da figura do Nasser em particular, ainda mais por conta de suas conexões com a URSS. Por conta disso, o Shah considerava de máxima importância impedir a subida de um governo pró-Egito no Líbano devido à importância desse país no quadro do Oriente Médio e o risco de que os demais governos da região pudessem vir a cair. Pahlevi foi um advogado da intervenção militar dos EUA para sufocar os rebeldes, considerando isso tão urgente que via como irrelevante a inaplicabilidade da Doutrina Eisenhower no caso do Líbano, bem como a busca por uma boa justificativa. Pahlevi também sublinhava a importância de Israel e da Arábia Saudita na contenção de Nasser, sendo que Israel, para o monarca iraniano, conseguia bloquear um pouco o "expansionismo árabe". O Shah

\footnotetext{
${ }^{637}$ CURTIS. The United Nations group observation in Lebanon... p. 752.

638 CURTIS. Idem. p. 757.

639 QALAWOUN. The struggle for Lebanon... p. 67.

${ }^{640}$ ATTIÉ. Struggle in the levant... p.193.
} 
também aconselhava a promover a Arábia Saudita pelo fato de que esse país possuía as duas maiores cidades santas do Islã e a construção da imagem do monarca saudita como guardião desses lugares santos poderia ser usada para combater a figura de Nasser ${ }^{641}$.

A política de aproximação dos EUA em relação a Nasser irritou bastante o Shah em um primeiro momento, pois isso poderia favorecer as ambições do líder egípcio para adquirir maior controle sobre os países do Oriente Médio mas, por outro lado, se o custo dessa política não fosse muito alto, Pahlevi poderia aceitá-la ${ }^{642}$. Durante a guerra civil o Shah, por meio de sua polícia política, a Savak, forneceu a Chamoun armas portáteis e munição.

A política iraniana para o Líbano a partir dos anos 50 foi tanto a de buscar aliança com os setores anti-pan-arabistas, bem como a de tentar impedir que setores importantes da população libanesa, como os xiitas, se sentissem atraídos pelo nasserismo. Essa ingerência iraniana era realizada principalmente pela Savak que, por meio de seus agentes, contatava os líderes dos partidos direitistas que se opunham a Nasser, como foi o caso das Falanges libanesas, que receberam fundos iranianos para financiar a campanha dos seus candidatos nas eleições de 1960 e 1964 e cujos jornais defendiam o regime do Shah.

O Bloco Nacional de Raymond Édde e o PNL de Chamoun também receberiam ajuda iraniana assim como o partido armênio Dashnak. Essas aproximações foram consequência do apoio do Shah ao presidente Chamoun durante os anos de crise com o Egito e ao longo da guerra civil de 1958 e se baseavam em uma crença de que tanto iranianos quanto os libaneses (ou ao menos sua população cristã) partilhavam de um sentimento comum de aversão ao nacionalismo árabe, o que os levaria a colaborarem entre si.

Israel, inimigo declarado do Egito e do nacionalismo árabe, também buscou se aproximar de Chamoun e ajudá-lo durante a guerra civil, embora fizesse isso de maneira discreta sem anunciar publicamente. Também apoiaram o presidente libanês por conta do que consideravam uma ameaça de sovietização do Oriente Médio caso os rebeldes vencessem a guerra civil.

De maneira similar aos iranianos, defendiam a necessidade de uma ação decisiva dos EUA na defesa do regime de Chamoun e que apenas os norte-americanos poderiam garantir a

\footnotetext{
641 GENDZIER. Notes from the minefields... p. 287-288.

642 GENDZIER. Idem. p. 289.
} 
sobrevivência do seu regime e da orientação ocidental do Líbano ${ }^{643}$. O próprio chefe da inteligência militar de Israel, o coronel Yehoshafat Harkabi disse de maneira clara que o seu país "[...] would like to see intervention in Lebanon by the West",644.

Todavia, para a resolução da crise, embora defendessem Chamoun, estavam dispostos a aceitar Chehab como presidente se isso fosse uma necessidade para os interesses israelenses. Em suas reuniões com o secretário de Estado Foster Dulles os funcionários israelenses afirmavam que a segurança de sua nação estava diretamente ligada aos destinos do Líbano e a manutenção de sua orientação política atual.

Como Nasser era inimigo de Israel e o nacionalismo árabe se opunha ao expansionismo sionista na Palestina os israelenses viam como urgente a necessidade de conter Nasser e o pan-arabismo para que o projeto sionista pudesse ser realizado. Nas descrições que faziam de Nasser e do pan-arabismo era frequente o fato de quererem buscar conexões com o nazismo e Hitler, além de fazerem analogias entre o pan-arabismo e o pan-germanismo ${ }^{645}$. No Oriente Médio, Israel também utilizou suas tropas na fronteira libanesa para impedir que os sírios ou os libaneses rebelados a usassem para transportar armas e munições para os teatros de guerra no interior e na capital do Líbano ${ }^{646}$. Essas ações eram feitas em cooperação com o governo libanês, como mais tarde lembraria o então chefe do Comando Norte de Israel Yitzhak Rabin. Além disso, como já foi visto mais acima, os israelenses enviaram armamento para Chamoun, que incluía cerca de quinhentas submetralhadoras Thompson, Beretta e Bren, as quais o próprio Presidente libanês declarou mais tarde, após a guerra, ter supostamente recebido ${ }^{647}$.

\subsection{As Negociações entre Nasser e os Norte-Americanos}

Enquanto a guerra se desenrolava no Líbano, Nasser estabelecia negociações com os americanos por meio do embaixador americano no Cairo Raymond Hare para discutir a respeito da crise libanesa e buscar uma aproximação com os EUA após certos desentendimentos com os

\footnotetext{
${ }^{643}$ GENDZIER. Notes from the minefields... p. 255-257

${ }^{644}$ GENDZIER. Idem. p. 273

${ }^{645}$ Idem... p. 257

${ }^{646}$ Idem... p. 257

${ }^{647}$ Idem... p. 291.
} 
soviéticos. Durante os encontros privados com Hare, Nasser garantiu desde o começo das negociações que usaria a sua influência sobre os rebeldes para buscar uma solução para a crise libanesa. Nessas reuniões Nasser não insistiu na renúncia de Chamoun, afirmando que ele deveria terminar o seu mandato e concordou que Chehab deveria ser o próximo Presidente.

Essas declarações haviam sido feitas às vésperas das queixas feitas no Conselho de Segurança da ONU por Chamoun contra a RAU em 22 de maio. Outro exemplo da aproximação entre a RAU e os EUA foi o fato de as delegações diplomáticas de ambos os países terem se reunido na ONU na tarde desse mesmo dia. Durante esse encontro os egípcios explicaram as razões de sua oposição a Chamoun e afirmaram que o desejo do Presidente libanês de se reeleger era a principal causa da guerra civil em seu país.

Essa aproximação de Nasser em relação aos americanos não convencia os britânicos que se mostravam favoráveis a uma intervenção no Líbano como forma de combater o líder egípcio, defendendo na ONU as posições de Chamoun a ponto que o próprio embaixador americano naquela entidade, Henry Cabot Lodge, afirmava se sentir pressionado pelos seus aliados britânicos a seguir as posições deles. Mesmo assim os americanos continuaram a informar o Foreign Officer (Ministério das Relações Exteriores da Grã-Bretanha) sobre o andamento das negociações com Nasser. Apesar dos britânicos se mostrarem céticos em relações às intenções do Rais, o embaixador britânico em Beirute, G. Middleton, se mostrou confiante nas intenções de Nasser, o que mostrava não haver unanimidade dentro do corpo diplomático britânico e afirmou, nas suas correspondências diplomáticas, que os próprios líderes rebeldes desejavam buscar uma trégua, considerando a insistência do Rais em se obter uma trégua para os rebeldes como um desejo dele de se afastar da crise libanesa ${ }^{648}$.

Por conta disso, Raymond Hare se mostrou confiante em manter as negociações com Nasser. Além disso, as aproximações entre os dois países já haviam começado antes da guerra civil libanesa quando o secretário de Estado Foster Dulles declarou-se favorável a descongelar os fundos egípcios nos bancos estadunidenses se o líder egípcio se comprometesse a indenizar os ex-acionistas da CIA de Suez ${ }^{649}$; da parte egípcia, o pedido de Saud, rei saudita, já em janeiro de 1957, para que os americanos abrissem negociações com Nasser, provavelmente refletisse um

\footnotetext{
648 ATTIÉ, Caroline. Struggle in the levant... p. 210-213.

${ }^{649}$ Idem... p. 219.
} 
pedido ou uma sugestão do líder egípcio ${ }^{650}$. Por isso, quando Hare começou a negociar no Cairo já existia uma predisposição de ambas as partes para ao menos considerar as posições um do outro.

Uma nova reunião entre Hare e Nasser ocorreu no dia sete de junho na qual o líder egípcio afirmou que não pretendia anexar o Líbano à RAU ou mesmo instalar uma administração em Beirute subserviente à sua, se comprometeu novamente a encontrar uma saída negociada para a crise libanesa e temia que a escalada da guerra libanesa pudesse provocar uma intervenção ocidental. Além disso, afirmou que os seus serviços de inteligência não interferiam nos assuntos libaneses e que possuíam recursos financeiros escassos para tal atividade.

O Rais propôs que uma comissão conjunta entre os EUA e a RAU negociasse com Chamoun ao invés dos americanos serem intermediários entre ele e o governo libanês, o que não foi aceito pelos estadunidenses. Mais uma vez Nasser pôs a sua proposta segundo o qual Chamoun deveria terminar o seu mandato, mas Chehab deveria ser eleito Presidente e os rebeldes anistiados. No dia seguinte, confirmando a sua vontade de resolver a crise, Nasser enviou o famoso jornalista Mustafa Amin para destacar a necessidade de se seguir no caminho acertado no dia anterior para a solução da crise libanesa. Essa aproximação entre egípcios e americanos preocupou Chamoun e seus aliados que temiam uma mudança de atitude das potências ocidentais em relação a eles ${ }^{651}$.

Em 24 de junho Nasser deu instruções ao primeiro-ministro sírio para não permitir mais que homens e material bélico chegassem aos rebeldes ${ }^{652}$. A emissão dessa ordem foi também informada a Dag Hammarskjöld. No dia 29 de abril os egípcios, em um passo importante na sua aproximação com os EUA e na busca de solucionara crise libanesa, aceitaram pagar uma compensação aos ex-acionistas da CIA do Canal de Suez, o que levou à liberação de \$26 milhões em fundos egípcios. Nesse meio tempo era grande a troca de correspondência diplomática entre ambos os países que só foi interrompida pela revolução no Iraque ${ }^{653}$.

Mesmo assim os rebeldes não interromperam as suas movimentações militares e

\footnotetext{
${ }^{650}$ Idem... p. 213.

${ }^{651}$ Idem... p. 221.

652 Idem ... p. 19.

${ }^{653}$ Idem... p. 223.
} 
realizaram na última semana de junho uma ofensiva de grande escala, visando a derrotar as forças do governo, na qual as forças da oposição chegaram a enfrentar o exército que se mobilizou para proteger posições estratégicas. Nas semanas seguintes o nível de violência caiu devido à visita do secretário-geral da ONU Dag Hammarskjöld ao Líbano ${ }^{654}$. Por sua vez, na segunda semana de julho houve a diminuição das atividades militares dos rebeldes e uma saída negociada visando eleger Chehab como Presidente estava em curso ${ }^{655}$. Nessa época também já se tinha o compromisso oficial do governo de que o Presidente não buscava mais a reeleição, pois já em 27 de maio o premier Sami el-Solh havia lido na rádio uma declaração, negando que Chamoun tivesse qualquer intenção de conseguir, por meio de uma emenda, uma alteração na constituição que lhe permitisse a reeleição ${ }^{656}$.

\subsection{A intervenção americana}

Em 15 de junho ocorreu a intervenção dos EUA na guerra civil libanesa através do desembarque em Beirute de fuzileiros navais vindos da Sexta Frota da Marinha estadunidense estabelecida no Mar Mediterrâneo, por meio de um plano batizado como operação Morcego Azul (Blue Bat em inglês).

Em agosto essas tropas chegariam a quase 15 mil homens (dos quais 8.500 eram soldados do exército e 5.400 marines), além de que outros 35 mil homens estavam de prontidão em 76 navios fora das costas do Líbano ${ }^{657}$. Ela foi realizada um dia após o golpe realizado por militares nacionalistas que derrubou a monarquia no Iraque e levou à execução do rei Faisal II e do primeiro-ministro Nuri al-Said.

O regime iraquiano era um dos mais firmes aliados dos britânicos e do Ocidente de maneira geral no Oriente Médio. Em seu lugar subiu um regime militar nacionalista que em um primeiro momento se aproximou de Nasser. Pensando que o Presidente egípcio estivesse por trás os EUA regiram rapidamente intervindo na guerra civil libanesa. Simultaneamente e sob a autorização de Washington, os britânicos intervieram na Jordânia para proteger o rei Hussein que

\footnotetext{
654 Idem... p. 190-191.

655 Idem ... p. 195.

656 Idem... p. 210.

${ }^{657}$ GENDZIER. Notes from the minefields... p.312.
} 
estava para ser derrubado por um complô nacionalista. A intervenção fora realizada assim que o próprio Presidente Eisenhower instruiu Chamoun a fazer um pedido de ajuda para dar um aspecto de legalidade à invasão. O pedido de intervenção fora feito também à Grã-Bretanha e França, mas esses países não enviaram soldados, apenas manifestaram publicamente o seu apoio à intervenção dos EUA.

A França ainda enviou um cruzador para Beirute, mas apenas como gesto simbólico. Uma dificuldade para os invasores foi encontrar uma justificativa para ela já que a Doutrina Eisenhower não era aplicável ao Líbano, pois o país não sofria um ataque armado de nenhum Estado alinhado com a União Soviética e o apoio do governo da RAU aos rebeldes era difícil de demonstrar, apesar das acusações feitas pelo governo libanês. A Emenda Mansfield melhorava um pouco a aplicabilidade da Doutrina Eisenhower ao definir que os interesses nacionais americanos se baseavam na necessidade de garantir a independência e integridade dos países do Oriente Médio ${ }^{658}$.

Como justificativa para sua operação militar, os americanos, por fim, disseram que ela visava a trazer estabilidade ao Líbano abalado pela guerra civil, além de supostamente defender a soberania e a integridade do país e o seu governo legitimo ameaçado por grupos apoiados por forças externas. Afirmaram que estavam em Beirute também para defender vidas americanas, mas que não iam como força de combate e que a operação não era um ato de guerra e retirariam seus contingentes militares o mais rápido possível.

Os americanos procuravam também combater as analogias com Suez para que não passassem como agressores aos olhos do mundo sendo que para isso era importante sempre frisar a defesa que eles faziam de um governo legalmente constituído que estava sob a ameaça de ser derrubado por meio de uma subversão promovida por um governo estrangeiro hostil. Os EUA também buscaram uma sanção da ONU promovendo uma reunião do Conselho de Segurança no mesmo dia do seu desembarque em Beirute. Nela o delegado americano Henry Cabot Lodge tentou argumentar afirmando que os EUA não procuravam substituir ou minar a ação da ONU no Líbano. Sua ação, aliás, seria respaldada pela carta da ONU. Lodge também tentou buscar uma resolução da Assembleia Geral a respeito de agressões indiretas ${ }^{659}$.

\footnotetext{
${ }^{658}$ GENDZIER. Idem. p. 248.

659 Idem... p. 324-325.
} 
A operação Morcego Azul contou com soldados vindos de bases americanas ou da OTAN em diversos países do Mediterrâneo, da Alemanha Ocidental e até dos EUA. 4.000 mil toneladas de carregamento foram desembarcadas ao longo dos vários meses que os militares americanos permaneceram em Beirute. Tanques, jipes, carros blindados, munição, equipamentos de comunicação etc. vieram da Alemanha, França e EUA em 418 viagens sem nenhum incidente. Até unidades médicas e de engenheiros especializados em serviços médicos e sanitários foram enviados para Beirute. Três navios de guerra, Saratoga, Essex e Wasp, estacionaram na costa equipados com armamentos nucleares. Juntos a esses navios estavam destroieres, cruzadores e outros barcos de guerra. Tudo isso foi uma demonstração de força para intimidar os rebeldes, Nasser e talvez os próprios soviéticos ${ }^{660}$. O desembarque aconteceu nas praias próximas ao aeroporto às $15 \mathrm{~h} 00 \mathrm{~min}$. Após obter o controle de Khalde, no sul de Beirute, os fuzileiros navais avançaram pela cidade no dia seguinte embora não ocupassem os bairros sob o controle dos rebeldes. Também controlaram os acessos à capital estabelecendo barreiras nas estradas ${ }^{661}$.

Ao longo de toda de todo o processo de ocupação, a operação americana pode ser dividida em três fases: 1) o desembarque situado entre 15 e 16 de julho; 2) a 'fase de operações' entre 26 de julho e 15 de setembro e 3 ) a fase de retirada entre 15 de setembro e 25 de outubro ${ }^{662}$. O custo total da operação Morcego Azul foi de 200 milhões de dólares ${ }^{663}$.

A invasão foi saudada pela direita cristã, sua imprensa e boa parte da população cristã que percebiam os americanos como salvadores da independência do país. O Jornal A-Amal do Katáeb chegou a estampar em sua capa: "Lebanese citizens go out to shore to welcome US troops" ${ }^{\text {,664 }}$. Porém, a invasão foi repudiada pela oposição e a maior parte da população muçulmana e drusa, que tinham um pensamento contrário aos dos cristãos, pois viram o desembarque americano como uma agressão imperialista. O jornal de oposição al-Teleghraf expressava essa opinião ao descrever o desembarque como: "flagrant aggression to Lebanon's independence; this is an occupation in the full sense of the word". Por outro lado havia políticos cristãos que condenaram a intervenção. Um deles foi Ghassam Tuwaini, que escreveu: "the

\footnotetext{
${ }^{660}$ GENDZIER... p. 311-312.

661 ATTIÉ. Struggle in the levant... p.198-199.

662 GENDZIER. Notes from the minefields... p. 312.

663 ATTIÉ. Struggle in the levant... p.200.

664 ATTIÉ. Idem. p.198.
} 
Government of Lebanon's policy of looking to the West for protection is patterned after the worn out crusades whereas by landing troops, the West is simply protecting its vital interests. [...] Foreign troops will not solve the Lebanese crisis" ${ }^{665}$. Henry Far'oun, Charles Hilu e o expresidente Bechara el-Khuri eram exemplos de importantes personagens políticos cristãos que também se opuseram à intervenção. Por outro lado existiam certos políticos muçulmanos que apoiaram o desembarque americano como foi o caso do primeiro-ministro sunita Sami elSolh $^{666}$.

Quem também se opôs ao desembarque americano foi o comandante em chefe Fuad Chehab. Para evitar um confronto entre os Chehab e os militares libaneses de um lado e os norteamericanos, o embaixador MacClintock procurou atuar como um intermediário tentando buscar um acordo entre eles ${ }^{667}$. Apesar dos americanos virem com um discurso a favor da cooperação entre eles e os libaneses, o exército libanês bloqueou em diversos pontos da capital a passagem das tropas estadunidenses obrigando-os a negociar com os libaneses. Após negociações com Chehab, chegou a um acordo segundo o qual as tropas americanas seriam acompanhadas por soldados libaneses, mas Chehab e o seu exército de imediato se recusaram a atacar qualquer posição dos rebeldes, dentro ou fora de Beirute, o que em um primeiro momento desagradou bastante aos estadunidenses $^{668}$. Chehab manteve sua postura de oposição à intervenção nos encontros com autoridades americanas como foi, por exemplo, durante as primeiras conversações com o emissário americano Robert Murphy no navio Saratoga ancorado no porto de Beirute, mesmo quando este proferiu ameaças ao comandante do exército. Posteriormente as relações melhoraram entre os dois lados a ponto de Murphy afirmar em um cabo enviado a Washington que Chehab estava colaborando com os americanos e mesmo mostrando a eles evidências das ligações entre os rebeldes do bairro de Basta e a Síria ${ }^{669}$.

Um opositor da intervenção foi o embaixador americano Robert MacClintock. Ele afirmava em seus despachos enviados para Dulles que a intervenção iria se opôr a uma série de grupos políticos libaneses que poderiam ter uma contribuição a dar para o fim do conflito; além

\footnotetext{
665 AL-NAHAR, 16 jul. 1958 apud ATTIÉ... p.199.

666 GENDZIER. Notes from the minefields... p.317.

667 GENDZIER. Idem. p. 315.

668 ATTIÉ, Caroline. Struggle in the levant... p.199.

${ }^{669}$ GENDZIER. Notes from the minefields... p.316.
} 
disso, MacClintock afirmava que a oposição à intervenção se encontrava até mesmo nos círculos considerados amistosos em relação aos EUA $^{670}$. Quando ela aconteceu o enviado americano Robert Murphy acabou ocupando grande parte da posição junto ao governo do Líbano e às demais forças políticas que eram de MacClintock.

Durante todo o desenrolar da intervenção a falta de coordenação entre a embaixada e o comando da Sexta Frota minaram a posição do embaixador americano ${ }^{671}$. A Sexta Frota também não conseguiu manter uma ligação por meio de rádio e telefone com a embaixada, falharam em manter MacClintock informado sobre o lugar do desembarque, além de manterem uma disputa com a embaixada: se a embaixada deveria chamar primeiro a Sexta Frota ou viceversa $^{672}$. Além disso, durante todo o desenrolar da intervenção as relações entre o embaixador americano e o almirante Holloway, comandante das forças navais americanas no Líbano, permaneceram bem tensas. Tudo isso pode não ter sido acidental e sim resultado de uma política para isolar MacClintock por conta de sua oposição à intervenção. Mesmo assim, o embaixador continuou atuando junto às forças políticas presentes no Líbano. Ele foi o principal representante dos EUA junto à UNOGIL e teria papel de destaque no processo de formação do governo de Chehab $^{673}$.

As reações no mundo em relação à intervenção americana foram bem variadas. Além da França e da Grã-Bretanha, Canadá (apesar de ter oposição dentro do governo) e Itália apoiaram a intervenção americana. Áustria e Suíça que eram Estados neutros na Europa fizeram objeções à intervenção $^{674}$. Já o primeiro-ministro da Índia e aliado de Nasser, J. Nehru, condenou a invasão e rejeitou os motivos alegados para que ela acontecesse tanto por Chamoun quanto pelos americanos. O Japão também criticou a intervenção americana lembrando que o relatório da ONU não confirmava a interferência maciça da RAU no conflito libanês. Para forçar a mudança da posição japonesa os americanos pressionaram o governo daquele país e levantaram o espectro da ameaça comunista.

No mundo Árabe e no Oriente Médio a resposta variou: Turquia e Irã a aprovaram, já

\footnotetext{
${ }^{670}$ GENDZIER. Idem. p. 282.

${ }^{671}$ GENDZIER... p. 314

672 THAYER, Charles apud GENDZIER. p. 314.

${ }^{673}$ GENDZIER... p. 314.

${ }^{674}$ GENDZIER. p. 314.
} 
o governo revolucionário da FLN na Argélia ficou do lado da RAU na condenação da ação americana. O Marrocos aprovou a intervenção embora afirmasse reconhecer as demandas da oposição. Na Arábia Saudita houve sinais de divisão dentro da família real entre os que apoiavam e os que ficaram contra a ação dos americanos ${ }^{675}$. A União Soviética evidentemente condenou a ação americana e exigiu a retiradas do exército invasor. Porém, ao mesmo tempo evitaram conduzir a crise libanesa para um confronto armado entre as duas superpotências, o que também não era o objetivo dos americanos. Os soviéticos apesar de terem continuado a apoiar a RAU, inclusive por meio de exercícios militares, pediam que Nasser agisse com cautela e que seu apoio não poderia significar aprovação a todo tipo de ação. Os soviéticos procuravam ser um ator político importante no Oriente Médio, porém estavam dispostos até mesmo a reconhecer os interesses petrolíferos americanos na região se o ocidente promovesse um comércio mais equitativo com os produtores de petróleo locais ${ }^{676}$.

Quanto aos chefes da Missão da ONU no Líbano, estes reagiram de maneira bem crítica à intervenção americana, vendo-a como uma interferência em seu trabalho, cujo resultado foi anular todo o seu esforço até então empreendido para averiguar se havia ou não contrabando de armas para os rebeldes. Galo Plaza nas primeiras semanas da intervenção se recusou a qualquer tipo de colaboração com os americanos ${ }^{677}$. Os governos da Áustria e da Suécia também afirmaram que a intervenção levou a um conflito dos EUA com a UNOGIL, sendo que Estocolmo se solidarizou com o secretário-geral Hammarskjöld pelo constrangimento a ele causado pela ação dos norte-americanos ${ }^{678}$.

Chamoun e Malik se entusiasmaram com a intervenção e passaram a pedir aos americanos que agissem o mais rápido possível e de maneira vigorosa contra os rebeldes. Uma semana após a intervenção, as relações entre o executivo libanês e os americanos eram amistosas e Chamoun enviou uma carta de agradecimento a Eisenhower, na qual louvava o presidente americano: "in responding to my call for help, based on decision by the legitimate government of Lebanon, through the landing of U.S. forces in Lebanon to help us defend our Independence and

\footnotetext{
675 Idem... p. 324-325.

${ }^{676}$ Idem... p. 320.

677 Idem... p. 319.

${ }^{678}$ Idem... p. 321.
} 
integrity in conformity with article 51 of the Uniteds Unions Charter" ${ }^{679}$.

Porém, com o tempo Chamoun passou a reclamar da ação dos estadunidenses, afirmando que tanto ela quanto a intervenção britânica na Jordânia não eram adequadas para conter o que ele considerava uma ação combinada do nasserismo e do comunismo no Oriente Médio. Ainda por cima o presidente libanês chegou a dizer que, caso a intenção dos EUA fosse a de delegar a questão do Líbano à ONU, então "it would be better if U.S. forces had not come in the first place" ${ }^{\circ 80}$.

Os norte-americanos, no entanto, não estavam dispostos a arcar com as consequências políticas e militares de uma ação contra a oposição, não havendo, portanto, entre os comandantes militares e representantes no Líbano a intenção de ampliar a intervenção. Essa percepção da falta de necessidade para atuar militarmente por parte dos americanos também se devia ao fato de que muitos dos líderes rebeldes eram conservadores com inclinação favorável aos EUA. Também o desejo de uma acomodação com Nasser, que continuava a favor de uma política de compromisso para a crise libanesa, levou os norte-americanos a buscarem o diálogo com a oposição e a uma política de compromisso para a resolução da guerra civil libanesa. Isso tudo levou os norteamericanos a se cansarem de Chamoun, que era visto por membros do governo americano como intransigente, incapaz de abandonar o poder e vítima de seus próprios excessos e a buscar um compromisso politico entre os diversos atores locais para formar um novo governo ${ }^{681}$.

Através do emissário de Eisenhower, Robert Murphy, os americanos em Beirute se reuniram com líderes de ambos os lados em confronto, bem como com lideranças religiosas e o general Chehab para encontrar uma saída negociada para a crise libanesa. Apesar disso, a ação dos americanos também envolveu intimidação, uma vez que sua presença militar servia para coagir as lideranças rebeldes a seguir os caminhos por eles propostos e, quando isso não era suficiente, ameaças veladas eram um outro instrumento usado para atingir esse objetivo.

Os encontros de Murphy com líderes muçulmanos da oposição como Saeb Salam, Hussein 'Uwayni e Abdallah al-Yafi foram caracterizados pelo uso de ameaças contra eles por parte do emissário norte-americano. A busca de uma saída política possuía três aspectos inter-

\footnotetext{
${ }^{679}$ Idem... p. 340.

680 Idem... p. 318.

681 Idem... p. 341.
} 
relacionados: a procura de um candidato aceitável, que fosse do consenso entre as diferentes facções políticas e comunidades religiosas libanesas e, ao mesmo tempo, fosse o menos propenso possível a uma política neutralista nas relações internacionais; a busca pela formação de um gabinete que pudesse ser aceito por um Parlamento chamounista; finalmente, a necessidade de se providenciar ajuda financeira e apoio em termos de segurança interna para o novo regime ${ }^{682}$. Vários candidatos foram propostos como Alfred Naqqash, o ex-presidente Bechara al-Khuri, Raymond Eddé, Salim Lahhud, Charles Hilu, Eli Abu Jawdeh, Fuad Chehab e outros.

As negociações para se buscar um novo Presidente para o Líbano por parte dos libaneses e dos EUA foram feitos conjuntamente com o governo egípcio que, como falado mais acima, também estava comprometido com uma solução negociada para a crise libanesa. Os egípcios chegaram a um consenso com os americanos e as forças políticas libanesas e concordam que Chehab, por conta de sua boa reputação na sociedade, sua capacidade de manter unido o heterogêneo exército libanês e seu papel durante a guerra civil, fosse eleito o próximo Presidente. Fuad Chehab foi eleito em 31 de julho, no Parlamento, com 48 votos a favor e 8 contra. Nesse momento Eisenhower pediu a Murphy que se ausentasse do Líbano para não dar a impressão de que os americanos estavam interferindo na eleição ${ }^{683}$.

Para que as normas constitucionais fossem respeitadas e com isso a estabilidade nacional, decidiu-se que Chamoun encerraria o seu mandato, o que aconteceu no dia 23 de setembro. Enquanto tudo isso acima acontecia, um dos grandes receios de Washington era de que o futuro presidente fizesse o Líbano adotar uma política de neutralidade nas relações internacionais, o que poderia prejudicar a posição dos EUA no Oriente Médio, ainda mais porque no Líbano essa posição era defendida por importantes nomes da vida política nacional.

Entretanto, eles perceberam que, mesmo no caso de Chehab seguir uma política neutralista, isso não significaria um prejuízo para os interesses americanos no Líbano, pois líderes da oposição a Chamoun que estavam subindo ao poder como Rachid Karami passaram a ter em relação aos EUA uma atitude totalmente cordial, não ameaçando nenhum interesse americano, embora mantivessem uma forte aproximação com Nasser. Além do mais, poucos líderes libaneses estavam interessados em romper as relações com os EUA e se alinhar exclusivamente com

\footnotetext{
682 GENDZIER... p. 339.

683 Idem... p. 341.
} 
Nasser. Algumas figuras como o chanceler Philippe Taqla chegaram a pedir que os EUA fossem os fiadores da neutralidade libanesa, ao mesmo tempo em que davam ao país o direito de determinar com quais países, tanto em nível regional como internacional, ele se relacionaria. Isso permitia ao Líbano que evitasse reconhecer Israel e simultaneamente mantivesse suas ligações com os EUA. Essa política foi chamada de 'neutralidade positiva' ou 'neutralidade pacífica' ${ }^{684}$.

Uma outra batalha que se seguiu à eleição de Chehab foi a questão da formação de seu gabinete. Durante o processo que se seguiu para a formação do gabinete do novo governo foi importante a ação do embaixador MacClintock, o qual procurou colocar ministros que estivessem sintonizados com a política e os interesses dos americanos como foi o caso de Pierre Gemayel ${ }^{685}$.

A questão da formação do gabinete de Chehab também mostrou as disputas existentes entre as diferentes forças políticas libanesas. Por fim, em 24 de setembro foi apontado o gabinete do novo governo. Dele faziam parte Rachid Karami como primeiro-ministro; Philippe Taqla como chanceler; Charles Hilu como ministro da Economia e da Informação; Rafiq Najah ministro das Finanças; Muhammad Safyuddin, ministro da Saúde; Fuad Najjar (um druso ligado a Jumblatt), ministro da Agricultura e dos Correios etc. Esse gabinete excluía indivíduos que haviam pertencido a ou eram aliados do governo de Chamoun, o que passava a ideia de que eles haviam sido derrotados apesar da intervenção norteamericana a seu favor.

Isso levou os chamounistas a fazer pesadas objeções ao gabinete de Chehab enquanto o próprio Malik chegou a pedir para Foster Dulles que usassem sua influência política para desacreditar esse ministério. O próprio diretor da CIA na época, Charles Cabell, chegou a se referir como antiamericano o corpo de ministros do novo presidente ${ }^{686}$.

Os americanos então procuraram se reunir com os líderes do novo governo para discutir sobre a composição do seu gabinete de ministro, que tanto descontentamento havia trazido aos chamounistas. Essa tensão havia aumentado ainda mais devido aos conflitos nas ruas entre chamounistas e anti-chamounistas que, aliás, nunca haviam parado e que se intensificaram após o sequestro do editor assistente do Al-Amal, Fuad Haddad, que foi vistos pelos falangistas como ato de provocação ou agressão contra eles.

\footnotetext{
684 Idem... p. 343-344.

${ }^{685}$ Idem... p.348.

${ }^{686}$ GENDZIER... p. 351.
} 
Em 19 de setembro o assassinato de Cesar Bustani, outro membro do Katáeb, fez com que as manifestações da direita cristã assumissem proporções bem sérias. No governo, Chehab e os membros do seu gabinete temiam ainda mais as consequências das agitações por considerar que nem Gemayel e nem Chamoun tinham controle sobre os atos de seus seguidores a quem viam como extremistas e fanáticos cristãos ${ }^{687}$. Por fim, as declarações de Karami afirmando que com o novo gabinete a revolução colhia os seus frutos criou um situação de insurreição nos bairros e vilas cristãs levando a um levante armado das Falanges em outubro, cujo resultado foi a queda do primeiro gabinete de Chehab. Durante o levante o Katáeb, apoiado por milícias chamounistas, manteve posições defensivas na região do Metn, para assegurar o acesso dos falangistas às regiões econômicas mais importantes de Beirute incluindo o porto ${ }^{688}$.

Emissões de mensagens marciais eram clandestinamente transmitidas pela rádio Voz do Líbano. Gemayel em uma mensagem de desafio para os muçulmanos e de estímulo para seus seguidores e sua comunidade na qual mostrava uma característica importante da visão de mundo cristã libanesa afirmou que "those who are mantaining in strike are the enlightened section of the population, that which count as $80 \%$ of the economy" ${ }^{\prime 689}$. A situação era tão tensa e ruim para Chehab e as divisões entre muçulmanos e cristãos cresciam a tal ponto que MacClintock havia afirmado a seus superiores em Washington que Chamoun estava pronto para uma nova luta e ele esperava outra guerra civil ou então uma ditadura. Chehab mesmo havia considerado a formação de um governo civil-militar ${ }^{690}$.

Após negociações entre as diferentes facções políticas libanesas, onde foi importante o papel intermediador de MacClintock e do almirante Holloway, decidiu-se por um gabinete encolhido no qual os ministros teriam funções sobrepostas e que seria composto por dois líderes muçulmanos e dois cristãos, representando os dois lados na guerra civil. Essas lideranças eram Rachid Karami e Husein Oueini do lado muçulmano e Pierre Gemayel e Raymond Eddé do lado cristão $^{691}$. O impacto que o levante do Kata`eb teve no processo de formação do novo governo de Chehab e na atitude dos políticos de oposição foi tão forte que esse movimento ficou conhecido

\footnotetext{
687 GENDZIER... p.348 e 352.

688 GORIA. Wade R. Sovereignty and leadership in Lebanon, 1943-1976. Londres: Ithaca Press, 1985. p.45.

689 GORIA. Idem. p. 48.

${ }^{690}$ GENDZIER. Notes from the minefields... p. 354.

${ }^{691}$ ATTIÉ, Caroline. Struggle in the levant... p. 224.
} 
como a contra-revolução falangista.

Ao mesmo tempo em que ocorriam as negociações a respeito da eleição do novo Presidente e da montagem de sua equipe ministerial, debatia-se acerca da retirada das tropas americanas, a qual começou em 29 de agosto, dois dias antes da eleição de Chehab. Na metade de setembro, o almirante Holloway começou a retirada do equipamento militar e das unidades de serviço como uma pré-condição para a saída de todas as forças de combate. Esperava-se que em 10 de novembro todos soldados americanos estivessem fora do Líbano, mas já em 23 de outubro a maior parte da tropa invasora havia saído. Holloway então retornou para o seu quartel-general em Londres e os últimos sinais de presença militar americana em Beirute foram retirados dia 2 de novembro. No meio desse processo Chehab e Eisenhower afirmaram votos de amizade entre os seus respectivos países. A retirada estadunidense seguiu ao desengajamento da questão libanesa na ONU; com isso Henry Cabot Lodge, representante dos EUA na ONU, o chanceler Hussein 'Uwaini e Dag Hammarskjöld anunciaram cada um a retirada das tropas, pediram a eliminação da queixa contra a RAU e anunciaram o fim da missão da UNOGIL ${ }^{692}$.

Enquanto se retiravam, os americanos ofereceram ao novo governo libanês ajuda financeira e assistência em termos de segurança para que ele não sofresse qualquer tipo de instabilidade nos seus primeiros meses. O plano de ajuda financeira foi acertado em uma reunião em Istambul entre MacClintock e o subsecretário de Estado para Negócios Estrangeiros Douglas Dillon na metade de outubro. Foi então decidido oferecer U\$S25 milhões em apoio ao orçamento para um período de quase um ano até 31 de setembro de 1959.

Mas, por outro lado, em virtude do fracasso do antigo plano do Point IV, MacClintock também recomendou ao seu governo que a assistência técnica fosse interrompida ${ }^{693}$. Debateu-se no governo americano a respeito da assistência que se deveria oferecer às forças de segurança do Líbano como uma maneira de garantir a estabilidade do governo Chehab. Para isso foi mantido no Líbano o Office of Public Safety, uma agência do governo americano especializada na modernização das forças policiais e no treinamento contra-insurgência. Para a direção da seção libanesa dessa agência foi aconselhada a escolha de um indivíduo - Albert E. du Bois - que havia participado das atividades de ajuda às políticas de repressão da ditadura militar

\footnotetext{
692 GENDZIER... p. 359.

693 Idem... p. 356.
} 
tailandesa.

Ao mesmo tempo o adido do Exército preparou uma lista de equipamentos e seus prováveis custos a serem entregues às forças de segurança libanesas. Eles incluíam desde caminhões até munição, armas de fogo, ambulâncias, granadas de mãos e capacetes. A embaixada americana participaria dessas ações por meio de MacClintock que iria coordenar essas atividades $^{694}$. Esses objetivos estavam em sintonia com um documento emitido em 4 de novembro de 1958 pelo Conselho de Segurança Nacional dos EUA, no qual se afirmava a necessidade de se manter uma certa distância da política libanesa, afastando-se de relações que possam ser prejudiciais aos interesses americanos. Porém, ao mesmo tempo, se procurava oferecer assistência militar para propósitos de segurança interna e buscava-se conseguir com que os países árabes vizinhos aceitassem o status único do Líbano ${ }^{695}$. O conflito libanês durou cerca de quatro meses. Entre 2.000 e 4.000 pessoas foram vítimas da guerra.

Para alguns autores como Kamal Salibi a intervenção americana parou a interferência estrangeira no Líbano, ajudou a colocar fim à insurreição e fez com que o conflito se reduzisse às suas demandas internas ao cortar o seu caráter pan-árabe (The modern history of Lebanon, 1965. p. 202), além de preservar a integridade do país (Lebanon under Fuad Chehab. p. 218). Para outros como Fawwas Traboulsi (A modern history of Lebanon, 2007) e Charles Winslow (Lebanon: war and politics in a fragmented society), a intervenção no Líbano, juntamente com a britânica na Jordânia, visava a salvar regimes pró-ocidentais ameaçados por sublevações internas.

Winslow ainda destaca que os americanos aceitavam que mudanças pudessem ocorrer, mas desde que fossem graduais e que não ameaçassem o equilíbrio de poder regional (p. 120). Já Caroline Attié (Struggle in the levant: Lebanon in the 1950s...) afirma que o conflito já se encaminhava para uma solução, mas os temores de que a revolução no Iraque se espalhasse pelo Oriente Médio e contagiasse os rebeldes libaneses fez com que os americanos, apoiados por ingleses e franceses, resolvessem intervir no país para dissuadir os revolucionários da região e Nasser que, em um momento inicial, pensaram que estava por trás da queda da monarquia iraquiana.

Outra autora, Irene Gendzier (Notes from the minefield, 1997), afirma que os

\footnotetext{
${ }^{694}$ GENDZIER... p. 361-362.

${ }^{695}$ Idem... p.360.
} 
americanos resolveram intervir devido principalmente a causas internas do Líbano: o fortalecimento dos rebeldes no mês de julho e a possibilidade de que eles pudessem derrubar Camille Chamoun; a conexão desse evento com o golpe no Iraque que, apesar da proximidade, não era tão evidente, pois se os americanos temiam a influência dos revolucionários iraquianos sobre os rebeldes e os muçulmanos libaneses. Bem como o Oriente Médio, por outro lado estabeleceu rapidamente contatos com o novo governo em Bagdá e este não cortou o fluxo de petróleo aos países ocidentais e nem estatizou as companhias petrolíferas estrangeiras. 


\section{CAPÍTULO 4}

\section{Alguns grupos políticos libaneses}

\subsection{O Kata`eb (as Falanges libanesas)}

Durante o período de 1950 à 1970, uma das mais importantes forças políticas do Líbano foi o partido da Falange, ou Kata`eb em árabe, que teve ampla penetração em diversas comunidades cristãs, mas particularmente entre os maronitas que sempre foram a sua principal base de apoio. O Kata`eb era caracterizado pela defesa de um nacionalismo libanês exclusivo para os cristãos do Líbano, afirmando a origem fenícia dos libaneses e seu caráter distinto dos seus vizinhos árabes, a suposta orientação ocidental de sua sociedade e a defesa do sistema econômico capitalista. Rejeitava todas as correntes políticas que defendiam a inclusão desse país em um movimento político mais geral pan-árabe quer viessem de muçulmanos, de cristãos ou fossem apresentados por forças políticas laicas. Rejeitava também políticas econômicas de tipo estatizante ou socializante. Nos anos 50 e 60 o partido foi um adversário firme do nasserismo e de sua influência no Líbano.

Fundado em 21 de novembro de 1936 como uma organização paramilitar inspirada nos movimentos fascistas europeus da época, era organizada em torno de uma estrutura hierarquizada na qual, quando o conselho central decidia a respeito de um programa, todo o partido e suas organizações locais as implementavam sem questionar. As seções locais das Falanges também tinham a função de divulgar a propaganda do partido, assisti-lo durante as campanhas eleitorais e, em caso de necessidade, pegar em armas. $\mathrm{O}$ seu aspecto paramilitar era evidenciado em sua disciplina, nos uniformes de seus militantes, nos seus desfiles e treinamento militar $^{696}$.

Os falangistas imaginavam que estavam trazendo ao Líbano um modelo de ordem e disciplina que seria positivo para a organização de sua sociedade considerada excessivamente anárquica e individualista. Defensores da unidade libanesa de imediato se opuseram aos grupos muçulmanos que não aceitavam a incorporação forçada de seus territórios ao Grande Líbano. Seu lema que sintetizou a sua ideologia sempre foi Deus, Pátria e Família. O Kataeb teve no

${ }^{696}$ HUDSON, Michael C. The precarious republic: political modernization in Lebanon. Nova Iorque: Random House, 1968. p.145. 
farmacêutico maronita Pierre Gemayel o seu grande líder por quase meio século e seus dois filhos Bashir e Amin seriam Presidentes durante a década de 1980. Os descendentes de Pierre ainda hoje se encontram ativos e influentes na política libanesa.

Por conta do seu caráter nacionalista e da organização paramilitar do Kataeb, o partido foi posto na ilegalidade pelos franceses em 1937, junto com outras agremiações políticas. Essa medida trouxe a simpatia de uma boa parcela da população maronita para aquele movimento. Como eram nacionalistas e defendiam a independência do Líbano em relação à França, se associaram a outros movimentos libaneses para lutar por esse objetivo, como durante a greve geral de novembro de 1943.

No desenrolar dos eventos que levaram a independência os franceses prenderam todos os membros do governo libanês. Nessa oportunidade o Kata`eb teve até o seu líder Pierre Gemayel preso. A participação ativa dos falangistas estabeleceu definitivamente o seu partido como uma das principais forças políticas do Líbano ${ }^{697}$.

Nos primeiros anos após a independência, os falangistas buscaram representar a comunidade cristã concorrendo contra outros grupos cristãos nas eleições. Perderam pleitos eleitorais importantes, mas conseguiram eleger determinados deputados o que permitiu ao partido continuar aparecendo na cena política libanesa.

Em 1952 participaram da coalizão de partidos que derrubou Bechara el-Khuri do poder. Posteriormente, ao longo dos anos 50, o falangistas iriam se opor firmemente ao nacionalismo árabe em ascensão, considerando-o um perigo para a soberania do Líbano. Posicionaram-se contra os grupos muçulmanos pan-arabistas e apoiaram Chamoun em sua política de alinhamento com o Ocidente e nos choques com Nasser e os seus aliados libaneses.

No fim dessa década o partido voltou a crescer tendo chegado a possuir cerca de 50 mil filiados. Nessa época, o partido havia se transformado em um firme defensor do modelo econômico libanês. Denunciava qualquer tentativa de se propor uma política estatizante, pois considerava isso uma ameaça subversiva, embora defendesse algum nível de intervenção do Estado na economia como uma maneira de corrigir imperfeições ou problemas que surgissem e

${ }^{697}$ ENTELIS, John P. Party transformation in Lebanon: Al-Kata'ib as a case study. In: Middle Eastern Studies. V. 9, 1973. p. 325-326 
se declara a favor da implantação de um esquema de seguridade social ${ }^{698}$.

Durante a guerra civil de 1958 continuaram do lado de Chamoun e em conjunto com esse presidente denunciaram o apoio da RAU aos rebeldes, pois consideravam isso uma intervenção e uma agressão indireta ao Líbano. Lutaram contra o que avaliavam ser uma ameaça à independência do seu país e ao seu sistema econômico de livre mercado e uma conspiração de nacionalistas árabes e soviéticos. Embora declarassem não estar a favor da reeleição de Chamoun deixaram claro que seu apoio ao Presidente libanês era em nome do país.

Os falangistas sempre viram o Líbano como um país cristão e por diversos momentos expressaram um ponto de vista desrespeitoso para com os muçulmanos. O próprio Gemayel, em algumas oportunidades, durante os anos 50, chegou a dizer que os muçulmanos deveriam abandonar os postos que tinham no governo e entregá-los aos cristãos. Alguns, dentre os falangistas (como também certos elementos entre os cristãos de outros grupos políticos), continuaram a defender um exclusivismo cristão ou mesmo maronita, não reconhecendo o Pacto Nacional e tratando com desprezo os libaneses muçulmanos. Alguns buscaram até mesmo se aproximar de Israel, sonhando com um possível Estado cristão ${ }^{699}$.

Como defensores do status quo os falangistas se opuseram ou viram com desconfianças qualquer ação ou proposta que questionasse a hegemonia cristã e particularmente maronita no Líbano. Dessa forma, afirmavam que um novo censo nacional deveria incluir os cristãos emigrados e seus descendentes. Nas Américas, Austrália e outros lugares onde residiam importantes comunidade de libaneses (em sua maioria cristãos), o Kataeb procurou organizá-los para a defesa de um Líbano independente e próspero. Também procuravam combater os líderes e grupos islâmicos que desejavam a concessão da cidadania libanesa a imigrantes árabes vindos da Síria e do Iraque e que eram majoritariamente muçulmanos ${ }^{700}$.

Por outro lado, apesar de ter uma ideologia ligada fortemente às comunidades cristãs, o partido também foi atraindo militantes não-cristãos como, por exemplo, os 2.000 mil xiitas filiados no começo dos anos 60 e que concorriam no sul do Líbano, Beka'a e no norte do país para as eleições legislativas nacionais. Esses filiados não-cristãos (também haviam alguns sunitas

\footnotetext{
698 GORIA, Wade R. Sovereignty and leadership in Lebanon... p. 47.

${ }^{699}$ GENDZIER, Irene L. Notes from the minefield... p. 188-191.

${ }^{700}$ HUDSON. The precarious republic: political modernization in Lebanon... p.144-145.
} 
e drusos) eram considerados motivo de certo orgulho e usados pelo partido como arma política para atacar os adversários que o acusavam de ser um partido sectário e não-nacional ${ }^{701}$. Esses números continuariam crescendo e, em 1965, o partido teria 10 mil xiitas filiados em um total de 68 mil membros ${ }^{702}$.

No governo de Chehab, os falangistas integraram a coalizão governista, sendo que Pierre Gemayel, após comandar um levante contra a preponderância dos líderes rebeldes, foi apontado como um dos quatro ministros do gabinete no novo governo do pós-guerra em 1958.

A partir desse momento, o Katáeb passou a se comprometer com o governo de unidade nacional de Chehab e com o seu esforço para resolver os desequilíbrios regionais e sectários do país. Sendo assim, se comprometiam com sua política externa neutra, embora mantivessem reservas para com Nasser e outros líderes nacionalistas árabes.

Os falangistas eram então um dos principais representantes das comunidades cristãs e dos maronitas, em particular no governo Chehab, e essenciais para o apoio delas a esse mandatário.

A partir de então, o programa do partido chegou a sublinhar a necessidade de se evitar qualquer resolução violenta dos problemas do Líbano e a destacar o uso das mobilizações e da pressão social para resolvê-los, além de se mostrar disposto a fazer parte de um Líbano multiconfessional $^{703}$. Nessa época, Pierre Gemayel chegou a fazer uma afirmação que contrastaria fortemente com as suas atitudes anos depois: "Lebanon shall be neither church nor a mosque",704.

Mas os acontecimentos durante o governo de Charles Helu modificaram a postura política dos falangistas ou fizeram emergir a natureza sectária do partido e sua postura nacionalista libanesa exclusivista. O Katáeb agora estava na oposição e aliado aos liberais do PNL de Chamoun.

O crescimento das atividades das organizações armadas palestinas no território libanês, as quais algumas eram patrocinadas pela Liga Árabe que o utilizavam como base para

\footnotetext{
${ }^{701}$ HUDSON. Idem. p. 144.

702 HUDSON. Nota 44. p. 166.

${ }^{703}$ ENTELIS, John P. Party transformation in Lebanon: Al-Kataib as a case study... p. 333-335.

${ }^{704}$ HUDSON... p. 144.
} 
operações dentro do Estado de Israel, levavam à crescente desestabilização e às ameaças de violentas retaliações israelenses. Isso fazia com que os falangistas vissem o seu país sofrendo uma grave ameaça.

Quando houve a derrota árabe em 1967, os falangistas tinham dificuldade em esconder a sua satisfação pela derrota do que consideravam o seu pior inimigo externo: o nacionalismo árabe. Internamente, o apoio cada vez maior dos líderes e da população muçulmana que, além disso, havia voltado a denunciar a preponderância cristã no Líbano aos guerrilheiros palestinos, exacerbava o sentimento antimuçulmano de muitos falangistas ${ }^{705}$.

Ao mesmo tempo, o prestigio de seu líder Pierre Gemayel crescia entre os cristãos maronitas e ia apagando o de antigas lideranças como Eddé e Chamoun ${ }^{706}$. Essa acentuação do exclusivismo maronita e cristão dentro do Katáeb, apoiado por boa parte da população cristã, especialmente a maronita, e o desenvolvimento de suas forças paramilitares levaram a choques com os palestinos e seus apoiadores que ajudaram a minar o Estado libanês até a sua implosão em abril de 1975.

\subsection{O Najaddah}

Se entre os cristãos o Katáeb era o partido que dizia representar o seu ethos e possuía fortes inclinações fascistas, dentre os muçulmanos, particularmente os sunitas, também iria se formar um partido que defendesse a ideia de que no Líbano o poder deveria estar sob o controle dessa comunidade a qual deveriam estar submetidos os cristãos.

Este partido foi o Najjadah (os 'socorredores' ou 'resgatadores' em árabe) e seu

surgimento foi uma resposta dos muçulmanos à existência das Falanges ${ }^{707}$. Fundado em 1936 pelo jornalista Muhieddin Nsouli, o Najjadah, como o Kataeb, era um partido de jovens, com inserção nas camadas populares, com um forte aspecto paramilitar e, como aquele partido cristão, também seria perseguido e posto na ilegalidade pelos franceses.

Em 1943, o partido participou ativamente do processo de independência e em 1952,

\footnotetext{
705 ENTELIS, John P. Idem... p. 336-337.

706 GORIA,Wade R. Sovereignty and leadership... p. 78.

${ }^{707}$ GORDON, David. Lebanon, a fragmented nation. Londres: Croom Helm, 1980. p. 152.
} 
fez parte da coalizão de partidos que derrubou Bechara el-Khuri. Apoiou Nasser (considerado um grande reformador árabe muçulmano), para quem organizavam marchas de apoio. Foram contra Chamoun antes e durante a guerra civil de 1958, embora durante esse conflito tenham brigado com Saeb Salam.

Em 1960 o partido tinha 10 mil membros, segundo suas próprias estimativas, vindos da comunidade sunita. Seu líder nos anos 50 e 60 era Adnan Hakim, dono de uma ótica em Beirute $^{708}$. O partido também se opôs aos zu`amas e ao clientelismo libanês e chegou a defender publicamente a incorporação do Líbano à RAU ${ }^{709}$.

A ideologia do Najjadah, formulada principalmente por Ramadan Lawand que era um antigo militante de grupos nacionalistas árabes, denunciava o Ocidente como decadente e pregava a ideia de se fazer ressurgir a cultura árabe-islâmica como base para a criação de um amplo Estado islâmico e no qual grande parte da influência ocidental estaria eliminada e apenas se emprestariam os aspectos considerados mais positivos para o Islã como, por exemplo, técnicas administrativas e burocráticas.

Nesse Estado os muçulmanos seriam o grupo dominante e os cristãos ocupariam a posição de autonomia que desfrutaram durante a época do califado. Não acreditavam que a instalação desse Estado aconteceria em seu tempo, mas sim no futuro, pois achavam que isso era parte do destino dos árabes muçulmanos.

Eles viam o Líbano como uma sociedade dividida entre um grupo ocidentalizado e um grupo oriental e islâmico. Isso era condenável porque o setor ocidentalizado controlava o poder no país e mantinha com pouca influência a parte oriental da população. Por isso, o Najjadah criticava o Pacto Nacional (que havia inicialmente apoiado) por permitir manter essa situação. Esse partido também defendia um grande programa de reforma social e apoio ao presidente Chehab, pois ele promovia reformas que favoreciam as camadas mais pobres da população muçulmana.

Durante os anos 50 e 60 o Najjadeh não conseguiu se difundir muito entre a população sunita por conta da competição de outros partidos islâmicos, grupos laicos e,

\footnotetext{
${ }^{708}$ HUDSON. The precarious republic: political modernization in Lebanon... p. 175.

${ }^{709}$ KHALAF, Samir. Civil and uncivil violence in Lebanon: a history of the internationalization of communal conflict. Nova Iorque e Chichester: Columbia University Press, 2002. p. 119.
} 
principalmente, devido à grande influencia do nacionalismo árabe secular, mas pôde continuar muito ativo se nutrindo do forte sentimento anti-establishment dos sunitas ${ }^{710}$.

\subsection{Kamal Jumblatt e o PSP}

O Partido Socialista Progressista (PSP), embora fosse uma agremiação política também com um caráter fortemente comunitário - nesse caso os drusos eram a sua base política como o Katáeb, ideologicamente se diferenciava bastante deste último, bem como de boa parte dos agrupamentos políticos libaneses das décadas posteriores à independência. Ele era contrário ao modelo liberal adotado no Líbano tanto pelas elites cristãs quanto por boa parte das elites muçulmanas (em especial, mas não apenas, as sunitas).

Centrado em torno da figura do seu líder e fundador, o za'im druso Kamal Jumblatt, herdeiro de uma tradicional família de grandes proprietários de terra da Região do Shuf, Monte Líbano, foi um dos mais importantes partidos das décadas de 1950 e 1960, tendo por meio do próprio Jumblatt participado de maneira decisiva dos acontecimentos mais importantes do Líbano no período: a queda de Bechara el-Khuri, a oposição ao governo de C. Chamoun, a aproximação ao nasserismo e ao nacionalismo árabe, a guerra civil de 1958, o governo Chehab, a ascenção da luta armada palestina e a oposição à elite liberal cristãs anti-chehabista do Hilf no final dos anos 60.

Jumblatt, a figura central desse partido, havia defendido e lutado publicamente por uma política de reforma do sistema confessional libanês (o qual ele denunciava como construído para favorecer os maronitas) ou mesmo o seu abandono, por uma política econômica caracterizada pela intervenção, planejamento e direção da economia pelo Estado na qual aos setores produtivos, indústria e agricultura seria dada prioridade e ao comércio e o sistema financeiro seria dispensada uma atenção menos destacada.

No projeto econômico do PSP estava a nacionalização das empresas prestadoras de serviços em posse de estrangeiros, bem como o de setores estratégicos como o petróleo. A plataforma do partido de Jumblatt também incluía reformas sociais como a distribuição das terras pertencentes aos grandes proprietários tradicionais, programas de segurança social como a

${ }^{710}$ HUDSON. The precarious republic: political modernization in Lebanon... p.175-177. 
criação de um seguro de saúde, o seguro desemprego, indenização para trabalhadores despedidos injustamente e além de outras propostas, a difusão da educação compulsória com a montagem de uma rede de escolas públicas. Defendia também, o sufrágio feminino e uma promulgação de uma carta de direitos. Todo esse conjunto de propostas era chamado coletivamente de socialismo, embora estivessem bem distante de um projeto revolucionário ${ }^{711}$.

Para o PSP em sua doutrina política e social era importante uma definição de sociedade harmônica feita pelo filósofo francês Henri Bergson, na qual uma boa sociedade era aquela em que haveria uma comunidade de obediência voluntária para uma elite superior de inteligência e virtude inata. Porém, essa ordem social deveria ser baseada em princípios democráticos com igualdade de direitos e obrigações para todos.

No caso, a democracia seria um empreendimento da razão humana aplicada às relações sociais. Por isso, muitos críticos afirmavam que esse partido não era socialista e nem progressista embora, como já falado, eles tivessem programas de melhoria e elevação da renda das camadas pobres da população, o que aparecia em seu slogan: "pão e trabalho na justiça e liberdade".

O partido acreditava que deveriam ser criadas no Líbano instituições para a realização da harmonia do homem na sociedade e na natureza. Para isso, era necessário aplicar programas que levassem ao pleno desenvolvimento do homem e ao enriquecimento da vida familiar em uma sociedade que fosse além da luta de classes. Para que isso se concretizasse eram necessários à criação ou desenvolvimento dos serviços públicos e a elevação dos níveis de renda da população libanesa ${ }^{712}$.

Apesar de sua identificação com o nacionalismo árabe, isso não impediu que Jumblatt, ao menos antes de 1957-1958, fizesse críticas a esse movimento, em especial ao conceito mesmo de nacionalismo árabe e a ausência nesse movimento e nos governos que o seguiam de atitudes e políticas democráticas ${ }^{713}$. Acusava muitos governantes árabes de imaturidade política, isolacionismo e de sempre acreditarem em vitórias imaginárias. Em determinado momento, por volta de 1956, Jumblatt chegou até a afirmar que o Líbano seria um

\footnotetext{
${ }^{711}$ GENDZIER. Notes from the minefields... p.164

${ }^{712}$ HUDSON. The precarious republic: political modernization in Lebanon... p.189.

713 AL-KHAZEM, Farid. Kamal Jumblatt, an Uncrowned Druze Prince of Left. In: Middle Eastern Studies, V. 24, n. 8, abr. 1988. p. 185.
} 
modelo para os árabes seguirem, em suas palavras: "a country of progress, wisdom, freedom, humanism and civilizations",714.

As suas relativas objeções ao nacionalismo árabe provocaram desconfianças em relação ao líder druso ao ponto que, em 1956, cinco importantes intelectuais de esquerda tinham se retirado do Partido Socialista Progressista ${ }^{715}$. Apesar disso, o líder do PSP foi, no entanto, muito influenciado pelas posições e a retórica do nacionalismo árabe adotando em seus discursos e práticas políticas muitas das posturas desse movimento, além de acreditar firmemente na vitória da causa árabe.

Quando ocorreu a formação da República Árabe Unida em 1 de fevereiro de 1958, Kamal Jumblatt foi um dos muitos líderes da oposição a Chamoun que louvaram publicamente o seu aparecimento e, mais tarde, fez parte da delegação de líderes libaneses que foi a Damasco congratular-se com Nasser, em 24 de fevereiro, quando este visitou a Síria ${ }^{716}$.

Jumblatt via o nacionalismo árabe como uma superação das estreitezas e egoísmos dos nacionalismos libanês e sírio, o que os tornava opostos a qualquer ideal internacionalista, mas pensava que o primeiro trazia um componente humanístico que propiciaria grandes benefícios para a sociedade libanesa. $\mathrm{O}$ nacionalismo árabe também estava ligado às grandes causas do seu tempo como o não-alinhamento, o anti-colonialismo e a luta pela emancipação do chamado Terceiro Mundo (grupo de países ao qual o Líbano pertencia) e sua libertação do atraso e da dependência econômica diferente, por exemplo, do nacionalismo libanês muito ligado aos imperialismos ocidentais $^{717}$.

Essa maneira de agir menos rígida em relação aos ideais políticos adotados era uma característica desse líder druso e também uma prática do PSP. Jumblatt também nunca esteve preso à obrigação de aceitar nenhuma plataforma ideológica a favor do Estado, mesmo quando fez parte do governo de Chehab. Isso por outro lado, também fazia com que o partido não se sentisse na obrigação de seguir nenhuma política mais consistente, adaptando sua ação e até

\footnotetext{
714 JUMBLATT apud AL-KHAZEM, Farid... p.187.

715 HUDSON. The precarious republic: political modernization in Lebanon... p. 187.

${ }^{716}$ GENDZIER. Notes from the minefields... p. 235.

${ }^{717}$ HUDSON. The precarious republic: political modernization in Lebanon... p.186.
} 
mesmo parte de sua retórica ao contexto de um determinado momento político ${ }^{718}$.

Mesmo estando ligado a um projeto alternativo para todo o Líbano, o PSP, por ser um partido de base comunitária e comandado por um político vindo da elite tradicional drusa, fazia que com muitos dos seus membros e apoiadores tivessem com ele uma maneira tradicional de se relacionar. Mais do que o programa, boa parte do apoio dado ao partido e a Jumblatt se devia ao fato de este ser ao mesmo tempo um za'im e o líder mais prestigioso da comunidade drusa.

Na vida política, o PSP funcionava como uma coalizão frouxa de deputados que incluía muitos dos amigos e apoiadores desses políticos ${ }^{719}$. Por outro lado, é justo reconhecer que o partido sempre atraiu jovens das mais variadas seitas insatisfeitos com o sistema político libanês e que reconheciam como positivo o projeto de seu líder Jumblatt.

O momento em que o PSP mais teve filiados foi o começo dos anos 50, quando chegou a contar com 18 mil membros inscritos e que pagavam regularmente a sua taxa como militantes. A pressão que sofrera do governo de Chamoun fez com que o partido contasse em 1957 com um número que variava entre 10 mil e 12 mil filiados. Em 1962 quando estava no governo de Chehab o número de filiados havia caído bem mais variando entre 4.000 e $6.000^{720}$.

As ideias diferenciadas de Kamal Jumblatt teriam vindo das suas leituras, dentre as quais estavam presentes autores como J. J. Rousseau, Henry Bergson, Teilhard de Chardin e mesmo Mahatma Gandhi, cujo retrato encontrava-se emoldurado em uma sala de sua casa, o Palácio de Mukhtara, embora tenha em sua vida política praticado o oposto do líder indiano ao formar uma milícia e ser um participante ativo na guerra civil de 1958 e depois na de 1975-1976, além do apoio dado à luta armada palestina contra a ocupação de israelense de suas terras ${ }^{721}$.

Jumblatt havia começado sua carreira como membro do Bloco Nacional de Emile Édde onde foi eleito deputado pelo Shuf em 1943 com menos de trinta anos. Isso acontecera porque sua mãe, que comandava a sua família após a morte de seu pai, forjara estreitos laços políticos com aquele líder maronita pró-francês e com o governo mandatário francês como forma

\footnotetext{
718 AL-KHAZEM, Farid. Kamal Jumblatt, an uncrowned Druze Prince of left... p.185

719 AL-KHAZEM. Idem. p. 185

${ }^{720}$ HUDSON. The precarious republic: political modernization in Lebanon... p.187

${ }^{721}$ GORIA. Wade R. Sovereignty and leadership in Lebanon, 1943-1976. Londres: Ithaca Press, 1985. p. 31
} 
de manter a proeminência de sua família ${ }^{722}$.

Se nos primeiros anos de sua carreira Jumblatt defendia as posições mais ocidentalistas e de alinhamento com a França do movimento de Eddé, após 1948, devido ao impacto da destruição da Palestina e do êxodo dos refugiados palestinos em direção ao Líbano, ele tornou-se mais identificado com o nacionalismo árabe, postura que defenderia toda a sua vida.

Jumblatt fez, a partir de 1946, parte do governo de Bechara El-Khuri como ministro da Economia, Agricultura e Negócios Sociais. No governo, o líder druso tentou promover medidas de reforma social, mas fracassou devido à falta de apoio do Presidente.

No fim, acabou deixando o governo em maio de 1947 por discordar da política econômica e social do governo formando então uma coalizão anti-governo no Parlamento denominada Frente Socialista Nacional que se tornou mais ativa após a reeleição de el-Khouri por meios fraudulentos. Em 1949, Jumblatt formou o Partido Socialista Progressista ${ }^{723}$.

Se por um lado Jumblatt acreditava nos ideais que pregava, sua ação também era motivada por interesses políticos pessoais. Seus críticos sempre o acusavam de desejar a reforma do sistema político para atender seu desejo de ser Presidente, algo que era evidentemente impossível pelo fato de não ser maronita. Segundo Goria (1985), Jumblatt sempre se ressentiu dos maiores privilégios que os políticos sunitas e maronitas tinham no sistema político libanês, ainda mais porque ele se considerava como tendo mais capacidades e um preparo maior.

Sobre o sistema confessional libanês que sempre foi um obstáculo à ação política de seu partido, Jumblatt uma vez afirmou: "Community sectarianism was a poison transfused by the Maronites into body of Grand Liban from the moment it was born. This sickness may have been tolerable in the homogeneous Petit Liban of 1864, but it became a festering sore in 1922. A state cannot be organized on the basis of such inequitable division into castes, or around a religious spirit which is not shared by other communities involved",724.

Durante os anos do governo de Chehab, Jumblatt e o seu partido fizeram parte do gabinete reformista do ex-general e, embora este não desejasse acabar com o sistema político confessional, ao buscar promover uma série de reformas sociais visando a desenvolver as regiões

\footnotetext{
722 GORIA. Idem. p. 31

723 GORIA... p. 31

${ }^{724}$ JUMBLATT apud GORIA. p. 32
} 
atrasadas do Líbano e diminuir as desigualdades sociais, especialmente as existentes entre muçulmanos e cristãos, seguia políticas, portanto, que sempre foram defendidas pelo PSP.

Jumblatt no governo Chehab estava na linha de frente da aplicação desses projetos de desenvolvimento social-econômico, pois foi o ministro do Interior dessa administração. Entretanto, mesmo dentro desse governo enfrentou a resistência de membros importantes que viam como radicais várias de suas propostas. Esse foi o caso da sua proposta de nacionalização parcial do trecho libanês do IPC que enfrentou a forte resistência de Pierre Gemayel contra a qual este chegou a apelar dizendo que o líder druso desejava mudar o sistema político libanês. As declarações de Jumblatt chegaram a provocar, fora do governo, a reação até do Patriarca Meushi, nessa época distanciado das políticas chehabistas, que afirmou que caso o Líbano adotasse uma política socialista o país estaria acabado. Durante o mandato de Chehab, Jumblatt e Gemayel mantiveram um forte antagonismo com o líder falangista afirmando que projetos socialistas do tipo do de Jumblatt eram um disfarce para o comunismo sempre procurando descrevê-lo como um extremista ${ }^{725}$.

Curiosamente, ao mesmo tempo Jumblatt e o PSP articularam com forças de esquerda (incluindo o Partido Comunista) e nacionalistas árabes buscando construir uma frente socialista composta desses partidos e dos sindicatos libaneses de esquerda ${ }^{726}$.

Essas atitudes de Jumblatt no cenário político libanês eram resultado do seu profundo desgosto em relação ao sistema político e econômico do seu país, bem como a visão de mundo de boa parte das classes dominantes libanesas.

Jumblatt descrevia a realidade política do Líbano em seu tempo como um ambiente no qual as instituições locais estavam repletas de ladrões e contrabandistas, cercadas de burocratas corruptos e políticos egoístas e no qual as embaixadas de países imperialistas conspiravam o tempo todo contra os interesses do país. A política libanesa era apenas um ordenamento resultante de um impasse entre os interesses de políticos rivais incapazes de impor a sua hegemonia sobre os grupos rivais. Por isso, o cenário político libanês era um ambiente inseguro, tenso, em constante luta e sobrevivendo à custa de um frágil equilíbrio. Por outro lado, por mais corrupta que fosse essa classe, para o líder druso era necessário se aliar e mesmo buscar

\footnotetext{
725 GORIA. Wade R. Sovereignty and leadership in Lebanon... p. 70-71.

${ }^{726}$ HUDSON. The precarious republic: political modernization in Lebanon... p. 185.
} 
um compromisso com determinados membros dela para assim conseguir transformá-la. Isso explica muito das atitudes e ações mais surpreendentes de Jumblatt ao longo de sua carreira. Era o que o líder do PSP chamava de "idealismo prático, ${ }^{, 727}$.

No entanto, com o passar dos anos, especialmente após o governo de Fuad Chehab e diante do distanciamento em relação ao sucessor deste, Charles Helu, essa postura crítica em relação ao sistema libanês e a cada vez maior proximidade com a causa palestina, que se acentuou ainda mais coma derrota do nacionalismo árabe em 1967, direcionaram Jumblatt e o seu partido para uma atitude de desafio cada vez maior às lideranças tradicionais libanesas.

Por conta disso, Jumblatt comandou a formação da Frente de Luta Nacional no Parlamento em março de 1965 que prenunciou o surgimento da Frente Progressista, uma ampla coalizão de partidos de esquerda que, em sua maior parte, tiveram seus direitos políticos cassados (comunistas, ba`athistas, nacionalistas árabes etc.) na qual o PSP tinha um papel destacado. Esse grupo passou a fazer uma ativa oposição à hegemonia maronita na sociedade libanesa.

Jumblatt e o seu partido ainda se aliaram a lideranças regionais que também eram adversárias da direita cristã como Maruf Saad em Sidon e Faruk Mukaddam e Abdul Majid Rifai de Trípoli, apesar de vários deles possuírem opiniões conservadoras.

Cada vez mais a forma de luta dos palestinos - também eles muito ressentidos com o Líbano - influenciava as atividades da oposição de esquerda no Líbano e Jumblatt surgia como o grande defensor e representante da população palestina no Líbano. A causa da libertação da Palestina, dessa maneira, parecia associada à luta contra o establishment libanês, particularmente o cristão, e ambas as lutas se vinculavam à causa árabe mais geral ${ }^{728}$.

Essa radicalização nos anos seguintes continuaria a se acentuar, ainda mais, após a formação da coalizão de partidos da direita cristã, o Hilf al-Thulathi de Chamoun e Gemayel, em reação tanto aos chehabistas como à ascensão da esquerda e do movimento palestino. Tudo isso levou a um aprofundamento das fraturas comunitárias cujo resultado seria a guerra civil iniciada em 1975.

\footnotetext{
${ }^{727}$ HUDSON. Idem. p. 185.

${ }^{728}$ GORIA. Wade R. Sovereignty and leadership in Lebanon... p. 92-93.
} 


\subsection{O partido Baath}

O Partido da Ressurreição (Baath) Árabe foi fundado no ano de 1943 em Damasco, capital da Síria, por jovens intelectuais nacionalistas vindos da classe média. Seus dois principais líderes eram professores e amigos que haviam se conhecido durante os anos de faculdade em Paris na década de1930. Michel Aflaq - um cristão ortodoxo - formado pela Sorbonne em Paris e Salah al-Din Bitar, um sunita, também formado na Sorbonne e futuro primeiro-ministro da Síria.

Aflaq foi o ideólogo principal do partido ao longo de toda a sua vida. No começo, a base social do Baath eram os estudantes de classe média das cidades sírias, os proprietários rurais de porte médio e os membros das elites rurais das comunidades alawita e drusa. Também há um grupo especifico que foi atraído pelo Baath e que seria importantíssimo na história contemporânea da Síria: os oficiais militares de origem rural ou vindo das comunidades islâmicas heterodoxas. O partido ajudou a abrir as carreiras das Forças Armadas para eles e a auxiliá-los em sua ascensão social.

No entanto, eram poucos os seguidores do Baath entre a população camponesa pobre e os trabalhadores urbanos que não sentiam muita atração por sua ideologia. Ele não atraía a maior parte da elite latifundiária rural, dos grandes comerciantes e dos industriais, assim como a maior parte da grande classe média, especialmente a sunita, por conta do secularismo do Baath e do seu socialismo.

O Baath defendia a ideia de que os árabes, embora estivessem espalhados por uma ampla área geográfica que ia desde o Maghreb até o Omã, faziam parte de uma única nação que fora artificialmente dividida pelo colonialismo europeu nos séculos XIX e XX. A recuperação da nação árabe somente seria bem sucedida quando ela fosse unificada em um único Estado.

Essa nação árabe havia sido uma entidade permanente ao longo da história, porém estava em uma situação de decadência e necessitava recuperar a sua grandeza perdida, ressuscitar para a história. Tal processo dar-se-ia por meio da regeneração pessoal de cada membro da nação árabe e por meio disso ela seria restaurada. Esse processo não era religioso, mas moral e para ser árabe não era necessário ser muçulmano. A essência da identidade árabe era o arabismo e não a religião, aí incluindo o Islã.

Depois do processo de unificação a nação árabe se organizaria por meio de um socialismo particular, o socialismo árabe. Os fundadores do Baath, no entanto, não aceitavam a 
ideia da luta de classes, pois como todos os árabes pertenciam a uma única nação não haveria conflito de classes e o socialismo não seria resultado dessa luta de $\operatorname{classes}^{729}$. Haveria a implementação de um programa social moderado, com a realização de um projeto de reforma agrária e nacionalizações parciais, porém ainda mantendo a propriedade privada em grande parte dos setores da economia e com isso a existência de classes proprietárias. No plano internacional o partido Baath reivindicava uma posição de neutralidade entre os blocos soviético e norteamericano no quadro da recém-surgida Guerra Fria ${ }^{730}$.

Em 1953 o Baath se fundiu com o Partido Socialista Árabe de Akram Hourani, líder do movimento dos camponeses que viviam no entorno da cidade de Hama. Com essa fusão o partido passou a se chamar Partido Baath Socialista Árabe e reforçou em sua ideologia o viés da reforma social e defesa dos grupos oprimidos da sociedade síria ${ }^{731}$.

De maneira geral, após 1953, podemos sintetizar a doutrina do Baath assim: o partido sempre fez questão de distinguir a sua posição nacionalista dos movimentos socialistas existentes no Ocidente e dos princípios do movimento comunista internacional. Como já foi dito, eles não se põem contra a religião como os socialismos ocidentais, vendo no islã, por exemplo, uma grande criação da nação árabe no passado e uma manifestação, também no passado, do nacionalismo árabe, louvando o papel de Maomé como líder político responsável pela unificação dos árabes no século VII.

Os baathistas condenam o ateísmo como um erro perigoso, pois para eles a religião é um importante elemento básico de qualquer sociedade ${ }^{732}$. Isso não significa que o partido, no século XX, defenda um Estado teocrático. Pelo contrário ele advoga a separação entre religião e Estado, porém resguardando o direito dos fiéis de qualquer crença praticá-la de maneira livre. $\mathrm{O}$ Baath, por outro lado, condenava líderes, movimentos e Estados religiosos no Mundo Árabe que sustentavam regimes antiquados e injustos acusando-os de serem colaboradores do

\footnotetext{
${ }^{729}$ GALVANI, John. Syria and the Baath party. In: MERIP Reports, N, 25, fev. 1974. p.3

${ }^{730}$ BEN-TZUR, Avraham. The neo-Baath Party of Syria. In: Journal of Contemporany History, V. 3, N. 3, The Middle East (jul. 1968). p. 161.

${ }^{731}$ DAWISHA, Adeed. Arab nationalism in the twentieth century: from triumph to despair. Princeton: Princeton University Press, 2003. p. 154.

732 SULEIMAN, Michel W. Political parties in Lebanon: the challenge of a fragmented culture. Nova Iorque: Cornell University Press, Ithaca, 1967. p. 141.
} 
imperialismo $^{733}$.

Com relação ao comunismo, eles o consideravam um produto externo ao Mundo Árabe, uma ameaça ao seu espirito nacional e modos de pensar. É adequado à União Soviética ou ao Ocidente, mas entre os árabes se fosse adotado supostamente obstaculizaria a liberdade individual e o enriquecimento espiritual, duas necessidades básicas para que aconteça o renascimento da nação árabe. Outra limitação do movimento comunista era o fato de sempre estar obedecendo às ordens que vinham de Moscou, o que acabou tendo como resultado minar o nacionalismo árabe. Além disso, este era apenas visto como um estágio do desenvolvimento histórico em direção ao socialismo e não um fim em si.

Para os baathistas o movimento comunista era um sistema de crença cujos objetivos seriam regular todos os aspectos da vida social, enquanto que eles apenas pretendiam redistribuir as riquezas produzidas nos países árabes. Para os baathistas anda deveria existir um limitado direito de propriedade bem como o direito de herança. No entanto, a propriedade privada não deveria se transformar em fonte de exploração ${ }^{734}$.

No entanto, ainda assim os baathistas afirmavam que o sistema de classes deveria ser abolido no Mundo Árabe, pois ele se fundamentava na exploração de classe cujo resultado era má distribuição de riqueza. Para que isso acontecesse afirmavam que o Estado deveria ser o proprietário dos principais meios de produção, dirigindo diretamente todas as instituições de direito público, o comércio externo e interno, criar um banco governamental para financiar a economia e proibir qualquer taxa de juros alta. Mesmo assim, chegaram a defender a autogestão nas fábricas e a partilha dos lucros entre os empregados como acréscimo aos seus salários.

Acreditavam que o Estado deveria garantir o pleno emprego, mas afirmavam que o trabalho deveria ser obrigatório para todos que estivessem em condições de realizá-lo. Também eram a favor da criação de um sistema de segurança social com o Estado oferecendo serviços de saúde, aposentadoria, pensões e auxílio aos desempregados, montando uma rede de ensino que atingisse toda sociedade ${ }^{735}$.

No começo dos anos 50 o partido se estendeu para outros países árabes independentes

\footnotetext{
733 Idem. p. 142.

734 Idem. p. 145.

735 Idem. p. 145-146.
} 
como o Iraque, a Jordânia, o Líbano, o Sudão e o Egito. Cada uma dessas representações não eram consideradas como partidos independentes e sim filiais de um único partido pan-árabe, entretanto os esforços do Baath se concentraram nos Estados governados pela dinastia Hashemita: o Iraque e a Jordânia ${ }^{736}$.

O lema que sintetizava tudo isso era: Unidade, Liberdade e Socialismo (em árabe: Wahda, Hurriyya e Ishtrakiya). Unidade refere-se à união de todos os árabes sob um único Estado, Liberdade faz referência à libertação de todo domínio estrangeiro ou interferência nos assuntos das terras árabes e Socialismo, ao projeto social para as populações do Mundo Árabe.

O Baath subiu ao poder na Síria e no Iraque em 1963. No Iraque, foi derrubado com a invasão norte-americana de 2003 e posteriormente organizou uma bem sucedida resistência armada contra os invasores. Na Síria ainda continua no poder apesar dos recentes esforços (2013) de Washington para derrubá-lo. Nesses dois países esteve associado aos militares responsáveis por promover políticas de modernização e desenvolvimento social e econômico. No entanto, em ambos os países o governo do Baath caracterizou-se por ser ditatorial, exercendo um forte controle sobre a sociedade e reprimindo, em vários casos violentamente, qualquer tipo de dissidência ou crítica.

No Líbano, o Baath foi estabelecido em 1952. Desde o começo, seus membros tiveram uma atitude de desdém em relação à política interna libanesa, pois seu objetivo principal era dar início à formação de um processo de unidade orgânica e total do Mundo Árabe. O partido tinha escritórios e representação em Tiro, Nabatieh, Sidom, Baalbek e Bint Jbeil.

Como pan-arabistas os baathistas libaneses se opuseram ao Pacto Nacional, ao confessionalismo e a todo o sistema político libanês, o qual acusavam ter agravado os conflitos políticos e sociais do Líbano, pois sempre os apresentavam de um modo sectário, confessional, marcado pelos particularismos tradicionais quando na realidade eram problemas relativos às relações entre os grupos despossuídos e os exploradores. Também os baathistas pensavam que as classes médias e altas do Líbano, à exceção de poucos indivíduos, tinham pouca ou nenhuma vontade de mudar o status quo do país, pois elas eram as beneficiárias do sistema político. Mesmo assim, para eles, seria muito mais fácil mobilizar a classe média do que as camadas populares, pois as primeiras estariam erodindo os particularismos que dificultavam nas segundas

${ }^{736}$ Dawisha. Arab nationalism in the twentieth century... p. 155. 
o desenvolvimento de uma maior consciência política.

No entanto, como acreditavam que o perfil do Líbano - um país capitalista com um sistema político confessional - era muito insatisfatório, com o tempo conseguiriam persuadir os libaneses a aceitar as suas ideias e os teóricos e militantes do partido estariam preparados para essa grande tarefa ${ }^{737}$.

$\mathrm{Na}$ década de 1950 a ideologia Baathista difundiu-se entre os estudantes e os intelectuais da Universidade Americana de Beirute. Esses estudantes procuraram difundir o programa do seu partido entre a população fazendo uma intensa atividade de militância em torno da capital e mesmo além dela. Em 1952 realizaram um comício de massas e em 1954 organizaram manifestações contra o acordo turco-paquistanês que no ano seguinte se transformaria no Pacto de Bagdá. Essas ações seguiam a política do partido adotada já em 1948 que condenava a formação de alianças dos países árabes com as grandes potências imperialistas. Em 1956 os baathistas organizaram o seu primeiro congresso nacional (considerado por eles como regional, pois como já foi dito, todos os países árabes é que constituíam a nação em sua visão de mundo) no qual elegeram um comando para o Líbano ${ }^{738}$.

Sua atividade militante no Líbano conseguiu atrair indivíduos de outros partidos da esquerda libanesa como do PSP de Jumblatt, do Movimento Nacionalista Árabe e mesmo do Partido Comunista. Nos anos 50 e 60 o Baath conseguiu atrair adeptos até mesmo entre os trabalhadores portuários de Trípoli e das fábricas de tabaco de Nabatieh no sul do país, então fortes bastiões comunistas ${ }^{739}$.

Uma característica do Baath era que ele recrutava a maioria dos seus militantes entre as comunidades muçulmanas. As regiões onde o partido era mais forte eram Baalbek, Tripoli e o sul Líbano, regiões de maioria muçulmana. Entre os cristãos libaneses, somente os cristãos ortodoxos, que sempre estiveram ligados a ideologias nacionalistas árabes, estavam bem representados no partido. Os maronitas eram bem poucos ${ }^{740}$. A presença majoritária de muçulmanos no partido foi reconhecida por uma das suas principais lideranças, Gebran

\footnotetext{
${ }^{737}$ HUDSON. The precarious republic: political modernization in Lebanon. p. 197-200

738 SULEIMAN. Political parties in Lebanon... p. 123-124.

${ }^{739}$ HUDSON. The precarious republic: political modernization in Lebanon.. p. 198.

${ }^{740}$ SULEIMAN... p. 134.
} 
Majdalani, que afirmou: "the Baath's support is almost wholly limited to the Mohammedans"741.

Os baathistas também eram fortes críticos do Movimento Nacionalista Árabe $(\mathrm{MNA})^{742}$, seus principais rivais na promoção do pan-arabismo no Líbano e nos demais países árabes, pois consideravam o pensamento político dessa organização incoerente ideologicamente e com um caráter reacionário. A falta de uma doutrina consistente teria levado o MNA a ações políticas aventureiras e a atitudes condenadas por vários de seus ex-militantes que se converteram em baathistas, como por exemplo o culto a figura do Presidente Nasser e a aceitação passiva de qualquer de suas políticas e declarações.

Com relação ao Partido Socialista Progressista, os baathistas o acusavam de não ter sido suficientemente comprometido com a causa árabe durante a crise de Suez, além de ser liderado por um indivíduo autocrático e excêntrico - Kamal Jumblatt - e dessa forma não ter o perfil correto de uma líder socialista ${ }^{743}$.

Durante a guerra civil de 1958 os baathistas naturalmente se opuseram a Chamoun e a qualquer intervenção norte-americana ou ocidental. Estiveram ao lado da Frente Unida Nacional e tiveram uma atuação importante na região de Trípoli e no Akaar, onde formaram uma guerrilha, mas lamentaram o caráter confessional que o conflito assumiu ${ }^{744}$.

Sua principal figura foi Abdel Majid Rifahi de Tripoli que teve 7.000 votos nas eleições de 1957. Em 1960, os votos do Baath foram ainda mais numerosos, pois muitos dos seus eleitores ainda acreditavam que eles apoiavam o presidente Nasser. No entanto, após o rompimento entre o Baath sírio e o líder egípcio bem como o fim da RAU, o partido nem mesmo chegou a participar das eleições de 1964, pois havia perdido muito apoio entre os muçulmanos libaneses. Em 1965 os não-Baathistas estimavam em 3.000 apenas o número de afiliados ao Partido Baath no Líbano.

\footnotetext{
${ }^{741}$ LAQUEUR Apud SULEIMAN. Nota 29. p. 134.

742 O Movimento dos Nacionalistas Árabes (MNA) foi um movimento pan-árabe fundado em 1951 por estudantes e profissionais liberais palestinos cujo líder era o palestino cristão George Habash (que posteriormente fundou a marxista-leninista Frente Popular de Libertação da Palestina). Ao longo das décadas de 1950 e 1960 o MNA ligou a sua atividade política à figura de Nasser e ao seu projeto político de socialismo árabe até a sua desintegração como resultado dos vários reveses políticos do Rais egípcio na década de 60, especialmente a Guerra dos Seis Dias de junho de 1967. DAWISHA. p.156.

${ }^{743}$ HUDSON. p. 197-200.

${ }^{744}$ SULEIMAN. p. 123-124.
} 
Também, especialmente após o rompimento com Nasser, nos anos do governo de Fuad Chehab, o Baath foi alvo de uma forte vigilância e controle por parte do Deuxieme Bureau. Embora nunca tenha sido posto na ilegalidade, muitos dos seus militantes e apoiadores eram frequentemente presos e interrogados. A vigilância das forças de segurança era tão sufocante que as lideranças baathistas não conseguiam sequer organizar reuniões do próprio partido. Tudo isto acontecia devido ao fato do Baath libanês ser uma sucursal do Baath sírio e, portanto, ser considerado pelo governo de Chehab como uma organização estrangeira que, se conseguisse se desenvolver, poderia vir a ameaçar a segurança ou a existência do Líbano como país independente ${ }^{745}$.

Aliás, durante o mandato de Chehab - a quem deram apoio - publicaram um semanário chamado 'As-Sahafa' com a permissão do governo. Em 26 de março de 1964 começaram a publicar um diário, o 'Al-Ahrar', que substituiu o As-Sahafa. Apesar disso, o partido não tinha permissão legal para funcionar e procurou ao longo dos anos 50 e 60 obter uma licença de funcionamento do Ministério do Interior. O partido sempre afirmava que enviava um pedido, mas o Ministério negava que o recebesse. Logo que o partido começou a difundir as suas atividades, políticos libaneses começaram a pressionar o Ministério para que o Baath fosse dissolvido $^{746}$.

Ao longo de sua existência o Baath libanês esteve sujeito às vicissitudes do partido em outros países e teve que aceitar a dissolução de sua contraparte síria quando houve a formação da RAU. Esse pedido feito por Nasser à liderança síria do Baath, para que a união acontecesse, provocaria descontentamento, ainda mais quando cresceu nas fileiras da seção síria uma forte frustração com relação ao líder egípcio.

Quando em setembro de 1961 a Síria se separou, outra divisão ocorreu no seio do partido entre os grupos favoráveis à secessão e os contrários, sendo que os favoráveis estavam reunidos em torno da figura do fundador Michel Aflaq. Esses episódios, principalmente o último, afetaram e atrapalharam as atividades políticas do Baath libanês ${ }^{747}$.

Outra dissensão ocorreu na disputa entre a ala mais 'moderada' e a mais 'radical' do

\footnotetext{
${ }^{745}$ HUDSON. p. 197-200.

${ }^{746}$ SULEIMAN ,nota 20, Pág. 127.

747 SULEIMAN. p. 124-125.
} 
movimento. Essa última tendia a defender políticas de cunho mais 'marxista' e um encaminhamento mais rápido para as mudanças nos países nos quais o Baath havia assumido o controle em 1963: Iraque e Síria. O vice-Presidente do Iraque na época, Ali Saleh Saadi, era o principal representante dessa ala que enfrentou o grupo 'moderado' liderado por Aflaq e Salah Bittar a quem chamavam os seus adversários de 'stalinistas'.

O grupo 'radical' chegou a ver os seus pontos de vistas serem dominantes no partido após o Sexto Congresso Internacional do Baath em Damasco no ano de 1963. Durante a realização do congresso seguinte, o grupo de Aflaq retomou a hegemonia, conseguindo moderar as resoluções 'marxistas' anteriores e apontando um novo comando para o ramo iraquiano do Baath e com isso, o partido acabou assistindo a um novo racha.

Esse grupo organizou uma reunião pouco tempo depois em Beirute que acabou sendo atendida por 35 dos 41 membros que constituíam a seção libanesa do Congresso do Baath. Os dissidentes baathistas acabaram elegendo um novo comando para o seu próprio país retirando o poder dos seguidores de Aflaq e passando-o para o grupo vinculado a Saadi.

O resultado dessa medida foi dividir o Baath libanês em três facções distintas: os grupos apoiando Aflaq e Saadi e um terceiro que considerava o líder histórico Salah el-Bittar como a melhor liderança para o partido sendo que esse terceiro grupo afirmava contar com o apoio da maior parte da militância ${ }^{748}$.

Em 1965-1966, novamente o Baath libanês foi influenciado por acontecimentos relativos ao Baath sírio. Nesse caso, disputas entre as fações 'radical' e 'moderada' acabaram levando Salah el-Bittar novamente ao governo no lugar de Youssef Zayyen cujo gabinete era composto de indivíduos 'radicais'.

Enquanto se esperava a reunião do Nono Congresso no qual seria eleito um novo comando sírio, o Supremo Comando do Partido autorizou o governo a realizar um expurgo nas Forças Armadas afastando os oficiais 'radicais'. Porém, esses reagiram rápido após um confronto breve e sangrento com as forças do Comando Internacional e assumiram o poder. Então, os baathistas libaneses leais a Bittar denunciaram os golpistas como secessionistas e oportunistas, entrando em contato com o grupo derrotado.

${ }^{748}$ Idem. p. $126-127$. 
O povo sírio foi chamado a derrubar o novo governo e isso levou as autoridades libanesas a reagirem prendendo seis das lideranças baathistas do país e a acabar com as atividades ilegais do partido sob a acusação de incitarem uma rebelião na Síria, fato considerado perigoso para a segurança nacional libanesa pelo governo de Charles Helu ${ }^{749}$.

Em 1970, finalmente, o partido foi legalizado junto com vários outros pelo governo de Suleiman Frangié.

\subsection{O Partido Comunista libanês}

O PC libanês apareceu como partido autônomo em 1944, mas a história do movimento comunista no Líbano remonta ao final da Primeira Guerra Mundial. No decorrer desse conflito, o país foi duramente afetado sofrendo uma grande devastação econômica que resultou no empobrecimento em massa de sua população e na morte de 100 mil pessoas por fome. A isso, se somou a repressão do governo turco que extinguiu o regime da Mutassarifiat.

Diante do quadro de penúria em que se encontrava a Síria e o Líbano após a Grande Guerra, a partir de 1919, um grupo de jornalistas e intelectuais sensibilizados com a situação de miséria da maioria dos libaneses começou a publicar em certos jornais artigos defendendo essa população, denunciando a sua situação econômica e advogando o socialismo como um meio para resolver os problemas do Líbano. Esse foi o caso do as-Sahafi el-Ta`ih editado na cidade Zahle por Iskander er-Riashi.

Esse jornal afirmava publicamente defender os trabalhadores e os miseráveis do país. Em 1922, começou a se pensar em criar um partido que defendesse a classe trabalhadora. Nessa época, um dos jornalistas conhecido por denunciar as condições em que viviam os pobres no Líbano, Yusuf Ibrahim Yazbek, que trabalhava no Departamento de Emigração do porto de Beirute, escreveu diversos artigos denunciando a exploração dos pobres pelos ricos, defendendo a igualdade social e a coletivização da terra. Ele atacava as guerras e os males por elas produzidos acusando os reis, governantes, capitalistas e os nacionalismos de as provocarem. Considerou o nacionalismo, em particular, um movimento brutal e reacionário.

Nessa mesma época, no Jornal as-Sahafi el-Ta`ih, Iskander el-Riashi, juntamente com

749

Idem. p. $128-130$ 
outros críticos sociais, defendeu a jornada de trabalho de oito horas por dia, com descanso aos sábados e domingos, a instituição de um sistema de aposentadorias e seguro social e a partilha dos ganhos da produção com os trabalhadores. Em 1923 formou-se o Sindicato dos Trabalhadores de Zahle, um dos primeiros do Líbano, que em junho daquele ano recebeu autorização do governo mandatário para funcionar ${ }^{750}$.

Por volta de 1925 começam a se estruturar no Líbano dois Partidos Comunistas. Um dos refugiados armênios e outro dos libaneses propriamente que, nos anos do mandato, seria uma seção regional do Partido Comunista da Síria.

Esse partido no Líbano formou-se a partir das conversações do representante do PC na Palestina, Joseph Berger, um judeu polonês emigrado, com Yusuf Yazbek e o grupo de críticos sociais a ele ligado. Eles concordaram em estabelecer o Partido Comunista no Líbano, mas com a condição de que fosse independente do existente na Palestina, o que acabou acontecendo.

Para evitar a repressão do governo mandatário francês chamaram seu partido de Hizb al-Shaab al-Lubnani (Partido do Povo Libanês). Em 30 de abril de 1925, eles receberam permissão para operar legalmente e organizaram em primeiro de maio uma reunião pública para celebrar a sua legalização e o dia dos trabalhadores. Esse ato serviu de estimulo para formação de novos sindicatos como os dos barbeiros e carpinteiros ${ }^{751}$.

Nos seus anos iniciais, o Partido Comunista contou para o seu processo de formação com as atividades de duas figuras principais: o já referido Yusuf Yazbek que foi importante no processo de estruturação do pensamento político e social dessa organização e Fuad al-Shimali, responsável pela desenvolvimento da estrutura organizativa do PC sírio-libanês.

Al-Shimali era um libanês étnico nascido no Egito que havia sido expulso deste país pelas autoridades coloniais britânicas por suspeita de atividades bolcheviques. Ele comandou o PC sírio-libanês a partir da metade de 1926 como secretário-geral. Sob sua direção o partido se reorganizou e expandiu suas atividades abrindo escritórios em várias cidades da Síria e do Líbano. Em 1932, al-Shimali foi derrubado da direção do partido após uma luta com o jovem militante curdo chamado Khalid Bakdash que passou a comandá-lo e foi seu dirigente por várias décadas. Outras lideranças importantes do partido no período do mandato são Rafiq Rida, Niqula

\footnotetext{
750 SULEIMAN. p. 58-59.

751 Idem. p. 60-61.
} 
Shawi, Farajallah el-Helu e o armênio Artin Madoyan ${ }^{752}$.

A eleição da Frente Popular de Leon Blum na França, em 1936, permitiu ao partido aparecer pela primeira vez de forma aberta na sociedade libanesa bem como na Síria vizinha. Enquanto a Frente Popular governou a França, o PCSL contou com o apoio e o encorajamento do governo. Com isso, o partido foi se aproximando cada vez mais do Partido Comunista francês e se distanciando do Partido Comunista da Palestina que o havia ajudado a se estruturar nos seus anos iniciais.

Os comunistas libaneses chegaram até mesmo a participar das eleições de 1937, embora nenhum dos seus candidatos tenha sido eleito. Nesses anos, até o jornal do partido na época, o Sawt al-Shaab (A voz do povo), era publicamente divulgado. No entanto, com a entrada da França na Segunda Guerra Mundial, o PCSL foi posto novamente na ilegalidade e só voltou a reaparecer publicamente em 1942, quando o Líbano e a Síria estavam sob a ocupação britânica e a URSS lutando contra a Alemanha nazista e aliada a Londres e Washington ${ }^{753}$.

A partir de 1934, os comunistas libaneses e sírios, juntos com outros grupos progressistas, organizaram uma frente para combater o nazi-fascismo e os divulgadores locais dessas ideologias de extrema direita: a Liga para a Luta Contra o Nazismo e o Fascismo na Síria e no Líbano. Em 1941, eles publicaram uma revista cultural-literária que divulgava os ideais da frente: a at-Tariq $(\mathrm{O} \text { caminho })^{754}$.

Nos anos que se seguiram à ocupação britânica e enquanto acontecia a luta contra os nazistas na Europa e no norte da África, os comunistas voltaram a publicar abertamente o Sawt al-Shaab, participaram das eleições de 1943 com quatro candidatos, embora nenhum deles tenha sido eleito para o Parlamento e, com a abertura da embaixada soviética em Beirute, os comunistas libaneses passaram a ter um contato bem mais estreito com Moscou, cujo governo e partido passaram a ser a referência essencial para eles formularem suas políticas e posições frente aos cenários libanês, árabe e mundial.

A participação na eleição e a aceitação da orientação política do Kremlin tiveram profundas consequências para os comunistas libaneses. No caso das eleições de 1943, eles

\footnotetext{
752 Idem. p. 64.

753 Idem. p. 66-67.

${ }^{754}$ Idem. p. 66-67.
} 
aparecerem em publico defendendo reformas democráticas moderadas e lutando pela solidariedade nacional. Afirmaram que não pretendiam construir um sistema socialista e nem sequer estatizar as companhias estrangeiras. Ou seja, não conseguiam falar abertamente para os seus eleitores o seu programa e projeto para o país. Apenas diziam desejar reformar a sociedade libanesa e melhorar as condições de vida do povo ${ }^{755}$. Essas afirmações seriam pouco depois incorporadas na Carta Nacional do partido durante o seu primeiro congresso publico realizado em Beirute entre 31 de dezembro de 1943 e 2 de janeiro de 1944 quando 108 delegados, representando mais de 10 mil militantes, redigiram o estatuto do partido ${ }^{756}$.

Ao longo de 1944 foi se dando a separação entre os PCs do Líbano e Síria como resultado da independência em curso de seus respectivos países e, talvez, do fím da III Internacional em junho de 1943. Já na conferência da virada de ano de 1943-1944, os comunistas libaneses enfatizaram o caráter nacional de seu partido em seu país e os delegados sírios fizeram o mesmo em relação a sua nação.

Nesse congresso, foi decidido que o partido nos dois países se chamaria respectivamente Partido Comunista Libanês e Partido Comunista Sírio. No entanto, ainda decidiram manter uma única liderança com apenas um comitê central para ambos os partidos. Em 23 de julho de 1944, os 118 delegados em uma nova conferência decidiram que cada PC deveria ter o seu próprio comitê central, mas que deveriam continuar cooperando em termos organizacionais, políticos e ideológicos visando ao bem comum de sírios e libaneses e de igual modo dos demais árabes. Essa cooperação se daria por meio de reuniões regulares entre os líderes dos dois Partidos Comunistas. Farajallah el-Helu tornou-se o presidente do PC libanês até 1946 quando foi substituído por Niqula Shawi ${ }^{757}$.

Quanto à orientação soviética, isto trouxe consequências nefastas para o partido e para a luta comunista tanto no Líbano quanto em outros países árabes, já que a URSS tomou atitudes contrárias aos povos árabes no fim dos anos 1940 como o apoio à partilha da Palestina na ONU em 14 de maio de 1947. Fato esse, anunciado publicamente pelo embaixador soviético daquela organização que se seguiu ao reconhecimento por parte de Stalin do novo governo israelense no

\footnotetext{
${ }^{755}$ Idem. p. 67.

${ }^{756}$ Idem. p. 67-68.

${ }^{757}$ SULEIMAN. p. 68.
} 
mesmo dia em que ele se formou.

Esse acontecimento forçou o PC Libanês a defender também as posições soviéticas, o que representava uma enorme mudança na política do partido que até o começo daquele ano se posicionava contra a divisão. Até então, eles afirmavam que a partilha era um plano das potências imperialistas contra os árabes, condenavam o sionismo como um movimento reacionário, diziam que judeus e árabes deveriam viver juntos na Palestina e criticavam a ideia segundo a qual os judeus seriam uma nação. De repente, passaram a afirmar que os judeus eram uma 'nação em evolução' com os mesmos direitos à Palestina quanto sua população árabe. Tudo isso complicou ainda mais a situação para os comunistas libaneses (bem como dos demais países árabes) que já começavam a sentir as pressões do inicio da Guerra Fria e os desmoralizou frente a sua sociedade ${ }^{758}$.

Quando houve o apoio dos estados comunistas aos sionistas na guerra de 1948 e estes colocaram em prática o seu plano de expulsão dos palestinos da maior parte do seu país, a postura dos comunistas tornou-se ainda mais comprometedora aos olhos da opinião pública libanesa e árabe em geral. Eles denunciaram a guerra árabe-israelense como um complô concebido pelos britânicos e o rei Abdullah da Transjordânia para impedir o estabelecimento de um Estado independente na parte árabe da Palestina.

Depois, afirmaram que a questão palestina era na verdade uma luta contra o imperialismo anglo-americano e por isso eles chamaram as forças políticas para juntar os seus esforços com intuito de conseguir a retirada das tropas árabes da Palestina, pois essa guerra era uma criação dos imperialismos britânico e americano junto com os regimes reacionários árabes e o sionismo reacionário para desviar a atenção das massas árabes e judias da luta conjunta contra esses grupos $^{759}$.

Mesmo quando o PC libanês voltou a rejeitar o plano de partilha da Palestina isso não se deveu à limpeza étnica dos árabes que esse plano ajudou a promover, mas porque isso seria nocivo ao Estado judeu ${ }^{760}$, embora não signifique que os comunistas tenham manifestado qualquer simpatia pelos sionistas. Eles eram vistos como um grupo reacionário a serviço das

\footnotetext{
${ }^{758}$ Idem. p. 88-89.

${ }^{759}$ Idem. p. 89-90.

${ }^{760}$ SULEIMAN. Nota 92. p. 98.
} 
potências imperialistas e expressão do chauvinismo da burguesia judaica da Palestina ${ }^{761}$. Para piorar a situação, o ano de 1948 foi ainda péssimo para o PC Libanês devido à crise interna, que resultou na saída de vários membros importantes e as ações do governo contra ele que o pôs na ilegalidade e prendeu e perseguiu seus líderes e militantes ${ }^{762}$.

A repressão ao PCs na Síria durante a ditadura de Hosni Zaim e depois com Sami alHinnawi levou muitos comunistas sírios a se exilarem no Líbano e fez de Beirute o centro do movimento comunista sírio-libanês. Em agosto de 1950, decidiu-se novamente pela reunificação dos partidos comunista dos dois países. Bakdash foi eleito secretário-geral, o novo secretariado era composto por Madoyan, Hussain Quraitim e o próprio Bakdash e o Politburo era composto pelo secretariado acrescido de Niqula Shawi ${ }^{763}$.

No plano do Oriente Médio, na década de 1950, o PCL se opôs a qualquer participação do Líbano em alianças militares comandadas pelos EUA ou pelas antigas potências coloniais europeias da região. Dessa forma, foram contra o Pacto de Bagdá e a entrada ou mesmo aproximação do Líbano a ele durante o regime de Chamoun. Também se oporiam mais tarde de maneira firme a esse Presidente quando ele aderiu à Doutrina Eisenhower em 16 de março de $1957^{764}$.

Quando houve a formação da Frente Nacional de Saeb Salam e Rachid Karami para fazer frente a Chamoun e suas políticas, os comunistas não foram aceitos como membros dela oficialmente, mas a apoiavam e diziam que vários dos seus militantes participavam de suas atividades $^{765}$. Em 1958, os comunistas lutaram na guerra civil contra Chamoun e condenaram a intervenção militar dos EUA no conflito em 15 de julho.

Em dezembro de 1958, em uma reunião do Comitê Central, decidiu-se que o Partido Comunista deveria se separar novamente devido às novas condições existentes nos dois países. Assim formaram-se os comitês centrais da Síria e do Líbano cujo surgimento foi anunciado

\footnotetext{
761 SULEIMAN. p. 90.

762 GENDZIER, Irene L. Notes from the minefields. p.

763 ISMAEL, Tarik; ISMAEL, Jacqueline S. The communist movement in Syria and Lebanon. Gainesville: University Press of Florida, 1998. p. 40.

${ }^{764}$ SULEIMAN. Political parties in Lebanon. p. 70.

765 ISMAEL. p. 53.
} 
publicamente na metade de janeiro de $1959^{766}$.

Nessa época, no plano interno libanês, o ramo libanês do PCSL era muito influente em diversos sindicatos e organizou vários movimentos pela paz no Líbano contrários às tensões militares entre EUA e URSS, como a ameaça de guerra nuclear.

No campo sindical esse foi o caso da Federação dos Sindicatos que foi comandada na década de 1950 por Mustafa al-Ariis, um dos mais importantes nos quadros do partido. Essa federação reunia, por exemplo, os sindicatos dos carpinteiros, pedreiros e tipógrafos, embora, por outro lado, isso não significasse que a maior parte desses trabalhadores fosse comunista ou mesmo de esquerda, pois havia outras forças políticas e sociais, como o pertencimento a uma determinada comunidade confessional, que atraía mais a atenção deles.

Em oposição à Federação dos Sindicatos existia a Confederação do Trabalho composta por cinquenta sindicatos e quatro federações cujo líder era Gabriel Khouri ${ }^{767}$. Existiam ainda outras organizações que o PC libanês apoiava ou dirigia no Líbano como os Amigos da União Soviética, o Comitê para a Cooperação Educacional entre o Líbano e a União Soviética, as editoras al-Fikr al-Jadid e al-Farabi. Também estavam presentes no movimento estudantil procurando organizá-lo ${ }^{768}$.

Durante a primavera de 1954, o partido emitiu um comunicado expressando as suas opiniões sobre a assinatura de tratados de defesa mútua do Líbano com os EUA, a penetração ocidental no país e a situação interna. O programa fazia uma defesa dos direitos das mulheres, da implementação de um programa de segurança social, da ampliação do código trabalhista e a defesa dos direitos dos trabalhadores bem como exigia uma reforma agrária. Farajallah el-Helu, Niqula Shawi, Artin Madoyan e Hussain Quraitim assinaram o documento. Como o partido estava proibido, os quatro líderes que o assinaram foram postos sob Lei Marcial e condenados em ausência a um mês de prisão ${ }^{769}$.

Curiosamente, o PC libanês não era nos anos 1950 e 1960 um partido composto em sua maior parte por militantes de origem proletária ou mesmo popular. A maioria de seus membros

\footnotetext{
${ }^{766}$ Idem. p. 52.

${ }^{767}$ SULEIMAN. p.75.

${ }^{768}$ SULEIMAN, Nota 46. p. 65.

${ }^{769}$ ISMAEL. p. 44.
} 
eram advogados, estudantes, professores, engenheiros e intelectuais, ou seja, membros da pequena burguesia no jargão marxista ou classe média. Só os primeiros compunham entre 50\% e $70 \%$ dos afiliados. Existiam trabalhadores e o partido dizia ter militantes que eram camponeses, artesãos e operários, mas na verdade não compunham o grosso dos seus filiados ${ }^{770}$.

Para tentar entender isso, os comunistas libaneses aceitavam a explicação oferecida pelo secretário-geral do PC sírio Khaled Bakdash para o mesmo fenômeno em seu país: a pequena presença das classes trabalhadoras era resultado do efeito combinado da dominação imperialista, da tirania feudal e da fraqueza do processo de luta de classes ${ }^{771}$.

Só a partir da segunda metade da década de 1960 é que os militantes vindos das classes trabalhadoras começaram a crescer no partido como resultado da crescente polarização esquerdadireita no Líbano da época. Assim, vários trabalhadores e camponeses das regiões de Baalbek, Nabatieh e Tripoli começaram a simpatizar com o Partido Comunista ${ }^{772}$.

Explicações para essa ausência de membros populares no PC libanês podem ser várias. Isso pode ser resultado da fraqueza da indústria na economia libanesa (em torno de 13\% do PIB) cuja consequência é fazer com que apenas uma parte da mão-de-obra se encontre no setor secundário da economia; a presença da classe dos zu'ama, os líderes 'feudais' responsáveis pela liderança política de uma cidade, região, zona rural ou comunidade religiosa, bem como das lideranças religiosas que sempre atraíram a obediência de seus seguidores e a forte presença da religião na sociedade libanesa na qual tem um papel central na definição da identidade dos indivíduos e sua posição frente ao mundo (Suleiman;1967).

Nesse contexto, mais do que as críticas às religiões, a pregação ateísta dos comunistas soaria como uma monstruosidade para a maioria dos trabalhadores libaneses. No interior, mas não apenas, também era muito forte a presença de comportamentos e relações sociais tradicionais, como as fidelidades tribais, que afastavam as pessoas que as seguiam da mensagem de revolução social dos comunistas ${ }^{773}$.

Para se ajustar a esse cenário social o Partido Comunista adaptou o seu programa para

\footnotetext{
${ }^{770}$ SULEIMAN. p.76.

${ }^{771}$ LAQUEUR apud SULEIMAN. p.76.

772 SULEIMAN. p. 76.

${ }^{773}$ Idem. p.77.
} 
se apresentar menos dissociado da sociedade libanesa. Assim, em um país onde o liberalismo econômico foi elevado à condição de elemento formador da identidade nacional, o PC libanês deixou de defender publicamente a imediata defesa da socialização dos meios de produção.

Para os comunistas libaneses o seu objetivo imediato era promover reformas sociais que melhorassem as condições de vidas dos trabalhadores e promover os direitos democráticos, a ordem constitucional e a garantia da independência do Líbano. Esta e o processo completo de libertação nacional deveriam vir antes de se pensar em implantar o socialismo no Líbano. Além disso, as condições internas do país com o seu atraso rural e o fraco desenvolvimento da indústria eram obstáculos para qualquer transformação de caráter revolucionário ${ }^{774}$.

Após a guerra civil de 1958, Niqula Shawi, o então líder do ramo Libanês do PCSL, reafirmou os objetivos não-revolucionários do seu partido a curto prazo: "The Question for us in Lebanon is not one setting up a communist or socialist order. All we aim at is the liberation of Lebanon from every trace of foreign influence, and the establishment of a democratic, parliamentary, burgeois system in which public liberties are guaranteed to all members",775.

Isso foi novamente afirmado em 1965, em um comunicado do PC libanês no qual eles diziam: "although our ultimate aim is to see Lebanon move on the road of socialism, we, for the present time, call for fulfillment of progressive reforms in the economic, social, political and administrative fields - reform now badly needed by the Lebanese people" ${ }^{\text {,776 }}$.

\subsection{O Partido Comunista Libanês, o Mundo Árabe e o Líbano}

Com relação ao Mundo Árabe, os comunistas libaneses (e também os sírios) começaram se opondo à noção dos nacionalistas árabes de que, independentemente das fronteiras e da distancia geográfica, as populações falantes de árabe seriam apenas um único povo.

Para essa definição foi importante a posição a respeito do assunto assumida por Bakdash. Segundo ele, como não havia capitalismo e nem uma vida econômica comum nas terras de língua árabe tampouco existiria uma nação árabe. Além disso, as distâncias entre países como

\footnotetext{
774 Idem. p.81.

775 MOKDESSI apud SULEIMAN. p. 81.

${ }^{776}$ Arab World, Oct.19, 1965 apud SULEIMAN, Nota 63. p. 81.
} 
Argélia e Síria, por exemplo, bem como as características históricas próprias de cada um faziam com que houve diferenças na cultura, vida econômica, mentalidade e aspectos psicológicos da população de cada nação.

A língua comum e a unidade de objetivos tampouco eram motivos para se defender a existência de uma única nação árabe. Essas afirmações de Bakdash serviram para que, no Congresso, na virada de ano de 1943-1944, os comunistas libaneses defendessem a independência do Líbano. Mas, isso não significava que os países árabes devessem permanecer isolados uns dos outros. Eles deveriam cooperar fortalecendo os seus laços econômicos e culturais $^{777}$.

Os comunistas libaneses também estiveram muito envolvidos com a política síria. Após a queda do ditador Adib al-Shishakli na Síria, em 25 de fevereiro de 1954, o PCSL concentrou as suas atividades nesse país o que fez com as lideranças libanesas tivessem que se deslocar e se instalar em Damasco envolvendo-se nos processos de redemocratização e nas eleições de novembro que acabaram levando a eleição do grande líder dos comunistas na Síria, K. Bakdash, para o Parlamento.

Essa foi a primeira vez que um comunista foi eleito para algum cargo no Mundo Árabe $^{778}$. A transferência das lideranças libanesas para a Síria, no entanto, foi considerada um erro pelos militantes e líderes libaneses, pois os afastou da realidade do Líbano e enfraqueceu ainda mais o Partido Comunista nessa nação. Isso causou ainda mais insatisfação porque tudo isso favoreceu apenas Bakdash nesse processo todo ${ }^{779}$.

Posteriormente, com a ascensão do nacionalismo árabe nos anos 50, o aparecimento da figura de Gamal Nasser e o seu forte impacto e de sua mensagem sobre os muçulmanos do Líbano, particularmente os sunitas, os comunistas defenderam a formação de uma federação entre os países árabes. Quando Síria e Egito se fundiram em 1961, o PC libanês acabou apoiando e defendeu a inclusão do Iraque quando a monarquia hachemita lá fosse derrubada. Quando Abdel Karim Qassem subiu ao poder no Iraque e trouxe o PC iraquiano para o governo e as negociações entre Qassem e Nasser fracassaram, os comunistas libaneses começaram a duvidar da viabilidade

\footnotetext{
777 SULEIMAN. p. 85-86.

778 ISMAEL. p. 45.

${ }^{779}$ Idem. p. 45.
} 
da unidade das terras árabes voltando a defender novamente a criação de uma federação ${ }^{780}$.

Após a fusão da Síria com o Egito, desenvolveu-se, a partir do fim de 1958, devido oa apoio aberto do PC sírio ao presidente iraquiano Abdel Qassim que havia rompido e brigado com o Rais egípcio, um conflito entre os comunistas e Nasser, o que teve consequências trágicas para os primeiros, pois acabaram sendo alvos de uma forte repressão que resultou no assassinato de diversos membros do partido, especialmente de Farajallah el-Helu, líder histórico dos comunistas libaneses que se encontrava trabalhando com os seu camaradas sírios, pelos serviços de inteligência instalados nesse país vizinho, o que causou profunda consternação entre os militantes e lideranças comunistas libanesas ${ }^{781}$.

A partir de então, os comunistas sírios e libaneses passaram a ver Nasser como mais um dos ditadores do Oriente Médio e comemoraram publicamente a secessão da Síria, ocorrida em 28 de setembro, embora isso tenha prejudicado seriamente a popularidade dos comunistas. Como exemplo do trauma dos comunistas em relação ao líder egípcio, Niqula Shawi, então secretário-geral do PCL, assim se expressou a respeito do fim da RAU: "The victory of Syrian nation in freeing itself from the regime dominated by tyranny and dictatorship" ${ }^{\text {"72 }}$.

Com relação ao Líbano, especificamente, afirmavam não estar preocupados com o caráter árabe ou não do país, mas desejavam manter a sua independência e buscavam fazê-lo cooperar com os Estados árabes anti-imperialistas. O Líbano era um caso especial entre as nações árabes devido ao caráter confessional do seu sistema político que havia sido artificialmente estabelecido e explorado pelo colonialismo francês ${ }^{783}$.

\subsection{O PC libanês e os movimentos nacionalistas árabes}

Durante o começo dos anos 50 o PCSL se manteve dentro de uma estreita ortodoxia política cujas linhas emanavam diretamente da União Soviética, em especial nos últimos anos do governo de Stalin, e isso era muito favorecido pelo cenário internacional da época com a corrida nuclear, a disputa Leste-Oeste e a guerra da Coreia a partir de 1950. Por outro lado, a repressão

\footnotetext{
780 SULEIMAN. p. 87.

781 ISMAEL. p. 53.

782 Idem. p. 55.

783 SULEIMAN. p. 87.
} 
que o partido sofria tanto no Líbano como na Síria e a posição assumida durante a destruição da Palestina árabe pelos sionistas em 1948 fez com que o partido se mantivesse em uma situação de marginalidade no cenário político libanês. Por isso, durante a década de 1950, os comunistas fizeram uma autocrítica e desenvolveram estratégias para se aproximar da população libanesa. $\mathrm{O}$ próprio Bakdash lamentou o fato de que o partido tivesse atraído poucos trabalhadores e camponeses e de que não tivesse realizado um trabalho mais sério com as classes trabalhadoras, mas, ao contrário, tenha apenas se desenvolvido no meio de um ambiente de classe média e assim atraindo para as suas fileiras estudantes e profissionais liberais.

Então, para acabar com a situação de marginalidade política do partido, Bakdash propôs se aproximar ou mesmo se aliar a forças reformistas durante as eleições, como o Baath sírio ou o Partido Socialista Progressista de Kamal Jumblatt, e até se aliar a setores antiimperialistas da burguesia libanesa. Junto a isso, planejava dar início a um forte trabalho de militância em relação aos trabalhadores libaneses para que o partido Comunista se transformasse em seu representante no cenário político e, ao mesmo tempo, os membros revolucionários das classes trabalhadores deveriam se transformar na base do partido. Bakdash também afirmava que a vanguarda do partido deveria representar política e intelectualmente os trabalhadores e não ser um conjunto de diferentes correntes de opinião como então acontecia ${ }^{784}$.

A vontade de estabelecer uma cooperação com os grupos nacionalistas árabes muito se devia também à aproximação entre o Egito e a União Soviética a partir de 1955, bem como a decisão do XX Congresso do PC Soviético em 1956 de reconhecer o neutralismo positivo advogado por Nasser em relação ao conflito Leste-Oeste da Guerra Fria como uma posição legítima dos governos do Terceiro Mundo e defenderam a necessidade da URSS de cooperar com esses países $^{785}$. Isso ajudou o PC a colaborar com grupos nacionalistas árabes no Líbano quando era necessário enfrentar a direita cristã como foi em 1965 com a Frente dos Partidos, Organizações e Personalidades Nacionalistas e Progressistas ou a campanha contra a 'Aliança Islâmica' de 1966 entre o Irã de Reza Pahlevi e a Arábia Saudita para fazer frente ao nacionalismo árabe, o comunismo, o ateísmo e a revolução no Oriente Médio ${ }^{786}$.

\footnotetext{
${ }^{784}$ ISMAEL. p. 41-42.

785 SULEIMAN. p. 84.

${ }^{786}$ Idem. p. 88.
} 


\subsection{O PC libanês após o XX Congresso do PC da União Soviética em 1956}

Uma grande mudança ocorreu nos PCSL após a realização do II Congresso do PC soviético que contou com a participação de Bakdash, Madoyan, Niqula Shawi e Yusuf Faisal como representantes da Síria e do Líbano.

Durante esse congresso houve a condenação oficial das políticas e crimes de Stalin e a alteração das políticas que os PCs do então Terceiro Mundo deveriam seguir. Como resultado disto, a cúpula dos PCSL organizou em Damasco duas reuniões, a primeira entre 22 e 27 e abril e a segunda entre 06 e 07 de maio nas quais foi adotado um conjunto de novas políticas a serem seguidas na Síria e no Líbano.

Com relação ao Líbano decidiu-se: a) fortalecer a independência do país e libertá-lo de influèncias estrangeiras danosas; b) criar condições melhores para a economia nacional; c) promover o desenvolvimento das liberdades democráticas; d) apoiar uma evolução pacifica no Líbano e e) estabelecer as bases de uma frente nacional ${ }^{787}$.

As primeiras críticas abertas à liderança de Bakdash vieram dos comunistas libaneses. Isso aconteceu devido à separação entre os partidos comunistas sírio e libanês, que fazia com que a influência de Bakdash no Líbano fosse pequena, bem como o clima político mais liberal nesse país.

Os comunistas libaneses denunciaram o culto à personalidade que se desenvolvera em torno de Bakdash e os métodos estalinistas da organização do partido cujo resultado foi a perda de qualquer prática democrática em sua vida interna. Como resultado disso, os congressos bianuais exigidos pelos estatutos dos PCs sírio e libanês não ocorriam desde o começo dos anos 1940. Lamentava-se muito a permanência de diversos aliados e protegidos de Bakdash na direção do PC libanês.

Em relação à condução política, se criticava o alinhamento estreito com a União Soviética, a maneira como os comunistas se relacionavam com o Movimento de Libertação

Nacional Árabe e o papel da pequena burguesia no movimento de libertação nacional. Em resposta à ação dos críticos, os aliados do líder sírio dentro do partido faziam de tudo para desacreditá-los e buscavam marginalizar os reformistas.

${ }^{787}$ Ismael. p. 47-48 
Dessa forma, chegaram até mesmo a censurar a divulgação da apresentação do próprio Shawi diante do Congresso do Partido Comunista Búlgaro em 1959 quando ele fez fortes crítica à condução do movimento comunista siro-libanês por Bakdash. Este respondia acusando os seus críticos de serem revisionistas desviacionistas e maoístas e de fazerem um culto de sua própria personalidade $^{788}$.

Nos anos sessenta, o partido foi atingido pelos efeitos do rompimento entre a China e a União Soviética. Vários de seus militantes passaram também a criticar a orientação excessivamente acrítica do PC libanês para com o governo soviético, que havia trazido consequências nefastas para o movimento comunista no Líbano, bem como a outros países do Oriente Médio.

Dois novos grupos surgiram dessas disputas ideológicas internas: um grupo pró-chinês, composto por alguns jovens militantes, que formaria mais tarde o Partido da Revolução Socialista $^{789}$; e um outro, liderado pelo editor do jornal al-Akhbar, Nassib Nimr, que saiu em 7 de abril de 1965 e formou uma organização em torno do Ela al-Amman, um antigo jornal armênio. Posteriormente adquiriram um jornal de língua árabe bimensal para expressão das suas ideias: o al-Fikr al-Jadid. Na sequencia, passaram a se chamar União dos Comunistas Libaneses (Itihad alShiouyieen al-Lubnanien em árabe ${ }^{790}$.

Na segunda parte dos anos sessenta, o PC libanês se aliou a Kamal Jumblatt na frente progressista e passou a se aproximar do movimento palestino, tendo essa política sido reforçado pela derrota árabe na guerra de junho de 1967. Em 1971, o Partido Comunista Libanês foi legalizado junto com vários outros partidos críticos do regime político e econômico libanês. Os

\footnotetext{
${ }^{788}$ Idem. p. 64.

789 O Partido da Revolução Socialista publicou um manifesto denunciando a liderança do PCL. Nele afirmavam: "They transformed the Party into refomist society. They transformed the Unions into tools to destroy the working class [...]. They paralized the party activity fearing the demands of the memberships which continuously called for a party congress [...]. We acussed Khalid bakdash and Nikola Shawi [...] of collusion with Khruschev for the annihilation of 40,000 iraqi communist. We also acusse them on the arab level of collusion with those who work very hard to eliminate the Palestinian issue [...]. Thus, we accuse them of treason to the principles of Marxism-Leninism. Because the faithful Lebanese communist could not endure this anymore, they decided to unify themselves and organize in a new Communist Party called Party of Socialist Revolution [...]. Which will be guided by the great principles of Marx, Engels, Lenin and Stalin. They declared their support to full marxist-leninist parties headed by the great Chinese Communist Party". ISMAEL 65.

790 SULEIMAN. p. 70-71. ISMAEL. p. 65-68.
} 
grupos dissidentes do PC libanês também passaram a ter políticas semelhantes ${ }^{791}$.

${ }^{791}$ ISMAEL. p. 65-68. 


\section{CAPÍTULO 5}

\section{Os Governos Chehabistas ou Nahjistas}

\subsection{Fuad Chehab}

Terceiro presidente após a independência, Fuad Chehab foi eleito mandatário máximo pelo Parlamento libanês no dia 31 de agosto e tomou posse no dia 23 de setembro. Tendo sido eleito para encerrar a guerra civil, estabelecer um compromisso entre os grupos que se enfrentaram, restabelecer o Pacto Nacional e atender às queixas dos muçulmanos, Chehab teve seu mandato marcado por uma política que buscou desenvolver as regiões que haviam sido abandonadas pelos presidentes anteriores por possuírem uma população majoritariamente muçulmana, procurando assim, incluí-los no processo de desenvolvimento econômico do Líbano, uma condição para manter a unidade nacional, restabelecer o Pacto Nacional e garantir a viabilidade política e econômica do país a longo prazo.

De imediato, sua eleição levou à pacificação do país, apesar de surtos esporádicos de violência. Os toques de recolher começaram a ser levantados e a vida começou a voltar ao normal nas cidades e no interior, enquanto as tropas americanas se retiravam do país e o grupo de observadores da ONU encerrava os seus trabalhos. Os jornais banidos, nacionais ou estrangeiros, voltaram a circular e as denúncias feitas a Chamoun contra a RAU foram retiradas enquanto o embaixador dela voltava a Beirute.

O Parlamento havia concedido ao Presidente uma extensão dos poderes de seu mandato até junho de 1959 enquanto o país ia restabelecendo a normalidade. No plano internacional, o Líbano optou por uma aproximação à RAU e aos regimes nacionalistas árabes sem comprometer seus laços com o Ocidente e seus vínculos econômicos com os regimes conservadores como a Arábia Saudita, Jordânia e os emirados do Golfo Pérsico.

Essa política de reconstrução, desenvolvimento material e unidade nacional ficou conhecida como 'Shihabismo' (al-Shahabiyyah em árabe) ou 'Al-Nahj' e os seus seguidores eram os shihabistas ou nahjistas. Ela se constituía nos seguintes elementos políticos ideológicos: 1) a afirmação de que o Líbano era um país árabe e pertencia ao conjunto do Mundo Árabe; 2) o estímulo ao secularismo como um passo inicial para se buscar a unidade nacional; 3) o 
desencorajamento de extremismos políticos quer no campo nacionalista árabe ou na direita cristã e 4) o uso do exército para sustentar uma estratégia geral ${ }^{792}$.

Ela consistia em dois estágios de aplicação: o primeiro situou-se mais ou menos entre 1958 e a metade de 1960 no qual a ideia de unidade nacional se baseava na reimplantação do Pacto Nacional como uma condição básica para garantir a existência e a prosperidade do Líbano; o segundo estágio estendeu-se desde as eleições legislativas de 1960 até 1964 e nele houve a promoção de uma nova ideia sobre o Pacto Nacional que passou a ser baseado na noção de cidadania e em se fundir todos os grupos libaneses em uma só nação. O complexo gabinete do governo Chehab, composto por lideranças políticas com visões distintas e, em vários casos, contraditórias, sintetizava esse projeto ${ }^{793}$.

A implantação do projeto chehabista se baseava em noções como a de 'equilíbrio', ou seja, criar um cenário na vida social, econômica e política libanesa no qual se procurava implementar projetos e noções novas sem romper elementos do passado considerados importantes. Um bom exemplo era a vida econômica, na qual se procurou manter a 'livre empresa', porém promovendo políticas econômicas e sociais que distribuíssem a riqueza nacional entre as diversas regiões e populações do Líbano. Reconheciam-se os limites do sistema político aceitando-se os seus princípios básicos, ainda que estes fossem contrários aos projetos de modernização. Essa ideia de equilíbrio também estava presente na política externa. Dessa forma, se procurava um "equilibrium between Lebanon`s unique situation and its limited external capabilities" ${ }^{, 794}$.

Outra noção importante era de le social (assim mesmo em francês) que serviu de base filosófica para as políticas sociais implantadas por Chehab. Significava a ideia de justa distribuição de riqueza em um sistema social-democrata liberal, uma política de modernização realizada por um governo que buscava uma forte promoção de uma maior igualdade econômica.

Esse pensamento se baseava nos escrito do padre Louis Joseph de Lebret que combinava os ensinamentos de São Tomás de Aquino com o marxismo, embora o sacerdote

\footnotetext{
792 QALAWOUN, Nasser. The Struggle for Lebanon: a modern history of a Lebanese-Egpitian relation. Londres e Nova Iorque: I. B. Tauris publisher, 2000. p.76.

${ }^{793}$ BESHARA: Lebanon: The politics of frustration - the failed coup of $1961 \ldots$ p.99.

${ }^{794}$ BESHARA: Idem. p. 101.
} 
francês criticasse no comunismo com a mesma ênfase com que criticava o capitalismo ${ }^{795}$. O exemplo mais evidente do comprometimento do regime de Chehab com esse pensamento foi a participação do padre Lebret nesse governo.

O governo de Chehab, embora afirmasse que o Líbano era uma nação árabe e que deveria ter o Mundo Árabe como uma das prioridades da sua política externa, via o nacionalismo árabe, por outro lado, como uma ameaça e um dos responsáveis, juntamente com o nacionalismo cristão libanês, pela guerra civil de 1958. O nacionalismo árabe deveria ser rejeitado devido a sua incapacidade de convencer a população cristã que a noção de unidade árabe não envolvia a dominação dos cristãos pelos muçulmanos. Por isso, o nacionalismo árabe era considerado uma ideologia deficiente e inadequada para o Líbano como o nacionalismo libanês dos cristãos ${ }^{796}$.

Quanto a sua imagem, Chehab foi considerado um político verdadeiramente patriota que procurava enxergar o Líbano acima das suas divisões comunitárias, era tido como honesto e avesso à classe política local, detestando seus jogos de poder e muitos acreditavam mesmo que ele não tivesse ambições políticas reais e nem apego ao poder. Sua ação durante a guerra civil, na qual evitou ao máximo envolver o Exército na repressão aos rebeldes, e o fato de reconhecer as suas demandas lhe davam uma grande autoridade e respeito. Também, o fato de não pertencer à classe política tradicional foi de grande importância para conseguir o apoio da sociedade, pois isso desligava sua imagem da corrupção e dos conchavos políticos tão característicos do Líbano de seu tempo. Sempre desfrutou de popularidade no Líbano, embora a comunidade maronita mantivesse em relação a sua figura uma constante desconfiança por causa de suas políticas favoráveis aos muçulmanos e sua aproximação e simpatia para com Nasser.

Tanto foi assim que, quando em 20 de julho de 1960 Chehab ameaçou renunciar, mesmo tendo conseguido suficiente apoio no congresso para pôr em prática as suas políticas e projetos de desenvolvimento, afirmando que sua missão havia sido completada e que o Líbano poderia voltar à normalidade constitucional e que ele já não era mais necessário, uma grande manifestação (que parece que foi organizada pelo serviço secreto - o Deuxième Bureau) ${ }^{797}$ de apoio a sua permanência apareceu nas ruas do país fazendo com que o Presidente Chehab

\footnotetext{
795 BESHARA: Idem. p. 102.

796 BESHARA... p. 99. QALAWOUN. The struggle for Lebanon... p. 76.

${ }^{797}$ BESHARA... p. 142.
} 
abandonasse essa ideia de renúncia, que pode ter sido uma encenação, mas provou a força que o Presidente libanês tinha em sua sociedade e reafirmou a imagem de desinteresse pela vida política e suas lutas mesquinhas por parte do Presidente, uma imagem que em muito garantia o amplo apoio popular que recebia ${ }^{798}$.

\subsection{A base política do regime}

Chehab para governar apoiou-se nos líderes comunitários mais importantes e que, muitas vezes, tinham diferentes visões de mundo e projetos distintos para o Líbano. Esse gabinete composto por figuras tão diferentes representava o seu projeto político de buscar a unidade nacional acima das profundas diferenças comunitárias e ideológicas que caracterizavam o Líbano, fazendo todos os seus cidadãos trabalhar por um bem comum maior que era o seu país. Seu gabinete, portanto, deveria representar todas as principais forças políticas e sociais existentes em sua nação.

Dessa forma, ele trabalhava tanto com Kamal Jumblatt, um dos líderes rebeldes, e que era um crítico do modelo econômico liberal e da estrutura política confessional do Líbano, quanto com Pierre Gemayel, líder do Katáeb - a Falange - um partido de direita, baseado na população maronita e defensor do liberalismo e do status quo político que havia ficado do lado de Chamoun durante a guerra civil.

Ele também o apoiava o clã xiita dos Assad (que depois romperiam com o governo) do sul, os armênios do Tashnak, diversos notáveis sunitas como Rashid Karami, Abdallah Yafi e, por algum tempo, Saeb Salam. Além de Suleiman Frangieh, notável maronita do norte do Líbano e o antigo aliado druso de Chamoun, Majid Arslan, participaram do governo.

Tendo um gabinete com representantes das principais comunidades, Chehab ainda conseguia equilibrar a forte influência que esses líderes tinham e impedir que um deles assumisse a completa hegemonia em sua comunidade ou que cada grupo radicalizasse o cenário político libanês para assim romper o consenso em torno das reformas. Essa composição garantiu a estabilidade do governo Chehab mesmo que brigas e rivalidades ocorressem entre os indivíduos que compunham o governo. Apesar das renúncias e trocas de ministros o governo pôde seguir em

${ }^{798}$ WINSLOW, Charles. Lebanon: war and politics... p. 141. 
frente com suas políticas.

Esse gabinete, que havia sido formado em outubro de 1958, foi uma consequência dos enfrentamentos ocorridos no país como resultado da formação de um primeiro gabinete de Chehab composto por oito homens dos quais os líderes rebeldes eram maioria esmagadora e teve como estopim a declaração de Rachid Karami de que, com o governo de Chehab a "revolução estava colhendo os seus frutos".

O sequestro do jornalista maronita anti-Nasser, Fuad Haddad, editor assistente do jornal Al-Amal do Katáeb, aumentou ainda mais a tensão e serviu de pretexto para a revolta dos falangistas que tomou conta de amplas áreas de população cristã do Líbano e caracterizou-se por choques armados, assassinatos e sequestros de adversários políticos. Para apaziguar o país e impedir o retorno da guerra civil, após diversas reuniões entre Chehab, os líderes muçulmanos e drusos e Gemayel, foi então organizado um novo gabinete de unidade nacional, conhecido como Gabinete de Salvação Nacional, que incluía dois líderes muçulmanos e dois cristãos.

Entre os cristãos Raymond Éddé do Bloco Nacional e Gemayel; do lado muçulmano Rashid Karami e Hussein Uwaini; se baseavam na ideia de que o Líbano não tinha nem vencedores e nem vencidos e que a unidade nacional estava acima das diferenças comunitárias e ideológicas. Também confirmava a força do Kata’eb como guardião do status quo no país e mostrava que eram uma força imprescindível para que qualquer governo tivesse viabilidade ${ }^{799}$.

As eleições legislativas de 1960 ampliaram o quadro de apoio a Chehab e impediram que muitos dos notáveis (que costumavam se opôr às políticas do ex-comandante das Forças Armadas) retornassem ao Parlamento mesmo com o aumento das cadeiras de 66 para 99.

O número de $72 \%$ dos novos deputados eram independentes e estavam, juntos com os partidos aliados, prontos para aprovar todas as propostas do governo mesmo que com o tempo voltassem às suas antigas afiliações comunitárias. Essas eleições também anularam a força política da oposição comandada por Chamoun permitindo ao governo trabalhar com o mínimo de obstáculos no campo político.

Entretanto, em seu entorno Chehab acreditava em um 'circulo interno' de figuras de confiança sem conexão com a classe política tradicional que tinham a função de vigiar e fiscalizar

${ }^{799}$ GORIA, Wade R. Sovereignty and leadership in Lebanon, 1943-1976... p. 48. 
a execução dos programas políticos do governo podendo ser enviados até para eliminar abusos e combater a corrupção e o mau uso dos recursos públicos. Alguns deles não eram libaneses.

Entre esses indivíduos, temos o padre jesuíta francês Louis Joseph Lebret, Chefe do IRFED, encarregado de desenvolver um amplo estudo da realidade socioeconômica do país; Jean Lay, um engenheiro militar francês da época do mandato; Elias Sarkis, presidente do conselho, mais tarde presidente do Banco Central e depois Presidente da república na segunda metade dos anos 70; assim como Georges Haimari que trabalhava ao lado de Chehab na implementação dos projetos governamentais $^{800}$.

\subsection{As forças de oposição}

Chehab, apesar de seu aparato de segurança e de sua ampla coalizão, governou o Líbano enfrentando uma oposição ativa que nunca aceitou as suas políticas reformistas, nem a presença dos rebeldes da guerra de 1958 no poder e sempre procurou denunciar e usar politicamente os excessos que as forças de seguranças cometiam. Essa oposição tinha na figura do ex-Presidente Chamoun o seu principal líder por meio de seu Partido Nacional Liberal (PNL, na sigla em francês), que era assumidamente defensor do liberalismo econômico e do total alinhamento do Líbano com o Ocidente no quadro da Guerra Fria, além de hostilizarem abertamente Nasser e o nacionalismo árabe.

A essa oposição se juntaram três ex-membros do governo, Raymond Eddé, um político liberal ligado ao sistema financeiro e que havia vindo do Bloco Constitucionalista, o exprimeiro ministro Saeb Salam, e mais tarde o líder xiita Kamal Assad. Os três acabaram por se aliar ao PNL de Chamoun e formaram uma frente parlamentar de oposição.

Contando com a imprensa cristã de direita como porta-voz, essa oposição tinha apoio em diversos setores das comunidades cristãs que consideravam Chamoun como um herói que tinha salvado o país de Nasser e avaliavam os líderes rebeldes muçulmanos como traidores. Mantinham uma permanente desconfiança com relação à população muçulmana e achavam que o governo de Chehab a favorecia em demasia ${ }^{801}$.

\footnotetext{
${ }^{800}$ WINSLOW, Charles. Lebanon: war and politics... p. 132.

${ }^{801}$ WINSLOW. War and politics... p. 141. GORIA, Wade R. p. 64.
} 
Quanto a Chamoun, que se posicionou como o principal inimigo político de Chehab ao longo de todo o seu mandato, a sua postura oposicionista não se deveu somente a suas diferenças ideológicas em relação ao Presidente e ao fato dele compor o seu gabinete com os inimigos do ex-mandatário, que eram motivos importantes, mas também devido ao ressentimento pessoal de Chamoun em relação ao seu rival que vinha das posturas que contra ele tomou em momentos de crise Chehab quando, como comandante das Forças Armadas, se recusara a obedecer às ordens do Presidente e privadamente o tratava com desdém ${ }^{802}$

A raiva de Chamoun em relação ao seu rival só foi aumentando por conta da política de Chehab em buscar o seu completo isolamento ao interferir nas eleições de 1959 e 1960 para impedir que seus candidatos fossem eleitos para o Parlamento.

A ação dos chehabistas contra Chamoun era tão intensa que ela se caracterizava por uma tentativa de boicote completo a sua pessoa no qual se procurava impedir sua figura de aparecer em fotos e reportagens de jornal.

Como forma de intimidá-lo chegou-se a colocar um destacamento de soldados em frente a sua casa molestando os visitantes ${ }^{803^{\circ}}$ Para combater o governo Chamoun fundou o Partido Nacional Liberal (Hizb al-Wattaniyyn al-Ahraar em árabe) onde reuniu seus apoiadores e pelo qual participou pelo resto de sua existência da vida política.

O PNL foi uma frouxa associação de lideranças políticas em torno da figura do exPresidente e que compartilhavam a sua visão sobre o Líbano, o nasserismo e o Mundo Árabe. Dela também faziam parte lideranças muçulmanas conservadoras como o xiita Kazim al-Khalil de Tiro e o sunita Suleyman al-`Ali do Akkar. Esse partido foi a encarnação do ethos cristão durante os anos sessenta e teve simpatizantes em todas as camadas sociais dessa população em todas as regiões do país. Até os mais pobres dos cristãos incluindo os que residiam em favelas no subúrbio de Beirute ou aldeias no Beka'a apoiavam Chamoun ${ }^{804}$.

Com relação a Chehab e os seus seguidores, a raiva que sentiam contra Chamoun devia-se a três motivos: 1) sua enorme popularidade entre os maronitas, o que enfraquecia

\footnotetext{
802 BESHARA. Lebanon: the politics of frustration - the failed coup of $1961 \ldots$ p. 107.

${ }^{803}$ KABBARA, Nawaf apud BESHARA. p. 109.

${ }^{804}$ SALIBI. Crossroad to civil war... p. 3-4.
} 
politicamente o Presidente e era um empecilho à realização do projeto chehabista de unidade nacional entre cristãos e muçulmanos e sua política externa neutralista; 2) por conta do primeiro fator, o ex-mandatário possuía a possibilidade de retornar à Presidência e 3) Chamoun era um dos mais ácidos e poderosos críticos do projeto chehabista e o grande porta-voz da causa maronita sendo que no plano internacional ele se aproximou dos piores inimigos do nasserismo: a Arábia Saudita e a Jordânia ${ }^{805}$.

Saeb Salam e Raymond Éddé eram outros dois grandes inimigos do Presidente Chehab. Este último atuava na vida política libanesa por meio do partido fundado por seu pai Èmile Éddé, o Bloco Nacional (em árabe al-Kutla al-Wataniyya).

Éddé, embora assim como o Presidente acreditasse que o Líbano precisava de um governo centralizado e forte e talvez reconhecesse a necessidade de reformas socioeconômicas, discordava fortemente dos métodos empregados por Chehab para alcançar esses fins.

Éddé teria uma postura mais democrática e não veria com bons olhos o forte uso das Forças Armadas na vida política e social por parte do governo e começou a vê-los como uma ameaça ao sistema democrático libanês. Essas discordâncias com os métodos chehabistas chegaram ao seu ponto máximo em outubro de 1959 quando houve a intervenção dos oficiais do Exército nas eleições. Revoltado com esse acontecimento Éddé deixou o governo onde havia ocupado o posto de superministro do Interior, Trabalho, Assuntos Sociais e dos Correios, Telefones e Telégrafos ${ }^{806}$ A partir desse momento ele seria um dos maiores críticos do Deuxième Bureau e das Forças Armadas.

No ano seguinte, ele próprio sofreria as consequências da ingerência na vida social das forças de seguranças chehabistas. Chehab usaria o Deuxième Bureau para interferir nas eleições legislativas em Beirute Oriental com o objetivo de forçar os eleitores a votarem por Gemayel e não Pierre Éddé, irmão de Raymond ${ }^{807}$. Aliás, a aproximação de Chehab com Gemayel foi uma das razões da oposição de Éddé ao Presidente. Isso se deveu ao fato de que as Falanges eram consideradas as principais rivais do clã Éddé dentro da comunidade maronita,

\footnotetext{
805 BESHARA. Lebanon: the politics of frustration - the failed coup of $1961 \ldots$ p. 109.

${ }^{806}$ BESHARA. Idem. p. 111. GORIA. Wade R. Sovereignty and leadership in Lebanon ... p.62.

${ }^{807}$ GORIA. Idem. p.62.
} 
sendo que em diversas ocasiões os dois partidos tinham feito oposição um ao outro ${ }^{808}$.

Todavia, Éddé também acabou se opondo ao projeto chehabista no fim das contas por razões ideológicas devido ao fato de este ir contra o ideal conservador do laissez-faire. Além disso, ele vinha de uma família com ampla influência nos círculos financeiros nacionais e que se beneficiara das políticas liberais dos governos anteriores. Como prova da ação política de Raymond Éddé em favor desses grupos, o próprio havia sido um dos responsáveis pela Lei do Segredo Bancário de 1956 que tantos benefícios trouxeram aos bancos libaneses. Como membro da classe financeira local ele passou a ver no projeto chehabista uma ameaça aos interesses da banca libanesa $^{809}$. No começo dos anos 60 ele se associou a Chamoun para compôr um bloco de oposição a Chehab, ainda que informal, pois eles tinham estilo e maneiras de atuar na vida política distintas e também enxergavam de modo diferente a realidade social libanesa. Embora Éddé não sofresse uma grande aversão por parte dos muçulmanos apesar de apelar aos sentimentos comunitários cristãos, seus pronunciamentos contra os chehabistas lembravam, em certos aspectos, os violentos ataques que seu pai fazia ao pan-arabismo no período do mandato francês o que talvez fosse uma manifestação dos mais profundos temores e impressões das comunidades cristãs, particularmente a maronitas e outros uniatas ${ }^{810}$.

Saeb Salam havia sido primeiro-ministro entre agosto de 1960 e outubro de 1961. Ele foi chamado para o posto após ter sido eleito para o Parlamento nas eleições de 1960. Porém, desde o principio Salam teve um relacionamento tenso com Chehab. Além da antipatia pessoal do Presidente por esse líder sunita, uma das grandes fontes de tensão para Salam no governo era o mau relacionamento do primeiro-ministro com Kamal Jumblatt, então ministro da Educação, que já vinha da época da guerra civil, apesar de ambos lutarem no mesmo lado.

No governo, Salam se mostrou irritado com a maneira independente de Jumblatt agir sem reconhecer a sua liderança o que o levava a frequentes queixas do líder sunita a Chehab, mas o Presidente não tomava nenhuma medida ${ }^{811}$.

Uma nova disputa com Jumblatt acabou terminando com a renúncia de Saeb Salam.

\footnotetext{
${ }^{808}$ BESHARA. Lebanon: The politics of frustration - the failed coup of $1961 \ldots$ p. 111 .

${ }^{809}$ BESHARA. Idem. p. 111.

${ }^{810}$ SALIBI. Crossroad to civil war... p. 6-7.

${ }^{811}$ GORIA. Wade R. Sovereignty and leadership in Lebanon... p. 66.
} 
Nessa disputa, o líder druso acusou o primeiro-ministro de adquirir para sua família terras nas imediações de Beirute de maneira ilegal e exigiu sua renúncia. Incapaz de obter o apoio do Presidente, acabou renunciando ${ }^{812}$.

Para piorar o seu ressentimento com o governo, no ano seguinte, Chehab usou o Deuxième Bureau em Beirute Ocidental para minar a influência política de Salam. Ele ainda tentou se aproximar de Chehab, mas ele continuou a usar os serviços de segurança para comprar os líderes dos bandos sunitas da capital que poderiam trabalhar para Salam ${ }^{813}$ e apoiar adversários sunitas beirutis do ex-primeiro-ministro como Abdallah al-Yafi. Isso o levou a romper completamente com o governo e a se aproximar de Chamoun e de seu Partido Nacional Liberal apesar de que no passado o tenha combatido militarmente e tenha estado associado a Nasser e ao pan-arabismo ${ }^{814}$. Esses políticos inimigos do chehabismo também ganharam o importantíssimo apoio de Paul Máushi, o patriarca maronita, ex-apoiador de Chehab que se reconciliou com Chamoun e passou a criticar o Presidente por conta da maneira centralizadora com a qual ele comandava o Executivo, os excessos praticados cotidianamente pelas forças de segurança e a intromissão do Exército na vida política do Líbano. Também havia motivos menos nobres para a oposição do patriarca ao Presidente. Dessa maneira, segundo Kamal Salibi ${ }^{815}$, o fato de Chehab governar de maneira discreta e não se aconselhar tanto com o patriarca desagradou em muito a este último. Outra razão pouco nobre teria sido a desconfiança em relação ao programa de reformas chehabistas que passou a ser visto por Ma`ushi como uma ameaça à posição social e econômica dos maronitas. Essa posição, segundo o patriarca, também poderia ser ameaçada pela excessiva inclinação de Chehab em direção a Nasser que interferia com frequência na política interna libanesa ${ }^{816}$.

Em suas falas, a partir de 1961, o patriarca lançava invectivas contra o comunismo e o socialismo como um ataque indireto às políticas de Chehab. Ele se dizia a favor das mudanças sociais preconizadas pelos relatórios da missão do IRFED, mas, ao mesmo tempo, buscava mobilizar os seus fiéis contra as políticas chehabistas de mudança social para assim tirar delas o

\footnotetext{
812 GORIA. Wade R. Sovereignty and leadership in Lebanon... p. 67.

813 SALIBI. Crossroad to civil war... p. 11.

${ }^{814}$ GORIA. Wade R. Sovereignty and leadership in Lebanon... p. 68.

815 SALIBI. Crossroad to civil war... p. 21.

${ }^{816}$ BESHARA. Lebanon: the politics of frustration - the failed coup of $1961 \ldots$ p. 113 .
} 
apoio de sua comunidade ${ }^{817}$.

Outra forma de pressionar Chehab e os seus seguidores eram as reuniões realizadas com Raymond Éddé e Chamoun em sua residência nas montanhas em Bkerky nas quais ele jogava todo o seu prestígio de líder comunitário na oposição cristã e liberal ${ }^{818}$. Por outro lado, o patriarca nunca defendeu o estabelecimento de um governo maronita forte, uma vez que este poderia ser um rival da igreja e, portanto, de sua autoridade na liderança dos fiéis $\operatorname{maronitas}^{819}$. Sua oposição aos chehabistas levaria Ma`ushi também a buscar se aproximar de regimes conservadores árabes como o rei Faisal da Arábia Saudita ${ }^{820}$.

Como o patriarca, os adversários políticos de Chehab também procuraram se aproximar de países que eram inimigos do nasserismo. Um desses países foi o Irã que havia desenvolvido uma política de apoio às lideranças conservadoras libanesas. Assim, os iranianos passaram a financiar os opositores de Chehab e a interferir no processo eleitoral libanês como foi o caso em 1960, quando os candidatos do Bloco Nacional de Raymond Éddé receberam ajuda financeira, embora não o próprio Éddé. Já Chamoun receberia $50 \mathrm{mil} \mathrm{em} \mathrm{dinheiro} \mathrm{das} \mathrm{mãos} \mathrm{do}$ próprio chefe da Savak (serviço secreto iraniano), o brigadeiro-general Teimur Bakhtiar. Os dirigentes da Savak pensaram até em oferecer uma ajuda financeira ao PNSS, mas o Reza Pahlevi foi contra ${ }^{821}$. Embora não formassem uma coalizão aberta contra Nasser, os políticos da oposição criticavam o líder egípcio e denunciavam as campanhas da imprensa nasserista libanesa contra os regimes conservadores como o saudita e o jordaniano ${ }^{822}$.

No plano econômico, essa oposição era constituída por poderosos setores das finanças e do comércio que ficaram descontentes com o abandono do laissez-faire radical do governo anterior e com as políticas de regulamentação do setor financeiro. Apesar da hostilidade dos setores capitalistas a Fuad Chehab, ele nunca procurou se intrometer nos assuntos dessa classe e sequer buscou restringir suas atividades, apenas regularizar e disciplinar esses setores como foi no caso da promulgação da nova Lei da Moeda e do Crédito que levou à criação do

\footnotetext{
${ }^{817}$ KABBARA apud BESHARA. p. 143.

${ }^{818}$ BESHARA... p. 113.

${ }^{819}$ SALIBI. Crossroads to civil war... p. 22.

${ }^{820}$ QALAWOUN. The struggle for Lebanon... p. 128.

${ }^{821}$ SAMII, Abbas. The Shah's Lebanon... p. 70

${ }^{822}$ QALAWOUN. The struggle for Lebanon.. p. 126
} 
Banco Central no ano seguinte. Para promover sua oposição às políticas Chehabistas, as elites mercantis e financeiras juntaram-se à oposição parlamentar cujos líderes passaram a representar os seus interesses e visões de mundo.

Toda essa oposição tinha como principal porta-voz o jornal an-Nahar de orientação liberal, cujo editor era o influente jornalista Ghassan al-Tuwayni. Crítico da política de Chehab e dos regimes árabes nacionalistas e de suas políticas de intervenção na economia, o jornal abria diariamente as suas páginas para que os adversários do governo criticassem cada proposta 2

O jornal an-Nahar foi o principal responsável por promover na sociedade libanesa a coalizão composta por Màushi, Éddé e Chamoun, particularmente no momento da eleição presidencial de 1964 quando a esse bloco estava associado Saeb Salam ${ }^{823}$.

Essa imprensa, da mesma maneira que a imprensa defensora de Nasser, também recebeu fundos ou ajuda dos Estados que combatiam o nacionalismo árabe ou simplesmente o nasserismo. Países como o Irã, a Arábia Saudita e as monarquias do Golfo financiaram inúmeros jornais de oposição a Chehab e que eram também contrários a Nasser. Alguns jornais como o Daily Star e o al-Hayat de Kamal Mrouweh, forte opositor de Nasser no Líbano, chegavam a ser comprados e distribuídos em regiões como o Golfo Pérsico, Jordânia e mesmo no Líbano pelo serviço secreto iraniano como forma de combater as emissões das rádios egípcias nessas regiões.

As relações entre Mrouweh e o serviço secreto iraniano eram tão boas que este forneceu 15 mil àquele para ajudá-lo a reconstruir a sede de seu jornal depois que ele fora destruído por uma bomba pouco tempo depois de publicar um artigo criticando fortemente Nasser por ele ter rompido relações com o Irã quando o Shah anunciou que poderia reconhecer Israel ${ }^{824}$.

Como dito mais acima, Chehab também contou com pouco apoio das populações cristãs, particularmente dos maronitas apesar de que em seu governo participava o Kata`eb de Pierre Gemayel, um dos principais líderes maronitas. Estas desconfianças vinham já da guerra civil por sua atitude em relação aos rebeldes muçulmanos e drusos que eram vistos como traidores por grande parte dessa população.

Os cristãos acusavam Chehab de ter impedido a vitória das forças cristãs. Alguns cristãos o acusavam de estar associado aos rebeldes enquanto outros o viam como um militar

\footnotetext{
${ }^{823}$ WINSLOW. War and politics... p. 141.

${ }^{824}$ SAMII, Abbas William. The Shah's Lebanon... p. 71.
} 
pouco comprometido com o seu país, irresponsável e incapaz de tomar decisões. Por mais que Chehab tentasse ganhar o apoio dessa população ela permaneceu desconfiada e distante. Nem mesmo a tentativa de golpe que Chehab sofreu do PNSS levou essa população a se aproximar do governo, apesar deles condenarem os golpistas ${ }^{825}$. Quando a oposição cresceu e passou a atacar constantemente o governo os cristãos passaram a apoiá-la sendo-lhes uma forte base de sustentação social.

\subsection{Os programas sociais e projetos de desenvolvimento}

Vários programas buscando desenvolver as regiões muçulmanas como o Akkar, a zona de Baalbek no Beka'a e o sul do Líbano foram postos em prática nos anos de mandato do general Chehab. Obras de infraestrutura como estradas, rodovias, redes de energia, abastecimento de água e esgotos foram levadas aos rincões mais distantes do Líbano. Hospitais, postos de saúde e clínicas médicas e uma rede de escolas públicas (que deveria reduzir a grande incidência de analfabetismo entre os muçulmanos, como mostra a tabela baixo, na qual vemos que no começo da década de 1960 atingia 39\% dos homens e 69\% das mulheres, enquanto entre os cristãos esse números eram menores) foi construída nas menores aldeias fazendo com que, pela primeira vez, muitos muçulmanos frequentassem uma escola ou tivessem atendimento hospitalar. Aliás, no campo do Ensino Superior, uma lei aprovada pelo parlamento em 1959 quebrou o monopólio das ordens religiosas no setor universitário e levou à fundação da Universidade Libanesa de caráter público e na qual as aulas eram ministradas em Árabe e não em Francês ou Inglês, o que permitiu a muitos muçulmanos pobres ingressarem no Ensino Superior.

Como prova desses empreendimentos houve um grande aumento dos gastos do governo que saltaram de 182 Milhões de dólares para 473 milhões entre 1958 e $1964^{826}$. No conjunto total dos investimentos novos no Líbano a participação do Estado saltou de $15 \%$ em 1958 para $30 \%$ ao longo do governo $\mathrm{Chehab}^{827}$. Na área de educação o orçamento aumentou $452 \%$ nesse período, indicando que, até Chehab, praticamente mal existiam políticas educacionais no Líbano. O setor público chegaria em 1964 a representar $23 \%$ do PIB quando em

${ }^{825}$ SALIBI. Lebanon under Fuad Chehab... p. 217.

${ }^{826}$ TRABOULSI, Fawwaz. A modern history of Lebanon... p. 141.

${ }^{827}$ COBBAN, Helena. The making of the modern Lebanon. Londres: Hutchinson and Co., 1985. p. 95. 
1959 era apenas $13 \%{ }^{828}$.

Tabela 41 - Taxa de analfabetismo rural (por volta de 1960)

\section{Porcentagem de Analfabetismo}

$\begin{array}{lcccc} & \text { Homens } & \text { Mulheres } & \text { Meninos } & \text { Meninas } \\ \text { Cristãos } & 23 & 45 & 22 & 29 \\ \text { Muçulmanos } & 39 & 69 & 28 & 33\end{array}$

Fonte: HUDSON, Michael. The precarious republic: political modernization in Lebanon. Nova Iorque: Ramdom House, 1968.

Essas medidas se tornavam ainda mais necessárias uma vez que com o crescimento populacional do Líbano no século XX aumentava a precariedade da vida nas aldeias do interior e estimulava-se a migração do campo para as cidades. Como estas não estavam preparadas para receber essa população ocorria um fenômeno típico dos países subdesenvolvidos: a formação de favelas que cresciam no entorno das cidades litorâneas como Beirute, Sidom e Trípoli, por exemplo. Portanto, um dos objetivos da política de Chehab foi conter o aprofundamento da crise social em curso nas grandes cidades.

No sul do Líbano foi dado prosseguimento ao projeto do Rio Litani que previa a construção da Represa de Qarun para gerar energia elétrica e fornecer água para projetos de irrigação. Também foi durante o mandato de Chehab que foram criados os programas de seguridade social no Líbano com a criação do Fundo de Segurança Social Nacional, estabelecidos no mandato seguinte de Charles Helu, em 1965, mas que entraram em operação plena apenas na década de $1970^{829}$.

As medidas sociais de Chehab estavam acompanhadas de políticas que visavam

${ }^{828}$ WINSLOW, Charles. Lebanon: war and politics... p. 134.

${ }^{829}$ GASPARD, Tufic K. A political economy of Lebanon, 1948-2002: the limits of laissez-faire. Leiden e Boston: Brill, 2004. p.64. 
conseguir a igualdade entre cristãos e não-cristãos. Uma dessas primeiras medidas foi a reforma administrativa que buscou dar uma distribuição mais justas para as comunidades muçulmanas nos cargos e postos das empresas públicas e na burocracia governamental. Dessa maneira, a porcentagem de cristãos foi reduzida a 50\%. Essa medida, apesar de elogiada por muitos, foi criticada pelos cristãos, pois se dizia que muitas vezes os postos administrativos no governo eram entregues a pessoas pouco qualificadas somente porque elas eram muçulmanas.

Um problema que surgiu de imediato foi a preponderância dos sunitas nos postos reservados aos muçulmanos. Isso acontecia por conta do fato de que os xiitas eram uma população pobre e ainda rural nessa época com poucos indivíduos com um bom nível de instrução e, portanto, condições de ocuparem postos administrativos no governo. A situação dos xiitas se tornou tão ruim que eles perdiam postos até para os drusos. Essa política foi uma das responsáveis pelo forte apoio das comunidades sunita e drusa ao presidente $\mathrm{Chehab}^{830}$.

\subsection{Exército e Deuxième Bureau}

Como foi dito acima, o Presidente Chehab também confiava no Exército e nas forças de segurança e inteligência (conhecidos como o Deuxième Bureau) para garantir o seu poder e governar o Líbano. Com isso, pela primeira vez na história do país, o Exército passou a exercer um papel mais ativo na vida política nacional. Muitos cargos estratégicos na administração foram entregues a militares de confiança enquanto o Deuxième Bureau espionava tanto adversários quanto aliados, intervinha em suas vidas e reunia informações sobre os primeiros que eram usadas contra eles quando desafiavam o governo.

Essas forças de segurança mantinham a sociedade sob um forte controle e com o tempo foram alvos de ferozes críticas por causa dos muitos abusos que cometiam. O Exército era usado, como em momentos anteriores da história independente do Líbano, para influenciar as eleições a favor do Presidente, como foi o caso nas eleições legislativas de 1960, quando o governo utilizou os militares para forçar os eleitores a não votarem nos candidatos do exPresidente Chamoun e do seu aliado Raymond Eddé. Por isso, o exército foi nos anos de Chehab uma presença constante na vida civil dos libaneses. Chehab pensava que, em última instância, o

${ }^{830}$ SALIBI, Kamal S. Lebanon under Fuad Chehab: 1958-1964. Middle Eastern Studies. V. 2, N. 3. abr. 1966. p. 218-219. 
Exército poderia obrigar a classe política a implementar as suas reformas caso os líderes tradicionais oferecessem resistência ${ }^{831}$.

Para os indivíduos que compunham o governo Chehab e o próprio Presidente a classe dos líderes tradicionais era um empecilho para o bom funcionamento do país e, como era arriscado tentar eliminá-los, buscou-se ignorá-los. Dessa maneira, o governo aplicava suas políticas sem levar em consideração o que essa classe pensava.

Acreditava-se que a prosperidade libanesa seria alcançada por meio da ação dos empresários privados na esfera econômica, como também era a crença de Chamoun e seus seguidores, mas, diferentes desses, os chehabistas achavam que para isso ocorrer era necessária à ação do Estado que, por meio dos seus técnicos, serviços de segurança e do Exército, criariam as condições adequadas para que o sistema econômico do Líbano pudesse funcionar ${ }^{832}$. Por isso, as autoridades do governo trabalharam para que nessa época houvesse um Parlamento que permitisse ao Executivo administrar o país com um mínimo de empecilhos, o que acabou acontecendo após as eleições legislativas de 1960 e que fez surgir uma maioria no Congresso que deixou, por exemplo, o primeiro-ministro Rashid Karami governar à base de decretos-leis (foi o premier que teve o gabinete mais longo, devido à estabilidade do governo Chehab, desde a independência em 1943 até a eclosão da guerra civil de 1975) ${ }^{833}$.

O Exército e o Deuxième Bureau foram usados também para colocar sob o controle diversos chefes políticos locais e bandos armados a eles associados que com frequência se envolviam em distúrbios e brigas políticas de todo tipo.

Essas medidas levaram as forças governamentais a combater e a diminuir o poder dos notáveis locais como uma maneira de aumentar a força e o poder do Executivo para assim conseguir implementar os seus projetos e impedir que eles pudessem vir a desafiar ou, ao menos, atrapalhar a autoridade do Presidente.

Nesse processo, os chefes de bandos que trabalhavam a serviço desses senhores - e com frequência espalhavam o caos sobre as zonas e locais por eles controlados - foram identificados e neutralizados. No interior, a ação dos serviços de segurança conseguiu acabar com

\footnotetext{
${ }^{831}$ WINSLOW, Charles. Lebanon: war and politics... p. 131-133.

${ }^{832}$ WINSLOW. Idem. p. 134.

${ }^{833}$ TRABOULSI, Fawwaz. A history of modern Lebanon... p. 140.
} 
as lutas entre grandes proprietários rurais ou entre as tribos que habitavam regiões distantes como o Akkar e a zona de Baalbek ${ }^{834}$.

Nessas ações, o Deuxième Bureau, em diversas oportunidades, passava por cima da Constituição e com frequência cometia abusos de todo o tipo como prisões arbitrárias, vexações públicas e tortura de prisioneiros. As forças de segurança tiveram sua presença na sociedade intensificada após a fracassada tentativa de golpe contra Chehab em dezembro de 1961. Intensificou-se com isso a interferência nos sindicatos, associações comunitárias e qualquer outra organização civil libanesa e, dentro dos campos de refugiados, houve forte interferência na vida civil palestina.

Agentes do Estado foram colocados em cada vizinhança das grandes cidades e principais vilas. O controle ditatorial do Deuxième Bureau foi tão intenso que, ao longo do mandato de Chehab, quase não aconteceu nenhuma agitação social importante embora, ainda assim, o movimento sindical tenha realizado diversas greves que acabavam com algum tipo de intervenção do Estado ${ }^{835}$.

Uma das piores medidas repressivas do Deuxième Bureau e cujas consequências foram mais nefastas para o futuro do Líbano foi o forte e sufocante controle dos dispositivos de segurança sobre a vida dos palestinos que foi crescendo até se tornar insuportável. Isso acontecia por que eles eram vistos como uma ameaça potencial à segurança do Estado libanês devido ao seu conflito com Israel e as suas conexões com os governos árabes estrangeiros. Esse fato em muito contribuía para a sua crescente frustração em relação ao Estado libanês e teria grande importância na sua adesão à luta armada a partir da metade dos anos 60 .

Causava tanto incômodo o modo como o Estado tratava os refugiados palestinos que gerou até queixas de setores da sociedade libanesa que chegaram, sem sucesso, a pedir que Chehab aliviasse a situação opressiva em que eles se encontravam ${ }^{836}$. Apesar do forte controle estatal, os palestinos foram se aproximando dos sunitas libaneses ao longo dos anos do governo Chehab, particularmente os sunitas pobres das periferias das cidades libanesas. Os outros

\footnotetext{
834 SALIBI. Lebanon under Fuad Chehab... p. 225.

835 TRABOULSI, Fawwaz. A history of modern Lebanon... p. 141.

${ }^{836}$ GORIA. Wade R. Sovereignty and leadership in Lebanon... p.72
} 
muçulmanos pobres também se mostravam simpáticos em relação aos palestinos e solidários com o seu infortúnio, mas os sunitas, como eram da mesma religião que a grande maioria dos palestinos, se identificavam mais facilmente com eles ${ }^{837}$.

No fim, a desenvoltura dos membros das forças de segurança era tão grande que chegaram ao ponto de nos últimos anos de seu mandato vários oficiais importantes apoiarem abertamente a reeleição de Chehab tendo até procurado realizar mobilizações abertas para conseguir que uma emenda permitindo que a reeleição fosse aprovada ${ }^{838}$.

Esse uso intenso do aparato repressivo do Estado por parte de Chehab revelava um grande temor ao longo de todo o mandato do Presidente e de seus seguidores a respeito da perda de controle do governo sobre o território libanês e as suas populações assim como o receio de que essa perda pudesse levar a uma nova guerra civil.

No fundo, a existência do Deuxième Bureau, sua atuação excessiva na vida política nacional, mais a interferência do Exército na vida civil eram mais uma manifestação da fragilidade do Estado libanês do que a comprovação de que ele havia sido restabelecido com força e que dificilmente voltaria a entrar em colapso como em 1958.

\subsection{Relações com o Egito e o Mundo Árabe}

No período de Fuad Chehab o Líbano voltou a estabelecer plenas relações diplomáticas com o Egito, reconhecendo o papel de Nasser como liderança principal do nacionalismo árabe, ao mesmo tempo em que mantinha relações com os demais regimes se abstendo o Líbano de tomar partido por um dos lados em caso de disputas e sempre buscando ser um arbitro neutro em casos de desavença. Também afirmava seu compromisso com causas de liberação do Mundo Árabe como a questão Palestina e o reconhecimento da FLN argelina.

Essa postura nova era algo essencial para o desenvolvimento econômico do país devido ao fato de sua economia ser centrada no comércio e no sistema bancário e ao peso que os países árabes tinham em sua balança comercial. Também a política de Chehab buscou, dessa maneira, retomar a 'face árabe' do Líbano, reafirmando o fato desse país pertencer ao Mundo

${ }^{837}$ SALIBI, Kamal S. Crossroad to civil war: Lebanon 1958-1976. Nova Iorque e Londres: Caravan Books Delmar \& Ithaca Press, 1976. p. 10.

${ }^{838}$ WINSLOW, Charles. Lebanon: war and politics... p. 141 
Árabe, uma condição muito necessária para que internamente as populações muçulmanas pudessem aceitar a existência do Líbano e manter o Pacto Nacional funcionando.

Essa nova política reassumia a neutralidade existente antes do mandato de Chamoun e era aceita por diversos grupos cristãos, entre os quais a própria Falange, apesar do seu exclusivismo cristão, e do fato que seu líder, Pierre Gemayel, não ter simpatias por Nasser e nem por nenhum outro líder nacionalista árabe. Isso ocorria porque essa política de Chehab era vista nesse momento como positiva para o Líbano até por membros da direita cristã como os militantes do Katá $\mathrm{eb}^{839}$.

Um exemplo do neutralismo do Líbano de Chehab foi a sua recusa em tomar partido na disputa entre Nasser e o Presidente do Iraque, o general Abdel Karim Qassim, que havia se oposto à liderança do Presidente egípcio no Mundo Árabe. Os libaneses procuraram assumir o papel de intermediadores, reunindo-se em separado com representantes de ambos os governos para tentar buscar um acordo de compromisso entre eles dois ${ }^{840}$.

Outro exemplo foi o episódio do conflito entre a RAU e a Jordânia em 1960. Essa disputa foi levada para a Conferência de Ministros das Relações Exteriores da Liga Árabe ocorrida no Líbano em 23 de agosto de 1960. Chehab já havia interferido ao enviar cartas aos líderes dos dois Estados pedindo que cessassem as hostilidades para que ambas as delegações pudessem participar da reunião. Porém, durante a reunião, a rivalidade se manifestou de forma acintosa. Posteriormente, o território libanês foi alvo de um atentado, possivelmente por parte de agentes jordanianos, quando a embaixada da RAU em Beirute foi explodida em 10 de setembro de 1960. Isso teria sido uma resposta ao assassinato do primeiro-ministro Haza`al-Majali em seu escritório por uma bomba, atentado esse que o Rei Hussein atribuiu a Nasser. O monarca levou a questão desse atentado à ONU.

Nesse ponto, o Líbano por meio do então primeiro-ministro Saeb Salam, recusou o papel de mediador apenas afirmando que daria à Liga Árabe o conselho de não levar essa disputa à ONU. Mesmo assim, o governo libanês não conseguiu se desenredar da disputa, pois o governo do Cairo acusou os agentes jordanianos que atuavam contra a RAU de cruzarem a fronteira síria com carteiras de identidade libanesas fornecidas pelo governo. Já o Líbano acusou o adido militar

\footnotetext{
${ }^{839}$ QALAWOUN, Nasser. The struggle for Lebanon... p. 78.

${ }^{840}$ QALAWOUN. Idem. p. 79.
} 
jordaniano de estar implicado em atentados em território libanês. No fim, para evitar um rompimento com a Jordânia, o governo libanês enviou uma mensagem aconselhando os jordanianos a retirarem o seu adido militar, enquanto publicamente Saeb Salam fazia denúncias contra os responsáveis por atentados contra alvos da RAU sem especificar nomes ${ }^{841}$.

A política de neutralidade de Chehab foi oficialmente estabelecida durante a reunião de cúpula entre o Líbano e a RAU realizada na fronteira entre os dois Estados em 26 de março de 1959. Nessa reunião, Nasser se comprometeu publicamente a aceitar a independência e não interferir em assuntos internos do Líbano enquanto os libaneses, além de se comprometerem a solucionar os problemas econômicos entre os dois países, afirmavam publicamente o seu compromisso com a causa árabe.

A realização da reunião na fronteira sírio-libanesa teve como objetivo não indispor a opinião pública cristã contra o governo de Chehab e, dessa forma, evitar dividir o Líbano, pois essa população reagiria mal a uma reunião em Damasco e, pior ainda, no Cairo, já que nesse caso veriam a presença ali do Presidente libanês como prova da submissão de seu governo ao domínio da República Árabe Unida. Também evitava que os muçulmanos viessem receber com grandes manifestações a Nasser, caso essa reunião fosse em Beirute, algo que também teria efeitos perigosos entre a maioria dos cristãos ${ }^{842}$.

No plano mais internacional o Líbano mantinha os seus vínculos com o Ocidente, mantendo relações diplomáticas, culturais e comerciais com Paris, Londres e Washington, reconhecendo a hegemonia dos EUA no mundo capitalista e sua liderança sobre os regimes conservadores árabes. Ao mesmo tempo mantinham relações diplomáticas e comerciais com a URSS e o Bloco Comunista, porém o Líbano se afirmava como um país capitalista tendo no livre mercado a base de sua economia.

Enquanto isso, os EUA, como já falado acima, percebiam que Chehab era o homem adequado para pacificar o Líbano e manter os nacionalistas sob controle, quaisquer que fossem as suas tendências, mantendo o Líbano em seu papel de Estado intermediário entre os países árabes e o Ocidente.

Chehab também procurou se aproximar da França de Charles de Gaulle que, após o

\footnotetext{
${ }^{841}$ QALAWOUN... p. 81-82.

${ }^{842}$ QALAWOUN... p. 77.
} 
fim da guerra da Argélia, havia adquirido um grande apoio no Mundo Árabe, além de procurar agradar a opinião pública cristã, uma vez que a França era considerada a sua protetora e o governo libanês não se apresentava, ao mesmo tempo, aos olhos dos nacionalistas árabes como um inimigo desse movimento. Essa aproximação havia sido uma maneira de compensar a excessiva influência norte-americana no Líbano e acabaria desagradando a esses que, com o tempo, sem romper ou hostilizar abertamente a Chehab, passaram a apoiar as forças de oposição $^{843}$.

No entanto, nem sempre o Líbano conseguia assumir um papel neutro em relação à RAU. Como Nasser era muito popular entre os muçulmanos e tinha muita influência entre os políticos libaneses, na impressa e na intelectualidade local, o governo libanês quase sempre se sentia pressionado a inclinar-se pelo lado egípcio. Por isso, quando a Síria se separou da RAU, em 28 de setembro de 1961, Beirute se recusou de imediato a reconhecer a secessão de Damasco. Ao mesmo tempo, membros do governo libanês criticaram os sírios e se puseram do lado de Nasser. O confronto com o novo governo sírio chegou ao ponto até de este acusar o Líbano de ser uma base para os agentes egípcios desestabilizarem o seu país, sendo o embaixador egípcio no Líbano, o general Ghalib, o homem por trás de tudo isso. Paralelo a isso, Damasco impunha várias restrições econômicas ao seu vizinho ${ }^{844}$.

Posteriormente, durante a Conferência de Shtura, no Líbano, em 22 de agosto de 1962, a representação de Beirute teve de ouvir nova acusação dos sírios de que seu país era uma base para a ação de agentes egípcios enquanto as delegações do Cairo e de seus adversários no Mundo Árabe trocavam ofensas e faziam manobras tentando cada um prejudicar o outro tendo a conferência sido encerrada com a saída da delegação egípcia e a decisão de Nasser de retirar o seu país da Liga Árabe. Curiosamente, o lugar escolhido para a conferência favorecia os sírios e os governos anti-nasseristas, pois a população da região era principalmente cristã e possuía sentimentos contrários ao líder egípcio.

Os conflitos continuaram entre o Egito e seus adversários no Mundo Árabe levando várias delegações árabes a acusarem o governo de Chehab de ser pró-Nasser devido a sua dificuldade em assumir uma postura crítica em relação ao Cairo. Isto colocou o governo libanês

\footnotetext{
${ }^{843}$ SALIBI. Crossroad to civil war... p. 15.

${ }^{844}$ QALAWOUN. The struggle for Lebanon... p. 105.
} 
numa situação de grande constrangimento, pois assumir de maneira firme uma posição significava antagonizar ou Damasco ou o Cairo.

A pressão contra os egípcios foi tão grande que eles acabaram por deixar a conferência em protesto diante da atitude das delegações adversárias, o que levou ao encerramento dela. Por causa dessa ambiguidade a Síria chegou a planejar, em conjunto com o Iraque, a Jordânia e a Arábia Saudita, no começo de1963, um embargo coletivo ao comércio de trânsito libanês o que acabou não acontecendo devido ao golpe que derrubou o governo do general Qassim no Iraque.

Com relação a esse embargo, o primeiro-ministro sírio Khalid al-Azm chegou ao ponto de impor ao Líbano condições para que ele não fosse aplicado. Entre essas condições havia a exigência de se expulsar o embaixador egípcio Abdul Ghalib, entregar a Damasco relatórios semanais detalhados sobre sírios e egípcios que viajavam entre o Líbano e o Egito e até a exigência de que o Líbano mudasse sua política neutralista. Apesar do embargo nunca ter sido aplicado, os sírios haviam posto em prática uma política de retaliação a Beirute, como as proibições a entrada de libaneses, bem como de produtos e capitais provenientes do país vizinho $^{845}$.

As estreitas relações com o Egito levaram o Líbano a adotar, internacionalmente, muitas das posturas que seu parceiro tinha em relação ao restante do Terceiro Mundo, como foi o caso da política anticolonial do Cairo no continente africano. Nesse contexto, os libaneses distanciaram-se até mesmo de seu representante na ONU, Charles Malik, muito conhecido por suas posturas pró-ocidentais, como mostrado mais acima. Dessa maneira, quando Malik visitou a seção israelense de uma feira de comércio em Nova Iorque em maio de 1959, o primeiro-ministro Rachid Karami e o chanceler Hussein Uwaini criticaram o ex-ministro de Chamoun e só não o expulsaram do governo para não antagonizarem os membros cristãos do ministério ${ }^{846}$.

A política de aproximação com o Egito em certos momentos trazia constrangimentos internos para Chehab, pois as autoridades do Cairo chegaram, em fevereiro de 1960, a acusar publicamente os falangistas de serem agentes das potências imperialistas ocidentais em um pronunciamento público em Damasco. Como o Kataeb era membro do governo isso obrigava o

\footnotetext{
${ }^{845}$ QALAWOUN... p. 108-110.

${ }^{846}$ QALAWOUN... p. 83.
} 
Presidente libanês a sair publicamente em defesa dos seus aliados, o que poderia levar a um conflito com o Cairo.

Essa ação de Nasser foi uma resposta a uma série de ensaios críticos em relação à política econômica da RAU aplicada na Síria publicadas no jornal al-Amal dos falangistas. Nasser também visaria com essas declarações a forçar a queda de Gemayel e a retirada da Falange do governo. O líder maronita por sua vez respondeu acusando o Presidente egípcio de procurar recrutar agentes e não amigos ou aliados no Líbano e de interferir nos assuntos internos do Líbano.

Para fazer essas declarações, Gemayel fora apoiado por vários partidos e políticos cristãos. Com a intenção de solucionar essa crise, o governo libanês evitou partir para o enfrentamento. Dessa maneira, Saeb Salam e o presidente do Parlamento foram a Damasco saudar Nasser pelo aniversário de formação da RAU enquanto Chehab promovia reuniões diplomáticas nos bastidores para tentar aliviar a tensão e procurar algum compromisso entre as partes. Posteriormente, o governo procurou aplicar sanções à imprensa, tanto aquela pró como antiNasser. Dessa forma, foi contornada uma crise grave entre a RAU e o Líbano ${ }^{847}$.

\subsection{A tentativa de golpe de 1961 pelo PNSS}

Nas primeiras horas do dia 31 de dezembro de 1961, ainda de madrugada, o Partido Nacional Socialista Sírio, por meio de várias centenas de civis armados em conjunto com membros das Forças Armadas descontentes com o governo, deu início a uma tentativa de derrubar o Presidente Fuad Chehab para substituí-lo por um governo de caráter civil, comandado por esse partido de maneira autoritária, com a intenção de realizar uma série de medidas que seriam impostas à sociedade libanesa: a) o desmantelamento do sistema confessional; b) a elaboração de uma legislação social em colaboração com os sindicatos; c) a introdução de novas leis eleitorais, d) a busca de uma verdadeira política de não-alinhamento, o que significava o afastamento em relação ao Egito de Nasser e a cooperação com os países vizinhos para se buscar a futura união entre esses Estados e e) a coordenação para o desenvolvimento equilibrado dos setores comercial e industrial da economia libanesa. Esperava-se que dentro de seis meses esses

${ }^{847}$ QALAWOUN... p.84-85. 
objetivos seriam alcançados e a vida constitucional poderia ser restabelecida ${ }^{848}$.

No entanto, o golpe fracassou o que levou à onda de repressão do governo contra o PNSS. No dia seguinte ao golpe, o partido foi oficialmente dissolvido por uma ordem executiva do Conselho de Ministros tendo os arquivos do partido sido apreendidos. Para impedir as fugas dos golpistas foram fechadas as fronteiras com a Síria. Unidades da polícia e do Exército foram despachadas por todas as partes do país para capturar os envolvidos no complô. As embaixadas foram colocadas sob forte vigilância para evitar que fugitivos buscassem refúgio nelas. $\mathrm{O}$ aeroporto de Beirute também foi colocado sob uma forte vigilância. Vários militantes do PNSS foram mortos em enfrentamentos com as forças policiais e militares.

Nos primeiros dias após o golpe, 3.000 pessoas haviam sido presas. No fim de janeiro, já era 6.000 o número de detidos. Entre esses presos havia um número considerável de inocentes. Quase todos os principais responsáveis por organizar a tentativa de golpe foram $\operatorname{presos}^{849}$ enquanto políticos da oposição, suspeitos de conspirarem com os nacionalistas sírios, como Camille Chamoun e Raymond Éddé, foram obrigados a prestar esclarecimento às forças de segurança e tiveram os seus passaportes retidos. Durante o julgamento dos golpistas os seus nomes chegaram a ser mencionados ${ }^{850}$. Toda a operação de repressão aos golpistas durou cerca de três meses. Nos meses que se seguiram ao golpe os suspeitos presos foram rotineiramente interrogados pelas forças de segurança que praticaram tortura e outros tipos de maus tratos, algo que foi denunciado na época.

A população em sua maioria condenou o golpe, ficando do lado de Chehab e aprovando a medidas de repressão contra os conspiradores apesar dela também sofrer com os excessos praticados pelas forças de segurança. Mesmo os cristãos maronitas, que, em geral, tinham pouca simpatia pelo Presidente, ficaram contra o golpe, pois eles sempre foram em sua maioria contrários às propostas políticas do PNSS.

O golpe se processou da seguinte maneira: começou com a marcha de um pequeno contingente de militares em direção a Beirute, a qual parou em Sidom para cortar as linhas telefônicas com a capital para em seguida se dirigir para tomar posições em frente ao Ministério

\footnotetext{
${ }^{848}$ BESHARA. Lebanon: the politics of frustration - the failed coup of $1961 \ldots$ p.123.

${ }^{849}$ BESHARA. Idem. p. 148

${ }^{850}$ GORIA. Wade R. Sovereignty and leadership in Lebanon... p.72
} 
da Defesa enquanto um grupo de civis armados do PNSS se dirigia para ocupar o prédio dos Correios e Telégrafos e conquistar o Seray (Casa do Governo) para capturar o Presidente e outros membros da alta cúpula militar e civil.

O prédio dos Correios e Telégrafos fora tomado e vários oficiais de alta patente capturados e detidos dentro do Ministério da Defesa que também estava ocupado, mas os planos para sequestrar outras autoridades militares como o chefe do Deuxième Bureau, coronel Antun Saad e o subchefe do Estado Maior fracassaram.

Enquanto isso, os grupos encarregados de sequestrar Chehab foram forçados a abandonar esse plano quando mudanças na movimentação desse pessoal atrasou o contato com o comandante dos militares sublevados que haviam voltado para Sidom, mas estavam retornando, o que permitiu ao Palácio Presidencial se inteirar da ação golpista e reagir.

Com a missão de capturar Chehab tendo fracassado, o golpistas tentaram se retirar do Ministério da Defesa, no entanto foram impedidos pelas forças do Exército leais ao governo. Após confusões nas fileiras rebeldes, trocas de tiros e tentativas de fuga de oficiais rebeldes, os amotinados se renderam por volta das 07h00min da manhã e os oficiais sequestrados foram libertados. No prédio dos Correios e Telégrafos os militantes do PNSS também haviam se rendido. A tentativa de golpe terminara ${ }^{851}$.

Outra razão para o fracasso da tentativa de golpe se deveu ao fato de que o Deuxième Bureau já suspeitaria de que o PNSS estava organizando um golpe. O serviço secreto tinha informantes dentro do partido e tanto eles quanto o Presidente já esperavam uma ação contra o governo e essa ação poderia se dar no feriado de ano-novo. Em uma entrevista dada à revista alWasat, um membro do Deuxième Bureau, Sami Al-Khattib, afirmou isso e ofereceu o nome de um suposto colaborador ${ }^{852}$.

Essa tentativa de golpe possuía características únicas que a distinguem dos golpes ou tentativas de golpes realizadas no Mundo Árabe nos anos de 1950 e 1960: 1) a sua realização fora feita por civis pertencentes a um partido nacionalista com inclinação ideológica para a direita do espectro político e associação com militares, os quais eram um pequeno grupo enquanto os civis chegavam às centenas, sendo estes os principais responsáveis pela preparação, recrutamento e

\footnotetext{
${ }^{851}$ BESHARA. Lebanon: the politics of frustration - the failed coup of 1961 ... p. 127-128.

852 BESHARA. Idem. p. 131-132.
} 
execução do golpe; 2) de maneira distinta em relação à maioria dos golpes no Mundo Árabe na mesma época, a tentativa do PNSS tinha fortes raízes históricas, ligadas à relação conflituosa entre esse partido e o Estado no Líbano; 3) o golpe ocorreu em uma situação na qual poucos acreditavam propícia para eventos como esse, com o Líbano atravessando um período de crescimento econômico e relativa estabilidade política $^{853}$.

São várias as causas que conduziram a essa tentativa de golpe. Em primeiro lugar a própria frustração política dos nacionalistas pan-sírios com o governo de Chehab. Eles inicialmente confiaram e apoiaram Fuad Chehab quando se candidatou para a Presidência, tendo saudado publicamente a sua eleição, pois o consideraram o indivíduo adequado para trazer o Líbano de volta à normalidade, reconstruir o Estado e promover a integração nacional ${ }^{854}$.

Isso não era uma atitude nova: desde 1952 quando houve a queda do governo de elKhuri, o partido apoiara Chehab em suas intervenções públicas em relação à política nacional. Esse apoio lhe granjeava simpatia por parte dos nacionalistas pan-sírios, mesmo quando o então comandante-em-chefe se opunha a Chamoun, aliado e protetor do PNSS.

Existiam semelhanças importantes entre alguns ideais desse partido e o projeto de Chehab, o que os aproximava: ambos defendiam a necessidade de um governo forte centralizador para realizar reformas econômicas e sociais reduzindo as desigualdades de renda, regionais e comunitárias, como também desejavam modernizar a burocracia e desprezavam a classe política tradicional $^{855}$.

Mas, pouco tempo após a subida do ex-comandante do Exército, uma sequência de fatos levou o partido e os seus militantes a se decepcionar com ele, cuja escalada rápida e profunda chegou ao ponto de desenvolverem uma aversão visceral ao novo Presidente. Isso se deveu tanto por conta das políticas adotadas pelo novo governo como por sua atitude em relação ao PNSS.

A primeira aconteceu durante a formação do primeiro gabinete. Os líderes pan-sírios se recusaram a formar parte do governo caso este incluísse líderes rebeldes. Somente após a formação do 'Governo de Coalizão' em 14 de outubro é que o PNSS começou a diminuir esse

\footnotetext{
${ }^{853}$ BESHARA... p. 2.

${ }^{854}$ BESHARA... p.48-49.

${ }^{855}$ BESHARA... p. $49-51$.
} 
pedido $^{856}$. O partido também tinha a esperança de participar do governo e Chehab havia assinalado sua intenção de integrá-lo em seu gabinete por meio de dois ministérios entregue a quadros de alto escalão do PNSS, no entanto isso não aconteceu e os nacionalistas pan-sírios sentiram-se traídos e desrespeitados. Uma nova exclusão aconteceria após a formação do segundo gabinete $^{857}$. A partir desse momento, começou um doloroso processo de marginalização política que seria uma das causas principais da tentativa de golpe no fim de 1961.

Dessa maneira, o PNSS foi sendo excluído do processo político por meio de derrotas nas eleições de 1959 e 1960 nas quais acusou o governo de interferir a favor dos adversários e contra o partido. Até mesmo na região de Kura, onde o PNSS tinha uma das suas principais bases, eles foram derrotaos nas eleições ${ }^{858}$. Além disso, o partido começou a ser acossado e maltratado pelo Deuxième Bureau. Seus escritórios passaram a ser invadidos pelas forças de seguranças e seus militantes eram publicamente humilhados com prisões e revistas vexatórias. Esse tratamento dado ao partido contrastava com a tolerância em relação às atividades paramilitares dos falangistas que estavam no governo. Uma possível explicação para essas atitudes em relação ao PNSS se devia ao fato de eles serem aliados de Chamoun, inimigo de Chehab. Atacar o PNSS era uma forma de atingir o ex-Presidente ${ }^{859}$.

Uma segunda decepção aconteceu com o projeto de governo de Chehab, no qual constava a retomada do Pacto Nacional como base para a unidade de todos os libaneses. O acordo intercomunitário libanês sempre fora condenado pelos nacionalistas pan-sírios por ser um impedimento à integração do Líbano em uma unidade política mais ampla e era considerado por eles um dos responsáveis da guerra civil de 1958 ao dividir confessionalmente a sociedade e criar privilégios para determinados grupos e setores e excluir outros ${ }^{860}$.

O alinhamento com o Egito foi outra causa profunda de descontentamento com a política do governo; além do PNSS se opôr ao projeto de Nasser, este ainda promovia a perseguição dos membros do partido na Síria. Junto a isso, existia a interferência da RAU nos assuntos internos libaneses por meio do embaixador Ghalib e a falta de reação de Chehab

\footnotetext{
${ }^{856}$ BESHARA... p.52.

${ }^{857}$ BESHARA... p.59-60.

${ }^{858}$ BESHARA ... p. $62-63$

${ }^{859}$ BESHARA ... p. $67-68$

${ }^{860}$ BESHARA... p.57-58
} 
revoltava os nacionalistas pan-sírios ${ }^{861}$.

A frustração do PNSS juntou-se à de setores das Forças Armadas, especialmente de militares cristãos com relação ao Presidente, que durante a guerra civil haviam se posicionado contra a política de Chehab de evitar ao máximo usar o Exército para combater a oposição e sua indiferença em relação à infiltração de armas para abastecerem os rebeldes e de homens vindos da RAU para ajudá-los. Estes militares se espantavam com a passividade diante das ações violentas da oposição e das deserções de soldados e oficiais, bem como da difusão entre eles do nasserismo, o que era considerado uma ameaça à estabilidade, disciplina e aos valores defendidos pelas Forças Armadas ${ }^{862}$.

Essa frustração, segundo duas lideranças desse setor golpista do exército, Fuad Awad e Shawki Khairallah, teria já começado em 1956 quando Chehab teria decidido se tornar Presidente $^{863}$ e se acentuou depois da guerra com a presença deles no governo. Os militares também se diziam incomodados com a interferência do Deuxième Bureau na vida política libanesa, especialmente dentro das Forças Armadas. Além disso, muitos desses militares viam a Chehab como um indivíduo que se utilizava de métodos sujos para satisfazer uma ambição pessoal: tornar-se Presidente ${ }^{864}$.

Como já foi dito mais acima, também estariam envolvidos com os golpistas políticos da oposição (ou ao menos eles teriam tomado conhecimento dos planos), entre os quais se encontrariam o ex-Presidente Camille Chamoun e Raymond Éddé do Bloco Nacional. Chamoun, inimigo político do Presidente, em um encontro com os conspiradores, teria dito que não se opunha à ideia de um golpe e, de acordo com o líder do PNSS Abdallah Saadeh, o próprio Chamoun teria sugerido que se matasse Chehab quando este estivesse sido capturado. Quanto a Raymond Éddé, ele teria se reunido três vezes com os organizadores do golpe nas quais manifestou as suas reservas em relação à operação.

Édde temia que o golpe pudesse levar a uma grande interferência das Forças Armadas no Estado libanês. Além do mais, esse líder conservador cristão não veria como reconciliar as

\footnotetext{
${ }^{861}$ BESHARA ... p. 66

862 BESHARA... p. 92

863 BESHARA ... p.87.

${ }^{864}$ BESHARA ... p.92-94.
} 
ideias antimilitaristas e de orientação democrática que ele publicamente pregava contra Chehab com a ideia de um golpe militar, mas, segundo o próprio Saadeh, na terceira reunião Éddé estaria propenso a aceitá-lo, porém com a condição de que não se envolvesse pessoalmente nele ${ }^{865}$.

O patriarca maronita Paul Ma`ushi, já rompido com o governo, também teve contato com os conspiradores, especialmente com Saadeh. Nesses encontros, ele teria se mostrado favorável a aceitar um golpe com a ressalva de que se devia proteger o sistema democrático ${ }^{866}$.

Por fim, uma questão que tem gerado muitos debates envolve a ideia da participação de governos estrangeiros no golpe frustrado de 1961. Desde 1962, foram acusados os governos da Grã-Bretanha e da Jordânia de estarem auxiliando os golpistas e isso por conta da orientação anti-nasserista de ambos os governos.

O governo egípcio e sua imprensa também faziam essas acusações, vendo na implantação do projeto pan-sírio uma política para afastar o Egito do levante e restringir sua influência apenas à África. Por causa dessa tentativa de golpe o Egito procurou reforçar suas relações com o Líbano e encorajou o governo libanês a recorrer ao Conselho de Segurança da ONU para fazer uma queixa contra a Jordânia e a Grã-Bretanha, algo que os libaneses não fizeram $^{867}$.

Vários fatores levaram muitos a suspeitarem dessa conexão: no dia da tentativa de golpe havia um destroier britânico nas águas territoriais libanesas ${ }^{868}$; a Jordânia de fato ajudava o PNSS como maneira de combater o nasserismo e o Rei Hussein chegou a declarar publicamente após a tentativa de golpe que o projeto da Grande Síria seria uma benção para o nacionalismo árabe; por fim o próprio primeiro-ministro sírio, Maaruf Dawalibi, declarou que a tentativa de golpe era parte de um grande plano contra a segurança e a independência dos países do Oriente Médio arquitetado pela OTAN ${ }^{869}$.

Dentro do governo libanês Kamal Jumblatt também acusava os golpistas de serem estimulados por forças externas. As acusações e suspeitas contra a Grã-Bretanha e a Jordânia

\footnotetext{
${ }^{865}$ BESHARA ... p. 116.

${ }^{866}$ BESHARA ... p. 117.

${ }^{867}$ QALAWOUN. The struggle for Lebanon... p. 105.

${ }^{868}$ BESHARA ... p. 133.

${ }^{869}$ BESHARA. Idem. p. 138-139.
} 
continuaram por muitos anos. Quanto ao governo libanês, este declarou oficialmente no Parlamento, por meio do ministro das Relações Exteriores Phelippe Taqla que não se tinha provas de envolvimento estrangeiro na tentativa de golpe ${ }^{870}$.

\subsection{A tentativa de reeleição de Chehab e a reação da oposição}

Uma das principais ações da oposição foi a de impedir que Chehab conseguisse do Parlamento uma emenda que lhe garantisse a possibilidade de se candidatar para um segundo mandato. Como a oposição, apesar dos esforços do governo, tinha ido bem nas eleições de 1964, ela organizou uma ampla campanha acusando Chehab de rasgar a Constituição e prometendo greves e manifestações de massas nas ruas caso essa emenda fosse aprovada. No auge da agitação, os políticos da oposição e o próprio Chamoun chegaram até mesmo a cogitar se levantar em armas caso isso acontecesse, como fizeram em 1958 contra o ex-Presidente, quando também existia a suspeita de que ele desejava se manter no poder por meio de uma mesma emenda que lhe permitia se recandidatar ${ }^{871}$.

Como controlava grande parte do Parlamento, a coalizão de oposição tinha força para impedir o governo de conseguir os dois terços de votos dos parlamentares que garantiriam a eleição de um sucessor que daria continuidade às políticas de Chehab, embora não tivesse força para eleger o seu próprio Presidente ${ }^{872}$. Durante a disputa eleitoral o Presidente chegou a perder força uma vez que o líder da Falange, Pierre Gemayel, tinha resolvido se candidatar. O primo dele, Maurice Gemayel, importante liderança falangista, também havia anunciado a sua intenção de se candidatar ${ }^{873}$.

Isto obrigou os nahjistas (os chehabistas) a buscar um Presidente de compromisso entre as duas forças e para isso escolheram Charles Helu, um jornalista e advogado, seguidor das ideias do intelectual e banqueiro Michel Chiha, que tinha sido membro fundador do Kata'eb na juventude, que havia participado em pastas de gabinetes anteriores e pertencido ao movimento 'Terceira Força' de Henry Faraoun nos tempos do governo de Chamoun. Helu era o candidato que ao

\footnotetext{
${ }^{870}$ BESHARA ... p. 140.

${ }^{871}$ TRABOULSI, Fawwasz. A moderny history of Lebanon... p. 143.

${ }^{872}$ WINSLOW, Charles. Lebanon: war and politics... p. 141.

873 Salibi. Crossroad to civil war... p. 21.
} 
mesmo tempo daria prosseguimento às políticas chehabistas e, devido ao fato de ter contatos com amplos setores das elites libanesas e não possuir um aparato político próprio, seria do agrado da oposição $^{874}$.

\subsection{Balanço do governo Chehab}

Em um balanço final, pode-se dizer que em sua época o governo Chehab despertou impressões contraditórias. Ele desfrutava de apoio em amplos setores da sociedade libanesa, particularmente entre os pobres muçulmanos do campo e da cidade. Os seus apoiadores afirmavam que Chehab procurou construir um Estado moderno e unificar a sociedade libanesa e buscar o seu desenvolvimento. Alguns apoiadores mais exaltados até descreviam-no como uma espécie de Santo ${ }^{875}$.

O governo Chehab, por outro lado, colecionou muitos inimigos, uma boa parte dos quais estavam contrariados com a política econômica e social do ex-general. Para muitos, Chehab não passava de um candidato a ditador pouco ou nada preocupado com o que causava na vida libanesa. Essa visão se baseava em boa parte na atuação sufocante dos serviços de segurança e das Forças Armadas na vida civil. Alguns chegaram até a dizer que o ex-general tentava remodelar o Líbano segundo o modelo existente na época dos seus ancestrais da dinastia chehabiana. Segundo Adel Beshara, essas imagens contraditórias da figura de Chehab se deviam à maneira pela qual ele conduzira a política libanesa ao tentar construir um Estado moderno dentro de um sistema político rígido e ao não levar em conta que os avanços feitos pelo governo não levaram em consideração os escassos recursos nacionais e os problemas colocados pelos conflitos políticos internos e internacionais.

Chehab, apesar de ter conseguido fazer muita coisa em seus poucos anos como Presidente, não conseguiu solucionar a grande disparidade entre os ricos de um lado e as massas pobres do campo e da cidade, nem a contradição entre os interesses das cidades do litoral e os da montanha que vinham desde a época do estabelecimento do mandato francês e, pior, fracassou em substituir as lealdades sectárias por uma identidade libanesa forte e acima das afiliações religiosas, um dos objetivos centrais de seu governo e vital para a reconstrução do país após a

\footnotetext{
${ }^{874}$ Winslow. Lebanon: war and politics... p. 142.

${ }^{875}$ Beshara. Nota 14, p. 196.
} 
guerra de 1958. No fim dos anos sessenta as consequências desses fracassos se fariam sentir nas disputas e desconfianças intercomunitárias que arruinaram o tecido social libanês ${ }^{876}$. Mesmo dentro do aparelho de Estado suas reformas não foram totalmente bem sucedidas, pois a corrupção e a ineficiência não foram eliminadas e isto contribuiu para impedir que suas reformas sociais fossem mais efetivas.

No entanto, com o tempo, o governo Chehab foi visto como positivo. Mesmo tendo feito amplo uso das Forças Armadas e do Deuxième Bureau contra inimigos políticos e para manter a sociedade libanesa sob controle, Chehab nunca as utilizou para tentar um golpe. Ele fazia declarações públicas a favor do respeito à Constituição e ao sistema democrático e dizia que seu único objetivo era trabalhar para a unidade da nação e o bem-estar de todos os libaneses.

Suas políticas de desenvolvimento favoreceram as regiões outrora abandonadas e criaram as bases para a seguridade social no Líbano apesar de não terem estabelecido uma igualdade de condições entre muçulmanos e cristãos nem terem de fato eliminado as profundas divisões sectárias que caracterizavam o país. Também ajudaram o sistema econômico libanês ao ampliar ou melhorar a infraestrutura que lhe permitia funcionar e instalar instituições (como o Banco Central) e mecanismos de regulação que pudessem corrigir os defeitos do sistema econômico, estabilizá-lo e resolver os problemas que aparecessem.

No plano externo, a volta ao neutralismo e o reconhecimento do papel de Nasser no Mundo Árabe sem romper as relações tradicionais com o Ocidente também tiveram um efeito positivo no Líbano. Apesar de trazer problemas momentâneos como, por exemplo, o que ocorreu após a dissolução da RAU devido à saída da Síria em setembro de 1961, que em muito contribuía para internamente pacificar o país e permitia ao Líbano continuar com o seu papel de intermediário econômico e cultural entre o Ocidente e os países árabes.

No futuro, o governo de Chehab seria lembrado como o melhor que o Líbano teve desde que adquiriu a independência e sua busca pela unidade nacional acima das divisões sectárias foi um exemplo ao qual os libaneses nunca deveriam ter abandonado.

Georges Corm (El Líbano contemporâneo: história y sociedad. biblioteca del Islam contemporâneo. Barcelona: Edicions Bellaterra, 2006), fazendo um balanço do governo Chehab, afirma que o governo dele, apesar de seus fracassos no plano político expressados e fatos como a

${ }^{876}$ Cobban, Helena: The Making of Modern Lebanon. Hutchinson and CO., London, 1985. p. 99 
inexistência de uma política de separação entre as comunidades religiosas e a ordem pública, ou a manutenção da divisão dos cargos públicos entre as diferentes seitas, além de não procurar sequer reformar a estrutura jurídica que garantia a existência da ordem comunitária, ou fazer uma reforma eleitoral que marginalizasse os notáveis tradicionais, ou limitasse a força do fator comunitário na ordem política libanesa, o que impediu os chehabistas de formarem um partido, ou movimento político que defendesse seu projeto nacional e pudesse se arraigar na sociedade, representou a possibilidade da existência de um Líbano forte, estável, pacificado e que sabia reconhecer a força política e social do nasserismo sem, no entanto, romper com o Ocidente, no qual o embrião de uma nova classe política estava se formando e que poderia servir para moldar um Estado fortalecido no futuro e, desse modo, consolidar o Grande Líbano.

O país terminou o mandato do ex-general em expansão econômica e em uma situação de estabilidade rara no Oriente Médio ${ }^{877}$. No entanto, as pressões e intrigas da classe tradicional, particularmente a cristã, fizeram esse projeto fracassar (fracasso esse exemplificado no abandono por Chehab do seu projeto de reeleição) e como consequência:

[...] el retorno de la vieja guardia política del país fue uma catástrofe sin precedentes em la história del Líbano, ya que no sólo rechazó el estado fuerte del Shehabismo (sic) sino también los prudentes princípios del Pacto Nacional. Fue um período politicamente regressivo, aunque nunca la dinâmica socioeconômica del país había sido tan floresciente ${ }^{878}$.

As tensões que essa classe política tradicional criou com as forças esquerdistas e revolucionárias ao longo dos anos sessenta, mais o problema palestino, enterraram o projeto chehabista e anunciaram os anos trágicos e sangrentos das décadas de 1970 e 1980 quando o Líbano sentiria saudades do presidente Chehab.

\subsection{Charles Helu}

Tendo tomado posse em 23 de setembro de 1964, após receber 92 dos 99 votos do parlamento, Helu fora escolhido para ser o candidato de compromisso entre as forças pró e anti-

\footnotetext{
${ }^{877}$ p. $125-126$.

878 p. 127.
} 
Chehab buscando manter a unidade nacional restabelecida durante o governo de seu antecessor, os programas de desenvolvimento e a política externa neutra dentro do cenário internacional. Porém, o mandato de Helu rapidamente se caracterizou pela acentuação das divisões comunitárias que nunca foram verdadeiramente apagadas.

Sucessivas e rápidas crises acabariam por minar o projeto político chehabista que ele deveria dar continuidade e, assim, foram criadas as condições para a deflagração da guerra civil em abril de 1975. Essas divisões foram acentuadas pelos efeitos da derrota árabe na guerra de 1967 cuja consequência imediata foi aumentar a radicalização política dos palestinos dentro do Líbano, dividindo ainda mais a sociedade libanesa.

Como candidato de compromisso dos chehabistas com as forças de oposição e sem contar com uma ampla base de apoio social, Helu era visto como um líder débil que precisava contar unicamente com o apoio das forças chehabistas e dos serviços secretos para que seu governo fosse viável.

Por conta disso, o novo Presidente era apresentado pelas forças de oposição como um fantoche dos seguidores de Chehab. Essa imagem foi amplamente divulgada na sociedade libanesa pelo jornal liberal an-Nahar. Para tentar se livrar dessa situação complicada Helu passou discretamente a estimular a oposição a agir contra os seus próprios aliados promovendo uma luta entre os dois grupos para, desse modo, tentar diminuir a pressão que faziam contra ele. $\mathrm{O}$ resultado dessas manobras foi irritar os chehabistas que começaram a obstruir o governo como forma de fazer com que Helu as interrompesse e voltasse a colaborar com eles ${ }^{879}$.

Para conturbar ainda mais a sua situação, Charles Helu, já no seu primeiro ano de mandato, se deparou com problemas graves que exigiam uma resposta firme do governo. Em outubro de 1964, o governo do Líbano foi à reunião da Liga Árabe no Cairo para debater a respeito das medidas que deveriam ser tomadas para impedir Israel de desviar as águas do rio Jordão. Como partes das cabeceiras do rio estavam no Líbano e originavam outros rios libaneses isso também afetava o sul do país.

Essa questão havia gerado um problema para Chehab nos últimos meses de seu mandato e o governo de Helu havia herdado: frente à ameaça de Israel, os governos árabes haviam decidido aplicar um plano próprio de desvio das águas do Jordão por meio do desvio dos

${ }^{879}$ SALIBI. Crossroad to civil war... p.23. 
afluentes desse rio que nasciam no Líbano. Para poder realizar essas obras com segurança e defender o Líbano frente a um ataque israelense, Síria e Egito haviam oferecido estacionar as suas tropas na fronteira meridional libanesa, mas o governo libanês recusou essa proposta afirmando que ao invés disso os países da Liga Árabe deveriam equipar materialmente as forças armadas do Líbano.

A decisão tomada pelas delegações na reunião de outubro de 1964 com relação ao Líbano foi a de realizar as obras para desviar as águas de dois afluentes do Jordão, os rios Wazzani e Hasbani, para a Síria e a Jordânia enquanto era estabelecido um Comando Árabe Unificado ao longo da fronteira líbano-israelense para impedir qualquer retaliação do Estado judeu cujos comandantes seriam estrangeiros. Esse exército responderia unicamente à direção da Liga Árabe e não às autoridades libanesas. Como ressalva se consentiu que essas tropas entrariam no Líbano só com consentimento de seu governo ${ }^{880}$.

A decisão de desviar as águas dos afluentes do Jordão fora, segundo Salibi (Crossroad, 1976), uma mudança de página na história do envolvimento do Líbano nos assuntos árabes. Os cristãos e os seus líderes conservadores viram esse episódio como uma chantagem realizada pelos países árabes contra o Líbano com o objetivo de interferir em sua soberania. Tanto eles quanto as demais lideranças libanesas temiam que a presença dos exércitos árabes no país levassem à intervenção nos assuntos internos por parte dos governos árabes, aliás, a ameaça israelense era vista como uma desculpa para esse procedimento. A partir de então, os cristãos libaneses que nunca tiveram muita confiança nos países árabes passariam a olhá-los cada vez mais com um crescente receio.

A mesma conferência decidiu pelo estabelecimento da Organização para a Libertação da Palestina tendo uma ala militar, o Exército de Libertação da Palestina, que também teria unidades instaladas no Líbano. Essa decisão também trazia sérios problemas para a soberania territorial libanesa. Isso ocorria porque a liberdade de ação dos guerrilheiros palestinos expunha o país às retaliações israelenses e também era um fator contínuo de subversão da autoridade do Estado libanês ${ }^{881}$. A ação dos palestinos também era vista com temor pelos cristãos por conta de suas inclinações pan-arabistas e pelo fato de na guerra de 1958 eles terem mostrado uma forte

\footnotetext{
${ }^{880}$ GORIA, Wade R. Sovereignty and leadership in Lebanon... p.77

${ }^{881}$ SALIBI. Crossroad to civil war... p. 24
} 
simpatia pelos rebeldes. O seu grande número em relação ao conjunto da população libanesa ( $10 \%$ do total) aumentava ainda mais os temores dos cristãos ${ }^{882}$.

A OLP iria recrutar os seus combatentes e militantes principalmente dos campos de refugiados do sul do Líbano. Um acordo entre a OLP e o governo do Líbano concedeu aos palestinos a permissão para desenvolverem suas atividades políticas com a condição de não realizarem ações militares. O documento do acordo não tinha caráter oficial e não impediu que as tensões entre os palestinos e governo ocorressem e elas só foram crescendo ao longo da década de 1960. Se inicialmente eram pequenas, no fim acabaram se transformando em um conflito aberto $^{883}$.

As atividades guerrilheiras palestinas levaram a frequentes choques com o Exército e as forças do Deuxième Bureau. Em um desses episódios, o Exército prendeu em 25 de dezembro de 1965 a Jalal Kawash, um dos mais altos comandos da OLP, quando se preparava para empreender ações armadas dentro de Israel. Alguns dias depois, em 11 de janeiro do ano seguinte, o ministro da Defesa veio a público anunciar que Kawash havia se suicidado dentro da prisão. Essa versão da morte do líder guerrilheiro palestino foi desmentida por várias figuras políticas palestinas e libanesas que acusaram as forças de segurança de assassinar Kawash sob tortura. Sua morte causou grande revolta entre os palestinos e criou uma grande agitação nos campos de refugiados. Essa agitação causada pela morte de Kawash era resultado de uma grande frustração e ressentimento acumulado nos palestinos por anos de maus tratos nas mãos das forças de segurança libanesas ${ }^{884}$.

Já em junho de 1966, como resultado da crescente tensão entre o governo e os grupos armados palestinos, produziram-se os primeiros choques armados entre o Exército e as guerrilhas deles cujo cenário foi o sul do país ${ }^{885}$. Cada vez mais os palestinos não se sentiam bem-vindos no Líbano e até a guerra de 1967 esse sentimento só foi crescendo, estimulado pelos frequentes choques entre os grupos armados da sua resistência e as forças armadas ou grupos paramilitares libaneses de direita, pela hostilidade das forças de segurança e, principalmente, pela falência

\footnotetext{
882 SALIBI. Idem. p. 25

${ }^{883}$ HAYEK, Domingo Garí. História contemporánea del Líbano: confesionalismo y política (1840-2005). Santa Cruz de Tenerife e las Palmas de Gran Castilla: Ideal Global, 2006. p. 121.

${ }^{884}$ GORIA, Sovereignty and leadership in Lebanon... p.78.

${ }^{885}$ HAYEK. p. 124.
} 
estrepitosa do Intra Bank em outubro de 1966, o maior banco privado do Líbano, que pertencia a um palestino, Yussef Beidas, e que não teria sido salvo pelo governo por esse motivo. Tudo isso foi fazendo com que os palestinos vissem na luta armada a única oportunidade e esperança de terem os seus direitos respeitados e um grande número de seus jovens se alistou, no fim dos anos 60 , nos diversos grupos guerrilheiros que se formavam, principalmente na OLP ${ }^{886}$.

\subsection{O chehabismo em relação a Helu}

Helu é visto por muitos como um continuador das políticas de Chehab, por meio do novo Presidente, e devido aos homens que colocou na administração e nos serviços de segurança (Deuxième Bureau), o ex-general teria mantido a sua influência sobre a vida política libanesa até 1970 quando Suleyman Frangié foi eleito Presidente e os chehabistas deixaram o poder.

Essa imagem era muito presente não apenas pelo fato de o ex-general ser ainda muito respeitado e a sua opinião escutada a cerca dos acontecimentos libaneses e médio-orientais de sua época, mas também por conta das frequentes conversas telefônicas que Chehab manteve com Helu no começo de seu mandato e da eleição para a presidência do Parlamento em 20 de outubro de Sabri Hamade, um político muito próximo ao ex-general durante os anos de seu governo ${ }^{887}$

No entanto, há quem diga o contrário afirmando que após 1964 Chehab foi perdendo a influência que tinha sobre a vida política de seu país e que o seu sucessor afastou-se dele e cada vez mais de seu projeto de nação para o Líbano. Ambos romperam as relações em 1965 quando os contatos telefônicos que mantinham se encerraram.

Isso se deveu às divergências que surgiram entre os dois líderes com relação à política a ser adotada para o país, mas também começou por conta dos indivíduos que eram nomeados para cargos importantes no governo como foi o caso da escolha feita por Helu de Emile Bustani para o comando das Forças Armadas no lugar de Adel Chehab, um militar próximo ao exPresidente ${ }^{888}$.

Contudo, essa divergência chegou ao ponto do próprio Helu rejeitar o plano de

\footnotetext{
${ }^{886}$ GORIA... p. 78.

${ }^{887}$ MALSAGNE, Stéphane. Fuad Chéhab 1902-1973: une figure oubliée de l'histoire Libanaise. Paris e Beirute: Karthala e IFPO, 2011. p. 430-431.

${ }^{888}$ MALSAGNE. Idem. p. 443.
} 
desenvolvimento econômico e social elaborado pela Missão do IRFED para ser aplicado ao Líbano entre 1964 e 1968 feito a pedido do próprio Chehab, sendo que uma versão reduzida desse projeto, com o nome de Plano de Desenvolvimento 1965-1969, foi aprovada pelo governo em abril de 1965.

Em novembro de 1964, após encontro com o Presidente, o padre Lebret deixou definitivamente o Líbano assinalando com sua partida o termino das atividades do IRFED no país. Com Helu se reduziu o ritmo de crescimento das despesas do governo (de 18,3\% ao ano para 6,4\%) tendo esse ritmo diminuído mais ainda após a guerra de 1967. Apesar de haver um aumento dos gastos sociais por conta da entrada em vigor de leis sociais promulgadas durante o mandato de Chehab, as despesas de investimento tiveram queda de 7 pontos ao longo de $1964^{889}$.

Na realidade, a subida de Charles Helu à Presidência significou também o começo do retorno do liberalismo extremado dos anos 1950. O próprio Presidente eleito indicou isso em seu discurso de posse quando afirmou que o Estado não podia substituir a iniciativa privada, pois se isso ocorresse a economia entraria em paralisação ${ }^{890}$.

Tanto foi assim que os anos iniciais de Helu também foram acompanhados pela difusão de uma crise social, com aumento do custo de vida e do desemprego que é agravado pelo constante influxo migratório do campo para os bairros pobres e favelas das principais cidades libanesas. A recusa do primeiro-ministro Rachid Karami em aumentar os salários acentuou o malestar social $^{891}$. Nessa situação, o plano de Chehab de fortalecer a classe média libanesa ficou comprometido por conta da situação econômica e social que a fragilizava ${ }^{892}$.

Helu também, seguindo política contrária à de seu sucessor, procurou reduzir o forte papel que o Exército possuía na vida política libanesa. Dessa maneira, ele colocou no comando das forças de segurança internas civis de sua confiança e utilizou-os para combater as ações do Exército, como pode ter ocorrido durante as eleições parciais de 11 de junho de 1965 nas quais Raymon Éddé recuperou o seu mandato no Parlamento vencendo um candidato de Chehab muito provavelmente por conta da ação de Helu por meio de suas forças de segurança que anularam as

\footnotetext{
${ }^{889}$ MALSAGNE... p.444.

${ }^{890}$ HAYEK... p. 122.

${ }^{891}$ MALSAGNE... p. 444.

892 MALSAGNE... p. 444.
} 
manobras do Deuxiéme Bureau contra aquele líder liberal. A eleição de Éddé foi uma derrota política dos chehabistas e demonstraria o distanciamento de Helu em relação a esse grupo ${ }^{893}$.

Esses exemplos colocados acima seriam fortes evidências de que Helu, embora escolhido para dar continuidade aos planos de Chehab, na verdade buscou seguir um caminho diferente do trilhado por seu antecessor e isso teria levado à ruptura definitiva entre os dois líderes e ao distanciamento do poder do antigo comandante do Exército.

A idéia de que Chehab continuaria a atuar sobre a vida política libanesa por meio dos homens que ele colocou no governo e do Deuxième Bureau (cuja ação dentro da sociedade libanesa foi forte até 1968) é parte de uma lenda negra criada pela oposição liberal para desacreditá-lo e combater o seu projeto nacional (Malsagne;2011).

As ações do Deuxième Bureau, as quais os excessos eram muito criticados por jornalistas e intelectuais, além de usadas politicamente pela oposição, ajudavam a alimentar essa ideia, ainda mais que eram atribuídas à vontade do ex-presidente Chehab. Porém, na verdade não existem provas documentais que corroborem tais acusações, tampouco os documentos das fontes diplomáticas ocidentais afirmam que Chehab tivesse tal domínio da vida política libanesa ${ }^{894}$.

\subsection{A política internacional árabe e as grandes crises do regime de Helu}

O mandato de Helu foi marcado por crises gravíssimas que abalaram a estabilidade política, social e confessional interna do Líbano e sua posição no cenário econômico internacional. A primeira foi a falência, em outubro de 1966, do maior banco do Líbano: o Intra Bank, de propriedade do self made man palestino Yussef Beidas, indivíduo muito ligado ao governo Chehab e ao seu projeto nacional.

A falência do Intra Bank revelou um grande problema de sua época. A crise criada pela quebra desse banco era uma manifestação do caráter aventureiro e especulativo da burguesia libanesa ligada ao chehabismo, da qual o dono do Intra Bank, Beidas, foi com os seus associados o maior representante, ainda mais que uma parcela importante dos favores que beneficiaram esse banqueiro fora providenciada pelo Deuxième Bureau.

\footnotetext{
${ }^{893}$ MALSAGNE... p. 447.

${ }^{894}$ MALSAGNE... p.432.
} 
Por sua vez, em troca, o banco financiava eleições, distribuía doações em dinheiro, empregava clientes dos chehabistas e pagava subornos para os principais membros do governo. A quebra do Intra Bank significava, no fim das contas, que o próprio projeto de desenvolvimento elaborado após 1958 fora posto em cheque. O ex-presidente Chamoun aproveitou o momento para denunciar os chehabistas, culpando-os por essa crise, sobre a qual afirmou publicamente que a partir de então o Líbano como Suíça do Oriente Médio não mais existia ${ }^{895}$.

A intervenção de Chamoun no caso da falência do Intra mostrava que o governo de Helu assistia ao crescimento de outro conflito em seu mandato: a crescente polarização entre os seguidores de Chehab, os nahjistas, e os seus opositores que tinham inicialmente no ex-Presidente Chamoun e Seu Partido Nacional Liberal sua principal liderança. No entanto, logo Chamoun e outras lideranças cristãs conservadoras começaram a ser eclipsadas pela ascensão das Falanges de Pierre Gemayel que se tornaram muito populares entre os cristãos, particularmente os maronitas.

Como resultado dessa ascensão, na sequência da derrota árabe em junho de 1967, Gemayel junto com Chamoun e Raymond Eddé formaram um grupo político para disputar as eleições legislativas de 1968.

Ao longo da década de 60 o Katáeb cada vez mais passou a representar a população maronita e, em alguma medida, outros grupos cristãos, cada vez mais incomodados com a agitação social entre os muçulmanos e a ascensão da guerrilha palestina, particularmente após $1967^{896}$. Helu também foi ao longo do seu mandato perdendo o apoio dos muçulmanos que Chehab desfrutou ao longo de todo o seu governo. Essa população cada vez mais via Charles Helu como um político que favorecia os maronitas e pouco se importava com a política anterior de seu antecessor. Finalmente, para piorar a situação do Presidente, suas relações com o Exército e o Deuxième Bureau iam piorando, pois achavam que Helu não tinha atitudes firmes frente aos grupos que ameaçavam subverter a ordem social libanesa ou a soberania do país.

De imediato, a crise do Intra Bank levou a uma crise política ao obrigar o primeiroministro Abdallah al-Yafi, um dos responsáveis pela falência daquele banco, a se demitir. Foi substituído por Rachid Karami, o qual sofreu a oposição forte tanto da direita cristã do Bloco Nacional de Raymond Éddé e do Partido Nacional Liberal de C. Chamoun como do PSP de

\footnotetext{
895 TRABOULSI, Fawwaz. A history of modern Lebanon. Londres: Pluto Press, 2008. p. 150.

${ }^{896}$ GORIA, Wade R. Sovereignty and leadership in Lebanon... p. 90.
} 
Kamal Jumblatt. Ao mesmo tempo, grupos sunitas pediam uma mudança constitucional que incluísse uma maior concessão de poder ao governo ao mesmo tempo em que reduzia a do Presidente. Essa proposta foi defendida por Abdallah al-Yafi junto com membros do establishment sunita como Saeb Salam, Rashid el-Solh e Amin Arayssi. Jumblatt a ela se opôs dizendo que a divisão dos poderes não poderia ser confessional. Os cristãos também se opuseram $^{897}$.

O governo Helu assistiu desde o seu início a saída de antigos membros vindos do mandato de Chehab que deixavam o governo, em alguns casos, por brigarem com o Presidente, como foi o caso de Kamal Jumblatt, que foi aos poucos se distanciando dos chehabistas e se aproximando dos grupos palestinos como a Frente Popular para a Libertação da Palestina (FPLP), liderada por Georges Habash, a Frente Democrática para a Libertação da Palestina de Nayef Hawatmeh e o próprio FATAH de Yasser Arafat.

No Parlamento, a partir de 1965, o líder druso comandou a formação da Frente de Luta Nacional e prenunciou a formação da Frente Progressista, coalizão de partidos e grupos políticos que atuavam fora do Parlamento e defendiam a mudança do sistema político libanês, então dominado pelos maronitas.

Isso levou a uma aproximação do Partido Socialista Progressista com grupos que haviam sido proibidos no Líbano como os Ba'athistas, nacionalistas árabes e sírios e os grupos comunistas e socialistas. Ao longo dos anos 60 a influência dessa frente sobre a população muçulmana só foi crescendo enquanto os líderes sunitas tradicionais como Saeb Salam, Abdullah al-Yafi e Rachid Karami tinham cada vez mais dificuldades em exercer sua tradicional influência sobre os seus distritos eleitorais e os muçulmanos ao longo do Líbano ${ }^{898}$.

O governo de Helu, no plano internacional, procurou continuar a política de neutralidade nos assuntos árabes tentando ao máximo evitar tomar partido nas disputas que envolviam os principais Estados árabes da época. Dessa maneira, o governo libanês procurava evitar as consequências da chamada Guerra Fria Árabe travada entre o Egito de Nasser e a Arábia Saudita de Faisal, pois o Líbano tinha relações econômicas e diplomáticas com ambos e sofria a influência política dos dois Estados.

\footnotetext{
${ }^{897}$ HAYEK... p. 125-126.

${ }^{898}$ GORIA, Wade R... p. 92-93.
} 
A situação libanesa era ainda mais complicada porque os dois governos também utilizavam a imprensa libanesa para realizar uma guerra ideológica pela hegemonia no Mundo Árabe. Os sauditas comandavam uma frente conservadora, defensora do capitalismo liberal e que tinha na bandeira do Islã uma arma para combater o nacionalismo árabe laico. Formaram com o Irã do Shah Reza Pahlevi uma frente anti-Nasser chamada de Pacto Islâmico. O governo saudita procurava sempre pressionar o governo de Helu para que este se distanciasse do Egito e costumava questionar publicamente a sua neutralidade nos assuntos árabes. Por outro lado, o governo de Riad sempre destacava os fortes laços econômicos entre os dois países como, por exemplo, o fato do Líbano receber um grande fluxo de capital saudita em seus bancos, a parceria comercial entre os dois países e o número enorme de turistas sauditas que visitavam a república libanesa todos os anos para mostrar que eles eram os melhores aliados dos libaneses ${ }^{899}$.

Nessa situação, a crise causada pela falência do Intra Bank foi aproveitada pela Arábia Saudita para chantagear o Líbano. Eles afirmvamam que, caso o governo de Beirute não reprimisse os ataques que a população de seu país fazia contra os interesses de Riad em defesa do Egito, eles retirariam os seus fundos dos bancos libaneses e fechariam o oleoduto que termina em Sidom. O resultado disso, caso os sauditas cumprissem suas ameaças, seria a completa falência da economia libanesa ${ }^{900}$.

O conflito saudita-egípcio tinha repercussões dentro do Líbano, pois diversos grupos muçulmanos permaneciam aliados de Nasser e pediam ao governo para se inclinar mais em direção ao Egito. Essa aliança continuava a ser realizada por meio da embaixada egípcia em Beirute que coordenava o apoio desses grupos ao presidente Nasser ${ }^{901}$.

Dentro do Líbano ainda eram frequentes grandes manifestações de apoio ao líder egípcio nas principais cidades onde os muçulmanos eram uma parcela importante da população. Em todos os conflitos que envolveram o Egito nos anos 60 a maioria da população muçulmana esteve do lado de Nasser e quando, após a derrota árabe em junho de 1967, o líder egípcio ameaçou renunciar, milhares de muçulmanos saíram às ruas nas cidades libanesas para pedir, como faziam os egípcios, para que Nasser continuasse como Presidente enquanto vários líderes

\footnotetext{
${ }^{899}$ QALAWUN, Nasser M. The struggle for Lebanon... p. 118-120.

900 HAYEK.. p. 125.

901 QALAWOUN... p. 121.
} 
políticos libaneses iam à embaixada do Egito em Beirute para expressar o seu apoio ao líder egípcio $^{902}$.

Já os grupos cristãos conservadores se inclinavam para a Arábia Saudita e pressionavam Helu para que interrompesse suas políticas de aproximação com Nasser e a continuada influência egípcia nos assuntos internos do país enquanto condenavam as posturas críticas em relação ao reino saudita que existiam na imprensa nasserista ou de esquerda e entre diversas autoridades políticas e religiosas libanesas.

Eles se sentiram aliviados com o fim da RAU, pois pensavam que isso diminuiria a pressão do nacionalismo árabe sobre o Líbano e diversas lideranças recusavam qualquer aproximação e conciliação com Nasser como era o caso de Chamoun ou Raymond Eddé apesar das tentativas egípcias para promover algum tipo de entendimento.

Antes da guerra de junho de 1967 figuras como o próprio Chamoun e até o patriarca maronita Paul Meushi estavam estabelecendo contatos com o monarca saudita que pretendia usálos contra o movimento nasserista. Por sua vez, durante todo o mandato de Helu a imprensa de direita continuadamente atacou o Egito e criticou a aproximação do Líbano em relação a esse país como algo contrário aos seus verdadeiros interesses.

De maneira geral, o mandato de Helu foi marcado, portanto, por uma constante crise que minou as bases do consenso político formado por Fuad Chehab após a guerra civil de 1958 promovendo uma grave divisão da sociedade libanesa com base na filiação religiosa que prenunciava o retorno da guerra civil e o rompimento do Pacto Nacional e do sistema social e político montado a partir desse acordo.

O Líbano também sofreu de maneira cada vez mais pesada o impacto dos conflitos no Oriente Médio como a Guerra Fria Árabe, os efeitos do fim da República Árabe Unida, a questão do desvio das águas do Rio Jordão, a ascensão do movimento guerrilheiro palestino e por fim a derrota árabe na guerra de 1967. Esses fatos acabaram dividindo a sociedade libanesa entre um setor pró-nacionalismo árabe e, depois, pró-palestino (a maioria dos muçulmanos e drusos mais os partidos de esquerda e nacionalistas) e outros anti-palestinos, antinacionalistas árabes e a favor de uma orientação exclusivamente ocidental para o Líbano.

902 QALAWOUN... p. 14. 
Essa divisão se mesclou aos conflitos de caráter comunitário aumentando ainda mais as tensões no país. Nesse cenário a figura do Presidente Helu acabou por não satisfazer a nenhum dos lados, pois ele sempre aparecia como favorecendo o grupo rival e, para os cristãos, o Presidente libanês era complacente com relação a Nasser e, posteriormente, com as ações dos palestinos dentro do território nacional, ao mesmo tempo em que se reclamava em todo o país dos excessos das forças de segurança.

Como resultado Charles Helu não conseguiria fazer o seu sucessor em 1970 e os chehabistas deixaram definitivamente o poder com a eleição de Suleiman Frangié. 


\section{CONSIDERAÇÕES FINAIS}

Durante o período que coincidiu com a ascensão do nacionalismo árabe, o Líbano assistiu ao maior período de crescimento econômico de sua história no século XX. Com uma média de $6 \%$ ao ano na década de 1950 e $4 \%$ na de 1960, o país consolidou-se como o grande centro de serviços e trocas do Oriente Médio, funcionando como um intermediário econômico entre os países árabes e os países capitalistas centrais.

No final da década de 1960, o volume das importações do país chegou a LL1913,7 milhões enquanto as exportações chegaram a LL510,3 milhões (ver Tabela 28 acima), sendo a Arábia Saudita e a Síria, com, respectivamente, 14,9\% e 12\% (ver Tabela 24 acima), os maiores importadores de mercadorias fabricadas ou que passaram pelo país do cedro.

Nessa época, bem antes da crise de 1966, os bancos libaneses haviam chegado a corresponder a 7\% da economia nacional enquanto o comércio representaria 40,6\% (ver Tabela 6 acima), sendo o valor dos serviços vendidos de LL1.164,8 bilhões e das mercadorias de LL584,1milhões (ver Tabela 22 acima).

Esse crescimento pode ser sentido no PIB do Líbano, que no Oriente Médio era superado apenas pelos Estados petroleiros, então fortemente ligados à república libanesa pelo comércio, transporte, finanças, turismo, setor imobiliário e o sistema de educação superior libanês.

Aliás, esses vínculos eram consolidados pelas fortes ligações entre as elites sunitas libanesas e as da Península Arábica, envolviam até casamentos e relações de parentesco e, fortíssimos, se acentuariam nas décadas de 1970 e 1980 como exemplificam a emigração libanesa para esses países durante a guerra civil de 1975-1990, a visita de Bachir Gemayel à Arábia Saudita pouco depois de se eleito Presidente em 1982, na qual foi acompanhado pelo líder sunita Saeb Salam, e o governo Hariri nos anos 1990 quando o governo saudita apareceu como uma das forças políticas externas hegemônicas na sociedade libanesa.

Porém, essa prosperidade não se desenvolveu em um cenário de tranquilidade. Embora as tensões nunca criassem crises suficientemente duradouras ou profundas para fazer o sistema econômico entrar em colapso, houve um clima permanente de tensão tanto entre o governo e seus adversários como entre muçulmanos e cristãos como resultado da hegemonia 
destes últimos (particularmente dos maronitas), de sua maior prosperidade e melhores condições de vida em relação à maioria dos muçulmanos (podemos lembrar que, por volta de 1960, 39\% dos homens muçulmanos no campo eram analfabetos enquanto para os cristãos na mesma situação esse número era de $23 \%$, enquanto entre as muçulmanas esse número chegava a $69 \%$ ver tabela 6 acima), excluindo nesse aspecto os importantes setores de sua elite, então sócias da burguesia cristã.

Essa tensão era muito fortalecida pelos acontecimentos e processos do cenário internacional das décadas de 1950 e 1960 como a ascensão do nacionalismo árabe e, particularmente, da figura de Gamal Abdel Nasser, da ação dos governos médio-orientais inimigos deste como Arábia Saudita e Irã, do permanente conflito árabe-israelense, da presença dos refugiados palestinos no Líbano que são maltratados e discriminados nesse país, assim como da forte presença norte-americana e ainda francesa e britânica no Oriente Médio.

Várias crises de origem interna e externas se sucedem rapidamente nesses anos: a 'Revolução das Águas de Rosas', a questão da adesão do Líbano ao Pacto de Bagdá, a crise de Suez, a guerra política entre Chamoun e Nasser, a guerra civil de 1958 que levou à intervenção dos EUA, a tentativa de golpe do PNSS em 1 de janeiro de 1962, a falência do Intra Bank, o despertar da luta armada palestina e a guerra de junho de 1967 que levou ao fechamento do Canal de Suez prejudicando assim seriamente o comércio libanês. Essas crises dividiam a sociedade libanesa: o muçulmanos apoiavam o campo anti-imperialista, os palestinos e o nacionalismo árabe enquanto os cristãos eram pró-ocidentais, embora não pró-israelenses, como aconteceria mais tarde durante a segunda guerra civil, pois esse Estado era visto como uma ameaça a existência do Líbano, apesar de haver setores minoritários cristãos - particularmente maronitas que movidos por um exclusivismo racista viam na aliança com o sionismo um meio de combater o nacionalismo árabe e garantir a existência de um Estado cristão como entidade política e militar viável.

Nesse período cabe destacar o mandato presidencial do general Fuad Chehab. Este descendente dos emires dos séculos XVIII e XIX, embora conservador, anticomunista e defensor do Líbano como entidade política separada da Síria, soube compreender que a existência de seu país somente seria assegurada pela inclusão social da população muçulmana e o reconhecimento de seu valor para a nação libanesa. 
Ao longo dos seus seis anos de mandato tentou estabelecer a ideia de um acordo entre as comunidades e classe sociais, no qual o seu próprio gabinete multiconfessional era o primeiro exemplo, para se implantar um sistema de segurança social e promover determinadas políticas de intervenção no sistema econômico que diminuíssem as desigualdades, integrassem nacionalmente todas as regiões e buscassem impedir o aparecimento de crises periódicas devido à natural instabilidade do mercado. No entanto, as elites libanesas não aceitaram, e aqui se incluem tanto as cristãs como as muçulmanas, e, por sua vez, muitos cristãos, particularmente os maronitas, se opuseram às políticas de investimento social nas regiões pobres majoritariamente muçulmanas do sul, Bekaa e Akkar como se fossem uma espécie de ‘privilégio’ ou de postura pró-muçulmana de um Estado que havia sido criado para os cristãos.

Com isso, Fuad Chehab, embora contasse ao longo de todo o seu mandato com a presença do Kataeb ultralibanista de Pierre Gemayel em seu governo, nunca atraiu o apoio da grande massa dos maronitas. No máximo, uma aceitação de sua Presidência. Seu rival, Camille Chamoun, o herói da 'resistência' cristã libanesa contra a 'ameaça' nasserista na guerra de 1958 é quem atraía a simpatia dos integrantes da própria comunidade de Fuad Chehab.

Por outro lado, a política repressiva de Chehab em relação aos palestinos, acossados por um forte controle das forças de segurança, que os fazia viver permanentemente em uma situação de ditadura real, a ausência de direitos políticos, econômicos e sociais, somadas à constante discriminação por parte dos libaneses cristãos e a nunca reconhecida importância de sua comunidade para o desenvolvimento do país como provava uma figura das dimensões de Yussef Beidas, provocou um ressentimento e uma alienação em relação ao país, acentuada pela destruição do Intra Bank de Beidas, que se manifestaria na adesão crescente de sua juventude à luta armada, quer nas fileiras da OLP ou de outros grupos.

A guerra de 1967 acentuou de maneira radical essa tendência e muito contribuiu para dividir a sociedade libanesa, pois os palestinos cada vez mais autônomos, apoiados pela Liga Árabe e dispostos a recuperar por todos os meios as suas terras roubadas, receberam um forte apoio da maioria dos muçulmanos que identificou a luta dos irmãos palestinos com a sua própria contra a elite cristã e os defensores do confessionalismo ou da hegemonia cristã (ou particularmente a maronita) dentro do sistema político libanês.

Já os cristãos viram a ação palestina, tanto pelo seu caráter independente em relação 
ao governo, por seu apoio recebido dos Estados árabes, como por provocar retaliações por parte de Israel, uma ameaça à independência ou mesmo à integridade do seu país, além de atiçar a metade muçulmana para que tentasse mudar o sistema ou mudar as relações de poder existentes assumindo o papel de liderança que muitos cristãos consideravam como natural para as suas comunidades. Por isso, havia apoio crescente a políticos e grupos com discurso cada vez mais extremista como o Kataeb pós-governo Chehab e o Partido Nacional Liberal de Chamoun. As eleições de 1968 mostrariam nas urnas essa postura dos cristãos.

Dessa forma, o Líbano permaneceria até 1975 no padrão que caracterizou a sua história desde a independência: crescimento econômico acompanhado de exclusão das regiões e camadas populares muçulmanas e uma constante tensão política e sectária agora mesclada ao conflito árabe-israelense. Em 10 de abril, as grandes tensões acumuladas finalmente explodiram em um violento confronto inicialmente maronita-palestino e cristão-muçulmano que traria várias invasões estrangeiras, arruinaria a economia, as finanças e a sociedade libanesa por quinze anos e acabaria com a autoimagem de Suíça do Oriente Médio. 


\section{REFERÊNCIAS BIBLIOGÁFICAS}

\section{Livros}

ALAMMUDDIN, Najib. The flying Sheikh. Londres: Quartet Book, 1987.

ASSEILY, Antoine E. Central banking in Lebanon: a central banking for the economic development of the country. Beirute: Khayat Books, 1967.

ATTIÉ, Caroline; Struggle in the levant: Lebanon in the 1950s. Oxford, Londres e Nova Iorque:

I. B. Tauris in association with Centre for Lebanese Studies, 2004.

BAER, Gabriel. Population and society in the Arab East. V. 11.

BESHARA, Adel. Lebanon: the politics of frustration - the failed coup of 1961. Londres e Nova Iorque: Routledge-Taylor and Francis Group, 2005.

CHAITANI, Yussef. Post-colonial Sirya and Lebanon: the decline of Arab nationalism and the triumph of State. I. B. Tauris, 2007.

COBBAN, Helena. The making of modern Lebanon. Londres: Hutchinson and Co., 1985.

Comunism and nationalism in the Middle East. Taylor and Francis Group.

CORM, Georges. El Líbano contemporâneo: história y sociedad. In: Biblioteca del Islam Contemporâneo. Barcelona: Edicions Bellaterra, 2006.

DAWISHA, Adeed. Arab nationalism in the twentieth century: from triumph to despair. Princeton: Princeton University Press, 2003.

DIB, Kamal. Warlords and merchants: the Lebanese business and political establishment. Londres: Ithaca Press, 2004.

ENTELIS, John P. Pluralism and party transformation in Lebanon: Al-Kataib, 1936-1970. Leiden: E. J. Brill, 1974.

FIRRO, Kais M.: A History of the Druzes. E. J. Brill, Leiden. 1992.

FINCH, Henry. Uruguay since 1930. In: BETHELL, Leslie. The Cambridge history of Latin America. V. 8 (VIII). Cambridge University Press, 1996. 
GASPARD, Toufic K. A political economy of Lebanon, 1948-2002: the limits of laissez-faire. Leiden: Koninklijke Brill NV, 2004.

GATES, Carolyn L. The historical role of political economy in the development of modern Lebanon. In: Paper on Lebanon. Oxford: Centre for Lebanese Studies, 1989.

, Carolyn L.: The merchant republic of Lebanon: rise of a open economy. Oxford e Londres: Center for Lebanese Studies in association with I. B. Tauris \& Co Ltd, 1998.

GENDZIER, Irene L. Notes from the minefield: United States intervention in Lebanon and Middle East, 1945-1958. Nova Iorque e Chichester: Columbia University Press, 1997.

GORDON, David. Lebanon, a fragmented nation. Londres: Croom Helm, 1980.

, David. The republic of Lebanon: nation in jeopardy. Boulder: Westview Press, 1983.

GORIA, Wade R. Sovereignty and leadeship in Lebanon, 1943-1976. Londres: Ithaca Press, 1985.

GUALTIERI, Sarah M. A. Between Arab and white: race and ethnicity in the early Syrian American diaspor. Londres e Los Angeles: University of California Press, 2009. p. 24.

HAYEK, Domingo Garí. História contemporánea del Líbano: confesionalismo y política (1840-2005). Santa Cruz de Tenerife e las Palmas de Gran Castilla: Ideal Global, 2006.

HUDSON, Michael C. The precarious republic: political modernization in Lebanon. Nova Iorque, Random House: 1968.

INTERNATIONAL ORGANIZATION FOR MIGRATION (IOM). Intra-regional labour mobility in the Arab world. p. 104.

ISMAEL, Tarik; ISMAEL, Jacqueline S. The communist movement in Syria and Lebanon. Gainesville: University Press of Florida, 1998.

JOHNSON, Michael. All honorable men: the social origin of war in Lebanon. Londres e Nova Iorque: Centre for Lebanese Studies of Oxford e I. B. Tauris, 2001.

KHALAF, Nadim G. Economic implications of the size of nations: with special reference to 
Lebanon. Leiden: E. J. Brill, 1971.

KHALAF, Samir. Civil and uncivil violence in Lebanon: a history of the internationalization of communal conflict. Nova Iorque e Chichester: Columbia University Press, 2002.

MAHFOUZ, Joseph: Maronitas, um marco na História. São Paulo, 1991.

MALLAT, Raymond A. 70 years of money muddling in Lebanon, 1900-1970, 77: a guide in monetary management for economic development in Lebanon. Beirute: Aleph, 1977.

, Raymond A. Fiscal policy for social justice \& economic development in

Lebanon: a guide in fiscal management for social and economic development in Lebanon. Beirute, 1980.

MALSAGNE, Stéphane. Fuad Chéhab, 1902-1973: une figure oubliée de 1'histoire libanaise. Paris e Beirute: Karthala e IFPO, 2011.

MAKDISI, Samir. Financial policy and economic growth: the Lebanese experience. Nova Iorque: Columbia University Press, 1979.

ORON, Yitzhak (Editor). Middle East Record, V. 2. 1961. p. 404. Published by the Israel program for scientific translation for Tel Aviv University. The Reuven Shloah Research Center, 1962.

PHAN, Peter C. (Editor). : Christianity in Asia. Wiley-Blackwell-A John Willians \& Sons, LTDA, Publications. Malden-USA, Oxford and West Susex- England, 2010.

QALAWOUN, Nasser M. The struggle for Lebanon: a modern history of Lebanese-Egyptian relations. Londres e Nova Iorque: I. B. Tauris Publisher, 2000.

SAYGH, Yussif Abdallah. Economies of the Arab World: development since 1945. Londres: Croom Helm, 1978.

SALIBI, Kamal S. Crossroad to civil war: Lebanon 1958-1976. Londres e Nova Iorque: Ithaca Press e Caravan Books-Delmar, 1976.

Kamal S. The modern history of Lebanon. Westport: Grenwood Press Publisher, reimpressão de 1976. 
TRABOULSI, Fawwaz. A modern history of Lebanon. Londres e Nova Iorque: Pluto Press, 2007.

WINSLOW, Charles. Lebanon: war and politics in a fragmented society. Londres e Nova Iorque: Routledge, 1996.

ZISSER, Eyal. Lebanon: the challenge of independence. Londres e Nova Iorque: I. B. Tauris, 2000.

\section{Artigos}

AL-KHAZEM, Farid. Kamal Jumblatt, an uncrowned Druze Prince of left. In: Middle Eastern Studies, V. 24, N. 8, abr. de 1988. Taylor and Francis Ltd. Disponível em: <http://www.jstor.org/stable/4283235>.

BAROUDI, Sami. Conflict and cooperation within Lebanon`s business community: relation between merchants and industrialists. In: Middle Eastern Studies, V. 37, N. 4, out 2001. Disponível em: 〈http://www.jstor.org/stable/4284197〉.

CURTIS, Gerald L. The United Nations group observation in Lebanon. In: International Organization, V. 18, N. 4, outono de 1964. Disponível em: <http://www.jstor.org/stable/270552>.

ENTELIS, John P. Party transformation in Lebanon: Al-Kata'ib as a Case Study. In: Middle Eastern Studies, V. 9, 1973. Disponível em: 〈htttp://www.jstor.org/stable/4282494>.

GALVANI, John. Syria and the Baath Party. In: MERIP Reports, N. 25, fev. 1974. p.3. Disponível em: 〈htttp://www.jstor.org/ stable/3011567〉.

HARTMAN, Michelle; OLSARETTI, Alessandro. "First boat and the first oar": inventions of Lebanon in the writings of Michel Chiha. Radical History Review, 86, Primavera, 2003.

KAUFMAN, Asher. Phoenicism: the formation of an identity in Lebanon in 1920. In: Middle Eastern Studies. V. 32, N. 1, jan. 2001. Disponível em: 〈http://www.jstor.org/stable/4284144>.

KLIOT, N. The collapse of Lebanese State. In: Middle Eastern Studies, V. 23, N.1, jan. 1987. Disponível em: 〈http://www.jstor.org/stable/4283154>. 
LANDAU, Jacob. Election in Lebanon. In: The Western political quaterly, V. 14, N. 1, mar. 1961.

MAKTABI, Rania. The Lebanese census revisited: who are the Lebaneses? In: British Middle Eastern Studies Journal, nov. 99, V. 26. Disponível em: 〈http://www.jstor.org/stable/195924>.

NARS, Salim. Backdrop to civil war: the crisis of Lebanese capitalism. In: MERIP Report. N. 3. dez. 1978. Disponível em: 〈http://www.jstor.org/stable/3012262>.

NIR, Omri. The Shiites during the 1958 Lebanese crisis. In: Middle Eastern Studies, V. 40, N. 6, nov. 2004. Taylor and Francis Ltd. Disponível em: 〈http://www.jstor.org/stable/4289955>.

RAPHAELI, N. Development planning: Lebanon. In: Political research quaterly, set. 1967, V. 20, N. 3. Disponível em: 〈http://www.jstor.org/stable/446204>.

SALIBI, Kamal S. Lebanon under Fuad Chehab: 1958-1964. Middle Eastern Studies. V. 2 N. 3. abr. 1966. Taylor and Francis Ltd. Disponível em: 〈http://www.jstor.org/stable/4282160〉.

SAMII, Abbas William. The Shah's Lebanon policy: the role of Savak. Middle Eastern Studies, V. 33, N. 1, jan. 1997. Taylor and Francis Ltd. Disponível em: <http://www.jstor.org/stable/4283847>.

SMITH, Pamela Ann. The Palestinian diaspora, 1948-1985. In: Journal of Palestinians Studies. V. XV. N. 3. Primavera de 1986.

BEN-TZUR, Avraham. The neo-Baath party of Syria. In: Journal of contemporary History, V. 3, N. 3, The Middle East (jul. 1968). Disponível em: 〈http://www.jstor.org/stable/259704>.

ZISSER, Eyal. The downfall of the Khury administration: a dubious revolution. In: Middle Eastern Studies, V. 30, N 3, jul. 1994. Taylor and Francis Ltd. Disponível em: <http://www.jstor.org/stable/4283654>.

\section{Dissertação de Mestrado}

MAALOUF, Ramez Ph.: Geoestratégias em confronto no Líbano. Dissertação de Mestrado Apresentada ao programa de Pós-Graduação em Geografia Humana do Departamento de Geografia da FFLCH-USP, São Paulo-2011. 


\section{Sitio da Internet}

Lebanese Banking and Financial Sectors. Disponível em: 〈http:www.bdl.gov.lb $>$.

Ministério de Economia y Finanzas del Uruguay. Disponível em: 〈http://www.mef.gub.uy >

Embaixada da China em Beirute. Disponível em: 〈http://lb2. mofcom.gov.cn〉.

Cia-Factbox. Disponível em: <http://www.cia.gov/library/publications/the-worldfactbook/geos/uy.html>.

$\mathrm{htttp} /$ www.islam.org

http:// www.islamismo.org/bem.htm.

http://www.academia.edu/4156975/Theodore_Abu_Qurrahs_Debate

http://melquita.fateback.com/igrejaarmenia.htm

http://melquita.fateback.com/historia.htm

\section{Reportagem de Revista}

DE CARVALHO, George. The fall of the 'Genius from Jerusalem'. Revista Life, 27 jan. 1967. p. 15 
MAPAS:

Líbano: Divisão Política (1958)

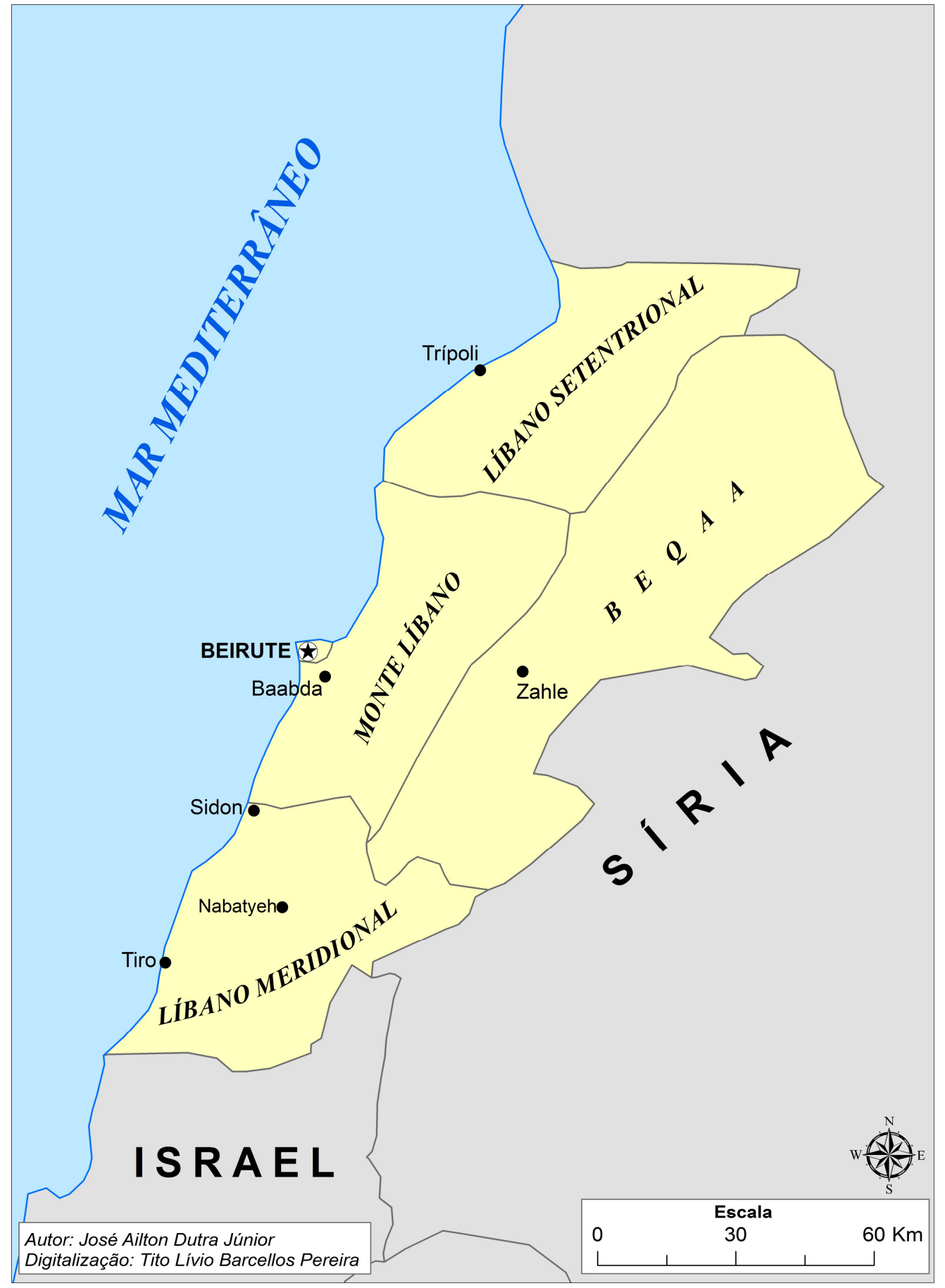




\section{O Monte Líbano Otomano e a atual distribuição religiosa}

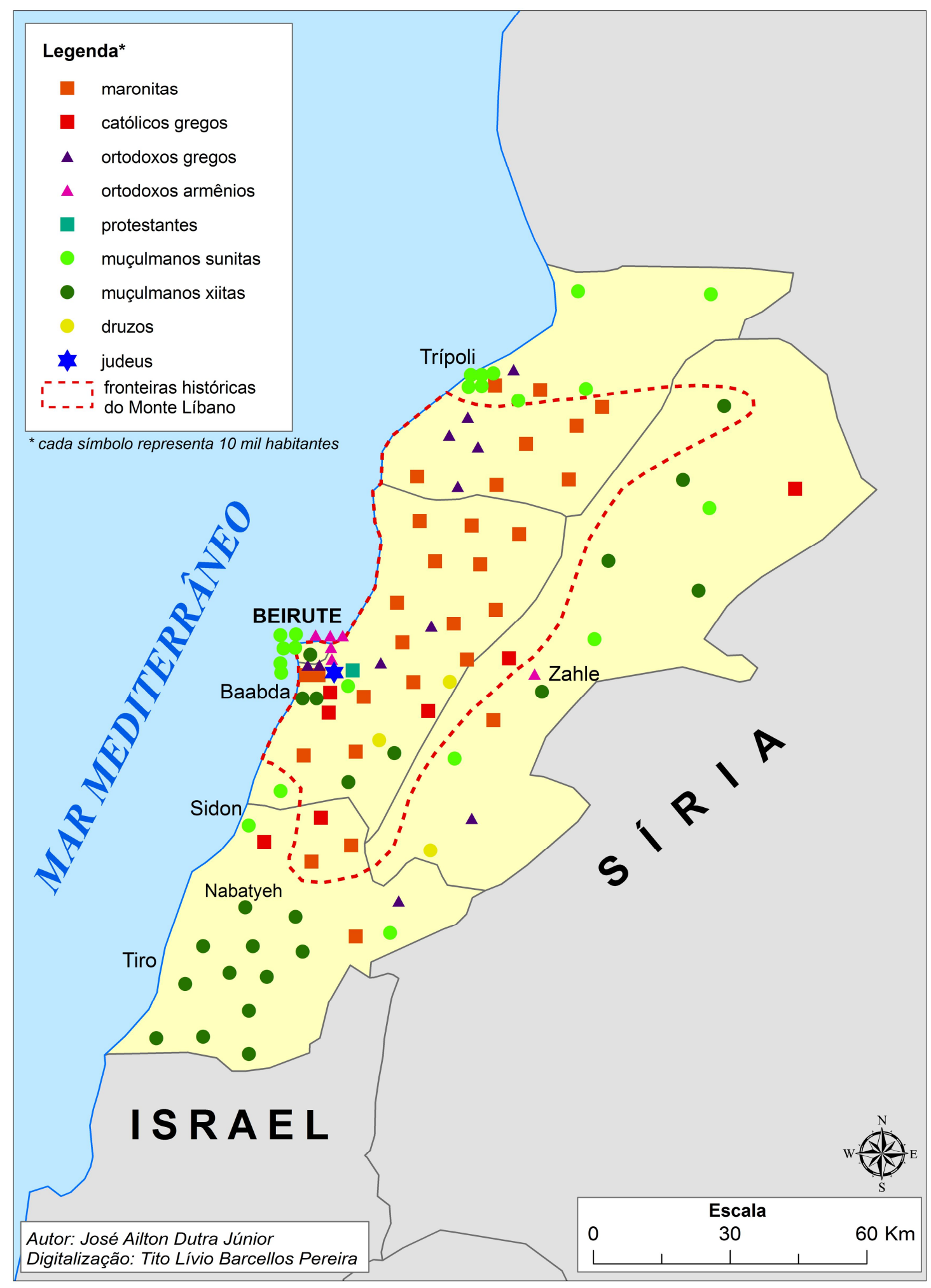




\section{Líbano: Províncias e Principais Cidades}

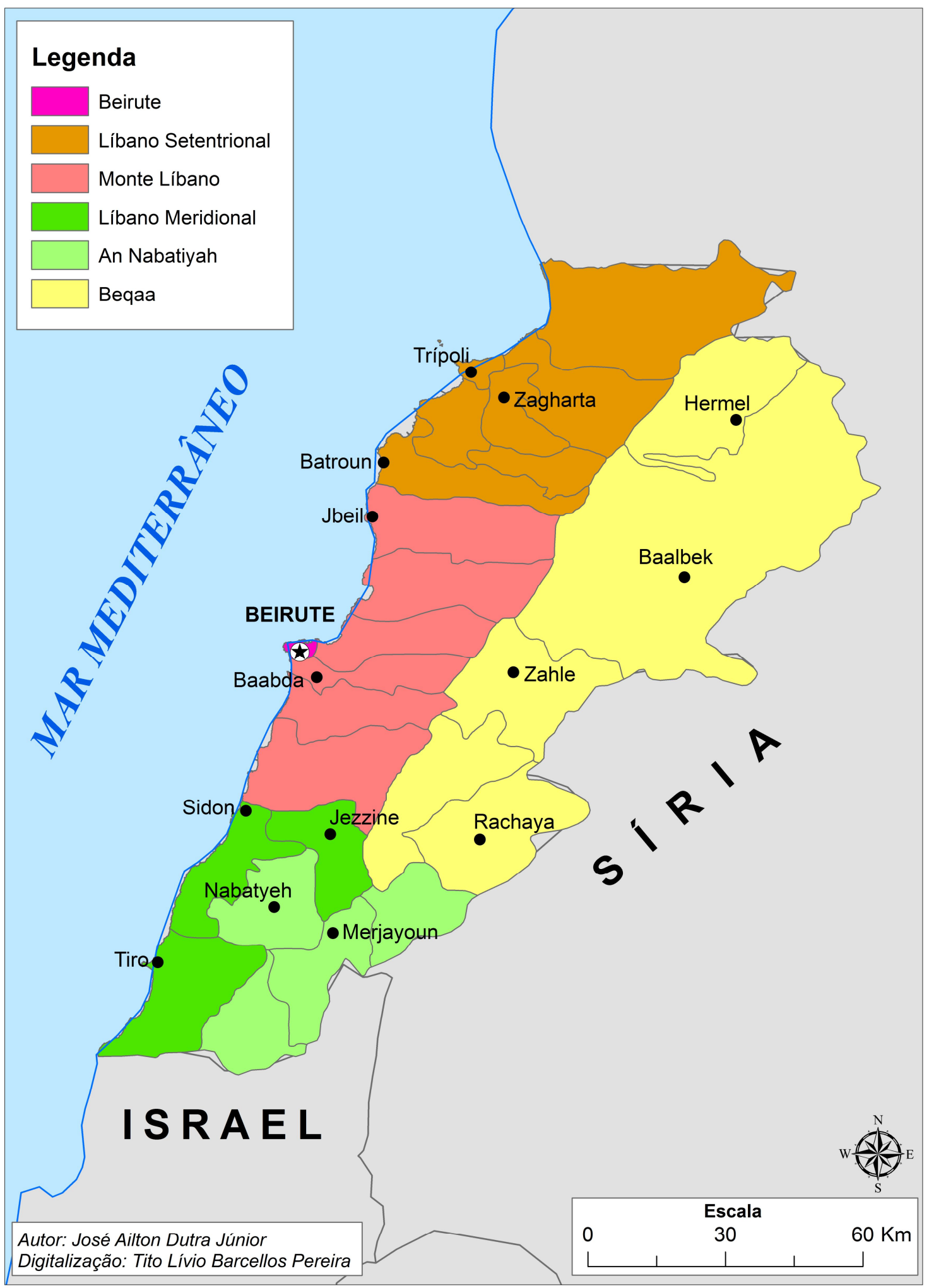




\section{Líbano: Áreas de insurgência armada na Crise de 1958}

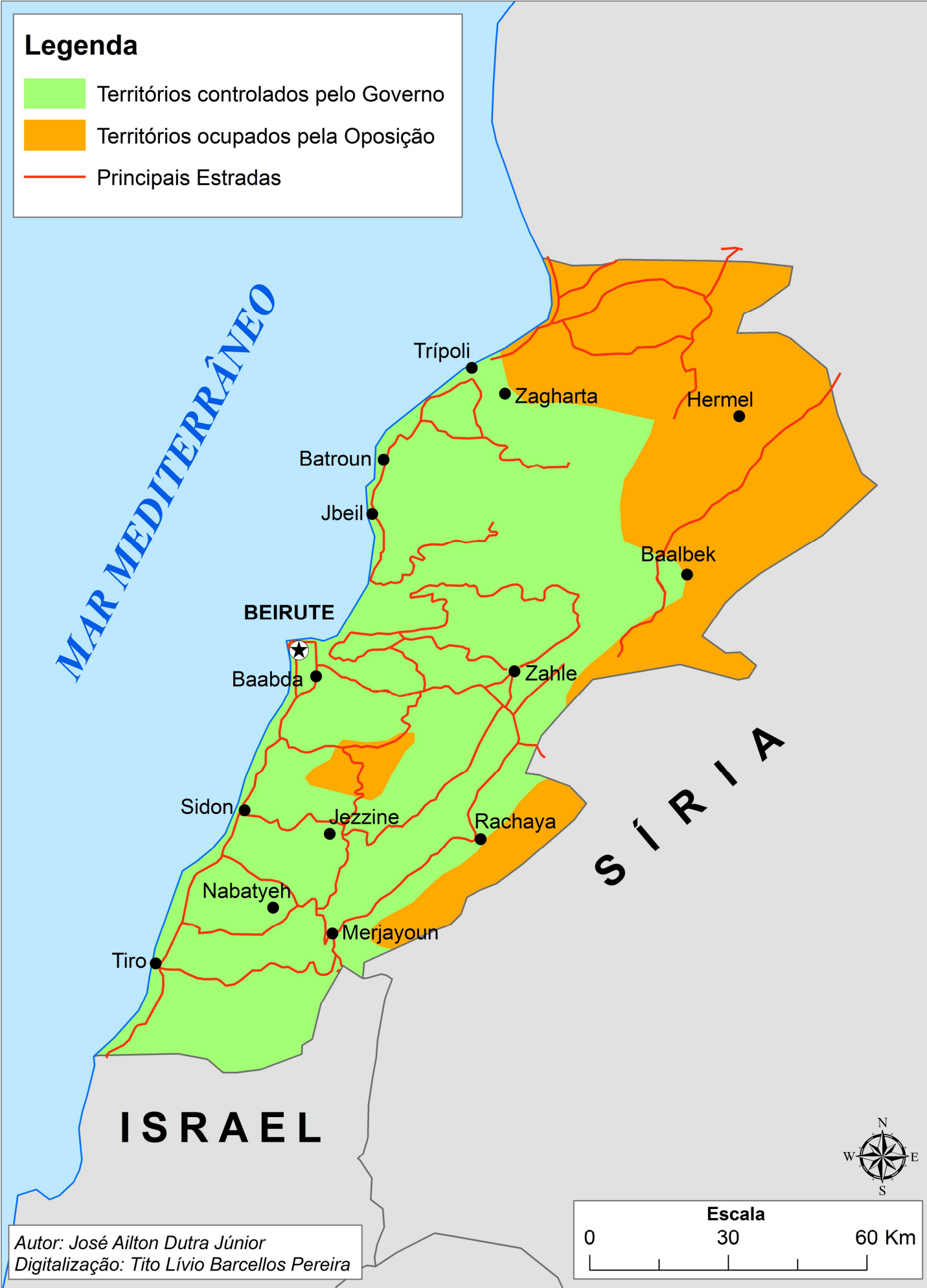




\section{O Monte Líbano e o "Grande Líbano"}

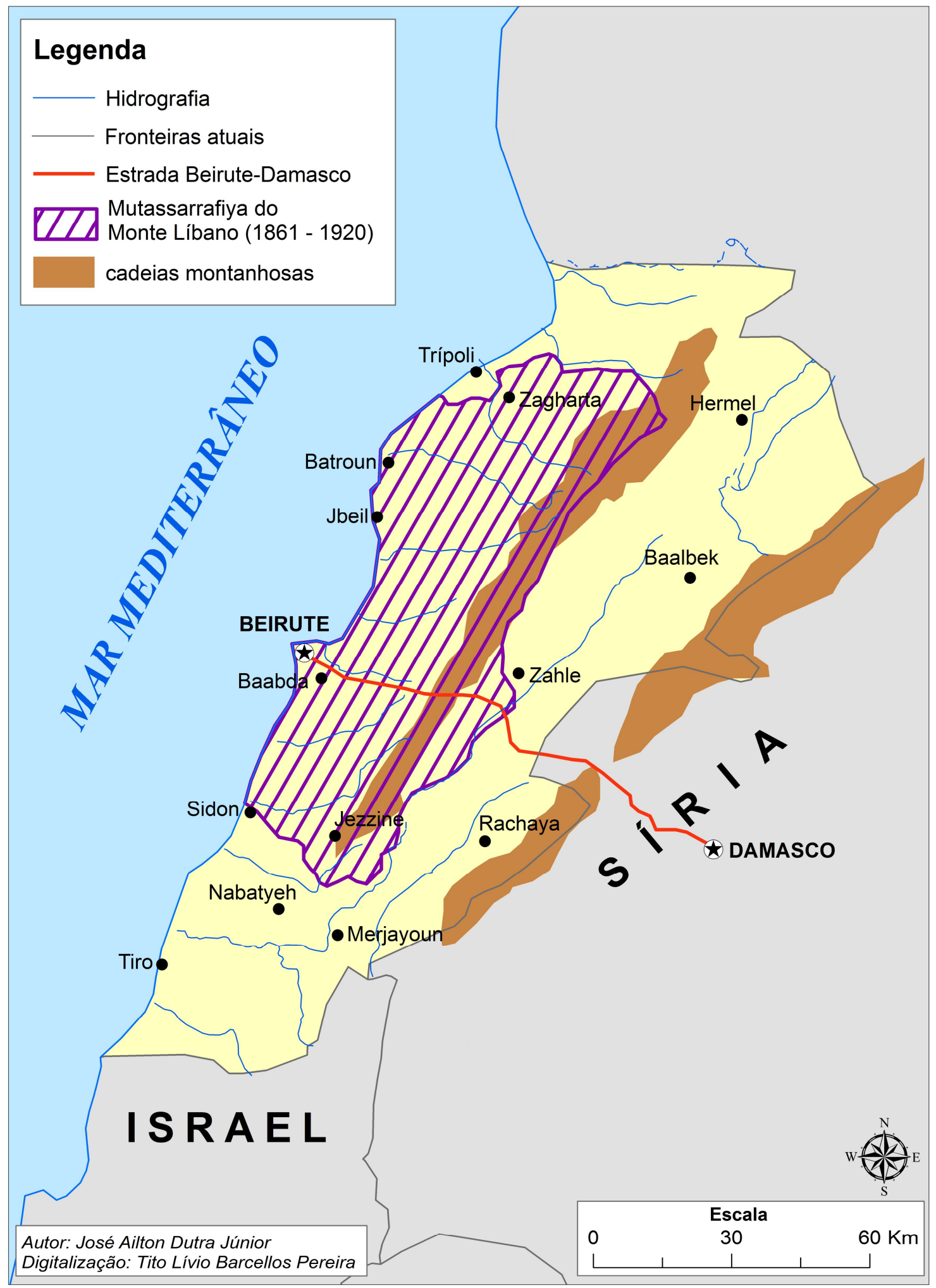


BEIRUTE: DIVISÃO ADMINISTRATIVA

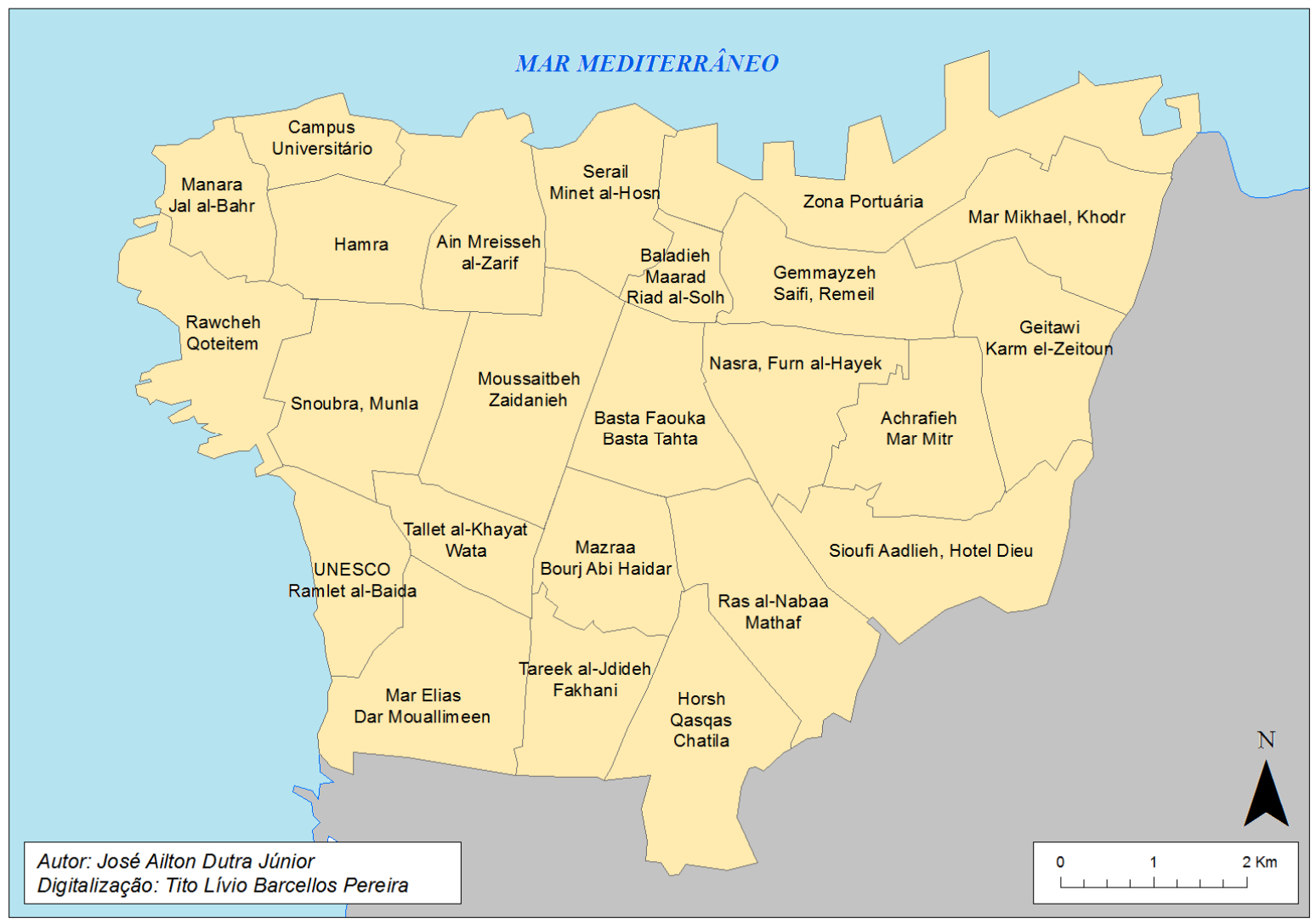

